\title{
doi) crossef
}
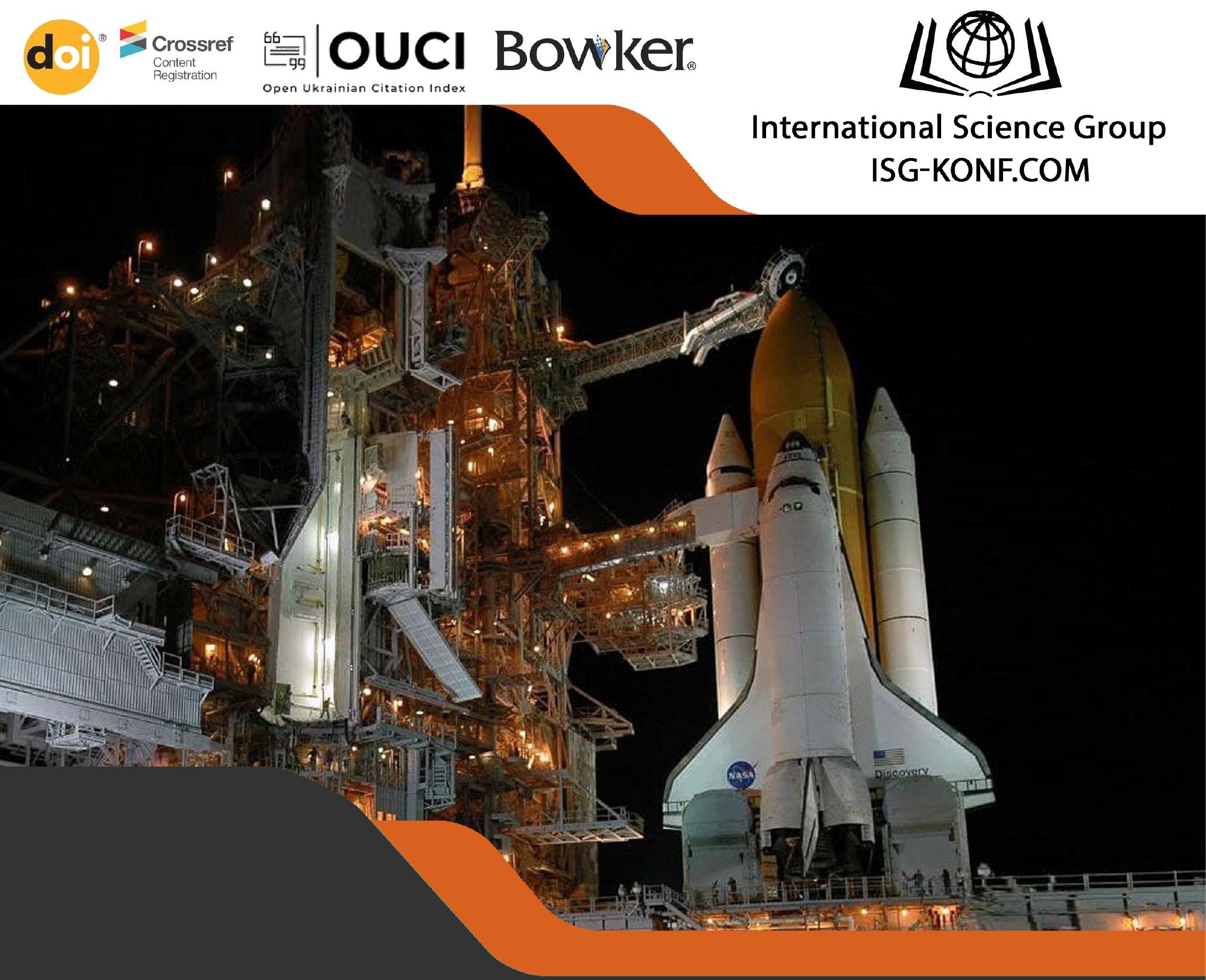

\section{THEORETICAL FOUNDATIONS OF ENGINEERING. TASKS AND PROBLEMS}

Collective monograph

ISBN 978-1-63972-067-5

DOI 10.46299/ISG.2021.MONO.TECH.III BOSTON(USA)-2021 
ISBN - 978-1-63972-067-5

DOL- 10.46299/ISG.2021.MONO.TECH.III

Theoretical foundations of engineering. Tasks and problems

Collective monograph

Boston 2021 
Library of Congress Cataloging-in-Publication Data

ISBN - 978-1-63972-067-5

DOI- 10.46299/ISG.2021.MONO.TECH.III

Authors - Boiko T., Boiko P., Muzyka N., Ключка С., Сорока М., Чемерис I., Білик Л., Сич В., Bereziuk O., Lemeshev M., Cherepakha D., Chovniuk Y., Moskvitina A., Shishina M., Kravchyuk V., Usenko V., Vorontsov O., Usenko I., Kodak O., Boyko V., Vasylenko O., Moskalenko K., Stashenko M., Tanirverdiev A., El Echcheikh A.D., Бабенцова О., Курілович К., Сліпченко В., Шаламова К., Коваленко А.С., Пузачова А.С., Шаламова К., Польщікова Н.В., Марценюк О.І., Жарська М., Вербовецька В., Goolak S., Petrenko A., Lukashova N., Shavkun V., Fediushko A., Fedyushko Y., Azarkhov A., Sili I., Fediushko M., Gorobets V., Trokhaniak V., Antypov I., Spodyniuk N., Kliuieva O., Rusanov S., Luniaka K., Kliuiev O., Lys S., Yurasova O., Galyanchuk I., Идрисова А.Е., Рахымбеков А.Ж., Horishnii P., Topchii O., Shevchenko I., Kotliar Y., Petryna A., Taranchuk A., Pidchenko S., Рижков Е., Синиціна Ю., Станіна О., Бернацький А., Соколовський М., Сіора О., Лукашенко В., Шамсутдінова Н., Пимонов И., Шевченко В., Олейникова А., Погорелый И., Щукін О., Орел O., Sigarev E., Dovzhenko O., Lobanov Y., Chernyatevich I., Chubina O., Sapronova S., Vdovychenko V., Ivanov I., Кара I., Карий O.

\section{REVIEWERS}

Ivan Katerynchuk - Doctor of Technical Sciences, Professor, Honoured Worker of Education of Ukraine, Laureate of the State Prize of Ukraine in Science and Technology, Professor of the Department of Telecommunication and Information Systems of Bohdan Khmelnytskyi National Academy of the State Border Guard Service of Ukraine.

\section{Published by Primedia eLaunch https://primediaelaunch.com/}

Text Copyright (C) 2021 by the International Science Group(isg-konf.com) and authors. Illustrations (C) 2021 by the International Science Group and authors.

Cover design: International Science Group(isg-konf.com). (C)

Cover art: International Science Group(isg-konf.com). C

All rights reserved. Printed in the United States of America. No part of this publication may be reproduced, distributed, or transmitted, in any form or by any means, or stored in a data base or retrieval system, without the prior written permission of the publisher. The content and reliability of the articles are the responsibility of the authors. When using and borrowing materials reference to the publication is required. 
Collection of scientific articles published is the scientific and practical publication, which contains scientific articles of students, graduate students, Candidates and Doctors of Sciences, research workers and practitioners from Europe and Ukraine. The articles contain the study, reflecting the processes and changes in the structure of modern science.

The recommended citation for this publication is:

Theoretical foundations of engineering. Tasks and problems: collective monograph / Boiko T., Boiko P., - etc. - International Science Group. - Boston : Primedia eLaunch, 2021. 485 p. Available at : DOI- 10.46299/ISG.2021.MONO.TECH.III 
TABLE OF CONTENTS

\begin{tabular}{|c|c|c|}
\hline \multicolumn{3}{|c|}{ AGRICULTURE AND FORESTRY } \\
\hline 1.1 & $\begin{array}{l}\text { Boiko Т. }{ }^{1}, \text { Boiko P. }{ }^{1} \\
\text { АНАЛІЗ ДЕРЕВНИХ РОСЛИН ПАРКОВИХ НАСАДЖЕНЬ } \\
\text { МІСТА ХЕРСОН } \\
{ }^{1} \text { Kherson State Agricultural University }\end{array}$ & 12 \\
\hline 1.2 & $\begin{array}{l}\text { Muzyka N. }{ }^{1} \\
\text { ІНСТИТУЦЙНЕ ЗАБЕЗПЕЧЕННЯ РАЦІОНАЛЬНОГО } \\
\text { ВИКОРИСТАННЯ I ОХОРОНИ ЗЕМЕЛЬНИХ РЕСУРСІВ } \\
\text { ' Institute of Geodesy, Lviv Polytechnic National University }\end{array}$ & 18 \\
\hline 1.3 & 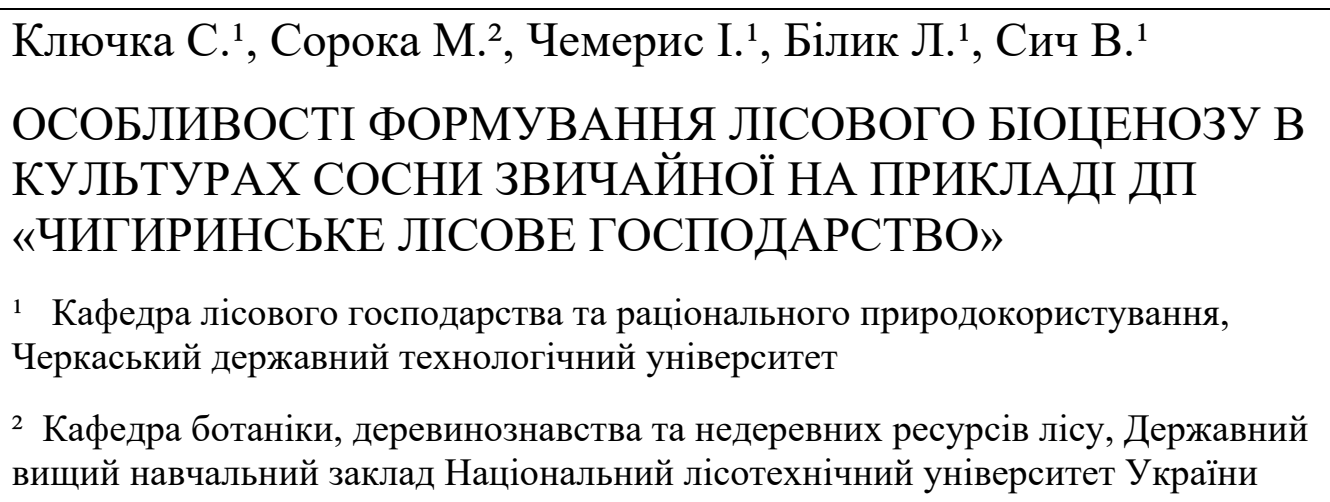 & 51 \\
\hline 2. & ARCHITECTURE AND CONSTRUCTION & \\
\hline 2.1 & $\begin{array}{l}\text { Bereziuk O. }{ }^{1} \text {, Lemeshev M. }{ }^{2} \text {, Cherepakha D. }{ }^{2} \\
\text { FORECASTING THE VOLUME OF CONSTRUCTION WASTE } \\
{ }^{1} \text { Department Security of Life and Pedagogic of Security, Vinnytsia National } \\
\text { Technical University } \\
{ }^{2} \text { Department of Construction, Urban Economy and Architecture, Vinnytsia National } \\
\text { Technical University }\end{array}$ & 70 \\
\hline 2.2 & $\begin{array}{l}\text { Chovniuk Y. }{ }^{1} \text {, Moskvitina A. }{ }^{2} \text {, Shishina } \mathrm{M}^{2}, \text { Kravchyuk V. } \\
\text { HYSTERESIS CURVES ANALYSIS IN THE PROCESSES OF } \\
\text { HEAT AND MOISTURE CONDUCTIVITY OF TEXTILES' } \\
\text { NANOSURFACES. } \\
{ }^{1} \text { Department of Transport, Management and Logistics, National Aviation University, } \\
{ }^{2} \text { Engineering Systems and Ecology Department, Kyiv National University of } \\
\text { Construction and Architecture }\end{array}$ & 75 \\
\hline
\end{tabular}




\begin{tabular}{|c|c|c|}
\hline 2.3 & $\begin{array}{l}\text { Usenko V. }{ }^{1} \text {, Vorontsov O. }{ }^{1} \text { Usenko I. }{ }^{1}, \text { Kodak O. }{ }^{1}, \text { Boyko V. } \\
\text { PROBLEMATIC ISSUES OF RESEARCHING THE } \\
\text { STRUCTURAL INCREASE IN THE RELIABILITY OF } \\
\text { ENGINEERING NETWORKS } \\
{ }^{1} \text { Department of Construction and Civil Engineering, National University "Yuri } \\
\text { Kondratyuk Poltava Polytechnic" }\end{array}$ & 92 \\
\hline 2.4 & $\begin{array}{l}\text { Vasylenko O. }{ }^{1}, \text { Moskalenko K. }{ }^{1}, \text { Stashenko M. }{ }^{1} \text {, Tanirverdiev A. }{ }^{1} \text {, } \\
\text { El Echcheikh A.D. }{ }^{1} \\
\text { NEW MATERIALS AND TECHNOLOGIES IN DESIGN } \\
{ }^{1} \text { Department of architect design, Odessa, Ukraine, Odessa State Academy of Civil } \\
\text { Engineering and Architecture }\end{array}$ & 102 \\
\hline 2.5 & $\begin{array}{l}\text { Бабенцова О. }{ }^{1}, \text { Курілович К. }{ }^{1}, \text { Сліпченко В. }{ }^{1}, \text { Шаламова К. }{ }^{1} \\
\text { АРХІТЕКТУРНА СИСТЕМА ТА АРХІТЕКТУРНА } \\
\text { СТРУКТУРА } \\
{ }^{1} \text { Кафедра Дизайну архітектурного середовища Одеської державної академії } \\
\text { будівництва та архітектури }\end{array}$ & 110 \\
\hline 2.6 & $\begin{array}{l}\text { Коваленко А.С. }{ }^{1}, \text { Пузачова А.С. } \\
\text { ФАКТОРИ, ЩО ВПЛИВАЮТЬ НА ОРГАНІЗАЦІЮ } \\
\text { БАГАТОПОВЕРХОВИХ ЖИТЛОВИХ БУДИНКІВ } \\
{ }^{1} \text { ДВНЗ «Приазовський державний технічний університет» }\end{array}$ & 117 \\
\hline 2.7 & $\begin{array}{l}\text { Шаламова К. }{ }^{1}, \text { Польщікова Н.В. }{ }^{1}, \text { Марценюк О.І. }{ }^{1}, \\
\text { Жарська М. }{ }^{1}, \text { Вербовецька В. }{ }^{1} \\
\text { СУЧАСНИЙ ЛАНДШАФТНИЙ КОМПОНЕНТ В } \\
\text { АРХІТЕКТУРІ ЖИТЛОВИХ КОМПЛЕКСІВ } \\
{ }^{1} \text { Кафедра дизайну архітектурного середовища, Одеська державна академія } \\
\text { будівництва та архітектури }\end{array}$ & 127 \\
\hline \multicolumn{3}{|c|}{ ELECTRICAL ENGINEERING } \\
\hline 3.1 & $\begin{array}{l}\text { Goolak S. }{ }^{1} \\
\text { IMPROVEMENT OF THE MODEL OF POWER LOSSES IN } \\
\text { THE PULSED CURRENT TRACTION MOTOR IN AN } \\
\text { ELECTRIC LOCOMOTIVE } \\
{ }^{1} \text { Department of electromechanics and rolling stock of railways, State University of } \\
\text { Infrastructure and Technologies }\end{array}$ & 135 \\
\hline
\end{tabular}




\begin{tabular}{|c|c|c|}
\hline 3.2 & $\begin{array}{l}\text { Goolak S. }{ }^{1} \\
\text { MODEL OF PULSATING CURRENT TRACTION MOTOR } \\
\text { TAKING INTO CONSIDERATION MAGNETIC LOSSES IN } \\
\text { STEEL } \\
{ }^{1} \text { Department of electromechanics and rolling stock of railways, State University of } \\
\text { Infrastructure and Technologies }\end{array}$ & 160 \\
\hline 3.3 & $\begin{array}{l}\text { Petrenko А. }{ }^{1} \text {, Lukashova N. }{ }^{1}, \text { Shavkun V. }{ }^{1} \\
\text { МОДЕЛЮВАННЯ ПРОЦЕСІВ РОБОТИ } \\
\text { ЕЛЕКТРОМЕХАНІЧНОГО АМОРТИЗАТОРА ТА } \\
\text { ЕФЕКТИВНІСТЬ ЙОГО ЗАСТОСУВАННЯ НА } \\
\text { РЕЙКОВОМУ МІСЬКОМУ ТРАНСПОРТІ } \\
{ }^{1} \text { Department of electric transport, O.М. Beketov National University of Urban } \\
\text { Economy in Kharkiv }\end{array}$ & 181 \\
\hline 4. & $\begin{array}{c}\text { ENERGY AND ENERGY ENGINEERING AND } \\
\text { TECHNOLOGIES }\end{array}$ & \\
\hline 4.1 & $\begin{array}{l}\text { Fediushko A. }{ }^{1} \text {, Fedyushko Y. }{ }^{1} \text {, Azarkhov A. }{ }^{2}, \text { Sili I. }{ }^{2} \text {, } \\
\text { Fediushko M. }{ }^{3} \\
\text { CALIBRATION OF PULSE REFLECTOMETRIC SYSTEMS } \\
\text { FOR THE STUDY OF BIOLOGICAL OBJECTS } \\
{ }^{1} \text { Digital Technology, Company Epam Systems } \\
{ }^{2} \text { Department of biomedical engineering, Priazovskyi State Technical University } \\
{ }^{3} \text { Department of ecology, general biology and environmental management, Bogdan } \\
\text { Khmelnitsky Melitopol State Pedagogical University }\end{array}$ & 194 \\
\hline 4.2 & $\begin{array}{l}\text { Gorobets V. }{ }^{1} \text {, Trokhaniak V. }{ }^{1} \text {, Antypov I. }{ }^{1}, \text { Spodyniuk N. }{ }^{1} \\
\text { NUMERICAL AND EXPERIMENTAL STUDY OF } \\
\text { PREPARATION PROCESSES OF LIQUID GRAIN FEED } \\
{ }^{1} \text { Department of Heat and Power Engineering, National University of Life and } \\
\text { Environmental Sciences of Ukraine }\end{array}$ & 207 \\
\hline 4.2 .1 & $\begin{array}{l}\text { NUMERICAL MODELING OF } \quad \text { ROTOR-PULSATION } \\
\text { APPARATUS WITH RECTANGULAR HOLES (3D MODEL) }\end{array}$ & 209 \\
\hline 4.2 .1 .1 & $\begin{array}{l}\text { USING THE FINITE ELEMENT METHOD TO BUILD A 3D } \\
\text { MESH IN ANSYS MESHING }\end{array}$ & 211 \\
\hline 4.2 .1 .2 & $\begin{array}{lllll}\text { MATHEMATICAL MODELING } & \text { OF } & \text { HEAT } & \text { AND } & \text { MASS } \\
\text { TRANSFER PROCESSES IN RPA } & & & & \end{array}$ & 216 \\
\hline
\end{tabular}




\begin{tabular}{|c|c|c|}
\hline 4.2.1.3 & $\begin{array}{l}\text { RESULTS OF NUMERICAL MODELING OF TRANSFER } \\
\text { PROCESSES IN RPA }\end{array}$ & 220 \\
\hline 4.2 .2 & $\begin{array}{lrlll}\text { DESIGN } & \text { AND } & \text { OPERATION } & \text { OF } & \text { EXPERIMENTAL } \\
\text { INSTALLATION } & & & \end{array}$ & 225 \\
\hline 4.2 .3 & $\begin{array}{l}\text { EXPERIMENTAL STUDIES OF FEED PREPARATION } \\
\text { PROCESSES IN RPA WITH RECTANGULAR HOLES }\end{array}$ & 228 \\
\hline 4.2.3.1 & $\begin{array}{l}\text { DETERMINATION OF PARTICLE SIZE DISTRIBUTION OF } \\
\text { LIQUID GRAIN MIXTURE }\end{array}$ & 228 \\
\hline 4.2.3.2 & $\begin{array}{l}\text { INVESTIGATION OF RPA ENERGY CHARACTERISTICS } \\
\text { DURING WATER-GRAIN MIXTURE PROCESSING }\end{array}$ & 230 \\
\hline 4.2 .3 .3 & $\begin{array}{l}\text { INVESTIGATION OF THERMAL EFFECTS IN RPA DURING } \\
\text { TREATMENT OF WATER-GRAIN MEDIUM }\end{array}$ & 232 \\
\hline 4.3 & $\begin{array}{l}\text { Kliuieva O. }{ }^{1} \text {, Rusanov S. }{ }^{1} \text {, Luniaka K. }{ }^{2}, \text { Kliuiev O. }{ }^{1} \\
\text { DESIGNING, MANUFACTURING AND RESEARCHING OF } \\
\text { THE HEAT ACCUMULATOR WORK FOR PRE-STARTING } \\
\text { PREPARATION OF THE CAR ENGINE } \\
{ }^{1} \text { Kherson National Technical University, Kherson } \\
{ }^{2} \text { Kherson Branch of the National University of Shipbuilding named after Admiral } \\
\text { Makarov, Kherson }\end{array}$ & 237 \\
\hline 4.4 & $\begin{array}{l}\text { Lys S. }^{1}, \text { Yurasova O. }{ }^{1} \text {, Galyanchuk I. }{ }^{1} \\
\text { ANALYSIS OF THE INFLUENCE IN LOSS OF COOLANT } \\
\text { ACCIDENT ON FUEL ROD STATE } \\
{ }^{1} \text { Department of Heat Engineering and Thermal and Nuclear Power Plants, Lviv } \\
\text { Polytechnic National University }\end{array}$ & 288 \\
\hline 4.5 & $\begin{array}{l}\text { Идрисова А.Е.․, Рахымбеков А.Ж.' } \\
\text { О БЕЗОПАСНОСТИ ЧЕЛОВЕЧЕСКОЙ ЖИЗНИ В } \\
\text { УСЛОВИЯХ ГЛОБАЛИЗАЦИИ } \\
\text { ' НАО Жетысуский университет им.И.Жансугурова }\end{array}$ & 298 \\
\hline 4.5 .1 & ОСНОВНАЯ ЧАСТЬ & 298 \\
\hline 4.5.1.1 & РОСТ ЧИСЛЕННОСТИ НАСЕЛЕНИЯ ЗЕМНОГО ШАРА & 299 \\
\hline
\end{tabular}




\begin{tabular}{|c|c|c|}
\hline 4.5.1.2 & ИСТОЩЕНИЕ ПРИРОДНЫХ РЕСУРСОВ & 300 \\
\hline 4.5 .2 & ПАРНИКОВЫЙ ЭФФЕКТ & 301 \\
\hline 4.5.2.1 & СТРАНЫ ЗАГРЯЗНИТЕЛИ АТМОСФЕРЫ & 302 \\
\hline 4.5.2.2 & ИЗМЕНЕНИЕ МИРОВОГО КЛИМАТА & 303 \\
\hline 4.5.2.3 & ОПАСНЫЕ ОТХОДЫ & 304 \\
\hline \multicolumn{3}{|c|}{$\begin{array}{ll}5 . & \text { FOOD TECHNOLOGY }\end{array}$} \\
\hline 5.1 & $\begin{array}{l}\text { Horishnii P. }{ }^{1} \text {, Topchii O. }{ }^{1} \text {, Shevchenko I. }{ }^{1} \text {, Kotliar Y. }{ }^{2} \text {, Petryna A. }{ }^{1} \\
\text { IMPROVING FOOD ADEQUACY LOW-VALUE COLLAGEN- } \\
\text { CONTAINING RAW MATERIALS IN THE TECHNOLOGY OF } \\
\text { SEMI-FINISHED PRODUCTS } \\
{ }^{1} \text { National University of Food Technologies } \\
{ }^{2} \text { Odessa National Academy of Food Technologies }\end{array}$ & 306 \\
\hline \multicolumn{3}{|c|}{$6 . \quad$ INFORMATION TECHNOLOGIES } \\
\hline 6.1 & $\begin{array}{l}\text { Taranchuk A. }{ }^{1} \text {, Pidchenko S. }{ }^{1} \\
\text { PRINCIPLES OF PIEZORESONANCE SENSORS } \\
\text { CONSTRUCTION WITH CAPACITIVE CONTROL AND } \\
\text { THEIR PRACTICAL APPLICATION FOR TELEMEDICINE } \\
\text { DIAGNOSTIC SYSTEMS } \\
\text { 'Department of Telecommunications, Media and Intelligent Technologies, } \\
\text { Khmelnitsky National University }\end{array}$ & 316 \\
\hline 6.2 & $\begin{array}{l}\text { Рижков Е. }{ }^{1}, \text { Синиціна Ю. }{ }^{1}, \text { Станіна О. } \\
\text { ШТУЧНИЙ ІНТЕЛЕКТ: ЩО ЗМІНИЛОСЯ ЗА } 50 \text { РОКІВ } \\
\text { ' Кафедра економічної та інформаційної безпеки, Дніпропетровський } \\
\text { державний університет внутрішніх справ }\end{array}$ & 341 \\
\hline 7. & INNOVATIVE TECHNOLOGIES & \\
\hline 7.1 & $\begin{array}{l}\text { Бернацький А. }{ }^{1} \text { Соколовський М. }{ }^{1}, \text { Сiора О. }{ }^{1} \text {, Лукашенко В. }{ }^{1}, \\
\text { Шамсутдінова Н. }{ }^{1} \\
\text { ДО ПИТАННЯ МОДЕЛЮВАННЯ ЛАЗЕРНОГО } \\
\text { ЗВАРЮВАННЯ ТА АДИТИВНИХ ПРОЦЕСІВ } \\
{ }^{1} \text { Інститут Електрозварювання ім. Є.О. Патона НАН України }\end{array}$ & 349 \\
\hline
\end{tabular}




\begin{tabular}{|c|c|c|}
\hline 8. & ENGINEERING & \\
\hline 8.1 & $\begin{array}{l}\text { Пимонов И. }{ }^{1}, \text { Шевченко В. }{ }^{1}, \text { Олейникова А. }{ }^{1}, \text { Погорелый И. }{ }^{1} \\
\text { АДАПТАЦИЯ ТЕМПЕРАТУРНЫХ РЕЖИМОВ РАБОЧЕЙ } \\
\text { ЖИДКОСТИ В ГИДРОПРИВОДАХ ЭКСКАВАТОРОВ ПРИ } \\
\text { РАЗЛИЧНЫХ УСЛОВИЯХ ЭКСПЛУАТАЦИИ } \\
{ }^{1} \text { Кафедра строительных и дорожных машин, Харьков, Харьковский } \\
\text { национальный автомобильно-дорожный университет }\end{array}$ & 359 \\
\hline 8.2 & $\begin{array}{l}\text { Щукін О. }{ }^{1}, \text { Орел О. }{ }^{1} \\
\text { МАТЕМАТИЧНА МОДЕЛЬ СУМАРНОЇ ВІРОГІДНОСТІ } \\
\text { БЕЗВІДМОВНОЇ РОБОТИ РОБОЧОГО ОБЛАДНАННЯ } \\
\text { АВТОГРЕЙДЕРА В ПРОЦЕСІ ВИКОНАННЯ РОБОЧИХ } \\
\text { ОПЕРАЦІЙ } \\
{ }^{1} \text { Кафедра будівельних і дорожніх машин, Харківський національний } \\
\text { автомобільно-дорожній університет }\end{array}$ & 367 \\
\hline 9. & METALLURGY AND ENERGY & \\
\hline 9.1 & $\begin{array}{l}\text { Sigarev Е. }{ }^{1} \text {, Dovzhenko O. }{ }^{1}, \text { Lobanov Y. }{ }^{1} \text {, Chernyatevich I. } \\
\text { Chubina O. } \\
\text { ДОСЛІДЖЕННЯ ВПЛИВУ ТЕХНОЛОГІЧНИХ ФАКТОРІВ } \\
\text { НА ВТРАТИ ЧАВУНУ ПРИ ВИДАЛЕННІ СІРКИ У КОВШІ } \\
{ }^{1} \text { Department of metallurgy, Dniprovsk State Technical University } \\
{ }^{2} \text { Technological Department, METINVEST ENGINEERING LLC }\end{array}$ & 375 \\
\hline \multicolumn{3}{|l|}{10.} \\
\hline 10.1 & 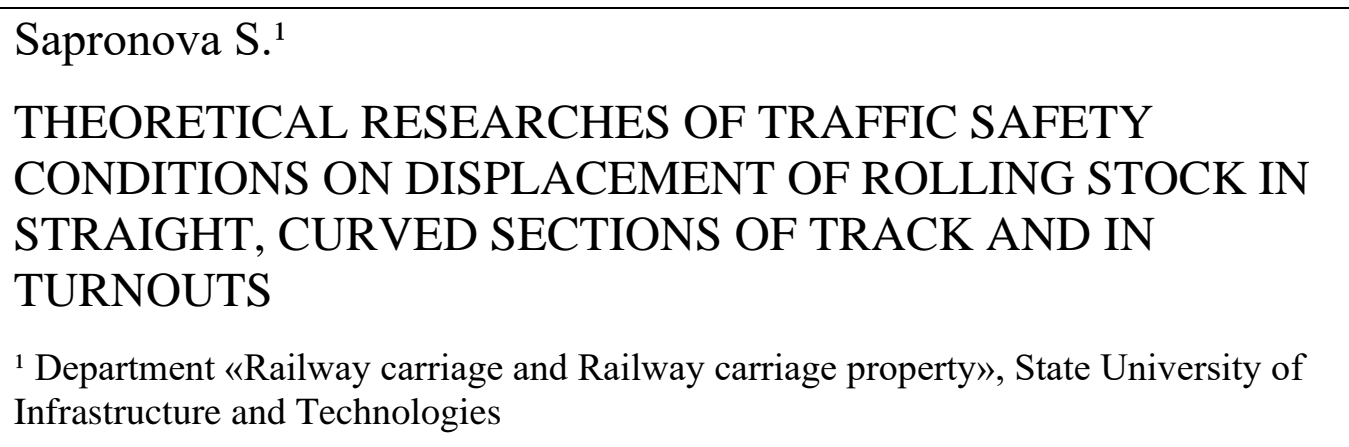 & 383 \\
\hline 10.1 .1 & $\begin{array}{l}\text { РОЗРАХУНКОВА } \\
\text { КООРДМА } \\
\text { ЕКІПАЖУ, }\end{array}$ & 383 \\
\hline
\end{tabular}




\begin{tabular}{|c|c|c|}
\hline 10.1 .2 & $\begin{array}{l}\text { ГЕОМЕТРИЧНІ І } \quad \text { КІНЕМАТИЧНІ } \\
\text { КОНТАКТУВАННЯ КОЛІСНОЇ ПАРИ З РЕЙКАМИ }\end{array}$ & 387 \\
\hline 10.1.2.1 & $\begin{array}{lll}\text { МОДЕЛЮВАННЯ } & \text { ПРОФІЛІВ } \\
\text { КОЛІС } & & \\
\end{array}$ & 388 \\
\hline 10.1.2.2 & $\begin{array}{l}\text { МОДЕЛЮВАННЯ КІНЕМАТИЧНИХ ХАРАКТЕРИСТИК } \\
\text { КОНТАКТУВАННЯ КОЛІС З РЕЙКАМИ }\end{array}$ & 394 \\
\hline 10.1 .3 & ДИФЕРЕНЦІАЛЬНІ РІВНЯННЯ РУХУ СИСТЕМИ & 401 \\
\hline 10.1.3.1 & КІНЕТИЧНА ЕНЕРГІЯ СИСТЕМИ & 402 \\
\hline 10.1 .3 .2 & $\begin{array}{l}\text { ЕНЕРГІЯ РОЗСІЮВАННЯ У } \\
\text { ЕЛЕМЕНТАХ }\end{array}$ & 403 \\
\hline 10.1.3.3 & 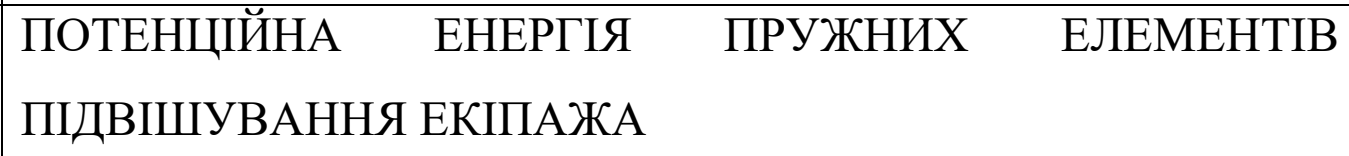 & 404 \\
\hline 10.1 .4 & $\begin{array}{l}\text { СТРУКТУРА СИЛОВОЇ ВЗАЄМОДІЇ В КОНТАКТАХ КОЛІС } \\
\text { ІЗ РЕЙКАМИ }\end{array}$ & 406 \\
\hline 10.1.4.1 & $\begin{array}{lrr}\text { РОЗПОДІЛ НОРМАЛЬНОГО } & \text { НАВАНТАЖЕННЯ } \\
\text { КОНТАКТАМИ } & \text { ПРИ } & \text { ДВОХ-ТОЧКОВОМУ } \\
\text { КОНТАКТУВАННІ } & & \end{array}$ & 409 \\
\hline 10.1.4.2 & $\begin{array}{l}\text { СИЛИ КОНТАКТНОЇ ФРИКЦИЙНОЇ ВЗАСМОДІЇ - СИЛИ } \\
\text { ЗЧЕПЛЕННЯ }\end{array}$ & 412 \\
\hline 10.1.4.2.2 & СИЛИ ЗЧЕПЛЕННЯ В ГРЕБЕНЕВИХ КОНТАКТАХ & 414 \\
\hline 10.1 .5 & $\begin{array}{l}\text { МОДЕЛЮВАННЯ РУХУ ЕКІПАЖА В КРИВИХ ДІЛЯНКАХ } \\
\text { КОЛІЇ }\end{array}$ & 420 \\
\hline 10.1 .6 & $\begin{array}{lllll}\text { МОДЕЛЮВАННЯ } & \text { РУХУ } & \text { ЕКІПАЖА } & \text { У } & \text { СТРІЛОЧНОМУ } \\
\text { ПЕРЕВОДІ } & & & & \end{array}$ & 422 \\
\hline 10.1 .7 & $\begin{array}{l}\text { ЧИСЕЛЬНЕ } \quad \text { ІНТЕГРУВАННЯ } \\
\text { ДИФЕРЕНЦІАЛЬНИХ РІВНЯНЬ РУХУ ЕКІПАЖА }\end{array}$ & 432 \\
\hline 10.1 .8 & ВИСНОВКИ & 436 \\
\hline
\end{tabular}




\begin{tabular}{|c|c|c|}
\hline 10.2 & $\begin{array}{l}\text { Vdovychenko V. }{ }^{1} \text {, Ivanov } .^{2} \\
\text { THE INFLUENCE OF THE CONFIGURATION OF } \\
\text { TRANSPORT WORK ON THE TIME PARAMETERS OF } \\
\text { TRANSPORT SERVICES } \\
{ }^{1} \text { Department of Transport Technology, Kharkiv National Automobile and Highway } \\
\text { University } \\
{ }^{2} \text { Prat «Zaporizhavtotrans» }\end{array}$ & 437 \\
\hline \multirow[t]{2}{*}{10.3} & $\begin{array}{l}\text { Кара І. }{ }^{1}, \text { Карий О. } \\
\text { ВИКОРИСТАННЯ ТЕХНОЛОГІЙ ІНТЕРНЕТУ РЕЧЕЙ (ІОТ) } \\
\text { У КЕРУВАННІ ГРОМАДСЬКИМ ТРАНСПОРТОМ У } \\
\text { СІЛЬСЬКІЙ МІСЦЕВОСТІ } \\
{ }^{1} \text { Кафедра транспортних технологій Національного університету "Львівська } \\
\text { політехніка" } \\
\text { ² Кафедра менеджменту організацій Національного університету "Львівська } \\
\text { політехніка" }\end{array}$ & 445 \\
\hline & REFERENCES & 452 \\
\hline
\end{tabular}




\section{SECTION 1. AGRICULTURE AND FORESTRY}

DOI 10.46299/ISG.2021.MONO.TECH.III.1.1

\section{1 Аналіз деревних рослин паркових насаджень міста Херсон}

3 ростом міста, розвитком його промисловості, стає все більш складною проблема охорони навколишнього середовища, створення нормальних умов для життя і діяльності людини. В останні десятиліття посилився негативний вплив людини на навколишнє середовище i, зокрема, на зелені насадження. Проблема зелених масивів (міських парків, лісів, садів, луків) - одна 3 найважливіших екологічних проблем сучасних міст. Рослинність, як середовищевідновлююча система, забезпечує комфортність умов проживання людей, регулює (в певних межах) газовий склад повітря і ступінь його забрудненості, кліматичні характеристики міських територій, знижує вплив шумового фактора і $є$ цінним рекреаційним ресурсом $[1,2]$.

Сьогодні більшість парків міста Херсона перебуває на різних стадіях деградації; вимагають заходів з реконструкції, реставрації та консервації, оскільки проблема їх відновлення має історичний, біологічний, ландшафтний та соціальний аспекти. Проте питання наближення нинішнього ландшафтного вигляду парків до їх первісного стану досить складне. Архітектурний простір парків має базуватись на біологічній основі, точніше на міцному фундаменті біологічних дисциплін, зокрема культурфітоценології, яка має враховувати соціальну зумовленість походження парків (цільова спрямованість, звичаї, смаки та традиції фундаторів) [3].

Дослідження фітоценозів паркових насаджень починається із дослідження їх видової структури, передусім дендрологічного складу. Не меншої уваги заслуговує дослідження довговічності, швидкості росту та декоративності окремо взятої породи. Необхідно більше уваги надавати збагаченню паркових композицій кущами, враховуючи їх декоративність. Дуже важливим завданням 
є збереження насаджень i навіть окремих екземплярів, які мають цінність передусім як об'єкти генофонду [3].

Парки міста Херсон були створені в 50-60-х роках XX століття. Відомо, що у міських умовах строк експлуатації дерев та кущів скорочується вдвічі, а іноді і в тричі. Відповідно потрібно дослідити їх сучасний стан. Отже, встановлення видового складу деревних рослин об'єктів загального користування міста Херсон та їі всебічний аналіз є актуальним та становлять значний науковий та практичний інтерес.

Дослідження деревно-чагарникової флори парків були проведені протягом вегетаційного сезону 2018-2020 років в межах району дослідження. В польових умовах маршрутним методом визначали флористичний склад дерев та кущів, який в камеральних умовах уточнювали за визначниками та посібниками [5-11]. У роботі було прийнято номенклатуру таксонів та їх систематичну приналежність за Визначником рослин України [5]. Життевість деревночагарникових видів визначали за Алексеевим [12].

В місті Херсоні налічується 10 парків. 3 них п’ять - об’єкти загального користування. Для них характерна одна спільна риса - всі вони потребують ремонту, збагачення видового різноманіття, заміни суховершинних, хворих дерев на аналоги з більш високими показниками інтродукційного потенціалу. Відмінності видового складу парків незначні, вікова різниця також невелика.

Таксономічний аналіз показав, що загалом на території парків ростуть рослини 31 родини представники двох класів Gymnospermae та Magnoliophyta (табл.1). 
Таблиця 1. Таксономічна структура дендрофлори найбільших парків міста Херсону

\begin{tabular}{|c|c|c|c|c|c|c|}
\hline \multirow{2}{*}{$\begin{array}{l}\text { № } \\
3 / \Pi\end{array}$} & \multirow[t]{2}{*}{ Назва родини } & \multicolumn{5}{|c|}{ Кількість видів кожного об’єкта } \\
\hline & & $\begin{array}{c}\text { Придні- } \\
\text { провський } \\
\text { парк }\end{array}$ & $\begin{array}{c}\text { Парк } \\
\text { Херсонська } \\
\text { Фортеця } \\
\end{array}$ & $\begin{array}{c}\text { Шевчен- } \\
\text { ківський } \\
\text { парк }\end{array}$ & $\begin{array}{l}\text { Шуменсь } \\
\text { кий парк }\end{array}$ & $\begin{array}{c}\text { Парк } \\
\text { Слави }\end{array}$ \\
\hline \multicolumn{7}{|c|}{ Gymnospermae } \\
\hline 1. & $\begin{array}{l}\text { Cupressaceae Bartl. } \\
\text { Lindl. }\end{array}$ & 2 & 4 & 4 & 2 & 4 \\
\hline 2. & Pinaceae Lindl. & 1 & 1 & 5 & 2 & 3 \\
\hline 3. & Taxaceae S.F.Gray. & 1 & 1 & 1 & - & - \\
\hline & ого Gymnospermae & 4 & 6 & 10 & 4 & 7 \\
\hline \multicolumn{7}{|c|}{ Magnoliophyta } \\
\hline 4. & Aceraceae Juss. & 3 & 5 & 6 & 2 & 2 \\
\hline 5. & $\begin{array}{l}\text { Anacardiaceae } \\
\text { Lindl. }\end{array}$ & 1 & 1 & - & 1 & 1 \\
\hline 6. & $\begin{array}{l}\text { Berberidaceae Torr. } \\
\text { et Gray. }\end{array}$ & 1 & 1 & 1 & 1 & - \\
\hline 7. & $\begin{array}{lll}\begin{array}{l}\text { Betulaceae } \\
\text { Gray }\end{array} & \text { S. } & \text { F. } \\
\end{array}$ & 2 & 2 & 2 & - & 2 \\
\hline 8. & Bignoniaceae Pers. & 2 & 2 & 2 & - & 2 \\
\hline 9. & $\begin{array}{l}\text { Caesalpiniaceae } \\
\text { R.Br. }\end{array}$ & 1 & 1 & 1 & 1 & 1 \\
\hline 10. & Caprifoliaceae Juss. & 4 & 4 & 4 & 6 & 4 \\
\hline 11. & Celastraceae & - & 1 & - & - & - \\
\hline 12. & Elaegnaceae Lindl. & 1 & - & - & - & - \\
\hline 13. & Fabaceae Lindl. & 3 & 3 & 3 & 4 & 3 \\
\hline 14. & Fagaceae Dumort. & 2 & 1 & 1 & 1 & 1 \\
\hline 15. & $\begin{array}{l}\text { Hippocastanaceae } \\
\text { Torr. et Gray }\end{array}$ & 2 & 1 & 1 & 1 & 1 \\
\hline 16. & $\begin{array}{l}\text { Hydrangeaceae } \\
\text { Dumort. }\end{array}$ & - & 1 & - & 1 & 1 \\
\hline 17. & $\begin{array}{lc}\text { Juglandaceae } & \text { A. } \\
\text { Rich. ex Kunth. } & \\
\end{array}$ & 1 & - & - & - & 1 \\
\hline 18. & Malvaceae Juss. & - & - & 1 & - & 1 \\
\hline 19. & Mimosaceae Brown. & - & - & - & - & - \\
\hline 20. & Moraceae Lindl. & 1 & 1 & 1 & 1 & 1 \\
\hline 21. & Oleaceae Lindl. & 6 & 4 & 4 & 7 & 5 \\
\hline 22. & Platanaceae Lindl. & 1 & 1 & 2 & 1 & 1 \\
\hline 23. & Rosaceae Juss. & 8 & 10 & 8 & 4 & 9 \\
\hline 24. & Rhamnaceae Juss. & 1 & - & - & - & - \\
\hline 25. & Salicaceae Lindl. & 3 & 2 & 1 & 1 & 1 \\
\hline 26. & Solanaceae Juss. & - & 1 & 1 & 1 & - \\
\hline 27. & Simarubaceae Juss. & 1 & 1 & 1 & 1 & 1 \\
\hline 28. & Tamaricaceae Desv & 2 & 2 & 1 & 1 & 2 \\
\hline 29. & Tiliaceae Juss. & 2 & 3 & 2 & 2 & 3 \\
\hline 30. & Ulmanaceae Mirb. & 3 & 3 & 2 & 2 & 2 \\
\hline 31. & Vitaceae Juss. & 1 & 1 & 1 & 1 & 1 \\
\hline \multicolumn{2}{|c|}{ Всього Magnoliophyta } & 50 & 52 & 45 & 50 & 45 \\
\hline \multicolumn{2}{|c|}{ Всього } & 54 & 58 & 55 & 54 & 52 \\
\hline
\end{tabular}


Найчисленніші родини Rosaceae (від 14,8\% до 17,5\%), Oleaceae (від 6,1\% до $13,8 \%$ в різних об'єктах). Лише у парку Шуменський за видовим різноманіттям переважає родина Oleaceae $(20,6 \%)$, а Rosaceae на другому місці (11,8\%). Рідкісні дерева парків представлені видами Robinia neomexicana A.Gray., R. viscosa Vent., Koelreuteria paniculata Laxm., Malus Niedzwetzkyana Dieck ex Koehne, reos Crataegus 'Paul Scarlet'.

Паркові насадження міста Херсон мають досить одноманітний склад деревних порід. Досить широко в досліджених об’єктах трапляються: Platanus orientalis L., Acer platanoides L., A. pseudoplatanus L., Morus nigra L., Robinia pseudoacacia L., Populus alba L., Populus italica (Du Roi) Moench, Fraxinus excelsior L., Catalpa speciosa (Warder ex Barney) Warder ex Engelm., Betula pendula Roth, Prunus domestica, Pyrus communis L., Quercus robur L., Rosa canina L., Salix alba L., Sambucus nigra L., Tilia cordata Mill. тощо. У багатьох випадках домінуючими видами парків виступають Acer platanoides, A. campestre L., Robinia pseudoacacia, Tilia cordata, Fraxinus excelsior, Catalpa speciosa, Sophora japonica тощо.

Дослідження хвойних та квіткових деревно-чагарникових порід показало, що в місті Херсоні $є$ як широко поширені пластичні види, які в природних умовах займають значні території (біота, ялівці, ялини), так і цінні малопоширені види iз незначними ареалами, а також рідкісні та ендемічні породи (тис, гінкго, кипарисовики, сакура, тюльпанне дерево тощо).

Види, які успішно пройшли первинне випробування в ботанічних садах, дослідних станціях та дендраропарках, вже тепер можна рекомендувати для використання у паркових насадженнях. Особливо для впровадження в об'єкти озеленення: модрини, сосни, ялини: колючу, сербську; ялиці: одноколірну, цільнолисту; псевдотсуги: тисолисту, сіру, сизу; туї, кипарисовики, гінкго.

Життєві форми рослин переважно представлені деревами 65\% відсотків і $33 \%$ кущів і 2\% деревних ліан.

Результати досліджень показали, що чисельність листяних порід значно переважає (від 82 до 94\%) порівняно з хвойними. Серед листяних деревних порід 
найрізноманітнішою за таксономічним складом є родина Rosaceae. За результатами Черевченко Т.М. та Кузнецова C.I. [13], у паркових деревостанах голонасінні поступаються у конкурентній боротьбі i все більшого едифікаторного значення набувають листяні автохтонні породи та деякі інтродуценти. Паркові насадження міста Херсон не є виключенням.

Географічний аналіз свідчить про значне переважання інтродукованих видів. У природних ценозах росте лише 15 видів деревних рослин. Переважання у флорі аллохтонних деревних видів загалом характерно для міст півдня України [14-21]. До аборигенів ми віднесли тільки ті види, які ростуть у природних фітоценозах степової зони України: Betula borysthenica Klok, Populus nigra L., P. alba L., P. tremula L., Quercus robur L., Corylus avellana L., Ephedra distachya L., Amygdalus nana L. та ін. Інші рослини були віднесені нами до алохтонної фракції.

Созологічний аналіз показав, що в паркових насадженнях Херсону ростуть занесені до Червоної книги України [22]: Betula borysthenica Klokov - ендемік Північного Причорномор'я та Syringa josikaea J.Jacq. ex Rchb., а також види, які включені до Переліку рослин, що охороняються в Херсонській області: Clematis integrifolia L., Ephedra distachya L. Ta Quercus robur L. [23, 24].

Вік деревних насаджень парків складає 40-80 років. Відрізняються окремі екземпляри Quercus robur, які досягли віку більш, ніж 100 років.

Фітосанітарний стан паркових насаджень є переважно задовільним [25, 26]. Незадовільним станом відрізняється парк Шуменський. У питанні покращення стану парків необхідно мати конструктивний підхід, який поєднує в собі правильний підбір порід, відповідно до умов півдня України, дотримання правил посадки (не допускати надмірного загущення), забезпечити належний догляд (вчасні санітарні рубки та рубки догляду, полив, лікування), залучення спеціалістів, науковців для цієї роботи.

Згідно наших спостережень видно, що деревостан у Придніпровському має вищій показник життевості (73\% здорових рослин), у порівнянні з деревостаном інших у парків. У Шуменському парку серед парків найменший показник життєвості (42\% рослин сильно пошкоджені). Не зважаючи на те, що парк 
знаходиться далеко від потужних автомагістралей та виробництв, багато дерев знаходяться в незадовільному стані: суховершинять, мають дупла та різноманітні пошкодження. Вважаємо, що відсутність регулярного догляду, призвела до майже критичного стану зелених насаджень Шуменського парку.

Догляд за зеленими насадженнями парків міста Херсон повинен грунтуватись на знаннях та практичному досвіді стійкості рослин до несприятливих умов комплексу екологічних факторів, повинні враховуватись стійкість рослин до шкідливих викидів виробництва та автотранспорту, місцерозташування зелених зон. Згідно цього потрібно організовувати догляд за рослинами парків, скверів, бульварів тощо. Запорукою довговічності та привабливого естетичного вигляду зелених насаджень є своєчасне проведення санітарних рубок та рубок формування, обкопування придеревних лунок, регулярний полив.

Враховуючи кліматичні умови міста Херсона, високу сонячну активність протягом літнього періоду, невелику кількість опадів, коливання температур протягом року та сезонів, а також враховуючи мікрокліматичні умови розташування міста пропонуємо для розширення асортименту деревних рослин парків в подальшому включити рослини, які поєднують декоративні якості зі стійкістю до умов міського середовища: Magnolia soulangeana Soul.-Bod., Liriodendron tulipiferum L., Cornus alba L., Cotoneaster horizontalis Dcne. та C. multiflorus Bunge, Prunus serrulata Lindl., Cercis canadensis L., Picea pungens f. glauca, Acer ginnala (Maxim.) Maxim. та Acer platanoides L., Cotinus coggygria Scop., а також розширити асортимент голонасінних рослин Pseudotsuga menziesii (Mirb.) Franco, декоративні форми видів родів Taxus L., Buxus L., Quercus L., Tilia L., Berberis L., Thuja L., Juniperus L. Chamaecyparis Spach та інші [27, 28].

Розширення асортименту деревних рослин підвищить естетичну привабливість та стійкість зелених насаджень. Підбір декоративних рослин обов'язково має грунтуватись на глибокому пізнанні онтогенезу та екологобіологічних особливостей рослин, а також з точки зору їх впливу на навколишнє середовище. 
DOI 10.46299/ISG.2021.MONO.TECH.III.1.2

\section{2 Інституційне забезпечення раціонального використання i охорони земельних ресурсів}

Земля відіграє найважливішу загально-біосферну роль i $\epsilon$ фундаментальною основою функціонування атмосфери, гідросфери та інших сфер розвитку рослинного і тваринного світів, а також людського суспільства. В аграрному секторі земля - головний засіб виробництва, найважливіша складова ресурсної бази землеробства. Продуктивні сільськогосподарські землі цілком справедливо вважають унікальним природним і виробничим ресурсом, який, на відміну від інших природних ресурсів, за умов раціонального та екологічно виваженого використання здатний не зменшуватися i не втрачати своєї родючості. Оскільки лише відносно невелика частина земної кулі вкрита родючим шаром грунту, що може використовуватися для ведення сільського господарства - основного продуцента продовольства, - то проблема всебічної охорони земель, збереження та відтворення родючості грунтів, раціоналізації та екологізації аграрного землекористування - це проблема продовольча, економічна, екологічна i загалом проблема національної безпеки будь-якої країни.

На сучасному етапі людської цивілізації охорона і раціональне використання земель - основне соціально-економічне й екологічне завдання суспільства, найважливіша передумова національної безпеки будь-якої держави. Особливо актуальною ця проблема є для України, оскільки її земельні ресурси зазнають значних антропогенних навантажень і деградують стрімко.

Україна має один із найвищих у світі рівнів сільськогосподарської освоєності й розораності території. У власності та користуванні аграрних підприємств і господарств понад 47 млн га земель, що становить близько 78 \% загальної території України. Сьогодні невиправдано розпорошуються дефіцитні матеріально-технічні й особливо енергетичні ресурси, а природі та суспільству завдають величезної шкоди - деградують і еродують чорноземи, забруднюються водойми, знижуються якість і екологічна чистота продовольства. Проблема 
організації раціонального використання й охорони земельних ресурсів залишається найбільш актуальною. Ринкові відносини суттєво впливають на раціональне природокористування.

А. Журавський та В. Акуленко стверджують, що питання охорони навколишнього середовища і раціонального використання природних ресурсів необхідно розглядати в єдності з розвитком продуктивних сил, так само як $\mathrm{i}$ розвиток останніх повинен бути пов’язаним із процесами відтворення природних умов і факторів [29, с. 64].

На думку А. Никонова, до причин виникнення економічної кризи необхідно віднести і фактичну відсутність природоохоронного економічного механізму, що проявлялось у відносно низьких, порівняно зі світовими, цінами, цін на сировину і матеріали, безоплатному користуванні природними ресурсами, зокрема землею, малих обсягах капітальних вкладень на екологічні цілі, пом’якшених санкцій за порушення природного середовища [30, с. 225].

Нераціональне природокористування пов’язане 3 відсутністю власника природних ресурсів, що спричиняло у природокористуванні інстинкти бездонності стосовно запасів природних благ та обсягів їх залучення у господарський обіг. Стосовно цього академік О. Богомолов зазначав: щоб нагодувати країну, потрібно дати селянину землю, надавши право вільно господарювати і реалізувати свою продукцію [31, с. 81].

На передачу права власності місцевим радам вказував Г. Попов, стверджуючи, що поява справжніх господарів на землі дозволить уникнути в значних обсягах сучасних згубних форм зрошення й осушення, неконтрольованого застосування пестицидів, нітратів і т. д. [32, с. 184]. Тим більше, для інституціоналізації нових для тогочасного суспільства форм власності на природні ресурси вже були не тільки інституціальні передумови, а й психологічні.

Деструктив у сферу природокористування внесли прорахунки, допущені під час проектування господарських заходів, що призвело до розбалансованості еколого-економічних систем (це стосується передусім меліорованих земель). 
Завдяки земельній реформі можливий рівноправний розвиток державної й приватної форм власності на землю з можливістю інституційного забезпечення організації раціонального використання землі. Домінуючий розвиток мають ті форми власності на землю, які зможуть забезпечити найвищу продуктивність праці та ефективність використання землі за умови збереження ії родючості.

Питання економічно ефективного та раціонального використання земель, охорони земельного фонду, відтворення родючості грунтів стали проблемою національної безпеки держави і потребують постійної уваги органів державної влади та органів місцевого самоврядування.

Із упровадженням в Україні приватної власності на землю докорінно змінилися земельні відносини. Приватизація земель в наслідок недостатнього інституційного забезпечення, відсутності державного контролю, призводить до масових порушень земельного законодавства на всіх рівнях щодо раціонального використання й охорони земель. Розподіл земель на земельні частки (паї) зумовив порушення організації території сільськогосподарських підприємств. Охорона земельного фонду в процесі земельної реформи перетворилась на значну загальнодержавну проблему, яка здебільшого формує питання екологічної безпеки держави. Земельні перетворення, формування сільськогосподарських підприємств, надання і вилучення земель відбувалися в стислий термін, що призвело до низки проблем та необхідності вдосконалення державної політики в галузі сільського господарства й економіки в загалом. Реалістичний стан земельної реформи з ії помилками відтворили М.А. Хвесик і В.А. Голян [33].

Серед помилок, які спричинили проблему в землекористуванні виокремлено:

- не було вироблено науково обгрунтованої стратегії й тактики, земельна реформа не мала програми чітко визначеної мети;

- не була підготовлена матеріальна і графічна бази, відсутні інвентаризаційні матеріали; 
- не визначено призначення малопродуктивних і деградованих земель щодо їх форми власності;

- зміна форми власності на землю, земельні відносини, організацію виробництва та управління зменшили ефективність використання земельних ресурсів;

- відсутність ведення в новостворених господарствах моніторингу грунтів, подальша деградація їх призводять до погіршення якості грунтів;

- відсутність розробки проектів землеустрою сільськогосподарських підприємств призвела до втрати функцій планування, як основи у системі управління використанням і охороною земельних ресурсів;

- відсутність конкретних заходів щодо виведення ріллі 3 обробітку (консервація деградованих земель, введення агролісомеліоративних заходів, гідротехнічної меліорації, розширення природно-заповідних територій).

Отже, початкові умови функціонування сільськогосподарського підприємства відіграють другорядну роль для організації високоефективного сільськогосподарського виробництва, а першочерговим $\epsilon$ інституційне забезпечення організації раціонального використання земель, які перебувають в інтенсивному сільськогосподарському обробітку.

Раціональне використання земель передбачає певні принципи:

- розподіл земель за формами власності;

- цільове використання земельних ресурсів;

- пріоритетне виділення сільському господарству родючих земель;

- врахування зональних особливостей використання землі;

- планомірність організації використання земельних ресурсів;

- збільшення родючості грунтів;

- охорона земель;

- впорядкування території.

Грунтозахисна та землезахисна спрямованість усіх заходів, які застосуються у використанні земельних ресурсів та розвитку земельних відносин, приведе до впровадження в усіх галузях та сферах економіки 
інституційного забезпечення раціонального, екологічно-врівноваженого й екологобезпечного землекористування та володіння землею.

Основним питанням на сучасному етапі формування земельних відносин $€$ питання про право власності на землю. У цьому аспекті особливого значення набувають нові землевласники та землекористувачі та впровадження в усіх галузях та сферах економіки інституційного забезпечення раціонального, екологічноврівноваженого й екологобезпечного землекористування та володіння землею.

У розвитку сільського господарства, особливого значення набуває проблема оренди землі як у теоретичному, так і в прикладному аспектах, а також передачі землі в оренду іноземним громадянам, підприємцям. Оренду земель слід розглядати як форму організації виробництва яка сформована на основі приватної форми власності в системі функціонування ринку земель сільськогосподарського призначення. Сьогодні оренда землі є основною формою масштабного виробництва сільськогосподарської продукції.

Оренда внутрішньо дуже суперечлива, що зумовлено протиріччям прав власника землі та іï орендаря, а також межею правового впливу держави на орендні відносини. Це передусім стосується терміну оренди, який власник намагається скоротити, а орендар - збільшити, щоб мати змогу окупити витрати на збереження родючості землі за інтенсифікації виробництва. 3 цієї позиції, особливе значення надається довгостроковій оренді правом успадкування та викупу, тобто наступному переходу землі у приватну власність.

Внесення земельних ресурсів у реальний економічний оборот на основі функціонування ринку землі є важливою передумовою створення необхідних фондів для інституційного збереження, охорони та відтворення родючості сільськогосподарських угідь, упровадження екологобезпечних та природонеруйнівних землеволодінь і землекористувань у державі. Крім того, значно поліпшиться розподіл земель між галузями і сферами народного господарства, пришвидшаться процеси формування екологічно стійких і природоощадних агроландшафтів у всіх природно-кліматичних зонах країни. 
У сучасних екологічних і економічних умовах об'єктивно назріла потреба вартісної оцінки земельних ресурсів залежно від рівня їх родючості, агроекологічного стану, стану хімічного забруднення пестицидами та елементами важких металів.

Виведення малопродуктивних $\mathrm{i}$ техногенно-забруднених земель iз сільськогосподарського обороту, переведення розораних земель у сінокоси та культурні пасовища, а у крайніх випадках - тимчасова консервація земель, сприятимуть відновленню ними природного екологічного стану. При цьому товаровиробники втрачатимуть прибуток від спаду інтенсифікації використання земель. Стимулююча роль держави виявиться у частковій компенсації таких втрат прибутку.

Важливим і не вирішеним залишається грунтозахисна спрямованість усіх заходів, що стосується використання земельних ресурсів і розвитку земельних відносин, має зумовити впровадження в усіх галузях та сферах економіки інституційного забезпечення раціонального використання земель 3 дотриманням еколого безпечного землекористування через:

- забезпечення раціонального, невиснаженого, грунтозахисного та екологобезпечного землекористування в інтересах ефективного і сталого соціально - економічного розвитку країни;

- комплексний, науково обгрунтований підхід до процесів використання, збереження та відтворення родючості сільськогосподарських угідь, здійснення збалансованих землемеліоративних і землеохоронних заходів;

- формування в усіх землеробських регіонах високопродуктивних, ерозійно стійких та екологобезпечних агроландшафтів;

- удосконалення структури сільськогосподарських угідь і посівів вирощуваних культур у напрямі істотного зменшення негативних антропотехногенних навантажень на навколишнє природне середовище та зростання його відтворювального, відновлювального і асиміляційного процесу.

Організація раціонального використання земель $є$ функцією землевпорядкування, де заходи спрямовуються на виконання положень 
земельного законодавства та рішень місцевих рад. Змінилася організація раціонального використання земель, де повинні враховуватися розвиток всіх форм власності на землю, збереження та відтворення родючості грунтів. Використання землі має обов'язково узгоджуватися 3 продуктивністю конкретної земельної ділянки, відповідно до чого і визначається пріоритетність та цільовий характер передачі земель у власність чи надання у користування.

Отже, інституційне забезпечення організації раціонального використання земель в умовах розвитку різних форм власності залишається відкритою проблемою у використанні земель із необхідністю дотримання приведених заходів охорони земель із збереженням їх родючості.

Важливими показниками щодо використання орних земель мають бути:

- нормативна грошова оцінка, яку доцільно визначити не за фактичними показниками, а за нормативами затрат на вирощення природного врожаю на різних за якістю землях і диференціального рентного доходу.

- для визначення диференціального рентного доходу, як стартовий відлік, Для більш організованого використання земель, особливо сільськогосподарського призначення, А. М. Третяком було запроваджено еколого-економічну оцінку придатності земель, яка дозволить зробити сільськогосподарські землекористування більш інвестиційно привабливими. Ця методика поділяла сільськогосподарські землі на 5 класів.

Найбільш інвестиційно привабливими є орні землі першого класу. Це кращі за грунтами й технологічними властивостями земельні ділянки ріллі, 3 рівним або слабохвилястим рельєфом, які не підлягають ерозії. Ступінь окультуреності грунтів висока або вища за середню, окупність затрат становить понад 1,35 за вирощування всіх сільськогосподарських культур.

Землі другого класу мають певні обмеження через ерозійну небезпеку, слабке перезволоження, яке регулюється агротехнікою, придатні для вирощування всіх сільськогосподарських культур, але потребують протиерозійних заходів. 
Землі третього класу мають певні обмеження, які призводять до скорочення набору можливих культур (низька водопроникність, кам’янистість, слаба ерозія, окупність затрат становить менше ніж 1,35).

Землі четвертого і п'ятого класів мають значні i, відповідно, сильні обмеження (великі схили, підданість ерозії). Це грунти з низькою родючістю, за винятком чорноземів і темно-сірих грунтів. За відповідної агротехніки можуть використовуватися як кормові угіддя або постійне залуження.

В таблиці 1 приведемо приклад еколого-економічної класифікації орних земель Тернопільської області.

Згідно із поданою класифікацією, землі одного й того самого класу мають оцінку відповідно до обмежень їх використання в сільському господарстві і показують відповідність комплексу грунтових і технологічних властивостей конкретної ділянки для вирощування певної сільськогосподарської культури, виходячи з економічної ефективності виробництва іï прибутковості.

Еколого-економічна класифікація орних земель формує інвестиційну привабливість сільськогосподарських підприємств.

Для зростання кредитоспроможності (сільськогосподарських землекористувачів) слід упровадити:

- економічну класифікацію придатності земель, оцінку стану сільськогосподарських підприємств та бізнес-планів розвитку;

- ринковий обіг земельних ділянок із можливістю їх застави під інвестиційні кредити за жорсткого контролю держави.

Отже, інвестиційно привабливі типи землекористувань передбачають створення науково обгрунтованого, високопродуктивного сільськогосподарського землекористування з визначенням придатності земель для ведення розширеного виробництва. 
Таблиця 1

Еколого-економічна класифікація орних земель Тернопільської області

\begin{tabular}{|c|c|c|c|c|}
\hline \multirow[t]{2}{*}{ Клас } & \multicolumn{2}{|c|}{$\begin{array}{c}\text { Площа } \\
\text { Сільськогосподарських угідь }\end{array}$} & \multicolumn{2}{|c|}{$\begin{array}{c}\text { Оцінка грунтів за рівнем } \\
\text { окупності затрат }\end{array}$} \\
\hline & га & $\%$ & зернових & цукр. буряків \\
\hline 1 & 2 & 3 & 4 & 5 \\
\hline \multicolumn{5}{|c|}{ Природно-сільськогосподарський район (01) - 25 балів } \\
\hline 1 & 5435 & 26,7 & 1,93 & 2013 \\
\hline 2 & 2990 & 14,7 & 1,60 & 1,65 \\
\hline 3 & 2851 & 14,0 & 1,51 & 1,03 \\
\hline 4 & 8971 & 44,1 & 1,44 & 0,72 \\
\hline 1 & 2 & 3 & 4 & 5 \\
\hline 5 & 98 & 0,5 & 0,73 & 0,47 \\
\hline всього & 20345 & 100,0 & 1,60 & 1,28 \\
\hline \multicolumn{5}{|c|}{ Природно-сільськогосподарський район (02) - 35 балів } \\
\hline 1 & 28283 & 34,7 & 2,23 & 2,09 \\
\hline 2 & 24073 & 29,5 & 1,82 & 1,87 \\
\hline 3 & 12877 & 15,8 & 1,35 & 1,10 \\
\hline 1 & 2 & 3 & 4 & 5 \\
\hline 4 & 12697 & 15,6 & 1,26 & 0,88 \\
\hline 5 & 3592 & 4,4 & 0,96 & 0,69 \\
\hline всього & 81522 & 100,0 & 1,76 & 1,62 \\
\hline \multicolumn{5}{|c|}{ Природно-сільськогосподарський район (03) - 44 балів } \\
\hline 1 & 156369 & 64,2 & 2,09 & 1,83 \\
\hline 2 & 56901 & 23,4 & 1,91 & 1,58 \\
\hline 3 & 9465 & 3,9 & 1,06 & 0,96 \\
\hline 4 & 16939 & 7,0 & 1,42 & 1,99 \\
\hline 5 & 3720 & 1,5 & 1,04 & 0,55 \\
\hline всього & 243394 & 100,0 & 1,95 & 1,66 \\
\hline \multicolumn{5}{|c|}{ Природно-сільськогосподарський район (04) } \\
\hline 1 & 1040085 & 49,3 & 2,56 & 2,19 \\
\hline 2 & 52925 & 25,1 & 2,26 & 1,94 \\
\hline 3 & 4231 & 2,0 & 1,28 & 0,92 \\
\hline 4 & 44016 & 20,9 & 1,81 & 1,22 \\
\hline 5 & 5667 & 2,7 & 1,36 & 0,95 \\
\hline всього & 210924 & 100,0 & 2,27 & 1,87 \\
\hline \multicolumn{5}{|c|}{ Природно-сільськогосподарський район (05) - 26 балів } \\
\hline 1 & 17419 & 29,7 & 2,09 & 1,85 \\
\hline 2 & 8028 & 13,7 & 1,79 & 1,63 \\
\hline
\end{tabular}


Продовж. табл. 1.

\begin{tabular}{|c|c|c|c|c|}
\hline 1 & 2 & 3 & 4 & 5 \\
\hline 1 & 2 & 3 & 4 & 5 \\
\hline 3 & 19881 & 33,9 & 1,12 & 0,94 \\
\hline 4 & 9021 & 15,4 & 1,13 & 0,77 \\
\hline 5 & 4323 & 7,4 & 0,89 & 0,64 \\
\hline всього & 58672 & 100,0 & 1,49 & 1,25 \\
\hline \multicolumn{5}{|c|}{ Природно-сільськогосподарський район (06)-25 балів } \\
\hline 1 & 49167 & 49,2 & 20,5 & 2,37 \\
\hline 2 & 41704 & 41,7 & 1,85 & 1,83 \\
\hline 3 & 4584 & 4,6 & 1,45 & 1,04 \\
\hline 4 & 3791 & 3,8 & 1,51 & 1,31 \\
\hline 5 & 782 & 0,8 & 0,91 & 0,94 \\
\hline всього & 100028 & 100,0 & 1,91 & 2,03 \\
\hline \multicolumn{5}{|c|}{ Природно-сільськогосподарський район (06)-25 балів } \\
\hline 1 & 22756 & 42,3 & 1,81 & 1,90 \\
\hline 1 & 2 & 3 & 4 & 5 \\
\hline 2 & 11608 & 21,6 & 1,59 & 1,65 \\
\hline 3 & 15073 & 28,0 & 1,21 & 0,92 \\
\hline 4 & 3512 & 6,5 & 1,05 & 0,91 \\
\hline 5 & 851 & 1,6 & 0,66 & 0,76 \\
\hline всього & 53800 & 100,0 & 1,53 & 1,49 \\
\hline
\end{tabular}

Така класифікація земель по областях дасть достовірну інформацію щодо оцінки грунтів за рівнем окупності затрат, а відтак і їх використання під вирощування конкретної сільськогосподарської культури.

Важливим напрямом інституційного забезпечення охорони земель області залишається боротьба з водною ерозією грунтів. Це стосується інституційного забезпечення грунтозахисної системи землеробства з контурно-меліоративною організацією території, що передбачає вилучення 3 інтенсивного обігу деградованих земель, ерозійно небезпечних земельних ділянок із подальшим залуженням схилів крутизною $3-7^{0}$, заліснення крутосхилів, будівництво протиерозійних гідротехнічних споруд, упровадження низки агротехнічних заходів, передбачених Національною програмою охорони земель. 
Через високу господарську освоєність земельного фонду з очевидно недостатніми обсягами заходів щодо охорони земель i ïx відтворення відбувається прогресуюча деградація грунтів, що створює загрозу екологічній безпеці області. Продуктивні землі продовжують деградувати внаслідок водної ерозії, підкислення, заболочення і перезволоження. Водній ерозії підлягає близько 40 \% сільськогосподарських угідь, і площа їх зростає стрімкими темпами за останні 40 років. Для покращення ситуації пропонується здійснити консервацію малопродуктивних і деградованих земель.

Суттєвою перешкодою для ефективного використання земель $\epsilon$ гідрологічний режим території, який спричиняє перезволоження і заболочення значного масиву угідь. Глибоке осушення грунтів спричиняє порушення водного балансу, режиму грунтових і підземних вод, що призводить до обводнення i появи нових ділянок заболочених земель. Для нормалізації водного балансу необхідно зменшити глибину дренування грунтів, залужувати такі землі вологолюбними травами та використовувати їх як поліпшені сіножаті. Тому скорочення площ осушених орних земель і виникнення повторно заболочених ділянок $\epsilon$ закономірним процесом. Такі ділянки необхідно залишити в нинішньому стані. Вони повинні формувати екологічний каркас території.

Інтенсивна втрата гумусу з грунтових горизонтів через ерозійні процеси та систематичне недодавання мінеральних і органічних добрив призводить до постійного спаду його вмісту в грунті сільськогосподарського призначення.

На сьогодні достатньо розроблена методика захисту грунтів від ерозії, економічного захисту цінних земель від необгрунтованого вилучення для несільськогосподарських потреб.

Впровадження інституційного забезпечення охорони земель допоможе забезпечити складання проектів, де, поряд із питаннями організації територій, вирішуються питання організаційно-господарського, агротехнічного, лісомеліоративного і гідротехнічного спрямування для ефективнішого використання земель, зростання культури землеробства та охорони земель на об’єднаних територіальних громад. 
Основним напрямом охорони земель області залишається:

- боротьба з водною ерозією грунтів;

- грунтозахисної системи землеробства 3 контурно-меліоративною організацією території;

- вилучення 3 інтенсивного обробітку деградованих земель, ерозійно небезпечних ділянок із подальшим залуженням схилів крутизною 3-7;

- залісненням крутосхилів;

- будівництвом протиерозійних гідротехнічних споруд, упровадження низки агротехнічних заходів.

- рекультивації проблемних територій, тобто комплексу організаційних, технічних і біотехнологічних заходів, спрямованих на відновлення грунтового покриву, поліпшення стану та зростання продуктивності порушених земель.

Водночас, у аграрному секторі економіки країни істотний вплив на використання земельних ресурсів мають внутрішньогосподарські причини, однією з яких є проблема недотримання науково обгрунтованого чергування культур у сівозмінах. Адже поява i розвиток невеликих за розміром сільськогосподарських підприємств сприяє поглибленню спеціалізації сільськогосподарського виробництва, що неминуче призводить до обмеження набору вирощуваних культур.

Приватизація земель громадянами також досі здійснюється без належного екологічного обгрунтування, дотримання вимог екобезпеки. Немає чітко встановленого механізму тимчасового або постійного вилучення 3 активного обігу земельних ділянок із природоохоронних міркувань (необхідність консервації, реабілітації, відведення під заліснення). Для ефективного вирішення цих актуальних питань необхідно було б керуватися комплексом обов'язкових заходів, щоб покласти край екстенсивному та екологічно необгрунтованому використанню земельних ресурсів у державі взагалі й у сільському господарстві зокрема. Було б реальним передати еродовані землі в приватну власність громадянину, який був би зацікавлений у їх збереженні. При цьому має 
спрацювати стимулюючий механізм: податкові канікули, зменшення земельного податку, за потреби - надання допомоги для виконання рекультивації земель.

Вагомий вплив в системі інституційного забезпечення хорони i використання земель сільськогосподарського призначення $\epsilon$ вливання інвестицій. Інвестиції розглядають як вкладення в капітал, як грошовий, так i реальний. Вони здійснюються у вигляді грошових коштів, банківських внесків, паїв, акцій та інших цінних паперів, внесків у рухоме та нерухоме майно, інтелектуальну власність, майнові права та інші цінності [34].

Розвиток будь-якої держави пов'язаний із динамікою інвестиційних процесів, структурним та якісним оновленням виробництва й створенням ринкової інфраструктури. Чим інтенсивніше здійснюється інвестування, тим швидше відбувається відтворювальний процес, i активніше - ефективні ринкові перетворення.

Інвестиції потрібні підприємствам i організаціям для переходу до нормальної господарської діяльності, для переозброєння виробництва, зростання якості продукції [35, с. 6].

Капітал і земля разом утворюють речове багатство України. I сьогодні, в умовах пошуку ефективної моделі функціонування пореформеного сільського господарства, не виникає суперечностей в надзвичайно важливій та стратегічній ролі інвестицій. Тому в період обмеженості інвестиційних ресурсів інвестиційна привабливість як категорія є основним критерієм, на основі якого формуються інвестиційна стратегія з боку інвестора та інвестиційна політика держави. Тому особливо актуальне питання визначення інвестиційної привабливості сільськогосподарського землекористування, як одного з перспективних напрямів залучення капіталу [36].

У здійсненні процесу інвестування сільського господарства має ряд особливостей, які випливають 3 умов та характеру сільськогосподарського виробництва. 
Основною відмінністю сільського господарства від інших галузей народного господарства $€$ не три а чотири виробничі ресурси - земля, основні і оборотні фонди, жива праця. Характерною ознакою $є$ те, що земля виступає і як знаряддя, і як предмет праці і є основним і незамінним засобом виробництва, на відміну від промисловості, де земля служить тільки просторовим базисом. Незамінним iї показником $\epsilon$ те, що при правильному використання земля не зношується, а навпаки, покращує свої якості.

Тому особливої актуальності набуває проблема інвестування природоохоронних заходів та впровадження нових технологій обробітку, вибір та складання заходів щодо реалізації інвестицій.

Ринкові зміни в економіці України вимагають чіткого визначення та дієвого управління поняттями й категоріями, стосовно інвестиційних відносин. Питання власності на землю $є$ важливим моментом довгострокових та великих інвестицій - саме тих інвестицій, які терміново необхідні потрібних Україні для розвитку іiї сільськогосподарського та промислового потенціалу [35].

Регіональний розвиток України відбувається досить складно і суперечливо конституція України визначила головний вектор перерозподілу економічних прав і повноважень на користь регіонів.

Зміна соціально-економічних умов господарювання визначає нові підходи до оцінки інвестиційного потенціалу регіонів. Це потребує аналізу, моніторингу та розробки шляхів вирішення проблем, пов'язаних з інвестиційною діяльністю на всіх регіональних рівнях. Формування ринкового інфраструктурного середовища передбачає створення диверсифікованої системи інвесторів, яка складається з агентів різних функціональних і соціально-економічних структур - виробничих, посередницьких, біржових, суто інвестиційних та інших підприємств.

У регіонах України ще не сформувалася мережа приватних інституційних інвесторів. Найбільшими потенційними приватними інституційними інвесторами є комерційні банки, які здійснюють переважно короткострокове 
кредитування найприбутковіших торгово-посередницьких операцій, а не інвестування.

Економіка країни, де вітчизняний інвестор практично не вкладає кошти у розвиток виробництва, не може бути привабливою для іноземного інвестора. Залучення іноземних інвестицій має здійснюватися 3 урахуванням цілей i завдань державних програм структурної переорієнтації виробництва, цільових програм міжгалузевого та галузевого розвитку, конверсії та розвитку експортного потенціалу. Слід брати до уваги також процеси внутрішньої й зовнішньої кооперації продукції виробничо-технічного призначення, приватизації державних підприємств із залученням іноземного капіталу.

Україна має змогу змінити свої позиції як покупець інвестицій за рахунок їх диверсифікації, отримуючи іноземні інвестиції у вигляді технологічного обладнання, матеріалів, прав інтелектуальної власності, ноу-хау, торгових знаків, деяких інших цінностей. Доцільність такого підходу підтверджена не тільки деякими зарубіжними фахівцями, а й досвідом окремих країн, наприклад, Японії, де закупівля та використання зарубіжних ліцензій значною мірою сприяли ії соціально-економічному розвитку.

У Державній цільовій програмі розвитку українського села визначені основні стратегічні напрями інноваційного розвитку аграрного сектора. Зокрема, впровадження сучасних технологій для вирощування i переробки сільськогосподарської продукції, розвитку селекції, меліорації та суттєвого поліпшення земель, а також створення умов для міжнародного співробітництва у сфері наукової та інноваційної діяльності.

Інвестиції необхідні сільському господарству, підприємствам, організаціям, особливо в нинішніх умовах реформування й переходу до ринкових відносин, для переходу до нормальної господарської діяльності, для переозброєння виробництва, зростання якості продукції. Для їхнього успішного функціонування держава повинна регулювати створення в країні сприятливого клімату, формування i розвиток фондового ринку, сприяти спрямуванню інвестицій у пріоритеті виробництва [37]. 
Для покращення становища сільськогосподарського землекористування доцільно запровадити заходи для розвитку інвестицій:

- інвестування здійснювати за власний рахунок (прибутків, амортизаційних відрахувань, відшкодування збитків землевласникам i землекористувачам при відчуженні земель);

за рахунок грошових нагромаджень і заощаджень власників землі тощо;

- позикових - банківських та бюджетних кредитів;

- залучення фінансових ресурсів інвестора (кошти, одержані від продажу акцій, пайові та інші внески громадян і юридичних осіб), а також бюджетних інвестиційних асигнувань та благодійних внесків, пожертв організацій, підприємств і громадян.

Формування інвестиційної привабливості сільськогосподарського землекористування та організації інвестиційного процесу в Україні тільки починають розвиватися. Тому одним із найактуальніших завдань сьогодення у сфері землекористування є дослідження та вдосконалення методологічних основ інвестиційної діяльності 3 метою зростання ефективності використання та охорони земель сільськогосподарських підприємств формуванням інвестиційної привабливості землекористування та удосконалення цього процесу через проекти землеустрою.

Сільськогосподарські підприємства як суб'єкти господарювання перебувають у сфері інвестиційної діяльності, де здійснюється практична реалізація інвестицій у їх землекористування. Вона охоплює сферу земельних відносин, землекористування, капітального будівництва, де реалізується вкладення інвестицій у майно, що належить до основного їі обігового капіталів, а також інноваційну сферу, де реалізуються науково-технічна продукція та інтелектуальні цінності, у сферу обігу фінансового капіталу (кошти, цінні папери й цільові грошові внески) та сферу реалізації майнових прав суб'єктів інвестиційної діяльності. 
Водночас, інвестування землекористування сільськогосподарських підприємств має певні характерні особливості. Зокрема, тут інвестиціями можуть бути інновації з організації сільськогосподарського землекористування, а інвесторами - як члени сільськогосподарських підприємств, так і зовнішні особи (організації) [38].

Враховуючи це структуру інвестиційного процесу у землекористування сільськогосподарських підприємств можна розглядати у такій послідовності виконання:

1) планування заходів (вибір інвестицій, розробка інвестицій, складання планів, програм, проектів);

2) місце прикладення інвестицій (земельні ділянки, матеріальні цінності, грошові кошти - банківські кредити тощо, трудова діяльність учасників та працівників;

3) реалізація інвестицій (організація землекористувань сільськогосподарських підприємств різного типу, поновлення матеріальнотехнічної бази господарств, грошові внески щодо поліпшення земель, будівництво нових та залучення старих інвестицій у господарства, розробка інших проектів).

Невід'ємною складовою, яка обов'язково повинна включатися в інвестиційну діяльність, є вартість земельних ділянок чи прав на них.

Оскільки засновниками сільськогосподарських підприємств можуть бути лише громадяни України, то й інвестиційна діяльність сільськогосподарських підприємств здійснюється за рахунок внутрішніх інвестицій і основними джерелами інвестицій сільськогосподарських підприємств $є$ прибуток та залучені кошти.

Слід ураховувати, що у сільськогосподарських виробничих кооперативах обмежені можливості залучення інвестиційних ресурсів випуском цінних паперів, тому вони переважно тільки реальні. Крім того, учасники кооперативу зацікавлені у використанні частини прибутку для спо-живання, тому його 
(прибутку) роль у розширенні інвестиційної діяльності сільськогосподарських виробничих кооперативів спадає. Обмеженість джерел інвестування зумовлює певну специфіку напрямів використання інвестицій залежно від інтересів засновників.

На нинішньому етапі розвитку економіки в загалом і для аграрного сектора зокрема, науково-інвестиційне забезпечення $\epsilon$ найважливішою складовою збільшення конкурентоздатності сільськогосподарської п продукції та продовольчих товарів як на внутрішньому, так і на зовнішніх ринках.

На сьогодні необхідно вирішити низку складних проблем, серед яких провідними $є$ стабілізація аграрного виробництва, істотне поліпшення фінансового стану сільськогосподарських підприємств різних форм власності, посилення інтенсивної діяльності в усіх сферах національного АПК.

Інвестиції можуть бути реальними лише тоді, коли держава створить усі умови найширшого розвитку приватного сектора сільського господарства та економіки загалом.

Інвестиційний процес охоплює:

- створення реального власника;

- залучення інвестицій;

- одержання засобів для поповнення державного бюджету, а також супровід процесу приватизації.

Слід відзначити, що важливу роль у формуванні сприятливого економічного середовища для активізації науково-інвестиційного забезпечення $\epsilon$ передусім ринкові реформи, які відбуваються в аграрному секторі поетапно. Урядова політика щодо вдосконалення й щорічного розширення обсягів державної підтримки розвитку аграрного сектора поступово формує таке сприятливе економічне середовище. Важливим також $є$ спад податкового навантаження на сільськогосподарські виробники.

Для розвитку інвестицій в аграрному секторі пропонуємо удосконалити систему заходів через: 
- розвиток системи іпотечного кредитування, зокрема іпотеки земельних ділянок;

- комплексне законодавче забезпечення впровадження ринку земель сільськогосподарського призначення;

- створення сучасної системи реєстрації нерухомості, зокрема земельних ділянок;

- розширення бюджетного фінансування фундаментальних наукових досліджень;

- розвиток системи страхування аграрних ризиків;

- забезпечення стабільної податкової політики та системи державної підтримки сільгоспвиробників;

- посилення гарантій захисту інвестицій та доходів інвесторів, забезпечення вільного руху капіталу та переміщення товарів.

Виконання цих заходів дасть змогу значно збільшити інвестиційну привабливість АПК, продовольчу безпеку держави та експортний потенціал галузі.

Інноваційно-інвестиційним заходам має належати довгострокове кредитування на підприємствах - інноваційно-інвестиційного фонду.

Аграрний сектор є одним із найпривабливіших для іноземних інвесторів, насамперед, можливостями росту, не обмеженими будь-яким втручаннями 3 боку держави” [39, с. 18], тим більше, що “...у Західній Свропі утворились значні доларові накопичення, які можуть бути використані й як інвестиції ”.

Важливим недоліком, який впливає на інвестування агропромислового комплексу України, є несприятливі ринкові умови виробництва: незначна прибутковість і високий ризик неповернення внесків, недосконале інвестиційне законодавство [40, с. 116]. Також до недоліків слід зарахувати відсутність податкових пільг для іноземних інвесторів, ефективної системи страхування інвестиційних ризиків, низький рівень розвитку інфраструктури села, доступ де банків, кредитних спілок у сільській місцевості. Гострою проблемою аграрних товаровиробників є відсутність шляхів збуту виробленої продукції (74% 
обстежених підприємств) і високі відсоткові ставки (близько 53 \%). Це дуже важливо для інвесторів, які мають можливості й доступ на зовнішні ринки щодо Сільськогосподарський i земельний фонд України характерний наявністю високого біопродуктивного потенціалу, в його структурі переважають землі 3 родючими грунтами. За експертними оцінками, за раціональної структури землекористування і відповідного наукового й ресурсного забезпечення, українські землі здатні виробляти продуктів харчування на 140-135 млн осіб.

Для створення привабливих земельних ресурсів необхідно вдосконалити систему рентних платежів.

Сутність схеми рентних платежів полягає у диференціації закупівельних цін на продукцію, виходячи зі середніх затрат виробництва у відповідній зоні. При цьому для зон із відносно гіршими умовами сільськогосподарського виробництва в землекористуванні встановлювався вищий рівень закупівельних цін. Отже, регулюючи закупівельні ціни на сільськогосподарську продукцію, державні органи вилучали більшу частину вартості продукції сільського господарства. Проте держава повертала частину вилученого в різних формах (постачала технікою, добривами, коштами). Цій формі економічної взаємодії держави і сільського господарства відповідала форма організації виробництваколгоспи, радгоспи.

За переходу до ринку змінюються методи регулювання економіки, де основою економічного управління стає державний бюджет, головним джерелом наповнення є податки. Отже, є потреба у відновленні науково обгрунтованих методів визначення ставок земельного податку.

До цього методу належить метод макроренти, через “... забезпечення реальних стартових економічних умов відтворення для всіх товаровиробників, стимулювання їх ефективнішого господарювання" [41, с. 43-44], застосування якого відновлює порушене плановою економікою істинне співвідношення між земельною рентою та ії формами - нормативною ціною землі, земельним податком, орендною платою. 
Земельний податок набуває значення як механізм забезпечення раціонального використання та охорони земель сільськогосподарського призначення, відтворення їх продуктивності, споживчих якостей та екологічної ролі грунтового покриву.

На сьогодні земельний податок розглядають як ставку, яка грунтується на нормативному розмірі земельної ренти, тобто є нормативом. Рента залежить від місця розташування земельних ділянок, ефективності додаткових вкладень у землю. Земельний податок $є$ механізмом розподілу земельної ренти, де необхідно враховувати умови:

- диференціальна рента є основною частиною земельної ренти, яка складається з ренти I і II. Джерелом диференціальної ренти I є вища родючість земельних ділянок i вигідніше їх місцерозташування щодо ринків збуту, порівняно з кращими ділянками, диференціальна рента II - ефективніша віддача витрат виробництва на земельних ділянках;

- принцип визначення й кількісні параметри податкових ставок будуть різними, залежно від форми власності на землю.

Держава економічно стимулюватиме охорону через правові та економічні механізми, які грунтується на удосконаленні механізму раціонального використання коштів від плати за землю.

В системі інституційного забезпечення раціонального використання i охорони земельних ресурсів важливою складовою $є$ вдосконалення інституційного механізму через формування ландшафтно-екологічних комплексів та земельних масивів угідь і сівозмін. Розглянемо детальніше.

Світовий досвід вказує на те, що у країнах з вільною ринковою економікою структура інститутів земельної власності збігається із загально цивілізованою структурою власності. Вона передбачає поділ їх на два основних інститути: публічну власність і приватну, яка в Україні конституційно закріплена. Публічна, тобто державна і комунальна власність, і приватна, охоплює власність фізичних та юридичних осіб 
Із інституційного погляду, землі - сукупність кадастрових, майнових та інших спеціальних закладів, а також структур органів юстиції, завдяки яким, відповідно до правил, чинних законів відбувається перерозподіл землі між учасниками земельних відносин. До цих закладів і структур належать: державні земельні служби, проектні інститути, бюро технічної інвентаризації, суди, різні страхові й кредитні установи.

Ринок землі - інституційна система, через яку здійснюються всі види діяльності, які пов'язані з передачею прав на земельні ділянки [42].

Сучасна інституційна структура класифікується за основними показниками:

- правовим - удосконалення і прийняття земельного законодавства (реєстрація прав власності одночасно на земельні ділянки і розташовані на них об'єкти нерухомості, забезпечення правових умов обороту земель сільськогосподарського призначення, у тому числі іпотека; здійснення різних цивільно-правових робіт із земельними ділянками і тощо );

- територіальним - завершення зонування територій і розмежування земель державної та комунальної власності;

- функціональним - продаж земельних ділянок, придбання земельних ділянок із відтермінуванням платежу тощо;

- процедурним - удосконалення механізму передачі права власності на земельні ділянки, які перебувають у державній або комунальній власності, спрощення процедурних прав на земельні ділянки в цілях реалізації інвестиційних процесів, удосконалення системи реєстрації прав на земельні ділянки тощо;

- природоохоронним - організація ефективного контролю за охороною й використанням земельних ресурсів, спрямованих на збереження й відновлення природних якостей земель.

Проблема інституційного забезпечення державної земельної політики на регіональному й місцевому рівнях пов'язана 3 незавершеністю формування 
сільськогосподарських підприємств на основі приватної форми власності. Місцеві органи влади не мають належного законодавчого забезпечення та фінансової бази для вирішення таких проблем. Розбудова системи державного управління земельними ресурсами є багатоаспектним комплексним завданням, яка потребує окремого розгляду й вироблення відповідної системи заходів.

Для ефективної реалізації державної земельної політики необхідно створити мережу недержавних інституцій регіонального і місцевого розвитку. Такі інституції покликані підвищити роль і відповідальність територіальних громад, землевласників і землекористувачів за розвиток відповідних територій, забезпечити їм можливість реальної участі та впливу на вирішення важливих проблем регіонального і місцевого розвитку. Також інституцією може бути мережа агентств регіонального розвитку 3 репрезентуванням державних, громадських, приватних інтересів.

Удосконалення правового регулювання земельних відносин є основною умовою для спрямування дій місцевих органів виконавчої влади та органів місцевого самоврядування на створення й підтримку сприятливого середовища для розвитку землеволодінь і землекористувань. Однак для цього необхідно впровадити дієві механізми взаємодії влади із власниками наділів (паїв) на підставі соціального партнерства, розробляти й реалізовувати регіональні та місцеві програми розвитку нових форм господарювання.

Регіональні програми повинні спрямовуватися на комплексне вирішення питань розвитку та підтримки нових форм господарювання на землях приватної форми власності, в межах повноважень місцевих органів влади, а саме: вдосконалення нормативно-правової бази; зменшення податкового тиску; впровадження системи фінансово-кредитної та ресурсної підтримки селянських господарств; сприяння розвитку інфраструктури підтримки господарств нового типу.

У більшості районів площі необроблюваних земель щороку зменшуються, а в окремих - усі продуктивні землі вже нині перебувають в обробітку. Отже, їх 
передусім слід упорядкувати 3 урахуванням змін, причин, чинників за багаторічний період, які тією чи іншою мірою вплинули на погіршення ситуації. Одним iз головних способів їх наукового 3’ясування $є$ складання схем землеустрою й охорони земель, які є основою для планування, впровадження заходів із раціонального використання земельних ресурсів, їх збереження та відтворення. Виконання цих робіт передбачається за кошти, які надходять у порядку відшкодування втрат сільськогосподарського та лісогосподарського виробництва. Водночас можна вирішувати питання використання і відтворення природних ресурсів, збереження цілісності природних комплексів (об'єктів природно-заповідного комплексу та природоохоронного призначення) та об’єктів історико-культурного призначення.

Для раціонального використання земельних ресурсів слід звернути увагу на ландшафтно-екологічні пріоритети території області. Поділ території області на ландшафтно-екологічні комплекси визначає напрямок розвитку області, специфіку їі господарської діяльності в масштабах країни та в природних територіальних комплексах, що сприяє розвитку антропогенних і екологічних функцій iз створенням комфортних i стабільних умов середовища для життєдіяльності людей та природоохоронні функції зі збереженням природних ландшафтів.

Для визначення природоохоронної функції як пріоритетної для будь-якого регіону, при виділенні ландшафтно-екологічних комплексів території області основним завданням $€$ визначення оптимального співвідношення між природними і освоєними господарськими територіями.

У науковій літературі існують різні обгрунтування щодо співвідношення між природними й антропогенними ландшафтами в межах регіону. Наприклад, В.О. Молчанов мінімальну лісистість території лісостепової зони визначив в межах 20 \%, а O.I. Воєйков - 17-23 \%. При узагальнені цих даних можна прийняти за середнє значення показника лісистості орієнтовно у лісостеповій зоні області у 20 \%. Приблизно таку саму площу займатимуть лучно-степові, водно-болотні рослинні утворення. Отже, близько 40 \% площі будь-якого 
регіону повинні бути зайняті під природною рослинністю, для забезпечення природної стабільності. Розглянемо детальніше формування ландшафтноекологічних комплексів за співвідношення між природними та антропогенними ландшафтами на прикладі тернопільської області.

У межах Тернопільської області під природною рослинністю перебуває близько 30 \% площ, що свідчить про нестабільність ландшафтно-екологічної структури території.

Проведемо розподіл земель області щодо їх співвідношення між природними та антропогенними ландшафтами з метою поетапного виводу цих земель із сільськогосподарського обробітку, 3 подальшим використанням масивів екологічної придатності земель на ріллі, та їх раціональному використанню. Вирішення цих завдань дозволить мата кращу картину щодо якості земель, можливостей їх використання, та інвестиційної привабливості.

Узагальнивши показники природних та антропогенних ландшафтів у районах Тернопільської області здійснено групування за процентним співвідношенням, результати яких показано в таблиці 2 . та рис. 1.

Таблиця 2

Утворення ландшафтно-екологічних комплексів за співвідношення між природними та антропогенними ландшафтами у районах в області.

\begin{tabular}{|c|l|c|c|c|}
\hline \multirow{2}{*}{$\begin{array}{c}\text { № } \\
\text { 3/п }\end{array}$} & \multirow{2}{*}{$\begin{array}{c}\text { Адміністративні } \\
\text { утворення }\end{array}$} & $\begin{array}{c}\text { Загальна } \\
\text { площа } \\
\text { земель, га }\end{array}$ & $\begin{array}{c}\text { Частка природних та } \\
\text { антропогенних ландшафтів, \% }\end{array}$ \\
\hline \multicolumn{5}{|c|}{ Найкраще співвідношення } \\
\hline 1 & 2 & 3 & 4 & 5 \\
\hline 1 & Бережанський & 66113,0 & 54,6 & 45,4 \\
\hline 2 & Шумський & 83800,0 & 43,6 & 56,4 \\
\hline 3 & Монастирський & 55815,0 & 47,2 & 52,8 \\
\hline \multicolumn{5}{|c|}{ Гірше співвідношення обласного (30\%-70\%) } \\
\hline 4 & Бучацький & 80212,0 & 33,1 & 66,9 \\
\hline 5 & Заліщицький & 68391,0 & 31,9 & 68,1 \\
\hline 6 & Зборівський & 97740,4 & 32,3 & 67,7 \\
\hline 7 & Кременецький & 91754,0 & 37,8 & 62,2 \\
\hline
\end{tabular}


Продовж. табл. 2

\begin{tabular}{|c|l|c|c|c|}
\hline 1 & 2 & 3 & 4 & 5 \\
\hline 8 & Борщівський & 100587,0 & 30,9 & 69,1 \\
\hline 9 & Підгаєцький & 49638,0 & 34,9 & 65,1 \\
\hline \multicolumn{5}{|c|}{ Погане співвідношення (вище за 70\%) } \\
\hline 10 & Густинський & 101616,0 & 27,7 & 72,3 \\
\hline 11 & Збаразький & 86306,0 & 23,6 & 76,4 \\
\hline 12 & Козівський & 69430,0 & 25,0 & 75,0 \\
\hline 13 & Лановецький & 63234,0 & 21,6 & 78,4 \\
\hline 14 & Підволочиський & 83726,0 & 18,6 & 81,4 \\
\hline 15 & Теребовлянський & 113003,0 & 22,2 & 77,8 \\
\hline 16 & Тернопільський & 74911,0 & 25,1 & 74,9 \\
\hline 17 & Чортківський & 90344,0 & 24,6 & 75,4 \\
\hline
\end{tabular}

Згідно 3 даними табл. 2, найкраще співвідношення між природними й антропогенними ландшафтами характерне тільки для трьох адміністративних районів - Бережанського (54,6 \% порівняно з 45,4 \%), Монастирського (47,2 \% порівняно 3 52,8 \%), Шумського (43,6 порівняно 56,4%); у шести адміністративних районах співвідношення гірше за встановлене обласне (30\% порівняно 3 70,0 \%), а в решти восьми адміністративних районів співвідношення погане. При цьому встановлено, що господарська освоєність території області становить 70\% площ, з яких 61,8 \% є розораними.

Враховуючи цю обставину, а також значну частину малопродуктивних і сильноеродованих земель, доцільним провести виведення їх 3 інтенсивного обробітку і на цих площах здійснювати заліснення і залуження, оскільки ці землі, зазвичай, малопродуктивні й деградовані, потребують консервації і спеціального використання. Залісненню підлягають деградовані орні землі з крутизною схилу понад 5-70 (понад 14 тис. га). Ці землі знаходяться переважно з одного боку до схилів горбистої місцевості, а з іншого до схилів річкових долин. Ці землі як правило малопродуктивні i деградовані i потребують спеціального функціонального використання, в тому числі консервації. Такі землі $є$ в кожному адміністративному районі області. Під заліснення доцільно відвести деградовані 
орні землі з крутизною схилу понад $7^{0}$ а це становить 40,1 тис. га, порушені та відпрацьовані землі промислового використання 4,7 тис. га, та радіаційно забруднені землі (17,8 тис. га), що загалом становлять 3,8 \% території області. Залуженню та залісненню, залежно від конкретних місцевих умов, підлягають малопродуктивні сільськогосподарські землі з крутизною схилів $5-7^{0}$ у межах річкових долин, місцях витоку річок (53,5 тис. га), частина малопродуктивних i деградованих орних земель із крутизною схилів $3-5^{0} 176,2$ тис. га що становить 13\% від площі області.

Співвідношення між природними та антропогенними ландшафтами у районах області показано на рисунку 1 згідно табличних даних 3 , де в кольоровому зображенні проведено групування адміністративних районів згідно частки в них природних та антропогенних ландшафтів.

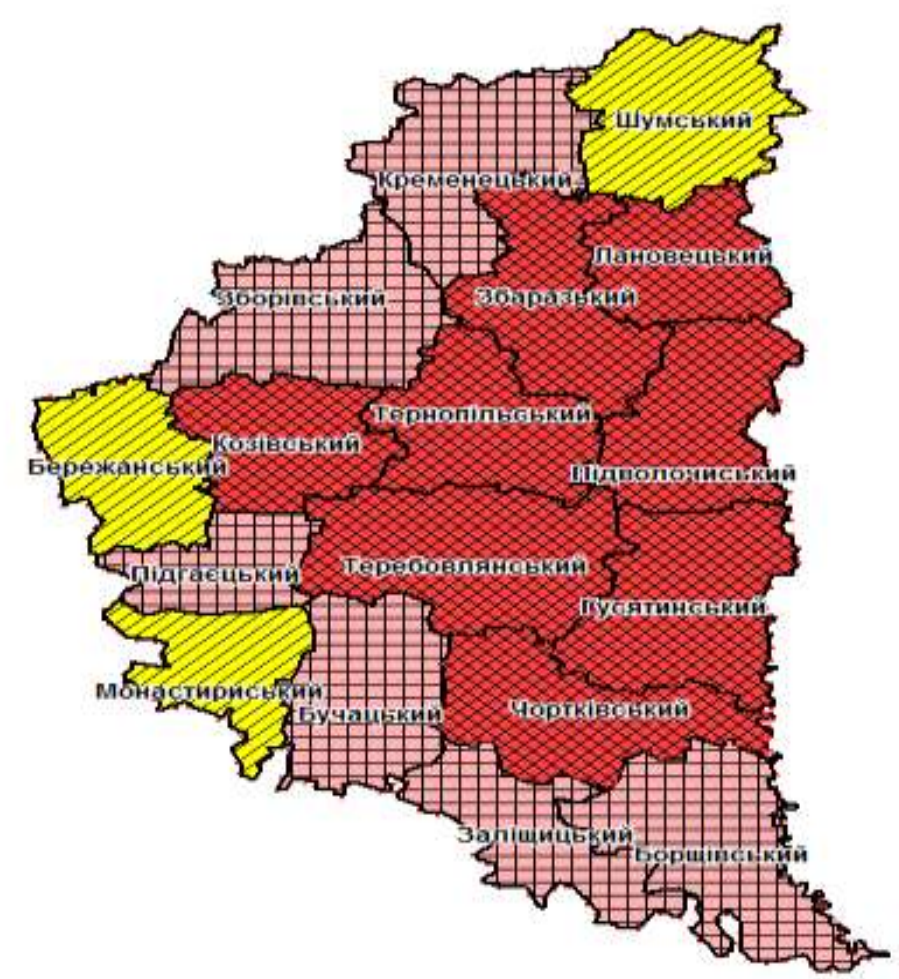

- найкраще співвідношення

\#\#- гірше співвідношення обласного (30\% - 70\%)

- погане співвідношення (більше за 70\%)

Рисунок 1. Співвідношення природних та антропогенних навантажень в районах області 
Згідно рисунку 1 нами відображено:

- в жовтих тонах - найкраще співвідношення між природними та антропогенними ландшафтами;

в рожевих тонах - гірше співвідношення між природними та антропогенними ландшафтами (30-70\%);

- $\quad$ в червоних - погане співвідношення (більше 70\%) між природними та антропогенними ландшафтами.

Провівши ці заходи (перший етап створення ландшафтно-екологічних комплексів) площа природної рослинності збільшиться до 50 \%.

Ha другому emani створення ландшафтно-екологічних комплексі пропонуємо надати статус перспективної екологічної мережі полезахисним лісосмугам, ділянкам витоку річок, водно-болотним масивам, землям під ярами, пісками, водою, а також луками, сіножатями, пасовищами, що в сукупності становитиме 439,0 тис. га (32,6 \%). Вилучення їх із господарського користування цілою площею неможливе. Це можна здійснити запровадивши поступову зміну режимів природокористування із залученням їх до складу буферних зон майбутніх коридорів. До них належать річкові долини Дністра, Золотої Липи, Стрипи, Серету, Збруча які становлять близько 158 тис. га (11,4 \%) земель річкових долин.

На основі звітних даних запропонована прогнозна структура земельних угідь регіональної екологічної мережі.

Таблиця 3.

Прогнозована структура земельних угідь в регіональній екологічній мережі області

\begin{tabular}{|c|c|c|c|}
\hline Угіддя & $\begin{array}{c}\text { Угіддя } \\
\text { тис. га }\end{array}$ & $\begin{array}{c}\text { Частка у } \\
\text { аг. площі } \\
2019 \text { р. \% }\end{array}$ & $\begin{array}{c}\text { Частка у аг. } \\
\text { площі на } \\
\text { перспективу } \\
\%\end{array}$ \\
\hline 1 & 2 & 3 & 4 \\
\hline Ліси та лісо вкриті площі, у т. ч. & 198,389 & 14,3 & 18,2 \\
\hline ліси & 132,258 & 9,6 & 12,6 \\
\hline лісосмуги & 60,998 & 4,4 & 4,8 \\
\hline
\end{tabular}


Продовж. табл. 3

\begin{tabular}{|c|c|c|c|}
\hline 1 & 2 & 3 & 4 \\
\hline Чагарники & 5,132 & 0,4 & 0,8 \\
\hline Сіножаті & 37,596 & 2,7 & 10,0 \\
\hline пасовища & 137,777 & 9,5 & 18,8 \\
\hline Заболочені землі & 4,970 & 0,3 & 0,5 \\
\hline $\begin{array}{c}\text { Землі з незначним рослинним } \\
\text { покривом, у т. ч. }\end{array}$ & 17,831 & 1,3 & 1,3 \\
\hline кам'янисті землі & 8,289 & 0,6 & 0,6 \\
\hline інші відкриті землі & 9,542 & 0,7 & 0,7 \\
\hline Землі під водою, у т. ч. & 19,381 & 1,4 & 1,4 \\
\hline природні водотоки & 5,935 & 0,4 & 0,4 \\
\hline штучні водотоки & 3,273 & 0,2 & 0,2 \\
\hline озера & 0,679 & 0,1 & 0,1 \\
\hline водосховища, ставки & 9,494 & 0,7 & 0,7 \\
\hline Всього & 409,946 & 29,6 & 50,2 \\
\hline
\end{tabular}

Tpemiŭ eman формування ландшафтно-екологічних комплексів повинен започаткувати роботу з функціонування цілісної екологічної мережі, коли до іiі складу будуть включені екологічні коридори, зони відновлення природної рослинності із певним режимом використання - антропоекологічноїим, агрогосподарським і рекреаційним.

Розвиток туристично-рекреаційного комплексу як пріоритетного господарського напряму сприяє залученню природних рекреаційних ресурсів до масового відпочинку й оздоровлення населення. Частка природної рослинності повинна невпинно зростати через відновлення регіональних та природних національних парків.

Серед областей країни, в Тернопільській області переважає сільськогосподарський напрямок ведення господарства. Тому дані оцінки земель на даний час для області $\epsilon$ важливими щодо іï ефективного ведення господарювання, залучення інвестицій як внутрішніх так іноземних на основі організації раціонального використання земель. 
Розглядав цю проблему і М.M. Третяк, який для більш організованого використання земель, особливо сільськогосподарського призначення, запропонував еколого-економічну оцінку придатності земель, за якою орні землі поділено на 3 групи та 5 класів придатності. В основі такого поділу покладено окупність затрат на вирощування сільськогосподарських культур в розмірі 1,35 i відповідна змитість земель.

Ми пропонуємо дещо іншу систему у вирішенні проблеми раціонального використання земель в новостворених господарствах, що дозволить зробити їх інвестиційно-привабливими - система формування земельних масивів угідь та сівозмін з врахуванням екологічної придатності земель.

В західних областях України і в тому числі в Тернопільській області, найбільш розповсюдженими культурами є: зернові, картопля, цукровий буряк та кормові культури. Враховуючи це, для вирішення питання ефективного використання орних земель допоможе формування земельних масивів в основі яких лежить екологічна придатності земель. Для цього необхідно застосувати матеріали обліку якості і оцінки земель виділяються найбільш родючі земельні ділянки, які характеризуються середньою і сильною ступенем змитості грунтів, а так же низькими показниками часткових оцінок по урожайності культур і окупності затрат. На таких землях, як правило, необхідно розміщувати культури суцільного посіву, які б носили грунтозахисний характер. Слабозмиті землі, якщо їх в господарствах багато, слід об’єднувати для раціонального використання.

В системі земле оціночних робіт, що входять в складову державного кадастру, важливе місце займають дані про оцінку землі в цілому і внутрігосподарської в тому числі в розрізі окремих земельних ділянок, масивів, угідь, які характеризують продуктивність, ефективність використання i дохідність з одиниці площі. Дані про внутрігосподарську оцінку землі відображують якісний склад грунтів які впродовж років змінюються і вплинули на такі економічні показники як окупність затрат (О3), урожайність (У), вартість валової продукції (ВВП), диференційний дохід (ДД). Це стримує науково- 
обгрунтоване вирішення багатьох питань планово-економічного регулювання виробництва в сільськогосподарських підприємствах які утворюються чи змінюються відповідно до правового статусу.

Для впровадження механізму формування земельних угідь та сівозмін основною вимогою $є$ вирішення питання екологічної придатності земель. Виділення екологічно придатних земель для вирощування сільськогосподарських культур проведено за показником окупності затрат, вихідний рівень якого по Україні встановлено в розмірі 1.6, часткових економічних оцінок, яка відображає величину урожайності відповідної культури та затрат на ії вирощування, що становить для зернових культур - 25, цукрового буряка - 39, картоплі - 27 та кормових -25 .

Застосовуючи встановлені показники окупності затрат, урожайності культур, бали часткової оцінки земель для кожного господарства, в умовах Лісостепової зони Західних областей України пропонується виділяти наступні земельні масиви:

1. масиви земель для вирощування всіх сільськогосподарських культур;

1. масиви земель придатні для вирощування зернових, цукрового буряка, картоплі;

2. масиви земель придатні для вирощування всіх сільськогосподарських культур, картоплі;

3. масиви земель придатних під посіви зернових культур;

4. землі обмеженої придатності земель під посів зернових культур.

При виділенні таких груп земель допускає переміщення посівів із однієї групи в іншу але в структурі посівних площ питома вага яких встановлюється диференційовано і має бути меншою ніж на землях попередніх груп.

Виходячи 3 цього, оптимальну вагу посівів культур у кожній групі в залежності від наявності площі екологічно придатних земель для їх вирощування можна визначити застосувавши формулу:

$$
\text { Voп }=\frac{V \times P n p}{P_{3 a 2}}
$$


Де Vоп - оптимальна питома вага посівів культур;

$\mathrm{V}$ - питома вага посівів культур, прийнята в цілому по господарству, \%

Рпр - виділена площа ріллі в масиві, екологічно придатна для вирощування даної культури, \%;

Рзаг - загальна посівна площа екологічно придатних по господарству земель для вирощування даної культури, \%.

Вирішивши питання формування земельних масивів необхідно звернути увагу на вдосконалення сівозмін та ефективність вирощування відповідних культур в цих масивах, яка залежить від розмірів матеріально-грошових затрат на один центнер продукції. Одержання однакової кількості продукції з одного гектара посівів на землях різної якості супроводжується різною величиною затрат. В зв'язку 3 цим, для створення інвестиційної привабливості сільськогосподарських підприємств які мають різні за якістю грунти, необхідно проаналізувати де доцільно вирощувати культуру - на земельних угіддях кращих в екологічному відношення землях, займаючи при цьому мінімально необхідну площу, чи на гірших грунтах , займаючи більшу площу.

Для оцінки варіантів розміщення посівів сільськогосподарських культур на грунтах різної якості рекомендується визначати і співставити розмір чистого доходу відповідної продукції з одиниці площі. Приріст чистого доходу буде характеризуватися ефективністю використання тої чи іншої продукції.

Розмір чистого доходу на вирощування одної і тої ж культури на землях різної якості не одинаків і визначається як різниця вартості валової продукції і затрат (ЧД = ВП - 3). Якщо виробник ставитиме завдання планування по виробництву і продажу конкретної продукції, то в структурі чистого доходу величина валової продукції потребує різної величини посівної площі на різних за якістю землях. яка співставляється у вигляді кадастрової (умовної) площі через бали оцінки землі. В цьому випадку посівна площа (P) на гірших землях повинна бути більшою, в залежності від різниці в балах оцінки земель. Відповідно, для одержання запланованої величини валової продукції на кращих землях необхідну посівну площу позначимо Рк, а на гірших - Рг, дорівнює: 


$$
\mathrm{P}_{\Gamma}=\text { РК } \mathrm{x} \text { БК / БГ }
$$

Враховуючи, чо чистий дохід становить ЧД $=$ ВП -3 , а валова в даному випадку на кращих і гірших землях повинна бути однаковою $(\mathrm{BПг}=$ ВПк), його величина на землях:

$$
\begin{aligned}
& \text { - кращої якості складе ЧДк = ВП - Зк } \\
& \text { - гіршої якості - ЧДг = ВП - Зг }
\end{aligned}
$$

Де ЧД - чистий дохід;

ВП - валова продукція;

Зк - затрати на кращих землях;

Зг - затрати на гірших землях;

Так, як затрати на гірших землях будуть більшими ніж на кращих на величину різниці площі гірших і кращих земель, то і величина чистого доходу зменшиться на цю величину $(\Delta 3)$, тобто, ЧДг = ВП - (Зл $+\Delta 3)$. Отже додатковий чистий дохід дорівнюватиме:

$$
\begin{gathered}
\Delta \text { ЧД = ЧДк - ЧДг }=\text { ВП - Зк }- \text { ВП }+(3 \kappa=\Delta 3)= \\
\text { ВП }-3 \kappa-\text { ВП }+3 \kappa+\Delta 3=\Delta 3
\end{gathered}
$$

Враховуючи те, що в основу формування сільськогосподарських підприємств покладена оренда земельних ділянок, кожна з яких має свій розмір відповідно до якості грунту, планування одержання продукції буде більш нагляднішим i реальним. Користувач-виробник зможе оцінити розміщення окремої культури на відповідних землях за їх якістю.

Отже, механізм формування ландшафтно-екологічних комплексів дасть можливість провести розподіл земель області між природними та антропогенними ландшафтами 3 метою поетапного виводу цих земель із сільськогосподарського обробітку, та запровадження масивів екологічної придатності земель на повноцінних сільськогосподарських угіддях, що забезпечить їх інституційне використання. 


\section{3 Особливості формування лісового біоценозу в культурах сосни звичайної на прикладі ДП «Чигиринське лісове господарство»}

Сучасні природні лісові біоценози пройшли довгий шлях формування й розвитку. Ліс $є$ представником найдревніших типів рослинності, укладеним 3 вищих рослин, предки яких з'явились на землі близько 300-400 млн. років тому. Всі еволюційні процеси органічного світу невіддільно, в єдиному конгломераті, впливали на об'єкти живої й неживої природи, при цьому зазнаючи певних змін, відбувалось становлення кожної складової живої оболонки нашої землі біосфери. Звичайно, царству рослин тут відведена неабияка роль, оскільки, саме автотрофи зуміли синтезувати органічні речовини з неорганічних, при цьому виділяючи кисень, що в подальшому дало поштовх для формування інших форм життя і сучасного біорізноманіття.

Ліс - складне утворення інтегрованих в єдину складну систему великої кількості різноманітних рослин та інших живих істот, які сильно різняться за своїми розмірами, будовою, способом розмноження, типом харчування. Дерева як весь флористичний склад в лісі в результаті взаємовідносин між собою, здійснюють взаємний вплив. Звідси, ліс насить назву рослинного угрупування, або фітоценоз.

Кожному типу лісу властивий певний набір лісових рослин, який відповідає тим чи іншим природним умовам. Звідси, у складі лісу можна знайти тих представників фауни, які пристосовані, крім сумісного існування, до певних грунтово-кліматичних факторів. Особливо яскраво це можна спостерігати на невеликих рівнинних просторах, зокрема на території лісництв.

В межах України надзвичайно поширеними є хвойні ліси, які займають другу позицію після листяних лісів. Особливої уваги на території України заслуговують соснові ліси - угруповання звичайнососнових, кримськососнових, кохососнових, піцундськососнових та європейськокедрових лісів. Найбільш поширеними $є$ угруповання звичайнососнових лісів, які відзначаються низкою особливостей: основним лісотвірним видом $є$ сосна звичайна; iii лісові 
угруповання характеризуються високою пластичністю та едифікаторною адаптивністю; досить широка популяційна територія едифікатора стали поштовхом до його кліматичної, рельєфної й грунтової неоднорідності; спостерігається значна синтаксономічна різноманітність. На території України сосні відводиться почесне місце. Зокрема, фактично існує 17 видів, 3 яких в культурі 11, найбільш розповсюджена сосна звичайна (Pinus sylvestris L.). Звичайнососнові ліси (Pineta sylvestris) різноманітні за флористичним складом, таксаційними даними та ценотичними особливостями [50, с. 42].

Формування соснових борів на території Черкаської області зумовлено іiі клімато-географічними умовами: за цими ознаками вона поділяється на дві великі частини - лівобережну та правобережну. Остання відноситься до Придніпровської височин, де можна спостерігати активні ерозійні процеси. Наявність глибоких ярів пояснюється різницею абсолютних відміток рельєфу, що набуває гірського характеру. Такі явища сприяли утворенню Канівських гір та Мошногірського кряжу. На Лівобережній частині наявна Придніпровська низовина, де місцями розміщена горбиста, заболочена рівнина.

На формування літосферних відкладів сучасної території області в процесі геологічних циклів впливали магматичні породи докембрійського періоду Українського кристалічного щита, також, на згадані процеси здійснювали достатній ефект осадові гірські породи палеозойської, мезозойської ери (глини, пісковики, мергелі). Продукти докембрійського періоду з’являються на верхніх відкладах Правобережної частини по берегах річок. Як свідчать наукові дослідження, у мезозойску і кайнозойску еру тут знаходилось море. У тріасовий період утворились різнозернисті піскові утворення з включеннями глиняного походження, а також залишків вапняків. На території Канівських гір часто зустрічаються відкладення піскових структур, глини темного сірого забарвлення, алевроліти i, звичайно, можна спостерігати нашарування пісковиків та вапняних порід юрського періоду, що відшаровуються на підвищеннях ярів і балок. Утворення періоду палеогену і неогену зустрічаються локально на Правобережжі. На кристалічних породах Українського щита 
знаходяться піщано-глинисті породи і вапняки. Льодовики, що відступили 12 тисяч років по тому, залишили піщано-глинисті опади, суглинки, лес. В тому числі на території області поширені льодовикові і водно-льодовикові відкладення, які під впливом геобіологічних процесів піддавались процесам ерозії [51].

Притясминські бори Черкаської області привертають увагу своїм походженням. Ще у 17 столітті на місці нинішнього Чигиринського лісгоспу можна було спостерігати сосново-дубові ліси. Це місце слугувало схованкою для гайдамак. За свідченням істориків, з метою знищення повстанців польські конфедерати випалювали прадавні ліси. Близько ста років по тому земські упорядники та науковці запроваджували новітні доробки 3 метою припинення сипучих пісків. Поруч із сосною звичайною висаджували до 9\% берези, бузини червоної, в’яза дрібнолистого, смородини золотистої. Однак, весняні суховії знищували саджанці, завіювали їх піском, пошкоджували бруньки. Звідси 3'явилось рішення: спочатку висадити шелюгу з метою закріплення та зупинення наступу пісків. По тому, через декілька років, між рядами шелюги насаджували саджанці сосни звичайної. Шелюгу спочатку зрубували на пні, яка потім сама гинула в тіні сосни. Застосовуючи сучасні підходи, використовуючи практику й досвід інших, працівники Чигиринського господарства всього за 10 років створили зелене море на місці колишньої рухомої пустелі [52].

Соснові ліси - світлохвойні ліси, що в своєму складі мають домінантний вид сосну звичайну в деревному ярусі. Такі деревостани найбільш поширені в лісовій і лісостеповій зонах помірного і субтропічних поясів, а також в гірському поясі. Представники цього виду активно виростають на супісках, пісках, вапняках, доломітах, торф'яних болотах. Соснові масиви виконують компенсаторну функцію щодо утримання грунтових вод та збільшенні врожаїв сільськогосподарських культур у зонах посушливого клімату, відіграють значну роль в зміцненні піщаних грунтів, ярів і гірських схилів, в захисті від снігових лавин та селевих потоків. 
Крони сосен вирізняються достатньою світлопроникністю, вони ажурні, пропускають багато сонця. Звідси, в сосновому лісі можна спостерігати слабке затінення, рослини нижніх ярусів досить добре освітлені. Тут, крім достатнього освітлення, і набагато сухіше. Під кронами сосен в різних грунтово-кліматичних умовах панують різні види рослини. На дуже сухих і бідних піщаних грунтах під деревами формується суцільний білий покрив із епіфітних кущових лишайників. На грунтах вологих, але збіднених і кислих, розвиваються густі зарості чорниці. Там, де грунт має помірну вологість і достатньо поживних речовин, розростається кислиця. На грунті в сосняках часто можна спостерігати суцільний моховий ярус, на тлі якого розвиваються характерні для всіх хвойних лісів мохи, трави і кущі.

Сосна звичайна - Pinus sylvestris L., родина соснові (Pinaceae). Латинська назва означає слово ріn - «скеля», що відображає найбільш улюблені місця сосни, яка часто вибирає скелясті обриви, схили гір. Слово sylvestris означає «лісовий». Походить це слово $з$ давнини, за припущеннями, бере початок від слова sop - сік, через соковитості, смолистості дерева. Сосна - одна з найбільш поширених деревних порід, їі деревостани утворюють чисті і змішані масиви на великих просторах. Pinus sylvestris - довговічний вид, що доживає до 300-400 років. Завдячуючи досить розгалуженій кореневій системі і численними якірними коренями, розташованими збоку від проекції стовбура, вона дуже вітростійка.

Сосна світлолюбна рослина. Характерною властивістю є мала густота крони, а також периферичне (на кінцях гілок і уздовж поверхні крони) розташування хвої, що покриває пагони останніх 2-3 років.

Стовбур сосни досить швидко очищається від сучків. Однак, соснові молодняки густі і тінисті, під ними створюється навіть мертвий покрив. Завдяки своїй малій вимогливості до тепла, ареал сосни поширюється далеко на північ, до кордонів тундри і в гори до альпійських галявин. Цю породу відносять до нестійкого, континентального клімату, як доказ цього іiі можна зустріти в географічних районах з широкою амплітудою температур, з суворою зимою і 
жарким літом. Лише молоді сходи і однорічні сіянці сосни страждають від сонячних опіків.

Сосна звичайна посухостійка порода. Про приналежність її до ксерофітів, свідчить досить розгалужена коренева система, що обумовлює її здатність брати вологу з великого обсягу товщі грунту. Можна сказати, що сосна подвійний ксерофіт: вона мало споживає вологи і вміє їі знаходити в умовах грунтової посухи за допомогою достатньо розгалуженої кореневої системи. Сосна маловимоглива до багатства грунту, оліготроф. Як доказ цієї властивості, вказують наступні ознаки: задовільно зростає на найбідніших піщаних грунтах, заселяє скелясті субстрати і піски, позбавлені нормального грунту.

Сосна - вид швидкоростучий. Фіксований приріст у висоту максимальний в віці 15-25 років, в південних районах - ще раніше. В сходів і саджанців низька чутливість до приморозків. Плодоношення настає рано: на просторі - у віці 1520 років, в насадженнях - в 50-60 років.

В сосни анемохорний тип запилення. Насіння іï крилате, висипається 3 шишок взимку. Воно може бути перенесене вітром на великі відстані, дерево 3 верхнього ярусу дає понад 100 шишок з 4500-5000 насінинами, а насадження на 1 га - понад мільйон насінин. Роль звичайної сосни в лісі подвійна. Цей вид серед перших розповсюджується на відкриті простори. Водночас, вона і основний лісоутворювач, здатний створювати свої довговічні насадження. Така властивість ऑї, як світлолюбність сприяє створенню змішаних насаджень, оскільки під наметом вікового соснового деревостану можуть проростати інші, більш тіньовитривалі види. Згодом вони можуть увійти до складу I ярусу, зайняти в ньому положення нарівні з сосною або навіть витіснити їі.

Сосна дає хорошу деревину, використовується для виробництва целюлози, 3 живиці добувають каніфоль і скипидар, з кори - дубильні речовини [53, 54].

Таким чином, виходячи 3 усього викладеного, науковий інтерес до соснових лісів залишається актуальним i, враховуючі всі вищезгадані властивості, можна активно їх використовувати в галузі розвитку сучасних технологій лісових культур та в подальшому розвитку лісівничої справи. 
Враховуючи, що тільки починає розвиватися синтаксономічний напрямок досліджень, недостатньо опрацьовані питання комплексного використання біологічного потенціалу соснових борів на Притясминських терасах 3 погляду сталого розвитку, відчувається брак табличного матеріалу для таксації деревостанів, що вимагає детальнішого їх вивчення та систематизації.

У зв’язку з цим важливе значення мають дослідження штучних лісів за участю сосни звичайної, без яких складно уявити регіональне природокористування і створення науково обгрунтованих підходів в системі наближеного до природи лісівництва.

Особливістю соснових борів на Притясминських пісках є їх рукотворне походження, оскільки під впливом антропогенного втручання вони зазнали радикальних змін. Ці бори відносяться до інтразональних природних лісових формацій Середнього Подніпров'я, де протягом багатьох років формувались деревостани сосни звичайної (Pinus sylvestris L.). Запровадження на практиці відповідних лісокультурних заходів, в напрямку штучного відтворення насаджень у соснових борах, дало позитивний результат на формування лісостанів. Однак, враховуючи відповідне значення лісів прирічкових екосистем, їх багатофункціональність вони й надалі потребують детального вивчення, оскільки бракує їх описів в лісівничій літературі.

Зрозуміло, що різноманітність рельєфу місцевості та окремі урочища відповідають певним лісорослинним умовам та мають подібність чи відмінності, що урізноманітнює якісні характеристики насаджень. Як відмічають ряд дослідників Бельгард А.Л. (1960), Герушинський 3.Ю. (1996), Гордієнко М.I. (2002), Краснов В.П. (2009) у повоєнні роки в нашій країні проведено значні роботи із залісення піщаних земель, ярів і балок, внаслідок чого на десятках тисяч гектарів з'явилися нові ліси та багаторічні насадження там, де їх не було впродовж сотень років $[55,56,57,54,58]$. До вищевказаних об'єктів відносяться і Притясминські піски.

Процес формування лісового біоценозу в культурах сосни звичайної створених на горбистих пісках, та їх типологічну оцінку досліджував 
В.В. Шлапак (2013), [59], зокрема, лісівничо-екологічні властивості Pinus sylvestris та особливості їі відтворення на Притясминських пісках.

В.П. Шлапак (2007) в своїх доробках висвітлював питання потенційних можливостей вирощування культур сосни в умовах пристепових борів на прикладі культур створених на початку минулого століття проф. 3.С. Голов'янком [60].

Особливості антропогенної трансформації трав'яних фітоценозів лісових екосистем Черкаського регіону, зокрема, Черкаського бору та Чигиринського соснового масиву вивчав Н.В. Мірошник (2016) [61].

Характеристику лісової рослинності за участю Daphne cneorum L. у межах Черкасько-Чигиринського геоботанічного району досліджувала Ю.Ю. Гайова (2013) [62].

Суспільно-економічне значення соснових насаджень на території України спонукало науковців різних напрямів до їх вивчення. Зокрема, свої наукові доробки їм присвятили 3.С. Голов'янко (1904, 1940), А.П. Тольський (1905, 1940), П.М. Погребняк $(1955,1971)$, П.П. Ізюмський (1987), I.I. Гордієнко (1969), Т.Т. Говорова (1965), А.Г. Гаєль (1952, 1965), В.М. Виноградов (1960, 1966), М.М. Дрюченко (1960), В.К. М'якушко (1978), .І. Редько (1980, 1990), М.I. Гордієнко (1979， 1992，2002，2007)， П.I. Мороз (2000，2006) та інші дослідники. Однак, їх праці висвітлювали проблеми формування соснових лісів рівнинної частини України, зокрема в Черкаському та Ізюмському борах і тільки деякою мірою вони дотичні Чигиринського бору, який входить до Притясминських борів, площею біля 23 тис. га, а враховуючи землі непридатні до сільськогосподарського використання, кар'єри, яри та балки, деяких заплав річки Тясмин площа під заліснення може бути збільшена до 100 тис. га [63].

Проте, вивчення особливостей формування соснових борів на Притясминських пісках на території Черкаської області потребують детальнішого вивчення. Фітоценотичний склад природної i культурної рослинності й визначають актуальність нашого дослідження. 
Вивчення та дослідження характеристик соснових лісів ДП «Чигиринське лісове господарство» грунтувалось на загальноприйнятих лісівничих та флористичних методиках. Для складання геоботанічних описів Притясминських фітоценозів та вивчення еколого-біологічних властивостей соснових борів проводилися маршрутні обстеження з описами та використанням довідкової літератури, насамперед, визначників [64, 65].

3 метою оцінювання ступеня відповідності сформованого фітоценозу умовам місцезростання ми використовували методику Й. Матушкевича та його визначник рослинних асоціацій, де за основу взято флористичну методику Браун-Бланке [66]. Згідно з цією методикою, Притясминські бори утворюють фітоценотичні групи хвойних бореальних лісів з досить рясно поширеним покривом за участі моху на території рівнинної та гірської частини України [66]. Їх синтаксономія є наступною:

VACCINIO-PICEETEA Br.-B1. 1939[67].

Cladonio-Vaccinietalia Kiell.-Lund 1967[67].

Dicrano-Pinion Libb. 1933[67].

Dicrano-Pinenion Seibert in Oberd. (ed.) 1992[67].

Cladonio-Pinetum Juraszek 1927[67].

Peucedano-Pinetum W. Mat. (1962) 1973[67].

Leucobryo-Pinetum Mat. (1962) 1973[67].

Molinio (caeruleae)-Pinetum W. Mat. et J. Mat. 1973[67].

Querco roboris-Pinetum (W. Mat. 1981) J. Mat. 1988[67].

Serratulo-Pinetum (W. Mat. 1981) J. Mat. 1988 [67].

Festuco ovinae-Pinetum Kobendza 1930[67].

Piceo-Vaccinienion uliginosi Seibert in Oberd. (ed.) 1992[67].

Vaccinio uliginosi-Betuletum pubescentis Libbert 1933[67].

Vaccinio uliginosi-Pinetum Kleist 1929[67].

Calamagrostio villosae-Pinetum Staszk. 1958 [67].

Vaccinio- Piceetalia Br.-B1. 1939[67].

Piceion abietis Pawt. et all. 1928[67]. 
Vaccinio-Abietenion Oberd. 1962[67].

Abietetum polonicum (Dziub. 1928) Br.-B1. Et Vlieg. 1939 [67].

Vaccinio-Piceenion Oberd. 1957[67].

Querco roboris-Piceetum (W. Mat. 1952) W. Mat. Et Poak. 1955 [67].

Згідно з дослідженнями Й. Матушкевича [66], сосновим лісам властивий набір характерних тільки для них видів, які утворюють комплекси характерних і діагностичних видів різного рангу (табл. 1).

Таблиця 1

Діагностичні види соснових лісів

\begin{tabular}{|c|c|}
\hline Українська назва виду & Латинська назва виду \\
\hline 1 & 2 \\
\hline Характерні види класу хвойних лісів - Vaccinio-Piceetea \\
\hline Дуб звичайний & Quercus robur \\
\hline Береза повисла & Betula pendula \\
\hline Груша звичайна & Pyrus communis \\
\hline Чорниця & Vaccinium myrtillus \\
\hline Брусниця & Vaccinium vitis-idea \\
\hline Верес & Calluna vulgaris \\
\hline Веснянка дволиста & Majanthenum bifolium \\
\hline Нечуйвітер волохатий & Hieracium pilosella \\
\hline Мітлиця тонка & Agrostis tenuis \\
\hline Чебрець повзучий & Thymus serpyllum \\
\hline Плевроцій Шребера & Pleurozium schreberi \\
\hline Дікран хвилястий & Dicranum polysetum \\
\hline Гілокомій блискучий & Hylocomium splendens \\
\hline Рунянка ялівцева & Polytrichum juniperinum \\
\hline Характерні види порядку соснових лісів Cladonio-Vaccinietalia \\
\hline Кладоніч оленяча & Cladonia rangiferina \\
\hline Дікран багатоніжковий & Dicranum polysetum \\
\hline Сосна звичайна & Pinus sylvestris \\
\hline Характерні види союзу соснових лісів Dicrano-Pinion \\
\hline Зимолюбка зонтична & Chimaphila umbellata \\
\hline
\end{tabular}


Продовження табл. 1

\begin{tabular}{|c|c|}
\hline 1 & 2 \\
\hline Конвалія звичайна & Convallaria majalis \\
\hline Щучка звивиста & Deschampsia flexuosa \\
\hline Діфазіаструм сплюснутий & Diphasiastrum complanatum \\
\hline Щитник австрійський & Dryopteris austriaca \\
\hline Гіпнум кипарисовидний & Hypnum cupressiforme \\
\hline Під ялинник звичайний & Hypopitys monotropa \\
\hline Ялівець звичайний & Juniperus communis \\
\hline Багно звичайне & Ledum palustre \\
\hline Левкобрій сизий & Leucobryum glaucum \\
\hline Плаун колючий & Lycopodium annotinum \\
\hline Ортилія однобока & Orthilia secunda \\
\hline Зозулин льон звичайний & Polytrichum commune \\
\hline Грушанка кругло листа & Pyrola chlorantha \\
\hline Золотушник звичайний & Solidago virgaurea \\
\hline
\end{tabular}

Для проведення досліджень, які включали флористичні описи, насамперед, необхідно було правильно підібрати та визначити мінімальні площі дослідних ділянок для здійснення опису, фіксації повного видового складу фітоценозу 3 урахуванням сезонних явищ. Також, необхідно було визначити застосування відповідних шкал для здійснення кількісних та якісних характеристик видів, діагностика таблиць. У соснових фітоценозах видовий склад ми констатували здійснюючи два описи, в різний вегетаційний період з інтервалом в один місяць - у момент появи найбільшої кількості видів. А саме - це середина травня та друга половина червня.

Як констатував Ф. Фукарек, мінімальна площа, на якій проявляються характерні для фітоценозу ценотичні взаємозв'язки, для лісового типу рослинності складає 500-2500 м² - ліси, деревний та кущовий яруси, 100-400 м² - трав'яні яруси, 1-4 м² - ярус мохів, 0,1-1 м² - угруповання лишайників [68]. Для вивчення необхідних параметрів соснових лісів дослідні ділянки фіксувались 
розміром 50х50 м, в межах яких закладалися дослідні площі розміром 2х2 м, для дослідження трав’яної рослинності.

Для опису ярусності фітоценозу використано систему позначок: деревний ярус - A, чагарниковий - B, трав'яний - C, мохово-лишайниковий - D. Виділяли також під’яруси: А1, C1.

У фітоценотичних описах для кожного виду наводили його кількісні (відсоток покриття, рясність, частота трапляння, постійність) та якісні характеристики (життєва форма, товариськість, феностан, життєвість). Кількісні характеристики видів у фітоценозі виражали 7-ступеневою комбінованою шкалою Ж. Браун-Бланке, яка водночас відображає рясність та відсоток вкриття виду на ділянці: 5 - кількість особин довільна, вкриття $>75 \%$ поверхні ділянки опису; 4 - кількість особин довільна, вкриття 50-75\%; 3 - кількість особин довільна, вкриття 25-50\%; 2 - кількість особин велика, вкриття 5-25\%; 1 кількість представників виду велика (від 5 до 50), площа покриття біля 5\%; + кількість особин мала (від 2 до 5), вкриття $<5 \%$; - одинична особина. Така шкала ступенями 5, 4, 3 і 2 краще характеризує процент вкриття виду, а ступенями 1, +, r - кількість особин. Вона дуже зручна для застосування у природі, на відміну від десятиступеневої, яку застосовували раніше [54,70,69].

Для визначення рясності користувались шкалою О. Друде: soc (sociales) (рясно) вид суцільно вкриває площу надземними органами; cop3 (copiosae)(розсіяно) надземні частини вкривають від 1/2 до 3/4 площі; cop2 - вегетативна частини фітоценозів вкривають від 1/4 до 1/2 площі; cop1 - (зрідка) вегетативна частини фітоценозів розміщена від 1/20 до 1/4 площі; sp (sparsae) - (рідко) вегетативні частини рослин вкривають менше 1/20 площі; sol (solitariae) (поодиноко) трапляються поодинокі рослини; un (unicum) - одна або дві особини на ділянці фітоценозу. Взята шкала ідентична шкалі рясності за Г.Висоцьким, у первинних описах ми використовували обидві із співставленням позначок: 5 суцільне вкриття даного виду; 4 - вид панує над іншими і займає $>50 \%$ площі; 3 - рясне поширення виду, вкриває 5 - 20\% площі; 2 - помірне поширення виду, 
вкриває 5 - 20\% площі; 1 - слабке поширення виду, вкриває $<5 \%$ площі; р розсіяні особини; $\mathrm{n}$ - поодинокі особини $[54,70,69]$.

Феностан покритонасінних рослин визначали за шкалою В. Альохіна [63,77,87], для спорових iї трохи коригували: - - вегетація до цвітіння; ^ бутонізація; ) - розцвітання; О - масове цвітіння; ( - відцвітання; + - рослина відцвіла, плоди не дозріли; \# - плоди та насінини опадають; - вегетація після плодоношення.

Життєвість, яка відображає рівень пристосування рослини до зовнішніх факторів і є мірою її зони комфорту, визначали за 4-ступеневою шкалою: 1 рослина проходить повний життєвий цикл; 2 - рослина проживає частину своєї онтогенетичної програми, але має досить потужну систему рослинних органів; 3 - рослина існує частину життєвого циклу, наявні мало пристосовані вегетативні органи; 4 - рослина гине після проростання [54, 70, 69].

Трапляння вираховували як відсоток або абсолютну кількість фітоценозів, які включають певний вид.

Постійність за А. Скамоні (частота трапляння виду в межах певного синтаксону), визначали як відсоток фітоценозів, у яких виступає вид [52]. Цей показник визначається за 5-ступеневою шкалою класів: I $-<10 \%$ фітоценозів містять вид; II - 10-30\% фітоценозів містять вид; III - 30-50\% фітоценозів містять вид; IV - 50-60\% фітоценозів містять вид; V - > 60\% фітоценозів містять вид.

Для виявлення взаємозв'язків та подібності між описами ми використовували коефіцієнт подібності Жаккара [70, 69]:

$$
K_{j}=\frac{c}{a+b-c},
$$

де $a$ - кількість видів в першому описі;

$b$ - кількість видів в другому описі;

$c$ - кількість спільних видів у двох описах.

Місцерозташування державної установи “Чигиринське лісове господарство", що знаходить в підпорядкуванні Черкаського обласного 
управління лісового та мисливського господарства, інша назва ДП “Чигиринський лісгосп” відповідає такому географічному положенню, а саме: північно-східній частині Черкаської області на межі Чигиринського i Черкаського адміністративних районів [71]. В структурі лісгоспу налічується шість лісництв. Адміністративно-господарська структура та загальна площа подана у табл. 2.

Таблиця 2

Територіально-адміністративна організація та територія ДП “Чигиринське лісове господарство”

\begin{tabular}{|c|c|c|}
\hline $\begin{array}{c}\text { Назва представництв, } \\
\text { розташування контор }\end{array}$ & $\begin{array}{c}\text { Адміністративно- } \\
\text { господарські райони }\end{array}$ & $\begin{array}{c}\text { Територія, } \\
\text { га }\end{array}$ \\
\hline 1 & 2 & 5628,6 \\
\hline $\begin{array}{c}\text { Чорнявське, } \\
\text { кв. } 36 \text { вид. 44, с. Чорнявка }\end{array}$ & Черкаський & 5327,1 \\
\hline Трушівське,кв. 19 вид. 4 & Чигиринський & 4043,6 \\
\hline $\begin{array}{c}\text { Чигиринське, } \\
\text { кв. 43 вид. } 1, \text { м. Чигирин }\end{array}$ & Чигиринський & 6192,9 \\
\hline $\begin{array}{c}\text { Матвіївське, } \\
\text { кв. } 59 \text { вид. 5, с. Матвіївка }\end{array}$ & Чигиринський & 5455,3 \\
\hline $\begin{array}{c}\text { Яничанське } \\
\text { кв. } 21 \text { вид.20, с. Іванівка }\end{array}$ & Чигиринський & 3313,3 \\
\hline Богданівське, с. Стецівка & Чигиринський & 29960,8 \\
\hline Всього по лісгоспу: & Черкаський & 5628,6 \\
\hline в т. ч. за адмінрайонами & Чигиринський & 24332,2 \\
\hline
\end{tabular}

ДП «Чигиринський лісгосп», як самостійна адміністративно господарська одиниця почав своє існування в 1958 р. відповідно до нормативно-правових актів Міністерства сільського господарства УРСР № 271 від 05.04.1958 р. і носив назву «Чигиринський степовий лісгосп» [71]. 
До складу «Чигиринського степового лісгоспу» входило п’ять лісництв: Чорнявське, Худоліївське (тепер Трушівське), Чигиринське, Матвіївське і Яничанське, а також урочища: Гущівське, Попово-Берестове, Чум'яне, Розсошинське, частина Чигиринського лісництва прийнятого від Олександрійського лісгоспу Кіровоградської області, а також Чорнявське лісництво Черкаського лісгоспу. Крім того, до складу лісгоспу увійшли захисні смуги вздовж Кременчуцького водосховища і Притясмянські піски [71].

На підставі постанови Ради Міністрів УРСР в 1959 році від 30.11.1959 р. № 134 «Чигиринський степовий лісгосп» був реорганізований в «Чигиринський лісгоспзаг» [75]. В період розбудови державної незалежності в 1991 році на реалізацію нормативних документів Міністерства лісового господарства України від 31.10.1991 р. № 133 на території «Чигиринського лісгоспзагу» був організований «Чигиринський державний лісгосп», до складу якого входили Чорнявське, Трушівське, Чигиринське, Матвіївське, Яничанське та Богданівське лісництво, яке було організоване в 2006 році переважно на основі земель лісового фонду колишніх сільськогосподарських підприємств, які були передані «Чигиринському лісгоспу» для охорони та ведення лісового господарства згідно з рішенням Черкаської обласної ради № 22-26 від 30.11.2001 року. Контора ДП «Чигиринське лісове господарство» розташована у м. Чигирин (рис. 2.1) [71].

Відповідно до районування за лісорослиними умовами місцерозташування лісгоспу належить до Правобережного лісостепу.

Якщо керуватись лісогосподарським розподіленням, то територія лісгоспу перебуває в зоні Дністровсько-Дніпровського лісостепового лісогосподарського округу.

Лісгосп перебуває під впливом природно-кліматичних факторів, які характерні для Південного лісостепу. Зокрема, характерні різкі перепади температур, мала кількість опадів, наявність у весняно-літній період досить великої кількості посушливих днів. 
Стисла інформація, що дає досить об'єктивну оцінку природногеографічних умов, що достатньо впливають на особливості ведення лісового господарства, приведена в таблиці 3.

Поміж кліматичних факторів, що здійснюють небажаний влив на життєві процеси деревних рослин, варто віднести значні коливання температурних показників ранньої весни й пізньої осені. Значні зміни температурного режиму, мала кількість опадів у вигляді дощу, досить велика кількість весняно-літніх спекотних днів. В загальному значенні, природно-кліматичні фактори згаданого лісорослинного району досить позитивно впливають на успішне зростання сосни, дуба, липи, ясеня, кленових, ряду завезених видів та екзотів.

Місцерозташування лісгоспу за типом рельєфу представляє собою територію з наявними глибокими низинами, ярами та байраками. На зіткненні 3 береговою долиною характеризується досить крутими береговими зниженнями. Весь лісовий резерв лісгоспу належить до рівнинних [71].

Таблиця 3

Природно-кліматичні характеристики ДП “Чигиринське лісове господарство” [71]

\begin{tabular}{|c|c|c|c|c|}
\hline $\begin{array}{l}\text { № } \\
\text { п/п }\end{array}$ & $\begin{array}{l}\text { Найменування } \\
\text { показників }\end{array}$ & $\begin{array}{c}\text { Одини } \\
\text { ці } \\
\text { вимірювання }\end{array}$ & $\begin{array}{r}\text { Значен } \\
\text { ня показника }\end{array}$ & Дата \\
\hline 1 & 2 & 3 & 4 & 5 \\
\hline 1. & $\begin{array}{c}\text { Температурні значення } \\
\text { повітря: } \\
\text { - середньорічна } \\
\text { - абсолютна максимальна } \\
\text { - абсолютна мінімальна }\end{array}$ & градус & $\begin{array}{r}7,5 \\
+37 \\
-35\end{array}$ & \\
\hline 2. & Кількість річних опадів & MM & 512 & \\
\hline 3. & Вегетаційний період & дні & 206 & \\
\hline 4. & Пізні весняні заморозки & & & 21.IV \\
\hline 5. & Перші осінні заморозки & & & $10 . \mathrm{X}$ \\
\hline 6. & Середня дата & & & 10-20.XII \\
\hline
\end{tabular}


Продовження табл. 3

\begin{tabular}{|c|c|c|c|c|}
\hline 1 & 2 & 3 & 4 & 5 \\
\hline 7. & Середня дата початку & & & 21.III \\
\hline 8. & $\begin{array}{c}\text { Снігові опади: } \\
\text { товщина } \\
\text { час появи } \\
\text { час сходження у лісі }\end{array}$ & $\mathrm{cm}$ & 20 & $\begin{array}{l}\text { 15. XI } \\
\text { 14. XII } \\
\text { 17. III }\end{array}$ \\
\hline 9. & Товщина промерзання & $\mathrm{cm}$ & 42 & \\
\hline 10. & $\begin{array}{l}\text { Напрямки найбільш } \\
\text { частих вітрів за } \\
\text { Порою року: } \\
\text { Зимовий період } \\
\text { Весняний період } \\
\text { Літній } \\
\text { Осінній }\end{array}$ & румб & $\begin{array}{r}3 \mathrm{x}, \\
\text { Пн3х } \\
\text { Пн3, } \\
\text { ПдСх, } \\
\text { Пд } \\
3 \mathrm{x}, \\
\text { Пн3х, ПдСх }\end{array}$ & \\
\hline 11. & $\begin{array}{l}\text { Середнє значення } \\
\text { швидкості вітрів за порою } \\
\begin{array}{lll}\text { року: } & & \\
& - & \text { зима } \\
& - & \text { весна } \\
& - & \text { літо } \\
& - & \text { осінь }\end{array}\end{array}$ & $\mathrm{M} / \mathrm{c}$ & $\begin{array}{l}4,3 \\
4,1 \\
3,5 \\
4,0\end{array}$ & \\
\hline 12. & $\begin{array}{l}\text { Відносна вологість } \\
\text { повітря (середньорічна) }\end{array}$ & $\%$ & 66 & \\
\hline
\end{tabular}

Проаналізувавши табл. 3, варто відмітити, що в загальному досить комфортний температурний режим, середня кількість надходження вологи, а також рівнинна місцевість даного регіону цілком сприятлива для зростання сосни звичайної (Pynus sylvestrys L.), дуба звичайного (Quercus robur L.), ясеня звичайного (Fraxinus excelsior L.), граба звичайного (Carpinus betulus L.), а також клена гостролистого (Acer platanoides L.) та інших цінних порід. Із факторів, що 
здійснюють деструктивний вплив на морфологічні, фізіологічні та інші життєві процеси лісових біоценозів, варто відзначити різкі зміни температурних режимів у весняно-осінній період.

В центральній частині лісогосподарської території простяглася Притясминська горбиста тераса з еоловими формами рельєфу. Вона має форму гряди, що простяглася вздовж берегової лінії р. Тясмин довжиною біля 50 км, завширшки 1,5-2,5 км від м. Черкаси до м. Чигирин, площею 12,7 тис. га. 3 цієї кількості площі під культури відведено 10,9 тис. га., які свого часу були створені на місці незадернілих пісків.

Переважають ясно-сірі і сірі середньо- та сильнозмиті грунти на схилах балок і підвищених пасом, горбів та останцевих ділянок лесового плато. У хвилястих межиріччях і на пологих схилах поширені сірі й темно-сірі опідзолені слабозмиті грунти, на ділянках плато - чорноземи типові та опідзолені. Грунтоутворюючі породи представлені лесами і лесовидними породами, на окремих ділянках - давніми та сучасними алювіальними відкладами.

На усій території підприємства можна виділити сім основних типів та видів грунтів:

- сірі лісові грунти - 38,7\% [71],

- чорноземи - 6,4\% [71],

- чорноземовидні - $1,4 \%$ [71],

- дернові - 49,6\% [71],

- лучні-0,1\%[71],

- лучно-болотні-0,1\% [71],

- болотні-0,6\% [71].

Деструктивні зміни грунтового середовища на території лісгосппідприємства мають низький відсоток впливу [71].

На грунтовій карті області (рис. 2.2) виділено 12 основних типів грунтів: темно-сірі опідзолені грунти, чорноземи опідзолені, сірі опідзолені грунти, чорноземи глибокі середньогумусні, лучні та чорноземно-лучні грунти, дерново- 
середньо- і слабопідзолисті супіщані і суглинкові грунти, дерново піщані та глинисто-піщані грунти, торфовища низинні та торфово-болотні грунти.

Таким чином, лісові фітоценози здійснюють достатній середовище формуючий вплив. Вирішальне значення при цьому мають еколого-біологічні властивості лісоутворюючих видів. Так, тіньовитривалі види дерев (ялини та ялиці), що утворюють в сприятливих умовах різновікові густі деревостани 3 зімкнутим пологом, сильніше впливають на середовище, ніж світлолюбні (сосна звичайна, модрина сибірська) одновікові рідкостійні деревостани з розріджені пологом. Територія лісгоспу розташована поблизу ріки Дніпро. За рівнем вологості значна частка грунтів належить до свіжих. Відсоток лісових земель 3 надмірним зволоженням складає 2,3 \% площі, вкритих лісовою рослинністю територій (табл.4).

Таблиця 4.

Особливості водотоку на території підприємства [71]

\begin{tabular}{|c|c|c|c|c|}
\hline \multirow{2}{*}{$\begin{array}{l}\text { Назва рік та } \\
\text { водоймищ }\end{array}$} & \multirow{2}{*}{ Куди впадає ріка } & \multirow{2}{*}{$\begin{array}{c}\text { Загальна } \\
\text { довжина, км; } \\
\text { площа } \\
\text { водоймищ, га }\end{array}$} & \multicolumn{2}{|c|}{$\begin{array}{c}\text { Параметри лісових посадок } \\
\text { поблизу берегових ліній річок, } \\
\text { біля озер та водоймищ м }\end{array}$} \\
\hline & & & $\begin{array}{c}\text { згідно } \\
\text { нормативів }\end{array}$ & фактична \\
\hline $\begin{array}{l}\text { Кременчуць } \\
\text { ке водосховище }\end{array}$ & p. Дніпро & 123 & 3000 & 3000 \\
\hline p. Тясмин & p. Дніпро & 62 & 300 & 300 \\
\hline р. Ірклій & р. Тясмин & 24 & 150 & 150 \\
\hline p. Чутка & p. Тясмин & 18 & 150 & 150 \\
\hline
\end{tabular}

До лісгоспу дотична низинна місцевість біля річки р. Тясмин. На ній свого часу були здійснені осушувально-меліоративні роботи й збудована система каналів, що створює необхідний вплив на життєві процеси лісових насаджень Чорнявського, Трушівського, Чигиринського лісництв. Рівень грунтових вод 
змінюється протягом року в низових долинах рік 0,5-3,0 м., та в борових ярусах рельєфу 5-7 м., на підвищеннях 18-26 м.

За результатами досліджень, здійснених у соснових деревостанах ДП «Чигиринське лісове господарство», можна зробити наступні висновки: Цінність лісів із участю чи домінуванням сосни звичайної (Pinus sylvestris L.) на території ДП «Чигиринське лісове господарство» полягає в тому, що вони єдині здатні формувати досить продуктивні насадження на Притясминських борових пісках, закріплюючи рухомі піщані дюни та утримуючи вологу у поверхневих шарах грунту. Особливістю Притясминських борів є їх штучне походження, що $\epsilon$ цікавим та цінним матеріалом для наукових досліджень, подальших пошуків зміцнення їх біоценотичних структур та збільшення їх біорізноманіття. Деревостани сосни звичайної, досліджені нами, є переважно чистими за складом, або 3 невеликою участю інших видів, одно- чи двоярусні, середньо- та високоповнотні, найбільші площі соснових борів у ДП «Чигиринське ЛГ»є у Чигиринському лісництві, де їх частка за площею складає 44\%. Для підвищення біологічної стійкості лісових культур слід вирощувати березу повислу та дуб звичайний. Також, враховуючи, наукові доробки фахівців лісівничої галузі, доречно проводити штучну мікоризацію угідь. Доцільним є також збереження лишайникового вкриття на пісках, оскільки окрім зниження температури грунту, лишайники мають здатність до первинної його мікоризації. 


\section{SECTION 2. ARCHITECTURE AND CONSTRUCTION}

DOI 10.46299/ISG.2021.MONO.TECH.III.2.1

\subsection{Forecasting the volume of construction waste}

Along with the problem of municipal solid waste [72-80], the problem of construction waste is important, the annual volume of which in Ukraine according to the Ministry of Environment is almost 1 million tons. The annual increase in the area occupied by waste is 50 thousand hectares [81]. Construction waste can be widely used in construction to obtain such valuable materials as filler [82] and binder [83-85] for the production of concrete, dry mixes and other building materials $[86,87]$, for the production of building materials from protective properties against electromagnetic radiation $[88,89]$ and static electricity [90], for the manufacture of anode grounding [91]. Many mineral and organic wastes in their chemical composition and technical properties are close to natural raw materials. Also promising is the use of fine metal waste to minimize the volume of immobilized liquid radioactive waste [92]. In world practice, about $90 \%$ of construction waste is recyclable and reusable. Therefore, forecasting the volume of construction waste in different countries from the main parameters of influence in order to develop a strategy for construction waste management is an urgent scientific and technical task.

The sludge-ash-carbonate press concrete proposed in [82] consists of waste stonecutting of carbonate rocks, ash-removal of Ladyzhyn TPP, red sludge of the Mykolayiv Alumina Plant with the addition of Portland cement. In [83] it is shown that the creation of new building materials for multifunctional purposes allows to solve the problem of energy and resource saving relevant for Ukraine. The main way to dispose of red sludge in the production of building materials is its use as a modifying additive to gold-cement binder [84]. In [85], a metal-ash-phosphate binder based on industrial waste was proposed. The technical and economic feasibility of wider use of thermal power plant waste in the production of cement and other building materials is shown in [86]. The article [87] shows that the production of concrete gravel, fine-grained screenings and their reuse is the final stage of a closed cycle of processing of concrete and reinforced 
concrete waste - "wear - export - processing - sale". The use of betel-m (electrically conductive metal-saturated concrete, which uses a special coating of biological protection against ionizing radiation inside buildings and structures) cellular, variotropic and dense structure allows to reduce the level of electromagnetic radiation and thus reduce the risk of radiation [88]. The expediency of using fine powders of SHH-15 steel sludge for the manufacture of a special protective coating against electromagnetic radiation is substantiated in the article [89]. In [90] it is proposed to use a coating of electrically conductive concrete to combat static electricity charges, the manufacturing technology of which is quite simple and does not require expensive materials and special equipment. Betel-m can be used for the manufacture of electrically conductive elements (anode grounding) of anti-corrosion cathodic protection systems of underground engineering networks [91]. The use of metalsaturated concrete as an antistatic coating is proposed in the article [92]. In [93], statistical data on the volume of construction waste production in different countries are presented. The article [94] defines the regression dependence, which describes the dynamics of the generation of construction and demolition waste in Vinnytsia region and allows to predict the mass of this waste. However, the authors did not identify specific mathematical dependences of the volume of construction waste production in different countries of the world on the main parameters of influence, as a result of the analysis of known publications.

Among the parameters on which the volume of construction waste in different countries depends, the following were considered: population density, gross domestic product (GDP) per capita, human development index, average latitude of the country, the values of which are given in table. 1 . In contrast to absolute parameters, relative ones allow comparing countries with different levels of economic development and human potential, population, area and climatic conditions. 
Table 1. Volumes of construction waste production in different countries of the world [93]

\begin{tabular}{|l|c|c|c|c|c|}
\hline \multirow{2}{*}{ Country } & \multirow{2}{*}{$\begin{array}{c}\text { Mass of } \\
\text { construction waste } \\
\text { per capita, } \\
\text { kg/person }\end{array}$} & $\begin{array}{c}\text { Population } \\
\text { density, } \\
\text { persons/ } \\
\mathrm{km}^{2}\end{array}$ & $\begin{array}{c}\text { GDP per } \\
\text { capita, } \\
\text { thousand } \\
\text { person }\end{array}$ & $\begin{array}{c}\text { Human } \\
\text { Develop- } \\
\text { ment Index }\end{array}$ & $\begin{array}{c}\text { Average } \\
\text { latitude, } \\
\text { o }\end{array}$ \\
\cline { 3 - 6 } nrd. 1. & & \\
\hline USA & 374.771 & 31 & 46.954 & 0.95 & 36.94 \\
\hline Great Britain & 450.113 & 247 & 46.432 & 0.942 & 55.38 \\
\hline Korea & 311.688 & 480 & 20.582 & 0.928 & 38.06 \\
\hline Italy & 331.345 & 199.4 & 39.565 & 0.945 & 41.28 \\
\hline Spain & 276.949 & 79.7 & 35.557 & 0.949 & 39.5 \\
\hline Netherlands & 636.574 & 394 & 51.657 & 0.958 & 52.15 \\
\hline Canada & 266.028 & 3.27 & 34.273 & 0.967 & 62.39 \\
\hline Belgium & 610.82 & 318 & 29.814 & 0.948 & 50.83 \\
\hline Portugal & 291.829 & 114 & 22.232 & 0.795 & 39.69 \\
\hline Denmark & 516.707 & 126.4 & 34.7 & 0.952 & 56.18 \\
\hline Greece & 186.567 & 85.3 & 30.661 & 0.947 & 39 \\
\hline Sweden & 195.503 & 21.9 & 55.427 & 0.958 & 62.2 \\
\hline Norway & 281.532 & 12 & 72.306 & 0.968 & 62 \\
\hline Finland & 181.225 & 16 & 36.217 & 0.954 & 64.8 \\
\hline Ukraine & 22.3023 & 76 & 7.532 & 0.786 & 48.38 \\
\hline
\end{tabular}

According to table. 1 using the planning of the experiment using rotatable central compositional planning of the second order using the developed software, protected by the certificate of the work [95] and described in detail in [96], obtained a regression equation that produces construction waste in different countries impact and looks like this [97] 


$$
\begin{aligned}
& m_{C V}=437.8 \frac{G D R}{n_{p}}-37.85 \frac{n_{p}}{S_{c}}-2093 H D I+128.3 L-0.02982 \frac{n_{p}}{S_{c}} \frac{G D R}{n_{p}}+ \\
& +39.29 \frac{n_{p}}{S_{c}} H D I-446.4 \frac{G D R}{n_{p}} H D I-1.082 \frac{G D R}{n_{p}} L+151.8 H D I \cdot L+ \\
& +0.004265\left(\frac{n_{p}}{S_{c}}\right)^{2}+0.5797\left(\frac{G D R}{n_{p}}\right)^{2}+597.1 H D I^{2}-2.283 L^{2}-5106
\end{aligned}
$$

where $m_{C V}-$ mass of construction waste per capita, $\mathrm{kg} /$ person; $n_{p} / S_{c}-$ population density, persons $/ \mathrm{km}^{2} ; G D P / n_{p}-$ GDP per capita, thousand \$/person; $n_{p}$ - the population of the country, persons; $S_{c}$-area of the country, $\mathrm{km}^{2} ; \mathrm{HDI}$ - human development index $(H D I=0 \ldots 1) ; L-$ average latitude, ${ }^{\circ}$ nrd. 1.

According to Student's criterion, all factors, their paired interaction effects, except $n_{p} / S_{c} L$, and quadratic effects were significant, most construction waste in different countries depends on GDP per capita, and least on the human development index.

It is established that according to Fisher's criterion the hypothesis about the adequacy of the regression model (1) can be considered correct with $95 \%$ reliability. The correlation coefficient was 0.99475 , which indicates sufficient reliability of the results.

A comparison of actual and theoretical volumes of construction waste production in different countries of the world, ranked in descending order, is shown in Figure 1. Figure 1 shows that the theoretical production volumes of construction waste in different countries of the world, calculated using the regression model (1), differ slightly from the actual data, which confirms the previously determined sufficient reliability of the dependence, which can be used to develop a strategy for construction waste.

Figure 2 shows the response surfaces of the target function - the volume of construction waste in different countries and their two-dimensional cross-sections in the planes of impact parameters, which can clearly reflect the dependence (1) and the nature of simultaneous influence of several factors on the target function. 


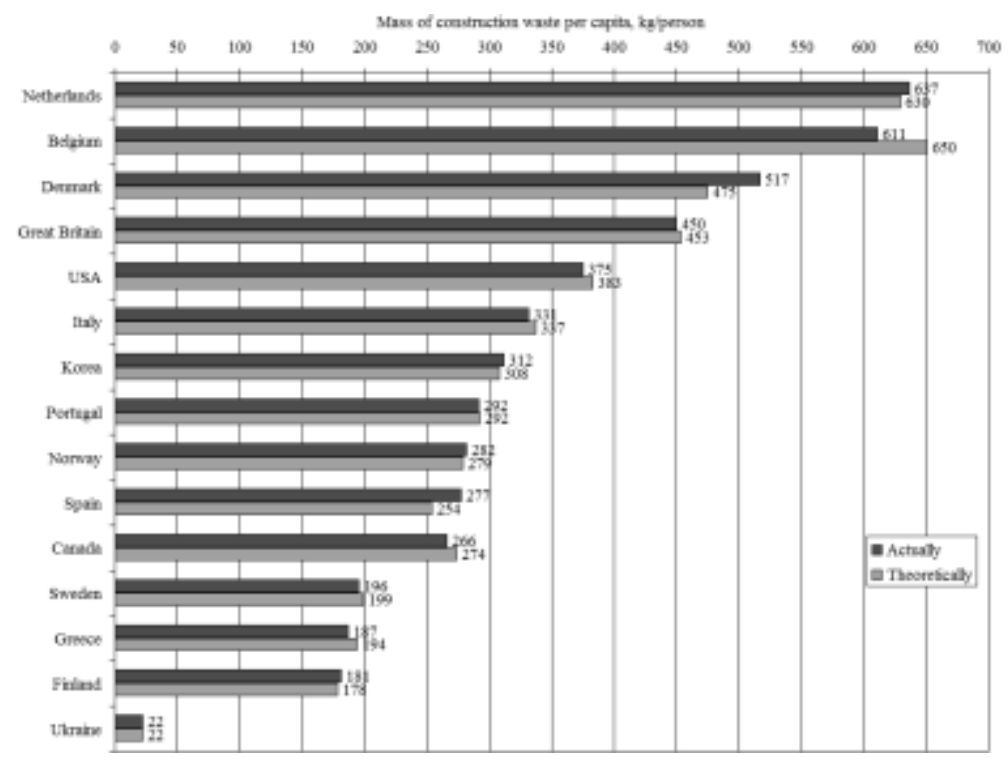

Figure 1. Comparison of actual and theoretical volumes of construction waste in different countries

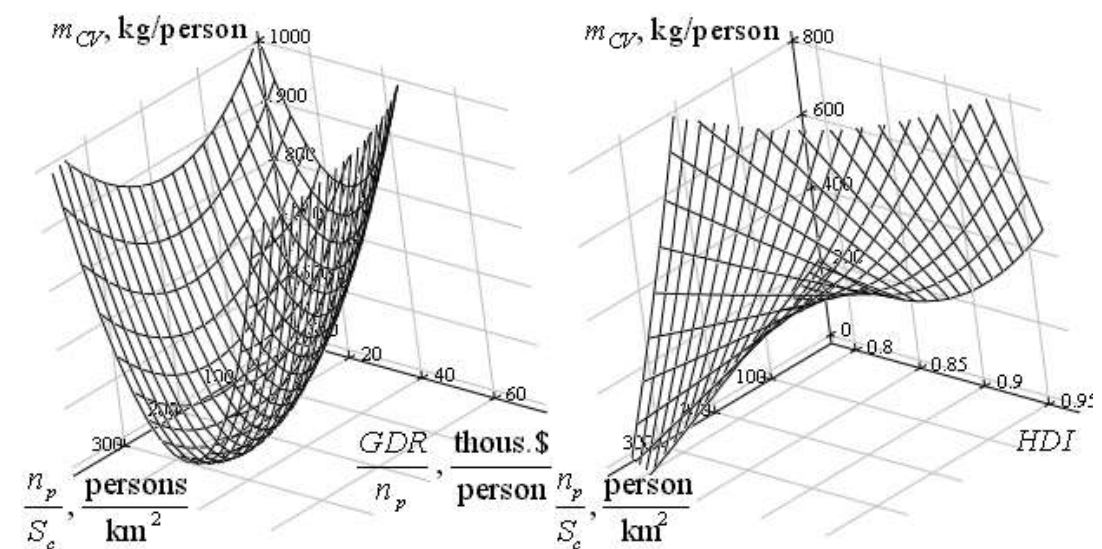

a)

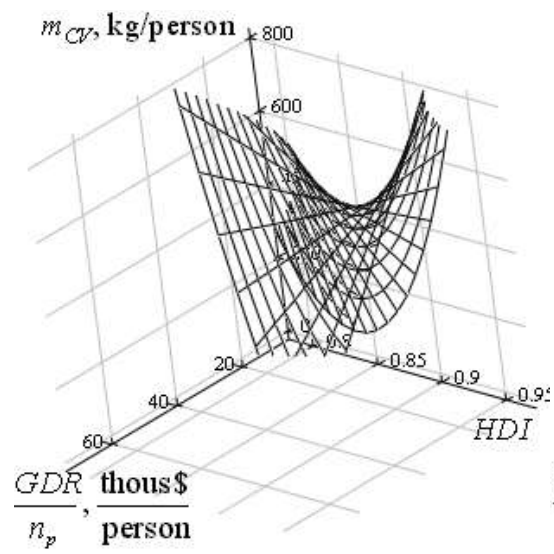

d) b)

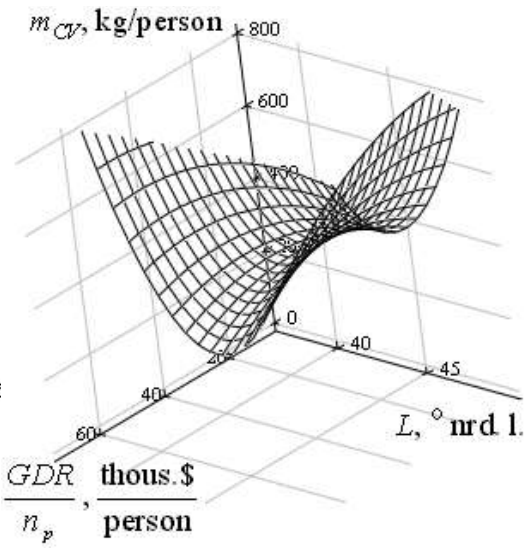

e)

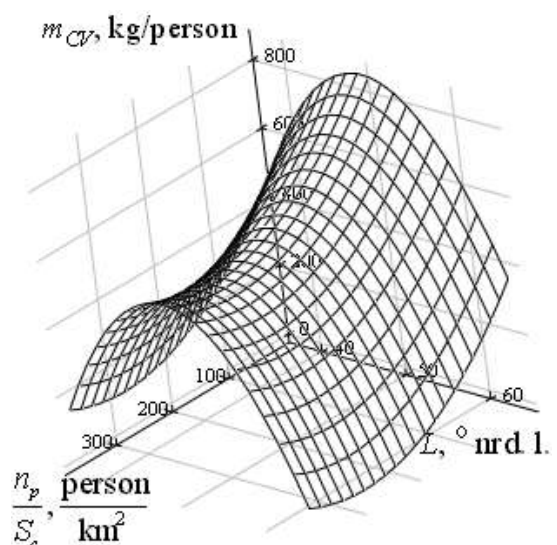

c)

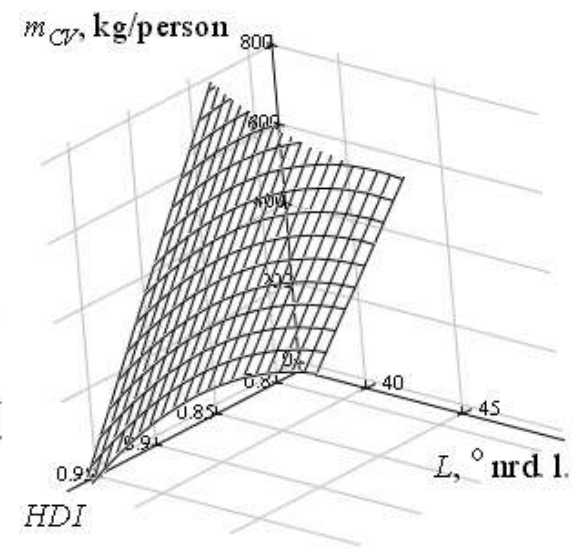

f)

Figure 2. Response surfaces of the target function: a) $m_{C V}=f\left(n_{p} / S_{c}, G D R / n_{p}\right)$; b) $m_{B B}=f\left(n_{p} / S_{c}, H D I\right)$; c) $m_{C V}=f\left(n_{p} / S_{c}, L\right)$; d) $m_{C V}=f\left(G D R / n_{p}, H D I\right)$; e) $m_{C V}=f\left(G D R / n_{p}, L\right)$; f) $m_{C V}=f(H D I, L)$ 


\subsection{Hysteresis curves analysis in the processes of heat and moisture conductivity of textiles' nanosurfaces}

The mechanism of moisture absorption in the general case includes the processes of adsorption, absorption, capillary condensation and is accompanied by swelling of bodies, which is especially characteristic of colloidal capillary-porous materials. Absorption processes predominate in bodies whose structural elements are located quite freely and sorbent molecules can diffuse into the material. Such bodies are contained in a most of museum materials. The adsorption processes on the surface of textile fibers are too small and can be neglected in comparison with the processes of vapor absorption by the inner layers of materials. The crucial role of absorption in the framework of moisture absorption processes can explain the dependence of the hygroscopic properties of dispersed bodies (textiles) on their fiber composition.

One of the most commonly used methods for studying the sorption is adsorption mechanism (the method of sorption-desorption isotherms), which allows to obtain structural characteristics of the adsorbent, differential moisture exchange properties and thermodynamic parameters of mass transfer in the material [98].

The analysis of isotherms of various fiber textile class and threads shows that all of them are similar in the form of curves and have the look characteristic of leading capillary-porous bodies. Hysteresis loops for almost all textiles are observed in the entire range of environment relative humidity. At high values of $\varphi$, the hysteresis is usually explained by the influence of the mechanism of vapors' (moisture) capillary condensation in the micropores, and the width of the loop characterizes the inheterogeneity of the micropores [98].

Thus, the fibers' absorption in materials can be explained by a combination of three processes [99]: linking of water molecules at the active centers of the main and side chains of macromolecules; displacement of water molecules and polymer macromolecules by way of immersion of water molecules in the intermolecular space of the polymer (swelling of the fibers); using the capillary condensation of moisture in the pores of fibers. The first process is decisive at the initial stage of sorption 
$(0<\varphi<20 \%)$, when the filling of the first hydrate layer, which, conditionally, corresponds to monomolecular adsorption. At this stage, normal diffusion is observed (according to Fick's law), and swelling of materials is insignificant. At the second stage $(20<\varphi<80 \%)$. as a result of anomalous diffusion of water molecules, the second and subsequent hydrate layers are filled, and associates (clusters) of water molecules are formed in the intermolecular space, which cause swelling of the polymer. At the third stage, the main is the process of displacement, which can be assumed as corresponding to the polymolecular absorption. Swelling of the fibers in water is limited, the structure is stabilized, and the sorption ends with capillary condensation of moisture in the pores $(80<\varphi<100 \%)$. The moisture content in the fiber when equilibrated at $\varphi \rightarrow 1$ corresponds to the maximum amount of hygroscopic moisture $W_{\text {г }}$.

The process of swelling destroys the structure due to the rupture of weak linkages and the way for sorbate molecules is opened into previously inaccessible cavities.

During desorption, the deformation of the structure is not completely reversible and some water molecules are closed in the pores. Therefore, for some types of fibers, the sorption isotherm is partially irreversible even after prolonged removal of moisture [99]. The textile deformation isotherms $\varepsilon(\varphi)$ referred to in this paper and obtained from the sorption unit simultaneously with the absorption isotherm $W(\varphi)$ (Fig. 1), show that during the moisture desorption, the change in textile size is also partially irreversible and may be the reason that some of water molecules are not desorbed. Sorption isotherms provide information about the sorption properties of the studied fibrous materials, but the vision of these properties will be insufficient and incomplete if the kinetics of moisture sorption processes in these materials is not considered.

In the paper [99], the experimental sorption curves $W(t)$ and the curves of samples' volume $\left(\frac{\Delta V}{V}\right)$ depending on the moisture content were obtained (Fig. 2). The curve $W(t)$, which is given on a logarithmic scale $(\lg W$ from $\lg t)$, shows three rectilinear type segments (Fig. 2, a). The first segment characterizes the diffusion, which corresponds to Fick's law (normal diffusion), the other two segments represent 
anomalous diffusion. In the first segment, the diffusion of water vapor into the polymer corresponds to mono- and polymolecular adsorption, when sorption occurs at active centers and in the free volume of the polymer, and its swelling is negligible. The higher the degree of crystallinity of the polymer, the smaller is the area (in time, at value of $\mathrm{W}$ and $\varphi$ accordingly), which determines the sorption according to Fick's law. For example, this type of sorption for phenyl fibers occurs only up to $W=5,4 \%$ ( $\varphi=52 \%$ ), and up to $W=15,1 \%(\varphi=75 \%)$ for viscose fibers [99].

a)

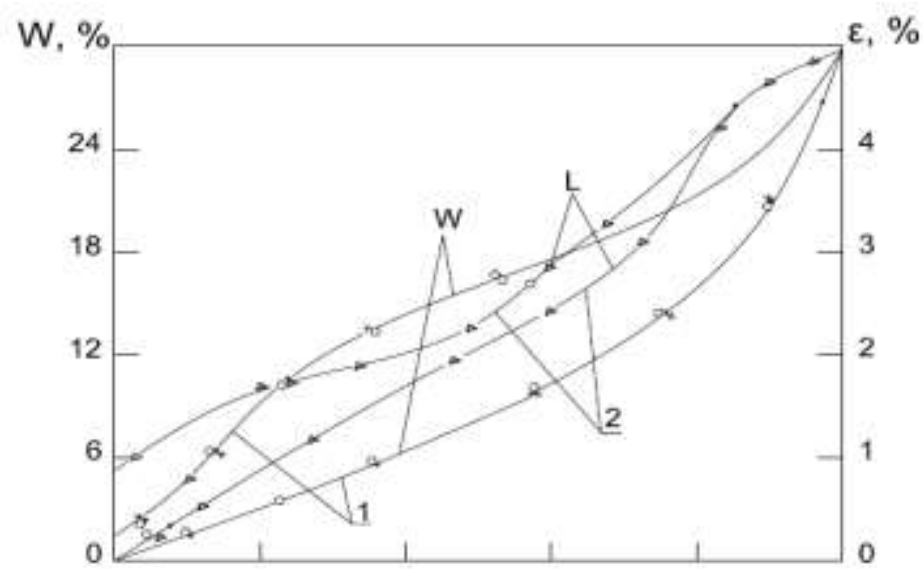

b)

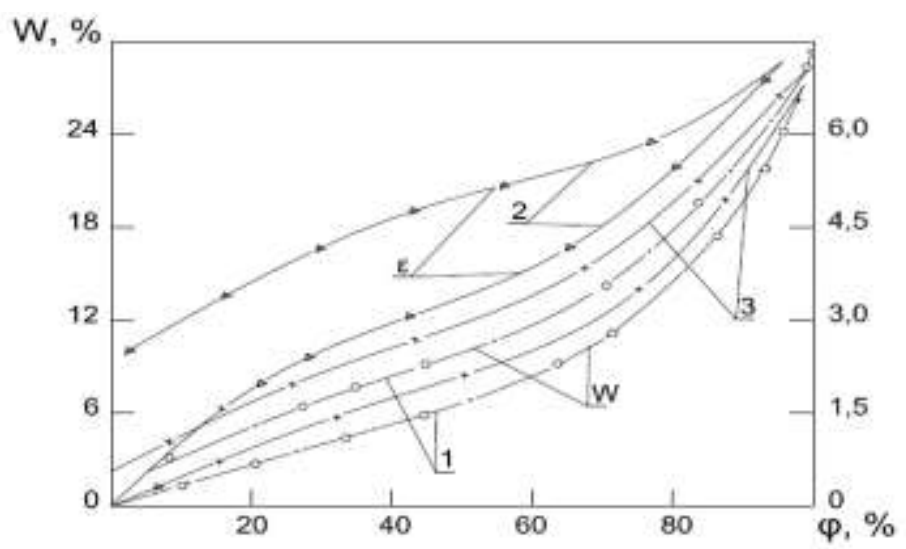

Fig. 1. Isotherms of sorption $W(\varphi)$ and deformation $\varepsilon(\varphi)$ of textile materials: a) viscose threads (1) and fabric (2); b) woolen thread (1) and fabric (2), phenylone (3).

An intense swelling of fibers and threads corresponds to segments with abnormal diffusion. At this stage of sorption, water molecules penetrate into the intermolecular space of the polymer, thus changing the conformation of macromolecules. The effect of increasing the rate of moisture vapor sorption associated with this relaxation process is not observed. The slope of curves $(\operatorname{tg} \alpha=\lg W / \lg t)$ shows less than 0,5 , i.e. the intensity of sorption decreases, which is explained by several reasons. Firstly, this is 
due to a decrease in the sum of the free mixing energy of components and the free energy of the conformation change in stretched macromolecules during the process of swelling. Secondly, macromolecules in considered polar polymers are rather rigid; they intensively form hydrogen linkages and changes of their conformation as a result of plastification are insignificant. Thirdly, the decrease in the rate of sorption with increasing $W$ is also explained by the increased effect of the formation of water molecules' clusters in intermolecular microcavities, and due to this, a part of the water molecules becomes relatively static [100].

a)

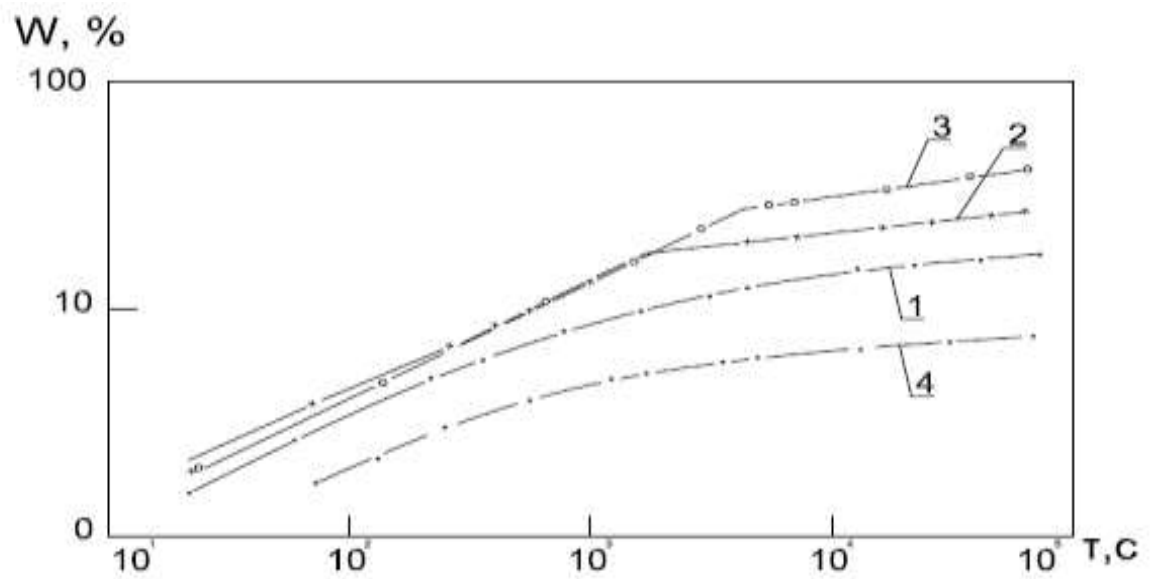

b)

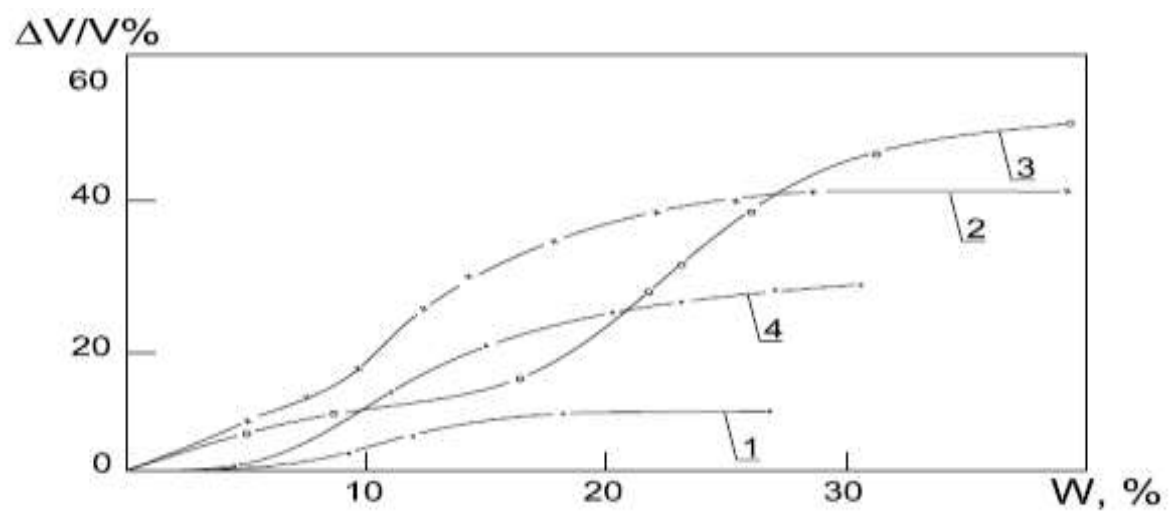

Fig. 2. Kinetics of sorption (a) and swelling of materials:

1 - cotton threads; 2 - woolen threads; 3 - viscose threads; 4 - phenolic threads.

In fig. 3 and fig. $4, W_{\max }$ and $\varepsilon_{\max }$ are the maximum values of moisture content and deformation of textile materials at $\varphi=100 \% . W_{\text {res }}$ and $\varepsilon_{\text {res }}$ are (residual) values of moisture content and deformation, which are retained in the materials after the desorption process is terminated. Conditionally, the index "1" further denotes the dependence $W(\varphi)$ and $\varepsilon(\varphi)$ for the sorption process, and the index "2" is applied for the dependence $W(\varphi)$ and $\varepsilon(\varphi)$ for the desorption process. A two-dimensional vector 
$U_{i}(\phi)=\left[W_{i}(\phi), \varepsilon_{i}(\phi)\right]^{T}, i=(1,2)$ is introduced. Then, according to mathematical analysis methods, the area limited by the hysteresis curve (Fig. 3,4 ) can be calculated as follows:

$$
\begin{aligned}
S_{W} & =\int_{0}^{\varphi \max }\left[W_{2}(\varphi)-W_{1}(\varphi)\right], \\
S_{\varepsilon} & =\int_{0}^{\varphi \max }\left[\varepsilon_{2}(\varphi)-\varepsilon_{1}(\varphi)\right] .
\end{aligned}
$$

Typical isotherms of sorption $W(\varphi)$ and deformation $\varepsilon(\varphi)$ (Fig. 3, Fig. 4) of colloidal capillary-porous (textile) materials are considered and their geometric analysis for a comprehensive study of their moisture absorption mechanisms is performed.

The geometric content of the indicators $S_{W}$ and $S_{\varepsilon}$ is as follows: the value of $S_{W}$ determines the moisture content and $S_{\varepsilon}$ determines the deformation of the material, which are remained in the material after one cycle of the sorption-desorption process is terminated. The length of the curve, which describes the hysteresis, is determined as follows:

$$
\begin{aligned}
& L_{w}=\int_{0}^{\varphi \max }\left\{\sqrt{1+\left(\frac{d W_{1}(\varphi)}{d \varphi}\right)^{2}}+\sqrt{1+\left(\frac{d W_{2}(\varphi)}{d \varphi}\right)^{2}}\right\} d \varphi, \\
& L_{\varepsilon}=\int_{0}^{\varphi \max }\left\{\sqrt{1+\left(\frac{d \varepsilon_{1}(\varphi)}{d \varphi}\right)^{2}}+\sqrt{1+\left(\frac{d \varepsilon_{2}(\varphi)}{d \varphi}\right)^{2}}\right\} d \varphi .
\end{aligned}
$$

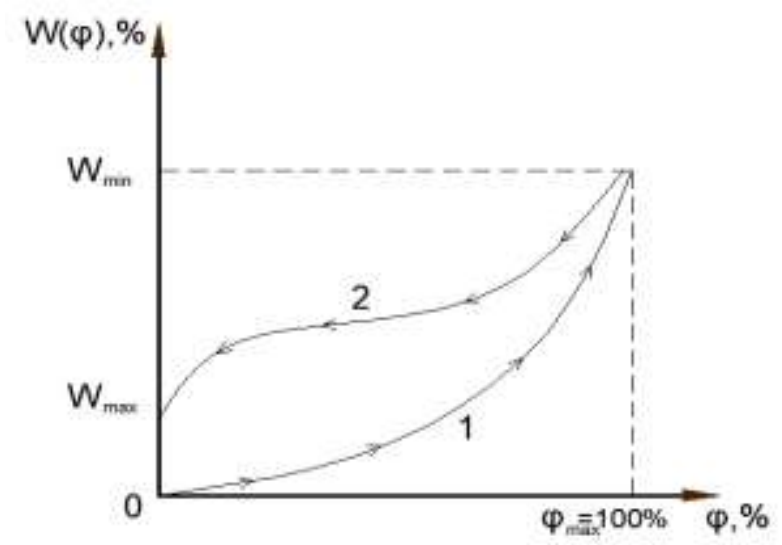

Fig. 3 - Adsorption isotherm $W(\varphi)$ of textile materials:

1 - sorption process, 2 - desorption process 




Fig. 4 - Deformation isotherm $\varepsilon(\varphi)$ of textile materials:

1 - sorption process, 2 - desorption process

Provided that the square of the expression under the sign of the radical is much greater than 1, i.e.:

$$
\frac{d W_{\mathrm{i}}(\varphi)}{d \varphi}>>1, \quad \frac{d \varepsilon_{i}(\varphi)}{d \varphi}>>1, \quad i=(1,2),
$$

Therefore:

$$
\begin{aligned}
L_{w} & \approx \int_{0}^{\varphi \max }\left\{\frac{d W_{1}(\varphi)}{d \varphi}+\frac{d W_{2}(\varphi)}{d \varphi}\right\} d \varphi \\
L_{\varepsilon} & \approx \int_{0}^{\varphi \max }\left\{\frac{d \varepsilon_{1}(\varphi)}{d \varphi}+\frac{d \varepsilon_{2}(\varphi)}{d \varphi}\right\} d \varphi .
\end{aligned}
$$

The geometric content of the expressions $L_{w}$ and $L_{\varepsilon}$ in this case is as follows: $L_{w}$ and $L_{\varepsilon}$ are proportional to the mean value at average relative humidity $\varphi$ of the total rate of sorption-desorption processes $W$ and deformation $\varepsilon$, respectively, for the full cycle of such a process. The following definition is used for the average at $\varphi$ total velocities of sorption-desorption processes $W$ and $\varepsilon$ :

$$
\begin{aligned}
& \overline{\left(\frac{d W}{d \varphi}\right)_{\varphi}}=\frac{L_{w}}{\varphi_{\max }} \\
& \overline{\left(\frac{d \varepsilon}{d \varphi}\right)_{\varphi}}=\frac{L_{\varepsilon}}{\varphi_{\max }}
\end{aligned}
$$


Next, a geometric analysis of the graph of the sorption kinetics of textile materials $W(t)$, which are close by structure to museum exhibits, is performed.

According to the diffusion mechanism (Fick's law), the absorption of moisture vapor by a fiber with a diameter $\mathrm{d}$ (absorption kinetics) is described by the equation [100]:

$$
\frac{M_{t}}{M_{\infty}}=1-\frac{8}{\pi^{2}} \cdot \sum_{n=0}^{\infty} \frac{1}{(2 n+1)} \cdot \exp \left\{-\frac{(2 n+1)^{2} \cdot \pi^{2} \cdot D \cdot t}{d^{2}}\right\},
$$

where $M_{t}$ and $M_{\infty}$ - the amount of absorbed moisture, respectively, during the time $\mathrm{t}$ at equilibrium; $d$ - diameter of the fiber; $D$ - diffusion coefficient; $\mathrm{t}$ - time. When calculating the sum of series is usually limited to three or four terms, and for large values of $t$, in general, only one term is used (the first one). At the beginning of the sorption process, until the moisture penetrates to the center of the fiber, it can be considered as a semi-infinite body. For this case, the amount of absorbed moisture is determined from the ratio $[101,102]$ :

$$
\frac{M_{t}}{M_{\infty}}=\frac{4}{d}\left\{\frac{D_{\text {init }} \cdot t}{\pi}\right\}^{1 / 2},
$$

where $D_{\text {init }}$ - the initial diffusion coefficient of the material.

If the logarithmic scale is taken, then (7) can be presented as follows:

$$
\ln \left(\frac{M_{t}}{M_{\infty}}\right)=\ln \left[\frac{4}{d}\left(\frac{D_{\text {init }} \cdot t}{\pi}\right)^{1 / 2}\right]+\frac{1}{2} \ln t
$$

Therefore, in the logarithmic scale $\left[\ln \left(\frac{M_{t}}{M_{\infty}}\right), \ln t\right]$ the tangent of the angle $(\alpha)$ of the graph slope of sorption kinetics (Fig. 2) has a value of $\frac{1}{2}$ :

$$
\operatorname{tg} \alpha=\frac{1}{2}
$$

For a finite interval/segment of the sorption kinetics curve, when $t$ is large according to (6):

$$
\ln \left\{1-\frac{M_{t}}{M_{\infty}}\right\}=\ln \left\{\frac{8}{\pi^{2}}\right\}-\frac{D_{\text {final }} \cdot \pi^{2}}{d^{2}} \cdot t
$$


where $D_{\text {final }}$ is the final (at the end of the sorption process) diffusion coefficient of the material.

The expression (10) can be presented differently:

$$
\ln \left\{1-\frac{M_{t}}{M_{\infty}}\right\}-\ln \left\{\frac{8}{\pi^{2}}\right\}=\ln \left\{\exp \left[-\frac{D_{\text {кінц }} \cdot \pi^{2}}{d^{2}} \cdot t\right]\right\} .
$$

In the general case of vapors sorption of low molecular weight substances in the polymer, the amount of moisture can be determined using the equation [100]:

$$
M_{t}=k \cdot t^{n},
$$

where the coefficient $k$ takes into account the diffusion and geometric factor (shape and size of samples). In the logarithmic scale $\left[\ln M_{t}, \ln t\right](18.7)$ :

$$
\ln M_{t}=\ln k+n \cdot \ln t,
$$

Therefore, in the general case, the tangent of the angle $(\alpha)$ of the graph slope, which describes the kinetics of sorption $W(t)$ in textile materials (for the logarithmic scale of the results interpretation), is important:

$$
\operatorname{tg} \alpha=n .
$$

This expression (14) allows to conclude the following:

1) the first segment corresponds to the diffusion according to Fick's law $\operatorname{tg} \alpha=0,5$, the second one ( $\operatorname{tg} \alpha \approx 0,33$ ) and the third one $\operatorname{tg} \alpha \approx 0,17$ correspond to an anomalous diffusion.

2) Normal diffusion of water vapor in the polymer corresponds to mono- and polymolecular adsorption, i.e. to the situations where sorption occurs at the active centers and in the free volume of the polymer, and its swelling is insignificant.

3) Segments with anomalous diffusion correspond to intense swelling of fibers and threads; at this stage of sorption, there is a deepening of water molecules in the intermolecular space of the polymer, and a change in the conformation of macromolecules.

The process of diffusion, when the limited swelling of polymers during the sorption of water vapor is considered as mixing of the active centers of macromolecular 
substance (sorbent) and sorbate molecules. The equation that determines the condition of sorption equilibrium has the following form:

$$
\ln \varphi=A-\frac{n_{0} M}{U}-\frac{N_{A} n_{0}^{2} M^{2}}{2 U^{2} R T} \beta(P, T),
$$

where $A$ - structural value that characterizes the swelling pressure; $n_{0}$ - number of active centers; $\varphi$ - relative humidity (expressed as a decimal fraction; $\beta(P, T)-$ variance coefficient; $U$ - specific moisture content, $\mathrm{kg} / \mathrm{kg} ; M$ - molecular weight of the adsorbed moisture; $N_{A}$ - Avogadro's number; $R$ - universal gas constant; $T-$ temperature of the wet body at time $t$.

Sometimes the term containing the variance coefficient $\beta(P, T)$ is excluded from the right-hand side of equation (18.15), then the sorption equilibrium equation takes the following form:

$$
\ln \varphi=A-n_{0} M \frac{1}{U}
$$

In the paper [99], experimental sorption-desorption isotherms in the coordinates $\left[\frac{1}{U}-(\lg \varphi)\right]$ for fabrics made of natural raw materials (Fig. 18.5) and fabrics made of chemical threads (Fig. 6) are plotted.



Fig. 5 - Isotherms of adsorption of textiles from natural raw materials:

$\mathrm{s}$ - sorption; d - desorption;

1 - cotton; 2 - wool; 3 - natural silk. 


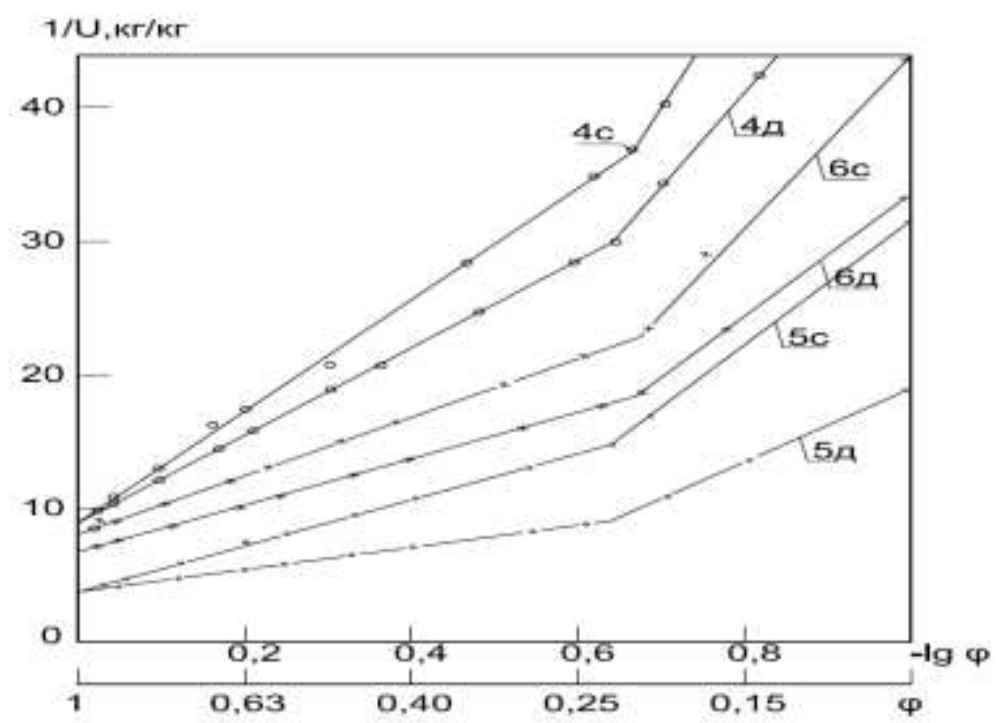

Fig. 6 - Isotherms of adsorption in textiles made from chemical fibers:

s - sorption; d - desorption;

4 - viscose; 5 - phenylone; 6 - kapron

Sorption and desorption isotherms are linear, but at $\varphi=0,2 \ldots 0,25$ they have an inflection point, which is associated with a change in the energy of intermolecular interaction (or chemical potential). At the beginning of the sorption process, when the first hydrate (or monomolecular) layer is filled $(\varphi<0,2)$, each active center of the sorbent interacts on average with one molecule of sorbate (moisture) so that these molecules do not form a continuous layer. Further at $\varphi>0,2 \ldots 0,25$, the number of molecules of the sorbed substance increases so much that each active center interacts already with two or three molecules and they form the second and subsequent hydrate (polymolecular) layers. In this case, since $\mu \sim(-\lg \varphi)$, the interaction energy in the sorbent-sorbate system changes, which corresponds to the inflection on the isotherm.

According to (18.16), within the linear segment of the isotherm in the coordinates $\left[\frac{1}{U}-(\lg \varphi)\right]$, the structural value $A$, which characterizes the swelling pressure, must remain constant that can be explained by the elastic deformation of fibers.

The reconsideration of the equation (15) allows to present it in the following form: 


$$
\mu \sim(-\lg \varphi) ;-\ln \varphi=-A+\frac{n_{0} M}{U}+\frac{N_{A} n_{0}^{2} M^{2}}{2 U^{2} R T} \beta(P, T)
$$

The notation $\frac{N_{A} M^{2}}{2 U^{2} R T} \beta(P, T)=a ; \frac{M}{U}=b$ is introduced, then (17) resolves itself into the following equation:

$$
a \cdot n_{0}^{2}+b \cdot n_{0}-A+\ln \varphi=0 .
$$

The equation (18) is quadratic with respect to $n_{0}$ and can be determined:

$$
n_{0_{1,2}}=\frac{-b \pm \sqrt{b^{2}-4 a(\ln \varphi-A)}}{2 a}
$$

or

$$
n_{0_{1,2}}=\frac{-b \pm \sqrt{b^{2}+4 a(-\ln \varphi+A)}}{2 a} .
$$

If $-\ln \varphi \sim 1$, then

$$
n_{0_{1,2}}=\frac{-b \pm \sqrt{b^{2}+4 a A}}{2 a} .
$$

The root with the sign (+) as physically justified is chosen, since for $\ln \varphi \rightarrow 0, n_{0} \rightarrow$ 0 , providing that $4 a A \sim b$.

If $4 a A \sim b$, then the number of active centers can be determined using the following expression:

$$
n_{0} \rightarrow \frac{\sqrt{4 a A}}{2 a}=\sqrt{\frac{A}{a}} .
$$

The dependence (18.21) with a positive sign in front of the root is further analyzed:

$$
n_{0_{1,2}}=\frac{-b+\sqrt{b^{2}+4 a A}}{2 a} .
$$

At $b \rightarrow 0\left(\frac{M}{U} \rightarrow 0\right), n_{0} \rightarrow \sqrt{\frac{A}{a}}$; at $b \gg 4 a \cdot A$ :

$$
n_{0} \cong \frac{-b+b \sqrt{1+\frac{4 a A}{b^{2}}}}{2 a} \approx \frac{-b+b\left(1+\frac{2 a A}{b^{2}}\right)}{2 a}=\frac{b \cdot 2 a A}{2 a \cdot b^{2}}=\frac{A}{b} .
$$

Formulas (21), (22), (23) are valid for $[-\ln \varphi] \ll 1$.

If this condition is not met, then: 


$$
n_{0}=\frac{-b+\sqrt{b^{2}+4 a(-\ln \varphi+A)}}{2 a} .
$$

Therefore, for the significant effect $(-\ln \varphi)$ (formula (25)), the following condition must be met:

$$
-\ln \varphi \sim A \Leftrightarrow \varphi \sim e^{-A} .
$$

It is from such values of $\varphi^{*} \approx e^{-A}$ that the increase in the number of active centers of moisture absorption begins.

The graphs of adsorption isotherms (Fig. 5, Fig. 6) allow to determine two important characteristics of materials: the number of active centers $n_{0}$ and the maximum amount of hygroscopic moisture.

The tangent of the slope angle of the linear segment of isotherms according to formula (18.16) allows to find the number of active centers $n_{0}$. So:

$$
(-\ln \varphi+A)=n_{0} \frac{M}{U^{*}} .
$$

Therefore:

$$
\begin{gathered}
\frac{1}{U^{*}}=\frac{A}{n_{0} M} \\
n_{0}=\frac{A \cdot U^{*}}{M} \Leftrightarrow n_{0}=\frac{A}{M}\left\{\frac{1}{U^{*}}\right\}^{-1} .
\end{gathered}
$$

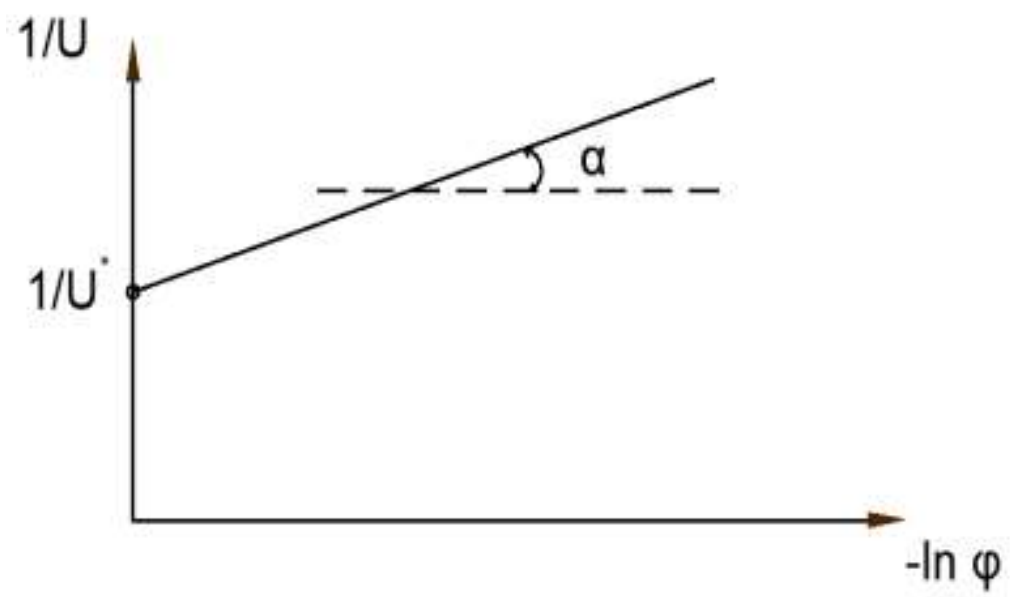

Fig. 18.7. Determining the slope angle of the adsorption isotherm's linear segment. 


$$
\operatorname{tg} \alpha=\frac{\frac{1}{U}}{(-\lg \varphi)} ; \frac{1}{U}=\frac{-\ln \varphi+A}{n_{0} M}=\frac{1}{n_{0} M}(-\ln \varphi)+\frac{A}{n_{0} M}
$$

So,

$$
\operatorname{tg} \alpha=\frac{1}{n_{0} M}
$$

Therefore:

$$
n_{0}=\frac{1}{\operatorname{Mtg} \alpha}=\frac{\operatorname{ctg} \alpha}{M} \text {. }
$$

The fig. 8 shows the scheme for determining the maximum amount of hygroscopic moisture $W$ on the fibers.

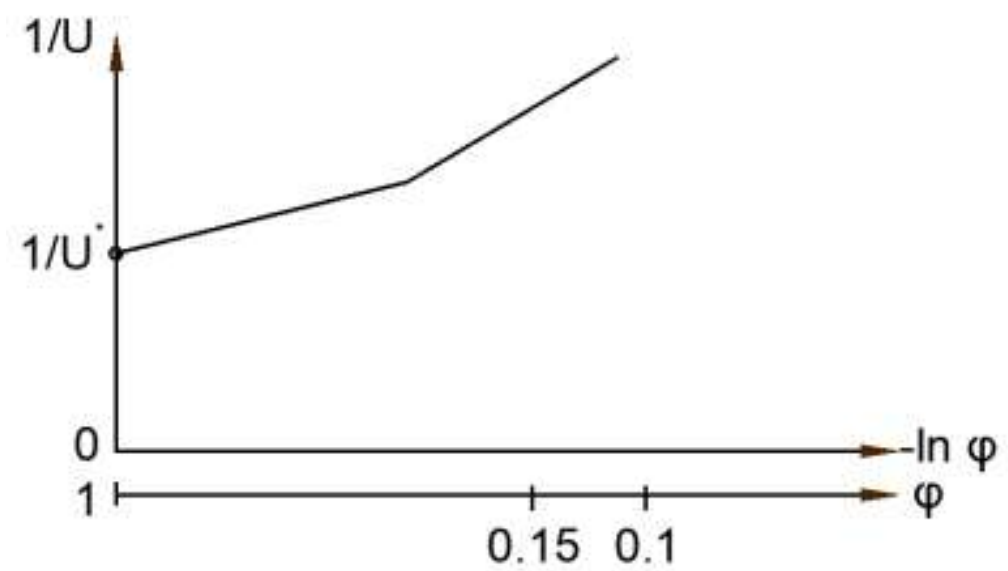

Fig. 8. Determining the maximum amount of hygroscopic moisture in the material.

The values of $n_{0}, A, M$, from the equation (27) allow to find the value $\frac{1}{U^{*}}$ [at $\varphi \rightarrow 1(\ln \varphi \rightarrow 0)$ ], which is put on the axis $\frac{1}{U}$. Next, the maximum amount of hygroscopic moisture on the fibers $(W)$ is calculated.

Thus, in the range of medium and high values of air relative humidity $\varphi$, which is practically important for the museum microclimate, the experimental adsorption isotherms of colloidal capillary-porous materials are well linearized using equation (15) of sorption equilibrium. The equation takes into account the effect of linking water molecules by certain discrete centers. This approach allows to explain the experimentally obtained isotherms of sorption-desorption of water vapor by fibrous materials [99]. 
Fig. 15 ... fig. 17 shows the comparison of experimental data [99] on the kinetics of sorption with the theoretical dependences for threads of wool, cotton, phenylone, and the desorption curves of these materials. Fig. 18... fig. 20 shows the comparison of experimental data regarding deformation dependence on moisture content $\varepsilon(W)$ for the same materials.

a)

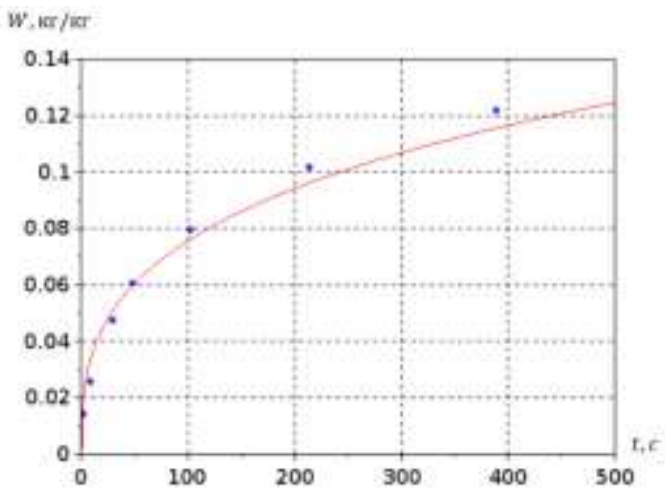

b)

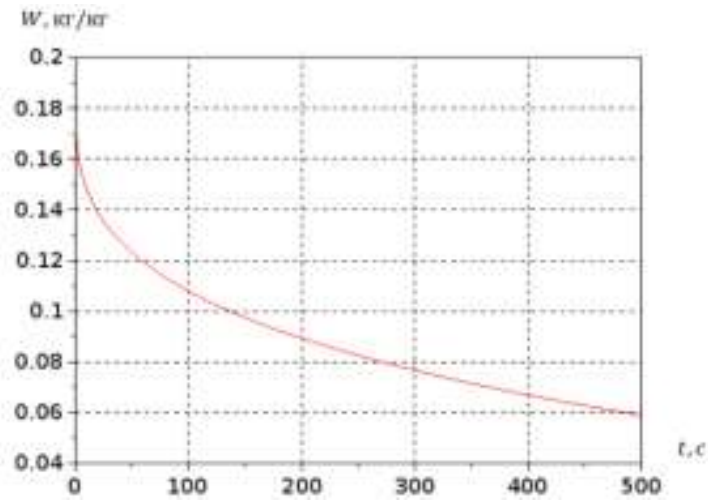

Fig. 15 - The comparison of experimental data [99] of sorption kinetics of cotton thread with theoretical curves (a) and theoretical curves of desorption (b)

a)

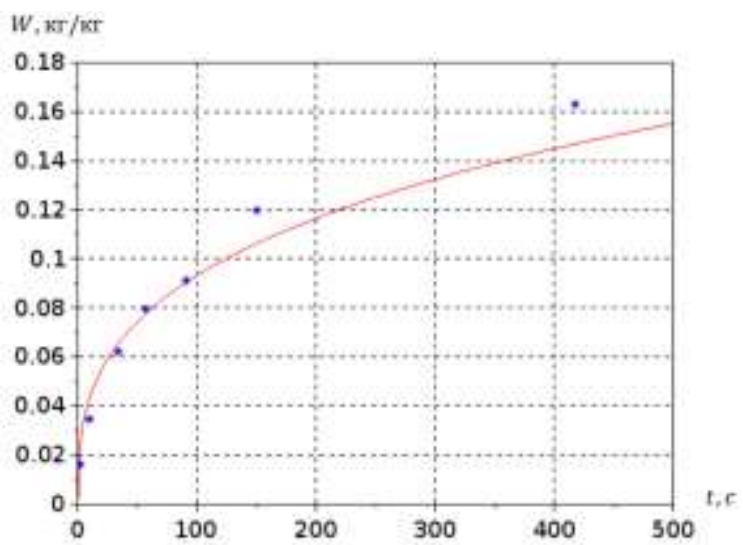

b)

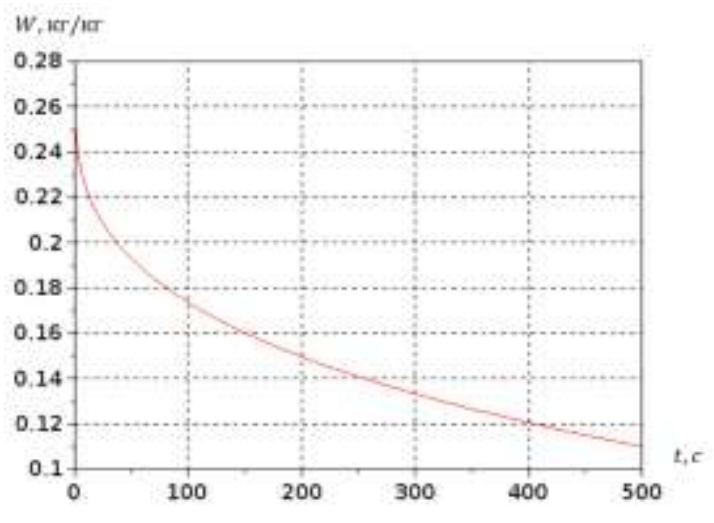

Fig. 16 - The comparison of experimental data [99] of sorption kinetics of wool threads with theoretical curves (a) and theoretical desorption curves (b) 
a)

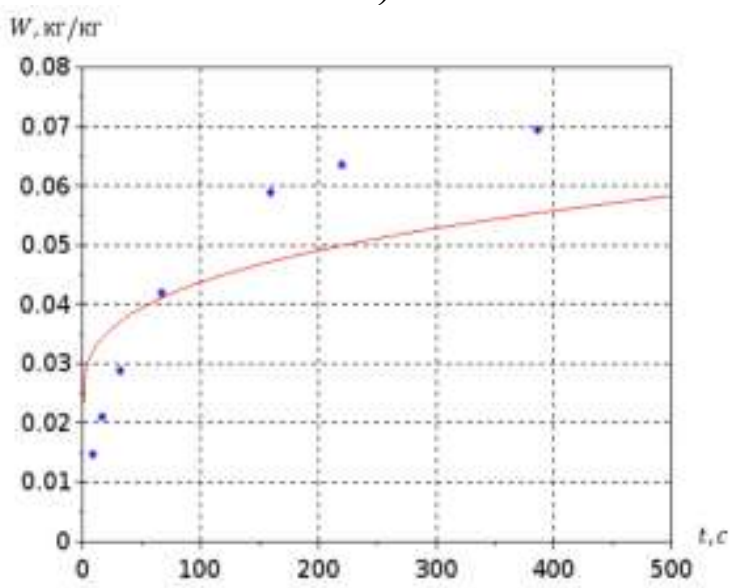

b)

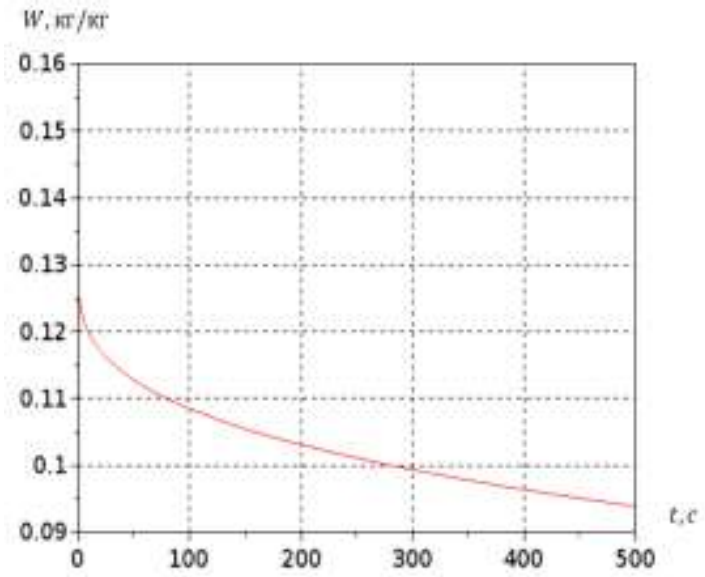

Fig. 17 - The comparison of experimental data [99] of sorption kinetics of phenylone threads with theoretical curves (a) and theoretical desorption curves (b)

a)



b)

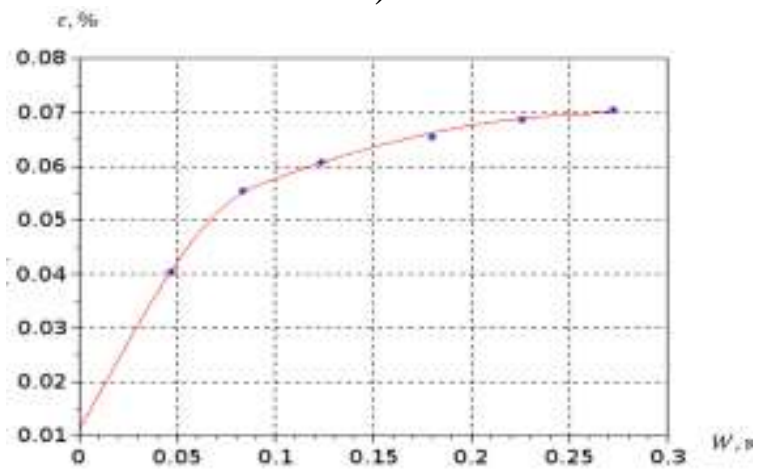

Fig. 18 - The comparison of experimental data [99] of the deformation dependence on the moisture content $\varepsilon(W)$ for wool with theoretical dependences

a) sorption; b) desorption.

a)

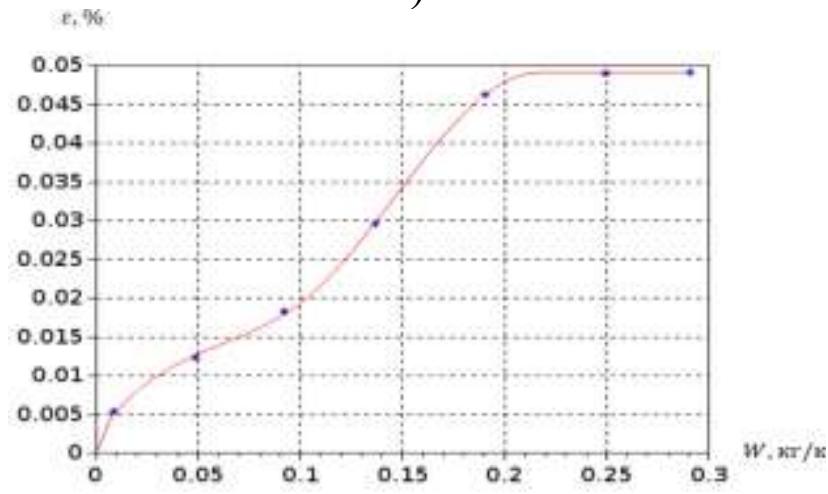

b)



Fig. 19 - The comparison of experimental data [99] of the deformation dependence on the moisture content $\varepsilon(W)$ for cotton with theoretical dependences $\mathrm{a}$ - sorption; b- desorption. 
a)

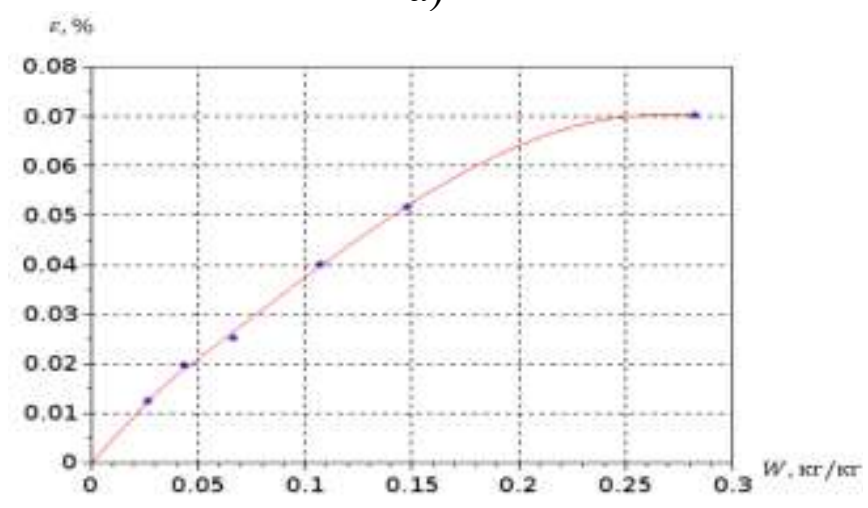

b)



Fig. 20 - Comparison of experimental data [99] of the deformation dependence on the moisture content $\varepsilon(W)$ for phenylone threads with theoretical dependences $\mathrm{a}$ - sorption; b - desorption.

The analysis of the experimental data and theoretical dependences (fig. 15 ... fig.20) shows that the isotherms of textile of different fibrous composition satisfactorily coincide with the experimental data. The size of the sorption curve segment, on which the diffusion of water vapor into colloidal capillary-porous materials is carried out according to Fick's law, depends on the degree of crystallinity of the material. The greater the degree of crystallinity of the material, the greater the segment with time $t$, sec, moisture content $W, \%$, relative humidity, $\varphi, \%$, deformation, $\varepsilon, \%$, which corresponds to normal (Fick) diffusion.

Thus, for the phenyl threads, the segment of normal diffusion ends $\operatorname{tg} \alpha \approx 0.5$ at $W=$ $5,4 \% ; \quad \varphi=52 ; \quad t=105 c, \varepsilon=2.4 \%$; for wool: $W=10,2 \% ; \varphi=80 \%, t=$ $245 c, \varepsilon=4,2 \%$; for cotton: $=7,9 \%, \varphi=60 \%, t=120 c, \varepsilon=3,3 \%$. The segments with anomalous diffusion (second $\operatorname{tg} \alpha=0,33$; third $\operatorname{tg} \alpha=0,17$ ) are characterized by intense swelling of threads (Fig. 15... Fig. 17), but the increase in the rate of sorption of water vapor does not take place. The deformation in these segments reaches: $6.9 \%$ for phenyl thread, i.e. it increases by 2.9 times; $7 \%$ for wool (increased by 1.67 times); $7.1 \%$ for cotton (increased by 2.15 times) (fig. 18 ... fig. 20) in comparison with the deformation in the segment with normal (fixed) diffusion. Thus, when storing museum collections, air conditioning control systems should be based on the dependences that describe the heat and mass transfer between the exhibit and conditioned air on the segment of the kinetic curve corresponding to normal (Fick) diffusion ( $\operatorname{tg} \alpha \approx 0,5)$ and describing processes of 
mono- and polymolecular adsorption (the sorption occurs at the active centers and in the free volume of colloidal capillary-porous material, and swelling is insignificant).

\section{Conclusion}

It is shown on the basis of comprehensive analysis of experimental studies of sorption-desorption and deformation isotherms of dispersed materials of different fiber composition that the curves $\mathrm{W}(\varphi), \varepsilon(\varphi)$ are similar in shape and have a configuration, which is characteristic of leading capillary-porous bodies. It is shown that the hysteresis loop for all fibrous materials is observed in the whole range of relative humidity of the environment. It was found on the basis of geometric analysis of moisture exchange properties and characteristics of the porous structure of (textile) materials, that such characteristics as total moisture content and volume of macropores depend mainly on the technological parameters (density, weave type, etc.) of the fabric. The hygroscopicity, the amount of moisture adsorbed, the volume of micropores, and the specific surface area depend on the fiber composition of textiles. The deformation isotherms $\varepsilon(\varphi)$ of threads show, that the deformation of the structure is not completely reversed during desorption. An irreversible change in the size of threads during the desorption of moisture can explain why some water molecules are not desorbed.

The method of geometric analysis of sorption $\mathrm{W}(\varphi)$ and deformation $\varepsilon(\varphi)$ isotherms of colloidal capillary-porous materials allowed to obtain the dependences, which determine: moisture content $S_{w}$ and deformation $S_{\varepsilon}$ of material remaining in the sorption-desorption process after one cycle of such process; average at relative humidity $\varphi$ total rate of sorption processes $\mathrm{L}_{\mathrm{w}}$ and deformation $\mathrm{L}_{\varepsilon}$ for one process cycle. 


\subsection{Problematic issues of researching the structural increase in the reliability of engineering networks}

In this monograph, the definition of engineering networks is presented, the formulation of the problem of maintaining their performance is considered. A large number of engineering networks functioning today are gradually reducing their capabilities as a result of the action of various destructive factors. Continuous maintenance and improvement of the level of performance of these systems is an important scientific problem. Therefore, the subject of this research is the process of geometric modeling of structural reliability on the example of redundant networks, which are one of the largest, most complex and important components of the engineering infrastructure.

Determining and ensuring reliability is an important problem in the design of water supply, heating, gas networks, networks of telecom operators, etc. Network-type structures are characteristic of many different extended geographically distributed systems. In a communication network, nodes are interconnected by channels that transmit flows of different origins: information (messages, data, control), energy (electrical or energy resources in the form of oil, gas or coal), material flows, transport. The structure of these systems and their functioning processes are quite similar, so their models can be same [119, 120, 124].

Today, a complex of effective measures is needed to improve the recovery of industries and individual enterprises. At the same time, there are significant difficulties in building new and operational reconstruction of existing systems of engineering infrastructure and their components due to the difficult economic situation, inconsistency of plans and the availability of limited resources. A significant number of operating engineering networks were created long ago. And due to their long operating time, the stock and possibilities inherent in them are constantly decreasing. According to this, ensuring and increasing the level of reliability of engineering networks, increasing the period of their work is an important scientific problem [103, $110,111,120,126,127]$. This problem is being solved as a result of research and 
practical measures in order to weaken the action of various destructive factors that cause economic damage and other negative consequences [118].

The problem of the performance of different systems was investigated in scientific sources [103, 109, 113]. In the study of complex systems, various optimization methods are used [104, 105, 109, 113, 114, 121]. In particular, the issues of network optimization were worked out in the works [119]. The need for extended run times raises the requirements for system reliability and stimulates the expansion of the scope of their use. Loss of system reliability has great negative consequences [118].

Engineering and technical support networks (engineering networks, systems or communications) are a complex of systems and communications that ensure the vital activity of users (population, utilities and industrial enterprises) (Fig. 1). They are systems of communications and other structures, namely:

- external and internal water supply and drainage systems (water supply sources, hydraulic structures, water supply and sewage treatment plants, collectors, pumping stations, intra-quarter networks);

- external and internal heat supply systems (city heating networks, heating points and intra-quarter networks);

- gas supply systems (gas distribution points, gas pipelines, etc.);

- communication networks (cellular network, telephone network, structured cabling system, automated dispatch control system, access control system, visualization system);

- external and internal power supply systems (power lines, transformer and traction substations, etc.); internal power supply systems in houses;

- outdoor lighting systems (streets, roads, shop windows, stands, etc. and power lines);

- ventilation and air conditioning systems (residential and public buildings and structures and engineering facilities). 


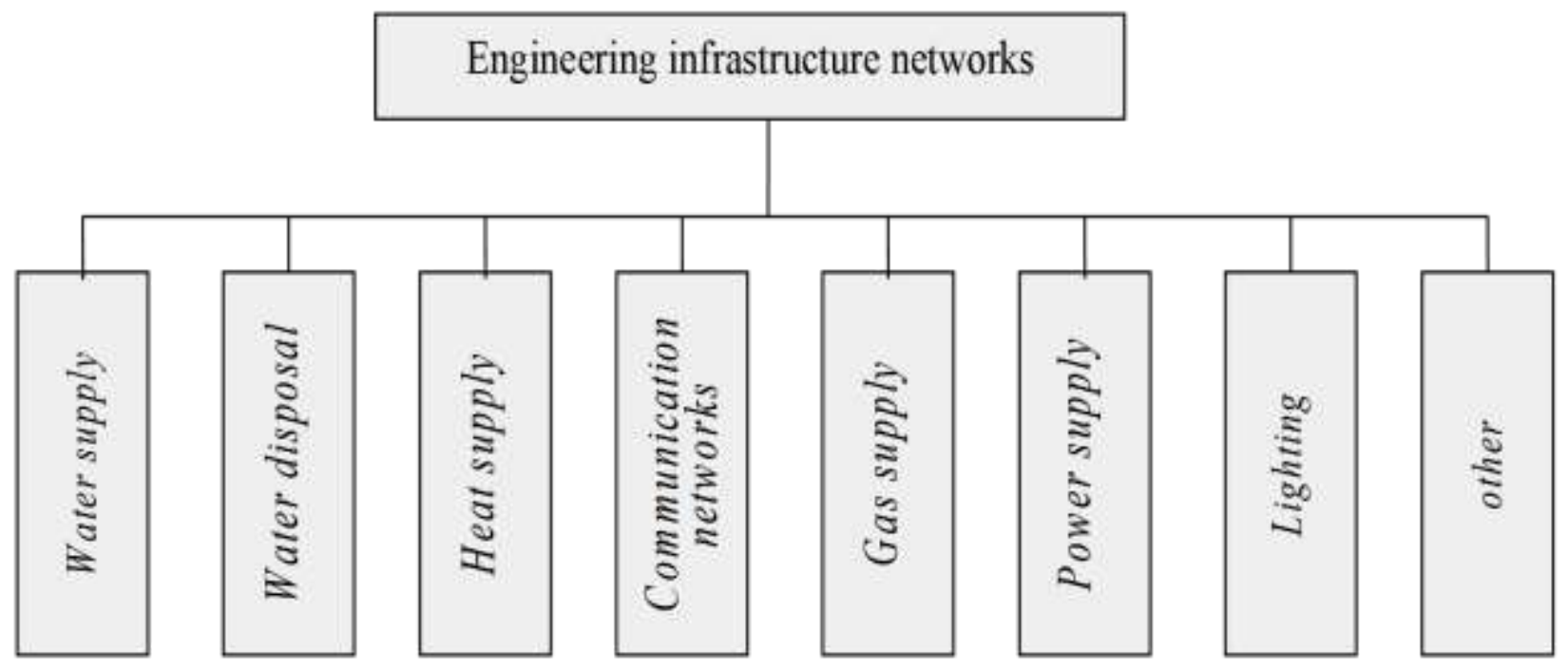

Figure 1. List of networks included in engineering infrastructure systems

Engineering networks are hierarchical and multilevel:

- they are perceived as a single complex object formed from interacting components of different levels, integrated to solve the assigned tasks with certain conditions:

- are systems of large dimension;

- losses from cessation of functioning are significant for society and the environment [103];

- significantly affect the economic situation and the efficiency of enterprises $[103,111]$.

The need to restore the utility network exists constantly for its functioning, the reliability of its elements is constantly decreasing and increasing, thereby affecting the operability of the system. An outstanding property of complex redundant engineering networks is the discrepancy between the volumes of losses from their serious failures and the costs of rational ensuring their performance [103, 111]. Maintaining a given level of reliable operation of these systems is critical, given certain limitations of the resources available for this. In the process of functioning, the object of the engineering infrastructure as a technical system performs its tasks of preserving a number of values of important quantities in the intervals specified in the regulatory documents [116]. To 
improve a certain level of reliability and upgrade complex systems, it is necessary to constantly invest large funds.

Reducing the technical capabilities of engineering networks and the need to continue their functioning is an urgent and difficult task to ensure their working condition. [103, 111]. The volume of an integrated study of this problem is insignificant, therefore, scientific support and finding hidden unused reserves is necessary. Structural redundancy uses additional components of the structure of the research object. According to [116]: redundancy is a method of ensuring system reliability by using additional capabilities that are more than the minimum necessary for the system to perform its tasks. The reserve element performs the functions of the main one in case of loss of its operability as part of a functioning system.

Modern objects of engineering infrastructure are characterized by high technical and functional-technological complexity, multi-level hierarchical and algorithmic functional link of constantly developing elements, improving in the process of adaptation to the environment. These objects are developing in several directions:

- more and more constituent elements are introduced into the systems;

- the structure of systems, formed by technological and functional connections of individual elements, becomes more complicated;

- different interactions of the components change during the functioning of the system. Today, engineering networks operate in conditions of the growing complexity of the tasks assigned to them, which are becoming more important, responsible and multivariate. Structural complexity, a number of increased requirements for performance, their numerous failures cause significant negative processes, significant losses of money and time. Research on these systems includes:

- finding a separate approach in their construction and analysis;

- consistency and application of methods for replacing or restoring components in the current state of the object in the process of their development;

- a variety of functions and scientific support for the entire period of existence.

- tasks of coordination, integration and interaction with subcontractors in the construction and operation of facilities; 
- limited amount of available resources for construction and operation.

Consequently, to maintain the performance of complex systems, it is necessary to improve, develop geometric methods, apply a systematic approach, methods of structural redundancy and geometric models to solve the assigned tasks.

Scientific literary sources indicate that the problem of reliability of complex network systems of engineering infrastructure is in the process of development and has not been finally solved [103, 111, 117, 120]. Today, the general methodology for solving the problem of reliability of technical systems and their components of different levels of complexity is relevant. In particular, in scientific research, generalization and simplification of the system of connections of constituent parts in the structure of engineering networks is widely used. [103, 111, 117, 120]. Due to various problems of introducing and detailing theoretical methods, scientific sources $[103,111,117]$ became the basis for an in-depth analysis of the state of affairs for the further development of methods for modeling the operability of engineering networks. The study of the reliability of individual parts and elements of complex systems is carried out by methods of analyzing the reliability of operating objects and monitoring the operation of components of various types and dimensions as part of systems.

Under conditions of a high initial level of reliability of components or significant structural redundancy of engineering networks, the performance analysis leads to positive results, which indicates its low information content. In solving a number of practical problems, there is a need to determine and apply a number of transformations of the network structure that reduce the primary reliability of its components and elements in order to quickly obtain the necessary data on the level of performance and the use of inverse structural transformations. This helps to use the obtained data of computer experiments in calculating the actual indicators of the health of various components of the engineering infrastructure network.

In the practice of design, methods for calculating the performance indicators of engineering networks should be sufficiently accessible and not laborious [103, 111, $117,120]$. The volume of calculations of the reliability of the object of analysis should not exceed the volume of other necessary engineering calculations associated with this 
system for sufficient practicality of the technique in the design process and in scientific support of the life of engineering networks.

Thus, the analysis of the state of the problem of the reliability of systems shows that for the development of research into the operability of engineering infrastructure networks, it is necessary to:

- construction of a generalized methodology for modeling their structural reliability and their various components;

- performing research on the reliability of individual components of network structures of different levels of complexity.

The development of science and technology and the preparation of a methodology for increasing and maintaining a given level of reliability of technical systems stimulate the deepening of theoretical methods of modeling reliability and methods of its practical calculations [129]. Scientific research methods are in constant development and open up broad prospects for solving a number of practical problems. Solving problems related to structural reliability uses graph analysis, checking them for the presence of different properties [119, 123]. Graphs as mathematical models that arise in solving real practical problems are rather cumbersome and difficult in solving problems with a large dimension of network objects. Therefore, for efficient processing of these models, processing of the corresponding computational algorithms is required. [119, 123, 125]. Scientific research includes the processes of finding, selecting, creating and improving adequate models $[119,123]$. In these processes, important factors of influence on the object of research are selected for consideration and insignificant factors that are less significant for the identified circumstances and characteristics of the subject of research are rejected.

Reliability is considered to be a key property of all technical systems, regardless of their complexity. [115, 116]. Without the required level of reliability, all other characteristics of the system have no practical meaning, because there is no possibility of their real application. [112, 115]. Therefore, reliability has an exceptional, leading role among all the properties of a technical system. [103, 107, 111, 112, 115, 119]. A number of qualitative characteristics of the subject of research have a significant impact 
on the level of its readiness for practical functioning in accordance with a given purpose. The study of the reliability of systems uses the means of mathematical statistics based on the results of experiments [106].

In the deterministic research approach, all the factors that determine the functioning of a certain system are taken completely unambiguous. Exceptionally accurate and specific data are used to consider the object of research with all its features. However, in practice, the process of functioning of various systems is stochastic and ambiguous [111, 112, 114, 119, 123, 125]. Therefore, the simulation results differ from the experimental data obtained under certain conditions [106]. Numerous system parameters are mostly of random origin. To model, determine and maintain the structural reliability of engineering infrastructure networks, it is necessary to take into account their constant changes during operation $[103,111,119,120,128$, 129]. Therefore, there are problems of finding the probabilistic properties of the processes in the system according to the given probabilistic properties of external conditions and in particular the geometric parameters of the system. This analysis is based on a scientific and technical problem, to solve which uses mathematical modeling, which should reflect the essence of this technical system.

In the scientific research of phenomena, objects and processes the description and forecasting of complex systems with the involvement of important probabilistic factors that constantly affect the course of their functioning is determined [108, 114]. Various relationships between stochastic laws and indicators of the level of system reliability are revealed. Experimental data are taken as probabilistic quantities varying according to some definite distribution law [106]. Of course, in describing the actions of the functioning of these engineering infrastructure systems, it is advisable to use a probabilistic analysis of their reliability.

The primary analysis of the reliability of the research object is carried out at the stage of system design. [103, 111]. The properties of the object's components are considered set. The study helps to remove unpromising solutions to the problem, identifies unreliable components of the research object and makes it possible to timely process all the "weak points" of the system. Further research of the system reliability 
is carried out according to the results of the statistical analysis of the experimental results obtained in the process of creating systems, their testing and operation. [106].

It is important to study the process of reducing the level of the primary parameters of the reliability of the system and its constituent parts. These changes depend on a number of existing patterns and are stochastic in nature, complex internal and external interactions and relationships. [114]. Interactions in the system are manifested through various characteristic manifestations of the existence of phenomena in the surrounding world. The accumulation of many significant influences stimulates changes in various parameters of the system's functioning in the direction of transition to another qualitative state. Therefore, changes occurring in the systems of engineering infrastructure in the course of their operation are a manifestation of many important properties of objects and surrounding processes.

Technical systems, in particular, engineering infrastructure facilities, at the beginning of work receive a certain maximum possible level of reliability under certain conditions. When performing the assigned tasks and under the influence of destructive factors, they lose the initial level of performance and go into a state of periodic failures. In general terms, the reliability of engineering infrastructure networks is determined by the probability of structural connectivity and random changes in the initial values of various parameters of the system within the limits corresponding to its performance. $[114,119,120,123]$. Therefore, the state of the system in one way or another depends on these fundamental parameters. In modeling the reliability of technical systems, research is constantly being conducted on the operability and reasons for the deterioration of the key properties of the system. The results of scientific developments are used to improve the theory, effectively organize experimental research (computer experiments), to develop means of regulating reliability and improve quality [106].

Based on the consideration of problematic issues, a generalized methodology for maintaining the operability of engineering infrastructure systems, in particular engineering networks, is drawn up, which is an integration of interrelated actions (stages) (Fig. 2). At the beginning of the study of the difficulty, a search is made for a method for analyzing and researching this system. In order to formalize dependencies, 
relationships, interactions and setting tasks in the process of performing a task, a system of geometric interpretations and ordering of initial data is built. In parallel, the formation (or improvement of the existing) object-oriented specialized terminology and notation system is underway, as well as the improvement of the system research method. The last step accompanies all stages of the research methodology.

Geometric modeling, analysis and synthesis of the research object are the next important stage in the search for a solution to the problem [129]. Here it is important to attract practical developments and generalize experience with a choice of methods for its study and the use of specialized terminology and a notation system. Obtaining the results of experiments, in particular computational ones, is necessary for their processing and appropriate interpretation. In order to accumulate, systematize and enrich scientific experience, theoretical descriptions and generalizations are carried out, solutions to the tasks and important conclusions are formulated.

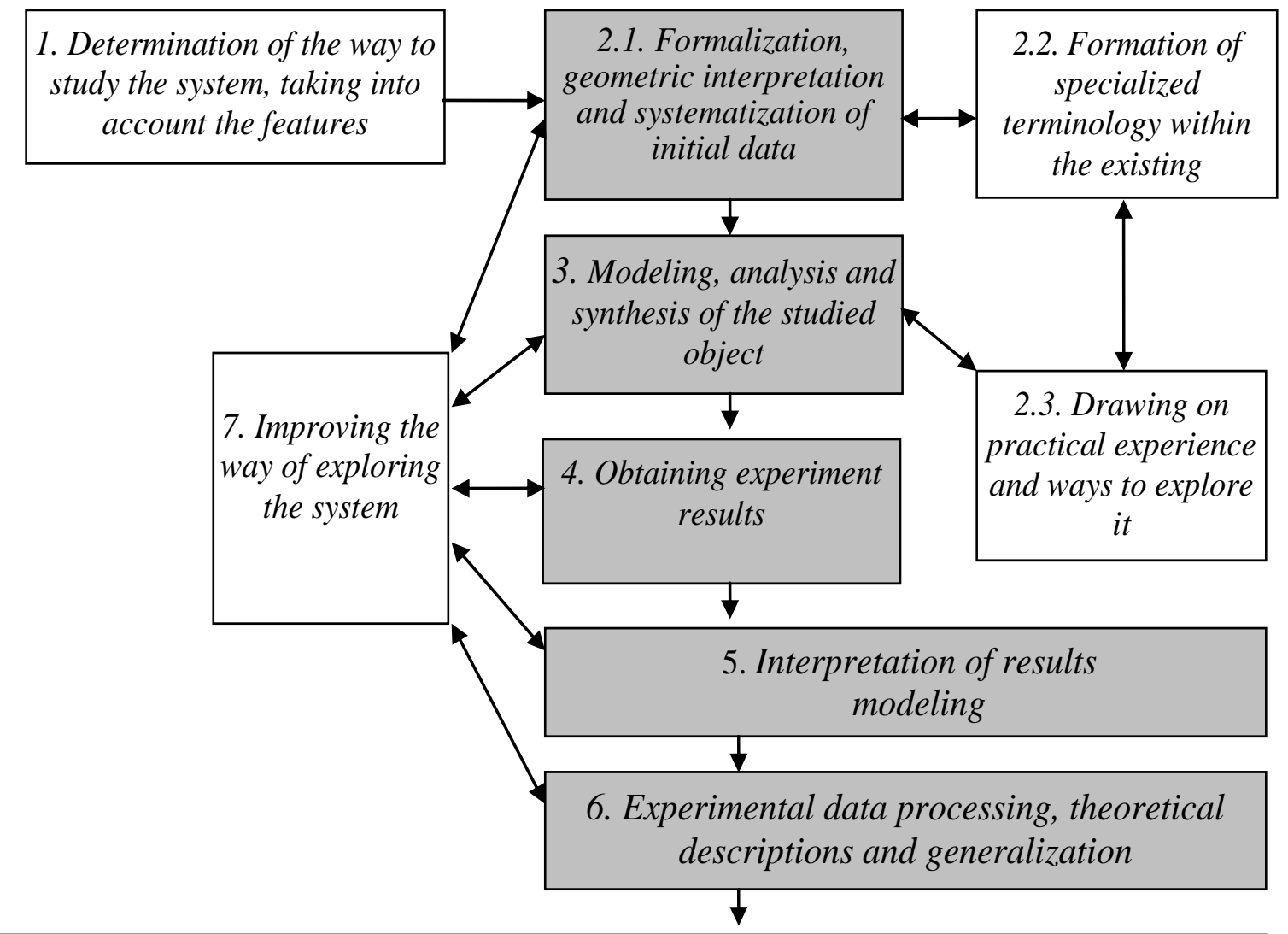

8. Formation of practical proposals and recommendations for solving the problem

Figure 2. Scheme of a generalized research methodology and ensuring the operability of engineering infrastructure systems from the standpoint of modeling 
The final stage of the methodology is the formation of a systematized series of proposals and recommendations for solving the problem of maintaining the operability of engineering infrastructure facilities. The generalized methodological structure of the theory of maintaining the operability of engineering infrastructure objects is based on geometric structural modeling [129]. The development of theoretical research in the field of applied geometry and engineering graphics is seen in the further formation and improvement of the system of their methods with the effective use of important factors influencing its important properties, in particular the reliability of various technical systems. The systems approach refines and integrates separate studies of these factors and properties. The methodological combination of a number of problems more adequately reflects the object and subject of research and expands the possibilities of geometric modeling and optimization. 


\subsection{New materials and technologies in design}

Currently, design as an artistic activity synthesizes scientific, technical and humanitarian knowledge. The design of the architectural environment is a generally recognized and priority area in all spheres of human life. The designer-architect is faced with a choice - from what material the project system will be made of and by what technology.

The growth rates of industrial production associated with the development of new technologies and materials are significantly ahead of the terms of their aesthetic development. The contradictions between beauty and functionality continue to deepen, especially in the area of ecology. All this is due to the fact that until now industrial design does not have a coherent theory of the aesthetics of industrial materials and technologies, which, in turn, makes it difficult to train specialists in the field of industrial design.

Recent work in this direction has been solving narrow specific problems and their results are considered only as prerequisites for the creation of such a theory. The need for a permanent solution to this problem determines the relevance of this work.

A systematic approach to solving problems of design of hinged facade systems using historical experience is proposed. A methodology has been developed for the classification of metallic materials for design according to their coloristic and structural properties. The scientific foundations of the design of metal products have been developed from the standpoint of the use of new materials and technologies in their manufacture.

In the middle of the 19th century, the outstanding German theorist of architecture and industrial art, Gottfried Semper (1803-1879), formulated the problem of the connection between aesthetics and technology. He showed that science and technological progress provide at the disposal of artistic practice such materials and methods of their processing that "have not yet been mastered aesthetically." He believed that the time required for the aesthetic mastering of innovations would be constantly reduced due to the ever-increasing resolution capabilities of technology and 
the increasing artistic experience accumulated with the development of the arts [131]. Semper Gottfried was born in Altona (a city near Hamburg, now its district) on November 29, 1803. Initially he studied law and mathematics at the local university, then studied in the workshops of architects F. Goertner in Munich (1825) and F. Gau in Paris (from 1826) ... In 1830-1833 he traveled to France, Greece and Italy. Professor of the Dresden Academy of Arts (since 1839), took part in the revolution of 1849, after which he was forced to emigrate. Lived in Paris, London (from 1851). In 1855-1871 professor at the Polytechnic and director of the School of Construction in Zurich. In 1871-1876 he worked in Vienna. In his architectural practice he was inspired by the ancient classics, but not in its pure form (as was the case with his friend K.F. Schinkel), but perceived through the prism of the Italian Renaissance and Baroque (Semper, Gottfried (1803-1879), German architect and art theorist, representative of romantic historicism).

Karl Friedrich Schinkel was born in 1871 in the family of an archdeacon. After the death of his father at the age of four, Schinkel moved to the capital and entered the Academy of Architecture. His mentors in the architectural field were David and Friedrich Gilly, the founders of the academy. He combines his studies with work as an artist in a porcelain factory (at first, Schinkel was engaged in painting and lithography). He published a number of theoretical works, the most important of which is the book Style in the technical and tectonic arts (1863) - an experience of "practical aesthetics", where, in contrast to the philosophical idealism of his time, he emphasized the basic style-forming significance of materials and technology. (Karl Friedrich Schinkel - an outstanding architect of German origin at the beginning of the 19th century).

He advocated the activation of the role of color in sculpture and architecture, devoting his scientific works to this problem "Notes on the Painted Architecture and Plastics of the Ancients (1834) and on Polychromes (1851)".

Learning the history of the surrounding world, primitive man had a desire to explain everything around him and everything that happens in himself, i.e. the world as a whole. The ancient people embodied their entire first secret experience in mythology, the most powerful layer of spiritual culture. Generalizations and 
individualization made the myths more artistic. Gradually, an artistic and mythological consciousness arose. The first forms of religion were born.

During the Paleolithic period, fine art was born. The objects of artistic embodiment were, first of all, those objects and natural phenomena that were most closely related to practical activities with the problem of survival.

The accumulation of material and technical experience has led to the emergence in the III millennium BC They arose on the territory of Northeast Africa, Anterior and Central Asia, the Chinese Plain and the Indian subcontinent. The peculiarity of these civilizations was the heterogeneity of the processes of their cultural and historical development. Aesthetic the picture of the world in the era of ancient civilizations is a synthesis of religion, philosophy and "aesthetics", and religious and mythological views played a major role.

At the time of the fall of the Roman Empire, the population of Europe was not homogeneous, and this was reflected in European culture. It absorbed the cultural traditions of the peoples inhabiting Europe, experienced the influence of Antiquity and the East, therefore, we can say that there is no single style in medieval art, there is only a general idea, to which all medieval art is subordinated. This common feature is a deeply mystical, religious character.

At the turn of the XIX - XX centuries. there was a crisis in the system of scientific, aesthetic and ethical values. An attempt is made to generalize the aesthetic experience of mankind, to combine the artistic traditions of the West and East, antiquity and the Middle Ages, classicism and romanticism. The new artistic style was called modern (from the French. Modem, Latin. Modemus - modern).

Ancient China was an important region for the development of metallurgy in Asia. At the turn of 3000-2000. BC. bronze was known on the territory of China. In the 7th century BC. here they began to smelt pig iron. Already at the dawn of the Bronze Age, the Caucasus was a large region of the ancient world for metalworking, supplying neighboring lands with metal products. In the III millennium BC. in Transcaucasia, decorative items were cast using wax models. The early culture of processing copper and precious metals in southeastern Europe is incomparably poorer than in the regions 
considered above. In the 4th century BC. made castings in open and closed molds. In ancient Greece in the classical period (V-IV century BC) bronze statues of deities, heroes, athletes were cast, which were installed in temples, sanctuaries, necropolises and squares [132].

The experience of the Chinese raw material metallurgy is unique. In China and the nearby territories of the Far East, already at the beginning of the 1st millennium BC. e. smelting of pig iron in crucibles was mastered. To obtain cast iron, a charge consisting of blast iron and charcoal was placed in crucibles. Then the crucibles were kept in the hearths for a long time at temperatures above $1200^{\circ} \mathrm{C}$. The gradual dissolution of carbon in iron made it possible to obtain liquid cast iron saturated with carbon from solid crucible iron (in Fig.1).

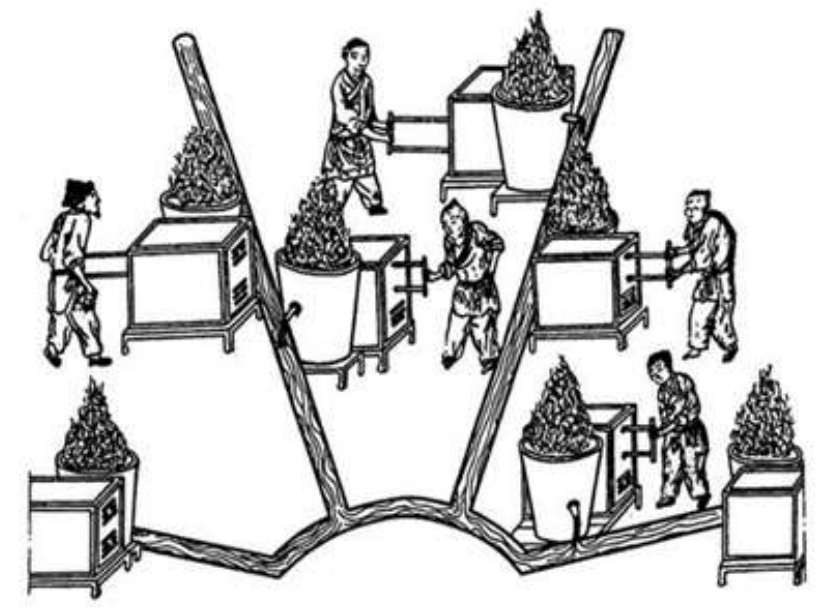

Figure 1. Chinese raw material metallurgy.

In ancient Italy, the Etruscans were skilled casters. Etruscan sculpture is characterized by a subtly expressed sense of plastic form. Monumental and easel sculpture in Ancient Rome of the period republics (V - I centuries BC) and empires (I - V centuries AD) were also located on high level. Particularly significant are the achievements of portraiture plastics.

In the Middle Ages (5th - 15th centuries AD), Byzantine culture is essentially a continuation of the Roman culture. The capital of the empire, Constantinople, became an important center of artistic crafts. there were Byzantine jewelers. They managed to develop and qualitatively in a new way comprehend the traditions of Hellenistic and late antique jewelry art[133]. 
Unlike Byzantium, the development of the countries of Western Europe proceeded otherwise. The leading area of creativity in the Middle Ages remained architecture that influenced other activities. Gothic (XII-XV centuries) is the period of the highest flowering of medieval European culture and its final stage. The period from the beginning of the 15th to the middle of the 16th centuries. in the history of European culture represents the Renaissance [134]. The achievements of this era were most clearly manifested in Italy. However, in the field of making bronze casting of a decorative nature, the leading place belonged to French craftsmen. From the XIV century, the architects of the Renaissance inherited as a universal building material hewn natural stone and ordinary brick on lime mortar, in the role of the leading structure - a frame cross vault, a craft organization of construction work [135].

A common misconception is that the architects of the Italian Renaissance built mainly from natural cut stone and ordinary clay bricks. However, Choisy, examining the unfinished Italian buildings of that time, found that the core of the wall is very often made of concrete, but significantly different from the Roman one [136]. Due to the cross vault, the predominance of rectangular cells in the naves of cathedrals did not meet new needs and aesthetic ideas. Alberti motivated the advantages of a round and multifaceted shape practically by the fact that under this condition "it is very easy to add a lot of chapels", and theoretically - by referring to the fact that "nature pleases the round and hexagonal most of all" (in Fig.2).
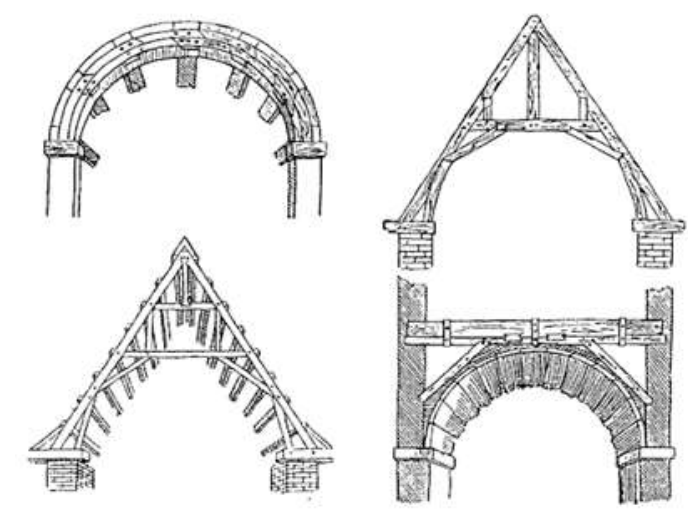

Figure 2. Construction machinery of the Renaissance in Italy.

All this prompted the architects of the Renaissance to prefer the ancient Roman dome, which was thoroughly forgotten in the Middle Ages, as the leading structure, 
leaving only an auxiliary role for the cross vault. The combination of the author and the performer in one person, characteristic of the craft, as well as the cooperation of equal, equally qualified craftsmen under the captious control of the workshop, impeded the grandiose construction of the era. Alberti essentially formulated the principles of manufacturing construction work. "The hand of an artisan," he says, "serves only as a tool for the architect," and recommends "finding clever, prudent, indefatigable assistants who will diligently, and unremittingly take care of everything necessary".

Instead of high-quality crushed stone, ordinary gravel was used here, instead of alternating masonry of leveled layers of mortar and crushed stone rammed into the solution, the components were simply thrown in a mess, without their preliminary mixing. Exactly so, according to the theorist of the late 18th and early 19th centuries. Rondela, the walls of the Cathedral of St. Peter in Rome.

Ordinary gravel, together with lime mortar, is randomly thrown into the formwork - cladding of travertine and bricks. Naturally, the question arises, for what reasons the architects of the Renaissance, borrowing architectural compositions and decor from the ancient Romans, did not borrow concrete either. In all likelihood, Roman concrete turned out to be of little use from an economic point of view for this era. What importance was attached to the cost of construction at that time can be seen from Barbaro's instructions that a cast column is cheaper than a stone one.

An important feature of the creative searches of Art Nouveau masters (end XIX - early XX centuries) was their conscious focus on creating synthetic works using the artistic possibilities of new designs of decorative plastic properties of materials, including non-traditional for art [137].

But compared to pouring gravel "mash" into stone formwork, which served at the same time as facing, the Roman technology was more laborious. Without requiring an increase in the number of workers with high-quality work engaged in masonry and backfilling, it was impracticable without a large number of laborers to beat crushed stone, level and ram components, etc. In the Middle Ages, customers, hiring craftsmen and apprentices, had the opportunity to use on construction of free unskilled labor, 
attracting it either in the order of feudal obligations, or with the promise of "absolution" (in Fig.3).

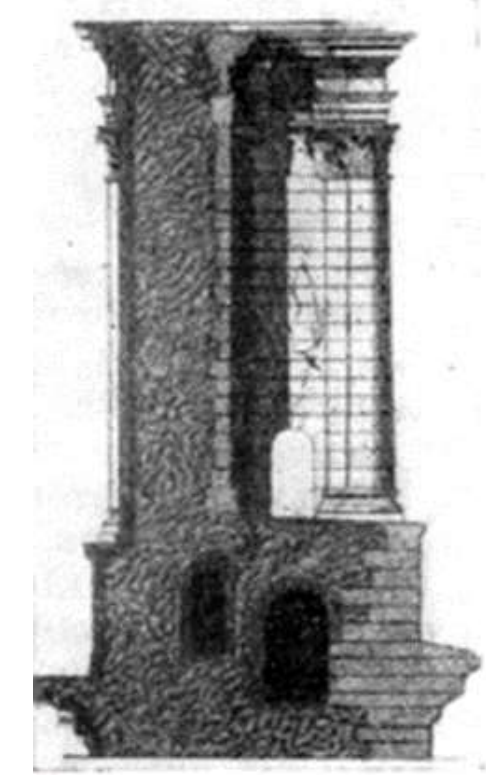

Figure 3. Concrete filling of the sinuses of the wall of the Cathedral of St. Peter in Rome.

The artist in his idea often proceeded from the metal processing technology, sometimes it was she who suggested to him the compositional solution. In the second half of the 20th century, interest in artistic forging reappeared. During mass industrial construction, the use of artistic metal was supposed to somewhat revive the overall picture. Artistic products of this period, as a rule, were made with blacksmith and metalwork tools. For the end of the XX century in the field of decorative and applied art, the creation of various compositions from geometric figures is characteristic.

The ergonomic properties of structures are assessed by the level of improvement in working conditions during its production in a progressive system. Quantitatively, this can be expressed in reducing the noise level at the workplace, facilitating transport operations by reducing weight, etc. This should also include improving the usability of the product by humans. The technological properties of the product include the "ability" of structures to be manufactured by the most productive method with the lowest economic costs, in compliance with environmental safety requirements.

The principles of the choice of material and technology for the manufacture of artificial products in their design from the standpoint of design can be formulated as 
follows: - the design of the designed product should not be lower than the design level of the prototype product; - compulsory compliance with the requirements of environmental safety, regulated by the current sanitary and hygienic standards, and the principles of environmental morality; - increasing economic efficiency by reducing costs, increasing durability and reducing operating costs; - reducing labor costs and improving working conditions, increasing the comfort of the working environment; increased convenience in use and operation for humans; - the manufacture of facade hinged systems should not require the creation of fundamentally new means of production [137].

The subject-spatial environment is perceived as a manifestation of the existing and historically developed color culture. Currently, three main problems of color design have emerged: first, the need for scientific and methodological support for color design; the second is to identify the specifics of the design of the colorist of various objects; the third is the creation of an aesthetically optimal range of materials. Studies of the color characteristics of copper alloys were carried out in order to determine the dependence of the color change of the alloy on the amount of alloying elements introduced [138].

The concept of an integrated approach to solving practical problems in design has been developed. The principles of choice of material and manufacturing technology of structures and finishing materials from the standpoint of design are proposed. A system of properties and parameters of new materials in design has been developed. Based on the analysis of the patterns of development of materials science and metal technology, a scientifically grounded concept of the choice of materials and technology in the design and manufacture of products from artificial materials of a finishing nature has been developed. The features of the constructive properties of new materials in the design of constructive systems for the finishing and artistic direction have been investigated. The theoretical foundations for the selection and development of new modern materials and technologies for the design of structures with specified properties have been developed. 


\section{5 Архітектурна система та архітектурна структура}

Архітектура є невичерпним джерелом інформації про життя суспільства, науково-технічний потенціал, ідеологію та мистецтво. Саме тому ії називають літописом світу. Архітектура є одною з тих дисциплін, що потребує постійного вивчення, дослідження та вдосконалення. Така діяльність дає змогу ознайомитись зі своєрідністюю конструктивних рішень.

Архітектурна фундаментальна наука відноситься як до технічних наук, так і до суспільних наук. Основне завдання архітектури - це створення штучного довкілля, що можна вважати комплексною задачею. Архітектура може поєднувати в собі багато аспектів, зважаючи на те, що сучасне будівництво базується як на суспільних, технічних науках , так і на нанотехнологіях. Але, архітектура має своє місце у ряді академічних наук, а саме тому вона має свою систему та структуру.

Існує варіант розгляду архітектури і їі окремих процесів як мовного явища. Тут варто згадати американського архітектора та творця органічної архітектури

- Ф.Л. Райта. Він був одним 3 перших, хто використав термін «граматика архітектурних форм» у своїх наукових роботах. Однак, архітектор вважав, що коли мова йде про способи поєднання простору, то треба використовувати термін « синтаксис архітектурних форм».

Результати архітектурної творчості можуть бути представлені як носії матеріальної та духовної цінності, а саму архітектуру потрібно розглядати як окреме явище, в якому можна виділити три актуальні області.

Насамперед слід згадати професійне навчання архітекторів в архітектурних школах, коли навчання проектуванню здійснюється так само за чіткими «граматичними» законами.

Другий аспект пов'язаний із тим, що архітектура як культурне явище може досліджуватися з естетичної точки зору. 
Останній, третій напрямок - це розгляд архітектури як системного структурного явища, що вимагає іiї вивчення як культурної та технологічної системи, що володіє геометричними, топологічними та цілісно-системними властивостями.

Розглядаючи архітектуру як системне явище треба виділити два напрями. Перший охоплює вивчення архітектурних форм та параметрів опису їхньої будови. Другий напрямок має справу з семантикою, тобто, системою значень, що надаються архітектурною формою, тому, як вони структуруються, як існують i як розвиваються.

Слід зазначити роботи, присвячені цьому напряму, таких вчених, як Норберг-Шульц, Ж.Х. Бонта, Ж. Бродбент, Л. Марч, Г. Віллоубі, В. Мітчелл. Їх дослідження планувальної будови архітектурних об'єктів спиралися на певні розділи математики, геометрії, графоаналітично теорію і теорію симетрії.

В основі цих досліджень лежить припущення, що вивчення геометричних обмежень просторового розгортання архітектурних об'єктів (у тому числі і містобудівних) допоможе архітектору-проектувальнику при вирішенні завдань професійної підготовки, так і при вирішенні практичних завдань проектування архітектурних об'єктів.

Ti, хто займались такими дослідженнями, математичні знання розглядають як вагоме доповнення до розумового процесу, що пов’язаний з архітектурною діяльністю. Що більше, стає очевидно, що комп’ютерна техніка неминуче все більше буде займати місця у діяльності архітектора, а математичні навички $є$ важливими для роботи з сучасними комп’ютерними програмами.

Математична компетентність підвищує професійну цінність проектувальника та дає більше можливостей для розвитку та діяльності.

Можливо тут варто роздумувати над розробкою програм, що будуть генерувати ймовірно «оптимальні» архітектурні рішення 3 урахуванням критеріїв різного роду.

Критерії обліку геометричних, топологічних, комунікаційних, технічних та інших обмежень під час виконання компонування плану необхідні під час 
розгляду варіантів планувальних рішень 3 використанням об'єктивно сформульованих методів їх генерації.

Можна сказати, що сама архітектура є багаторівневою системою, якій підвладні безліч взаємозалежних елементів і підсистем, що утворюють ієрархію в рамках цілого і включають до свого складу окремі елементи одного виду. В такому випадку більше уваги треба приділяти не стільки основі архітектурних елементів, скільки їх реляційним характеристикам, які набуваються ними в результаті функціонування у структурі архітектури.

Можна сказати, що архітектура зводиться певним способом до структури, точніше до мережі відносин між її елементами. В такому разі, можна оголосити про залежність кожного архітектурного елемента від структури, до якої він належить, та від його місця відносно інших елементів.

Розгляд просторової організації архітектурних елементів дозволяє проаналізувати та виділити узагальнені інваріативні одиниці - просторовопланувальні рішення і спів віднести їх з конкретними просторовими ситуаціями з урахуванням строгих правил їх просторової реалізації.

Прикладом такого аналізу можна вважати роботу Роба Кріє «Architectural composition» (1988), у якій робиться докладний розбір будови архітектурних об'єктів в історичній ретроспективі з позицій їхньої особистої творчої оцінки. Р. Кріє розбирає обумовленості архітектурної форми з чотирьох позицій:

• по-перше, взаємозалежність форми та функції ;

• по-друге, розглядається форма як архітектонічна система організованих елементів;

• по-третє, окремі елементи , що визначають архітектурну форму;

• по-четверте, архітектурна форма як результат співвідношення пропорцій.

Така система дає змогу охопити головні описові характеристики для будьякої архітектурної форми, включаючи як природньо-фізичний аспект, так i художньо-виразний.

Гармонічний взаємозв’язок функції та форми в архітектурному об’єкті приводить нас до розуміння системності та цілісності архітектури. Саме функція 
задає типологічно стійкі образи в архітектурі. Це своєю чергою призводить до впізнаванності будівлі.

Друга позиція опису - архітектоніка форми - визначає опис системних властивостей, що виявляються в будові архітектурних об'єктів і описуються складними матрицями, побудованими з різних підстав: точка - лінія - площина обсяг - внутрішній простір - зовнішній простір; графіка - пластика - архітектура - урбанізм; регулярна геометрична форма - нерегулярна хаотична форма копіювання та доповнення - гетерогенні форми.

Подібні матриці дозволили Р.Кріє описати 3 єдиних позицій все образотворче «поле» художньої творчості художника, яким може бути i скульптор, i дизайнер, i фотограф, і графік, i архітектор. Всі вони у своїй творчості займаються пошуком виразності форми, її тектонікою, мотивацією для якої може стати будь-яка із заданих їм підстав.

При розгляді архітектури з точки зору класифікації наук, треба виділити три окремі розділи для досліджень, що включають інновації на стику 3 технічними науками, на стику із суспільними науками та 3 природознавством. Зважаючи на все це, можна сказати, що архітектура охоплює широкий спектр дисциплін, які мають гармонійно поєднуватись та взаємодіяти під гаслом архітектурної творчості.

Усі етапи розвитку архітектури характеризувались великою кількістю суперечок щодо ऑii місця серед інших наук. Архітектура пройшла тривале становлення від періоду моністичних знань до власної диференціації, коли науковці підрозділяли їі на декілька окремих предметів, що формували окремі дисципліни. Наразі технічний прогрес вимагає чіткої систематизації знань а сама архітектура потребує гострого синтезу здобутих знань .

Науково-технічна революція поставила перед людством багато нових завдань. Прискорення розвитку нових технологій потребує швидкого навчання та впровадження. Якщо раніше зміни навколишньої дійсності були одиничними та припадали на декілька століть. То тепер їх можна спостерігати неодноразово протягом життя одного покоління. Містобудування є багатоскладною та 
трудомісткою сферою, однак разом і 3 тим найінертнішою, бо у 21 столітті нововведення будуть впроваджуватись кожні 50 років, що у 10 разів більше, ніж у інших сферах діяльності людини. Це пов'язано з дедалі більшою концентрацією населення у містах, необхідністю покращувати та розвивати інфраструктуру транспорту, туризму, виробництва, зводити житло, загалом забезпечувати зростаюче населення планети об'єктами, що формують матеріальне середовище життедіяльності.

При цьому вимоги до якості штучного довкілля людей постійно підвищуються. Нові технології дозволяють реалізувати абсолютно фантастичні проекти у змісті яких приховані зусилля великого загону спеціалістів. Вони забезпечують «міцність та користь» у контексті глобальних викликів сучасності, використовуючи нові методи розрахунку та конструювання проектованих об'єктів. У їх зовнішній формі та внутрішньому просторі реалізуються вимоги «краси», закладаються глибокі філософські та естетичні концептуальні ідеї, привабливі для професіоналів та масових споживачів мистецтва архітектури.

Сучасна архітектурна освіта має відповідати викликам нового часу. Середовище повсякчас змінюється, а професійні завдання стають все складнішими. Студенти мають отримувати актуальні знання, що не застаріють на етапі отримання диплому.

Введення в ужиток сучасного архітектора комп'ютерної техніки дозволяє підвищити якість технічної проробки проектів, прискорити процеси обгрунтованості, можливості нелінійного програмування, відкривають шляхи прийняття проміжних рішень по ходу виконання проекту на різних стадіях і при цьому включати можливості техніки в творчий процес архітектора, повніше та багатостороннє враховувати природні геометричні та структурно-топологічні обмеження формоутворення.

Вирішення проблем впровадження комп'ютерного проектування визначить низку нових напрямів архітектурної діяльності, пов'язаних з умовами проектування, використанням необхідної техніки та програмного забезпечення у практиці проектування, комп'ютеризацією процесів професійного навчання та 
неминучим коригуванням самих навчальних програм, орієнтованих на нові методи проектування та будівництва.

Впровадження в програми навчання нових методик, заснованих на структурному трактуванні будівлі архітектурних об'єктів, ознайомлення 3 логікою природного формоутворення у реальному просторі ув'язування архітектури з усім предметно-просторовим штучним та природним оточенням, 3 одного боку, продовжить традиції Л. Да Вінчі, А. Дюрера та Кр. Рейя, які бачили в архітектурі не протиставлення природі, а наближення до неї та вписування у логіку їі розвитку.

Архітектори та студенти вже сьогодні використовують комп'ютерні моделі - віртуальні, кібер-реальні, і в найближчому майбутньому слід очікувати на розширення сфери їх застосування для вирішення професійних завдань. Комп'ютерні моделі стають найбільш перспективними в архітектурному проектуванні та навчанні.

Таким чином, архітектурна система визначається як умоглядно пов'язана сукупність фактів штучного середовища оточення людини та лежачих у іï основі механізмів їх природного існування.

Архітектурна система передбачає багаторівневу організацію 3 наявністю підсистем, що співвідносяться 3 вже сформованою в архітектурі об'єктної масштабно-цілісної класифікації: інтер'єрна організація об'єкта, що передбачає цілісну побудову його внутрішнього простору; об'єкт (будівля, споруда) як самостійна одиниця, протиставлена зовнішньому оточенню; комплекс об'єктів 3 включенням їх внутрішніх та зовнішніх просторів (багатофункціональні комплекси, житлові освіти, квартали, населені пункти, фрагменти міського середовища); містобудівні комплекси, де простір замінюється поняттям території, але ще не зменшує своєї пропорційності людині.

Виділення підсистем в архітектурній системі необхідно у зв'язку 3 необхідністю визначення об'єкта архітектури як цілісної структурної одиниці відповідного ітераційного рівня. 
3 архітектурною системою також співвідноситься поняття архітектурної структури як абстрактної мережі співвідношень різних частин архітектурного об'єкта, тобто їхню просторову структурну організацію.

Структура являє собою сукупність стійких зв'язків об'єкта, що забезпечують його цілісність та тотожність самому собі, тобто збереження основних властивостей при різних зовнішніх і внутрішніх змін.

У вище приведеному зіставленні слідує Важливо відрізняти поняття архітектурної системи та структури.

Система - це реальний феномен, явище, об'єкт чи їхня група, розглядаються як сукупність пов'язаних певним чином складових частин, тоді як структура $\epsilon$ абстрактною мережую відносин цих елементів. Тому кожна архітектурна система завжди передбачає наявність у ній своєї структури.

Структура не може бути створена штучно, безвідносно до будь-якої архітектурної системи.

За зовні простим процесом організації архітектурного простору, що зводиться до членування цілого на частини, з'єднані по певним закономірностям, ховаються фундаментальні властивості архітектурного простору.

3 цих закономірностей випливають численні формально-логічні та практичні наслідки, що базуються на тому, що структурні властивості простору архітектурних об'єктів лежать в основі прояву загальних закономірностей реалізації процесів формоутворення, серед яких головними є геометричні, топологічні та цілісні. 


\section{6 Фактори, що впливають на організацію багатоповерхових житлових будинків}

Українські вчені проаналізували найважливіші показники рівня розвитку і поширену поверховість житлових будинків в різних країнах світу. Виявлено пропорційну залежність поверховості багатоквартирного житла для постійного проживання від загального рівня розвитку країни: чим вище рівень життя в країні, тим менше поверховість будинків.

Ця залежність дійсна лише щодо житла, призначеного для постійного проживання. Також проведено аналіз, на основі отриманих результатів якого виявлено три основні варіанти розміщення багатоповерхової забудови на території міст різних країн світу: багатоповерхова забудова в історичному центрі

міста (США, Канада, Австралія), багатоповерхова забудова, віддалена від історичного центру міста (країни Західної і Центральної Свропи), змішана забудова (країни, що розвиваються).

Проблеми багатоповерхового житла пов'язані з цілою низкою соціальноекономічних обставин, що мають об'єктивний і суб'єктивний контекст. Основними проблемами багатоповерхового житла є: порушення взаємозв'язку людини і природи; погіршення санітарно-гігієнічних умов; ускладнення заходів безпеки проживання і подорожчання експлуатації будівлі; психічні розлади у мешканців.

Світова практика містобудування свідчить про усвідомлення в суспільстві того, що багатоповерхові будинки не повинні бути житловими. В умовах активного економічного і соціального розвитку міст архітектура перетворюється на дієвий фактор ефективного вирішення проблем сучасного урбанізованого світу. В результаті аналітичного огляду було виділено фактори, що впливають на поверховість та комфортність багатоквартирного житлового будинку.

Природно-кліматичні чинники враховують особливості клімату місцевості, впливають на архітектуру житла, його функціональну і просторову організацію, 
вибір конструкцій, матеріалів. До них відносять: інсоляцію, температуру та вологість повітря, шумовий, вітровий, аераційний режими, вентиляцію.

Для формування комфортного житлового середовища необхідно враховувати характеристики регіонального i локального мікроклімату. Регіональний напрямок пов’язаний з урахуванням загальних умов клімату, характерних для великих територій, районів, міст. На регіональному рівні до житла пред’являють загальні типологічні вимоги, регламентовані нормами. Локальний мікроклімат обумовлений особливостями конкретної місцевості. На цьому рівні уточнюють типологічні вимоги до житла. Житлові будинки набувають певну спрямованість у зв’язку з місцевим напрямком вітрів, 3 конкретними умовами інсоляції, орієнтації схилів, видових перспектив і т. п.

Індивідуальний мікроклімат в багатоповерховому житловому будинку створюють з урахуванням регіонального та локального клімату. Він повинен створюватися в системі інтер'єрних і екстер'єрних просторів. Інсоляція повинна забезпечувати достатнє потрапляння прямого сонячного світла всередину приміщень будинку. Обмежена прозорість скління світлопрорізів, їх затемненість, а часто невідповідність розмірів площі вікон глибині приміщень викликають дефіцит природного світла, що погіршує умови життя людини. Можливий перегрів приміщення в спекотні літні дні усувають за допомогою козирків, жалюзі, штор, озеленення. Акустичний режим залежить від зовнішніх i внутрішніх джерел шуму. Згідно 3 нормами, рівень шуму не повинен перевищувати 25 дБ і 20 дБ (в нічний час). Додатковими джерелами шуму є: ліфтове обладнання, обладнання відведення води, система центрального кондиціювання, вентиляції і т. п. Рівень шуму може бути зменшений засобами раціонального планування будинку, його озеленення, застосування шумозахисних матеріалів. Згідно з результатами досліджень в сфері звукових коливань житловий будинок може відповідати вимогам акустичного комфорту завдяки його обмеженню 5-ю поверхами. Вологість повітря прямим чином впливає на здоров’я і самопочуття людини: високий рівень призводить до ослаблення імунної системи, виникненню різних захворювань і алергічних 
реакцій, занадто низький негативно впливає на людський організм в цілому. Тому рівень відносної вологості повітря в житловому будинку з комфортним мікрокліматом - 40-60 \%.

Істотно впливає на планування житлового утворення вітровий режим місцевості. Раціональне проектування житлового будинку з урахуванням вітрів передбачає ефективне використання природного провітрювання приміщень та зниження негативного впливу вітрового напору. В цілому індивідуальний мікроклімат формують з урахуванням умов підвищених і знижених температур. Ландшафтні фактори враховують характер природного середовища.

Рельєф місцевості значно впливає на вибір прийомів житлової забудови і формоутворення будинків. Як правило, на крутих схилах розташування житлових будинків безпосередньо залежить від пластики рельєфу. Забудова цих територій вимагає додаткових інженерних заходів для їх підготовки та обладнання. Несприятливими для житлової забудови є північні схили, так як на них не відбувається інсоляція приміщень і території. Слід підкреслити, що освоєння крутих схилів для забудови є дуже актуальним завданням, оскільки більшість великих міських поселень вже вичерпали свої територіальні резерви. Містобудівні фактори (місце розташування та розміри ділянки будівництва, морфологічні особливості навколишньої забудови, іiі функціональна структура) активно впливають на формування житлових будинків. У місті, яке має тривалу історію розвитку, будівництво житлових будинків може бути здійснене в умовах реконструкції центральних районів і на нових освоюваних територіях. Ділянка може бути відведена на магістральній вулиці і всередині кварталу, на міській площі і в пішохідній зоні, в складі житлового комплексу і в суспільноадміністративному центрі. Аналогічні ситуації можна зустріти в новому місті. Тому при проектуванні житлового будинку і забудови в цілому необхідно комплексно враховувати специфіку ситуації. Так істотне значення для проектування житлових будинків має морфологія навколишньої забудови (геометрія її планів, розмірність будівель і утворених ними просторів). 
Компонування будівель і комплексів, що розміщують в історичних центрах, як правило, орієнтовано на підтримання і в ряді випадків повторення геометричних конфігурацій і розмірностей, властивих оточенню. У районах, що виникли в 60-70-і роки, навпаки, більш привабливим може виявитися не уподібнення, а контраст, якого досягають засобами зменшення дворових просторів i ускладнення геометричних характеристик планів. Важлива властивість міського середовища - поверховість формуючих ії будівель.

У зонах суворо регульованої забудови, заснованої для збереження архітектурної та містобудівної спадщини, визначають гранично допустиму висоту новозведених споруд. Для кожного місця обмеження встановлюють індивідуально на основі вивчення ситуації. Поверховість проектованих багатоповерхових житлових будинків може бути лімітована також і з метою збереження видів на ландшафтні і архітектурні пам’ятки. В інших випадках поверховість регулюють, виходячи 3 інших міркувань, в тому числі композиційних.

Великий вплив на проектування багатоповерхового житла надає функціональна структура міського середовища. У практиці останніх років помітне місце займає будівництво житла в складі багатофункціональних комплексів і у вигляді будинків з вбудованими або прибудованими закладами громадського призначення.

Еколого-гігієнічні фактори комфортності: коливання будинку, атмосферний тиск, хімічний склад повітря, озеленення прибудинкових територій. Коливання багатоповерхових будинків чинять негативний вплив на вестибулярний апарат людини і можливість входження їх в резонанс з низькочастотними коливаннями внутрішніх органів людини. Обидві причини можуть викликати небезпечні психофізичні розлади організму i хронічні захворювання. 3 точки зору уникнення негативного впливу можливих коливань будинку поверховість житла для постійного проживання запропоновано обмежити 12-ма поверхами.

Атмосферний тиск визначено одним 3 показників комфортності житла. Вважається, що до висоти 100 м рівень тиску порівняно стабільний, але навіть на 
висоті 20-поверхового будинку (60 м) тиск менше на 8-10 мм від тиску на рівні 5 м над землею. Зниження атмосферного тиску спостерігається в міру віддалення від земної поверхні і погіршує самопочуття людини.

Отже, поверховість житлових будинків в цьому відношенні запропоновано обмежити 9-ю поверхами. Зміни в хімічному складі повітря 3 підвищенням висоти можуть бути небезпечними для здоров’я людей похилого віку і дітей. Зі збільшенням висоти розрідженість повітря безперервно збільшується, а тиск зменшується. Зростає температура, вологість, концентрація оксиду вуглецю i пилу. 3 цієї причини в багатоповерховому житлі повинна бути передбачена централізована система вентиляції та кондиціювання повітря. Однак кондиційоване повітря може негативно впливати на стан здоров’я мешканців, тому необхідним є природне провітрювання. Озеленення територій визначено як один $з$ факторів комфортності в аспекті створення безпечного для здоров’я людини мікроклімату багатоквартирного житла.

Демографічні та національно-побутові чинники враховують цілу низку ознак: чисельність і темпи зростання населення, його статевовіковий склад, число, розмір і структура сімей. Показники, що характеризують загальну чисельність населення важливі при визначенні об'ємів і темпів будівництва житла. 3 показниками статевовікової структури населення безпосередньо пов’язана типологія житлових будинків і квартир. Суттєве значення має факт старіння населення, що призводить до збільшення чисельності груп пенсійного віку.

Певний вплив на проектування квартир в багатоповерховому будинку має рівень освіти населення. 3 підвищенням рівня освіти зростають потреби в квартирах 3 можливістю створення робочого місця. Проектування житла неможливо без урахування сімейного складу населення, що впливає на формування типології квартир. Демографічні дані дозволяють зблизити структуру нового житлового фонду і попит населення. Важливою ознакою є структура родини. 
Соціально-психологічні чинники. Форми житла виникають і розвиваються в прямому зв’ язку зі способом життя окремих людей і соціальних груп. Усім видам житла притаманні деякі загальні соціальні функції: збереження здоров’я людей, що в ньому проживають; зміцнення сім’ї та створення в ній здорового психологічного клімату; сприяння розвитку сім’i; організація позаробочого часу; підвищення професійної кваліфікації; виховання дітей; створення умов для відпочинку; виконання ролі психологічного «притулку». Кожна з цих функцій повинна отримати певне матеріальнопросторове втілення, як в структурі всього будинку, так і в окремій квартирі.

Соціальна модель житла - це система вимог сім’ї до його функціональної програми і просторової структури. Вимоги визначають способом життя людей: сукупністю форм і умов життєдіяльності індивідуума, соціальної групи, суспільства. Так виникає необхідність цілісного підходу в архітектурній інтерпретації системи «спосіб життя - житлове середовище». Відступ від системного формування житлового середовища завжди обертається значним збитком для населення. На сучасному етапі набуває великого значення облік різноманіття індивідуальних і колективних потреб, висунених до житла. Кожна сім’я прагне організувати процеси життєдіяльності в квартирі з можливістю максимальної реалізації своїх професійних інтересів, ціннісних орієнтацій і звичок. Тому актуально питання про розширення номенклатури квартир i гнучкість їх архітектурно-планувальних параметрів. По-справжньому гуманне тільки те житло, яке в повній мірі відповідає своєму соціальному призначенню.

Eстетичні фактори. Предметне втілення естетичних ідеалів і традицій в архітектурі житла здійснюється в ході його формоутворення на всіх рівнях: забудова - будинок - велика пластика будинку - деталь - квартира. При вирішенні певних композиційних завдань визначають конкретні характеристики забудови: стилістичні ознаки, системи пропорцій і масштабність, метро-ритмічні закономірності, малюнок деталей, матеріал і фактура огороджувальних конструкцій, колір і т.п. У зарубіжній практиці крім цього велике значення надається суспільній оцінці вигляду міста, перевагам жителів, визначенню 
особливо значущих для населення якостей міського середовища, розкриття образних уявлень про місто, що склалися в свідомості людей. Подібна інформація допомагає точніше сформулювати проектну задачу і обгрунтовано вибрати засоби ії вирішення, вписати багатоповерховий будинок в середовище. Залежно від умов сприйняття і ролі будинку в заданій ситуації необхідно відображати його активність або пріоритетність. Чим далі об’єкт сприйняття, тим більша його частина потрапляє в поле зору. Окремий будинок починає сприйматися разом з оточенням і оцінюється в порівнянні з сусідніми будівлями. У міру віддалення від об’єкта сприйняття змінюється зміст цілого і частини. Так само змінюються просторові відчуття. Істотною умовою виявляється швидкість пересування глядача. Отже, забудова повинна бути досить інформативною для сприйняття при різній швидкості руху. Різноманітність зорового сприйняття житлових будинків актуалізує всі їх характеристики: від загальної форми до малюнка балконних огороджень i віконних рам. Нехтування будь-яким інформаційним елементом призводить до збіднення архітектурних якостей забудови.

Інженерно-технічні фактори: площа інженерних, комунікаційних і конструктивних елементів, системи і методи зведення будівель; інженерне обладнання; будівельні матеріали. Інженерне обладнання сучасного будинку дуже різноманітно, призначене для створення комфортних умов проживання та передбачає системи: опалення, вентиляції, водопостачання, каналізації, ліфтового господарства, сміттєвидалення, а також електромережу, газопровід, слабкострумові мережі, телевізійні кабелі тощо. У багатоповерхових житлових будинках потрібно обладнання технічного поверху для горизонтальної розводки мереж, ліфтова шахта і сміттєпровід. У деяких країнах система сміттєвидалення включає також і первинну обробку сміття. Широке застосування отримали санітарно-технічні кабіни. Для опалення будинків найчастіше застосовують радіатори 3 нагрітою водою. Також є системи променевого опалення, коли обігрівальні елементи розміщують за підвісною стелею або всередині стінових панелей. В даний час поширений прийом - система теплої підлоги. 
Техніко-економічні чинники формують огороджувальний простір будинку матеріально-конструктивну оболонку будівлі; відображають технічні та економічні можливості забудовника. При проектуванні багатоповерхових житлових будинків зростає значення раціонального використання матеріальних, фінансових і трудових ресурсів, спрямованих на вирішення житлової проблеми.

У США, Австралії, Канаді та країнах СС відповідність експлуатаційних витрат рівню комфортності житлового будинку є важливим критерієм при виборі житла. У міру збільшення економічного потенціалу суспільства і вдосконалення організації проектнобудівельної справи будуть зростати можливості для підвищення комфорту житла і поліпшення його архітектурних якостей. Bсі вищевикладені фактори впливають на архітектурні особливості житлового будинку і $є$ формотворчими. Своєрідності архітектури житлових будинків досягають в результаті всебічного i індивідуального врахування всіх вищезазначених чинників. Багаторічний світовий досвід висотного будівництва та відповідні наукові дослідження свідчать про різні прийоми розміщення хмарочосів у міському середовищі. Для забудови відносно молодих міст (НьюЙорк, Глазго та інші), в яких немає значних історичних архітектурних споруд, характерним є формування центральної частини міста за рахунок нових, в тому числі і багатоповерхових будівель. Це має певні позитивні містобудівні аспекти, особливо в архітектурно-композиційному відношенні та економному використанні територіальних ресурсів, адже вартість землі в сучасних мегаполісах надто висока. Однак під час будівництва хмарочосів в центральній частині міста ускладнюються проблеми транспортно-містобудівного характеру та створення необхідної інженерної інфраструктури.

Інша концепція розвитку, яка застосовується переважно в містах зі своєрідною історичною забудовою, не передбачає спорудження хмарочосів в центральній частині міста. В більшості історичних міст Західної Європи нові багатоповерхові громадські комплекси формуються переважно в периферійних зонах. Прикладом може бути Париж, де висотна офісна споруда «Тур де Монпарнас» (57 поверхів) в центральній частині міста не викликала особливого 
захоплення фахівців та мешканців міста. Тому в 1960-70-х роках створено сучасний діловий та громадський центр в восьми кілометрах від історичного центру в районі Дефанс з метою активізації економіки та придання нового стильового звучання архітектурі міста. За сучасними вимірами висоту будинків в новому районі Парижу неможна віднести до хмарочосів. Взагалі генеральним планом даної місцевості багатоповерховим (переважно офісним) будинкам віддавалось лише 5 відсотків території, житло передбачалося середньої поверховості, а громадські установи культурно-дозвільного, торговельного та виставкового призначення розмістились в малоповерхових спорудах зальної структури.

Дещо подібними є підходи до висотної забудови в Берліні. Нова забудова в центральному районі Фрідріхштадт регламентована максимальною висотою в 30 м. Висотні будинки в новому діловому та громадському центрі Потсдамер Плац обмежені 25 поверхами. Відносно менше обмежень стосовно висотності забудови в інших містах Німеччини, особливо у Франкфурті-на-Майні, де поряд 3 колоритним історичним ядром сформовано діловий центр зі своєрідними висотними архітектурними акцентами (рис. 1).

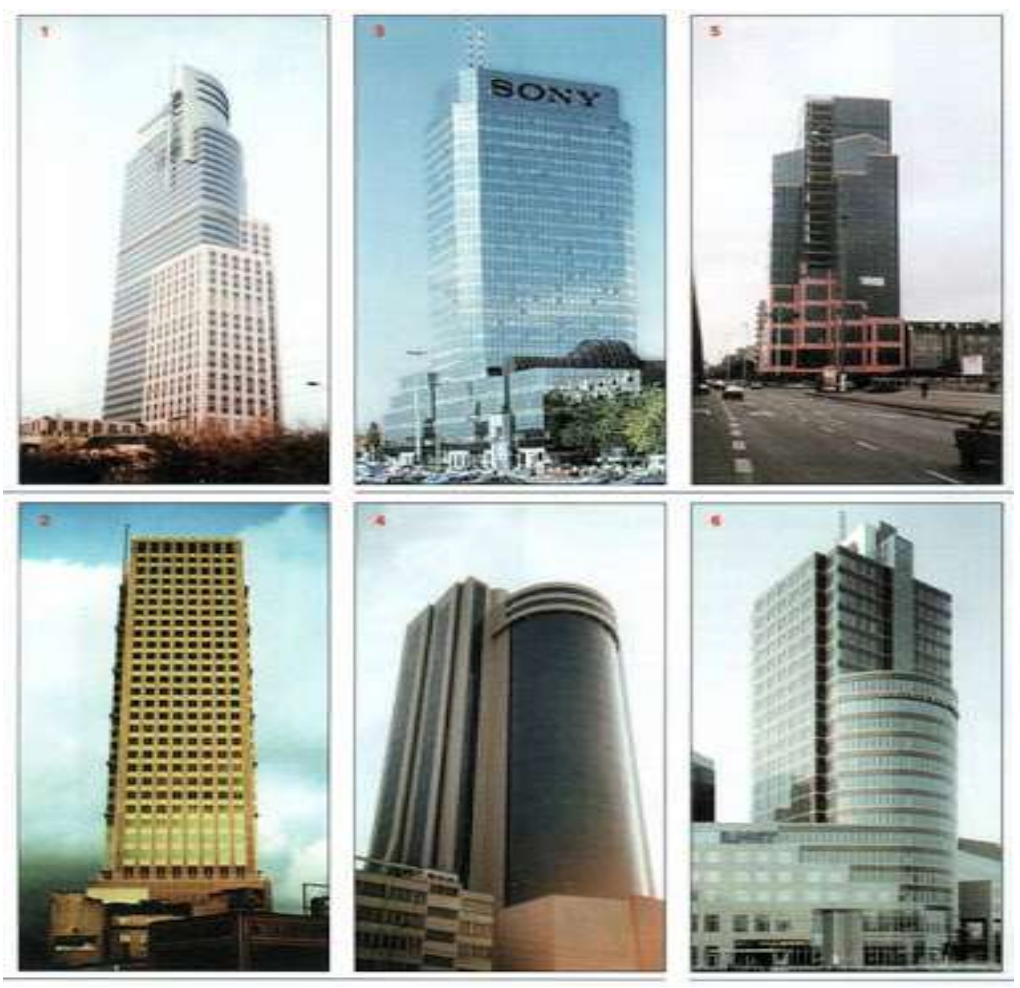

Рисунок 1 - Висотні забудови 
Дослідники проблем висотного будівництва відмічають, що у Лондоні також більш ліберальні підходи до нових висотних містобудівних акцентів, ніж у інших столичних містах Західної Свропи [148]. Незважаючи на те, що на протязі більше двох віків знаковою домінантою міста був і залишається Собор Святого Павла (120 м) та башти парламенту, в даний час в столиці Англії реалізується декілька висотних ділових комплексів: район Лондон Сіті, центр Канарі Уорф, група висотних споруд в районі Саутворк та інші. Керівництво міста сприяє подальшій урбанізації історичного середовища, висота споруд державними указами не регламентується.

Творення міського простору - одне з найважливіших людських зусиль, адже йдеться про те, щоб різні групи людей жили разом у відносній гармонії одне 3 одним та природою. Останнє є критично важливим, беручи до уваги драматичні наслідки змін клімату. Це має бути основним правилом будь-яких майбутніх креативних ініціатив в архітектурі міста. Планування, яким ми його знаємо, все ще сильно концентрується на фізичних аспектах, - урбаністичному дизайні та архітектурі. Воно добре виглядає з висоти пташиного польоту, тому зазвичай демонструється згори, але це не все, що має значення в містобудуванні. 


\section{7 Сучасний ландшафтний компонент в архітектурі житлових комплексів}

Природа, вірніше, природні форми завжди були першоосновою поняття досконалості та краси, визнавалися їх еталоном. У сучасному місті відчувається брак земельних ресурсів, що веде до виникнення ущільненої та точкової забудови. Екологічна проблема сьогодні стала актуальною в усіх сферах життя людини. Озеленення територій є недостатнім для вирішення проблеми, тому архітектура повинна враховувати екологічну реальність нашого часу і вирішити низки екологічних проблем за допомогою так званої “зеленої архітектури”.

Необхідна людині зелень, яка може бути розміщена на землі, піднімається на вертикальні і горизонтальні площини будинків. Ефект присутності природи та їі багаторівневе розміщення $є$ трендом ландшафтного дизайну та благоустрою міста. Вертикальне озеленення: “зелені” дахи, фасади, балкони, тераси сьогодні можна побачити у різних куточках світу. Зелені стіни стали використовувати в декорації інтер'єрів на початку 21-го століття: офіси, музеї та приватні будинки стали відводити невеликі стіни під висячі сади-оранжереї. Озеленення будинків починають використовувати у своїх проектах багато відомих архітекторів i декораторів, наприклад, Ренцо Піано та Андре Путман, Р. Хакні, Ф. Хундертвассер, Ральф Хенкок та інші. Зелена будівля — міст, що сполучає природу та рукотворний світ людини. Такий будинок коштує дорожче, але майже завжди окупається економією на рахунках за енергію. Зелений дах будинку не дозволить знехтувати водою, а рослини, що вимагають сонячне світло, можна вирощувати на балконі. Ландшафтна архітектура спирається на взаємовідносини між суспільством та природним світом. Ландшафтна архітектура націлена на:

•функціонально-просторову організацію середовища життєдіяльності людини;

•перетворення ландшафтів при охороні їх природних особливостей;

•естетику зовнішнього благоустрою.

Завданням ландшафтної архітектури вважають: охорону, перетворення (формування) та відновлення (рекультивацію) ландшафтів. 
Відтворення природного середовища стає все більш актуальною задачею для великих житлових кварталів: використання поверхонь фасадів і дахів будівель, розміщення природних компонентів у внутрішніх структурах будівлі 3 поширенням озеленених поверхонь у просторі.

На сьогоднішній день, існує два основних напрямки впровадження ландшафтних та ландшафтно-рекреаційних одиниць у забудову житлового кварталу: ландшафтна організація зовнішніх просторів території біля будинка та використання закритих внутрішніх просторів для ландшафтних утворень. Також використовують різноманітні техніки, що дають змогу створювати окремі об’єкти та споруди, малі архітектурні форми з живих рослин: pooktre, pleaching, “дерева на шпалерах”, арбо-скульптура або “жива скульптура”, арбоархітектура, ботанічна архітектура та багато інших. 3 рослин можна формувати різноманітні арки, альтанки, літні житлові приміщення, меблі, та предмети. Для них не потрібен дорогий інвентар та складні технології, щоб їх створити треба лише фантазія, терпіння та час.

Цікавий приклад такої архітектури проект “Живого храму”, який створив Джуліано Маурі, відомий італійський архітектор, який не дожив до сучасних днів, проте цей храм, що став його останнім проектом, зростає - тобто “самодобудовується” й дотепер (рис.1). Споруда розташована на околиці італійського міста Бергамо біля підніжжя гори Арера, що на Півночі Італії.

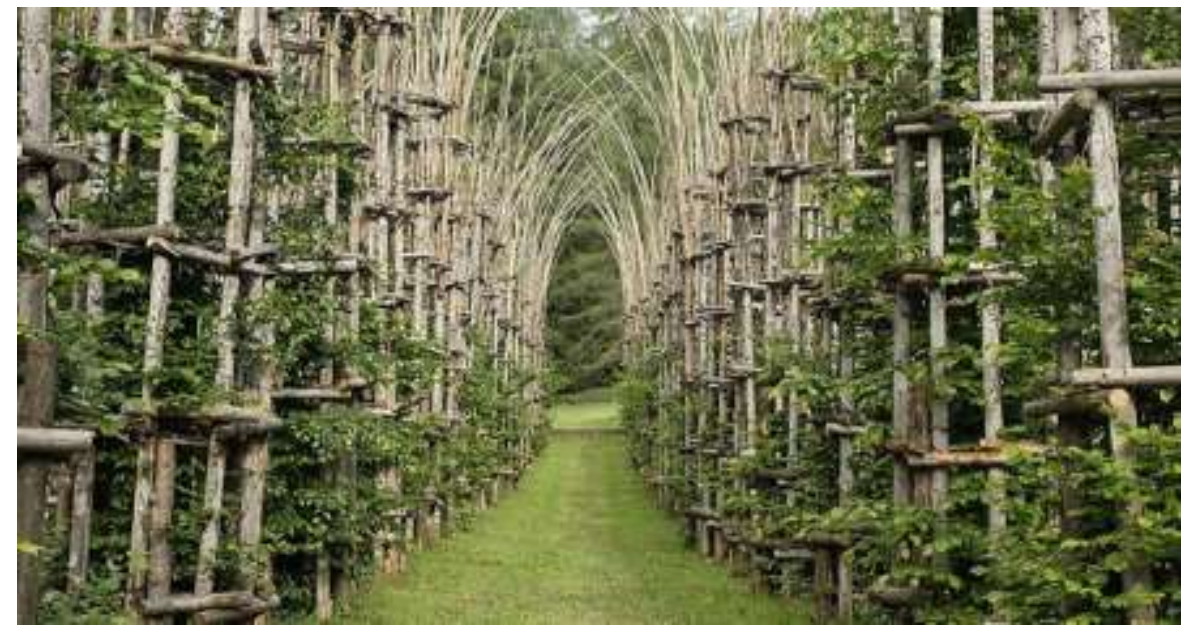

Рис. 1. Житловий храм. Архітектор Джуліано Маурі. 
Суть проекту полягає в тому, що всередині створених із дерева 42-х колон, були посаджені саджанці граба. За задумом Джуліано, приблизно через п’ятнадцять років каркас-колони стануть “тісні” для дерев і природно зруйнуються. А самі граби утворять природну конструкцію справжнього собору з живого дерева. Проект займає значну площу в 650 м (рис. 2).

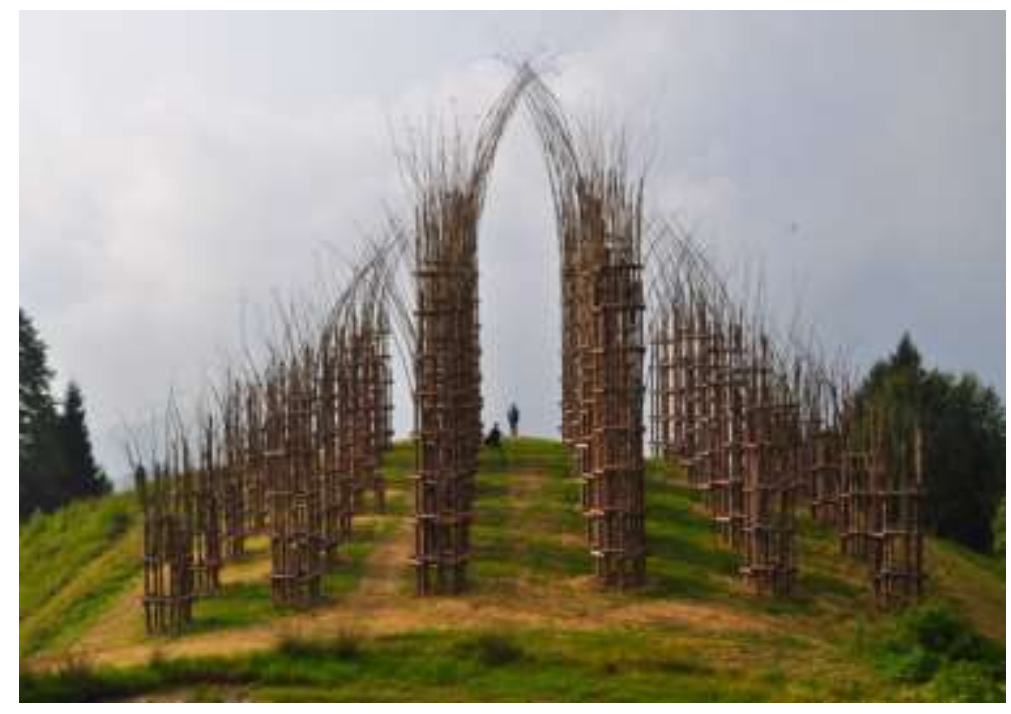

Рис. 2. Житловий храм. Архітектор Джуліано Маурі.

Житловий квартал же вважають багатофункціональною структурою, яка складається із зовнішніх просторів, таких як: двори, дахи, фасади, та внутрішніх - інтер'єри квартир, атріумні простори та інші рекреаційно-функціональні зони. Двір - це перша ланка у зв'язку людського житла із природою. Правильно організоване озеленення території дворів важливе з кількох причин:

- По-перше, зелені насадження сприяють формуванню комфортабельного мікроклімату. Висадка рослин призводить до формування тіні та зменшення швидкості вітру. Також зменшується акустичне навантаження за допомогою зниження рівня шуму.

• По-друге, рослини у дворі нейтралізують значну частину вихлопних газів та інших токсинів, що містяться у повітрі.

- По-третє, озеленення є важливим для формування гармонійного вигляду, оскільки рослинність - це важлива складова ландшафтного дизайну. 
До системи озеленення дворових територій входять сади, зелені насадження на ділянках окремих або груп житлових будівель, озеленені ділянки при школах, дитячих садках, фізкультурних майданчиках та спортивних комплексах. Важлива роль відводиться деревам і чагарникам, що є захисними посадками за межами мікрорайону, вздовж внутрішніх мікрорайонних проїздів, вздовж пішохідних сполучень, навколо господарських споруд, майданчиків сміттєзбірників, гаражів. Зелені насадження прибудинкової території багатоповерхових житлових будинків зазвичай відповідають мінімальним нормативним вимогам.

Японські архітектори розробили систему багатоярусних скверів. Такі композиції ідеально підходять для відпочинку з елементами споглядання. Вони включають декоративні стінки і сходи, тераси і скульптуры, фонтани і водойми. У 1995 році в стилі зеленої архітектури у Фукуоці було збудовано 15-ти поверховий будинок ACROS Fukuoka foundation (Рис. 3). Він і дотепер вважається головною визначною пам'яткою міста. Тут створено конструкцію водовідведення наче вода стікає з гір. Цей метод дозволяє здійснити природне зрощення.

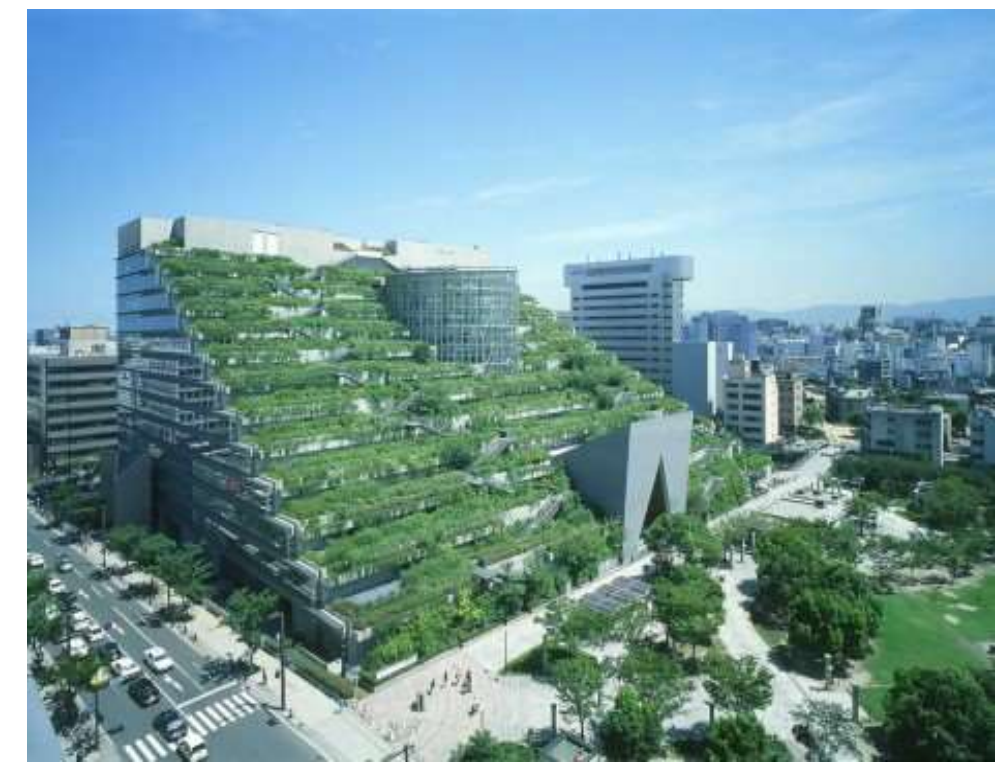

Рис. 3. 15-ти поверховий будинок ACROS, Fukuoka foundation. 
Відвідувачі можуть піднятися зигзагоподібними сходами в сад на верхньому майданчику даху, щоб помилуватися навколишньою природою.

Озеленення балконів та лоджій є поширеним прийомом створення акцентів на поверхні зовнішніх стін. В озелененні балконів з'явилася популярна тенденція висаджування міні-садів та городів.

Озеленення покрівлі — відповідь на виклик поточної кризи недоступності громадських просторів. Сад на даху будинку — це додатковий простір для відпочинку та покращення екологічної ситуації в місті. Зелена покрівля вже давно пропагується як ефективна стратегія з благоустрою зарубіжних будівель для поліпшення якості оточуючого середовища та збільшення інвестиційних можливостей. Система зеленого даху - це використання існуючого даху як додаткового джерела озеленення, який включає високоякісну водозахисну i дренажну систему, фільтрувальну тканину - середовище для вирощування рослин. “Зелене покривало” покращує теплоізоляцію, захищає від дощу, очищає повітря і є заміною зеленим насадженням, які доводиться знищувати заради будівництва споруд. Рослини не тільки виробляють кисень, але і створюють приємну атмосферу у великих просторах, знімаючи стрес і підвищуючи кількість відвідувачів, створюють комфортне і привабливе середовище перебування та проживання.

Живі дахи поділяють на дві групи: екстенсивну (необслуговувану) та інтенсивну (з обов'язковим доглядом). Покрівля екстенсивного типу - це автономна екосистема 3 мінімальним втручанням людини. У завершеному вигляді конструкція являє собою суцільний килим з низькорослих посухостійких рослин. Перевага інтенсивної конструкції - можливість створення унікального ландшафту із місцями відпочинку. Крім декоративного призначення, така покрівля задовольняє тягу людини до землі. Є місця, де попрацювати та відпочити. Цей зелений простір може бути нижче або вище рівня землі, але завжди він існує окремо від землі. Зелені дахи можуть забезпечити широкий спектр суспільних та приватних переваг та успішно використовуються в країнах по всьому світу. Основними перевагами використання зелених дахів є: 
1. Покращена якість повітря.

2. Нові зручні рекреаційні простори.

3. Придушення шуму.

4. Збільшення біорізноманіття.

5. Покращення здоров'я.

6. Помірність ефекту міського теплового острова.

Одними з перших до реалізації цієї ідеї підключилися міланські архітектори: вони вирішили посадити ліс прямо на дахах багатоповерхових будинків. Проект «зеленого хмарочоса» був розроблений в 2011 році. А вже через два роки в місті було завершено будівництво двох величезних хмарочосів, повністю покритих лісом. Житлові будинки Bosco Verticale (рис. 4) вважаються «очисником повітря» Мілана. Вони стали справжнім вертикальним парком в центрі, бо на горизонтальній площині місця для нього вже не було. Будівлі висотою 80 та 111 метрів являють собою два блоки з різноманітною рослинністю, яка розсаджена по фасаду. На думку архітекторів, дерева підвищують вологість повітря, поглинають CO2 і частинки пилу, виділяють кисень, захищають від випромінювання та забруднення, покращуючи якість життя.

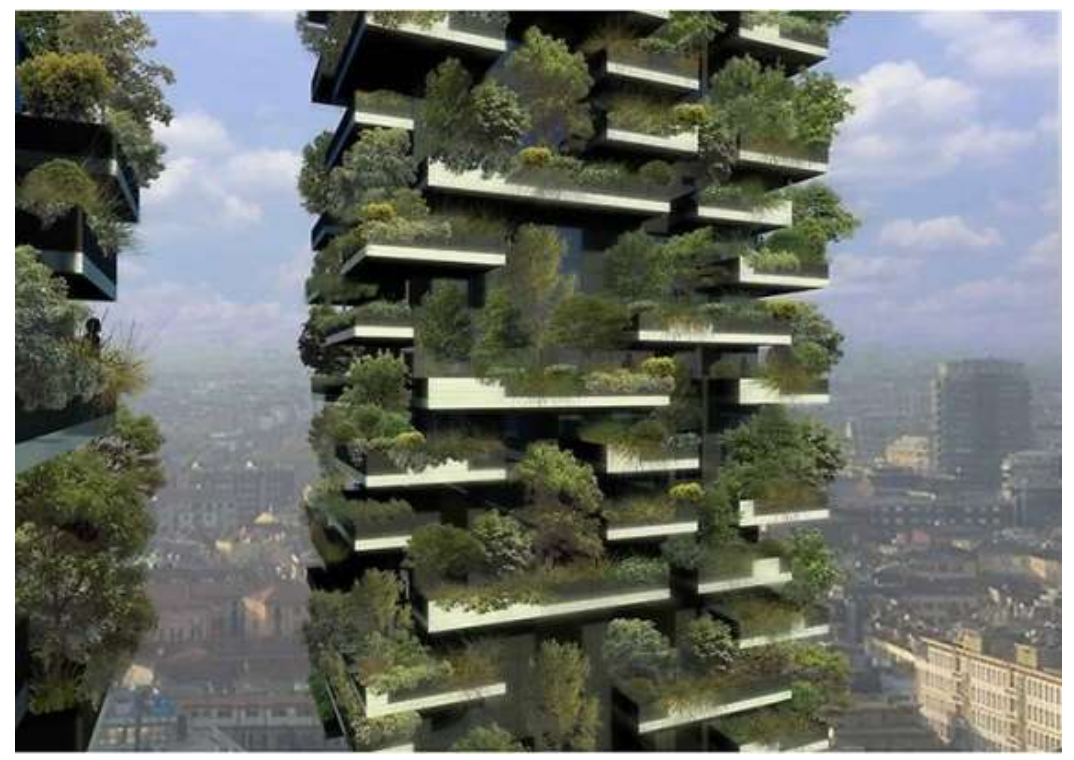

Рис. 4. Житлові будинки Bosco Verticale.

Крім того, така зелена «завіса» не дозволяє проникнути до квартири нестерпній літній спеці, в цей час температура повітря в Мілані досягає 40 градусів 
і вище. Всього на обох будинках посаджено близько 800 дерев, 4 тисяч кущів і 11 тисяч грунтопокривних рослин (рис. 5).

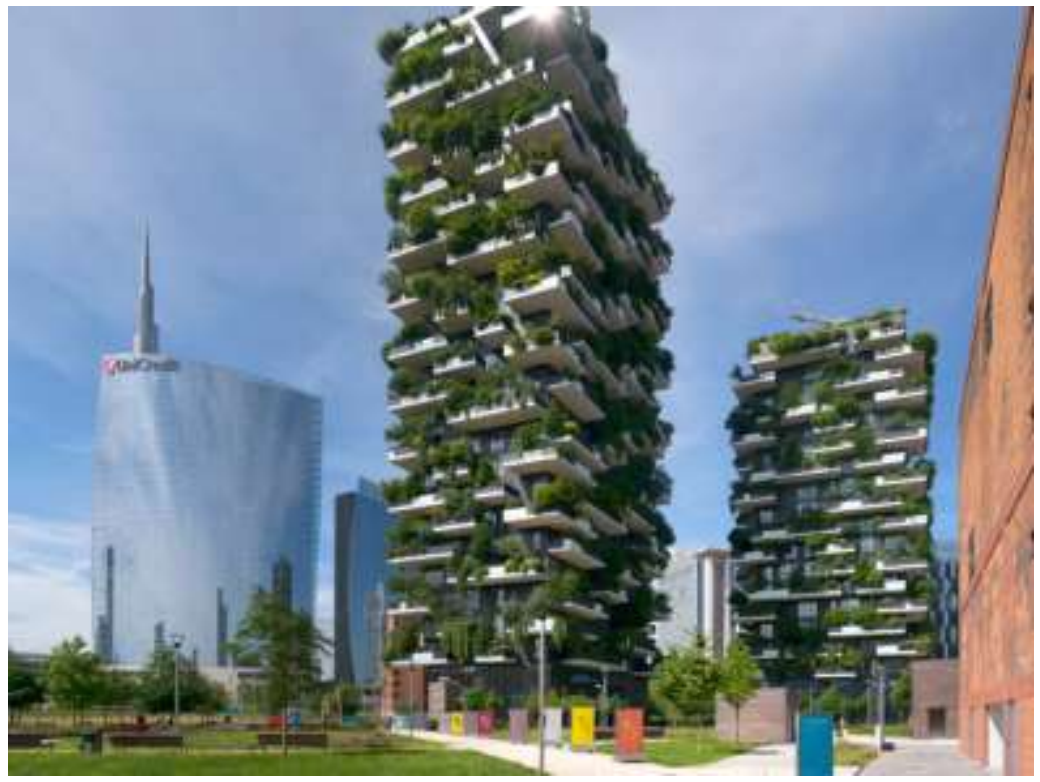

Рис. 5. Житлові будинки Bosco Verticale.

Принципово новий напрямок у фітодизайні - це зелені стіни 3 живих рослин, які можуть застосовуватися як в інтер'єрі, так і в екстер'єрі. Зелені стіни ділять на активні (з грунтом/живильним середовищем) та пасивні (епіфіти мохи, лишайники, папороті). Найбільш розповсюдженими типами сучасних конструкцій зелених стін $є$ модульні системи (панелі із субстратом), килимові системи (з кишенями для рослин) та контейнерні (горщики 3 ампельними рослинами).

За допомогою такого прогресивного методу оформлення житлових квартир можна вирішувати безліч завдань щодо їх благоустрою. Раніше озеленення квартир обмежувалося лише розстановкою рослин у горщиках. Сьогодні в житловому просторі успішно використовуються цілі композиції з живих рослин та квітів. Прямостоячі рослини середньої висоти візуально "піднімають" низькі стелі. Підвішені кашпо - розлогі аналоги - "опускають" надто високі стелі. Велику вітальню за допомогою ступінчастих стелажів з низькорослими та середнього розміру рослинами можна ефектно поділити на кілька функціональних зон. Таке зонування дуже актуально для квартир-студій. Також в інтер'єрах квартир, під'їздах будинків та сходових клітках використовують фіто 
стіни. Цей дизайнерський підхід допомагає покращити якість середовища, в якому перебуває людина.

Таким чином, в результаті розгляду наведених сучасних тенденцій, що застосовуються в озелененні багатоповерхових житлових будівель, можна сформулювати ряд висновків та рекомендацій: 3 підвищенням антропогенного середовища зростає потреба єднання мегаполісів із природою. Стає необхідною інтеграція рослин у структуру житлових споруд для покращення екології та, як наслідок, якості життя людини, сучасні технології дозволяють розміщувати рослини практично у всіх частинах будівлі.

Принцип взаємозв'язку зовнішнього i внутрішнього просторого i природного середовища, на перший погляд, дуже простий. Природа має увійти у внутрішній простір архітектурного об'єкта, а архітектура має вийти у зовнішній простір, створивши поблизу будівлі більш безпечну та комфортну, «окультурену» природу. Завдання розвитку “зеленої архітектури” в проектуванні та будівництві полягає в тому, щоб знайти серед будівель відповідне місце для рослин (як живого матеріалу), котрі будуть приносити користь та красу навколишньому середовищу, створюючи вдале поєднання з архітектурними спорудами, розташовуючись у найвигідніших умовах життя.

“Зелена архітектура” прагне мінімізувати негативний вплив будівництва на природу і надати тільки позитивний вплив на життя теперішніх та наступних поколінь. 


\section{SECTION 3. ELECTRICAL ENGINEERING}

DOI 10.46299/ISG.2021.MONO.TECH.III.3.1

\subsection{Improvement of the model of power losses in the pulsed current traction motor in an electric locomotive}

Most tractive electric rolling stock units are equipped with pulsed current motors that serve as traction engines. In particular, these are the alternating current electric locomotives, series $\mathrm{VL}-80^{\mathrm{T}}$ and $\mathrm{VL}-80^{\mathrm{K}}$, equipped with NB-418-K6 engines. In addition, pulsed current motors are used in the electric locomotives ChS4, VL8, VL40, VL60, 2EL5K, as well as industrial traction units OPEL1A(M).

The study of dynamic processes that occur in the traction drive of an electric locomotive requires the construction of an adequate mathematical model. The traction drive of the AC electric locomotive includes such functional units as a traction transformer, a rectifying unit, a smoothing reactor, as well as traction engines. The most complex element in an electric locomotive traction drive is traction motors. Building a mathematical model of the traction motor causes certain difficulties. First, these difficulties are associated with the nonlinearity of the universal magnetic characteristic of the traction motor. Second, with the implementation of the model of losses in the motor's active power.

The issue related to power losses by traction rolling stock was considered in several studies. Paper [155] scientifically grounded directions for reducing the power losses of traction engines by improving the process of directing the wheelsets with a rail track. Work [156] examines the cases of power loss in traction motors under extreme driving parameters, in particular when wheelsets derail.

The losses of active power could be divided into the following:

- magnetic losses in steel caused by hysteresis and eddy currents;

- electrical losses in the motor's windings and brush-collector contact;

- additional losses, whose magnitude depends on the load current;

- mechanical losses. 
In terms of determining them, the most difficult are the losses caused by hysteresis and eddy currents.

Existing models of induction motors have a separate magnetization circuit. With this chain, magnetic processes in the induction motor could be investigated separately, in particular, magnetic losses, as reported in $[157,158]$. Unlike the induction motor, there is no separate magnetization circuit in the existing models of pulsed current motors, making it difficult to investigate magnetic processes.

Mathematical modeling of magnetic losses in the steel of the pulsed current traction motor is associated with the need to take into consideration a series of dependences accompanying electromechanical processes. First, the dependence of magnetic flux on the load current of a traction motor is a nonlinear function, which should be approximated when building the model; it was performed in [4-7]. Second, it is necessary to take into consideration the parameters of a hysteresis loop inherent in the magnetic characteristic of electrical steel $[162,163]$. Third, the dependence of specific magnetic losses in electrical steel on the magnetization reversal frequency, which, in turn, is a function of the rotation frequency of the traction motor shaft $[164,165]$. Fourth, the motor shaft rotation frequency depends on the load, which, for the traction motor, is the wheelset of an electric locomotive. The load is affected by external factors, which are the condition and profile of a railroad track [166, 167]. Fifth, when moving from specific magnetic losses in motor steel, the geometric motor dimensions should be taken into consideration, in particular the intersection area and the volume of the armature yoke and teeth [168].

In addition, when designing traction motors, calculating these losses involves formulae most of which are empirical. It is very difficult to implement such a model using software packages. For the dynamic modes of operation, for example, when starting, braking, in the transition from one position of the driver controller to another, the performance of such a model would be incorrect. Consequently, the results of simulating dynamic processes in the traction drive of an electric locomotive, produced by such a model, would not be adequate. 
Determining magnetic losses in the steel of a traction motor, which change over time, could make it possible to define with higher accuracy the spectral components in the traction current of an AC electric locomotive. This would make it possible to adjust the operation of the reactive power compensator control system to the operating modes of the electric locomotive. This renders relevance to the subject of our research aimed at determining the instantaneous values of magnetic losses in motor steel.

Work [169] stated that modeling magnetic losses in electrical steel should consider a series of assumptions. The concept of loss division, based on the statistical loss theory, ensures a complete and accurate description of the frequency dependence of energy losses under the assumption of the uniform reverse magnetization through the cross-section of a sheet. However, this assumption is incorrect for nonlinear materials, at high induction values, and hysteresis contours [169].

The solution to this task, when predicting the losses in magnetic materials, is proposed in works $[170,171]$, based on a new model of dynamic energy hysteresis, which combines the statistical theory of losses and a static model of energy hysteresis. However, the cited works considered only a case where the magnetic field was shifted by DC, but the change in induction, as a function of the magnetization reversal frequency, has a sinusoidal shape. However, in a pulsed current motor, the magnetic field offset would be driven by a pulsed current. In addition, when one changes the motor shaft rotation frequency, the magnetization reversal frequency would also change. All these factors confirm that the shape of change in induction could be nonsinusoidal.

A solution to this task in the modeling of magnetic losses in electrical steel is reported in work [172], which considered magnetic losses in electrical steel at the triangular symmetrical and asymmetrical shapes of changes in induction. In the cited work, the shortcomings of the popular approach to calculating losses in inductive components, based on the empirical Steinmetz equation, are overcome by the generalized application of the statistical theory of losses and the associated concept of magnetic loss division. The work shows that this concept applies to both ferrites and metal alloys and hysteresis losses (quasi-static) and classical loss components. The 
authors related magnetic energy losses at the symmetrical triangular induction and sinusoidal induction. The behavior of losses at the asymmetric triangular induction was derived from the symmetrical one by averaging energy losses belonging to two different half-periods. However, the cited work considered only the case for a triangular shape of induction change.

Study [173] considered a generalized case for the non-sinusoidal induction change shape; the analytical expressions were built on the basis of the improved generalized Steinmetz equation to calculate magnetic losses in electrical steel at the above shapes of change in induction. Despite the correct statement of the problem, the cited study does not show the connection between magnetic losses in the steel of the motor with the geometry of the motor magnetic circuit, the connection between the universal magnetic characteristic and the load on a traction motor.

The above allows us to argue about the expediency of modeling magnetic losses in a traction motor steel. In addition, our analysis revealed that investigating the impact exerted by different modes of traction motors' operation on magnetic losses requires a new approach to the mathematical modeling of the electromagnetic processes in a pulsed current traction motor. That implies choosing a procedure for determining magnetic losses as a function of time, as well as adapting this procedure to the geometry and load of the traction motor.

The aim of this study is to improve the procedure for determining power losses in a pulsed current traction motor based on the refined model of eddy and hysteresis losses in the steel elements of magnetic circuits.

To accomplish the aim, the following tasks have been set:

- to improve the procedure for calculating losses due to hysteresis and eddy currents in the armature of a traction motor;

- to design a simulation model of the magnetic losses in a pulsed current motor using the traction motor NB-418-K6 as an example.

The object of this study is the magnetization reversal processes in the steel elements of magnetic circuits in a pulsed current traction motor.

The subject of the study is the pulsed current traction motor in an electric 
locomotive. The prototype chosen for our research was the NB-418-K6 engine with the following technical parameters for the long-term operation mode:

- power, $740 \mathrm{~kW}$;

- the rated armature rotation frequency, $915 \mathrm{rpm}$;

- power supply voltage, $950 \mathrm{~V}$;

- efficiency, $94.8 \%$;

- the number of poles, 6 .

For the rated mode of this motor, the following parameters were calculated based on the procedure given in [174]:

- the intersection area of the armature yoke and the armature teeth;

- the volume of the armature yoke and the armature teeth;

- the rated armature current.

The calculation results are given in Table 1 .

The yoke and armature teeth are made from electrotechnical steel, grade 1312, whose relative magnetic permeability $\left(\mu_{r 1}\right)$ at a frequency of $50 \mathrm{~Hz}$ and induction of $1.8 \mathrm{Tl}$ is equal to 2,400 [174].

Underlying our study are the following hypotheses about the dependence of eddy and hysteresis power losses in the steel magnetic circuits in a pulsed current motor on the shape of the curve of change in the magnetic flux parameters over the period of magnetization reversal.

Most models of losses due to eddy currents and hysteresis are based on the Preisach theory, whereby the losses in electrical steel are represented by a frequency function $[164,165]$. However, in these studies, the equation of the model describing magnetic losses in an electrotechnical steel sheet is described as averages over the period of current fluctuations. 
Table 1

Results of calculating the NB-418-K6 motor parameters

\begin{tabular}{|l|c|}
\hline \multicolumn{1}{|c|}{ Parameter } & Parameter value \\
\hline Armature yoke intersection area $-S_{Y}, \mathrm{~cm}^{2}$ & 810 \\
\hline Armature teeth intersection area $-S_{z}, \mathrm{~cm}^{2}$ & 415 \\
\hline Armature yoke volume $-V_{Y}, \mathrm{~cm}^{3}$ & $1,751.3$ \\
\hline Armature teeth volume $-V_{z}, \mathrm{~cm}^{3}$ & 12,150 \\
\hline Armature rated current $-I_{a}, \mathrm{~A}$ & 820 \\
\hline Pole pairs' number $-p$ & 3 \\
\hline Pair quantity of armature winding parallel branches $-a$ & 3 \\
\hline Quantity of armature winding active conductors $-N$ & 696 \\
\hline
\end{tabular}

Work analyzes the instantaneous values of magnetic losses in armature steel as a function of time over the period of fluctuations. The equations of specific losses take into consideration the accumulation of magnetic energy in steel. The reported equations could be used for any magnetic material and any geometry for which the properties of the material and magnetic flux density are known. Specific power losses in electrical steel on eddy currents and hysteresis, taking into consideration the accumulation of magnetic energy at the reduced magnetic permeability $\mu_{r}=1$ as a function of time, according to, could be recorded in the form of the following equation

$$
\begin{aligned}
& p_{\text {loss }}(t)=\left(H_{c}+K_{\text {hyst }} \cdot\left|B_{p} \cdot \sin (\omega t)\right|\right) \times \\
& \times\left|B_{p} \cdot \omega \cdot \cos (\omega t)\right|+K_{\text {addy }} \cdot B_{p}^{2} \cdot \omega^{2} \cdot \cos ^{2}(\omega t),
\end{aligned}
$$

where $H_{c}$ is the coercive force, $\mathrm{A} / \mathrm{m}$;

$B_{p}$ is the induction amplitude, Tl;

$\omega$ is the magnetization reversal frequency, $\mathrm{rad} / \mathrm{s}$;

$t$ is the time, s;

$K_{\text {hyst }}$ is the coefficient taking into consideration specific losses due to hysteresis, 
$\mathrm{A} /\left(\mathrm{kg} \cdot \mathrm{s} \cdot \mathrm{Tl}^{2}\right)$

$K_{\text {addy }}$ is the coefficient that takes into consideration specific losses due to eddy currents, $\mathrm{W} /\left(\mathrm{kg} \cdot \mathrm{s}^{2} \cdot \mathrm{Tl}^{2}\right)$;

$p_{\text {loss }}$ is the specific power loss, $\mathrm{W} / \mathrm{m}^{3}$.

Average losses in steel per unit of volume are

$$
\left\langle p_{\text {loss }}(t)\right\rangle=\left(\frac{2 \cdot H_{c}}{\pi} \cdot B_{p}+\frac{K_{\text {hyst }}}{\pi} \cdot B_{p}^{2}\right) \cdot \omega+\frac{K_{a d d y}}{2} \cdot B_{p}^{2} \cdot \omega^{2} .
$$

The magnetization reversal frequency is determined from the expression given in [174]

$$
\omega=p \cdot n_{\text {eng }}
$$

where $p$ is the number of pairs of poles;

$\mathrm{n}_{\text {eng }}$ is the electric motor shaft rotation frequency, $\mathrm{rad} / \mathrm{s}$.

The coefficients $H_{c}, K_{h y s t}$, and $K_{a d d y}$ could be found in the specifications provided by manufacturers of electrical steel subject to approximation.

The specific specification-based losses in electrical steel 1312 are given in Table 2.

In Table 2: $f$ is the frequency, $\mathrm{Hz} ; p_{p 50}, p_{M 50}, p_{p 50}, p_{M 50}$ are, respectively, the specific losses in the electrical steel 1312 depending on frequency (50 and $60 \mathrm{~Hz}$ ) specification-based $\left(p_{p 50}\right.$ and $\left.p_{p 60}\right)$ and data from the approximation ( $p_{M 50}$ and $p_{M 60}$ ).

For ease of approximation, expression (2) is represented in the following form

$$
p_{p 50}=4 \cdot H_{c} \cdot f \cdot B_{p}+\left(2 \cdot K_{\text {hyst }} \cdot f+2 \cdot \pi^{2} \cdot K_{a d d y} \cdot f^{2}\right) \cdot B_{p}^{2} .
$$


Table 2

Specifications and data resulting from the approximation of specific losses in the electrical steel 1312

\begin{tabular}{|c|c|c|c|c|c|c|c|c|c|}
\hline \multicolumn{2}{|c|}{$B, \mathrm{Tl}$} & 0 & 0.5 & 0.6 & 0.7 & 0.8 & 0.9 & 1.0 & 1.1 \\
\hline \multirow{2}{*}{$f=50 \mathrm{~Hz}$} & $p_{p 50}, \mathrm{~W}$ & 0 & 0.755 & 1.085 & 1.472 & 1.782 & 2.17 & 2.558 & 3.115 \\
\cline { 2 - 10 } & $p_{M 50}, \mathrm{~W}$ & 0 & 0.713 & 1.011 & 1.361 & 1.764 & 2.218 & 2.724 & 3.282 \\
\hline \multirow{2}{*}{$f=60 \mathrm{~Hz}$} & $p_{p 60}, \mathrm{~W}$ & 0 & 0.953 & 1.335 & 1.811 & 2.192 & 2.669 & 3.146 & 3.832 \\
\cline { 2 - 10 } & $p_{M 60}, \mathrm{~W}$ & 0 & 0.877 & 1.244 & 1.675 & 2.169 & 2.728 & 3.351 & 4.037 \\
\hline \multirow{2}{*}{$B, \mathrm{Tl}$} & 1,2 & 1.3 & 1.4 & 1.5 & 1.6 & 1.8 & 1.9 & 1.3 \\
\hline \multirow{2}{*}{$f=50 \mathrm{~Hz}$} & $p_{p 50}, \mathrm{~W}$ & 3.798 & 4.573 & 5.348 & 6.123 & 6.975 & 7.673 & 8.525 & 9.688 \\
\cline { 2 - 10 } & $p_{M 50,} \mathrm{~W}$ & 3.892 & 4.554 & 5.268 & 6.034 & 6.852 & 7.722 & 8.644 & 9.617 \\
\hline \multirow{2}{*}{$f=60 \mathrm{~Hz}$} & $p_{p 60}, \mathrm{~W}$ & 4.671 & 5.624 & 6.577 & 7.531 & 8.579 & 9.437 & 10.486 & 11.916 \\
\cline { 2 - 9 } & $p_{M 60}, \mathrm{~W}$ & 4.788 & 5.602 & 6.48 & 7.422 & 8.428 & 9.498 & 10.632 & 11.829 \\
\hline
\end{tabular}

Expression (4) is a function of induction and the square of induction. It is approximated using a least-square method. Since, according to Table 2, at a zero input value $\left(B_{p}=0\right)$, the value of the function $p_{p 50}=0$ in the equation based on a least-square method would lack a free term. Thus, expression (4) is represented in the following form

$$
p_{M 50}=a \cdot B_{p}+b \cdot B_{p}^{2},
$$

where $a$ and $b$ are the coefficients of approximation for a least-square method.

For the convenience of approximating using a least-square method, expression (5) is represented in the form

$$
p_{M 50}^{\prime}=\frac{p_{M 50}}{B_{p}}=a+b \cdot B_{p} .
$$


The approximation yielded a value for the coefficients $a=0.127 \mathrm{~W} /(\mathrm{kg} \cdot \mathrm{Tl})$; $b=2.597 \mathrm{~W} /\left(\mathrm{kg} \cdot \mathrm{Tl}^{2}\right)$.

Values of the specific losses at a magnetization reversal frequency of $50 \mathrm{~Hz}$, obtained by using the approximating function, are given in Table 2. A deviation in the approximation data from the specifications was determined as follows

$$
\delta_{50}=\frac{p_{p 50}-p_{M 50}}{p_{p 50}} \cdot 100 \%
$$

To determine the unknown coefficients $H_{c}, K_{\text {hyst }}, K_{a d d y}$ in equations (4), (5), we derived an additional equation by approximating specific losses in steel at a magnetization reversal frequency of $60 \mathrm{~Hz}$. Our calculations were based on the following considerations. GOST 33212-2014 gives specific losses at a magnetization reversal frequency of $50 \mathrm{~Hz}$ and an amplitude of induction of $1.0 \mathrm{Tl}$, as well as at a magnetization reversal frequency of $60 \mathrm{~Hz}$ and an amplitude of induction of $1.5 \mathrm{Tl}$. We calculated a transition factor to determine specific losses at a magnetization reversal frequency of $60 \mathrm{~Hz}$, which was defined from the following expression

$$
k_{p}=\frac{p_{1.5 / 60}}{p_{1.5 / 50}}=\frac{7.53}{6.123}=1.23,
$$

where $p_{1,5 / 50}=6.123 \mathrm{~W} / \mathrm{kg}$ are the specific losses at a magnetization reversal frequency of $50 \mathrm{~Hz}$ and an amplitude of induction of $1.5 \mathrm{Tl}$ (Table 2).

Considering the above, the specific losses at a magnetization reversal frequency of $60 \mathrm{~Hz}$ could be determined from the following ratio

$$
p_{p 60}=k_{p} \cdot p_{p 50} .
$$

The results are given in Table 2, according to which at a zero input value $\left(B_{p}=0\right)$ 
the value of the function $p_{p 60}=0$ in the equation using a least-square method would lack a free term. Thus, expression (4) is represented in the following form

$$
p_{M 60}=a_{1} \cdot B_{p}+b_{1} \cdot B_{p}^{2},
$$

For the convenience of approximation using a least-square method, expression (10) is represented in the following form

$$
p_{M 60}^{\prime}=\frac{p_{M 60}}{B_{p}}=a_{1}+b_{1} \cdot B_{p},
$$

where $a_{1}$ and $b_{1}$ are the coefficients of the approximating function by a least-square method for a frequency of $60 \mathrm{~Hz}$.

The approximation using a least-square method yielded the values for the coefficients $a_{1}=0.16 \mathrm{~W} /(\mathrm{kg} \cdot \mathrm{Tl}) ; b_{1}=3.29 \mathrm{~W} /\left(\mathrm{kg} \cdot \mathrm{Tl}^{2}\right)$.

Values of the specific losses at a magnetization reversal frequency of $60 \mathrm{~Hz}$, derived by using the approximating function, are given in Table 2 .

Based on the results given in Table 2, we constructed the charts of the dependence of specification-based specific losses in the electrical steel 1312 at frequencies $50 \mathrm{~Hz}$ and $60 \mathrm{~Hz}$ ( $p_{p 50}$ and $p_{p 60}$, respectively) and their approximation ( $p_{M 50}$ and $p_{M 60}$, respectively) (Fig. 1).

A root-mean square error of approximation was determined, calculated from the following expression:

$$
\sigma_{\delta}=\sqrt{D_{\delta}}=\sqrt{\frac{1}{N-1} \cdot \sum_{i=1}^{N}\left(\delta_{M i}-\delta M_{\text {mean }}\right)^{2}},
$$

where $N$ is the number of approximation points; $\delta_{M i}$ is the error of approximation at the $i$-th point; 
$\delta M_{\text {mean }}$ is the mean error value.

The rms error of approximation was $1.14 \%$, which indicates a high degree of reliability of our results.

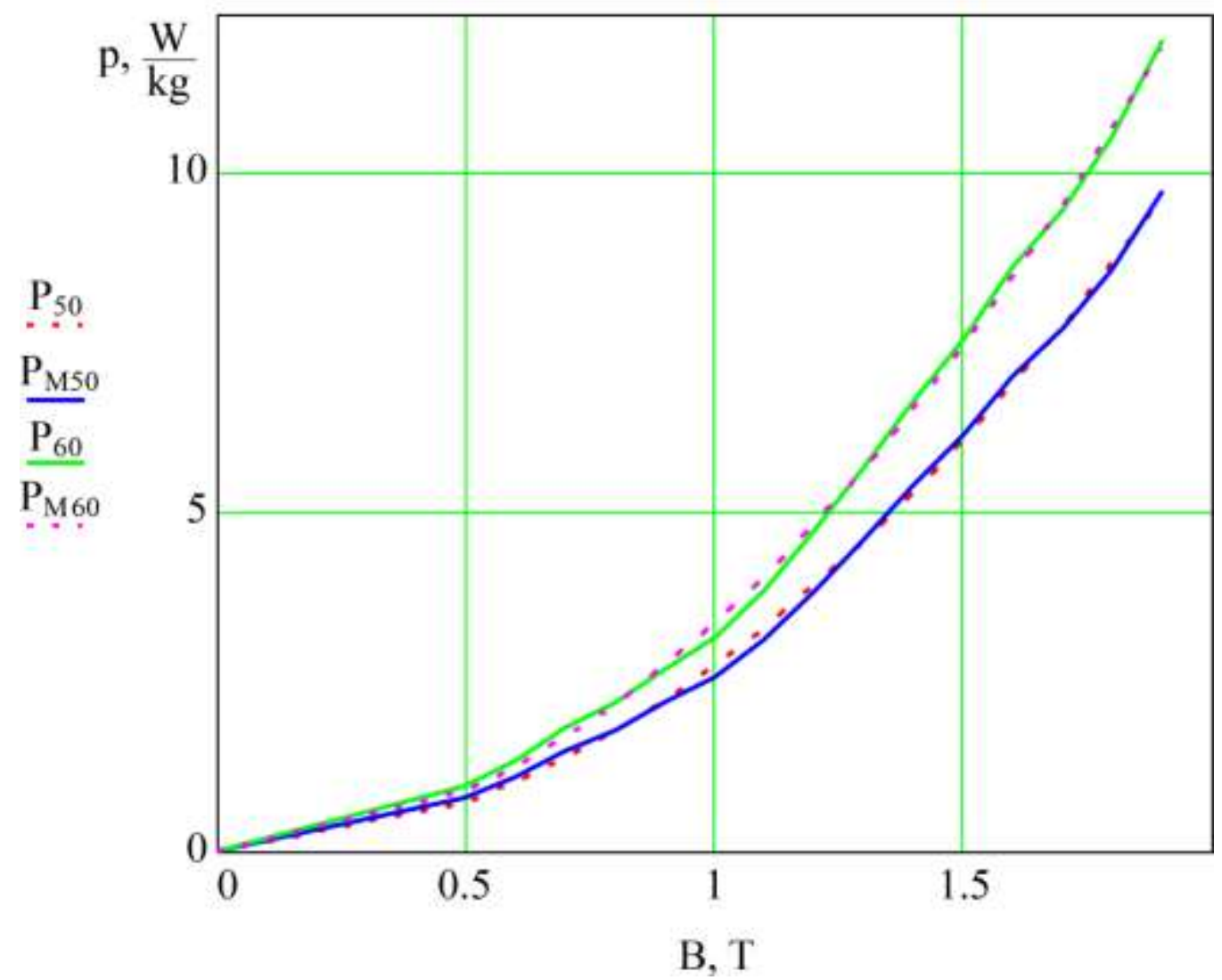

Fig. 1. Specific specification-based losses in electrical steel and approximation results for the magnetization reversal frequencies 50 and $60 \mathrm{~Hz}$

Equations (4), (5) were used to derive an expression for the coercive force at 50 and $60 \mathrm{~Hz}$ :

$$
H_{c}=\frac{a}{4 \cdot f}=0.000634 \frac{A}{\mathrm{~kg} \cdot \mathrm{m}} ; H_{c 1}=\frac{a_{1}}{4 \cdot f}=0.00065 .
$$

To determine the coefficients $K_{\text {hyst }}$ and $K_{a d d y}$, we considered the system of equations (4), (5), and (4), (11).

It takes the following form: 


$$
\left\{\begin{array}{l}
2 \cdot K_{h y s t} \cdot f+2 \cdot \pi^{2} \cdot K_{a d d y} \cdot f^{2}=b, \\
2 \cdot K_{h y s t} \cdot f_{1}+2 \cdot \pi^{2} \cdot K_{a d d y} \cdot f_{1}^{2}=b_{1},
\end{array}\right.
$$

where $f=50 \mathrm{~Hz}, f_{1}=60 \mathrm{~Hz}$.

The following values of the coefficients $K_{h y s t}$ and $K_{a d d y}$ were obtained: $K_{\text {hyst }}=0.018 \mathrm{~W} /\left(\mathrm{kg} \cdot \mathrm{s} \cdot \mathrm{Tl}^{2}\right) ; K_{a d d y}=1.449 \cdot 10^{-5} \mathrm{~W} /\left(\mathrm{kg} \cdot \mathrm{s}^{2} \cdot \mathrm{Tl}^{2}\right)$.

To implement the model of magnetic losses in electrical steel (1), (2), it is necessary to find the amplitudes of inductions in nodes made from electrical steel - the armature yoke and teeth [174].

Magnetic induction in the armature yoke is determined from the following expression

$$
B_{a}=\frac{2 \cdot \Phi_{a}}{S_{a}},
$$

where $S_{a}$ is the intersection area of the armature yoke (Table 1); $\Phi_{a}$ is the magnetic flux of the armature.

Magnetic induction in the armature teeth is determined from the following expression

$$
B_{z}=\frac{\Phi_{a}}{S_{z}},
$$

where $S_{z}$ is the intersection area of the armature teeth (Table 1).

The armature's magnetic flux is determined from the universal magnetic characteristic of the traction motor.

The universal magnetic characteristic of the traction motor NB-418-K6 is given in work. In practice, it is more convenient to use the dependence of the electromotive 
force (EMF), reduced to the motor shaft rotation frequency, as a function of the traction motor excitation current. That is

$$
\frac{E}{n}=f\left(I_{e x}\right),
$$

where $E$ is the motor EMF, V;

$n$ is the motor shaft rotation frequency, rps;

$I_{e x}$ is the excitation current, A.

A traction motor EMF is calculated from the formula given in

$$
E=C_{E} \cdot n \cdot \Phi,
$$

where $\Phi$ is the magnetic flux of motor excitation, $\mathrm{Wb}$;

$C_{E}$ is the structural motor coefficient for EMF, 1/s, which is determined from the expression given in

$$
C_{E}=\frac{p \cdot N}{a}=\frac{3 \cdot 696}{3}=696 \frac{1}{\mathrm{~s}},
$$

where $p=3$ is the number of pairs of poles;

$a=3$ is the number of pairs of parallel branches of the armature windings;

$N=696$ is the number of active armature winding conductors (Table 1).

Expression (16) is used to determine the magnetic flux of motor excitation

$$
\Phi=\frac{E}{C_{E} \cdot n} .
$$

We have recalculated from the universal magnetic characteristic the numerical values for building a dependence of EMF reduced to the motor shaft rotation frequency 
as a function of the excitation current of the traction motor NB-418-K6. Recalculations were based on the following conditions. The traction motor NB-418 K6 is a sequential excitation engine with a rated excitation degree of $95.7 \%$. That is

$$
I_{e x}=0.957 \cdot I_{a} .
$$

When an electric locomotive runs, the rim of a wheelset moves at linear speed ( $v$, $\mathrm{m} / \mathrm{s}$ ). The linear speed of the roll surfaces is the same for both wheels in the wheelset

$$
v=\frac{\pi \cdot D \cdot n \cdot k_{P}}{60 \cdot \mu},
$$

where $n$ is the motor shaft rotation frequency, $1 / \mathrm{s}$;

$D=1.25$ is the wheel diameter, $\mathrm{m}$;

$\mu=88: 21$ is the gear ratio;

$k_{P}=0.975$ is the gear efficiency.

Then the motor shaft rotation frequency is

$$
n=\frac{60 \cdot \mu \cdot v}{\pi \cdot D \cdot k_{P}} .
$$

Our calculations were carried out for an unloaded mode of operation of an electric locomotive, that is, without a train. When switching to the operation of an electric locomotive with a load, the following formula should be used

$$
\Phi_{e l}=\frac{E}{C_{E} \cdot n} \cdot \frac{n}{n_{e l}},
$$

where $n$ is the motor shaft rotation frequency for the predefined excitation current when an electric locomotive operates without loading, rps; 
$\mathrm{n}_{e l}$ is the motor shaft rotation frequency for the predefined excitation current when an electric locomotive operates with a load, $1 / \mathrm{s}$.

Study noted that in the approximation of a magnetic characteristic a high enough accuracy was demonstrated by the approximating functions based on arctangent functions. In addition, when choosing an approximating function, in addition to the high accuracy of the approximation, it is necessary to take into consideration the simplicity of implementing an approximating function. These requirements are met by the mathematical model of the reduced EMF, which takes the following form

$$
\frac{E}{n}=p_{1} \cdot \operatorname{arctg}\left(p_{2} \cdot I_{e x}\right)+p_{3} \cdot I_{e x},
$$

where $p_{1}, p_{2}, p_{3}$ are the coefficients of approximation.

The dependences $E / n\left(I_{e x}\right)$ and $n\left(I_{e x}\right)$ are shown in Fig. 2, 3.

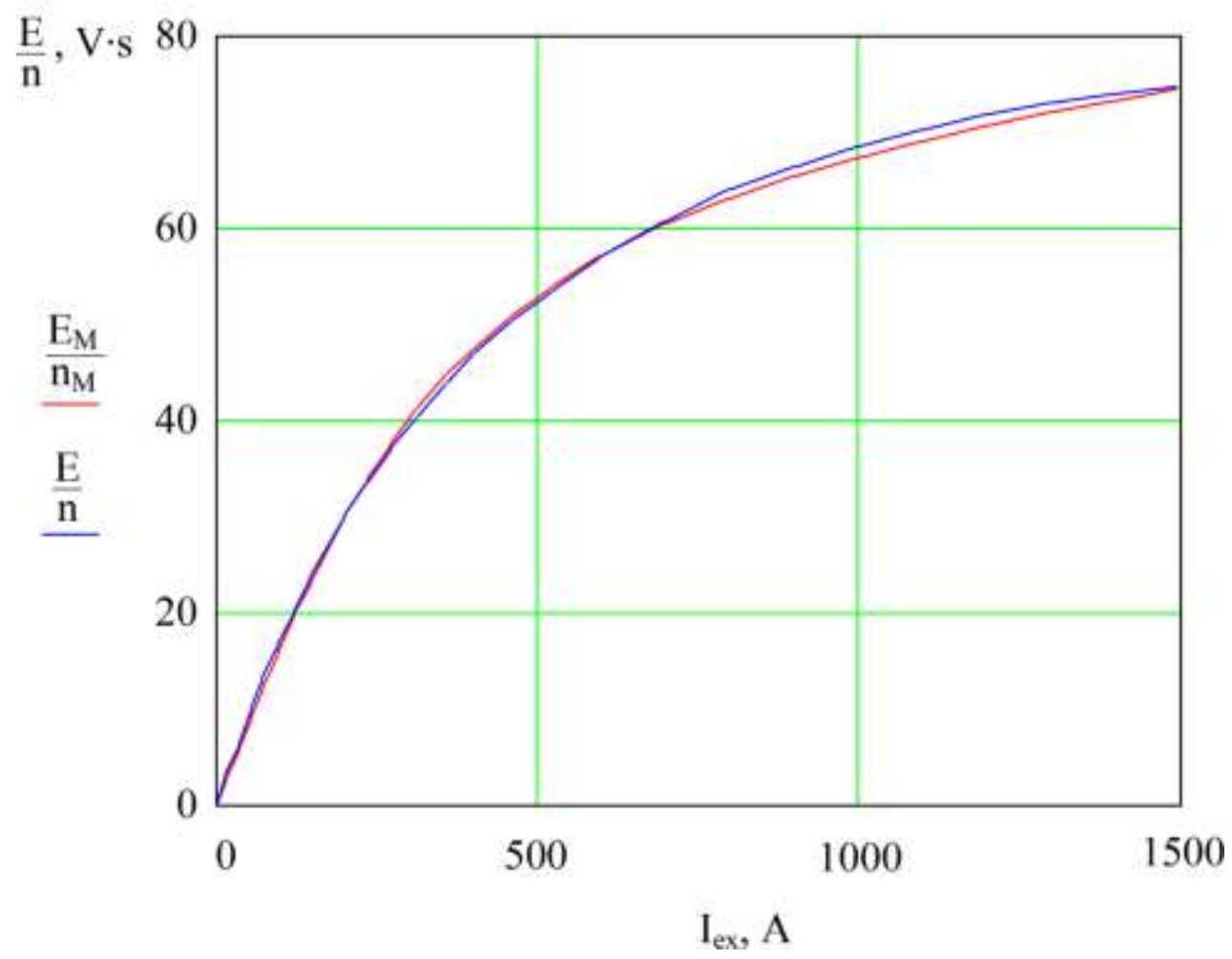

Fig. 2. Dependence of $E / n$ of the traction motor NB-418-K6 on excitation current: $E / n$ - specification data: $E_{M} / n_{M}$ - the results of approximation 


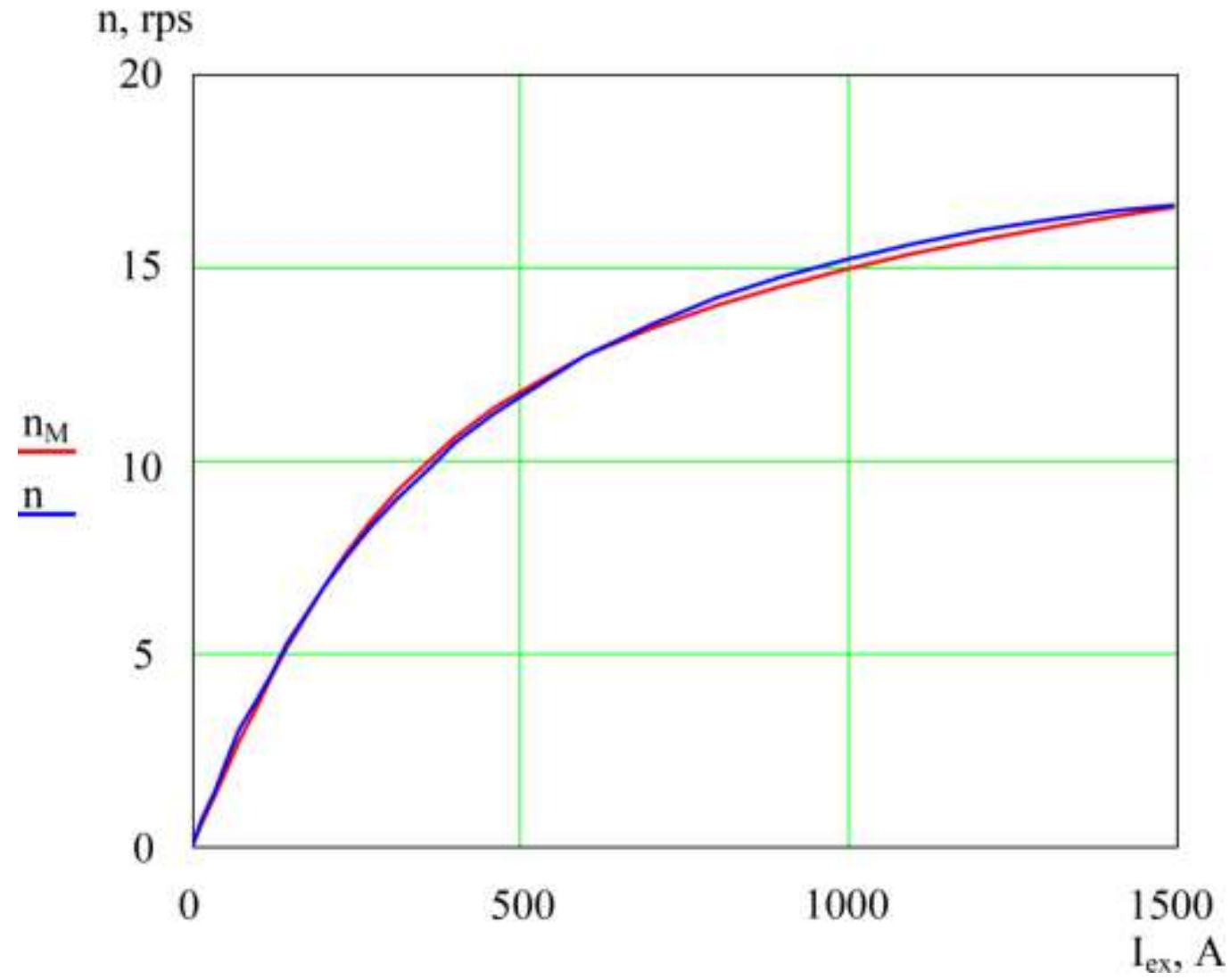

Fig. 3. Dependence of rotation frequency on excitation current at voltage $U=950 \mathrm{~V}: n$ - specifications: $n_{M}$ - results of approximation

The approximation rms error was $0.98 \%$, which indicates a high degree of reliability of our results.

Total magnetic losses are the sum of magnetic losses in an armature and the armature teeth. That is

$$
P_{\text {loss } \Sigma}(t)=P_{\text {loss } Y}(t)+P_{\text {lossz }}(t),
$$

where $P_{\text {loss }}(t), P_{\text {lossz }}(t)$ are the magnetic losses in the core of the armature and the armature teeth, respectively. Similarly, the mean magnetic losses over a period are calculated

$$
\left\langle P_{\text {loss } \Sigma}(t)\right\rangle=\left\langle P_{\text {lossY }}(t)\right\rangle+\left\langle P_{\text {lossz }}(t)\right\rangle,
$$


where $<P_{\text {loss } Y}(t)>,<P_{\text {lossz }}(t)>$ are the mean magnetic losses in the core of the armature and the armature teeth, respectively.

The resulting magnetic permeability of the steel 1312 differs from 1 [174]. That is, to move from a generalized sheet of steel with the reduced magnetic permeability $\mu_{r}=1$, for which equations (1), (2) are recorded, to the sheet of the steel 1312 with permeability $\mu_{r 1}$, equations (1), (2) are multiplied by $\mu_{r 1}$.

The coefficients in equations $H_{c}, K_{h y s t}$ and $K_{a d d y}$ (4) were determined for the specific power losses expressed in $\mathrm{Wt} / \mathrm{kg}$. To move to the losses expressed in $\mathrm{W}$, equations (25) and (26) are multiplied by the weight of steel of the corresponding structural element of the motor. The weight of the steel of the structural element is determined from the following expression

$$
m_{i}=\rho \cdot V_{\mathrm{i}},
$$

where $V_{i}$ is the volume of the structural element, $\mathrm{m}^{3}$.

The instantaneous values of losses in the armature yoke and teeth, taking into consideration equation (1), take the following form:

$$
\begin{aligned}
& P_{\text {loss } Y}(t)=p_{\text {loss }}(t) \cdot \rho \cdot V_{Y}^{2} \cdot \mu_{r 1}, \\
& P_{\text {lossz }}(t)=p_{\text {loss }}(t) \cdot \rho \cdot V_{z}^{2} \cdot \mu_{r 1},
\end{aligned}
$$

where $\rho=7,750 \mathrm{~kg} / \mathrm{m}^{3}$ is the specific weight of the electrical steel 1312 ;

$V_{Y}, V_{z}$ are the volumes of steel in the armature yoke and teeth, respectively, $\mathrm{m}^{3}$ (Table 1).

Similarly, the mean magnetic losses were found

$$
\left\langle P_{\text {loss }}(t)\right\rangle=\left\langle p_{\text {loss }}(t)\right\rangle \cdot \rho \cdot V_{Y}^{2} \cdot \mu_{r 1},
$$




$$
\left\langle P_{\text {lossz }}(t)\right\rangle=\left\langle p_{\text {loss }}(t)\right\rangle \cdot \rho \cdot V_{z}^{2} \cdot \mu_{r 1},
$$

where $<p_{\text {loss }}(t)>$ are the specific losses in steel, calculated from expression (2); $\mu_{r 1}=2,400$ is the relative magnetic permeability of the steel 1312 at a frequency of $50 \mathrm{~Hz}$ and induction $B=1.82 \mathrm{Tl}$ [174].

The study of magnetic losses in the traction motor's steel began by determining the magnetic flux of the traction motor armature, which is defined from expression (23). To this end, based on expression (24), we approximated the reduced EMF and the shaft rotation frequency and combined them into one block "Magnetic flux detection unit". The block structure is shown in Fig. 4.

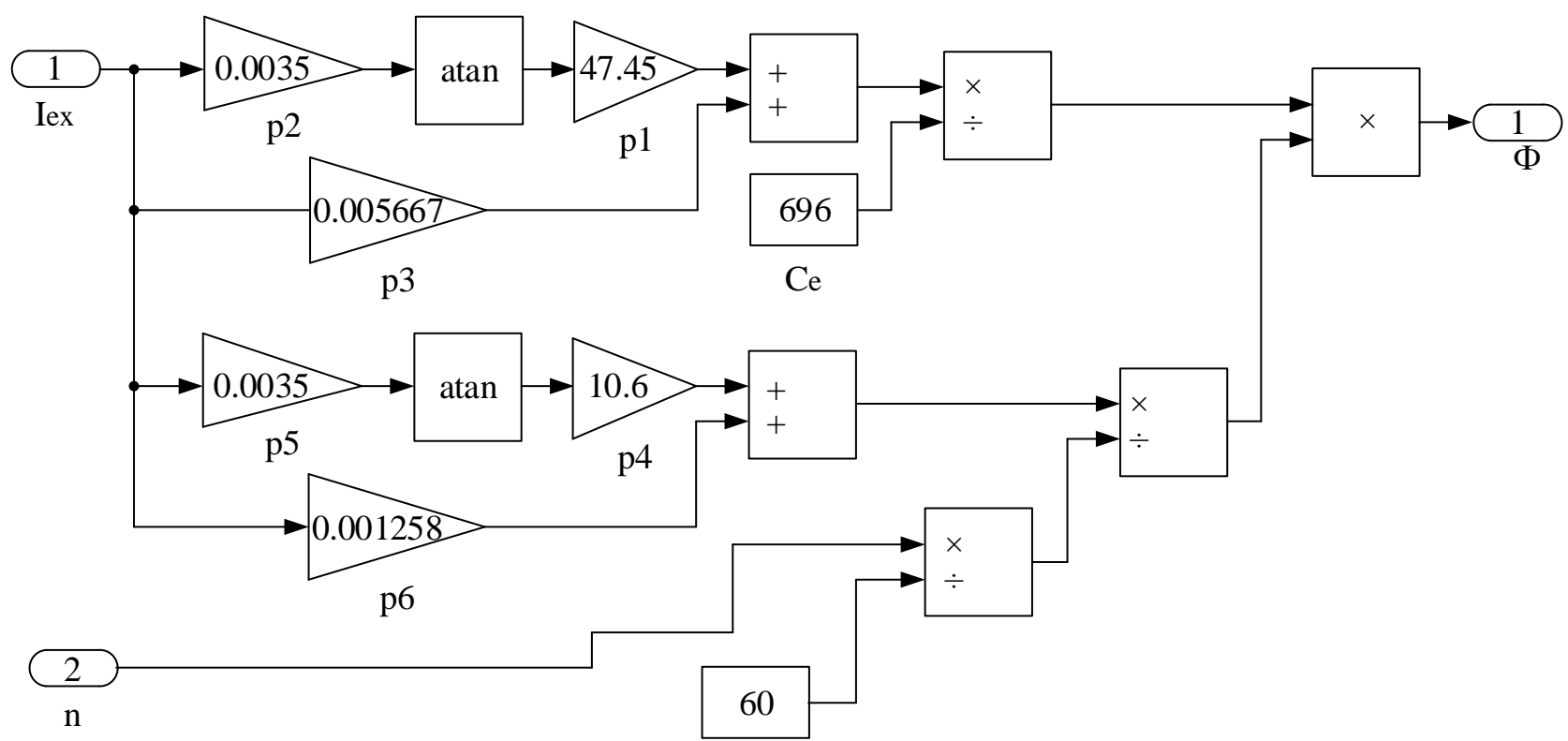

Fig. 4. Implementation of magnetic flux calculation in MatLAB

The next step of our simulation involved the calculation of inductions in the armature yoke and teeth based on expressions (14), (15).

The elements in the calculation of inductions in the structural elements of a traction motor were combined into one block "Block of induction calculation". The block structure is shown in Fig. 5. 


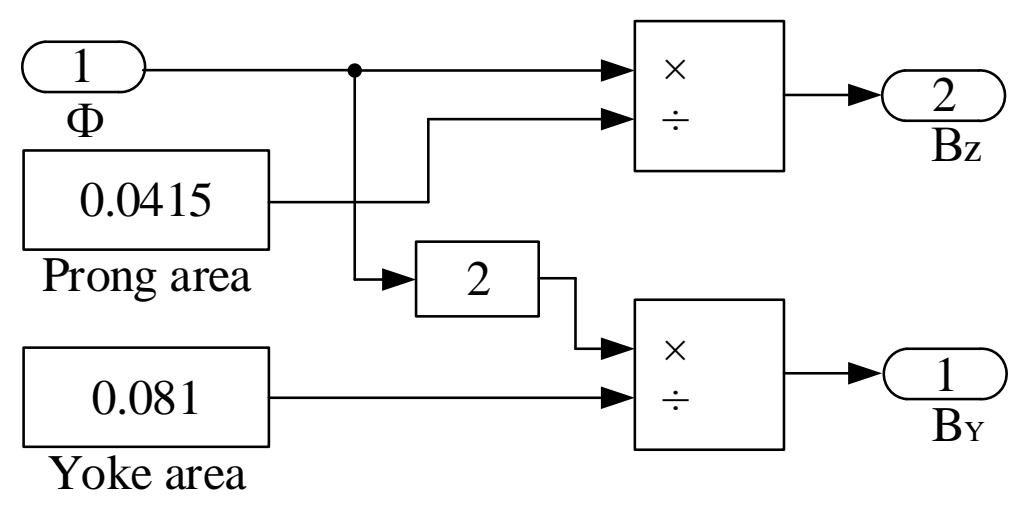

Fig. 5. Implementation of the calculation of inductions in the structural elements of the traction engine in the MatLAB

The estimation of time-dependent steel losses based on equations (28), (29) and the calculation of average losses in steel over a period from equation (30), (31), "Block of total loss calculation". The block structure is shown in Fig. 6.

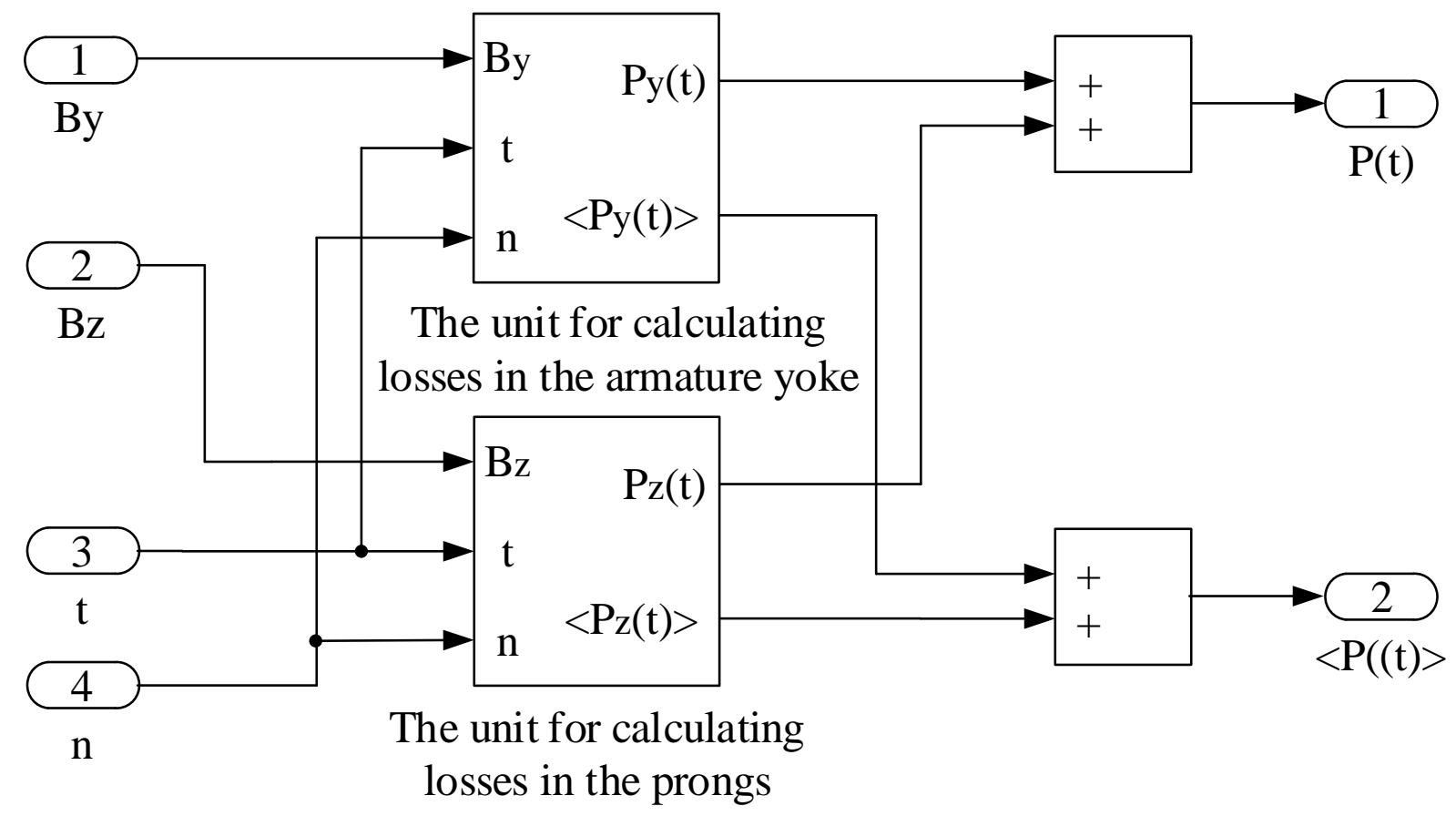

Fig. 6. Implementation of total magnetic losses in the steel of the traction engine

The realization of losses in steel that change over time and the realization of average losses in steel for the period are shown on the example of the realization of losses in the armature yoke and are shown in Fig. 7. 


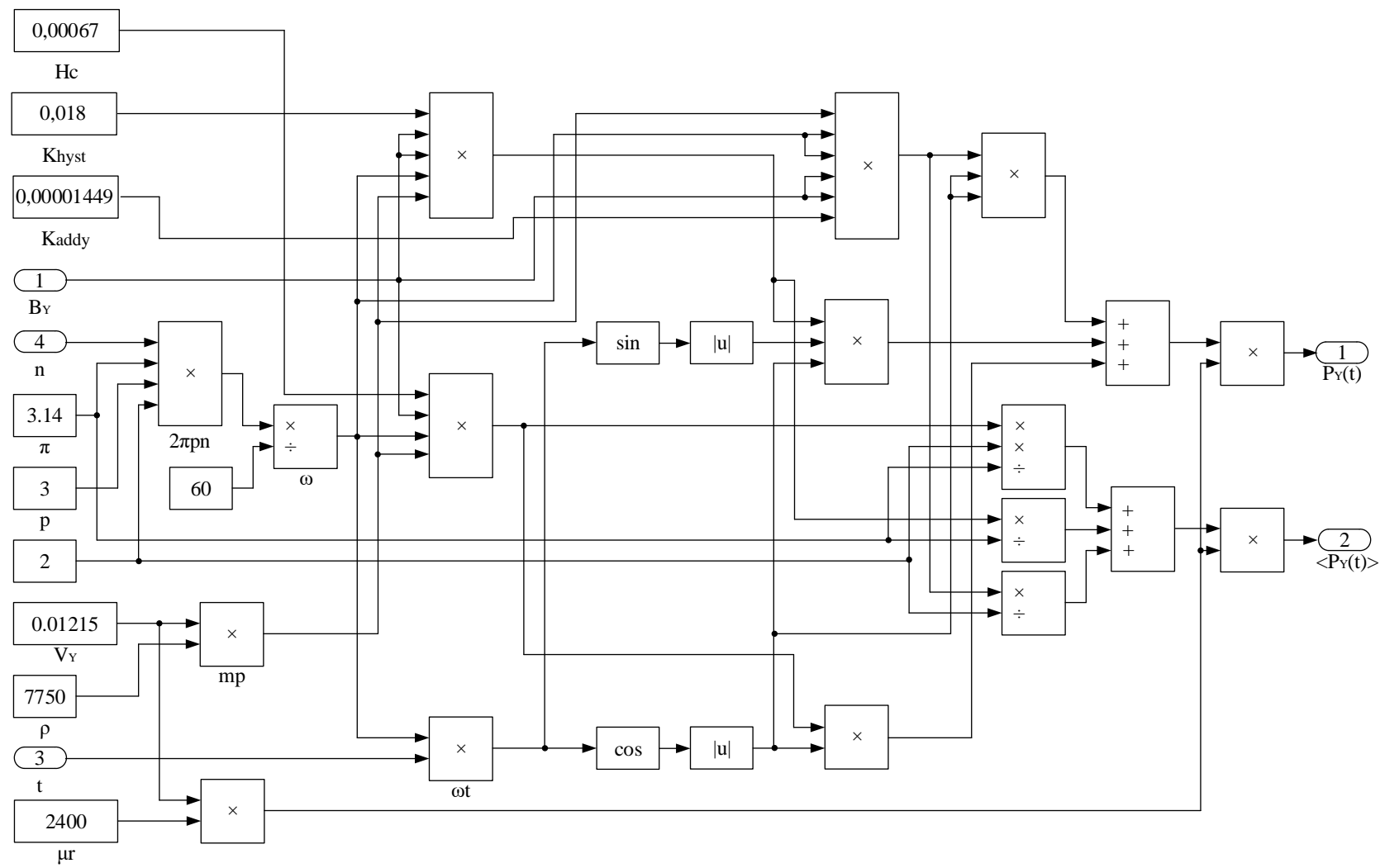

Fig. 7. Implementation of the calculation of magnetic losses in the yoke of the motor armature in the MatLAB

The general simulation model for calculating magnetic losses in a pulsed current traction motor is shown in Fig. 8.

The simulation model shown in Fig. 8 could be used to analyze magnetic losses in a traction motor's steel. Using a constant Iex, it sets the value of the excitation current in a traction motor. The time dependences of magnetic losses are displayed at an oscilloscope as $\operatorname{Ploss}(t)$; the mean losses over a period - in the measurement block $<\operatorname{Ploss}(t)>$.

For the rated values of the excitation current and the rated motor shaft rotation frequency, the model (Fig. 8) produced the average value of magnetic power losses $(7,800 \mathrm{~W})$. We also derived the dependences of instantaneous values of the magnetic power losses in steel on time. The dependences are shown in Fig. 9. 


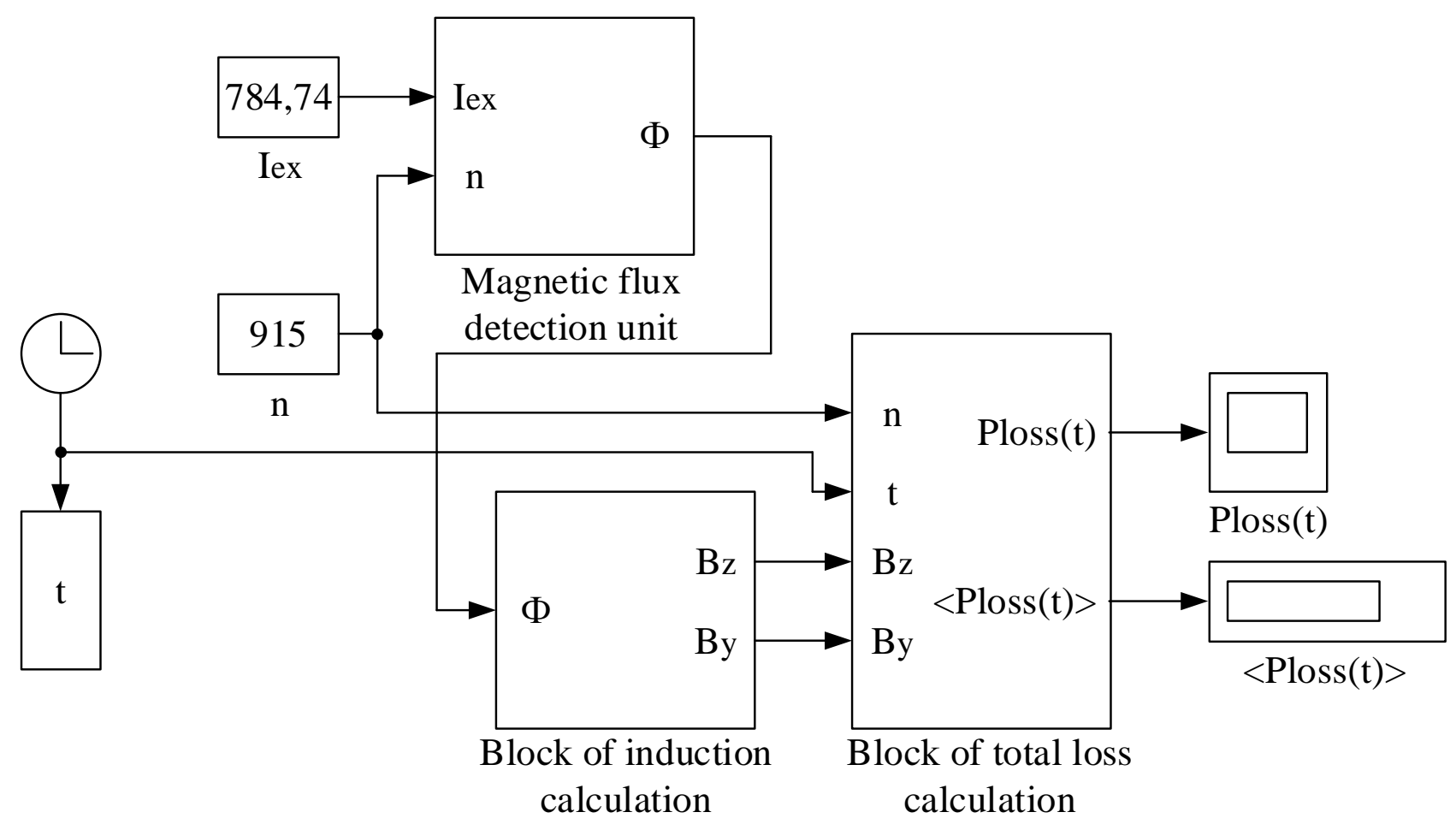

Fig. 8. Simulation model for calculating magnetic losses in a pulsed current traction motor

The accuracy of the calculation of losses in an engine could be evaluated by comparing the estimated efficiency of the motor against its specification value. Work [174] analyzed the calculations of losses in the motor of series NB418K6 based on several known procedures. Table 3 gives the results of comparing the estimated data, obtained by different procedures, with the specifications. Table 3 also gives the value of the efficiency calculated according to the procedure proposed in this work. 




Fig. 9. Dependences of the instantaneous values of magnetic power losses in steel on time using the traction motor NB-418-K6 as an example

Table 3

The efficiency of the traction motor, series NB418K6, calculated by known

procedures

\begin{tabular}{|c|c|c|}
\hline $\begin{array}{c}\text { Estimated efficiency of } \\
\text { traction motor, } \eta \%\end{array}$ & $\begin{array}{c}\text { Error in determining } \\
\text { the efficiency } \delta_{\eta}, \%\end{array}$ & Source \\
\hline 94.00 & -0.23 & {$[181]$} \\
\hline 93.78 & 0.05 & {$[182]$} \\
\hline 94.05 & 1.5 & {$[183]$} \\
\hline 94.14 & 0.02 & {$[184]$} \\
\hline 94.02 & 0.09 & {$[185]$} \\
\hline 94.09 & -0.38 & Specifications \\
\hline 93.64 & 0.00 & Procedure by this paper's \\
\hline 94.00 & & authors \\
\hline
\end{tabular}


The analysis of the results given in Table 3 shows that our proposed procedure is more accurate compared to known ones. The high accuracy was achieved by taking into consideration a series of factors that were disregarded by available techniques.

Thus, when calculating magnetic losses in the steel of a traction motor, other procedures accounted for the loss on the accumulation of magnetic energy by the introduction of correcting coefficients. The expression for determining the average magnetic losses (2), namely its component $\left.\left(2 \cdot H_{c} \cdot B_{p} \cdot \omega\right) / \pi\right)$, makes it possible to accurately calculate these losses. In expression (2), the coercive force $\left(H_{c}\right)$, the loss factor on eddy currents $\left(K_{a d d y}\right)$, and the loss factor for hysteresis $\left(K_{h y s t}\right)$ make it possible to establish a link between the specific losses of electrical material and magnetic losses.

That is, one could consider the simulation model of magnetic power losses in the steel of a traction motor adequate with a high degree of reliability.

The proposed improved procedure for calculating losses due to the hysteresis and eddy currents in a pulsed current traction motor is based on the representation of magnetic transformations in the steel elements of the motor in the form of a stationary deterministic process. According to these ideas, the total losses on hysteresis, eddy currents, and the accumulation of magnetic energy are considered as the functions of time (1). In the process of research, we have found a confirmation of the hypothesis about the dependence of the eddy and hysteresis losses of motor power on the shape of the magnetic flux change curve (15), (16), as well as inductiveness (1), (2), during the period of magnetization reversal.

The procedure for building a model of magnetic losses makes it possible to investigate magnetic processes under any modes of operation of engines (24). The advantage of the proposed technique is the possibility to analyze the current (instantaneous) values of a series of time-dependent parameters of the motor magnetic system (1).

The adaptation of the model by taking into consideration the magnetic properties of the material and the geometry of the magnetic circuit of a traction motor ((29) to (32)) contributed to improving the accuracy of the model.

The simulation model built on the basis of the proposed methodology makes it 
possible to investigate magnetic losses for any magnetic system with known materials properties and law of change in the density of magnetic flux. In addition, the model takes into consideration the geometry of magnetic circuit chains and makes it possible to determine both average, over a period (2), and instantaneous values of magnetic losses (1).

The model is built using the traction motor NB-418-K6 as an example. The adequacy of modeling was assessed by the accuracy in determining the magnetic losses relative to the specifications (Table 3). Our calculations have confirmed the high accuracy of the proposed model.

However, as noted, the proposed procedure assumes the stationarity of the magnetization reversal process in the steel of a motor, which imposes a certain limitation for its use. For cases of the non-stationary, non-deterministic nature of a voltage change, additional research is needed. At the same time, we realize the difficulties associated with acquiring experimental data in the operation of an electric locomotive. This study could be advanced in the following ways:

- to study traction drive operation in an AC electric locomotive equipped with DC traction motors;

- to investigate the impact of the modes of operation of electric locomotives (starting and decelerating a train, transition from one position of the driver controller to another, towing, slip) on the energy indicators of a traction drive equipped with pulsed current traction motors.

Based on the results of the study, the following conclusions can be drawn:

1. The procedure for calculating losses due to hysteresis and eddy currents in the traction motor armature has been improved. Underlying the improvement is a new approach to representing magnetic transformations in the steel elements of the motor. This approach implies the possibility to analyze the current (instantaneous) transformations of magnetic loss parameters during the period of magnetization reversal. This distinguishes our methodology from those known that estimate magnetic losses based on the average values over a magnetization reversal period.

2. The designed simulation model of magnetic losses in the traction motor NB- 
418-K6 has demonstrated the advantages of the proposed procedure compared to known ones in terms of the accuracy of approximation of the estimated characteristics of losses to those given in specifications. In particular, as regards the motor's overall efficiency coefficient, the result that we obtained fully coincides with its specificationbased characteristics. 


\subsection{Model of pulsating current traction motor taking into consideration magnetic losses in steel}

Development and modeling of control algorithms for traction electric drives of single-phase DC electric locomotives with pulsating current traction motors require a reasonable choice of the model of traction electric motors. Simulation of work performed by pulsating current traction electric motors and systems used to control these motors should give a possibility to take into account a number of uncertainties. These uncertainties are related to the nonlinear nature of motor magnetization curve, occurrence of eddy currents in the magnetic circuit, and magnetic losses in the motor magnetic circuit caused by these currents. In addition, traction electric motor can operate with both full and attenuated excitation.

In this regard, one important circumstance can be noted. Taking into account a large number of works devoted to development of a model of pulsating current traction electric motor demanded models are those that take into account nonlinearity of magnetization characteristics and occurrence of eddy currents and magnetic losses in the motor magnetic circuit. This can be confirmed by works on approximation of magnetization characteristic [181, 182] and simulation of pulsating current traction electric motors of pulsating current taking into consideration influence of eddy currents on the nature of the magnetization curve [183]. Simulation models obtained in the result of applying these methods give an opportunity to determine with high accuracy such traction motor parameters as motor shaft speed at any load, currents flowing in traction motor circuits, electromotive force (EMF) generated by the motor, but taking into account all power losses in traction motor. This indicates that the subject of researches on development of a model of a pulsating current traction motor taking into account the nonlinear nature of the magnetization curve and the magnetic system as well as power losses in the traction motor is topical.

When modeling a direct current traction motor (DCM) of series excitation the main problem is to reproduce the dependence of magnetic flux on currents of field winding and armature currents; and this implies presence of load characteristics. In 
the work by [181] the authors propose to use universal magnetization curve for DCM of series excitation, and on the basis of universal magnetic characteristic to calculate universal expressions for the intrusive parameters of direct current traction electric machines and those of pulsating current traction motors. Since the universal magnetic characteristic is built for machines working under load, in order to reduce the error of approximation the author proposed to approximate the universal magnetic characteristic by means of two functions: magnetomotive force of the field winding and magnetomotive force of the armature reaction. For a particular rating of attenuation of excitation, it is possible to convert this expression into a function of one variable, such as armature current.

With an obviously correct approach to modeling the dependence of the magnetic flux on field winding currents this approach is not very convenient for modeling. This is due to the need to change the model parameters for each excitation attenuation mode.

The solution of this problem is given in the work by [182] where it is proposed to calculate the weber-ampere characteristic at certain coefficients of field attenuation based on electromechanical and mechanical characteristics of DCM. Also this work proposes a model for determining the dependence of magnetic flux on field winding currents and the armature winding currents. The transfer function with unknown parameters in this model is considered as an adaptive model with coefficients adapted to the experimental data.

Since DCM used for traction purposes have certain peculiarities of design and magnetic system, the use of universal magnetic characteristics is not always correct. Motor magnetic circuits consist of electrical materials that have both high magnetic conductivity and high electrical conductivity. These materials are characterized by eddy currents that occur during change of magnetic flux. These processes significantly affect the change of magnetic flux in the motor steel and, accordingly, the nature of electromagnetic processes occurring in it. In works by $[181,182]$ the influence caused by eddy currents in the motor magnetic circuit on the change of magnetic flux is not taken into account. Solution of this problem can be found in the work by [183]. In this study the authors propose a mathematical model of 
the pulsating current traction motor taking into account influence of eddy currents on the nature of electrodynamic processes occurring in the electric motor.

Since DC motors of series excitation always operate in the loaded mode, electrodynamic processes in the electric motor should also be modeled taking into account the load. This can be confirmed by studies presented in works by [184-186]. The authors show relationship between the nature of load and mechanical characteristics of DCM.

In addition, the works by [187-189] represent the effect of load on motor magnetic characteristic, which, in turn determine electromagnetic characteristics of DCM. But the above works do not show the transition from mathematical models to their implementation in simulation models.

The study by [190] states that during electric locomotive operation movement parameters are constantly changing starting, traction mode, braking mode, braking mode, skidding, etc.). As the operating mode (rating) is changed the motor shaft speed also changes. Magnetic losses in the magnetic circuit of the traction motor depend on the motor shaft speed [191-193].

When calculating magnetic losses in magnetic circuit of pulsating current traction electric motor certain difficulties occur. These difficulties are associated with the choice of loss calculation method. Different loss calculation methods use different normalization coefficients or ratios at the same approach to loss determination in DCM. Moreover, in different methods, the value of similar coefficients may differ significantly from each other. This leads to discrepancies in the results of loss calculations in DCM when applying different methods [194-196].

The solution to this problem can be found in the study by [197] where the authors based on the analysis of existing methods have identified and proposed the most accurate approach to calculation and modeling of instant magnetic losses in steel of DC traction motor on the example of NB-418K6 motor.

Therefore, is to develop a mathematical model of a traction motor with pulsating current taking into account magnetic losses to study electrodynamic processes.

Simulation of electrodynamics processes in a pulsating current traction motor was 
performed on the example of the NB-418K6 traction motor. Rating data of NB-418 K6 pulsating current traction motor is presented in Table 1.

Table 1

Rating data of NB-418 K6 pulsating current traction motor

\begin{tabular}{|c|c|c|c|}
\hline Parameter & Designation & Units & Value \\
\hline Nominal voltage & $U_{d}$ & $V$ & 950 \\
\hline Nominal power in the continuous rating & $P$ & $k W$ & 740 \\
\hline Nominal current in continuous rating & $I_{a}$ & $A$ & 820 \\
\hline $\begin{array}{l}\text { Nominal speed of the motor } \\
\text { shaft in continuous rating }\end{array}$ & $n$ & rpm & 915 \\
\hline Nominal torque on the motor shaft & $T$ & $N \cdot m$ & 7727 \\
\hline $\begin{array}{l}\text { Armature winding resistance } \\
\text { at } t=115^{\circ} \mathrm{C}\end{array}$ & $r_{a w}$ & $\Omega$ & 0.01612 \\
\hline $\begin{array}{l}\text { Resistance of additional poles } \\
\text { and field winding at } t=115^{\circ} \mathrm{C}\end{array}$ & $r_{a p+c w}$ & $\Omega$ & 0.01612 \\
\hline Resistance of main poles at $t=115^{\circ} \mathrm{C}$ & $r_{m p}$ & $\Omega$ & 0.01064 \\
\hline Field winding resistance at $t=115^{\circ} \mathrm{C}$ & $r_{f}$ & $\Omega$ & 0.001 \\
\hline Number of pole pairs & $p$ & - & 3 \\
\hline $\begin{array}{l}\text { Number of pairs of parallel } \\
\text { branches in armature winding }\end{array}$ & $a$ & - & 3 \\
\hline Number of armature winding conductors & $N$ & - & 696 \\
\hline Inertia moment of the motor rotor & $J$ & $\mathrm{~kg} \cdot \mathrm{m}^{2}$ & 73 \\
\hline Cross sectional area of the armature yoke & $S_{Y}$ & $\mathrm{~m}^{2}$ & 0.0810 \\
\hline Cross sectional area of the armature teeth & $S_{z}$ & $\mathrm{~m}^{2}$ & 0.0415 \\
\hline
\end{tabular}

Electric scheme of the DC traction motor is presented in Fig. 1. 


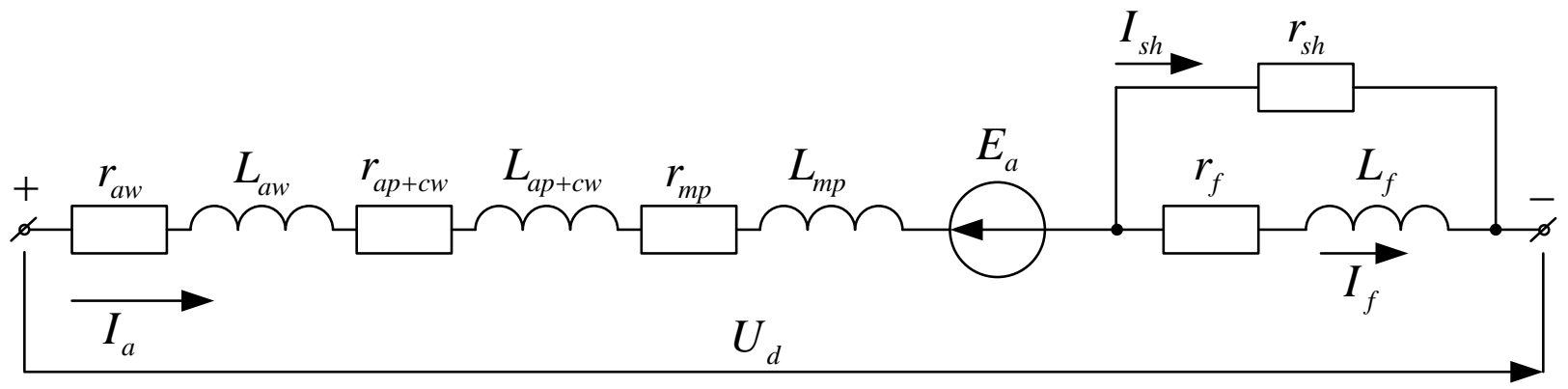

Fig. 1. Electric scheme of the pulsating current traction motor windings:

$r_{a w}, r_{a p+c w}, r_{m p}, r_{s h}, r_{f}$ - active resistances of armature winding, additional poles and compensation winding, main poles, shunt, field winding; $L_{a w}, L_{a p+c w}, L_{m p}$, $L_{f}$ - inductances of armature winding, additional poles and compensation winding, main poles, field winding; $U_{d}$ - armature voltage; $E_{a}$ - armature EMF; $I_{a}, I_{s h}, I_{f}-$ currents of armature, shunt and field winding

According to Kirchhoff's laws equations of the motor electrics for the circuit shown in Fig. 1 are as follows:

$$
\begin{gathered}
U_{d}=E_{a}+r_{a} \cdot I_{a}+L_{a} \cdot \frac{d I_{a}}{d t}+r_{s h} \cdot I_{s h} ; \\
r_{s h} \cdot I_{s h}=L_{f} \cdot \frac{d I_{f}}{d t}+r_{f} \cdot I_{f} \\
I_{a}=I_{s h}+I_{f},
\end{gathered}
$$

where $E_{a}$ is the armature electromotive force;

$r_{a}, L_{a}$ are the active resistance and inductance of armature circuit respectively; $r_{f}, L_{f}$ are the active resistance and inductance of field winding respectively; $r_{s h}$ is the resistance of shunt resistor; $I_{a}$ is the armature current; $I_{f}$ is the field winding current; 
$r_{s h}$ is the resistance of shunt resistor; $U_{d}$ is the armature voltage.

For convenience of modeling electrical scheme of the pulsating current traction motor windings is shown in the following form (Fig. 2).

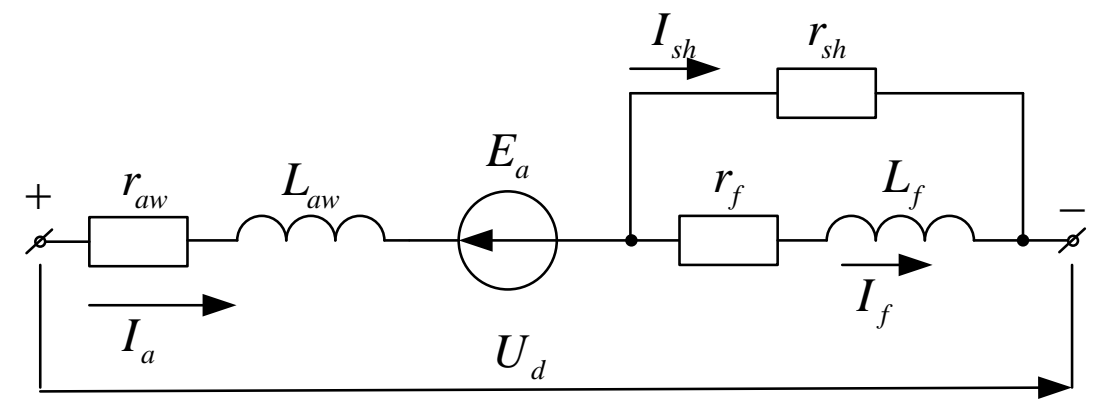

Fig. 2. Simplified electric scheme of the pulsating current traction motor windings:

$$
\begin{gathered}
r_{a} \text { - active resistance of armature; } \\
L_{a} \text { - inductance of armature circuit }
\end{gathered}
$$

Armature resistance is defined as

$$
r_{a}=r_{a w}+r_{a p+c w},
$$

where $r_{a w}$ is the armature winding active resistance;

$r_{a p+c w}$ is the active resistance of additional poles and compensation winding.

Armature inductance is defined as

$$
L_{a}=L_{a w}+L_{a p+c w}
$$

where $L_{a w}$ is the inductance of armature winding;

$L_{a p+c w}$ is the inductance of additional poles and compensation winding.

Electromotive force $E_{a}$ is calculated as

$$
E_{a}=C_{E} \cdot \Phi \cdot \omega,
$$


where $C_{E}$ is the constructive constant coefficient for EMF;

$\Phi$ is the total magnetic flux of the motor.

Constructive constant coefficient for EMF for shaft speed expressed in rpm is determined by the following expression

$$
C_{E}=\frac{N \cdot p}{2 \cdot \pi \cdot a},
$$

where $N$ is the number of armature winding conductors;

$p$ is the number of pole pairs;

$a$ is the number of pairs of parallel branches in armature winding.

Equation of motor mechanical equilibrium:

$$
M-M_{c}=J \cdot \frac{d \omega}{d t},
$$

where $M$ is the torque moment;

$M_{c}$ is the load moment on the motor shaft;

$J$ is the inertia moment of the motor rotor;

$\omega$ is the angular motor shaft speed.

For modeling convenience expression (8) is represented as a derivative of the angular velocity over time:

$$
\frac{d \omega}{d t}=\frac{1}{J} \cdot\left(M-M_{c}\right) .
$$

Torque moment is determined according to the following expression:

$$
M=C_{M} \cdot \Phi \cdot I_{a},
$$


where $C_{M}$ is the constructive constant coefficient for the moment.

Constructive constant coefficients for the EMF and for the moment are equal ( $C_{E}$ $\left.=C_{M}\right)$.

In this research, the authors propose to implement the model of pulsating current traction motor on the basis of real magnetic characteristics of the motor.

Magnetic characteristics of NB-418 K6 traction motor is presented in Fig. 3 [197].

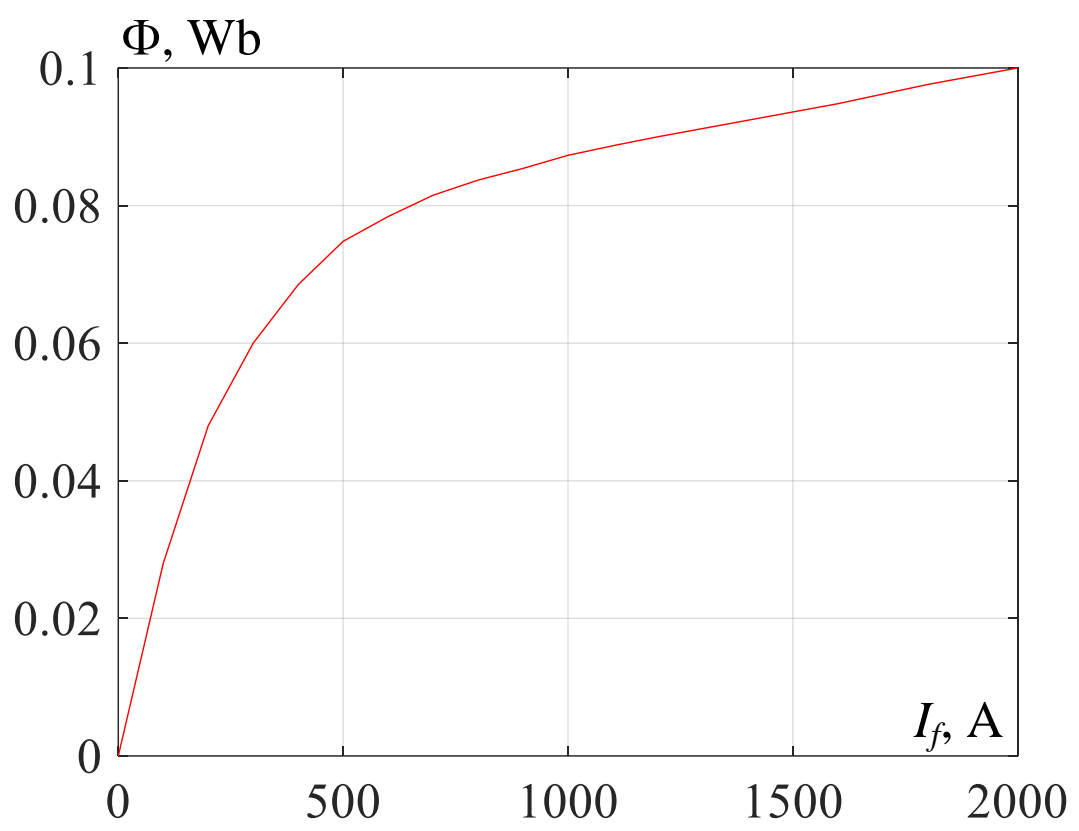

Fig. 3. Dependence of the magnetic flux $\Phi$ of the NB-418 K6 traction motor on the field current $I_{f}$

Consideration of magnetic losses in traction motor steel is performed according to the algorithm presented in equations (11) - (20).

Specific power losses in electrical steel on eddy currents and hysteresis, taking into account the accumulation of magnetic energy at a given magnetic permeability $\mu_{r}=1$, as a function of time, respectively [197] can be presented by the following equations:

$$
\begin{aligned}
& p_{\text {loss }}(t)=\left(H_{c}+K_{\text {hyst }} \cdot\left|B_{p} \cdot \sin \left(\omega_{r} \cdot t\right)\right|\right) \cdot\left(B_{p} \cdot \omega_{r} \cdot \cos \left(\omega_{r} \cdot t\right)\right)+ \\
& +K_{\text {addy }} \cdot B_{p}^{2} \cdot \omega_{r}^{2} \cdot \cos ^{2}\left(\omega_{r} \cdot t\right)
\end{aligned}
$$


where $p_{\text {loss }}$ is the specific power losses, $\mathrm{W} / \mathrm{m}^{3}$;

$H_{c}$ is the coercive force; $V_{i s}$ is the induction amplitude of the charge;

$\omega_{r}$ is the frequency of alternating magnetization;

$t$ is the time;

$K_{a d d y}$ is the coefficient taking into account specific losses on eddy currents;

$K_{\text {hyst }}$ is the coefficient taking into account the specific losses on hysteresis.

Frequency of alternating magnetization can be found from the expression

$$
\omega_{r}=p \cdot \omega,
$$

where $p$ is the number of pole pairs;

$\omega$ is the rotation frequency of electric motor shaft.

In order to implement the model of magnetic losses in electrical steel, it is necessary to find the amplitudes of inductions in the nodes made of electrical steel - yoke and anchor teeth [197].

Magnetic induction in the armature yoke can be calculated by means of the following expression

$$
B_{a}=\frac{2 \cdot \Phi_{\alpha}}{S_{a}},
$$

where $S_{a}$ is the cross sectional area of the armature yoke [197];

$\Phi_{a}$ is the armature magnetic flux.

Magnetic induction in the armature teeth can be calculated by means of the following expression

$$
B_{z}=\frac{\Phi_{a}}{S_{z}},
$$


where $S_{z}$ is the cross sectional area of the armature teeth [197].

The armature magnetic flux is equal to the total magnetic flux of the traction motor.

The total magnetic loss is the sum of magnetic losses in the armature and armature teeth, i.e.

$$
p_{\text {loss }}(t)=p_{\text {lossY }}(t)+p_{\text {lossz }}(t)
$$

where $P_{\text {loss }}(t), P_{\text {lossz }}(t)$ are the magnetic losses in the armature core and armature teeth.

The given magnetic permeability of 2212 steel differs from 1 [197]. That is, for the transition from a generalized steel sheet with reduced magnetic permeability $\mu_{r}=1$, defined by means of equation (11), to a 2212 steel sheet with permeability $\mu_{r 1}$ equation (15) should be multiplied by $\mu_{r 1}$.

Coefficients $H_{c}, K_{\text {hyst }}$ and $K_{a d d y}$ in equation (11) were determined for specific power losses expressed in W/kg. For transition to losses expressed in watts, equation (11) should be multiplied by the mass of steel of the corresponding motor structural element. Mass of steel of the structural element is determined by the following expression

$$
m_{i}=\rho \cdot V_{i}
$$

where $V_{i}$ is the volume of the structural element; $\rho=7750 \mathrm{~kg} / \mathrm{m}^{3}$ is the specific weight of 2212 electrical steel.

Then the instantaneous values of losses in the yoke and anchor teeth, taking into account equation (11) can be expressed as follows:

$$
\begin{aligned}
& P_{\text {loss } Y}(t)=p_{\text {loss } Y}(t) \cdot \rho \cdot V_{Y}^{2} \cdot \mu_{r 1} ; \\
& P_{\text {lossz }}(t)=p_{\text {lossz }}(t) \cdot \rho \cdot V_{z}^{2} \cdot \mu_{r 1},
\end{aligned}
$$

where $V_{Y}, V_{z}$ are the volumes of armature yoke steel and steel of armature teeth 
respectively;

$\mu_{r 1}=2400$ is the relative magnetic permeability of 2212 steel at frequency of $50 \mathrm{~Hz}$ and inductance $B=1.82 \mathrm{~T}$ [197].

Magnetic losses in the motor steel of the model are taken into account as follows. Relationship between active power and engine shaft speed is defined by the following expression:

$$
P_{\text {loss }}=\omega \cdot M_{\text {closs }} \text {, }
$$

where $M_{\text {closs }}$ is the static moment caused by magnetic losses in the motor steel.

Hence the static moment caused by the magnetic losses in the motor steel is $\mathrm{s}$ follows

$$
M_{\text {closs }}=\frac{P_{\text {loss }}}{\omega} .
$$

The work by [198] shows that both armature circuit inductance and inductance of field winding have a non-linear dependence on armature current and field current respectively. In this regard, the model of the electrical part of the traction motor in the MATLAB software environment was implemented in the Special Power System section of the Simulink library. This gave an opportunity to use real values of motor winding resistances, and the nonlinear dependences of the armature circuit inductance and field winding inductance on the corresponding currents was substituted with units of controlled current sources. Control signals for current sources simulating armature circuit inductance and field winding inductance were presented as the following dependences

$$
I_{a}=f\left(\psi_{a}\right),
$$




$$
I_{f}=f\left(\psi_{f}\right),
$$

where $\psi_{a}$ is the flux linkage of armature;

$\psi_{f}$ is the flux linkage of field winding.

Flux linkages $\psi_{a}$ and $\psi_{f}$ were obtained based on expressions (1) i (2) respectively.

With this end in view, based on the results for dependences of the armature circuit inductance and field winding inductance on the corresponding currents presented in the work [198], dependence of the armature current on the armature circuit flux linkage (Fig. 4) and dependence of field winding current from field current (Fig. 5) were calculated and constructed.



Fig. 4. Dependence of armature circuit current $I_{a}$ on flux linkage $\psi_{a}$ 


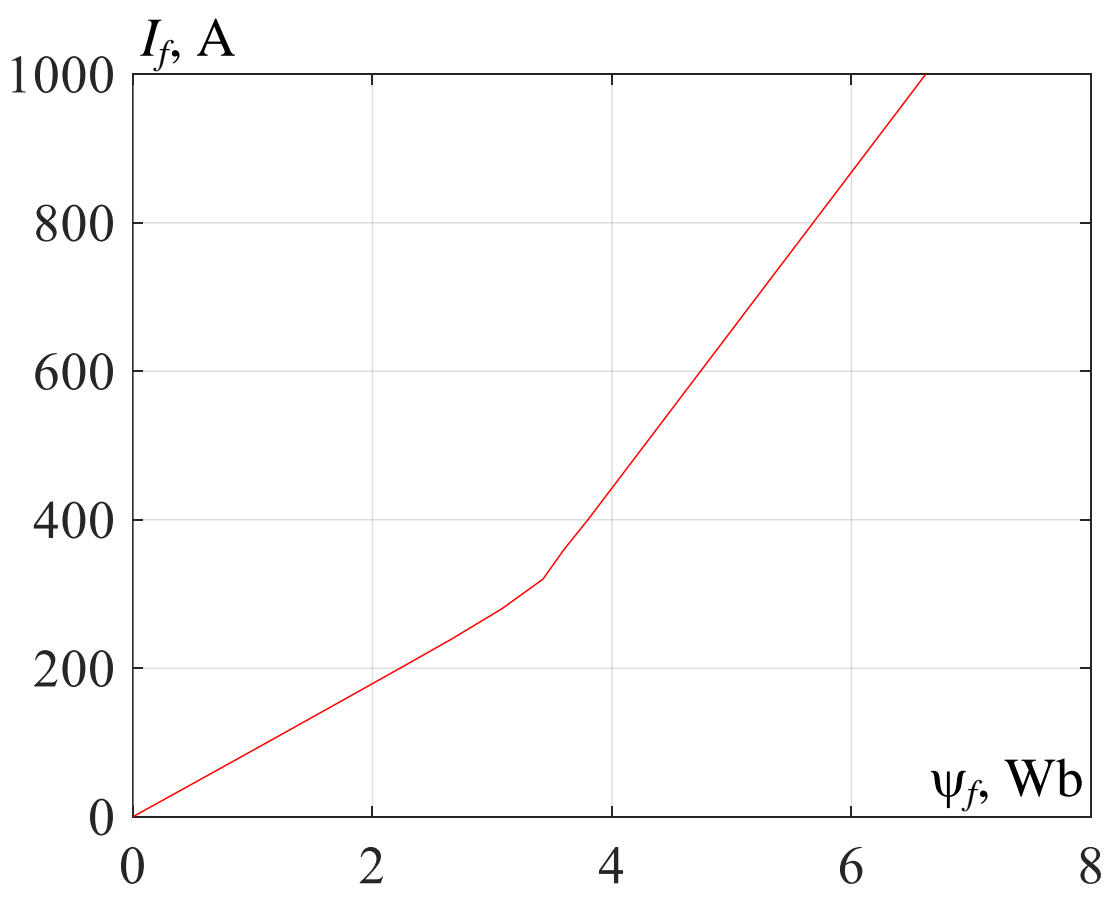

Fig. 5. Dependence of field current $I_{f}$ on flux linkage of field winding $\psi_{f}$

All other structural elements of the traction motor model were presented in form of structural diagrams.

Simulation model performed on the example of the NB-418 K6 traction electric motor used on electric locomotives of alternating current VL-80T, VL-80K (Fig. 6).

Implementation of the traction motor electrical part in the MATLab software environment is shown in Fig. 6 in form of the «Engine currents determination unit». Calculation of magnetic flux performed by approximation of the magnetic characteristic (Fig. 3) based on the arctangent function. In Fig. 6 implementation of Magnetic Characteristic is presented in form of the «Magnetic flux detection unit». Electric motor mechanical part in Fig. 6 is represented in form of the «Unit for calculating the mechanical parameters of the engine» that implements equations (9), (10). Calculation of instantaneous values of magnetic losses in electric motor steel that implements equations (11) - (20) is presented in the simulation model in form of the «Unit for calculating the static moment caused by magnetic losses» (Fig. 6). 


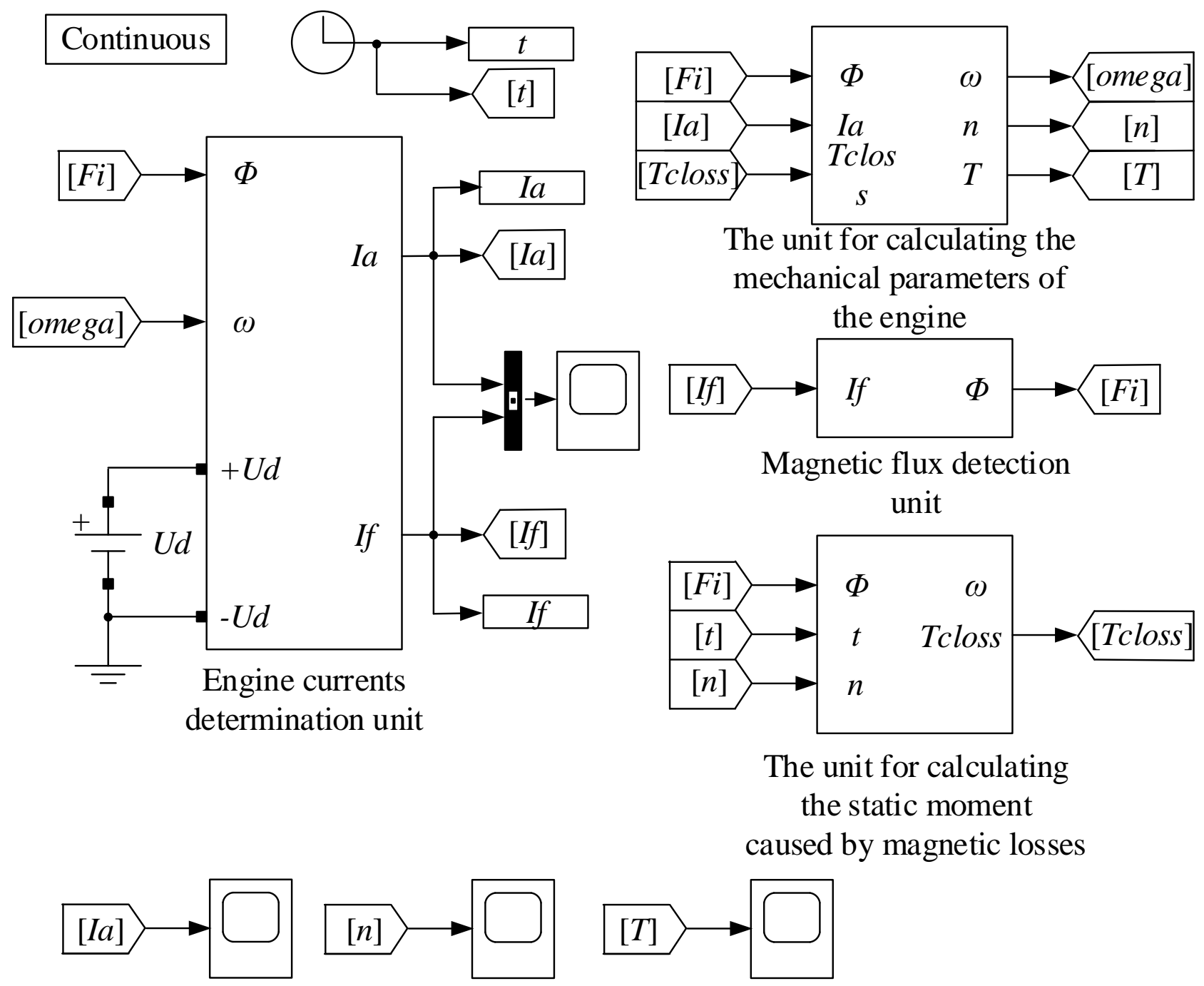

Fig. 6. Simulation model of a traction electric motor implemented in the MATLAB software environment

«Engine currents determination unit» structure is shown in Fig. 7. 


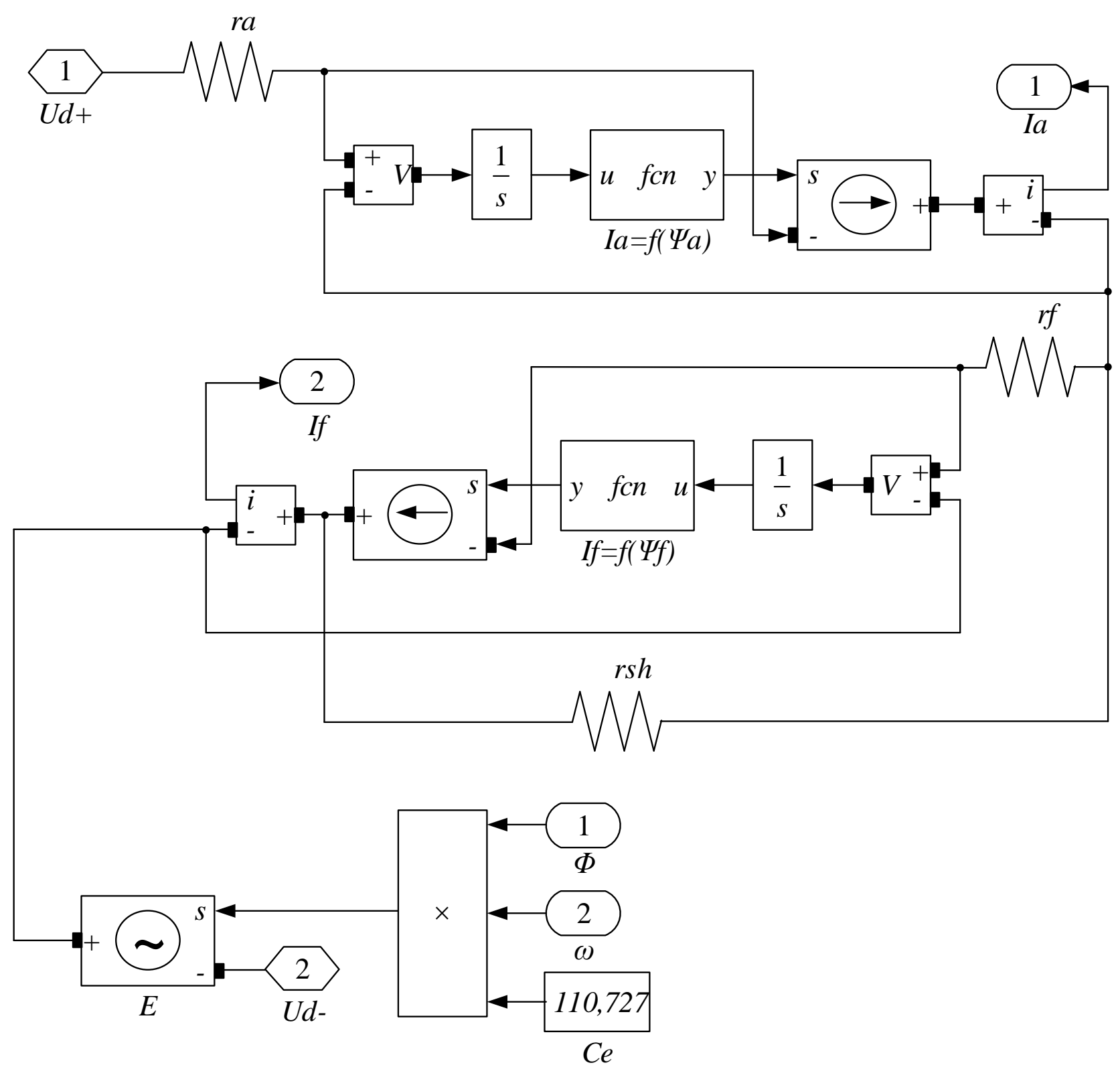

Fig. 7. Implementation of "Engine currents determination unit" at MATLab

«Unit for calculating the mechanical parameters of the engine» structure is shown in Fig. 8. 


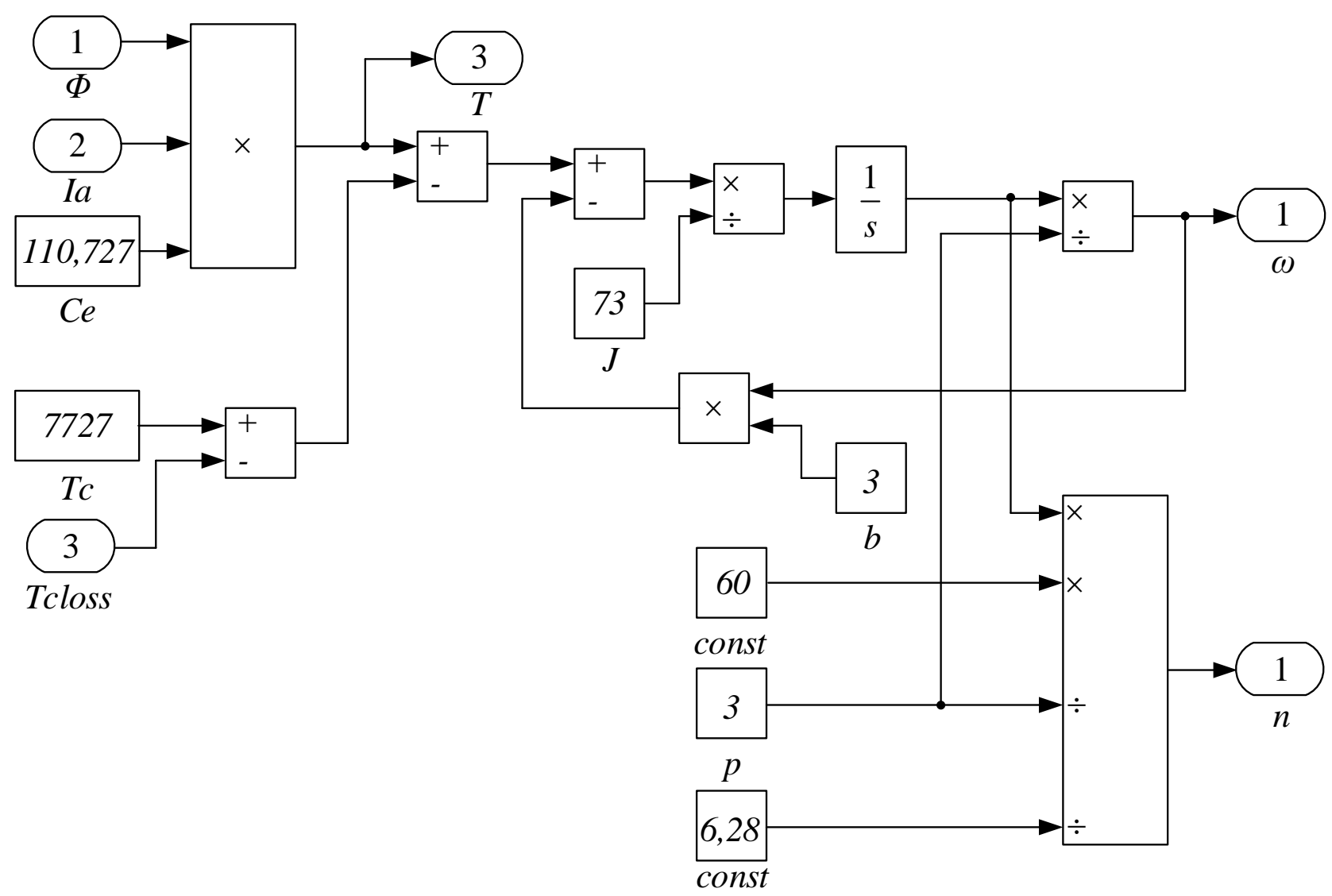

Fig. 8. Implementation of "Engine currents determination unit" at MATLab

In order to determine starting characteristics of pulsating current traction electric motor a constant voltage $U_{d}$ of $950 \mathrm{~V}$ corresponding to the nominal voltage value for NB-418 K6 traction motor. In the «Unit for calculating the mechanical parameters of the engine» a static moment $T_{c}$ of $7727 \mathrm{~N} \cdot \mathrm{m}$ was created; and in the «Engine currents determination unit» shunt resistance $r_{s h}$ was accepted as $0.24 \Omega$ and these values also correspond to the nominal mode of electric motor operation.

On the simulation model (Fig. 6) obtained are time diagrams of armature current (Fig. 9), torque moment on the electric motor shaft (Fig. 10) and motor shaft speed (Fig. 11).

For the steady-state rating a value of excitation flux $\Phi$ was equal to $0.0819 \mathrm{~Wb}$. 


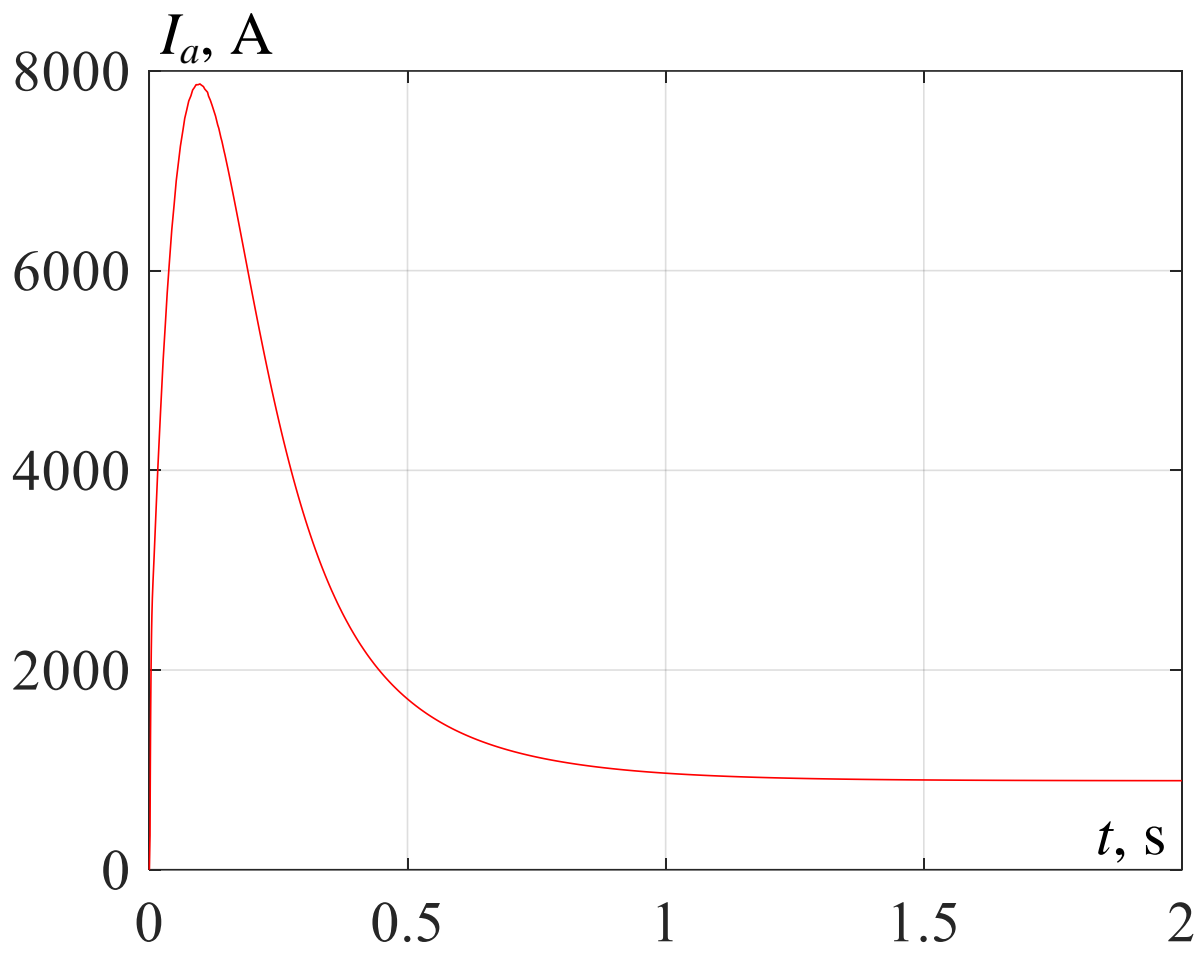

Fig. 9. Time diagrams of armature current $I_{a}$

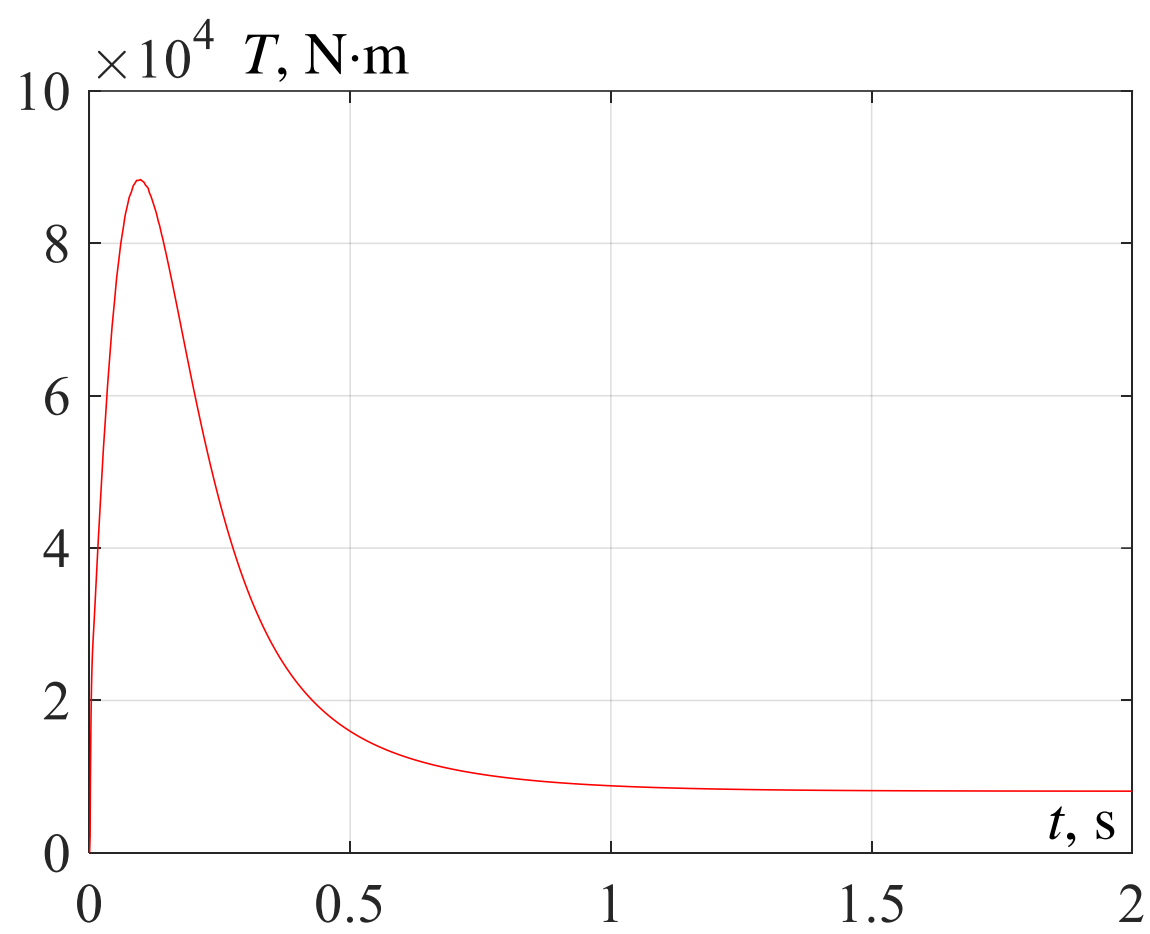

Fig. 10. Time diagram of torque moment $T$ on the motor shaft 


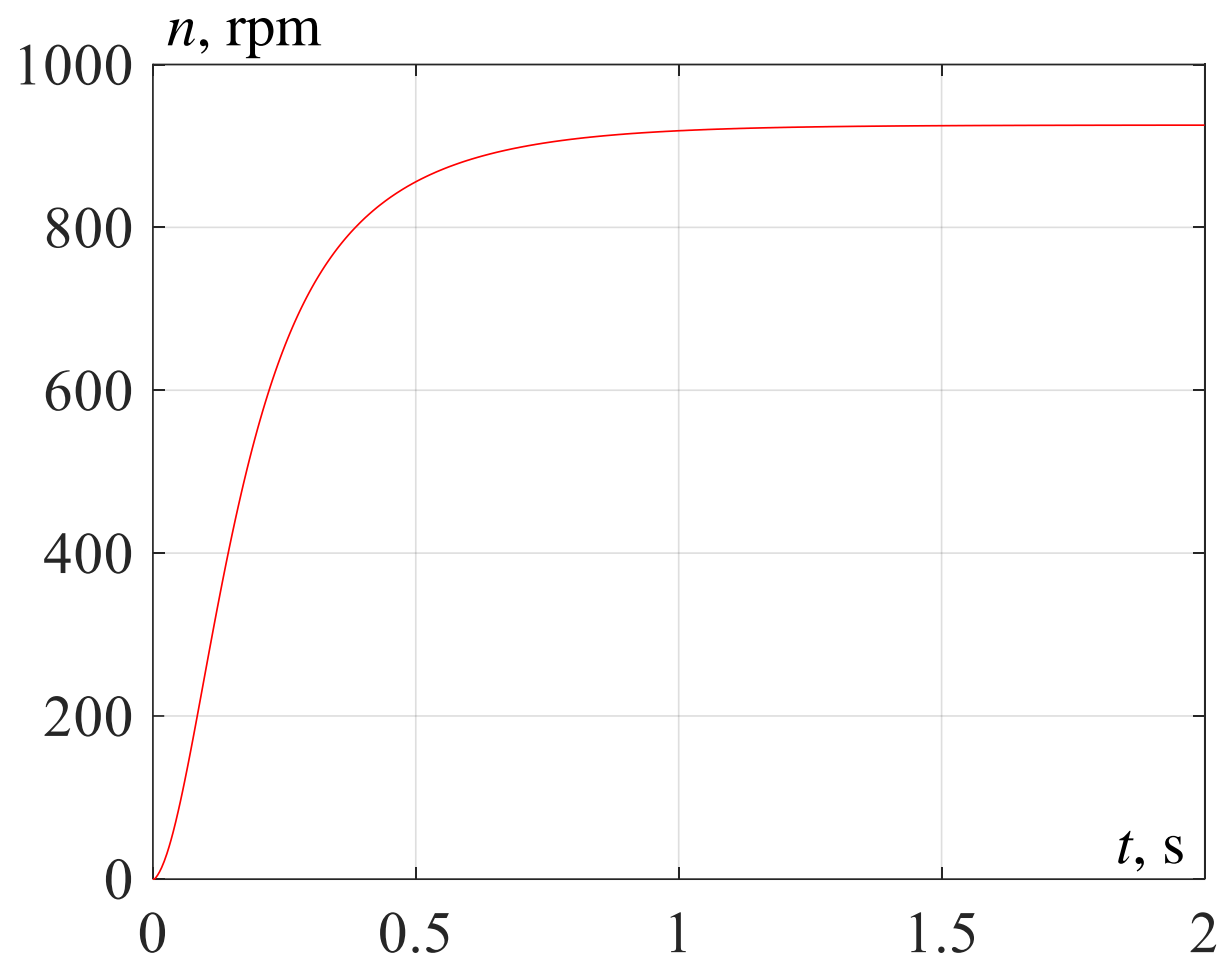

Fig. 11. Time diagram of motor shaft speed $n$

Values of armature circuit current, the torque moment on the motor shaft, motor shaft speed and the magnetic flux for the steady-state rating obtained during the simulation were used to calculate errors in determining these values.

Error in determination of armature circuit current

$$
\delta_{I_{a}}=\left|\frac{I_{\text {anom }}-I_{\text {amod }}}{I_{\text {anom }}}\right| \cdot 100 \%=\left|\frac{820-881}{820}\right| \cdot 100 \%=6,93 \%,
$$

where $I_{\text {anom }}=820$ A is the armature nominal current (see Table 1); $I_{\text {amod }}=881 \mathrm{~A}$ is the armature current obtained in the result of modeling for the steadystate rating.

Flux determination error

$$
\delta_{\Phi}=\left|\frac{\Phi_{\text {nom }}-\Phi_{\text {mod }}}{\Phi_{\text {nom }}}\right| \cdot 100 \%=\left|\frac{0,08-0,0819}{0,08}\right| \cdot 100 \%=2,375 \%,
$$


where $\Phi_{\text {anom }}=0.08 \mathrm{~Wb}$ is the nominal magnetic flux (see Table 1 );

$\Phi_{\text {amod }}=0.0819 \mathrm{~Wb}$ is the magnetic flux obtained in the result of modeling for the steadystate rating.

Error in determination of torque moment on the motor shaft:

$$
\delta_{T}=\left|\frac{T_{\text {nom }}-T_{\text {mod }}}{T_{\text {nom }}}\right| \cdot 100 \%=\left|\frac{7727-7990}{7727}\right| \cdot 100 \%=3,4 \%,
$$

where $T_{\text {anom }}=7727 \mathrm{~N} \cdot \mathrm{m}$ is the nominal torque moment on the motor shaft (see Table $1)$;

$T_{\text {amod }}=7990 \mathrm{~N} \cdot \mathrm{m}$ is the torque moment on the motor shaft obtained in the result of modeling for the steady-state rating.

Error in determination of torque moment on the motor shaft:

$$
\delta_{n}=\left|\frac{n_{\text {nom }}-n_{\text {mod }}}{n_{\text {nom }}}\right| \cdot 100 \%=\left|\frac{915-951,6}{915}\right| \cdot 100 \%=4 \%,
$$

where $n_{\text {anom }}=915 \mathrm{rpm}$ is the rated motor shaft speed (Table 1);

$n_{\text {amod }}=951.6 \mathrm{rpm}$ is the motor shaft speed obtained in the result of modeling for the steadystate rating.

Results of modeling and calculation of errors in determination of controlled motor parameters are listed in Table 2. 
Table 2

Results of calculation of errors in determination of controlled parameters during modeling

\begin{tabular}{|c|c|c|c|c|c|c|c|c|c|c|c|c|}
\hline \multirow{3}{*}{ Rating } & \multicolumn{12}{|c|}{ Controlled parameter } \\
\hline & \multicolumn{3}{|c|}{ Armature current $I_{a}$, A } & \multicolumn{3}{|c|}{$\begin{array}{l}\text { Static moment } T \text {, } \\
\qquad \mathrm{N} \cdot \mathrm{m}\end{array}$} & \multicolumn{3}{|c|}{$\begin{array}{c}\text { Motor shaft speed } n \text {, } \\
\text { rpm }\end{array}$} & \multicolumn{3}{|c|}{ Flux $\Phi, \mathrm{Wb}$} \\
\hline & $I_{a}$ & Iamod & $\begin{array}{c}\delta_{I a} \\
\%\end{array}$ & $T$ & $T_{\text {mod }}$ & $\begin{array}{c}\delta T, \\
\%\end{array}$ & $n$ & $n_{\text {mod }}$ & $\delta_{n}, \%$ & $\Phi$ & $\Phi_{\text {mod }}$ & $\delta \Phi, \%$ \\
\hline 1 & 2 & 3 & 4 & 5 & 6 & 7 & 8 & 9 & 10 & 11 & 12 & 13 \\
\hline$U_{d}=950 \mathrm{~V}$ & \multirow[b]{2}{*}{820} & \multirow[b]{2}{*}{881} & \multirow[b]{2}{*}{6.93} & \multirow[b]{2}{*}{7727} & \multirow[b]{2}{*}{7990} & \multirow[b]{2}{*}{3.4} & \multirow[b]{2}{*}{915} & \multirow[b]{2}{*}{951.6} & \multirow[b]{2}{*}{4.0} & \multirow[b]{2}{*}{0,08} & \multirow[b]{2}{*}{0,0819} & \multirow[b]{2}{*}{2,375} \\
\hline $\begin{array}{l}\text { Excitation } \\
96 \% \\
T_{c}=7727 \\
\mathrm{~N} \cdot \mathrm{m}\end{array}$ & & & & & & & & & & & & \\
\hline $\begin{array}{l}U_{d}=1080 \\
\mathrm{~V}\end{array}$ & \multirow{3}{*}{840} & \multirow{3}{*}{885.3} & \multirow{3}{*}{5.39} & \multirow{3}{*}{7727} & \multirow{3}{*}{8030} & \multirow{3}{*}{3.9} & \multirow{3}{*}{1050} & \multirow{3}{*}{1088} & \multirow{3}{*}{3.5} & \multirow{3}{*}{0,082} & \multirow{3}{*}{20,0839} & \multirow{3}{*}{2,317} \\
\hline $\begin{array}{l}\text { Excitation } \\
96 \%\end{array}$ & & & & & & & & & & & & \\
\hline $\begin{array}{l}T_{c}=7727 \\
\mathrm{~N} \cdot \mathrm{m}\end{array}$ & & & & & & & & & & & & \\
\hline$U_{d}=950 \mathrm{~V}$ & \multirow{3}{*}{1155} & \multirow{3}{*}{1212} & \multirow{3}{*}{4.93} & \multirow{3}{*}{7727} & \multirow{3}{*}{8174} & & & & & & & \\
\hline $\begin{array}{l}\text { Excitation } \\
43 \%\end{array}$ & & & & & & 5.78 & 1055 & 1091 & 3.41 & 0,11 & 0,1127 & 2,45 \\
\hline $\begin{array}{l}T_{c}=7727 \\
\mathrm{~N} \cdot \mathrm{m}\end{array}$ & & & & & & & & & & & & \\
\hline$U_{d}=950 \mathrm{~V}$ & & & & & & & & & & & & \\
\hline $\begin{array}{l}\text { Excitation } \\
96 \%\end{array}$ & 665 & 691.8 & 4.03 & 5597 & 5859 & 4.68 & 965 & 996.2 & 3.23 & 0,065 & 0,0664 & 2,154 \\
\hline $\begin{array}{l}T_{c}=5597 \\
\mathrm{~N} \cdot \mathrm{m}\end{array}$ & & & & & & & & & & & & \\
\hline
\end{tabular}


The results shown in Table 2 indicate a high reliability of measuring controlled parameters. Thus, the armature current measurement error for all measurement modes did not exceed $7 \%$; torque measurement error was up to $6 \%$; the error of measuring the motor shaft speed was not more than $4 \%$ and the error of measuring the magnetic flux did not exceed $3 \%$. This indicates a high reliability of the modeling results and increases the accuracy of calculations of energy-intensive modes of rolling stock [199, 200].

Based on the results of the study, the following conclusions can be drawn:

1. The use of the unit for determining the magnetic losses in the motor armature of the motor made it possible to clarify values of the controlled parameters during modeling. Comparison of the controlled parameters in the steady-state rating with the motor passport data showed a high degree of reliability of the simulation results. Thus, the armature current measurement error for all measurement modes did not exceed 7 $\%$; torque measurement error was up to $6 \%$; the error of measuring the motor shaft speed was not more than $4 \%$, the error of measuring the magnetic flux did not exceed $3 \%$. Further refinement of the mathematical model is related to taking into account all types of losses in the motor components when it is powered from a pulsating voltage source.

2. The proposed approach to modeling of a pulsating current traction electric motor will give an opportunity to apply this model for development of a mathematical model of the traction electric drive of an electric locomotive aimed at studying electrodynamic processes occurring in the electric drive.

3. The presence of the unit for determining magnetic losses in the motor steel will give an opportunity to reliably assess spectral composition of the traction current and voltage in the secondary winding of the traction transformer at various modes of electric locomotive operation. This, in turn, will give an opportunity to evaluate operation of reactive power compensators taking into account various modes of electric locomotive operation 
DOI 10.46299/ISG.2021.MONO.TECH.III.3.3

\section{3 Моделювання процесів роботи електромеханічного амортизатора та ефективність його застосування на рейковому міському транспорті}

Безпека руху і ефективність використання рухомого складу міського електротранспорту залежить від його конструкції, особливо від систем, що забезпечують динамічні показники. Це, в першу чергу, відноситься до ходових частин та тягового електроприводу.

Невід’ємним елементом ходових частин візків вагонів є системи ресорного підвішування, що забезпечує надійність роботи рухомого складу, комфортність поїздки та безпеку руху. Їх робота пов'язана з гасінням коливань кузова від нерівності рейок та зовнішніх впливів.

Для гасіння коливань кузова застосовують різні конструкції амортизаторів (гасителів): гідравлічні, фрикційні, пневматичні. Але вони мають ряд недоліків. При використанні гідравлічних гасителів неможливе регулювання їх параметрів при різному навантаженні вагонів. Фрикційні гасителі мають нерівномірний знос їх частин під час експлуатації, внаслідок чого змінюється характеристика їх конструкції. Пневматичні гасителі коливань потребують додаткових витрат енергії та потужностей пневматичної системи вагонів. Гасителі коливань, що використовуються в своїй більшості витрачають енергію коливань на нагрівання, що $є$ не ефективним.

Перспективним $є$ використання електромеханічних амортизаторів, які можуть додаткового генерувати електричну енергію для внутрішніх потреб рухомого складу.

Вибір електромеханічного амортизатора заснований на типі, конструкції і тяговій (механічній) характеристиці лінійного електромеханічного перетворювача. Обираючи тип i конструкції такого перетворювача для електромеханічного амортизатору відзначимо, що він не підпадає ні під один 3 видів існуючої їх класифікації: силовий, енергетичний i потужний [208-210, 215]. 
Електромеханічний перетворювач для амортизатору знаходиться в рамках класифікації усіх типів перетворювачів одночасно.

Для електромагнітного перетворювача характерна досить нерівномірна характеристика залежності сили тяги від переміщення, яка близька до гіперболічної.

Для системи ресорного підвішування ходової частини візка по своїм характеристикам та параметрам регулювання струму підходить лінійний електромеханічний перетворювач, який має постійну тягову характеристику, яка змінюється лише від швидкості руху якоря [202].

Для визначення параметрів i характеристик електромеханічного амортизатору розглянемо його особливості конструкції та принцип дії (рис. 2.1).

Принцип дії амортизатора заснований на електромагнітних явищах. Постійний магніт 4 (див. мал. 1) має радіальне намагнічення. Силові магнітні лінії потоку збудження замикаються по колу: повітряний зазор 3 якорем 1 та обмоткою якорю 2, спинка станини та станина 3, постійний магніт 4. Потік збудження зчіплюється з обмоткою якоря і під дією зовнішніх динамічних сил, які виникають під час коливання кузова та візка, якір рухається (униз або вгору).

У обмотці якоря виникає ЕРС. При навантаженні на обмотку якоря виникає струм якоря. 


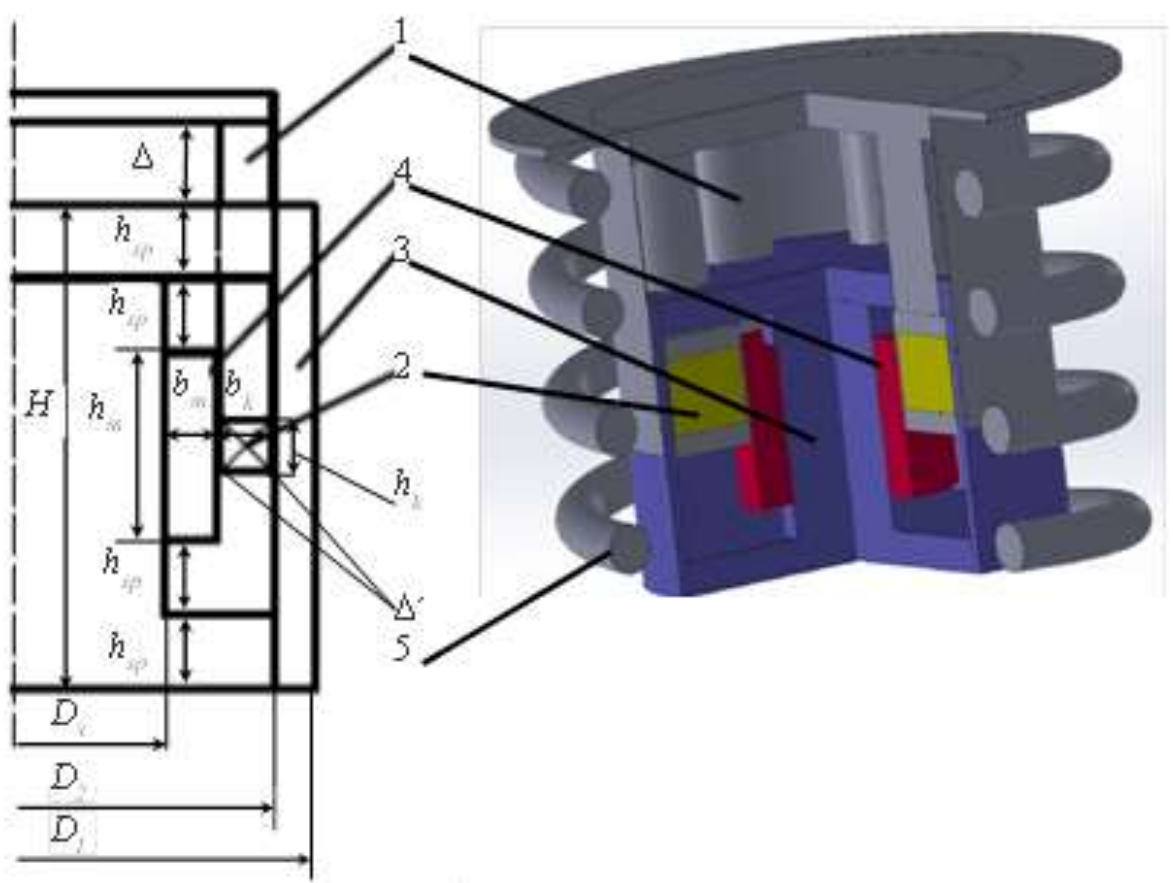

Малюнок 1. Електромеханічний амортизатор постійного струму:

1 - якір; 2 - обмотка якорю; 3 - станина; 4 - постійний магніт

Основні параметри характеристики електромеханічного амортизатору наведені у таблиці 1 згідно малюнку 1. Вони обрані евристично та приблизно відповідають вимогам щодо амортизатору вагону метрополітену.

Електромагнітну силу, що діє на обмотку якоря з магніторушійною силою (МРC) $F=i w$ та електрорушійну силу (ЕРC), можливо обчислити за виразом [218]:

$$
\begin{aligned}
& F_{d e m}=B_{\delta}(i w) l_{s r}, \\
& E_{d e m}=B_{\delta} V_{d e m} l_{s r} .
\end{aligned}
$$

де $B_{\delta}$-індукція магнітного поля у повітряному зазорі $\delta$;

$l_{s r}-$ середня довжина вітка, яку можливо обчислити 3 геометричних параметрів амортизатору за виразом:

$$
l_{s r}=\pi\left(D_{3}+2 b_{m}+2 \Delta^{\prime}+b_{k}\right),
$$


де $V_{d e m}-$ номінальна швидкість якоря амортизатора.

У останній час в якості матеріалів для постійних магнітів використовуються сплави NdFeB. Вони мають приблизно лінійну криву розмагнічення (мал. 2).

Основний опір магнітному потоку $є$ повітряний зазор між постійним магнітом та станиною. Він складається $з$ товщини обмотки та двох технологічних зазорів $\left(b_{k}+2 \Delta^{\prime}\right)$.

Таблиця 1.

Основні характеристики електромеханічного дослідного амортизатору

\begin{tabular}{|l|l|l|}
\hline Параметр & \multicolumn{1}{|c|}{ Величина } & \multicolumn{1}{|c|}{ Примітки } \\
\hline$F_{d e m}$ & $2000 \mathrm{H}$ & $\begin{array}{l}\text { Номінальна електромагнітна сила на якорі } \\
\text { амортизатора }\end{array}$ \\
\hline$V_{d e m}$ & $0,08 \mathrm{M} / \mathrm{c}$ & Номінальна швидкість якоря амортизатора \\
\hline$\Delta$ & $0,08 \mathrm{м}$ & $\begin{array}{l}\text { Максимальний хід амортизатора, згідно } \\
\text { рисунку 2.1 }\end{array}$ \\
\hline$H_{c}$ & $9,510^{5} \mathrm{~A} / \mathrm{M}$ & Коерцитивна сила постійного магніту \\
\hline$B_{o s t}$ & $1,05 \mathrm{Tл}$ & Остаточна індукція постійного магніту \\
\hline$I_{W}$ & $5120 \mathrm{~A}$ & МРС обмотки якоря у номінальному режимі \\
\hline$h$ & $0,293 \mathrm{м}$ & Висота ярма амортизатора, згідно малюнку 1 \\
\hline$D_{1}$ & $0,360 \mathrm{м}$ & $\begin{array}{l}\text { Зовнішній діаметр амортизатора, згідно } \\
\text { малюнку 1 }\end{array}$ \\
\hline$D_{2}$ & $0,312 \mathrm{м}$ & Згідно малюнку 1 \\
\hline$D_{3}$ & $0,18 \mathrm{м}$ & Згідно малюнку 1 \\
\hline$h_{m}$ & $0,114 \mathrm{м}$ & Висота постійного магніту, згідно малюнку 1 \\
\hline$b_{m}$ & $0,032 \mathrm{м}$ & Товщина постійного магніту, згідно малюнку 1 \\
\hline$h_{k}$ & $0,034 \mathrm{м}$ & Висота обмотки якоря, згідно малюнку 1 \\
\hline$b_{k}$ & $0,0325 \mathrm{м}$ & Товщина обмотки якоря, згідно малюнку 1 \\
\hline$h_{s p}$ & $0,045 \mathrm{м}$ & Товщина спинки якоря, згідно малюнку 1 \\
\hline$\Delta^{\prime}$ & $0,001 \mathrm{м}$ & Технологічні повітряні зазори, згідно малюнку 1 \\
\hline
\end{tabular}

Для розрахунку параметрів приймаються наступні припущення: 
- опір магнітному потоку складається з опору повітряного зазору,

- незначність впливу потоку струму обмотки якоря на режим роботи постійного магніту,

- визначення індукції у постійному магніті, яка дорівнює індукції у повітряному зазорі можливо за геометричними відношеннями з малюнку 2.



Малюнок 2. До визначення індукції магнітного поля у повітряному зазорі: 1 - магнітна характеристики постійного магніту; 2 - магнітна характеристика повітряного зазору.

Магніторушійна сила у робочий точці А визначається виразом:

$$
\frac{B_{o s t}-B_{\delta}}{B_{o s t}}=\frac{\frac{B_{\delta}}{\mu_{0}}\left(b_{k}+2 \Delta^{\prime}\right)}{H_{c} b_{m}} .
$$

3 виразу (3) отримаємо:

$$
B_{\delta}=\frac{1}{\frac{1}{B_{o s t}}+\frac{\left(b_{k}+2 \Delta^{\prime}\right)}{\mu_{0} H_{c} b_{m}}} .
$$

Підставивши вирази (2) та (4) у (1) отримаємо: 


$$
\begin{aligned}
F_{\text {dem }}= & \pi \frac{D_{3}+2 b_{m}+2 \Delta^{\prime}+b_{k}}{\frac{1}{B_{o s t}}+\frac{\left(b_{k}+2 \Delta^{\prime}\right)}{\mu_{0} H_{c} b_{m}}} I W, \\
E_{d e m}= & \pi \frac{D_{3}+2 b_{m}+2 \Delta^{\prime}+b_{k}}{\frac{1}{B_{\text {ost }}}+\frac{\left(b_{k}+2 \Delta^{\prime}\right)}{\mu_{0} H_{c} b_{m}}} V_{d e m} .
\end{aligned}
$$

Вираз (5) $є$ спрощена математична модель щодо визначення електромагнітної сили та ЕРС електромеханічного амортизатору.

При створенні моделі прийнято допущення - запасена електромагнітна енергія, яка використовується для опису машини, розглядається лише як енергія поля нульового порядку, тобто енергія статичного магнітного поля. Енергія електростатичного поля сконцентрована лише в конденсаторі.

Розробка динамічної моделі заснована на узагальненій схемі [201, 219], яка має у центральному ступені ресорного підвішування пружини і паралельно ним встановлені гідравлічні гасителі, а також пневматичні ресори. Для рішення задачі обрана розробка просторової кінематичної схеми динамічної системи екіпаж-колія для метровагону з осьовою формулою $20-20$.

При цьому параметри буксового ступеня не змінювалися і були прийняті відповідно до результатів, отриманих в [219]. Виходячи з них відзначено, що модель створення рейкового шляху має спрощений вигляд і представлена як дискретна модель, відповідно якої до кожного колеса колісної пари приведена зосереджена маса шляху, пружина і гідравлічний гаситель. Такий підхід найбільш прийнятний для дослідження характеристик електромеханічного амортизатору. 3 урахуванням змін у подібної схемі розроблена узагальнена механічна модель центрального ступеня ресорного підвішування вагону метрополітену.

Для визначення положень математичної моделі обрані наступні узагальнені енергетичні параметри амортизатору: узагальнена координата $q_{k}$, узагальнена швидкість $q_{k}^{\prime}$, узагальнений імпульс сили $p_{k}$, узагальнена сила $f_{k}$. Для механічної системи взагалі не виникає сумнівів, що розуміти під 
координатою, швидкістю, силою або імпульсом. Інша ж ситуація виникає при виборі електричних координат.

Збережена електрична енергія електромеханічної системи складається 3 потенційної енергії і кінетичної коенергіi. Це означає, що якщо визначити заряд $q$ як узагальнену координату $q_{k}$, то збережена електрична енергія буде визначена як потенційна.

Представимо амортизатор у вигляді системи, що має одну електричну $q_{1}$ та одну механічну координату $q_{2}$. (мал. 3). 3 урахуванням комплексу попередніх досліджень для підвищення швидкодії амортизатору в електричне коло включено конденсатор $C$. Створене, таким чином електричне коло $L-R-C$ уявляє собою резонансний контур, який настроєно на частоту власних коливань кузова вагону метрополітену.

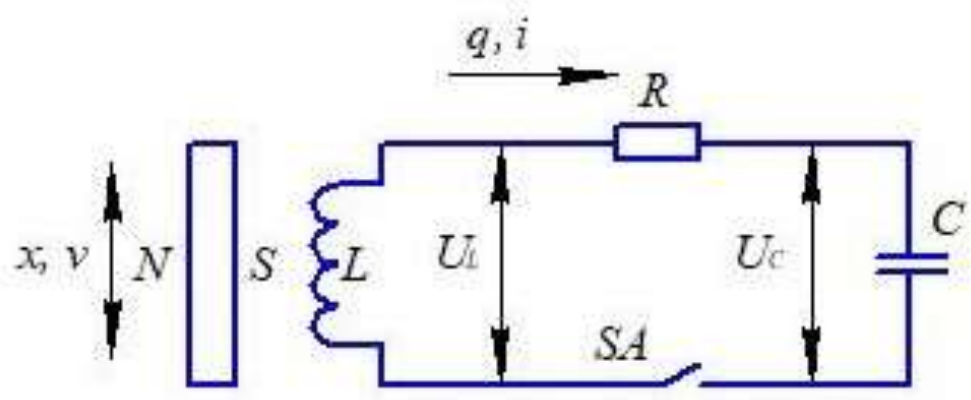

Малюнок 3. Електромеханічна схема амортизатору

Якщо розглядати дію неконсервативної сили $Q_{k}$ по $k$-ой координаті $q_{k}$ спільно з консервативними силами системи, то згідно з принципом Даламбера при динамічній рівновазі сума всіх сил, включаючи не консервативні, повинна дорівнювати нулю. Тому рівняння Лагранжа має такий вигляд [205]:

$$
\frac{\partial L}{\partial q_{k}}-\frac{d}{d t}\left(\frac{\partial L}{\partial \dot{q}_{k}}\right)-\left(\frac{\partial F}{\partial \dot{q}_{k}}\right)+Q_{k}=0,
$$

де $\boldsymbol{L}$ - силова функція Лагранжа,

$F$ - релеєва функція, яка враховує втрати в системі. 
Після визначення узагальнених координат вибираємо силову функцію Лагранжа або лагранжіан, $L(q, \dot{q}, t)$, який будемо використовувати для отримання рівнянь руху. Лагранжіан визначається як різниця між кінетичною коенергіей $\boldsymbol{T}$ і потенційною енергією $V$, тобто

$$
L=T-V \text {. }
$$

Основні складові рівняння (6) наведено у таблиці 2.

Таблиця 2.

Узагальнені електромеханічні параметри електромеханічного амортизатору

\begin{tabular}{|l|l|}
\hline \multicolumn{1}{|c|}{ Узагальнений параметр } & \multicolumn{1}{|c|}{ Фізичний параметр } \\
\hline$q_{1}$ - координата 1 & $q$ - заряд \\
\hline$q_{2}$ - координата 2 & $x$ - переміщення якоря \\
\hline$q_{1}^{\prime}$ - швидкість 1 & $i$ - струм в обмотці \\
\hline$q_{2}^{\prime}$ - швидкість 2 & $V$ - швидкість якоря \\
\hline$Q_{1}$ - зовнішня сила 1 & 0 \\
\hline$Q_{2}$ - зовнішня сила 2 & $F$ - сила, що прикладена до якоря \\
\hline
\end{tabular}

Через узагальнені змінні визначені параметри для кінетичної коенергіi i потенційної енергії консервативної частини системи за наступними рівняннями:

- кінетична коенергія:

$$
T=\int_{0, \ldots, 0}^{q_{1}, \ldots, q M} \sum_{k=1}^{M+1} p_{k}\left(q_{1}, \ldots, q_{M+1} ; \dot{q}_{1}, \ldots, \dot{q}_{M+1} ; t\right) d \dot{q}_{k}
$$

- потенційна енергія

$$
V=\int_{0, \ldots, 0}^{q_{1}, \ldots, q M} \sum_{k=1}^{M+1}-f_{k}\left(q_{1}, \ldots, q_{M+1} ; t\right) d q_{k} .
$$

3 урахуванням (6), (8) та (9) отримано вирази для коенергії і потенційної енергії консервативної частини системи:

$$
T=\frac{1}{2} \cdot M v^{2}+\int_{0}^{i} \Psi(i, x) d i,
$$




$$
V=-\frac{1}{2} k\left(x+x_{n}\right)^{2}-\frac{1}{2} C q^{2} .
$$

Консервативний лагранжіан по (6) дорівнює:

$$
L=\frac{1}{2} \cdot M v^{2}+\int_{0}^{i} \Psi(i, x) d i,-\frac{1}{2} k\left(x+x_{n}\right)^{2}-\frac{1}{2} C q^{2} .
$$

Релеєва функція втрат:

$$
F=\frac{1}{2}\left(R i^{2}+\alpha v^{2}\right)
$$

де $\quad \alpha-$ коефіцієнт механічного демпфування.

Підставляючи (10)-(13) в (6) і з урахуванням похідних:

$$
\begin{gathered}
\frac{\partial L}{\partial q_{1}}=\frac{\partial L}{\partial q}=-C q, \\
\frac{\partial L}{\partial q_{2}}=\frac{\partial L}{\partial x}=\frac{\int_{0}^{i} \Psi(i, x) d i}{\partial x}-k\left(x+x_{n}\right), \\
\frac{\partial L}{\partial \dot{q}_{1}}=\frac{\partial L}{\partial i}=\Psi\left(i^{\prime} x\right), \\
\frac{\partial L}{\partial \dot{q}_{2}}=\frac{\partial L}{\partial v}=M v, \\
\frac{\partial F}{\partial \dot{q}_{1}}=\frac{\partial F}{\partial i}=R i, \\
\frac{\partial F}{\partial \dot{q}_{2}}=\frac{\partial F}{\partial v}=\alpha v,
\end{gathered}
$$

отримаємо для електричних координат рівняння виду:

$$
-C q-\frac{d}{d t}(\Psi(i, x))-R i=0,
$$




$$
\frac{\int_{0}^{i} \Psi(i, x) d i}{\partial x}-k\left(x+x_{n}\right)-\frac{d}{d t}(M v)-\alpha v+F_{g}=0 .
$$

Вираз $\frac{\int_{0}^{i} \Psi(i, x) d i}{\partial x}=F_{e}$ визначає електромагнітну силу, яку створює амортизатор.

Оскільки потокозчеплення $\Psi$ - це складна функція, яка залежить від всіх координат, то загальну похідну $\frac{d \Psi}{d t}$ можна уявити в такому вигляді:

$$
\frac{d \Psi}{d t}=\frac{\partial \Psi}{\partial i} \cdot \frac{d i}{d t}+\frac{\partial \Psi}{\partial x} \cdot \frac{d x}{d t}
$$

Ураховуючи, що $U_{c}=-C q$, рівняння (20) має вигляд:

$$
U_{c}-\frac{\partial \Psi}{\partial i} \cdot \frac{d i}{d t}-\frac{\partial \Psi}{\partial x} \cdot \frac{d x}{d t}-R i=0
$$

Вирази $\frac{\partial \Psi}{\partial i}=L$ та $\frac{\partial \Psi}{\partial x}=K$ визначають диференціальну індуктивність та коефіцієнт при протиЕРС [203], які можливо ідентифікувати за результатами розрахунків магнітного поля.

Загалом вираз (23) можливо представити у вигляді:

$$
\left\{\begin{array}{l}
\frac{d i}{d t}=\frac{U_{c}-i \cdot R-K \cdot v}{L}, \\
\frac{d U_{c}}{d t}=-\frac{i}{C} .
\end{array}\right.
$$

Враховуючи, що $F_{g}=M g$, де $g$ - прискорення вільного падіння, а $M-$ приведенні маса кузова, вираз (3.16) можливо перетворити до вигляду

$$
\frac{d v}{d t}=\frac{F_{e}-m g-k\left(x+x_{n}\right)-\alpha v}{M} .
$$


Додавши до (24) та (25) рівняння зв'язку $\frac{d x}{d t}=v$ отримаємо узагальнену математичну модель електромеханічного амортизатору у вигляді задачі Коши.

$$
\left\{\begin{array}{l}
\frac{d i}{d t}=\frac{U_{c}-i \cdot R-K \cdot v}{L}, \\
\frac{d U_{c}}{d t}=-\frac{i}{C}, \\
\frac{d v}{d t}=\frac{F_{e}-m g-k\left(x+x_{n}\right)-\alpha v}{M}, \\
\frac{d x}{d t}=v .
\end{array}\right.
$$

Математична модель (26) має вигляд, який сприйнятливий для використання при моделюванні процесів роботи електромеханічного амортизатору, але для іiі використання необхідно ідентифікувати параметри моделі - диференціальну індуктивність та коефіцієнт при протиЕРС.

Результати моделювання показано на малюнках 4-7.

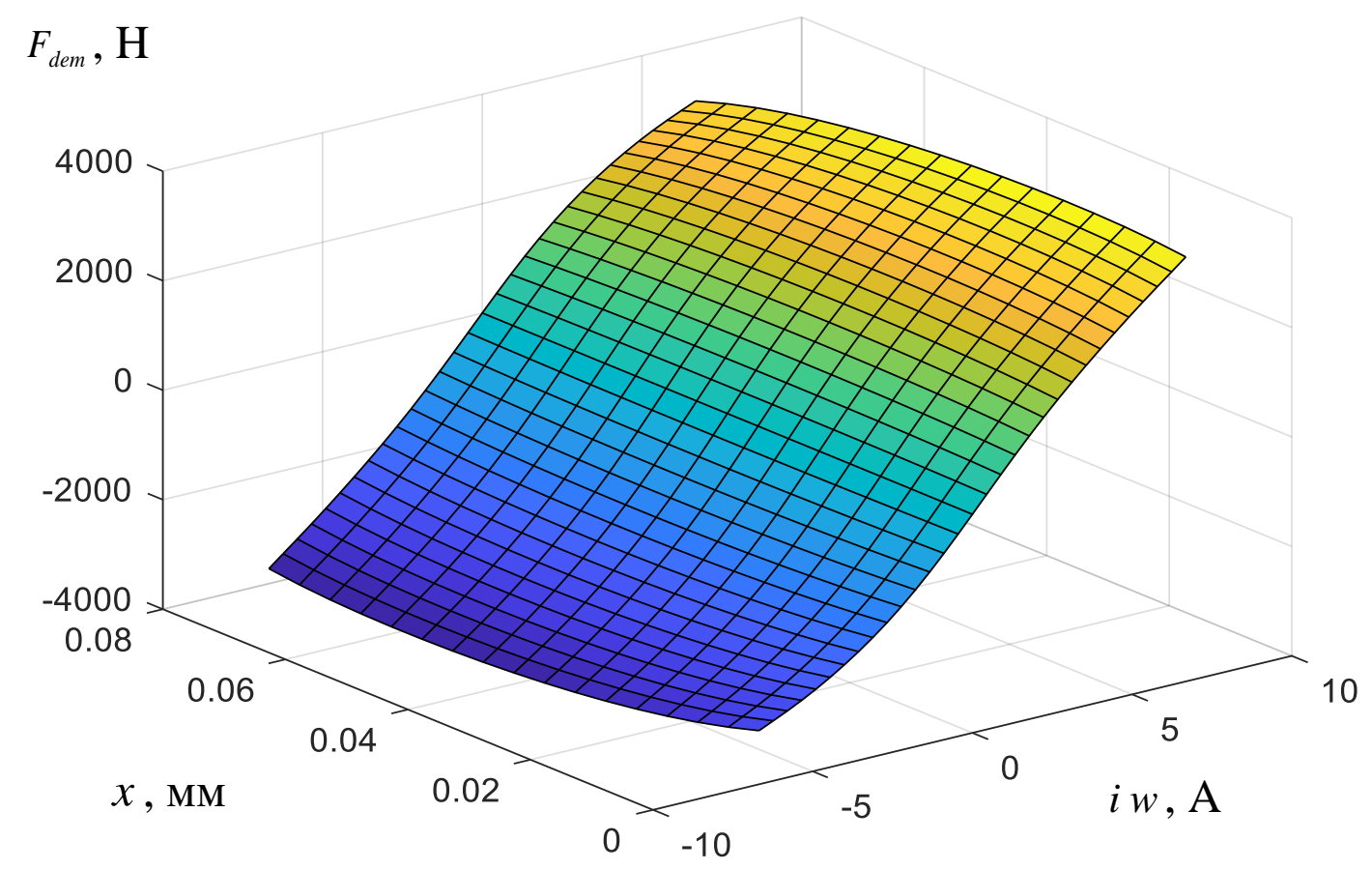

Малюнок 4. Залежність електромагнітної сили від переміщення та струму обмотки 


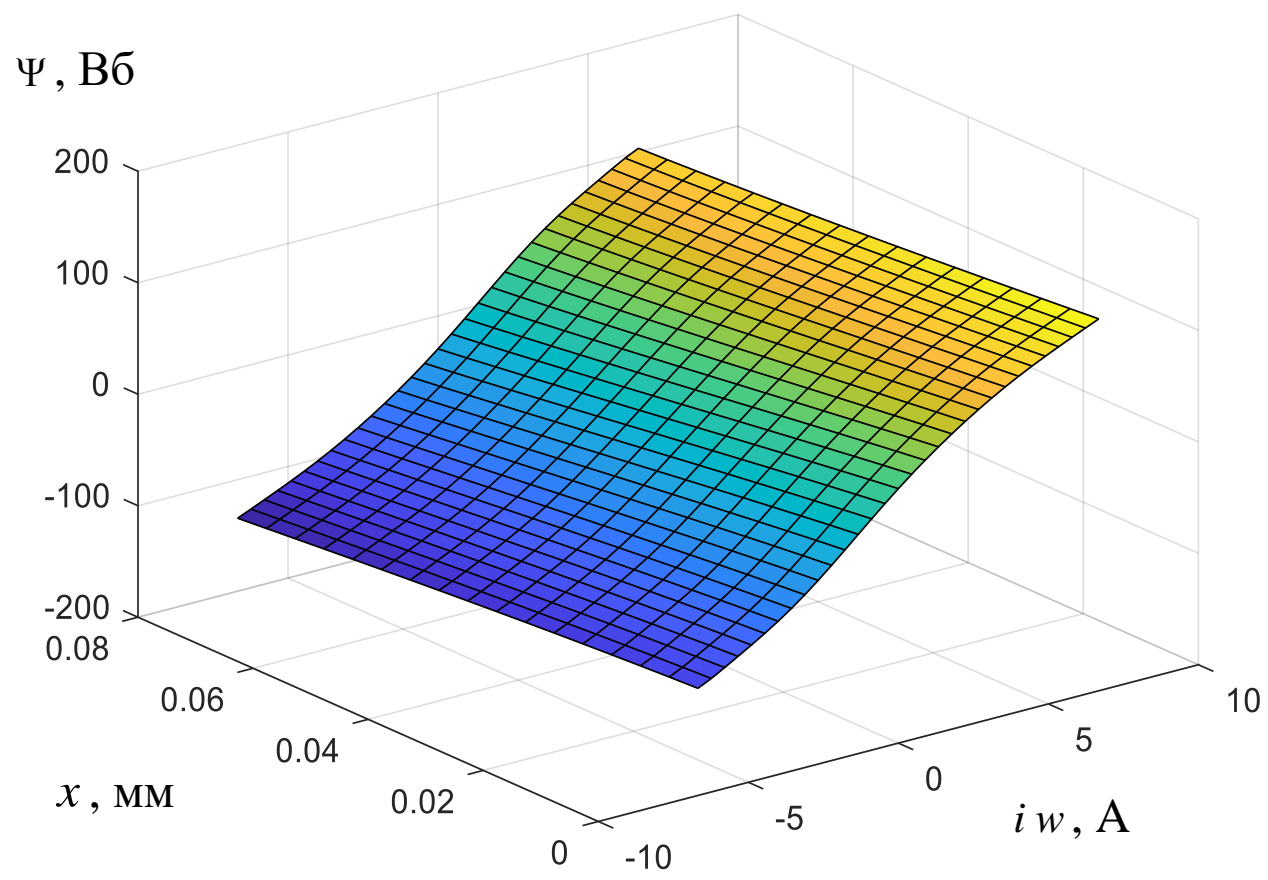

Малюнок 5. Залежність потокозчеплення котушки якоря від переміщення та струму обмотки



Малюнок 6. Залежність диференційної індуктивності від переміщення та струму обмотки 


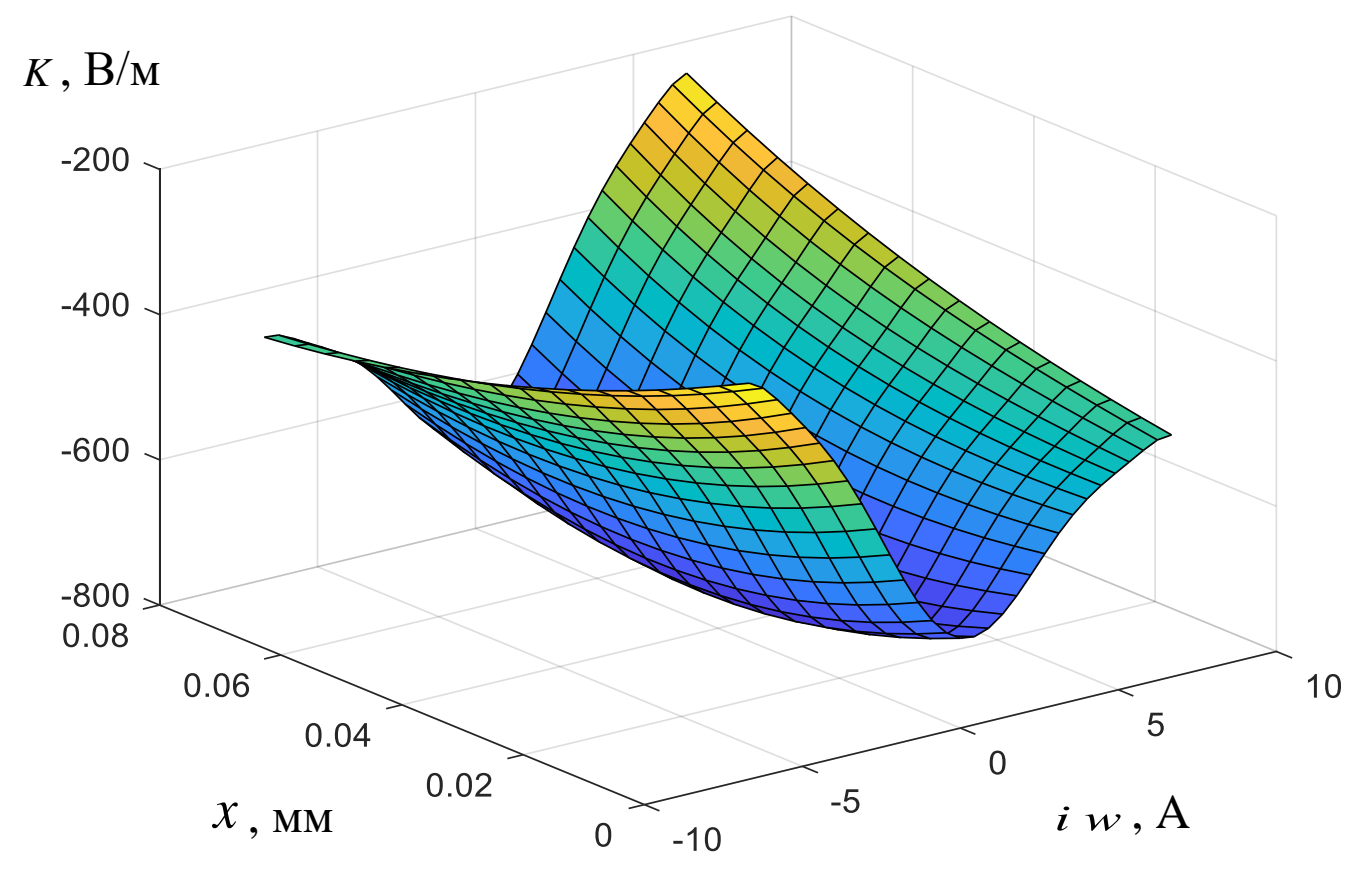

Малюнок 7. Залежність коефіцієнту при протиЕРС від переміщення та струму обмотки

Таким чином, за результатами розрахунку магнітного поля і подальшого регресійного аналізу отримано поліноміальні залежності похідних потокозчеплення по струму i лінійному переміщенню якоря, які дають можливість ідентифікувати узагальнену математичну модель електромеханічного амортизатора.

У роботі проведено аналіз умов роботи та конструкцій ходових частин рейкового транспорту; розроблено методи визначення оптимальних параметрів електромеханічного амортизатора для вагону метрополітену; проведено математичне моделювання електромеханічного амортизатора з урахуванням нестаціонарних процесів. 


\section{SECTION 4. ENERGY AND ENERGY ENGINEERING AND TECHNOLOGIES}

DOI 10.46299/ISG.2021.MONO.TECH.III.4.1

\subsection{Calibration of pulse reflectometric systems for the study of biological objects}

Внедрение импульсной рефлектометрии в практику исследования диэлектрических параметров биологических объектов на сверхвысоких частотах выдвигает на первый план проблемы метрологического обеспечения импульсных рефлектометрических систем.

Для поверки (калибровки) средств измерений во временной области в настоящее время отсутствует нормативная база и методы поверки (калибровки) и аттестации импульсных рефлектометрических систем, в том числе рефлектометров для исследования биологических объектов.

В связи с этим, необходимо разработать методику поверки (калибровки) импульсных рефлектометрических систем для исследования диэлектрической спектроскопии биологических объектов. В процессе работы будем использовать приёмы и методы, которые используются для поверки (калибровки) радиоизмерительных систем с распределенными параметрами в частотной области [220...230].

Эквивалентная схема входной цепи рефлектометра при измерении коэффициента отражения показана на рис. 1. Последовательность операций при определении коэффициента отражения во временной области следующая:

- к плоскости подключения присоединяется короткозамыкатель (КЗ) и регистрируется сигнал $U_{k}(t)$;

- подключается согласованная нагрузка и регистрируется сигнал $U_{H}(t)$;

- подключается исследуемый объект и регистрируется сигнал $U_{0}(t)$;

- коэффициент отражения определяется по формуле:

$$
\Gamma(\omega)=\frac{F\left[U_{o}(t)-U_{H}(t)\right]}{F\left[U_{\kappa}(t)-U_{H}(t)\right]}=\frac{S_{2}(\omega)}{S_{1}(\omega)},
$$


где $F$ - обозначает операцию БПФ;

$S_{1}(\omega)$ - спектр зондирующего сигнала;

$S_{2}(\omega)$ - спектр сигнала, отраженного объектом.

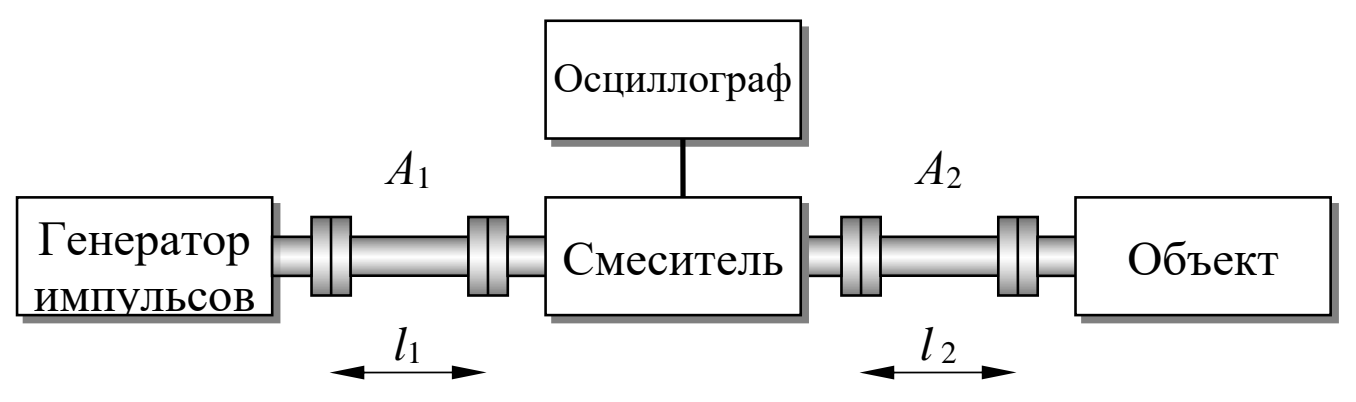

Рисунок 1. Схема подключения при измерении коэффициента отражения

Покажем, что использование данного метода позволяет в пределах временного окна $T_{c}=2 l / C$ исключить влияние несогласованности генератора и смесителя с волноводным трактом на точность измерений.

В соответствии с временной диаграммой (рис. 2) спектр сигнала $U_{k}(\omega)$ в пределах временного окна $T_{0}$ можно представить в виде:

$$
U_{\kappa}(\omega)=U_{H}(\omega)+\Gamma_{\kappa}(\omega) e^{-j \omega 2 l_{2} / C}+\Gamma_{\kappa}(\omega)\left[1+\Gamma_{c}(\omega)\right] \Gamma_{2}(\omega) e^{-j \omega 2\left(l_{2}+h_{1}\right) / C},
$$

где $\Gamma_{\kappa}(\omega), \Gamma_{c}(\omega)$ - коэффициенты отражения КЗ смесителя; $U_{n}(\omega)=F\left[U_{n}(t)\right]-$ колебание, регистрируемое стробоскопическим преобразователем при поглощении всех волн, распространяющихся в сторону объекта. 


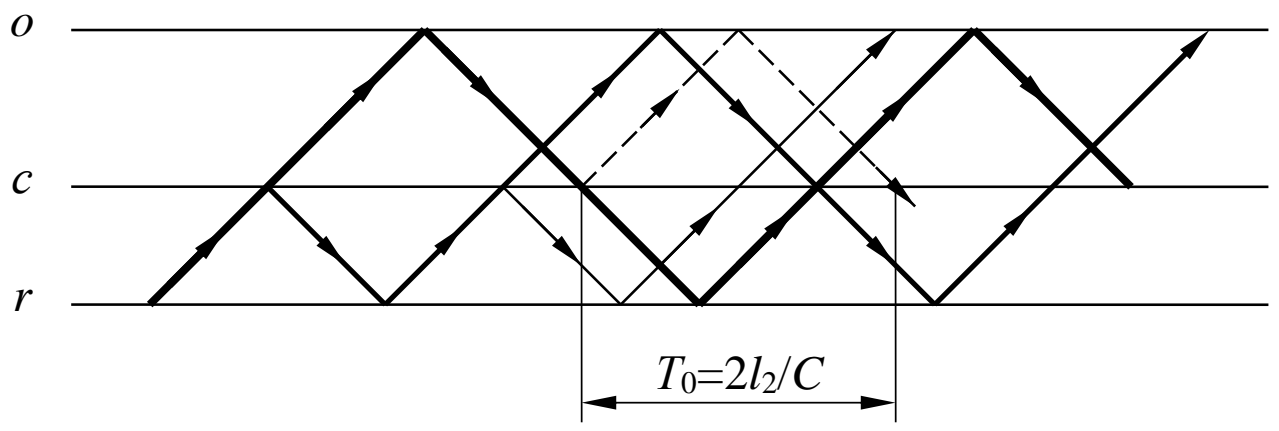

a)

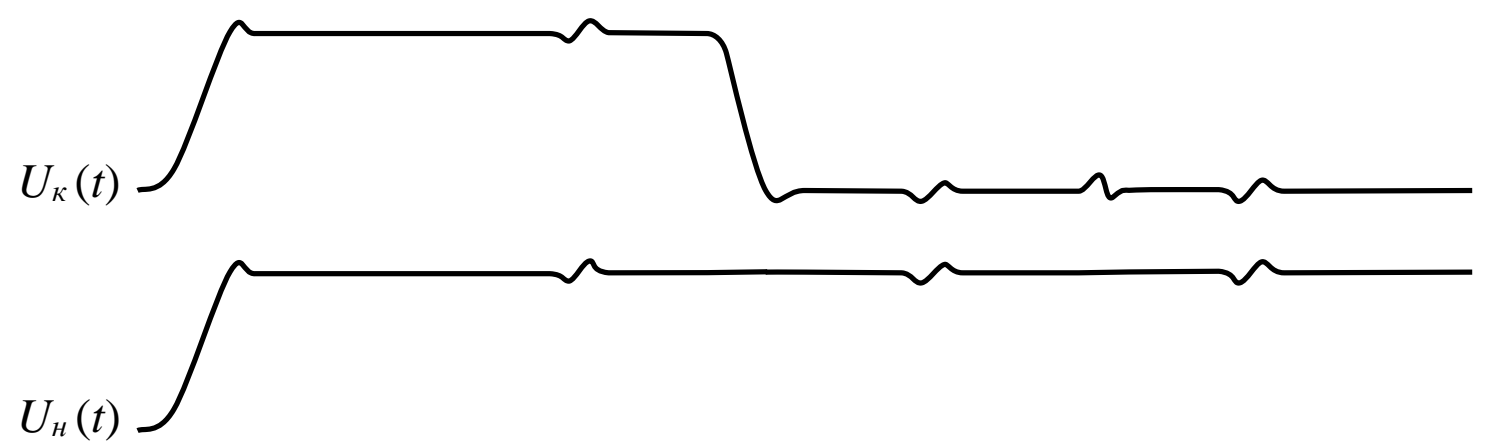

б)

Рисунок 2. Диаграмма распространения сигналов во входной цепи при измерении

Аналогично спектр $U_{0}(\omega)$ можно записать в виде:

$$
U_{0}(\omega)=U_{H}(\omega)+\Gamma_{0}(\omega) e^{-j \omega 2 l_{2} / C}+\Gamma_{0}(\omega)\left[\left(1+\Gamma_{0}(\omega)\right)\right] \Gamma_{2}(\omega) e^{-j \omega 2 l\left(2+l_{1}\right) / C} .
$$

Таким образом, указанная последовательность операций позволяет полностью исключить в пределах временного окна $T_{0}=2 l_{2} / C$ влияние несогласованности генератора и смесителя на точность измерений. Длина линии $Л_{1}$ не имеет принципиального значения.

Заметим, что вместо согласованной нагрузки можно использовать образцовую воздушную линию длиной $l \geq l_{2}$, при этом в пределах временного окна $T_{0}$ не будет наблюдаться сигналов, распространяющихся от смесителя в сторону объекта. Так как качество воздушной линии с подвижным центральным 
проводником может быть достаточно высоким, то вычисление $\Gamma(\omega)$ по формуле (1) позволяет добиться высокой точности измерений.

Временное окно $T_{0}$ определяет нижние границы диапазона измерений (для $\left.l_{2}=15 \mathrm{~cm} T_{0}=1 \mathrm{Hc}\right)$ и частотного диапазона (1 ГГц).

Определение погрешности измерения $\Gamma(\omega)$ осуществляется с использованием меры коэффициента отражения. В качестве меры можно использовать рассогласованную нагрузку в виде коаксиального волновода со скачкообразным изменением диаметра центрального проводника. Если длина волновода $l \geq l_{2}$, то отражение от конца волновода не будет входить во временное окно $T_{0}$. Поэтому нагрузку можно аттестовать по геометрическим размерам. Использование волновода длиной $15 \mathrm{~cm}$ позволяет аттестовать нагрузку в диапазоне частот $1 . .26$ ГГц.

Для проверки точности измерения коэффициента достаточно рассогласованной нагрузки на одно значение коэффициента отражения, если выполняется условие линейности стробоскопического преобразователя:

$$
\delta_{U}=\Delta U / U \leq \delta_{\Gamma}\left(\Gamma=U / U_{j}\right),
$$

где $\delta_{U}$ - относительная погрешность вследствие нелинейности измерения напряжения;

$\delta_{\Gamma}-$ требуемая относительная погрешность измерения коэффициента отражения $\Gamma$ с отраженным сигналом амплитудой $U$.

Поскольку при малых уровнях сигналов стробоскопический преобразователь линеен, то условие линейности достаточно проверить для двухчетырех уровней напряжений в пределах рабочего динамического диапазона преобразователя. 
Погрешность определения коэффициента отражения для значений, отличных от значений используемой меры, можно найти, используя результаты работы [231].

Дисперсия оценки модуля и фазы определяется из выражения [232]:

$$
\begin{gathered}
\sigma_{\Gamma}^{2}(\omega)=\frac{1}{\mid S_{1}(\omega)^{2}} \sigma_{\left|S_{2}\right|}^{2}(\omega)+\frac{\mid S_{2}(\omega)^{2}}{\mid S_{1}(\omega)^{4}} \sigma_{\left|S_{1}\right|}^{2}(\omega), \\
\sigma_{\varphi}^{2}(\omega)=\sigma_{\varphi_{1}}^{2}(\omega)+\sigma_{\varphi_{2}}^{2}(\omega),
\end{gathered}
$$

где дисперсия определения спектров сигналов $S_{i}(\omega),(i=1,2)$ может быть оценена из выражений:

$$
\begin{gathered}
\sigma_{\left|S_{i}\right|}^{2}(\omega)=\frac{N \sigma_{r}^{2}}{2}, i=1,2 ; \\
\sigma_{\left|\varphi_{i}\right|}^{2}(\omega)=\frac{N \sigma_{r}^{2}}{2} \frac{1}{\left|S_{i}(\omega)\right|^{2}}, i=1,2,
\end{gathered}
$$

где $\sigma_{r}^{2}-$ дисперсия шума измерения сигналов $U_{o}(t)-U_{H}(t)$ и $U_{\kappa}(t)-U_{H}(t)$ во временной области; $N$ - число точек ДПФ.

$$
\sigma_{r}^{2}=2 \sigma^{2}
$$

где $\sigma^{2}$ - дисперсия аддитивного шума во временной области. Если измеряется коэффициент отражения $\Gamma$, то:

$$
\left|S_{2}(\omega)\right|=|\Gamma|\left|S_{1}(\omega)\right|
$$

Подставляя соотношения (9) и (10) в формулу (8), получаем:

$$
\Gamma(\omega)=\Gamma_{0}(\omega) / \Gamma_{\kappa}(\omega)
$$


Подставляя выражения (7)...(10) в соотношения (5), (6), получим зависимость дисперсии измерения коэффициента отражения от его величины:

$$
\begin{aligned}
& \sigma_{|\Gamma|}^{2}(\omega)=\gamma_{\Gamma}(\omega)\left(|\Gamma|^{2}+1\right) ; \\
& \sigma_{\varphi}^{2}(\omega)=\gamma_{\Gamma}(\omega)\left(|\Gamma|^{-2}+1\right) ;
\end{aligned}
$$

где

$$
\gamma_{\Gamma}(\omega)=N \sigma^{2} /\left|S_{1}(\omega)\right|^{2}
$$

Параметр $\gamma_{\Gamma}(\omega)$ определяется отношением дисперсии шума в спектральной области, квадрату модуля спектра сигнала $\left|S_{1}(\omega)\right|^{2}$, падающего на исследуемый объект, т.е. определяется уровнем шума и спектром зондирующего сигнала. Он может быть определен из выражения (12) для известного значения коэффициента отражения $|\Gamma|=\Gamma_{0}$ по модулю:

$$
\gamma_{\Gamma}(\omega)=\sigma_{|\Gamma|}^{2}(\omega) /\left(1+\Gamma_{0}^{2}\right)
$$

или по фазе:

$$
\gamma_{\Gamma}(\omega)=\sigma_{\varphi_{o}}^{2}(\omega) /\left(1+\Gamma_{0}^{-2}\right)
$$

Величины $\sigma_{\Gamma}^{2}(\omega)$ и $\sigma_{\varphi_{o}}^{2}(\omega)$ определяются экспериментально с помощью аттестованной меры отражения.

Кроме случайной составляющей при измерении коэффициента отражения возникает и систематическая составляющая погрешности, обусловленная несоответствием волнового сопротивления волновода $J_{2}$ номинальному значению, несовершенством КЗ и согласованной нагрузки. Эта составляющая может быть оценена с помощью меры коэффициента отражения определением среднего отклонения измеренного значения от паспортного. 
При правильном конструировании измерительной системы систематическая составляющая значительно меньше случайной.

Волновое сопротивление.

При измерениях во временной области волновое сопротивление определяется из выражений:

$$
\begin{aligned}
& Z=Z_{0}(1+|\Gamma|) /(1-|\Gamma|), \text { для } Z>Z_{0} ; \\
& Z=Z_{0}(1-|\Gamma|) /(1+|\Gamma|), \text { для } Z<Z_{0} .
\end{aligned}
$$

Если погрешность измерения модуля коэффициента отражения обозначить как $|\Delta \Gamma|$, то погрешность $\Delta Z$ измерения волнового сопротивления определяется на основании выражений (17), (18).

$$
Z+\Delta Z=Z_{0} \frac{1+|\Gamma|+|\Delta \Gamma|}{1-|\Gamma|-|\Delta \Gamma|}=Z_{0} \frac{\frac{1+|\Gamma|}{1-|\Gamma|}+\frac{\Delta \Gamma}{1-|\Gamma|}}{1-|\Delta \Gamma| / 1-|\Gamma|}
$$

Если $|\Delta \Gamma|<<1-|\Gamma| \quad, \quad$ то используя приближенное равенство $1 /(1-x) \approx 1+x(x<<1)$, получаем:

$$
Z+\Delta Z=Z_{0}\left[\frac{1+|\Gamma|}{1-|\Gamma|}+\frac{\Delta \Gamma}{1-|\Gamma|}+\frac{|\Delta \Gamma|(1+|\Gamma|)}{(1-|\Gamma|)(1-|\Gamma|)}\right]
$$

Расчеты по приближенной формуле (20) дают погрешность не более чем $2 \%$, если $|\Delta \Gamma| \leq 0,4$ и $|\Delta \Gamma| / \Gamma \mid<0,1$. Значение $\Gamma=0,4$ обеспечивает диапазон измерения $Z_{0} / 2,33-2,33 Z_{0}$.

Из соотношения (17) следуют выражения для погрешности:

$$
\Delta Z=2|\Delta \Gamma| Z_{0} /(1-|\Gamma|)^{2}
$$

и среднеквадратического значения этой погрешности: 


$$
\sigma_{z}=Z_{0} \frac{2 \sigma_{|\Gamma|}}{(1-|\Gamma|)^{2}},
$$

где $\sigma_{|\Gamma|}-$ среднеквадратическая погрешность определения коэффициента отражения, определяемая из соотношения (12).

Относительная среднеквадратическая погрешность определения волнового сопротивления:

$$
\sigma_{Z}=\frac{\sigma_{Z}}{Z}=\frac{2 \sigma_{|\Gamma|}}{1-|\Gamma|^{2}} .
$$

Коэффициент стоячей волны,_ $K_{c m U}$, определяется выражением:

$$
K_{c m U}=\frac{1+|\Gamma|}{1-|\Gamma|},
$$

поэтому относительная среднеквадратичная погрешность измерения $K_{c m U} \sigma_{K}$, вызванная погрешностью измерения коэффициента отражения $\Gamma$, определяется в соответствии с формулой (23):

$$
\delta_{K}=\frac{\sigma_{K_{c m U}}}{K_{c m U}}=\frac{2 \sigma_{|\Gamma|}}{1-|\Gamma|^{2}} .
$$

Комплексный коэффициент передачи.

Эквивалентная схема входной цепи при измерении коэффициента передачи объекта приведена на рис. 3. Комплексный коэффициент передачи определяется в следующей последовательности:

- линии $Л_{1}$ и $J_{2}$ соединяются и регистрируется сигнал $U_{k}(t)$;

- между линиями $Л_{1}$ и $Л_{2}$ включается исследуемый объект и регистрируется сигнал $U_{0}(t)$; 


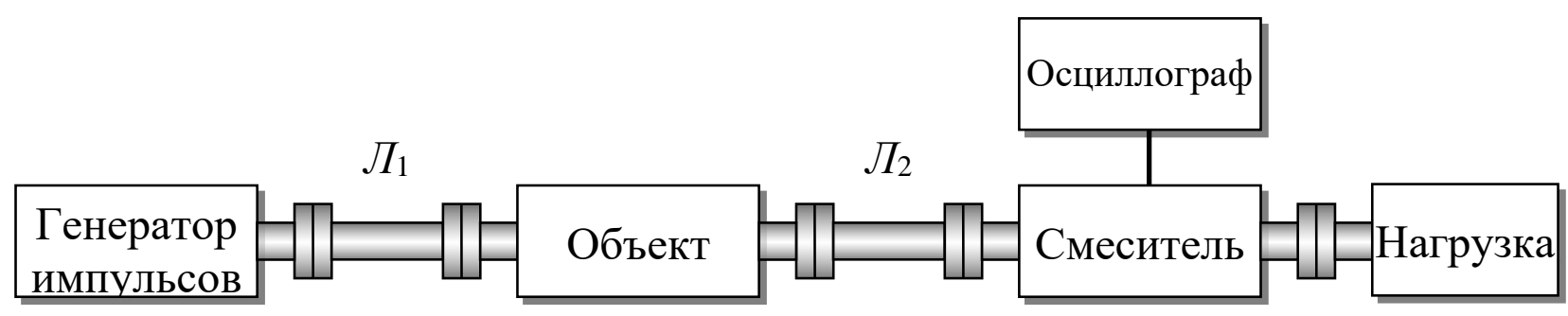

Рисунок 3. Схема подключения при измерении коэффициента передачи

Коэффициент передачи определяется по следующей формуле:

$$
K(\omega)=\frac{F\left[U_{o}(t)\right]}{F\left[U_{K}(t)\right]}=\frac{S_{2}(\omega)}{S_{1}(\omega)} .
$$

Диаграмма распространения сигналов при измерении коэффициента передачи (рис. 4) показывает, что если длина линии $J_{1} l_{1} \geq l_{2}$, то переотражения от выхода генератора и смесителя стробоскопического преобразователя не войдут во временное окно длительностью $T_{0}=2 l_{2} / C$.

Отражения от нагрузки $H$ входят в сигналы $U_{0}(t)$ и $U_{K}(t)$ и при вычислении по (24) компенсируются. При необходимости переотражения от нагрузки могут быть устранены, если в качестве ее использовать воздушную линию длиной $l \geq l_{2}$.

Так как коэффициент передачи определяется на основе выражения (26) отношением спектров двух сигналов, то влияние аддитивных шумов и неравномерности спектра зондирующего сигнала на точность измерения определяется по формулам (12), (13), в которые вместо $\Gamma_{0}(\omega)$ следует подставлять $K(\omega)$. 
Таким образом, при измерении коэффициента передачи отсутствуют систематические искажения сигналов $U_{K}(t)$ и $U_{0}(t)$ вследствие переотражений во входной цепи прибора.

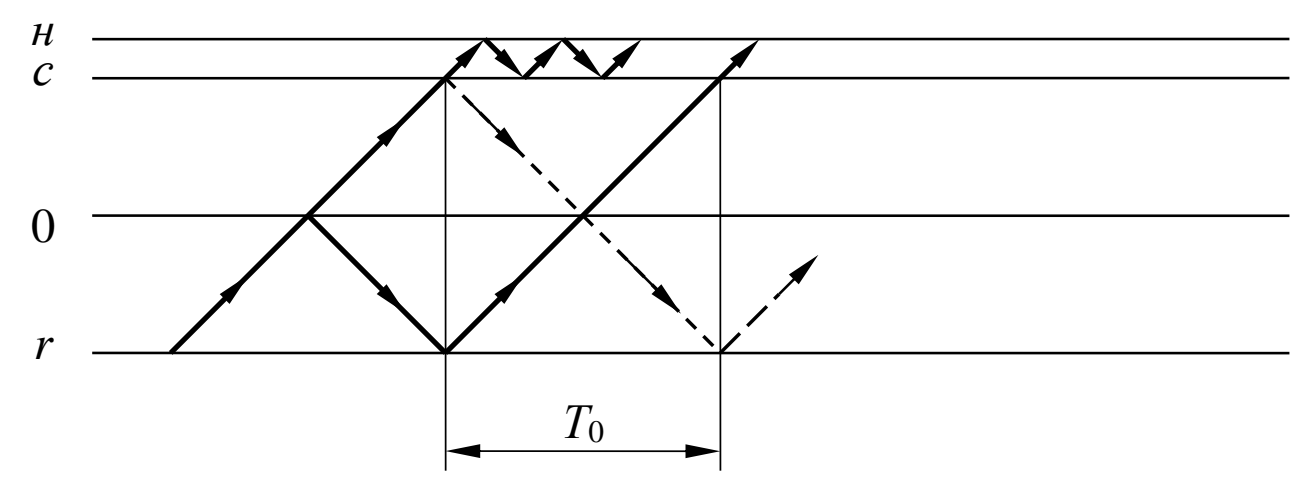

Рисунок 4. Диаграмма распространения сигналов во входной цепи при измерении коэффициента передачи

Поскольку меру отражения можно изготовить с более высокой точностью, чем меру коэффициента передачи, то целесообразно для оценки $\gamma(\omega)$ пользоваться функциями, полученными при измерении коэффициента отражения.

В числителе и знаменателе выражения (24) отсутствует вычитание сигналов, поэтому $\gamma(\omega)=\gamma_{\Gamma}(\omega) / 2$. Тогда среднеквадратическую погрешность измерения коэффициента передачи можно выразить формулами:

$$
\begin{gathered}
\sigma_{|K|}(\omega)=1 / \sqrt{2} \sqrt{\gamma_{\Gamma}(\omega)\left(|K|^{2}+1\right)} ; \\
\sigma_{\varphi_{K}}(\omega)=1 / \sqrt{2} \sqrt{\gamma_{\Gamma}(\omega)\left(|K|^{-2}+1\right)} .
\end{gathered}
$$

Вносимое ослабление измеряется при помощи схемы входной цепи, показанной на рис. 3 .

Последовательность операций измерения вносимого ослабления: 
- линии $Л_{1}$ и $Л_{2}$ соединяются друг с другом, и регистрируется зондирующий сигнал $U_{K}(t)$;

- между линиями $Л_{1}$ и $Л_{2}$ включается исследуемый объект, и регистрируется сигнал $U_{0}(t)$;

- вносимое ослабление определяется по формуле:

$$
A(\omega)=20 \lg \frac{F\left[U_{K}(t)\right]}{U_{o}(t)}=20 \lg \frac{S_{2}(\omega)}{S_{1}(\omega)} .
$$

Из формулы (23) следует выражение для погрешности измерения ослабления $\triangle A$ :

$$
\Delta A=20 \lg (1+\Delta K(\omega) / K)
$$

где $\Delta K(\omega)$ - погрешность измерения отношения $\left|S_{2}(\omega)\right| /\left|S_{1}(\omega)\right|$ :

$$
K=10^{-A / 20}
$$

где $A$ - измеряемое значение ослабления.

Если $\Delta K(\omega) / K<<1$, то используя приближенную формулу:

$$
\lg (1+x) \approx 0,434 x \quad(x<<1)
$$

получаем $\Delta A \approx 8,68 \Delta K(\omega) / K$.

При $\Delta K(\omega) / K \leq 0,1$, относительная погрешность вычисления ослабления не превышает $5 \%$.

Из последнего соотношения следует выражение для среднеквадратического значения погрешности измерения ослабления:

$$
\sigma_{A}=8,68 \frac{\sigma_{K}}{K} .
$$

Дисперсия измерения $K(\omega) \sigma_{K}^{2}(\omega)$ может быть получена по формуле 23: 


$$
\sigma_{K}(\omega)=\sqrt{\gamma_{K}(\omega)\left(K^{2}+1\right)} .
$$

Спектр $S_{1}(\omega)$ соответствует в данном случае сигналу, прошедшему объект. Поэтому для выражения $\gamma_{K}(\omega)$ через $\gamma_{\Gamma}(\omega)$ следует подставить $S_{1}(\omega)$, выраженное через спектр зондирующего сигнала $S_{2}(\omega)$.

$$
S_{1}(\omega)=S_{2}(\omega) / K
$$

Использование этого соотношения дает:

$$
\gamma_{K}(\omega)=K^{2} \frac{\Delta \sigma^{2}}{2\left|Y_{2}(\omega)\right|^{2}}=\frac{K^{2}}{2} \gamma_{\Gamma}(\omega)
$$

Подставляя уравнения (25) и (26) в соотношение (24), получаем:

$$
\sigma_{A}=6,14 \sqrt{\gamma_{\Gamma}(\omega)\left(10^{A / 10}+1\right)} .
$$

Изложенное выше, позволяет сформулировать следующую методику определения погрешности измерения коэффициента передачи, волнового сопротивления, $K_{c m U}$, ослабления:

1. К входу рефлектометра подключается рассогласованная нагрузка, аттестованная по геометрическим размерам.

2. Определяется дисперсия измерения модуля коэффициента отражения при подключении рассогласованной нагрузки.

3. По формуле (13) определяется значение $\gamma_{\Gamma}(\omega)$ на граничных и центральной частотах диапазона измерений.

4. По формулам (9) и (10) определяется дисперсия модуля коэффициента отражения и фазы, на центральном и граничных значениях диапазона измерений по коэффициенту отражения.

5. Рассчитывается среднеквадратическое значение погрешностей измерения модуля и фазы коэффициента отражения. 
6. По формуле (20) определяется погрешность измерения волнового сопротивления на граничных и центральном значениях диапазона измерений волнового сопротивления.

7. По формуле (22) определяется погрешность измерения $K_{c m U}$ на граничных и центральном значениях диапазона.

8. По формулам (25), (26) определяется погрешность измерения модуля и фазы коэффициента передачи на граничных и центральном значениях диапазона измерений модуля коэффициента передачи.

9. По формуле (26) определяется погрешность измерения ослабления на граничных и центральной частотах диапазона измерения ослабления.

Так как метод определения параметров рассеяния $S_{11}$ и $S_{22}$ при измерениях во временной области не отличается от метода измерения коэффициента отражения, то погрешность их определения будет соответствовать погрешности определения коэффициента отражения и рассчитываться по формулам (9) и (10).

Аналогично - погрешность определения $S_{21}$ и $S_{12}$ соответствует погрешности определения коэффициента передачи и рассчитывается по формулам (26) и (18).

Таким образом, для определения погрешностей измерений различных характеристик импульсных рефлектометрических систем для исследования диэлектрических характеристик биологических объектов можно использовать образцовые коаксиальные волноводы со скачкообразным изменением диаметра центрального проводника, аттестованные по геометрическим размерам. 


\title{
4.2 Numerical and experimental study of preparation processes of liquid grain
} feed

\begin{abstract}
Numerical and experimental study of heat and mass transfer processes in rotarypulsation apparatus for the preparation of liquid grain feed has been carried out. The basic hydraulic and thermal characteristics of such devices are received and geometrical characteristics of such device are defined. An experimental sample of a device with rectangular holes in rotor-stator system was developed and manufactured. Experimental studies of such characteristics as granulometric composition of grain feed mixture, power consumption in feed production and temperature change of water-grain mixture during its processing have been carried out.
\end{abstract}

\section{Introduction}

Existing devices for the production of feed for livestock in the vast majority are based on the use of technologies for the preparation of solid feed mixtures. The basis of such technologies is the use of hammer rotors, the rotation of which is the grinding of grain or other solid components of the feed. At contact of a surface of a hammer with grain owing to shock loadings there is its cracking and formation of the mix having the different size of fractions. The design of the hammer rotors can be different, for example, in the form of cylindrical rollers or disks. The size and geometry of the surface of the hammers are selected depending on the size of the fractions of the feed mixture to be obtained at the outlet of the hammer crusher. Crusher designs with airflow can be used to improve the operation of the crushers. The main purpose in the process of preparation is to obtain a feed mixture in which the size of the feed particles are optimal for assimilation during feeding of cattle with minimal energy costs per unit of feed mass.

In [233-240], studies were conducted to develop new designs of hammer crushers, which have advantages in terms of optimal grain grinding, reduction of energy consumption per unit of output and reducing the share of dust fractions in the 
feed mixture. In the monograph [233] various types of crushers, their designs are considered, theoretical and experimental data on preparation of firm forage mixes are resulted. In [234], a two-stage crusher was developed, which improves the throughput and particle size distribution of the produced feed. The influence of air flows on improving the efficiency of hammer crushers was studied in [235, 236]. Of great importance in the operation of crushers is the amount of specific energy consumption spent on the preparation of feed. These issues were studied in the authors of [237, 238], where the optimal designs and modes of operation of two-stage and three-stage roller crushers are proposed. The amount of energy consumption required to prepare a unit mass of feed products when grinding different types of products in a hammer crusher was studied in [239]. The study of the specific energy consumption and fractional composition of grain feed in the disk crusher is devoted to [240].

Known designs of hammer, roller and disc crushers, which are the most common devices for preparing feed, can have a number of disadvantages: large volume and weight; significant specific energy consumption for the preparation of feed products; unbalanced granular composition of feed products (the presence of small fractions that are poorly digested by cattle); dry feed is inferior to liquid feed in its nutritional properties and digestibility for pigs, young cattle, sheep, goats and other animals. In this regard, it is of interest to develop new designs of devices for the preparation of liquid feed mixtures, the principle of which is based on the use of other technologies with lower energy consumption to produce a unit mass of feed product. From this point of view, technologies in which rotary-pulsation mechanisms of product processing are used are promising. Such technologies are used in the processes of preparation of food, pastes, medicines and other products for various purposes.

The main designs of rotary-pulsation devices and the processes that take place in them are considered in the monograph [241]. In [242], hydrodynamics and heat exchange in rotating-pulsating flows, which take place in rotary-pulsating devices, were studied. A number of works are devoted to the use of rotor-pulsation technologies in specific technological processes. In [243] such technologies were used in the processes of grinding and dissolving polydisperse materials, which were studied 
experimentally and by numerical simulation methods. In [244] a new design of a rotorpulsation apparatus with holes of a special shape was proposed and the formation of various emulsions in this apparatus was investigated. The study of the mechanisms that occur in the rotor-pulsation apparatus in the processing of heterogeneous materials was carried out in [245]. In [246] rotor-pulsation principles were used for preparation of liquid feed mixtures on a grain basis. In [246] the results of researches of hydraulic characteristics of the rotor-pulsation device at processing of a grain mix with water are resulted. The processes that take place in rotary-pulsation apparatus for the preparation of liquid grain feed are insufficiently studied, and the design of such devices requires further improvement.

\subsubsection{Numerical modeling of rotor-pulsation apparatus with rectangular holes (3D model).}

The following section presents the results of numerical simulations in the working chamber of RPA with rectangular holes using a 3D model. In Fig. 1 schematically shows a rotary pulsation apparatus (RPA) for feed preparation. The boot device is made in SOLID WORKS, then loaded into ANSYS Design Modeler. The Fill component is selected to simulate the mixture. Boundary conditions were set and the project was transferred to ANSYS Meshing.

Fig. 2 shows the boundary conditions of RPA. At the inlet limit of the inlet, a mixture with a mass flow rate of $0.92 \mathrm{~kg} / \mathrm{s}$ with a temperature of $+20^{\circ} \mathrm{C}$ is loaded. The output limit of the outlet is set by pressure (pressure outlet). RPA case is made of aluminum. The temperature $+20^{\circ} \mathrm{C}$ is set on the surface of the metal case. The volume of RPA stator is $2.181 \cdot 10^{-3} \mathrm{~m}^{3}$ (Fig. 1). 


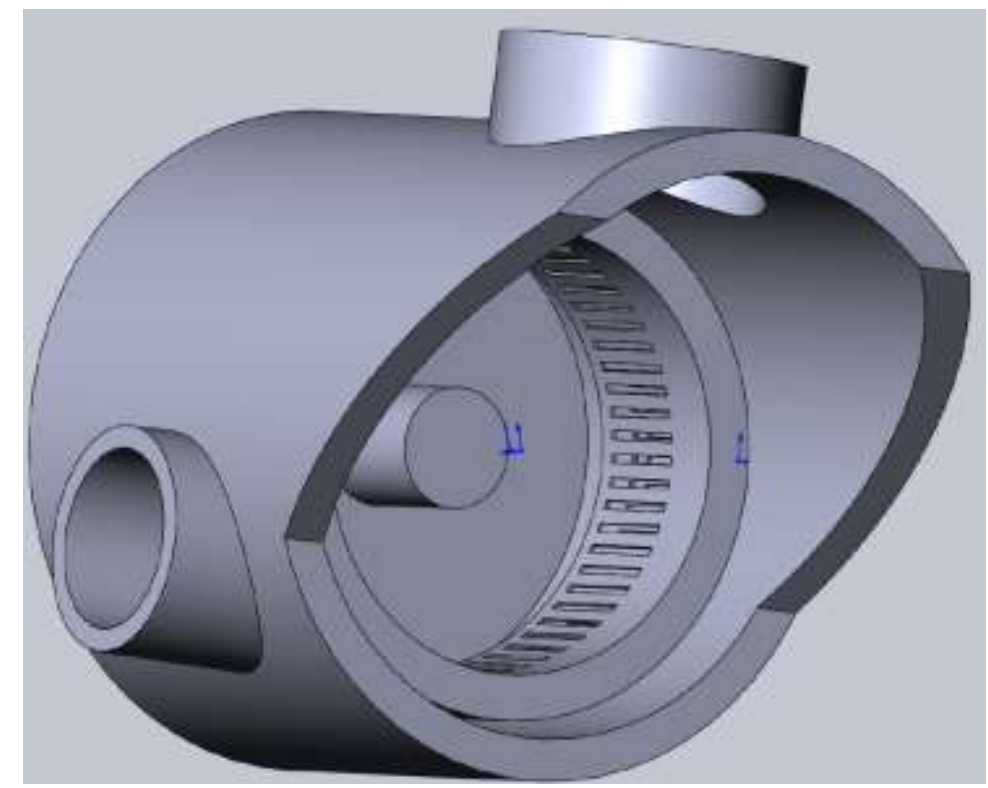

Figure 1. General view of the rotor-stator system in RPA

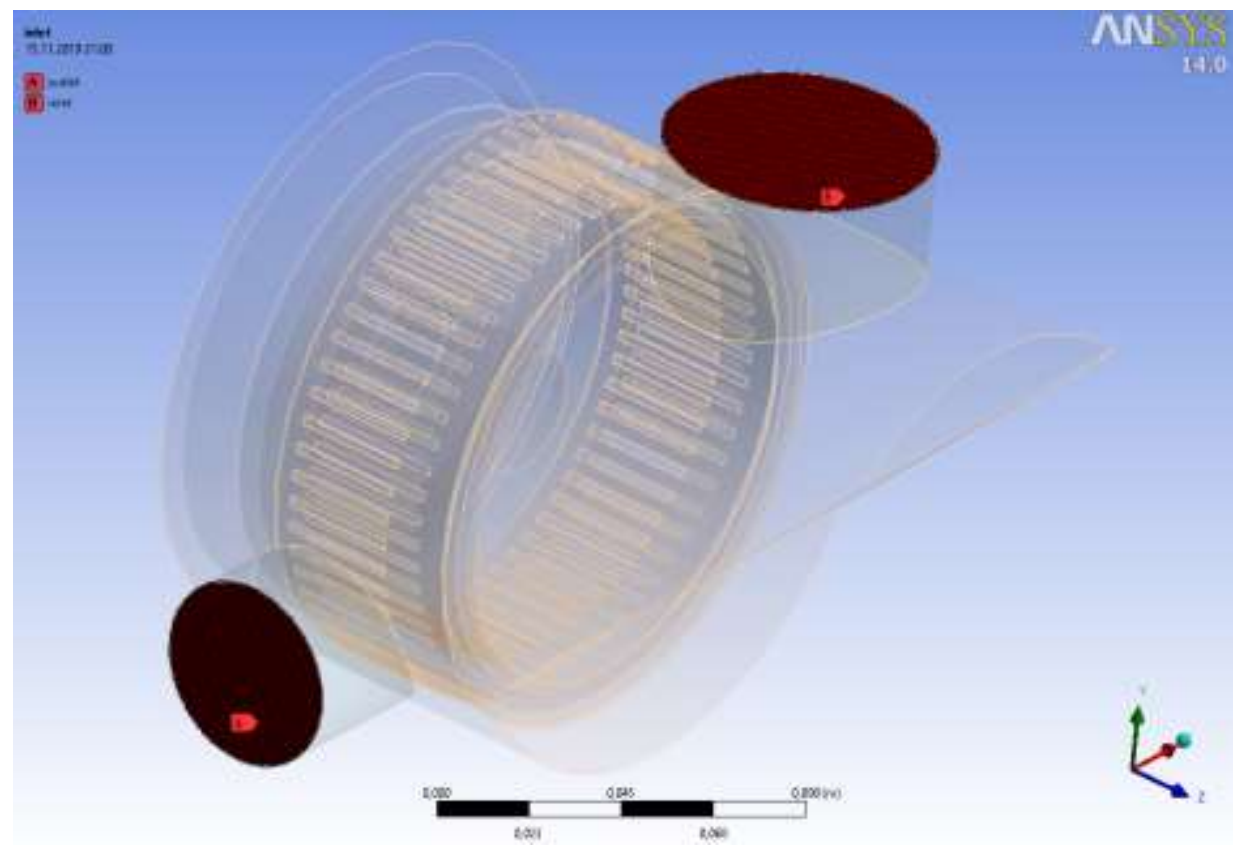

Figure 2. Boundary conditions in RPA channels

The volume of RPA rotor is $3,798 \cdot 10^{-4} \mathrm{~m}^{3}$. The rotor, on the $\mathrm{z}$ axis, rotates at a speed of $3000 \mathrm{rpm}$. Numerical simulations were performed three times with a constant dynamic viscosity 0.2 ; 1.1 and $2.1 \mathrm{~Pa}$.

For numerical modeling, a mixture of water and grain in the ratio $10 \times 1$ was introduced. Thermophysical properties of water, which varies with temperature, are 
taken from the relevant tables. Thermophysical properties of grain are considered independent of temperature and equal to:

- Density 770 kg/m³;

- The thermal conductivity coefficient $0.11 \mathrm{~W} /\left(\mathrm{m}^{0} \mathrm{C}\right)$;

- Heat capacity $1550 \mathrm{~kJ} /\left(\mathrm{kg}^{0} \mathrm{C}\right)$

The mixture of water/grain $(\mathrm{Y})$, for all required thermophysical quantities, is calculated by the following formula:

$$
Y=\frac{10 \cdot x_{1}+1 \cdot x_{2}}{x_{1}+x_{2}}
$$

where $x$ is the thermophysical quantity, index 1 is the value of water, 2 is the value of grain. The thermophysical properties of the liquid grain mixture depend on the temperature.

Thermophysical properties of the feed mixture are presented in Table 1.

Table 1

Thermophysical properties of the mixture

\begin{tabular}{|c|c|c|c|}
\hline $\begin{array}{c}\text { Temperature, } \\
{ }^{\circ} \mathrm{C}\end{array}$ & Density, $\mathrm{kg} / \mathrm{m}^{3}$ & $\begin{array}{c}\text { Heat capacity, } \\
\mathrm{kJ} /\left(\mathrm{kg} \cdot{ }^{\circ} \mathrm{C}\right)\end{array}$ & $\begin{array}{c}\text { Thermal conductivity } \\
\text { coefficient } \\
\mathrm{W} /\left(\mathrm{m} \cdot{ }^{\circ} \mathrm{C}\right)\end{array}$ \\
\hline 20 & 977.5364 & 3933.63636 & 0.55454545 \\
\hline 30 & 975.1909 & 3939.09091 & 0.57181818 \\
\hline 40 & 972.0455 & 3940.0 & 0.58727273 \\
\hline 50 & 968.2 & 3941.81818 & 0.59909091 \\
\hline 60 & 963.7545 & 3945,45455 & 0.60909091 \\
\hline 70 & 958.7545 & 3950.0 & 0.61727273 \\
\hline 80 & 953.2727 & 3955.45455 & 0.62272727 \\
\hline 90 & 947.3273 & 3963.63636 & 0.62636364 \\
\hline
\end{tabular}

\subsubsection{Using the finite element method to build a 3D mesh in ANSYS Meshing}

The finite element method (FEM) is used to numerically calculate the problems of hydrodynamics and heat transfer. In English literature it is called Finite Elements 
Method (FEM). The essence of the method is an approximate solution of the variational problem. To formulate this problem, we use the concept of functionality. The operator I $[\mathrm{f}(\mathrm{x})$ ] is called a functional that is given on some set of functions, if for each function $f(x)$ a certain numerical value of I [ $f(x)$ ] is matched [248]. In other words, a functional that is a "function from a function." Often functionals have the form of integrals. The variational problem is to find a function $\mathrm{f}(\mathrm{x})$ that corresponds to the minimum value of the functional I [ $\mathrm{f}(\mathrm{x})]$. The appearance of this functionality is different for different tasks and is selected by special choice.

Currently, FEM has found wide application in solving problems of thermal conductivity in solids and in the calculation of materials for strength. In addition, this method is used to calculate the flow of liquids and gases [247]. There are also methods that combine elements of the finite volume method and the finite element method $[249,250]$. The combination of these methods allows the use of a wider range of computational grids (tetragonal grids, pyramidal, prismatic, polyhedral), which is necessary when solving problems with complex geometry. This approach is used by CFD packages Ansys CFX, Ansys Fluent, Star-CD, Star-CCM +, Comsol and others.

The ANSYS package has many applications for almost all fields of modern science and technology, including agriculture. It should be borne in mind that different physical tasks require different approaches to modeling and creating a calculation grid. Consider some features of the construction of the grid for problems of hydrodynamics, heat and mass transfer - its creation in ANSYS Meshing, in particular 2D. ANSYS Meshing is well adapted to create a grid for CFD applications ANSYS - CFX or FLUENT, but keep in mind that the general logic of building a grid can be transferred to other programs, including programs that are not used in ANSYS.

The grid was built in the ANSYS Meshing grid generator on the Workbench platform. In ANSYS Meshing Application there are the following breakdown methods for 3D geometry:

- Automatic;

- Methods of constructing a tetrahedron grid (Tetrahedrons):

- on the basis of a surface grid (Patch Conforming); 
- independent of surfaces (Patch Independent);

- CFX-Mesh;

- Methods of constructing a hexahedral grid:

- broach (Sweep);

- broach for shell bodies (Thin sweep);

- Multi Zone;

- multi-zone (based on ICEM CFD block grid);

- with a predominance of hexahedrons (Hex Dominant).

Software packages use several basic types of grid for 3D: tetrahedral, Cartesian and hexahedral. The tetrahedral grid allows to create the cells close in the form to borders of settlement area and to zones with big gradients of speeds and temperatures that allows to model boundary layers. At the same time, creating a tetrahedral grid is a very time consuming process. Cartesian grid allows only rectangular cells to be created, which can worsen the solutions of the boundary layer equations, but Cartesian grid is easier to create. There are a number of ways to solve the transfer equation in the region of boundary layers in the presence of high gradients of flow parameters.

The hexahedral grid, to solve the problem with the same accuracy, will contain more than 2 times fewer nodes, compared to the tetrahedral grid. Therefore, its application requires fewer elements to solve the problem of CFD.

Anisotropic elements can be combined with anisotropic geometry (boundary layers, areas with large curvature and long finite elements). For arbitrary configurations, the hexahedral grid requires a lot of preparatory operations, but this leads to a better result. For many simpler broach configurations, grids can be created more easily and quickly using sweep and multi-zone construction.

In the table 3.4 shows the settings and mesh results in ANSYS Meshing for further transfer of the calculation of heat and mass transfer and hydrodynamics in ANSYS Fluent. Geometry is built in real size. The number of elements and faces is quite large (Table 2). Due to the large size of the RPA, the size of the element and the face is not increased much due to limited production and design power of the computer. 
In Fig. 3-5 shows the constructed RPA mesh. The maximum mesh size for the entire volume does not exceed $1 \cdot 10^{-3} \mathrm{~m}$. These measures are used to improve the calculation of hydrodynamics. In the section YZ and YX (Fig. 4) the thickening of the mesh in the grooves of the rotor and stator is clearly visible.

Table 2

Mesh construction parameters for RPA

\begin{tabular}{|c|c|}
\hline Parameter & Value \\
\hline Mesh quality indicator (orthogonal quality) & 0.161 \\
\hline Number of elements, pcs & 4485359 \\
\hline Number of nodes, pcs & 4791394 \\
\hline Curvature angle, city & 45 \\
\hline Method & Cut-Cell \\
\hline Maximum size, $\mathrm{m}$ & $1 \cdot 10^{-3}$ \\
\hline Minimum size, $\mathrm{m}$ & $5 \cdot 10^{-4}$ \\
\hline
\end{tabular}

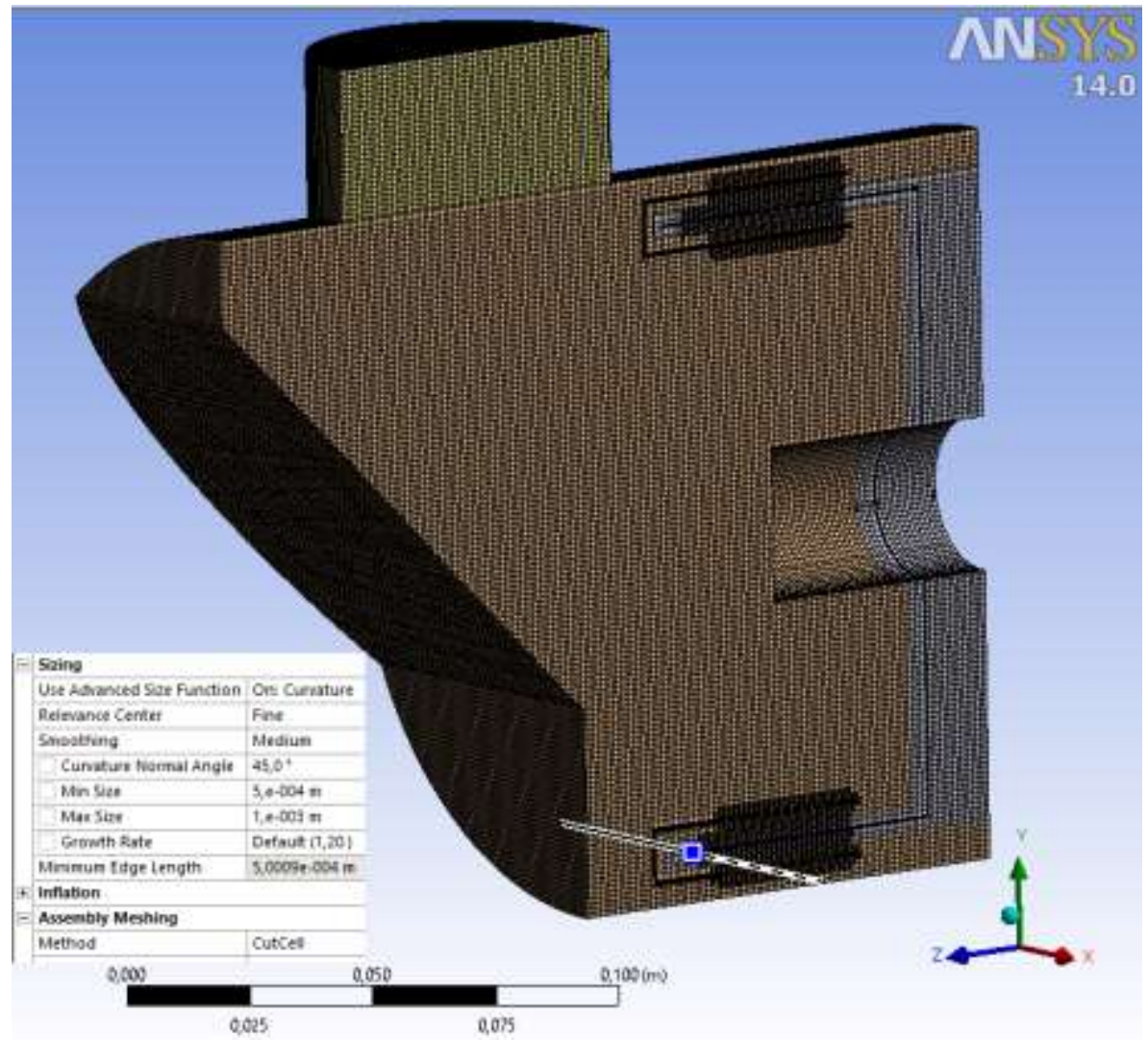

Figure 3. The result of the constructed mesh in the longitudinal section YZ 


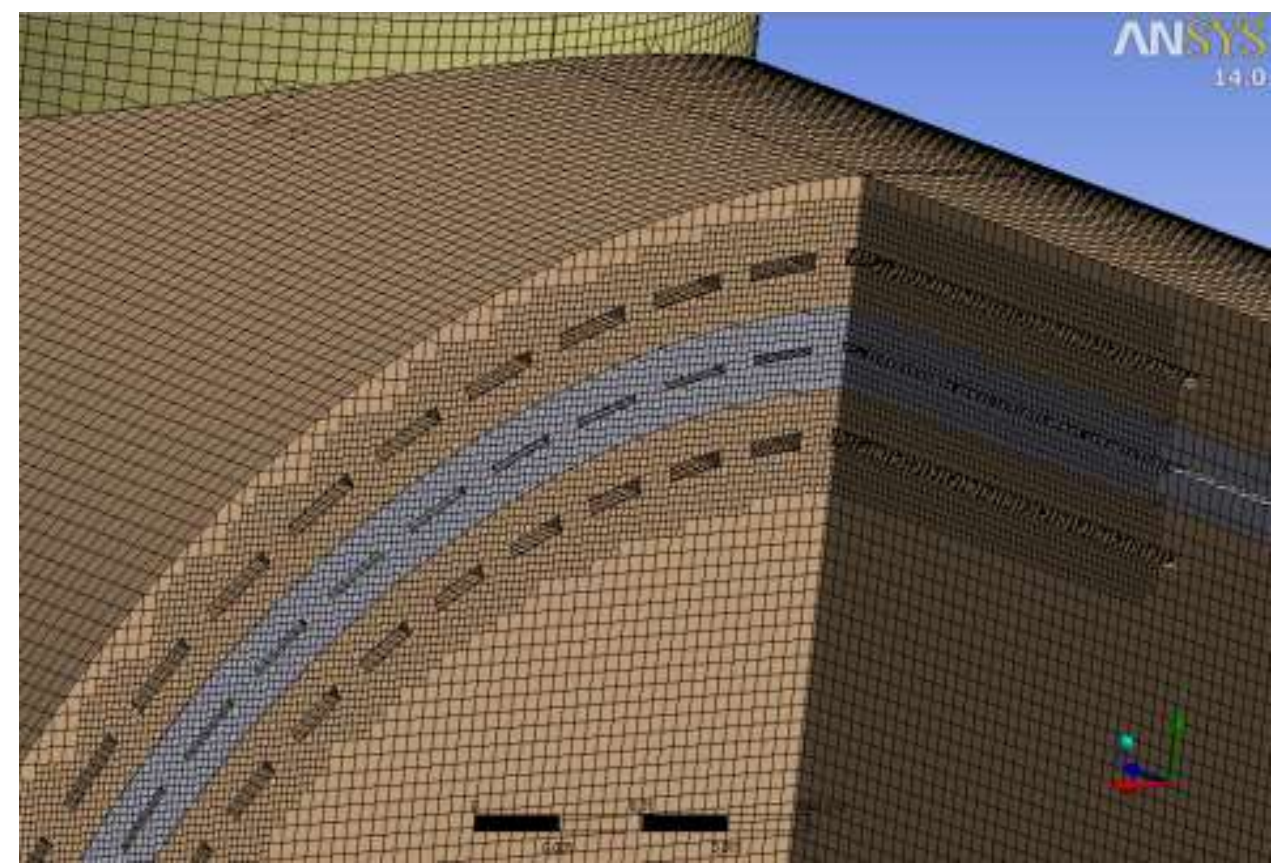

Figure 4. The result of the constructed mesh in the section of YZ and YX

The size of the thickening of the mesh near the grooves is $5 \cdot 10^{-4} \mathrm{~m}$ (Fig. 5). Thanks to which you can better assess the quality and shortcomings of the grid itself. The number of mesh elements is about 4.5 million. The quality of the mesh in orthogonal quality is 0.161 . Detailed results are given in Table 2 .

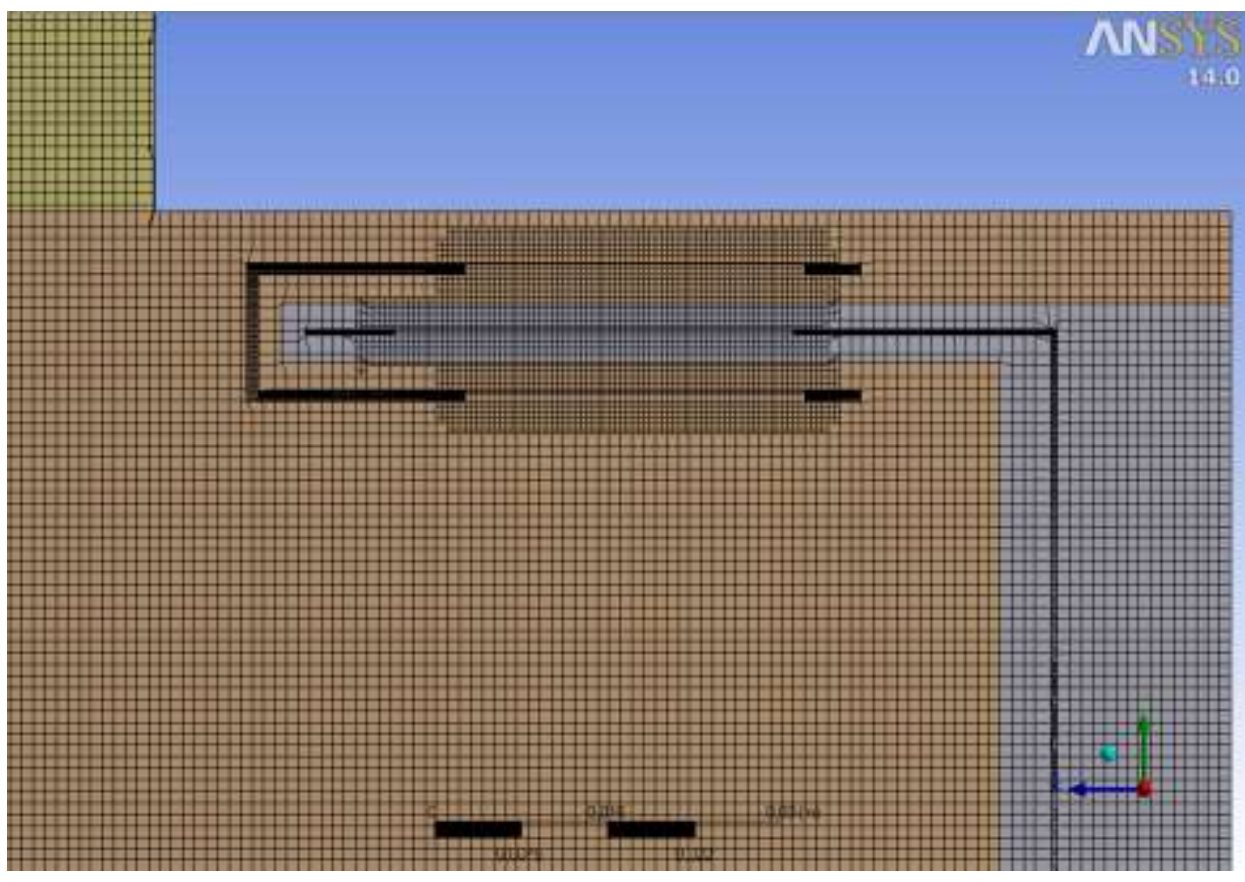

Figure 5. The result of the constructed mesh between the grooves in the longitudinal section YZ 
Using the finite element method, a 3D calculation grid in ANSYS Meshing software package for solving hydrodynamics and heat transfer problems in RPA was constructed. As a result of building various grids for CFD models, the most optimal and high-quality one was chosen, which allows to obtain reliable and most accurate results of heat and mass transfer processes in RPA.

\subsubsection{Mathematical modeling of heat and mass transfer processes in RPA}

The motion of a viscous liquid or gas is described by a system of equations, which includes the equation of continuity and the equation of conservation of momentum in projections on the coordinate axis. If the motion of the medium is accompanied by heat transfer, the equation of energy conservation is added to the system of these equations.

The mathematical model is based on the Navier-Stokes equation [251] and the energy transfer equation for convective flows. The standard k- $\varepsilon$ turbulence model was used in the calculations [252]. The initial equations are given below.

Navier-Stokes equations:

$$
\left.\begin{array}{l}
\rho\left(\frac{\partial u}{\partial t}+u \frac{\partial u}{\partial x}+v \frac{\partial u}{\partial y}+w \frac{\partial u}{\partial z}\right)=\rho g_{x}-\frac{\partial p}{\partial x}+\mu\left(\frac{\partial^{2} u}{\partial x^{2}}+\frac{\partial^{2} u}{\partial y^{2}}+\frac{\partial^{2} u}{\partial z^{2}}\right), \\
\rho\left(\frac{\partial v}{\partial t}+u \frac{\partial v}{\partial x}+v \frac{\partial v}{\partial y}+w \frac{\partial v}{\partial z}\right)=\rho g_{y}-\frac{\partial p}{\partial y}+\mu\left(\frac{\partial^{2} v}{\partial x^{2}}+\frac{\partial^{2} v}{\partial y^{2}}+\frac{\partial^{2} v}{\partial z^{2}}\right), \\
\rho\left(\frac{\partial w}{\partial t}+u \frac{\partial w}{\partial x}+v \frac{\partial w}{\partial y}+w \frac{\partial w}{\partial z}\right)=\rho g_{z}-\frac{\partial p}{\partial z}+\mu\left(\frac{\partial^{2} w}{\partial x^{2}}+\frac{\partial^{2} w}{\partial y^{2}}+\frac{\partial^{2} w}{\partial z^{2}}\right),
\end{array}\right\}
$$

where $\rho$ is the density of the medium, $\mathrm{kg} / \mathrm{m}^{3} ; \mu$ - dynamic viscosity of the medium, $\mathrm{Pa}$ - s; p - pressure, Pa; u, v, w, - vector field of velocities, m/s; t - time, s.

Continuity equation:

$$
\frac{\partial \rho}{\partial \tau}+\frac{\partial(u \rho)}{\partial x}+\frac{\partial(v \rho)}{\partial y}+\frac{\partial(w \rho)}{\partial z}=0,
$$

Energy conservation equation:

$$
\rho C_{p}\left(\frac{\partial T}{\partial \tau}+u \frac{\partial T}{\partial x}+v \frac{\partial T}{\partial y}+w \frac{\partial T}{\partial z}\right)=\frac{\partial}{\partial x}\left(\lambda \frac{\partial T}{\partial x}\right)+\frac{\partial}{\partial y}\left(\lambda \frac{\partial T}{\partial y}\right)+\frac{\partial}{\partial z}\left(\lambda \frac{\partial T}{\partial z}\right)+Q(\tau, x, y, z) .
$$


where $\mathrm{T}$ is the temperature at some point, $\mathrm{K} ; \lambda$ is the thermal conductivity of the medium, $\mathrm{Wt} / \mathrm{m} \bullet \mathrm{K} ; \mathrm{C}_{\mathrm{p}}$ - specific heat of the medium, $\mathrm{J} / \mathrm{kg} \bullet \mathrm{K}$.

\section{Turbulence model}

For the flow of coolants in the channels it is necessary to choose a model of turbulence that corresponds to the conditions of hydrodynamic flow in these channels. One of the most common is the standard $\mathrm{k}-\varepsilon$ model used in ANSYS FLUENT software package, used in practical engineering calculations of flows in channels and was proposed by Launder and Spalding [252]. The reliability, economy and accuracy of this model for a wide range of turbulent flows explains its wide application for modeling heat transfer in channels of different configurations.

The standard k- $\varepsilon$ [252] model is based on the model of the turbulence transfer equation of kinetic energy $(\mathrm{k})$ and its dissipation rate $(\varepsilon)$. The equation of the transport model for $\mathrm{k}$ is from the exact equation, and the equation of the transport model for $\varepsilon$ is obtained for physical reasons.

In deriving the $\mathrm{k}-\varepsilon$ model, the flow is assumed to be completely turbulent and the effects of molecular viscosity are negligible, ie the standard k- $\varepsilon$ model is used for fully turbulent flows.

Subsequently, the standard k- $\varepsilon$ model was improved, which increased its efficiency. There are two improved versions of this model, which are available in the software package ANSYS FLUENT, namely, RNG k- $\varepsilon$ model [254] and implemented (realizable) k- $\varepsilon$ model [253].

The transfer equation of the standard $k-\varepsilon$ model.

The kinetic energy of turbulence $\mathrm{k}$ and its dissipation rate $\varepsilon$ is found from the solution of the following transport equations [255-257]:

$$
\begin{gathered}
\frac{\partial}{\partial t}(\rho k)+\frac{\partial}{\partial x_{i}}\left(\rho k u_{i}\right)=\frac{\partial}{\partial x_{j}}\left[\left(\mu+\frac{\mu_{t}}{\sigma_{k}}\right) \frac{\partial k}{\partial x_{j}}\right]+G_{k}+G_{b}-\rho \varepsilon-Y_{M}+S_{k} \\
\frac{\partial}{\partial t}(\rho \varepsilon)+\frac{\partial}{\partial x_{i}}\left(\rho \varepsilon u_{i}\right)=\frac{\partial}{\partial x_{j}}\left[\left(\mu+\frac{\mu_{t}}{\sigma_{\varepsilon}}\right) \frac{\partial \varepsilon}{\partial x_{j}}\right]+G_{1 \varepsilon} \frac{\varepsilon}{k}\left(G_{k}+G_{3 \varepsilon} G_{b}\right)-C_{2 \varepsilon} \rho \frac{\varepsilon^{2}}{k}+S_{\varepsilon}
\end{gathered}
$$


where, $G_{k}$ is the generation of kinetic energy turbulence due to velocity gradients (see equation (12)); $\mathrm{G}_{\mathrm{b}}$ is the generation of kinetic energy turbulence (see equation (15)); $\mathrm{Y}_{\mathrm{M}}$ is the contribution to the expansion of the compressibility fluctuations of turbulent flows in the total dissipation rate (see equation (18)); $\mathrm{C}_{1 \mathrm{e}}, \mathrm{C}_{2 \mathrm{e}}$ and $\mathrm{C}_{3 \mathrm{e}}$ - are constants; $\sigma \mathrm{k}$ and $\sigma \mathrm{e}$ are Prandtl turbulent numbers for $\mathrm{k}$ and $\varepsilon$, respectively. The values of $S_{\mathrm{k}}, \mathrm{S}_{\mathrm{e}}$ - are defined as the characteristics of the kinetics of kinetic energy and the dissipation of this energy:

$$
\begin{gathered}
S_{k}=\tau_{i j} \frac{\partial u_{i}}{\partial x_{j}}-\rho \varepsilon-\mu_{t}\left(\frac{g_{i} \partial \rho}{\sigma_{B} \rho \partial x_{i}}\right) \\
S_{\varepsilon}=C_{\varepsilon 1} \frac{\varepsilon}{k}\left(f_{1} \tau_{i j} \frac{\partial u_{i}}{\partial x_{j}}+\mu_{t} C_{B}\left(\frac{g_{i} \partial \rho}{\sigma_{B} \rho \partial x_{i}}\right)\right)-C_{\varepsilon 2} f_{2} \frac{\rho \varepsilon^{2}}{k}
\end{gathered}
$$

where $\mathrm{C}_{\varepsilon 1}=1.44, \mathrm{C}_{\varepsilon 2}=1.92, \sigma_{\varepsilon}=1.3, \sigma_{\mathrm{k}}=1$ - empirical coefficients [257]; $\mathrm{f}_{1}, \mathrm{f}_{2}$ variables that depend on the coefficients of dynamic and turbulent viscosity and are determined by the following formulas:

$$
f_{1}=1+\left(\frac{0,05}{f_{\mu}}\right)^{3}, \quad f_{2}=1-e^{-R_{T}^{2}} .
$$

The values of constants and parameters in this model were determined from experiments for fundamental turbulent flows, including shear flows, boundary layers, mixed layers, as well as for the decomposition of an isotropic turbulence grid. They have proven to be quite effective for a wide range of wall-bound landslides.

Modeling of turbulent viscosity.

Turbulent (or vortex) viscosity $\mu \mathrm{t}$ 'is calculated through $\mathrm{k}$ and $\varepsilon$ as follows:

$$
\mu_{t}=\rho C_{\mu} \frac{k^{2}}{\varepsilon}
$$

where, $\mathrm{C}_{\mu}$ is a constant.

The degree to which $\varepsilon$ depends on buoyancy is determined by the constant $\mathrm{C}_{3 \mathrm{e}}$. In ANSYS FLUENT, the value of $\mathrm{C}_{3 \mathrm{e}}$ is calculated by the following ratio [258]:

$$
C_{3 e}=\tanh \left|\frac{v}{u}\right|
$$


where $v$ is the component of the flow velocity that is parallel to the gravitational vector, $u$ is the component of the flow velocity perpendicular to the gravitational vector. Thus, $\mathrm{C}_{3 \mathrm{e}}$ will be equal to 1.0 for floating shear layers, for which the main flow direction is combined with the direction of gravity. For floating shear layers that are perpendicular to the gravitational vector, $\mathrm{C}_{3 \mathrm{e}}$ becomes zero.

Modeling of turbulent processes in the $k-\varepsilon$ model.

The parameter $\mathrm{G}_{\mathrm{k}}$, is a process of kinetic energy of turbulence, which is modeled equally for standard, RNG and realizable k- $\varepsilon$ models and is defined as:

$$
G_{k}=-\rho \overline{u_{i}^{\prime} u_{j}^{\prime}} \frac{\partial u_{j}}{\partial x_{i}}
$$

To estimate $\mathrm{G}_{\mathrm{k}}$ according to Bussinesc's hypothesis:

$$
G_{k}=\mu_{t} S^{2}
$$

where $S$ is the modulus of the average rate of change of the strain tensor, defined as:

$$
S \equiv \sqrt{2 S_{j} S_{/ j}}
$$

Effects of the effect of buoyancy on turbulence in the $k-\varepsilon$ model

Generation of turbulence due to buoyancy is determined by:

$$
G_{b}=\beta g_{i} \frac{\mu_{t}}{\operatorname{Pr}_{t}} \frac{\partial T}{\partial x_{i}}
$$

where Pr is the turbulent Prandtl number for the energy and $g_{i}$ and the component of the gravitational vector in the $i$-th direction. For standard $\mathrm{k}-\varepsilon$ models, its value is $\operatorname{Pr}=$ 0.85 .

The coefficient of thermal expansion $\beta$ is defined as:

$$
\beta=-\frac{1}{\rho}\left(\frac{\partial \rho}{\partial T}\right)_{p}
$$

For ideal gases, the ratio (15) is as follows:

$$
G_{b}=-g_{i} \frac{\mu_{t}}{\rho \operatorname{Pr}_{t}} \frac{\partial \rho}{\partial x_{i}}
$$

As can be seen from the transfer equations for the parameter $k$ (see equation (5)), the turbulence of the kinetic energy is usually increased $\left(\mathrm{G}_{\mathrm{b}}>0\right)$ under conditions of 
unstable flow stratification. For stable stratification we have a reduction of this turbulence $\left(\mathrm{G}_{\mathrm{b}}<0\right)$. In ANSYS FLUENT package, the effects of buoyancy on the generation $\mathrm{k}$ are always taken into account if there is a non-zero gravitational field and a non-zero temperature gradient.

To account for these effects in the k- $\varepsilon$ model in ANSYS FLUENT, we use the scattering parameter of the extension YM, which is included in k equation (6). This parameter is modeled according to Sarkar's proposal [259]:

$$
Y_{M}=2 \rho \varepsilon M_{t}^{2}
$$

where $\mathrm{M}_{\mathrm{t}}$ - is a turbulent Mach number, defined as:

$$
M_{t}=\sqrt{\frac{k}{a^{2}}}
$$

where $(a \equiv \sqrt{\gamma R T})$ is the speed of sound.

\subsubsection{Results of numerical modeling of transfer processes in RPA}

As a result of numerical calculations in ANSYS FLUENT application package, all dynamic and thermal characteristics of the liquid feed mixture during its passage through the rotor-stator system were obtained [260-265]. The results of the calculations are presented in Fig. 6-8.

In Fig. 6 shows the pressure distribution in the channels of the rotary-pulsation apparatus during the flow of the feed mixture. As shown by the analysis of the pressure distribution, the maximum pressure increase in the flow of the feed mixture is observed in the areas between the rotor and the stator. In these areas, the pressure increase may be $55 \mathrm{kPa}$ compared to the pressure at the inlet to the channel. This indicates a significant effect of the viscosity of the mixture on the change in pressure in the rotorstator channels, which is accompanied by the conversion of the kinetic energy of rotation of the rotor into the thermal energy of the feed mixture.

In Fig. 7 shows the speed distributions in the channels of the working area in rotor-stator system. The maximum values of flow rate of the feed mixture are observed in the channels between the rotor and stator, where these values can exceed $7 \mathrm{~m} / \mathrm{s}$. 
When the liquid leaves the rotor-stator channel the flow vorticity areas are formed, which turbulizes the flow in the channels and leads to intensive mixing of the grain mixture. The result is a homogeneous feed grain mixture.

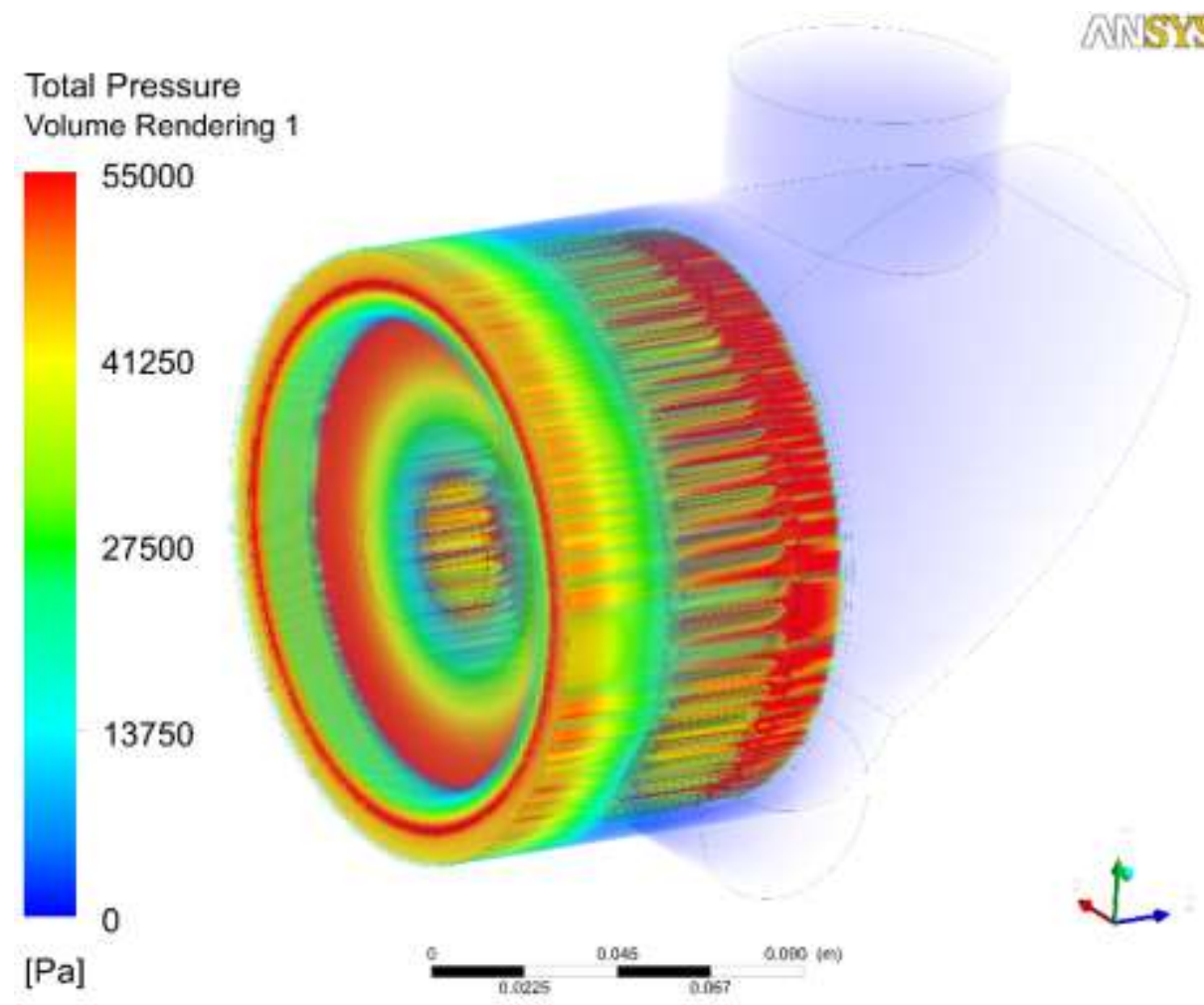

a)

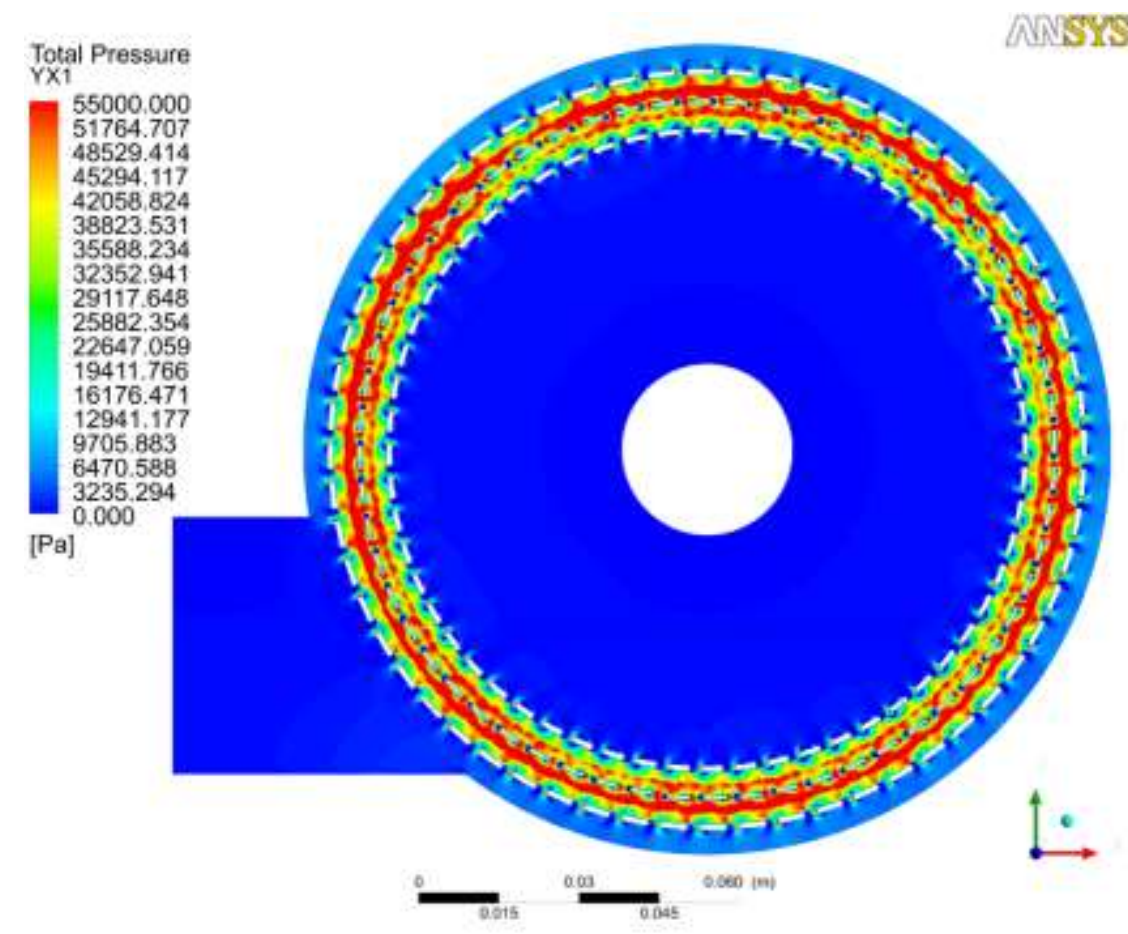

b) 


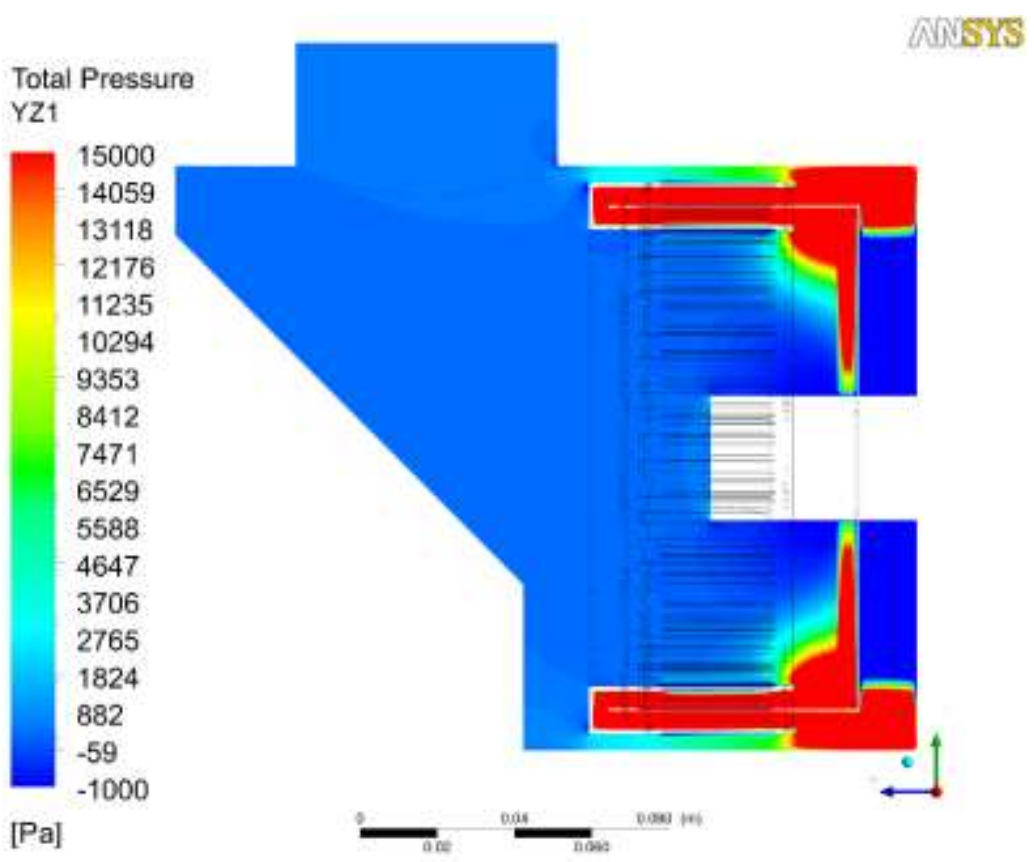

c)

Figure 6. Pressure distribution in the rotor-stator system: $a$ - 3D format; $b$ - cross section; $c$ - longitudinal section

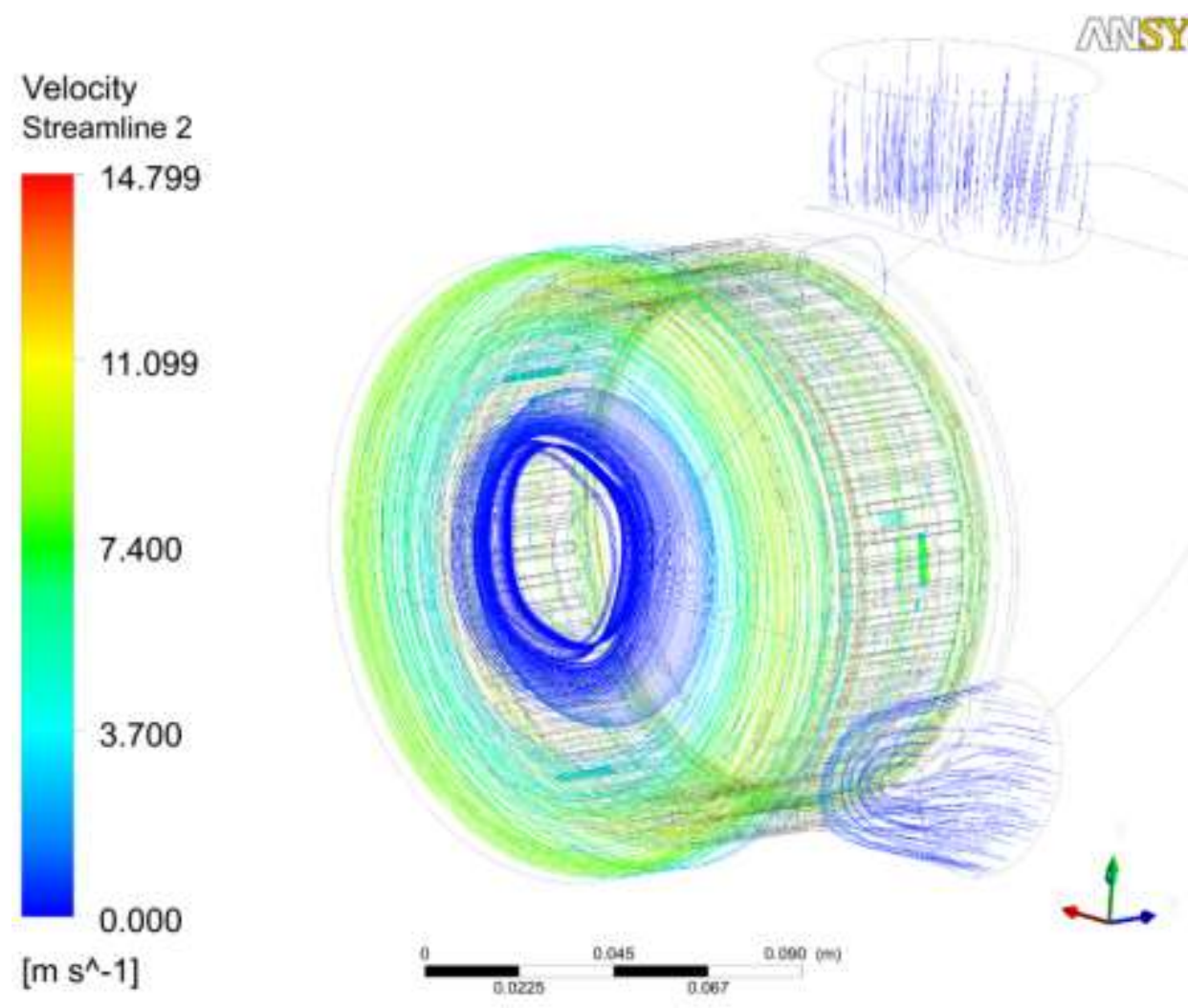

a) 


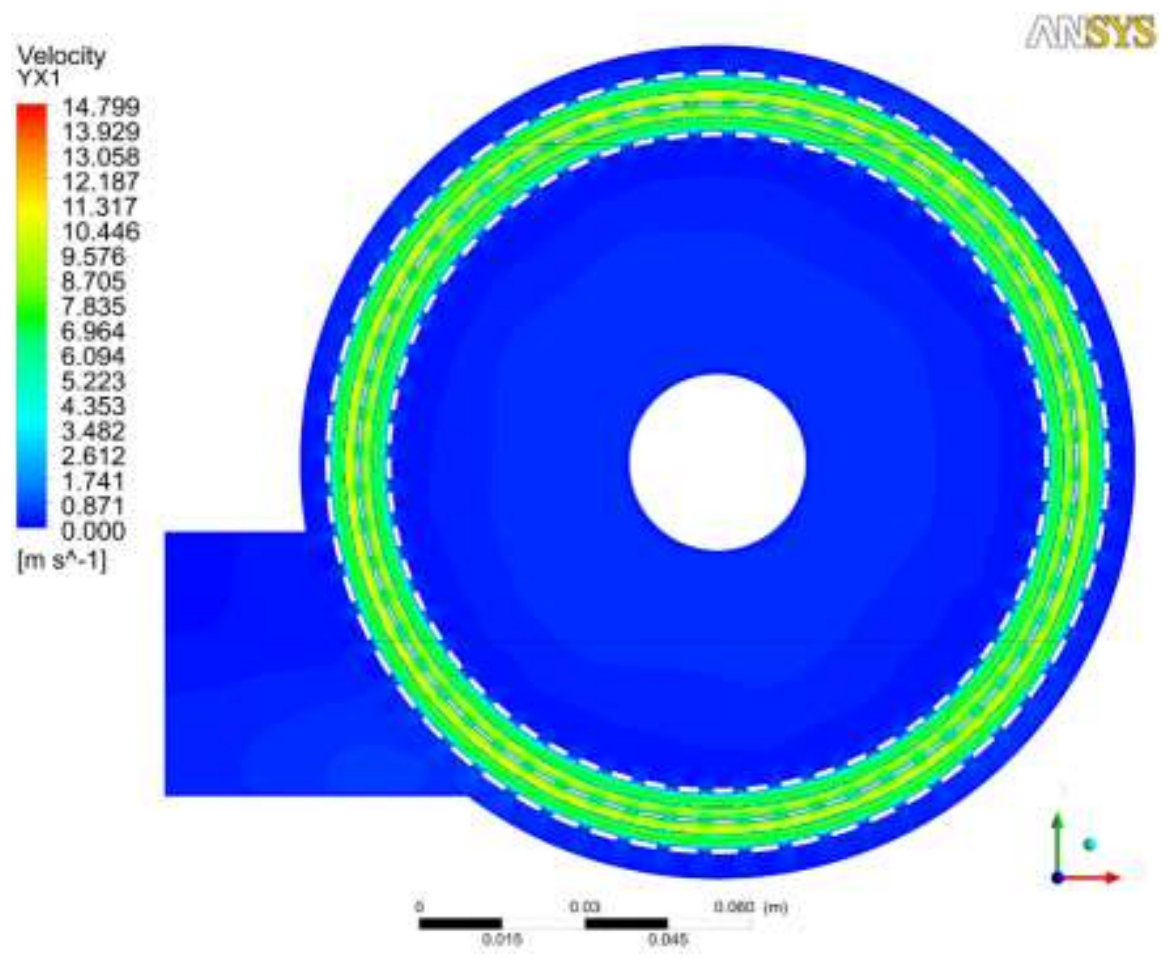

b)



c)

Figure 7. Speed distribution in the rotor-stator system: $a$ - 3D format; $b$ - cross section; $c$ - longitudinal section 
Temperature distributions in the liquid mixture in the cross section of the channel are shown in Fig. 8. The highest values of temperatures in the liquid feed mixture take place in the areas adjacent to the surface of the end plane of the rotor and can exceed $21{ }^{0} \mathrm{C}$.

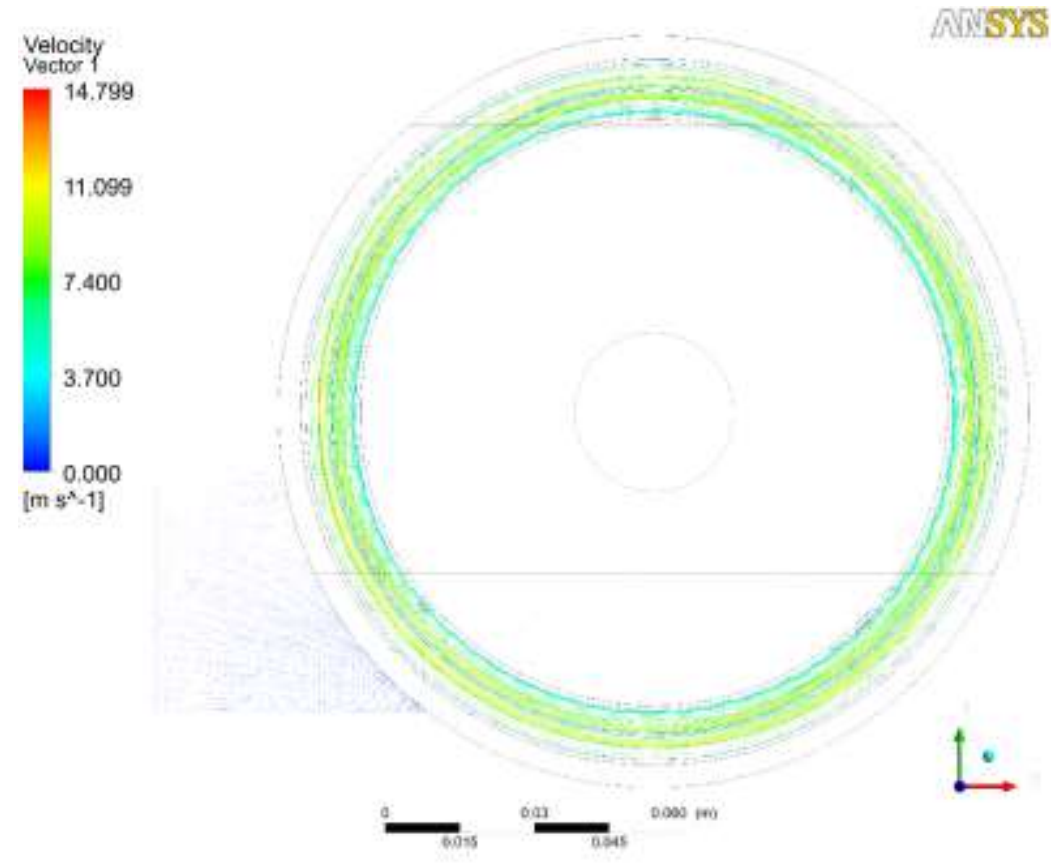

a)

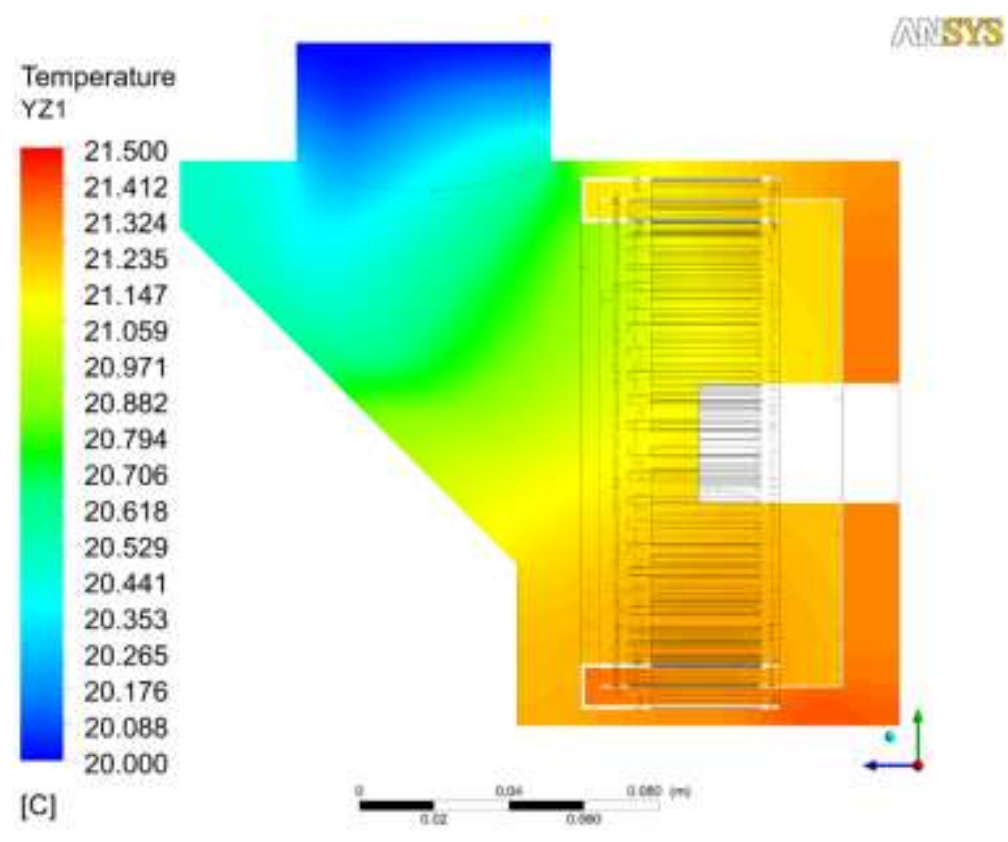

b)

Figure 8. Temperature distribution in the feed mixture for longitudinal (a) and cross

(b) cross section in the rotor-stator system 
This indicates a dissipation of the kinetic energy of rotation of the rotor and an increase in the temperature of the feed mixture during its processing. As a result, the feed mixture is heated, which is especially important in the winter and allows you not to heat the feed mixture during this period.

As a result of numerical simulation, the fields of pressures, velocities and temperatures in the liquid feed mixture were obtained, which made it possible to choose the design of the rotor-pulsation apparatus, which will be used to develop an experimental sample. such a device.

\subsubsection{Design and operation of experimental installation}

To study the process of processing starch-containing raw materials for the preparation of liquid feed, an experimental-industrial installation was developed and manufactured. This installation allows to study the nature of the heat and mass transfer processes in the processing of starch-containing medium. On the basis of the received experimental data it is possible to estimate reliability of theoretical researches, and also to work out technological process of preparation of liquid forages for farm animals.

Developed experimental installations provide: high efficiency of heat and mass transfer processes; dispersion, mixing, heating; ability to withstand operating stresses; tightness of detachable and non-detachable (welded) joints; safety and compliance with sanitary norms; convenience and reliability of service and repair. The experimental installation is presented in Fig. 9.

Experimental installation works on the following principle. According to the recipe of feed preparation, the grain mixture is fed into the receiver-dispenser, then the required amount of water is fed into the main hopper. After inclusion of the device in a stream of water flowing through the pipeline, grain moves and the mix is processed in RPA in the recirculation mode. The working chamber includes a rotor and a stator, which can have rectangular holes (Fig. 10). 


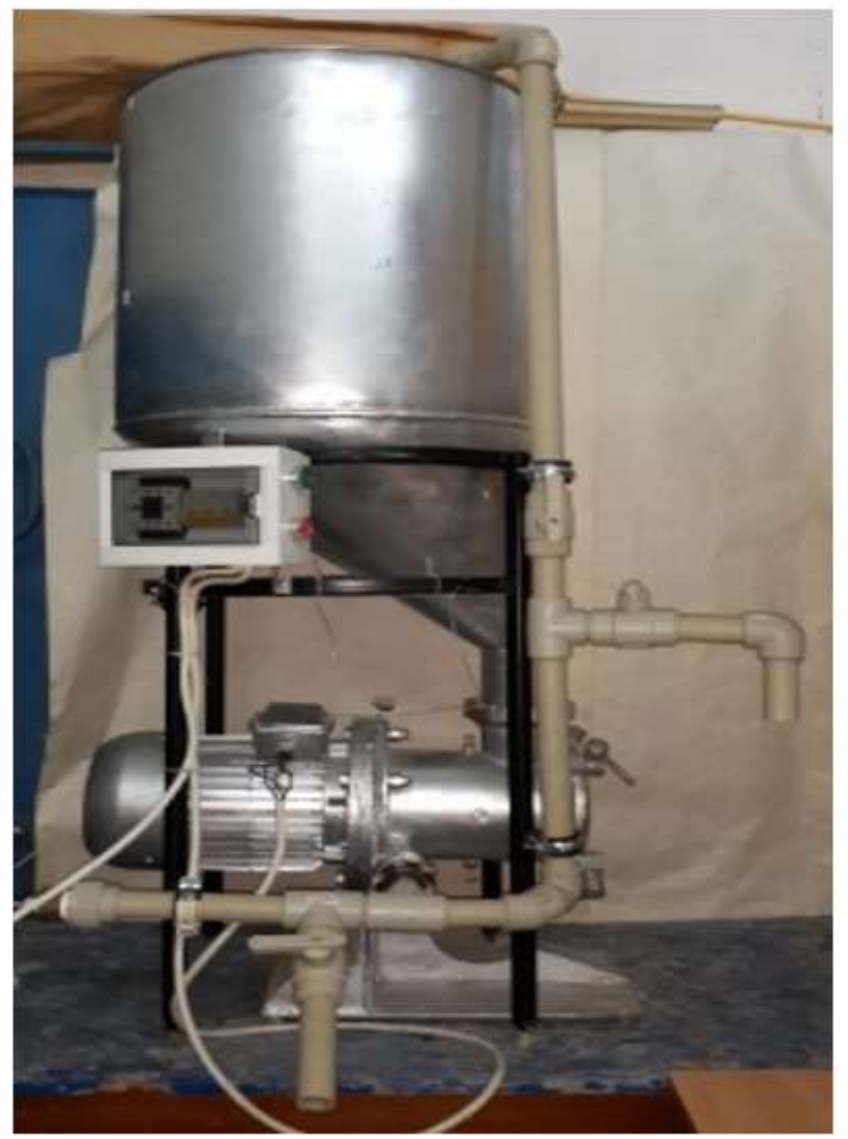

Figure 9. Rotary pulsation units for liquid feed preparation

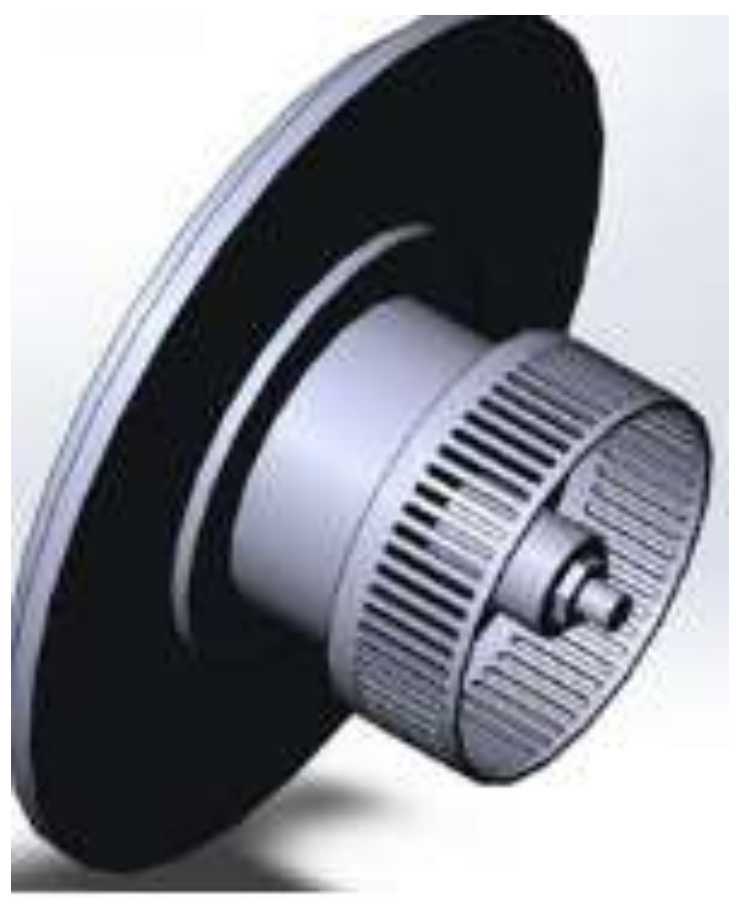

a)

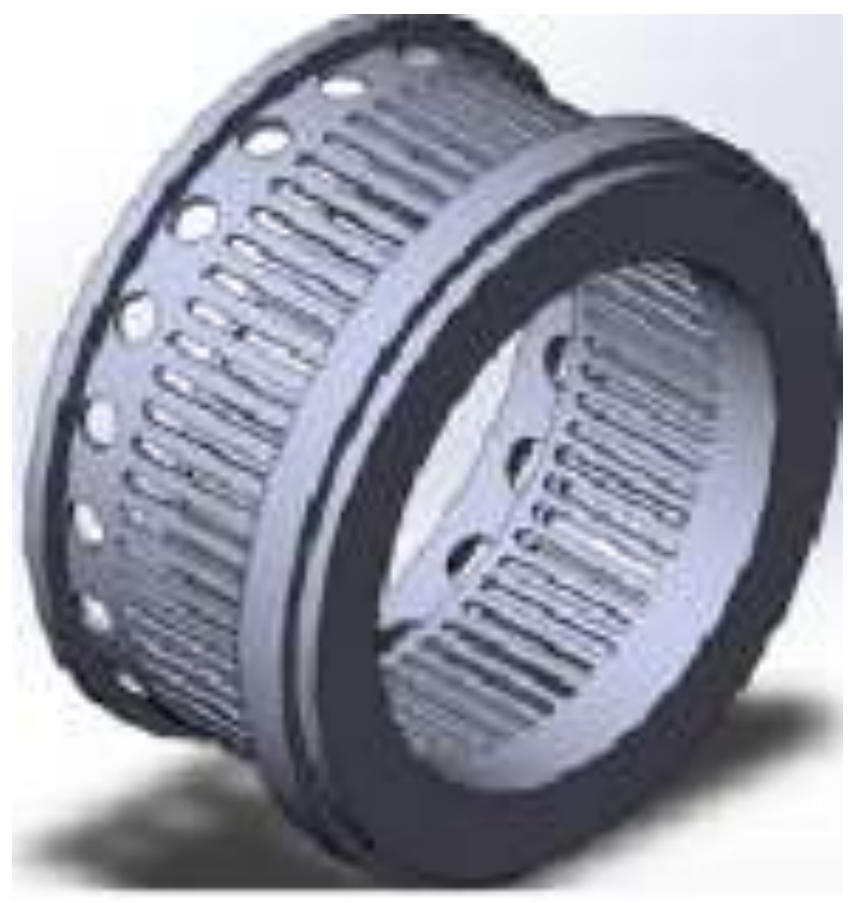

b)

Figure 10. General view of the rotor and stator in working chamber with rectangular holes: a) rotor; b) stator 
At such processing there is a grain crushing and its mixing with water. Since during the processing of the grain mixture it is heated due to energy dissipation, a bimetallic thermometer is provided on the hopper to monitor the temperature of the mixture. The scheme of the experimental setup is presented in Fig. 11.

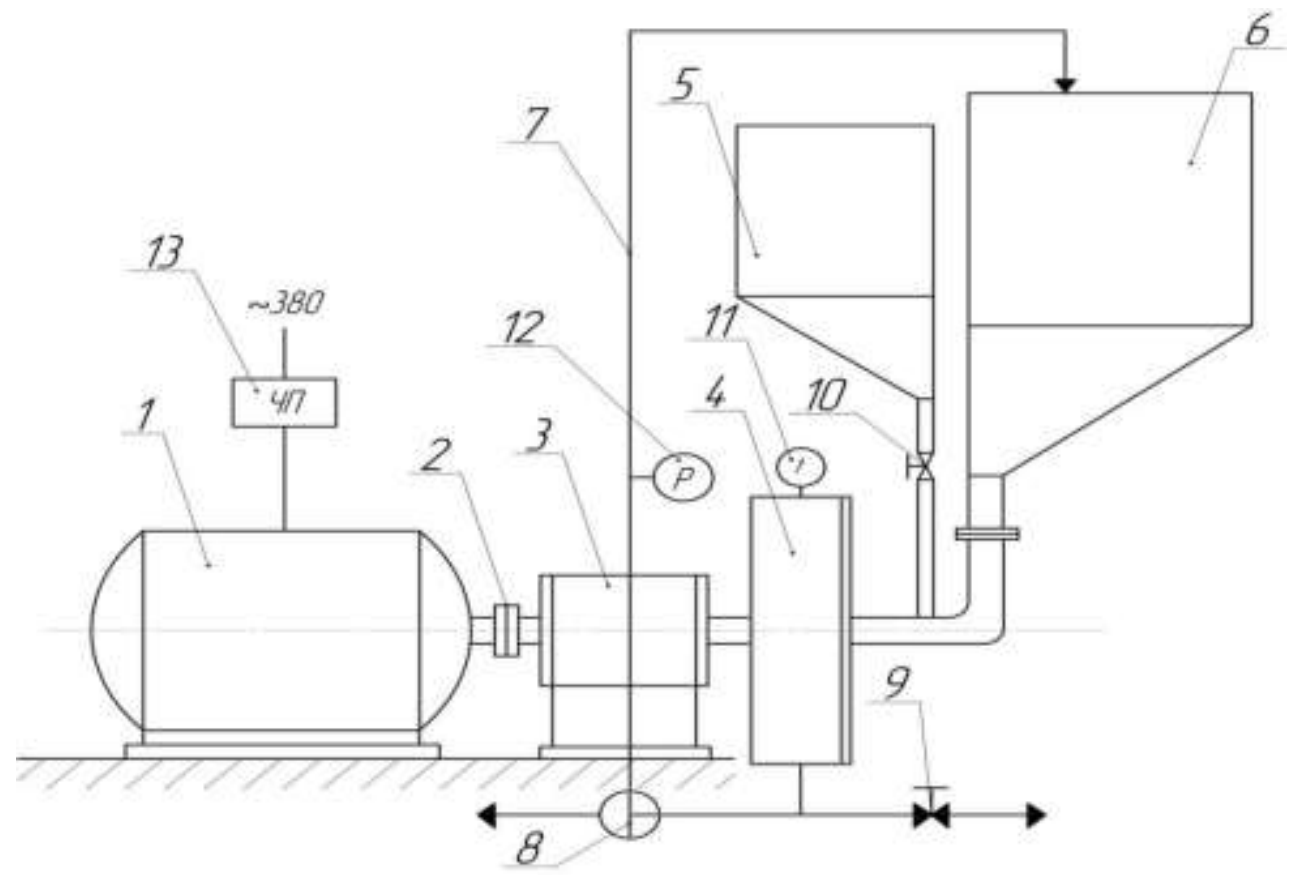

Figure 11. Schematic diagram of the experimental setup:

1 - electric motor; 2 - coupling; 3 - bearing assembly; 4 - RPA; 5 - receiving hopper for grain; 6 - bunker; 7 - recirculation pipeline; 8 - three-way crane; 9,10 - adjusting ball valves; 11 - bimetallic thermometer; 12 - manometer; 13 - frequency converter.

An experimental installation has been developed and manufactured which provides: high efficiency of heat and mass transfer processes; dispersion, mixing, heating; ability to withstand operating stresses; tightness of detachable and nondetachable (welded) joints; safety and compliance with sanitary norms; convenience and reliability of service and repair

Hydraulic characteristics: flow rate, pressure, as well as instrument readings were determined in a steady-state mode of operation of RPA at a given converter speed 
of the motor shaft. Temperature measurements were performed using measuring devices - bimetallic thermometer, manometer, vacuum gauge, wattmeter.

The electric motor 1 is designed to drive RPA rotor. In the control panel 13 the introductory automatic machine, the frequency converter, buttons of inclusion and switching off, signal armature are placed. Structurally RPA 4, mounted on a frame made of channel № 24. An electric motor is installed on the frame, connected to the bearing unit by means of a coupling. RPA is fixed on the flange of the bearing unit. The energy consumption of the electric motor was determined by a wattmeter.

\subsubsection{Experimental studies of feed preparation processes in RPA with rectangular holes.}

Experimental studies were performed for RPA with rectangular holes. In addition to studying the dynamics of changes in the average particle size of grain and the viscosity of the feed mixture at different times during its processing (see Section 4), parameters such as energy consumption and temperature of the mixture during its processing were determined. The last parameter is important, because the traditional methods of preparation of feed mixture based on dry feed requires additional energy costs for its heating, especially in winter.

\subsubsection{Determination of particle size distribution of liquid grain mixture}

The use of an electron microscope to determine the particle size distribution of the grain mixture during its processing makes it possible to observe how the average grain particle size changes depending on the processing time and the number of cycles of passage of the mixture through the working chamber. The main purpose of these studies is to determine the processing time and the number of cycles in which the composition of the mixture will be optimal in terms of maximum assimilation by domestic animals. At the same time, grain mixtures were studied using different types of grain - wheat, corn, barley. 
The results of research to determine the average particle size of grain as a function of time are shown in Fig. 12. Studies were performed for different grain types at different grain concentrations in the liquid grain mixture.

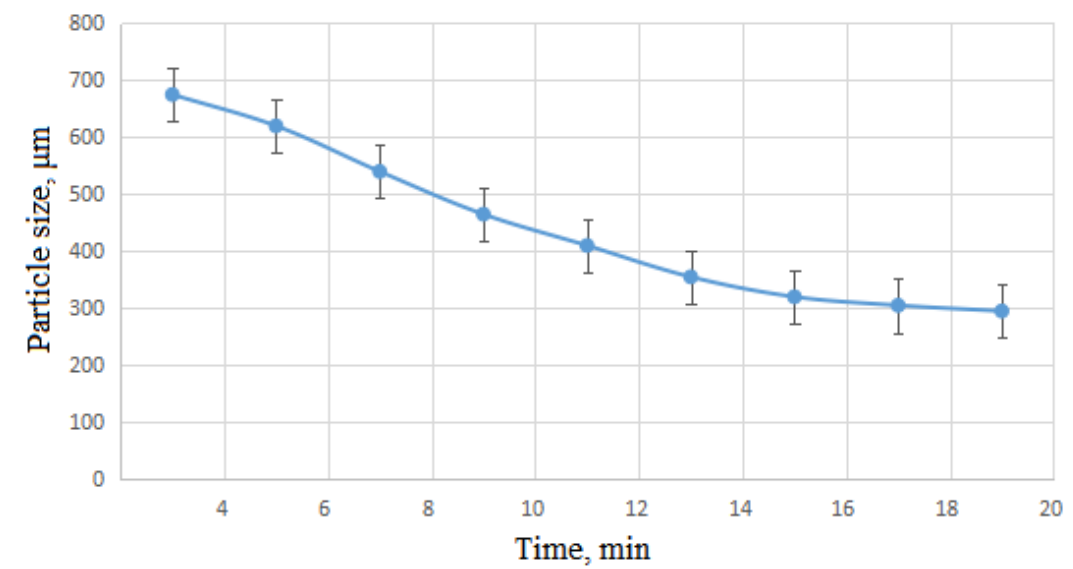

a)

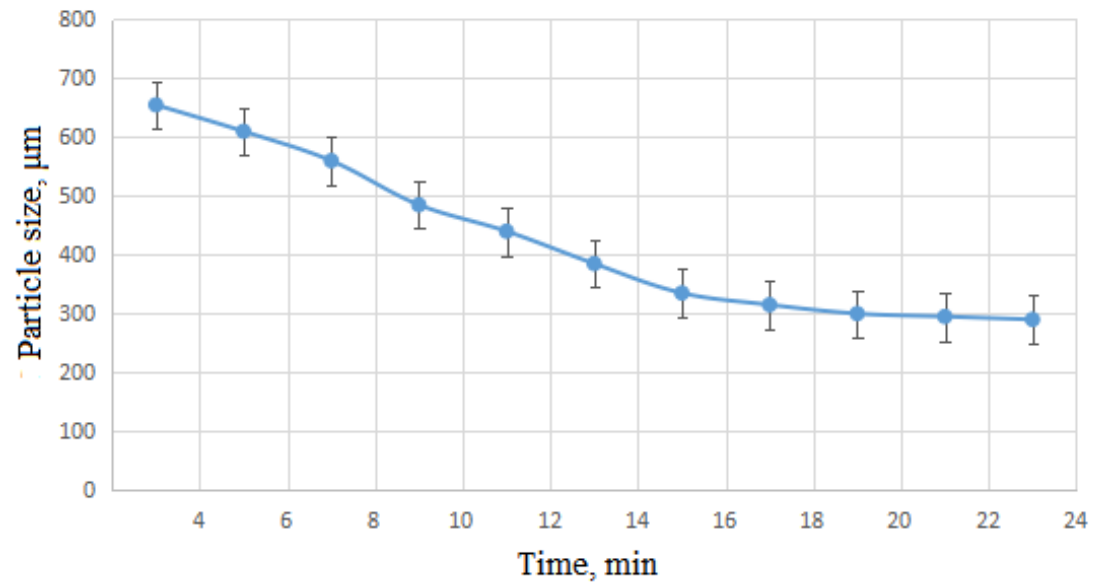

b)

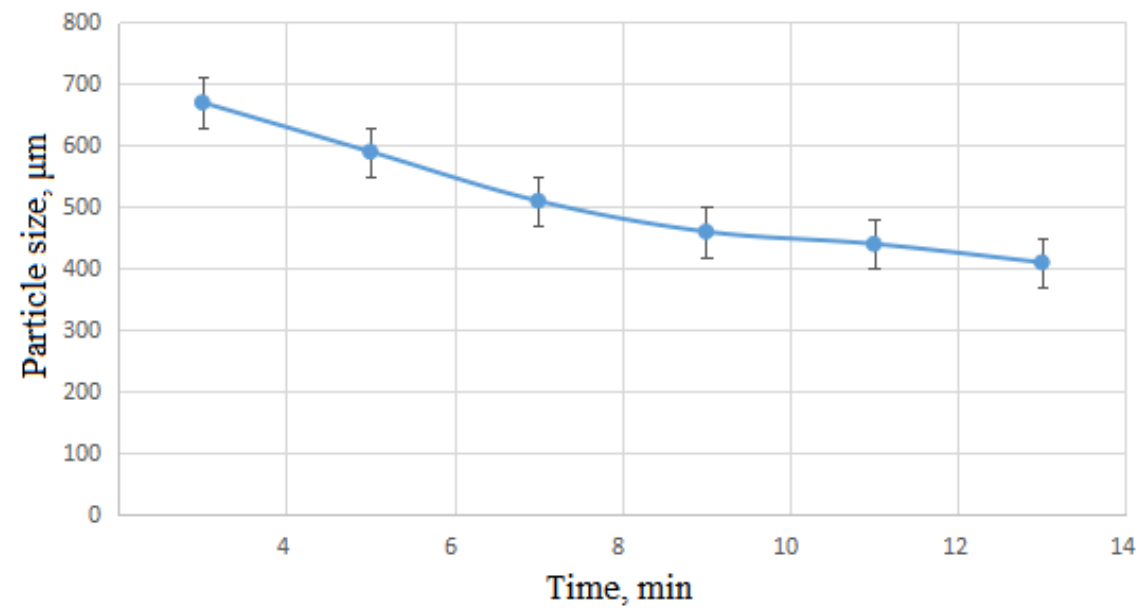

c)

Figure 12. Dependence of the average particle size of wheat in the liquid feed mixture on the processing time at different grain concentrations:

a) $10 \%$; b) $20 \%$; c) $30 \%$ 
As follows from the obtained dependences, the processing time of the grain mixture at a grain concentration of $10 \%$ is about 25 minutes or 30 cycles of processing the mixture in the working chamber of RPA. Increasing the grain concentration in the mixture to $20 \%$ reduces the processing time, which is 20 minutes or 25 processing cycles in the working chamber. At a wheat grain concentration of $30 \%$ in the watergrain mixture, the number of processing cycles decreases.

Analysis of the obtained dependences for different types of grains shows that the required processing time of the liquid grain mixture is $20-25$ minutes or $25-30$ processing cycles. With this duration of preparation of liquid feed, the average particle size of the grain will be close to $300 \mu \mathrm{m}$, which is the most optimal for its assimilation by domestic animals. It is necessary that the feed grain mixture has undergone 25-30 cycles of processing in the working chamber of RPA.

\subsubsection{Investigation of RPA energy characteristics during water-grain mixture processing.}

An important parameter of RPA for the preparation of liquid grain feed is to determine the required energy costs for the preparation of a unit of feed production. To determine this parameter, a wattmeter СТK3 - 10A 1H6PB was used, which was used to measure the power consumption of RPA motor at different points in time for different grain concentrations in the feed mixture. The research results are shown in Fig. 13.

In Fig. 13a shows the values of power consumption at different points in time and at a wheat concentration $10 \%$ in the feed mixture. Analysis of the obtained data shows that at the initial time the power consumption is maximum and gradually decreases during the processing of the water-grain environment. Increasing the concentration of wheat in the feed mixture leads to an increase in consumption capacity with less time spent on processing the water-grain environment (Fig. 13c).

It is characteristic that at the last stages of preparation of forage mix at high concentration of grain there is an increase in the consumed power of the electric motor. 
This fact is due to the increase in the viscosity of the feed mixture when it is heated in the last stages of processing.

It should be noted that the highest engine power consumption, as for the watergrain mixture using wheat, is observed in the initial stages of processing, when most of the energy is spent on grinding grain. With an increase in the concentration of grain fraction in 3 times (Fig. 13) energy costs also increase. However, in the final stages of processing, power consumption, as shown in experimental studies, is almost independent of concentration of corn grain in liquid feed.

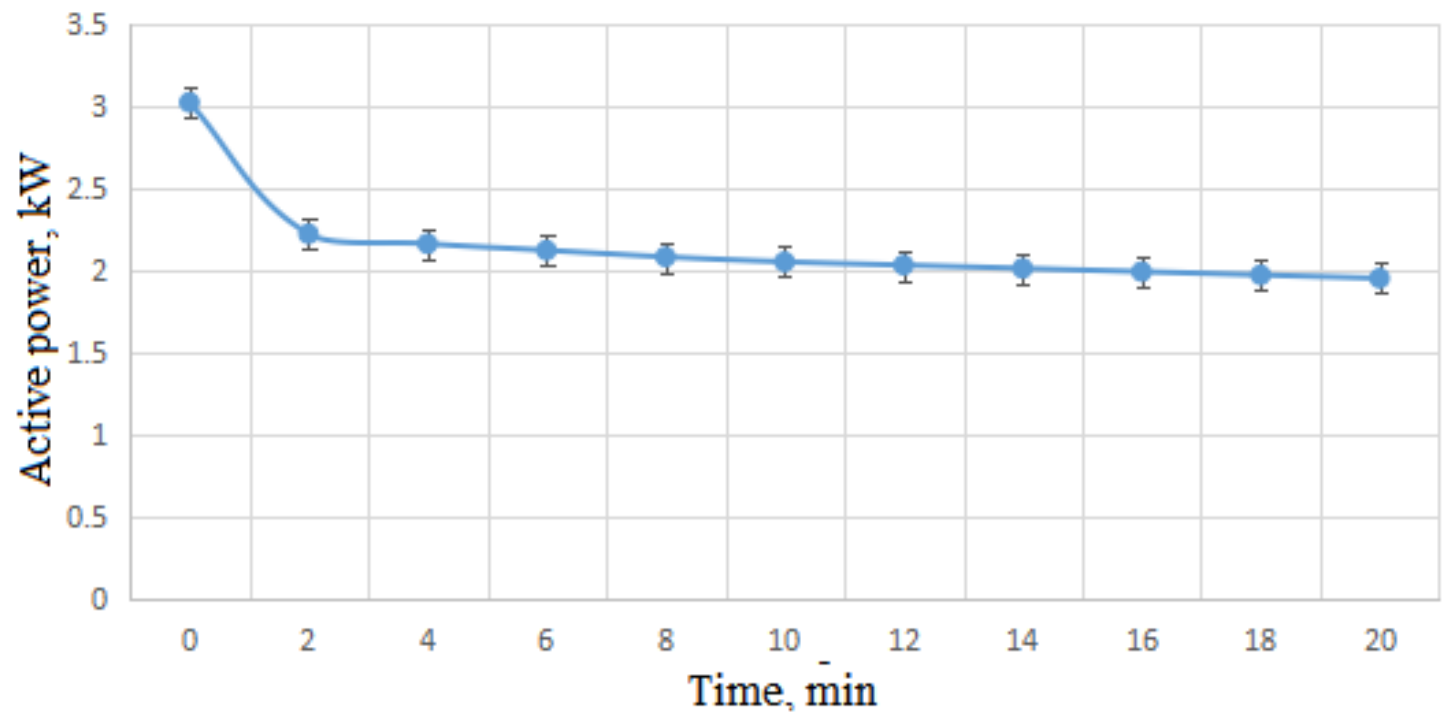

a)

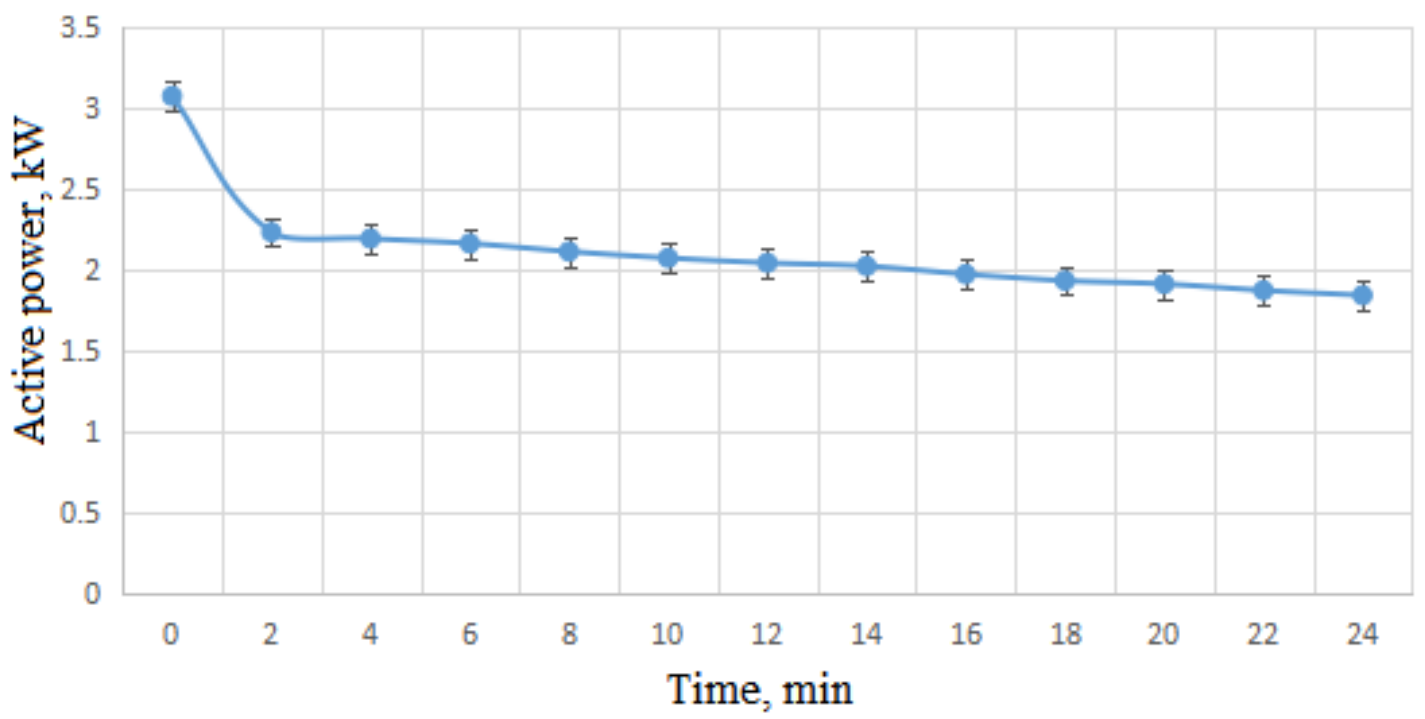

b) 




c)

Figure 13. Change in power consumption when processing the feed mixture at different concentrations of wheat in the mixture:

a) $10 \%$; b) $20 \%$; c) $30 \%$

\subsubsection{Investigation of thermal effects in RPA during treatment of water-grain medium.}

Temperature characteristics of liquid grain feeds play an important role in their preparation, as additional energy consumption is required to heat the feed. In this regard, the temperature of the feed mixture was measured depending on the processing time using wheat, corn and barley. The results of the study are shown in Fig. 14.

In Fig. 14 presents the temperature dependences of the wheat mixture at a grain concentration in the feed, respectively $10 \%, 20 \%$ and $30 \%$. The obtained dependences indicate an increase in the temperature of liquid grain feed with increasing time during its processing. These processes are due to the scattering of the kinetic energy of rotation of the rotor and its conversion into thermal energy. As follows from the obtained graphical dependences, with a higher concentration of grain in the water-grain mixture, the temperature rise will be higher, which is caused by higher energy consumption for its preparation. 


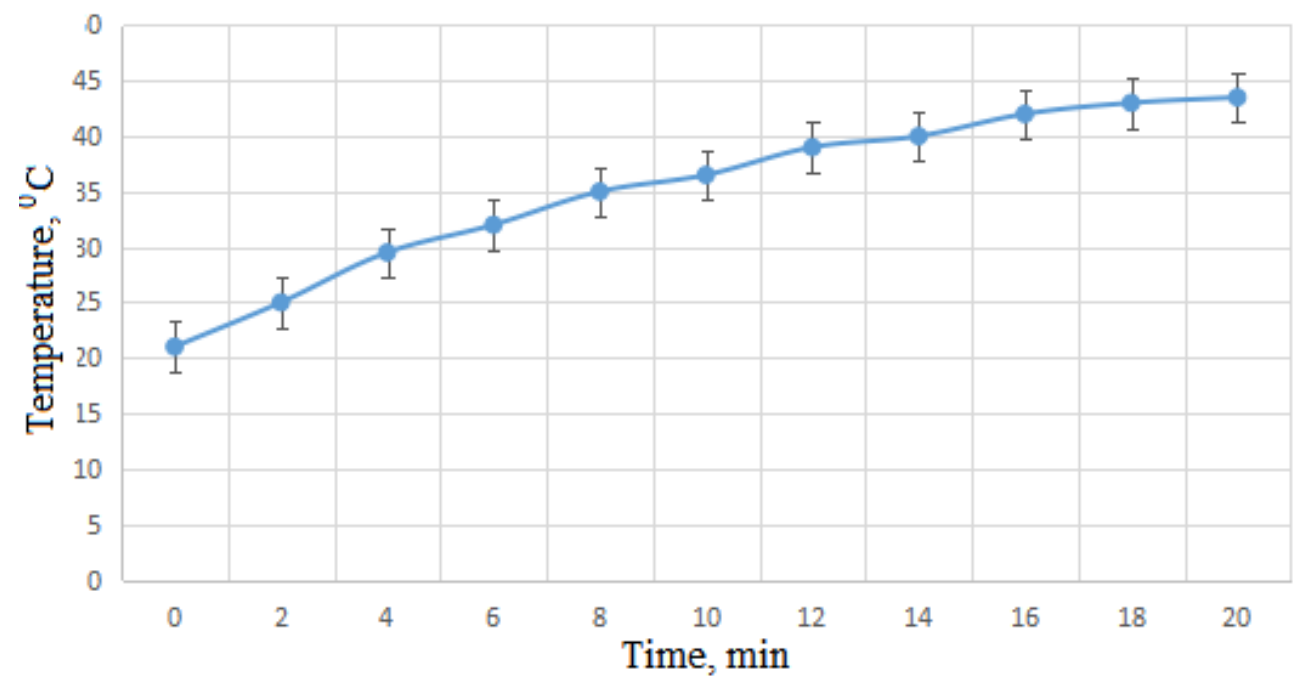

a)

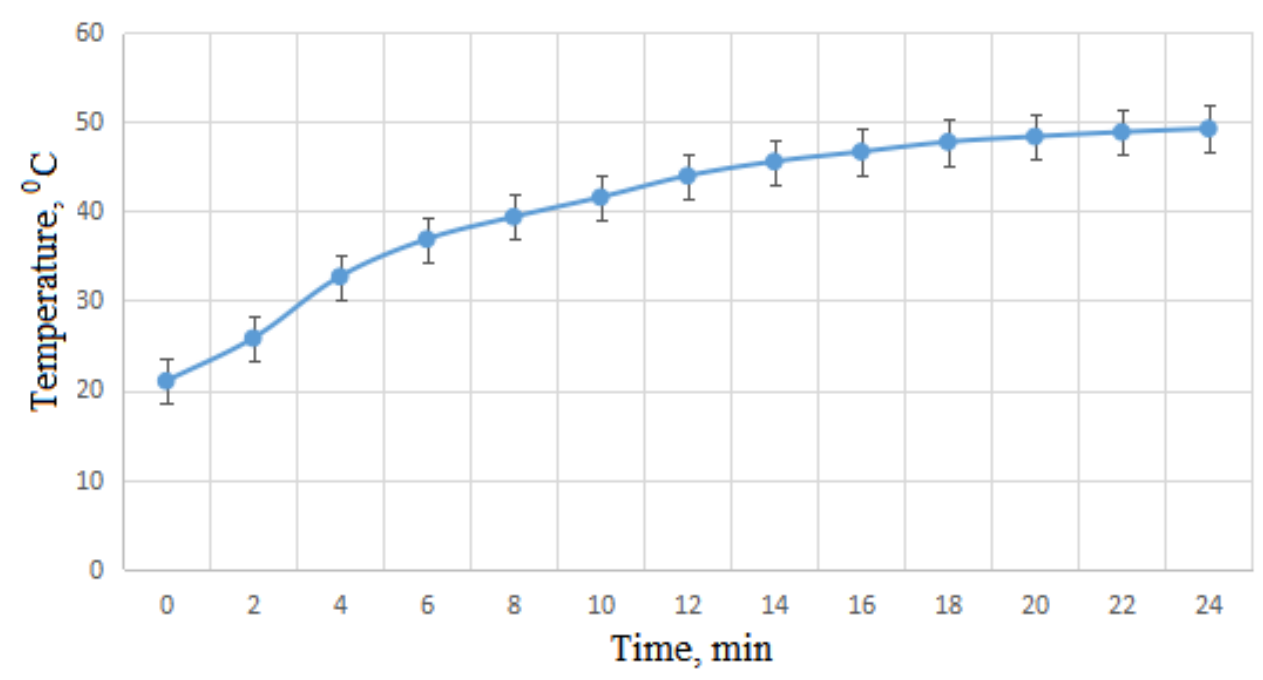

b)

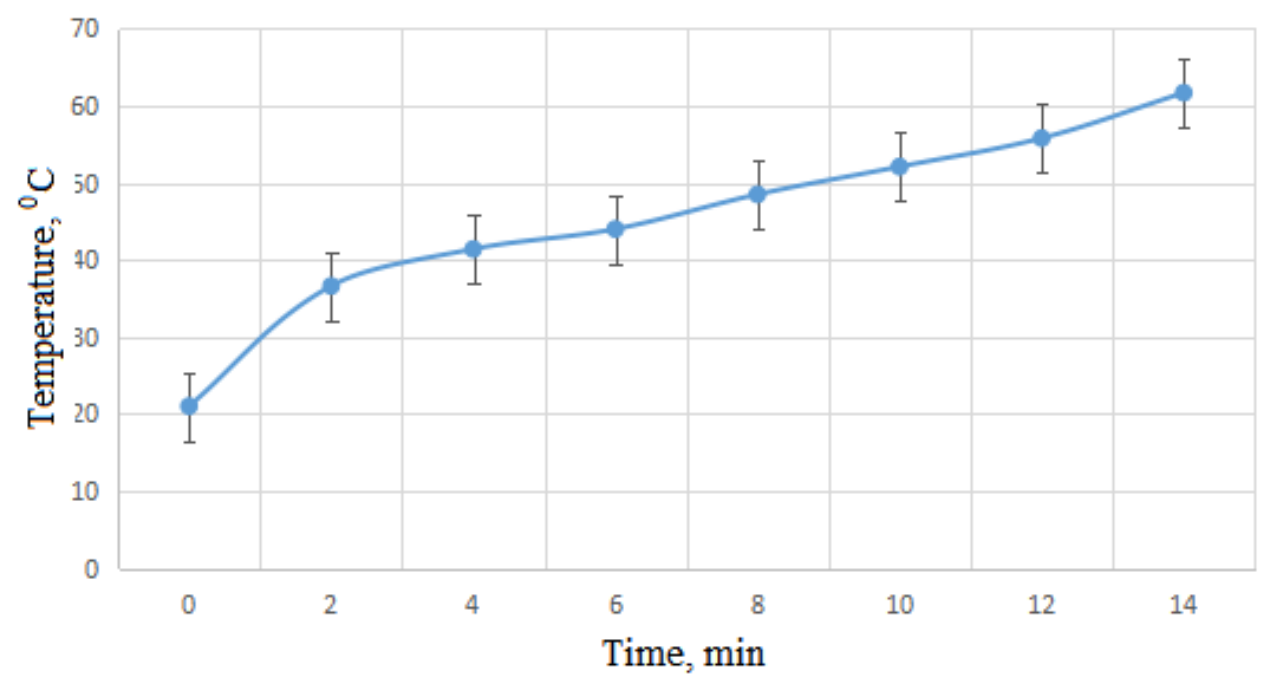

c)

Figure 14. The dependence of the temperature of the liquid grain mixture at different concentrations of wheat: a) 10\%; b) 20\%; c) $30 \%$ 
Thus, we can conclude that the use of discrete-pulse energy input into the starchcontaining medium, which is a water-grain mixture, is accompanied by the dissipation of the kinetic energy of rotation of the rotor into thermal energy. These phenomena are due turbulence, cavitation and other processes in the fluid flow that occur in the working chamber of RPA during the preparation of liquid grain feed.

For preparation of liquid highly dispersed forages by DPEI method it is necessary to mix 1 part of grain with 2 parts of water, ie on $70 \mathrm{~kg}$ of water $30 \mathrm{~kg}$ of grain are necessary. For 15 minutes of operation of the device the output of finished goods makes $100 \mathrm{~kg}$, and for 1 hour $-450-500 \mathrm{~kg}$.

From Fig. 13c shows that for the preparation of $100 \mathrm{~kg}$ of feed for 13 minutes requires $0.42 \mathrm{~kW} / \mathrm{h}$ of electricity. The consumption of electricity per 1 ton of finished product is $4.2 \mathrm{~kW} / \mathrm{h}$. The calculation of the economic effect from the introduction of one RPA with a capacity of 450 - $500 \mathrm{~kg} / \mathrm{h}$ for the finished product is given below.

Table 3

Economic effect from the preparation of $300 \mathrm{~kg}$ of liquid feed with the use of RPA

\begin{tabular}{|c|c|c|c|c|c|c|}
\hline spending & \multicolumn{3}{|c|}{ existing technology } & \multicolumn{3}{c|}{ DPEI method } \\
\hline \multirow{2}{*}{$\begin{array}{c}\text { energy } \\
\text { consumpti } \\
\text { on }\end{array}$} & $\mathrm{kW} / \mathrm{h}$ & $\begin{array}{c}\text { price for 1 } \\
\mathrm{kW} / \mathrm{h}, \\
\mathrm{UAH}\end{array}$ & $\begin{array}{c}\text { cost, } \\
\mathrm{UAH}\end{array}$ & $\mathrm{kW} / \mathrm{h}$ & $\begin{array}{c}\text { price for 1 } \\
\mathrm{kW} / \mathrm{h}, \\
\mathrm{UAH}\end{array}$ & $\begin{array}{c}\text { cost, } \\
\mathrm{UAH}\end{array}$ \\
\cline { 2 - 7 } & 9.10 & 1.68 & 15.29 & 4.20 & 1.68 & 7.06 \\
\hline $\begin{array}{c}\text { raw } \\
\text { materials } \\
\text { costs }\end{array}$ & $\begin{array}{c}\text { number, } \\
\mathrm{kg}\end{array}$ & $\begin{array}{c}\text { price for } 1 \mathrm{~kg}, \\
\mathrm{UAH}\end{array}$ & $\begin{array}{c}\text { cost, } \\
\mathrm{UAH}\end{array}$ & $\begin{array}{c}\text { number, } \\
\mathrm{kg}\end{array}$ & $\begin{array}{c}\text { price for 1 } \\
\mathrm{kg}, \mathrm{UAH}\end{array}$ & $\begin{array}{c}\text { cost, } \\
\mathrm{UAH}\end{array}$ \\
\cline { 2 - 7 } & 333.00 & 3.00 & 999.00 & 289.00 & 3.00 & 867.00 \\
\hline $\begin{array}{c}\text { general } \\
\text { expenses }\end{array}$ & \multicolumn{7}{|c|}{1014.29} & & 874.06 \\
\hline $\begin{array}{c}\text { economic } \\
\text { effect }\end{array}$ & \multicolumn{7}{|c|}{$1014.29-874.06=140.23 \mathrm{UAH}}$. \\
\hline
\end{tabular}


For comparison, the costs of the existing technology of feed preparation, which includes three separate stages: grinding (hammer crusher), mixing with water (mixing apparatus), heating (steam head). Table 3 shows the energy and resource costs of liquid feed preparation according to the existing technology and according to the technology using DPEI method.

Experimental studies have shown that liquid highly dispersed feed prepared by DPEI method has 15\% greater nutritional and energy value and is more fully absorbed by animals than prepared by existing technology. Therefore, when calculating the economic effect, the costs by the amount of grain were reduced by the same amount.

To feed 100 pigs you need $1000 \mathrm{~kg}$ of feed per day, $360000 \mathrm{~kg}$ per year. The annual economic effect of feeding 100 pigs will be UAH 170000 .

\section{Conclusions}

1. New design of the rotor-pulsation apparatus has been developed, which uses a working chamber with rotor and stator having rectangular holes for the passage of the feed mixture.

2. As a result of numerical three-dimensional modeling of the dynamics of fluid motion in the rotary pulsation apparatus obtained pressure and temperature fields in the working area of the apparatus at different times, which allows you to choose the optimal geometric characteristics of rotary pulsation apparatus.

3. Developed and manufactured experimental setup and developed methods of experimental research, which made it possible to determine the kinematic and dynamic characteristics, as well as features of discrete-pulse energy input during dispersion of liquid grain mixture in a rotary pulsation apparatus. The chemical and biological properties of the obtained liquid grain mixtures have been studied.

4. It is experimentally established that the use of rotary pulsation apparatus in the technology of preparation of liquid grain feed for farm animals can reduce the energy consumption of the process by 2-3 times compared to traditional technology, as well as increase productivity by $10-15 \%$ on the finished product. 


\section{Acknowledgement}

Supported by Ministry of Education and Science of Ukraine project № 110/10-pr-2019 "Development of a new method of feed preparation using rotary pulsation devices to improve the quality of feed mixture" 
DOI 10.46299/ISG.2021.MONO.TECH.III.4.3

\subsection{Designing, manufacturing and researching of the heat accumulator work for pre-starting preparation of the car engine}

\section{Using the heat accumulators in various departments. Problems of using the heat accumulators in transport.}

Heat accumulation followed by its use has been the subject of many studies in recent years. To accumulate heat developed devices - heat accumulators (HA). Heat accumulation with its subsequent use is the topic of many studies in recent years. To accumulate heat, heat accumulators (HA) have been developed [266-268]. The work of the heat accumulator is carried out due to the absorption (during melting) and release (during crystallization) of heat as a result of heating and cooling of the working fluid - a material with a phase transition, or heat-accumulating material (HAM). Crystalline hydrates of inorganic salt and bases or organic compounds based on kinds of paraffin are the most often used as heat accumulator actuating fluid [269, 270]. Phase transition heat accumulators are used in the construction industry, where they are used in wall panels [271]; in agriculture for heating greenhouses at night [267, 272]; in ventilation systems to maintain a comfortable temperature during the day [270]; for heating system and hot water supply systems [270]; for some technological processes, such as drying [272]. The heat-accumulating material melts and thus absorbs heat in the warm period of the day (for example, from the sun) and gives it away at night during crystallization, which is accompanied by the release of heat.

In transport equipment, thermal batteries of the phase transition are used to solve the problem of quick engine starting and heating the interior of the vehicle in the cold season [273-275].

The question is that at low ambient temperatures during a layover of a car, for example, at night, there are difficulties with the engine start at the beginning of operation (so-called "cold start"). It takes a long time for the engine to warm up, with the car's engine idling, consuming a significant amount of fuel, releasing exhaust gases into the atmosphere, and keeping the car's interior cold for a long time, creating discomfort for the driver and passengers. 
Cold start is characterized by decreasing engine life, increasing in specific fuel consumption, difficulty in ensuring the starting speed of the crankshaft, deterioration of the conditions of mixture formation, and ignition of the combustible mixture. It is caused by decreasing in the temperature of motor oil, fuel, the storage battery, details of the engine, and features of its starting properties.

One of the solutions to minimize the negative effects of cold start is pre-start thermal preparation of the engine [275]. The specified preparation is realized using preheaters which depending on the principle of work are subdivided into electric (220 V and $12 \mathrm{~V}$ ), independent, executed in the form of the separate petrol or diesel module, and the thermal accumulators representing devices for accumulation of the released parasitic heat during the engine work in the form of heated fluid in the cooling circuit or the thermal energy of the exhaust gases.

When choosing a heat source between the exhaust gases and the engine coolant it should be noted that the engine exhaust gases have a temperature of $600-700{ }^{\circ} \mathrm{C}$, which has a negative impact on HAM, the metal of HA structure, and overheating (boiling) of the engine coolant. In addition, providing the heat accumulator with exhaust gases requires engine operation, so when a layover of a car for a long time, to melt HAM you need to use other heat sources. Therefore, we consider a more promising use as a heat transfer fluid for HA engine coolant.

In addition to the heat of the phase transition, the heat of heating of the solid and liquid phases is used. The advantage of such structures is the high thermal capacitance, which determines the compactness of the structure. In addition, the constancy of their discharging temperature provides greater efficiency than the temperature of the declining storage systems with heated coolant.

Thus, the most acceptable from a practical point of view for transport equipment is to use heat accumulators based on the phase transition solid-liquid (fusible heataccumulating materials) [276-279].

There is not enough research in this area. There are a limited number of design solutions of phase transition heat accumulators for the prelaunch procedure of internal combustion engines. The specific of such a heat accumulator work is not taken into 
account, which is that unlike other industries (e.g. construction, heating systems, drying process), where the whole HAM mass is constantly in contact with the substance to which HAM gives its heat, in our case the engine coolant is in both of the HA and the cooling cladding and is mixed immediately before the engine start, while its temperature decreases. This feature requires a slightly different approach to creating conditions for the stable operation of the entire system. The lack of data on temperature changes of HAM, coolant liquid, and engine over time at different stages of HA use does not allow to give recommendations on the HAM mass required to ensure quick engine starting, HA charging time, and in the charged state.

From the perspective of the above, the purpose of the work is to develop a methodology for designing a heat accumulator for pre-starting the car engine, based on obtained by modeling data from the manufacture of experimental setups and production prototype and research work of HA.

\section{Designs of phase transition heat accumulator for cars}

We offer the following options as constructive solutions of phase transition HA: encapsulated; shell and tube, lamellar, screw, and also with scraper removal of HAM, with removal HAM by ultrasound; with direct contact and pumping HAM; with evaporative-convective heat transfer [280-282].

The most common are heat accumulators with HAM in capsules or the intertube space. This ensures the rational use of the internal volume of the heat accumulator and applies traditional technology for the manufacture of heat exchangers. Each of these types of devices has its advantages. Capsule type HA is not only highly reliable and efficient but also allows you to create a heat transfer surface that can balance for the consumption of phase transitions. Heat accumulators - shell-and-tube heat exchangers are characterized by resistance to water hammer, reduced requirements for the purity of the environment, the relative ease of manufacture. The engine coolant moves in the tubular space of the device, and in the intertube space, there is a heat-accumulating material. 


\section{Stages of heat accumulator design for pre-starting preparation of the car engine}

The design of shell-and-tube heat storage equipment involves several stages (steps). At the first stage, we carried out the orientation of the thermal load on the device, taking into account the expected operating conditions, thermal parameters of the engine's working process, and thermal capacity indicators of materials. At this stage, it is possible to conduct design studies in CFD systems to clarify the heat balance, fluid flow regimes and resistance in the system channels, to assess the uneven heating of the cylinders [283].

At the second stage, we selected the constructional design and layout of the apparatus with the detailed prediction of the fluid flow regimes in the intertube space, the choice of the configuration of the arrangement of tubes or capsules with a heataccumulating substance, the calculation of heat losses, hydraulic resistance of sections, etc. Calculations at this stage are also conveniently performed in CFD systems, with a multivariate choice from a variety of possible CAD layouts.

At the next stage, we carried out a calculated analysis of the dynamics of engine heating elements for the selected heat storage material (often there is a lack of the necessary passport parameters of the material from the supplier, in connection with the additional laboratory studies thet may be required). The calculations are performed based on averaged numerical schemes, the input parameters for which are the data of the first stage (or full-scale characteristics). At this stage, it is possible to predict the dynamics of not only the working process but also modeling the accumulation phase and the standstill phase.

At the last stage, we created a bench model with conducting full-scale proofing.

We consider stages of designing the heat accumulator in more detail and concerning the heat accumulator for preparation for starting the car engine.

\section{The first stage is the orientation of the thermal load on the device.}

This step is because we determine the efficiency of the preheater by the speed and uniformity of heating of the car engine. When designing or selecting preheaters, it 
is necessary to take into account the distinctives of the circulating fluid heat exchange in the cooling circuit with the engine and the outer surface of the cylinder block and the cylinder head with the environment. Excessive power of the tubular heater leads to local overheating of the liquid in the area close to the heater, and, as a consequence, the decomposition of the liquid, which reduces its service life. In addition, overheating the heater also adversely affects its operating life. Therefore, the power of the heater must be consistent with the speed of the liquid inside the circuit.

This preliminary agreement can be made by calculation studies of hydrodynamics and heat transfer for the main types of engines to determine the uneven heating of the cylinder block and cylinder head, the required warm-up time by supplying heated fluid to the engine with a temperature that will ensure sufficient system efficiency for the environment. This unevenness will be significantly influenced by several factors, including the geometry of the internal channels and the conditions of fluid circulation in the shell, the state of the inner surface of the channels, the properties of the circulating fluid and its consumption, the dimensions of engine elements and their thermophysical parameters, ambient temperature and heat transfer from the engine surface for the relevant season. The approximate solution of such a problem using, for example, the average heat capacity and engine mass, average hydraulic and thermal resistance, etc. [284] allows us to consider the process only at a qualitative level. In this paper, we conducted a numerical simulation of the flow with heat transfer in the channels of the engine shell. We used computer fluid dynamics (CFD) methods for this purpose. The list of tasks to be solved by CFD methods is constantly expanding. There is a constant renewal of models, in particular, models of turbulence, improving numerical calculation methods, increasing the productivity of computer technology. The vast majority of CFD software products use methods based on solving Navier-Stokes equations to describe turbulent flows.

As applied to a stationary process, the equations consist, as always, of the equations of continuity and motion (1,2 - summation over repeated indices is performed): 


$$
\begin{gathered}
\frac{\partial u_{i}}{\partial x_{i}}=0 \\
\frac{\partial}{\partial x_{j}}\left(u_{i} u_{j}\right)=-\frac{1}{\rho} \frac{\partial}{\partial x_{i}} p^{*}+\frac{\partial}{\partial x_{j}}\left(v_{e} \tau_{i j}\right)+f_{i}, \\
p^{*}=p+\frac{2}{3} \rho k, \tau_{i j}=\frac{\partial u_{i}}{\partial x_{j}}+\frac{\partial u_{j}}{\partial x_{i}}, v_{e}=v+v_{t}
\end{gathered}
$$

where

$k$ - specific kinetic energy of turbulence, $\mathrm{m}^{2} / \mathrm{s}^{2}, v-$ kinematic viscosity coefficient of the liquid, $\mathrm{m}^{2} / \mathrm{s}, v_{t}$ - turbulent viscosity, $\mathrm{m}^{2} / \mathrm{s}, p$ - the averaged pressure, $\mathrm{Pa}, u_{i}$ - averaged components of the velocity vector in the Cartesian coordinate system, $\mathrm{m} / \mathrm{s}, f_{i}$ - vector of mass forces, $\mathrm{m} / \mathrm{s}^{2}$.

To close $(1,2)$ a two-parameter $k-\varepsilon$ turbulence model has recently become widespread due to the good coincidence of the obtained numerical results with the experimental data, as well as the significant rate of convergence of the basic algorithm. In this model, the turbulence parameters are calculated from the equations:

$$
\begin{gathered}
\frac{\partial}{\partial x_{j}}\left(k u_{j}-v_{k} \frac{\partial k}{\partial x_{j}}\right)=H_{k} \\
\frac{\partial}{\partial x_{j}}\left(\varepsilon u_{j}-v_{\varepsilon} \frac{\partial \varepsilon}{\partial x_{j}}\right)=H_{\varepsilon} \\
v_{t}=C_{\mu} \frac{k^{2}}{\varepsilon},
\end{gathered}
$$

where $\varepsilon$ - turbulent energy dissipation rate, $\mathrm{m}^{2} / \mathrm{s}^{3}$,

$$
\begin{gathered}
H_{k}=G-\varepsilon, H_{\varepsilon}=C_{\varepsilon 1}^{*} \frac{\varepsilon}{k} G-C_{\varepsilon 2} \frac{\varepsilon^{2}}{k}, G=v_{t} \tau_{i j} \frac{\partial u_{i}}{\partial x_{j}}, C_{\varepsilon 1}^{*}=C_{\varepsilon 1}-\eta \frac{1-\eta / \eta_{0}}{1+\beta \eta^{3}}, \\
\eta=\sqrt{\frac{G}{C_{\mu} \varepsilon}}, \\
v_{k}=v+\frac{v_{t}}{\sigma_{k}}, v_{\varepsilon}=v+\frac{v_{t}}{\sigma_{\varepsilon}} .
\end{gathered}
$$

The empirical constants in the reduced equations are equal: 


$$
C_{\mu}=0.0845, C_{\varepsilon 1}=1.42, C_{\varepsilon 2}=1.68, \sigma_{k}=\sigma_{\varepsilon}=0.72, \eta_{0}=4.38, \beta=0.015 \text {. }
$$

It is known that such a model gives acceptable results for areas with developed turbulence, thus when $v_{t}>>v$. Of course, this is not done near a solid wall. In this regard, empirically derived laws of fluid behavior are additionally set in the form of wall functions to determine the parameters of turbulence near the wall. This issue is considered in detail in the works [284].

The calculated study was performed using the package CFX-5.7 [285]. The calculation area with the calculation grid is presented in Fig. 1, $a$. The design area consisted of 4 sub-areas: the area adjacent to the cylinder block (solid), the area of the cylinder head (solid), the flow zone in the cylinder block (fluid), the flow zone in the cylinder head (fluid). We performed construction of the calculation grid using the CFX-Mesh module. The calculated grid numbered 3 million elements (Fig. 1), grid independence was verified by performing calculations for one of the modes on denser and more sparse grids, taking into account the control over the required values of the parameter $\mathrm{y}^{+}$on the wall [285].

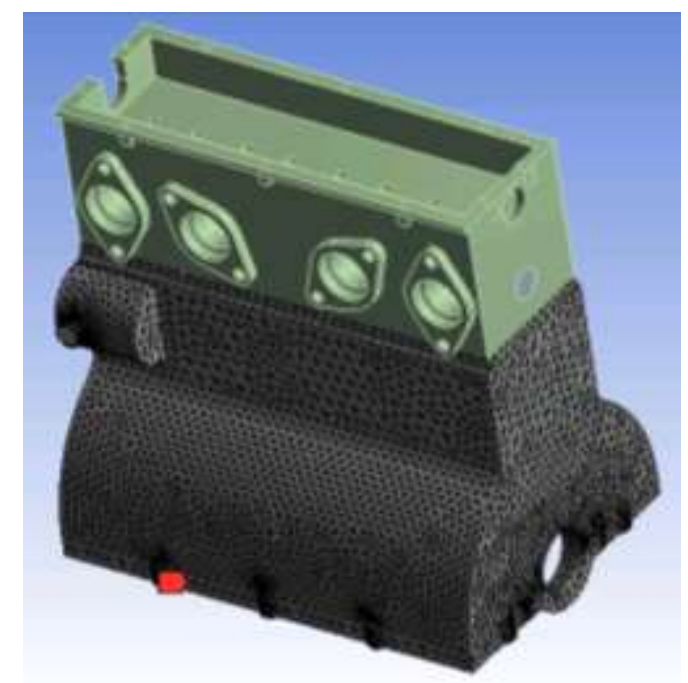

a)

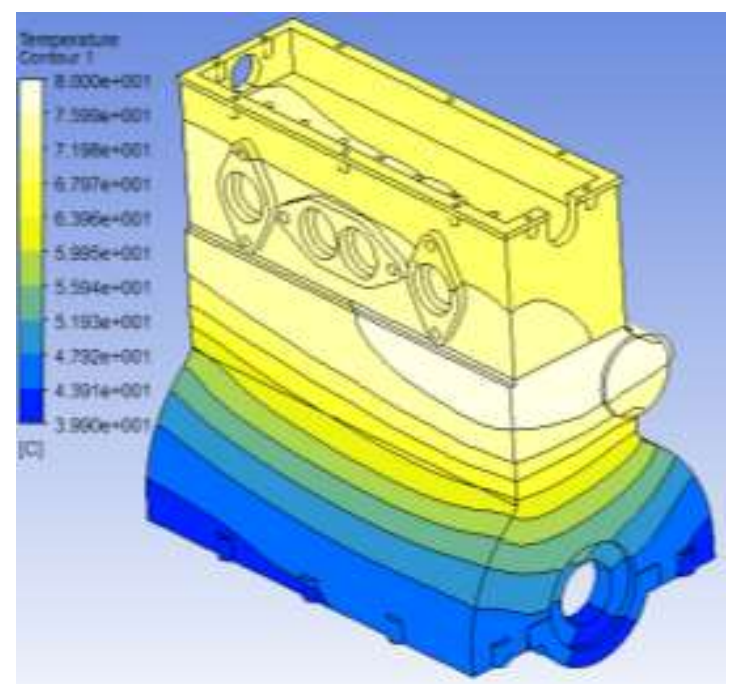

b)

Figure 1. Computational grid $(a)$ and the picture of heating the outer surfaces of the engine $(b)$. 
In all cases, the flow rate was set at the inlet, which corresponds to the available field data with a temperature of $80{ }^{\circ} \mathrm{C}$, at the outlet - static pressure. We set the condition Conservative Interface Flux for solid-liquid interfaces, General Connection for the liquid-liquid interface, and heat transfer for external walls of solid domains. The average heat transfer coefficient $\alpha$ for natural convection according to [286] was calculated from the equation:

$$
N u=0.75(\mathrm{Gr} \cdot \mathrm{Pr})^{0.25},
$$

where $N u=\alpha L / \lambda$ - Nusselt criterion, $G r=g \beta\left(\bar{t}_{c}-t_{o}\right) L / v^{2}$ - Grashof number, $L-$ characteristic wall size for the task (engine height), $\mathrm{m}, \lambda$ - thermal conductivity of air, $\mathrm{W} /(\mathrm{m} \cdot \mathrm{K}) ; \mathrm{g}$ - free-fall acceleration, $\mathrm{m} / \mathrm{s}^{2} ; \quad \beta$ - coefficient of volumetric expansion of the environment, $\mathrm{K}^{-1} ; \mathrm{v}$ - kinematic viscosity of air, $\mathrm{m}^{2} / \mathrm{s} ; \Delta t=\bar{t}_{\mathrm{c}}-t_{\mathrm{o}}-$ temperature pressure, ${ }^{\circ} \mathrm{C}, t_{\mathrm{o}}=0{ }^{\circ} \mathrm{C}$ - model ambient temperature. Consecutive calculations of heat transfer were defined as $\alpha \approx 10 \mathrm{~W} /\left(\mathrm{m}^{2} \cdot \mathrm{K}\right)$.

We performed current calculations in a stationary setting. At a low cost, the convergence of calculations was complicated, which requires a detailed comparison with experimental data. As a result of calculations, we received the warming up picture of engine blocks (Fig. 1, $b$ ), according to which there is noticeable uneven heating of the cylinders in the unit on one side (Fig. 2, $a, b$ ), however, a sufficient temperature that provides a comfortable start in the area of the cylinder head for a given state of the environment on the other. 


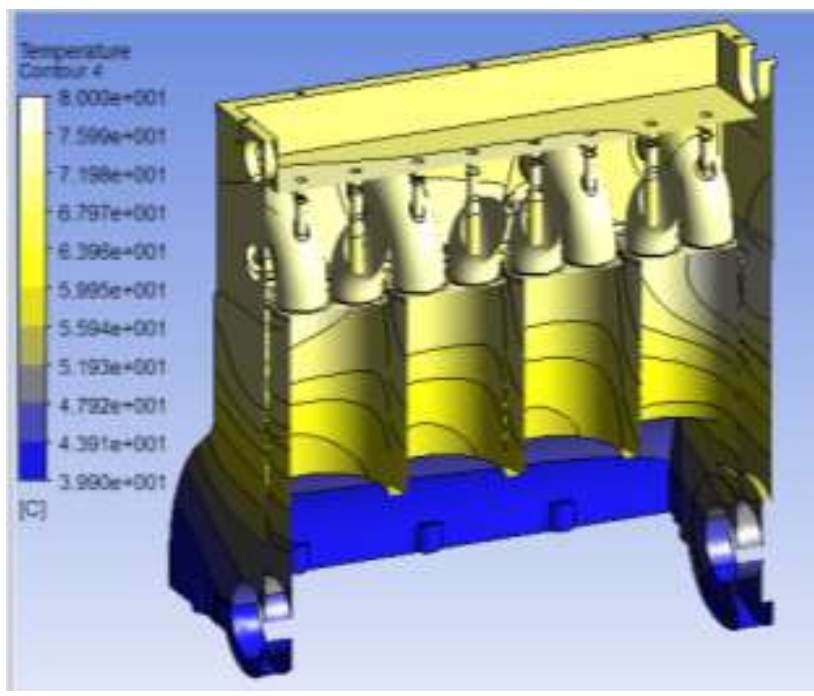

a)
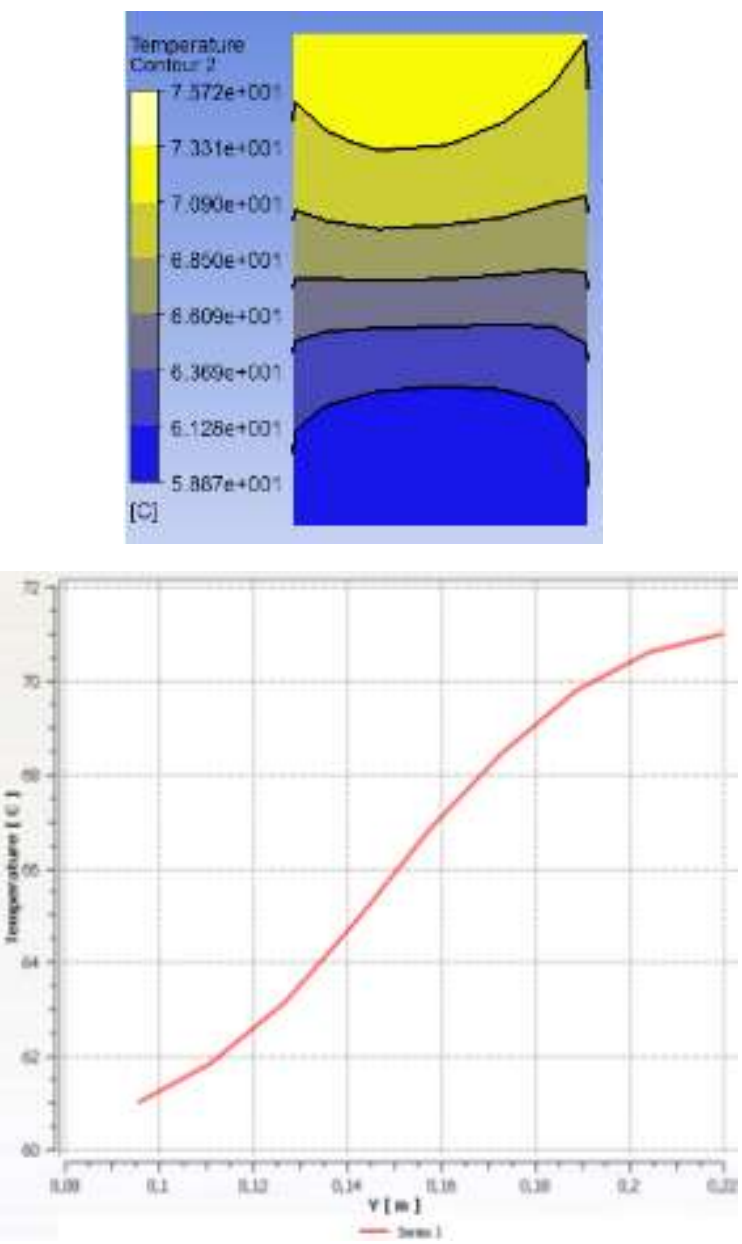

b)

Figure 2. Warming up of internal surfaces of the engine $(a)$ and a picture of warming up of a surface of the cylinder $(b)$.

The significant uneven flow of fluid through the engine channels and a complex hydrodynamic picture in general with the presence of a large number of stagnant zones (Fig. 3, a, b). It should be noted, in addition, that this picture can vary greatly depending on the performance of the channels in the engine shell and the specific model of the engine as a whole.

Thus, the implementation of the first stage of design guides on the heat load on the device, and, in addition, makes it possible to obtain a picture of the warming of the engine units and to conclude on the sufficiency of temperature to ensure a comfortable start of the engine. 


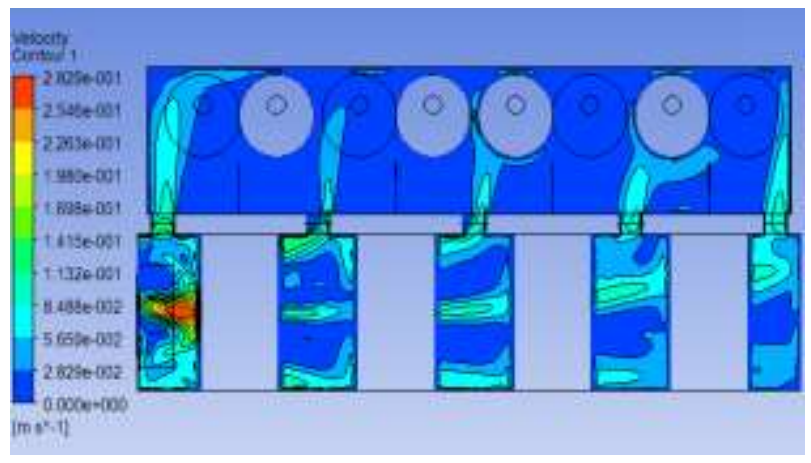

a)

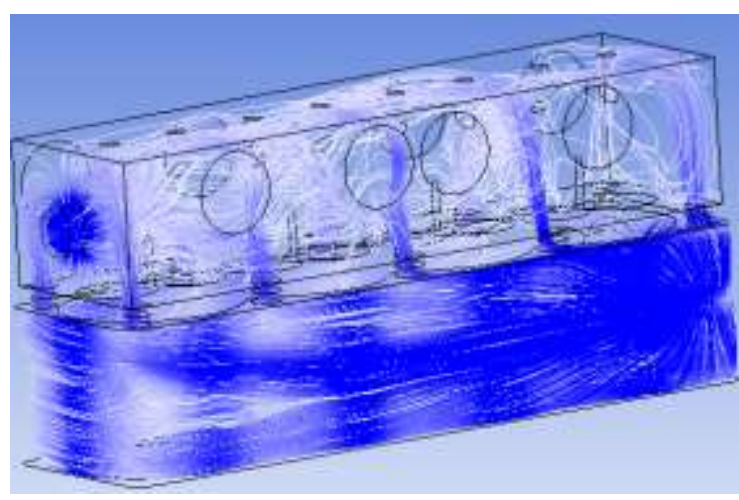

b)

Figure 3. Distribution of velocities in the longitudinal section $(a)$ and the flow line $(b)$.

\section{The second stage is the choice of structural design and layout design of the} device.

Capsule and shell-and-tube types of constructive execution of the heat accumulator are considered as the most acceptable in work. We consider examples of arrangement of such heat accumulators on three options of constructive execution.

Capsule HA (option 1) represents capacity on which the heat carrier circulates and in which capsules with heat-accumulating material are fixed.

We chose a seamless aluminum tube with an outer diameter of $22 \mathrm{~mm}$ and a wall thickness of $1.25 \mathrm{~mm}$ as blanks for the capsules. The selected diameter seems to us to be the most optimal, as it allows us to obtain a sufficient surface area of the coolant contact with the capsules while maintaining an acceptable complexity of manufacture. The capsules were filled with molten heat-accumulating material - barium hydroxide octahydrate $\left(\mathrm{T}_{\mathrm{mol}}=78^{\circ} \mathrm{C}\right)$. At the same time, there was free space on top to compensate for thermal expansion. We carried out sealing of the capsules by pipe flaring on a lathe after pressing into it pre-made steel plugs. The plugs are provided with shaped grooves filled with high-temperature sealant (Fig. 4). 


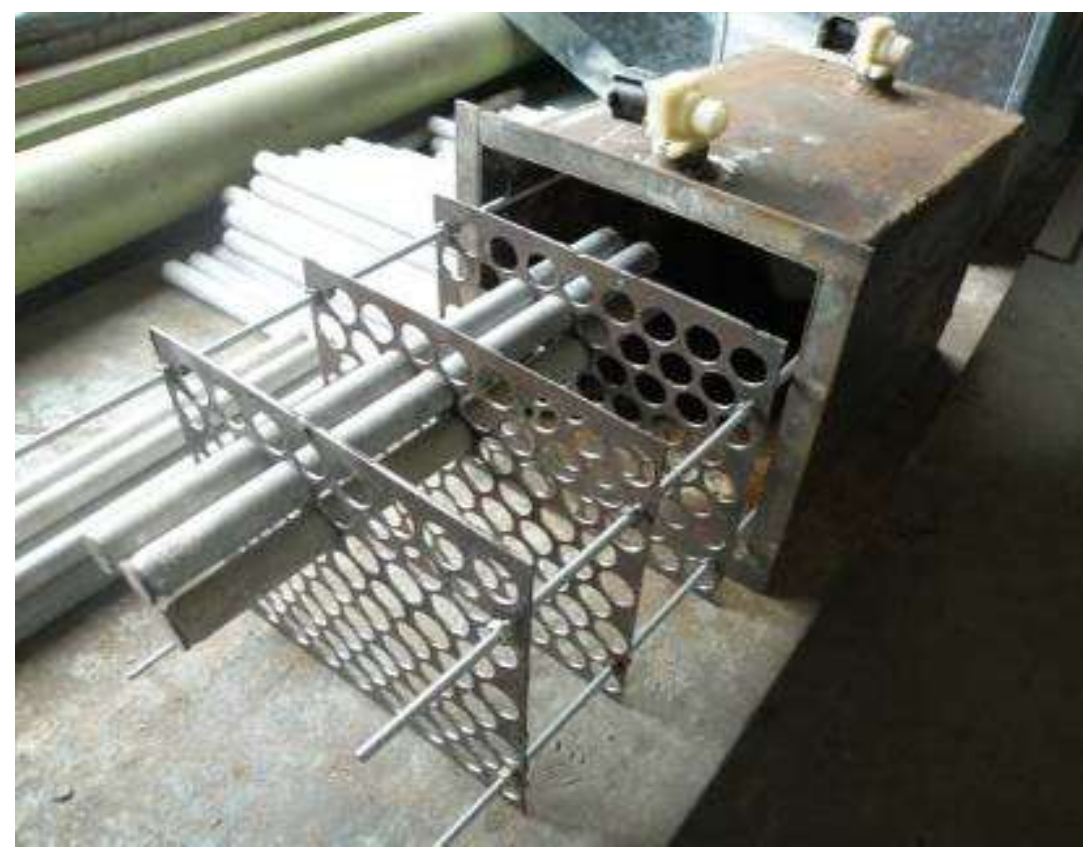

Figure 4. The first design option of the experimental sample - with capsules of heat-accumulating substance.

Liquid flow is formed in the internal volume by the mutual arrangement of the capsules with the heat-accumulating material, thanks to which it is possible to minimize hydraulic losses and improve the heat exchange between the heat carrier and the heat-accumulating substance contained in the flasks.

Fig. 5 shows the structural design of the HA indirect storage (option 2) in the form of a shell-and-tube heat exchanger with a shell. The volume is constant, the circulation is forced by a water pump. Casing - all-metal cylinder with flanges. Heat carrying agent - fluid from the engine cooling system, enters the casing through threaded pipes on the side cover with built-in solenoid valves (the normally closed type with a supply voltage of $12 \mathrm{~V}$, included in the general electrical network of the car in parallel with the electric circulating pump) to prevent convective heat exchange with the engine cooling system during idle time. Heat-accumulating material fills the tubes located throughout the space of the casing and absorbs thermal energy. The main advantage of this design is the simplicity of manufacture and operation, as well as significant cheapness. This design also eliminates uneven heating HAM and allows us to make covers and flanges as light as possible. This heat accumulator is powerful, able to reach operating parameters in a short period. The disadvantages include: 
- the possibility of premature crystallization due to uneven heating, which leads to faster discharge;

- increased dimensions and weight due to the complex system of pipelines, material thickness, bolted fasteners, etc.;

- difficulties in thermal insulation;

- the complexity of cleaning the intertube space;

- corrosion problems in places of tubes flaring with HAM.

All these disadvantages listed above negatively affect the possibility of installation on a modern car, but it is possible to install it on trucks and buses.

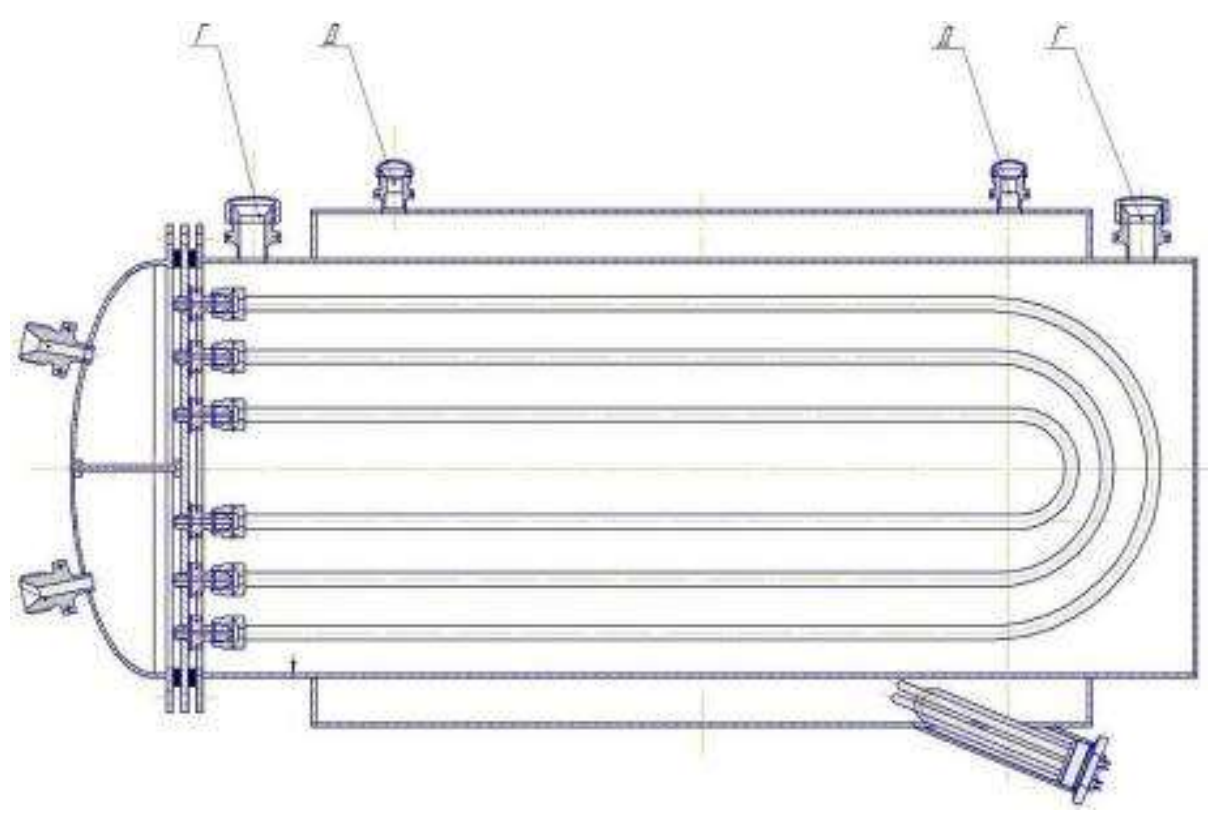

Figure 5. The second design option of the heat accumulator in the form of a shelland-tube heat exchanger.

Heat-accumulating substance - crystal hydrates or paraffins (waxes).

The design of option 3 (Fig. 6) is similar to option 2, but to eliminate all the shortcomings of the previous design, we made the following changes: we reduced the size of the entire system by almost 1.5 times, which allowed to install this system on a much larger number of cars; welds, flanges - have been replaced by bolted joints; we changed the installation of the tubular heating element (THE) to horizontal; the heatstoring material was replaced by ozokerite; to improve heat transfer to ozokerite, copper wire was evenly decomposed around the tubes. 




Figure 6. The third option of the heat accumulator design.

\section{Constructive optimization}

Detailed forecasting of fluid flow regimes in the intertube space and heat flows makes it possible to choose the configuration of the location of tubes or capsules with heat-accumulating substance, calculate heat loss and hydraulic support sections, etc. We consider the above example of the capsule design of the heat accumulator.

We designed and manufactured steel partitions for the spatial orientation of the capsules inside the casing. They are fastened together with threaded pins and sealed against the walls of the heat accumulator housing. This design allows you to divide the internal volume of the heat accumulator into compartments and increase several times the path traversed by the liquid when passing inside the device with high heat capture in one pass. The mutual placement of the capsules inside the heat accumulator creates a labyrinthine flow of coolant, which allows you to evenly heat the heat accumulating substance in the capsules, as well as intensify the heat transfer process by increasing the speed of the coolant that washes them. At the same time it is necessary to try to place in the set volume the maximum volume of heat-accumulating material.

We developed several options of the mutual arrangement of the capsules inside the casing. From them the two most acceptable options which became object of modeling are chosen.

Option 1 involves the checkerboard arrangement of the capsules along the flow of liquid cooling (Fig. 7). 


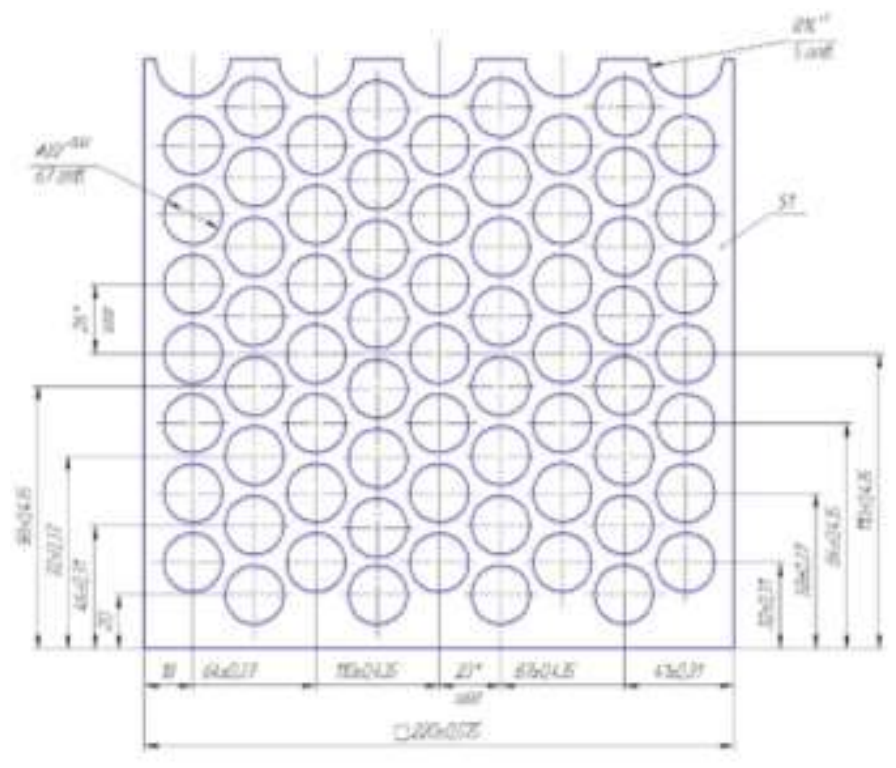

a)

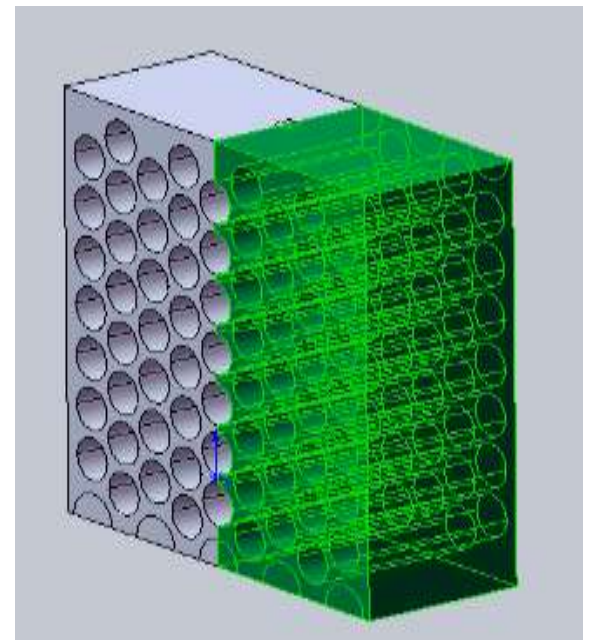

b)

Figure 7. Option structural design of the heat accumulator:

a) - working drawing of the partition; $b$ ) - spatial model of one section.

We carried out the modeling of hydrodynamic and thermal processes taking place inside the heat accumulator. Calculations at this stage are convenient to perform in CFD-systems, with a variety of choices from many possible CAD-layouts. Fig.8 presented the finite element model of one section, taking into account the symmetry and the scheme of fluid supply.

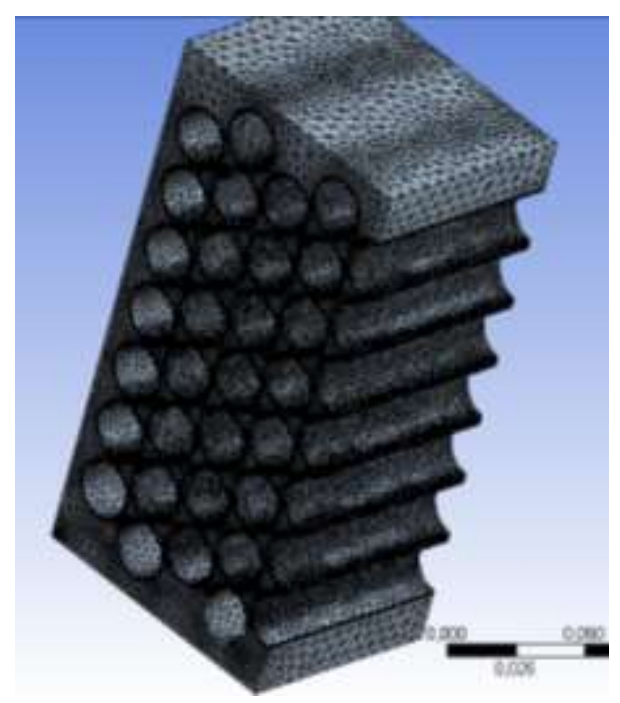

a)

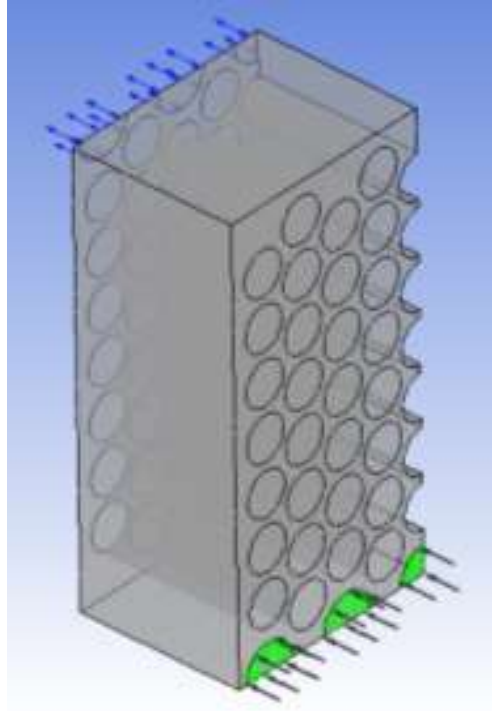

b)

Figure 8. Finite element model of one section (a) taking into account the symmetry and the scheme of fluid supply. 
In this option, the liquid moves in the vertical direction through virtually rectilinear channels formed by the space between the capsules (Fig. 9). This arrangement is characterized by low hydraulic resistance and a high fluid flow rate. This has a positive effect on the performance of the electric circulation pump but leads to uneven distribution of coolant flows within the volume of the heat accumulator. In fig. 9 arrow shows the undesirable increased flow along the wall, which accounts for $30 \%$ of the total consumption.

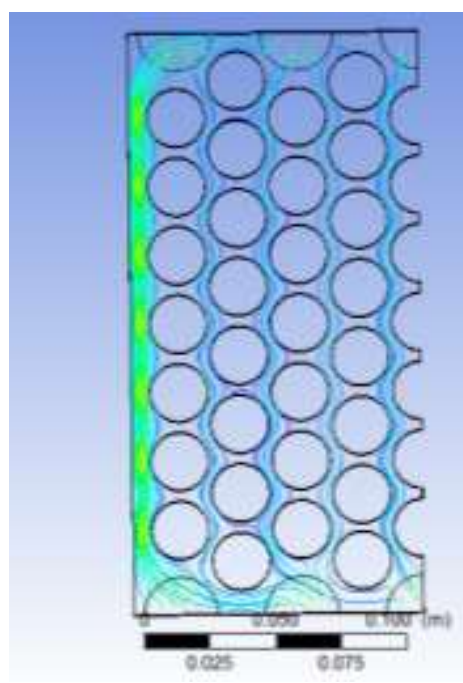

a)

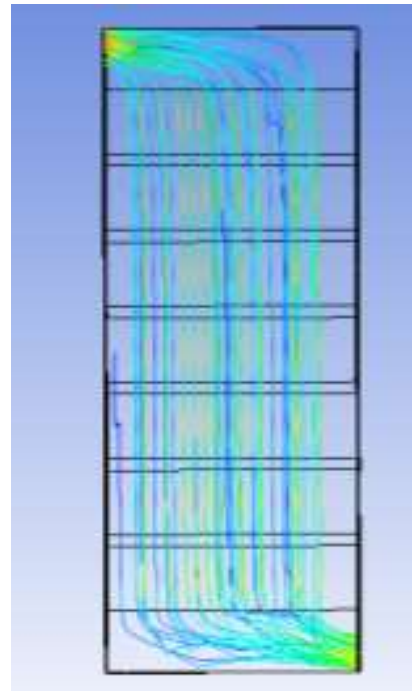

b)

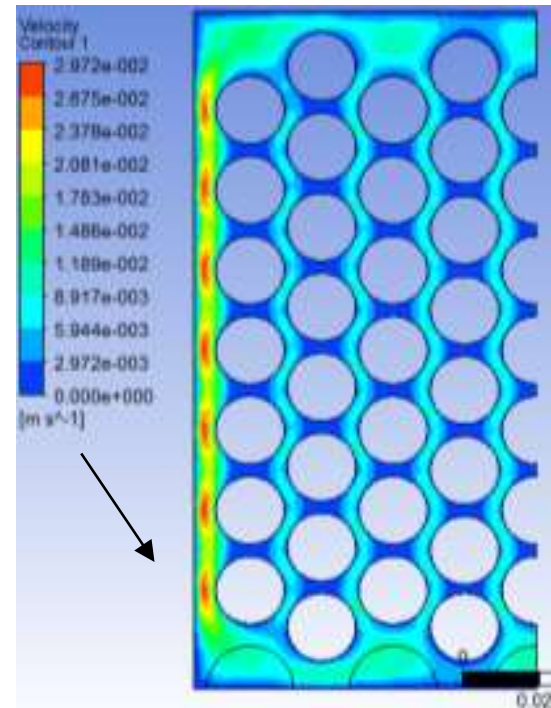

c)

Figure 9. The results of modeling the current line in the cross section $(a)$ and longitudinal section $(b)$ and the distribution of velocities in the cross section $(c)$.

The surface area may not be sufficient for efficient heat transfer. To reduce the effect of near-wall flow, it is advisable to close the supply through the extreme lumens in the septum (Fig. 10). However, this solution only partially solves the problem. The total pressure drop is $320 \mathrm{~Pa}$. 




a)

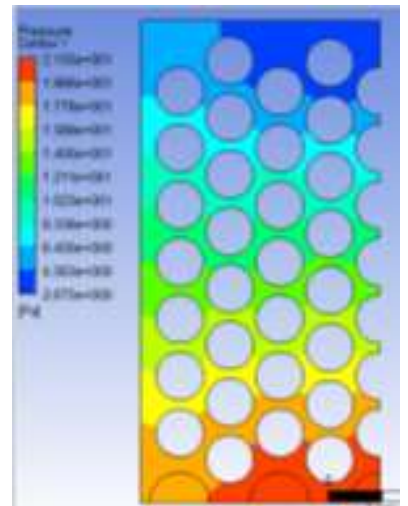

b)

Figure 10. The results of modeling the distribution of velocities $(a)$ and pressure $(b)$ in the cross section when feeding only through the central lumens.

As a result, a laminar flow regime is observed in the entire volume of liquid at a given flow rate $(3 \mathrm{l} / \mathrm{min})$. We performed thermal calculation for a fully and evenly charged heat accumulator in the phase transition mode in all tubes (Fig. 11). The phase transition temperature was thus set on the surface of the tubes (it is assumed that the heat of the phase transition is consumed over a period of time longer than the time of the liquid particle in the sections; in this case the phase transition temperature is $78^{\circ} \mathrm{C}$ ). Ambient temperature $-10{ }^{\circ} \mathrm{C}$. Thermal insulation of the casing of the heat accumulator - expanded polystyrene $\left(\mathrm{K}=0.8 \mathrm{~W} / \mathrm{m}^{2} \mathrm{~K}\right)$ on all perimeter $50 \mathrm{~mm}$ thick. The liquid (tosol cooling agent) is fed at a temperature of $0{ }^{\circ} \mathrm{C}$ (antifreeze parameters are taken for the worst conditions - viscosity and density correspond to a temperature of $0{ }^{\circ} \mathrm{C}$ ).

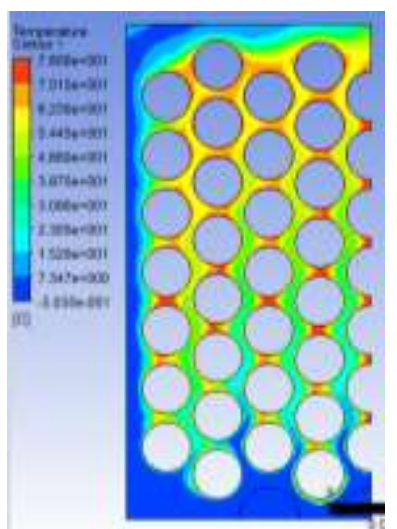

a)

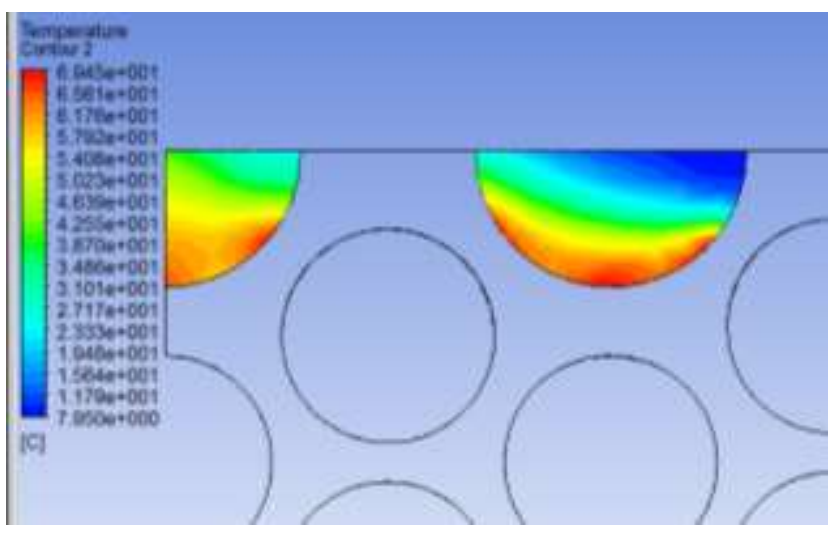

b)

Figure 11. Temperature field in the cross section $(a)$ and at the exit $(b)$. 
Thus, at a tube temperature of $78{ }^{\circ} \mathrm{C}$ (phase transition for barium hydroxide octahydrate), ambient temperature $-10{ }^{\circ} \mathrm{C}$, tosol cooling agent temperature at the inlet to the section $0{ }^{\circ} \mathrm{C}$ and the specified insulation temperature of the coolant at the outlet of the heat accumulator averaged $40{ }^{\circ} \mathrm{C}$. Along the entire wall, the negative impact of the wall-flow is noticeable - the liquid with low temperature reaches the outlets. Thus, to get rid of unwanted near-wall flow and flow equalization in general, a simple overlap of the extreme inlets in the partition is not enough.

To solve the problem, option 2 is considered, which assumes a checkerboard arrangement of tubes across the flow (Fig. 12). We modeled the section completely due to the lack of a vertical plane of symmetry, which can be attributed to the disadvantages of this arrangement, as there will be thermal asymmetry.

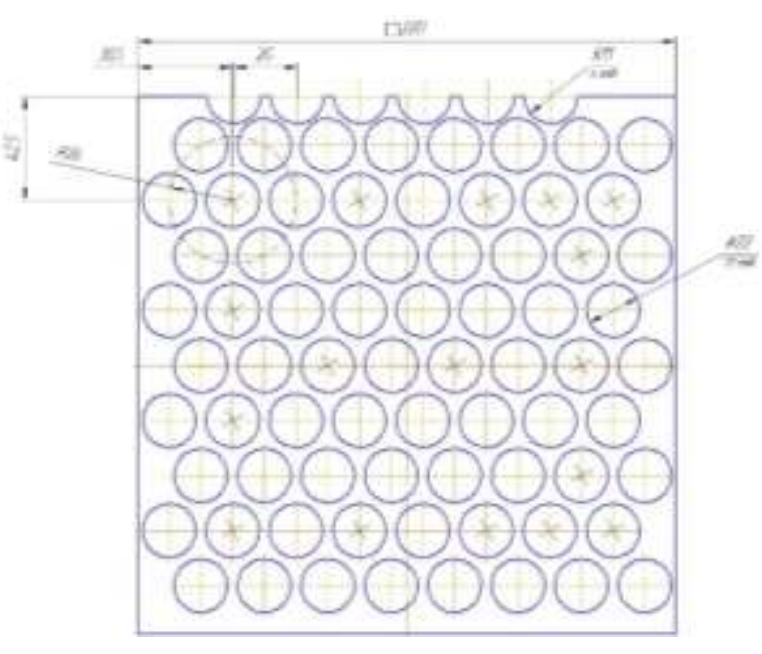

a)

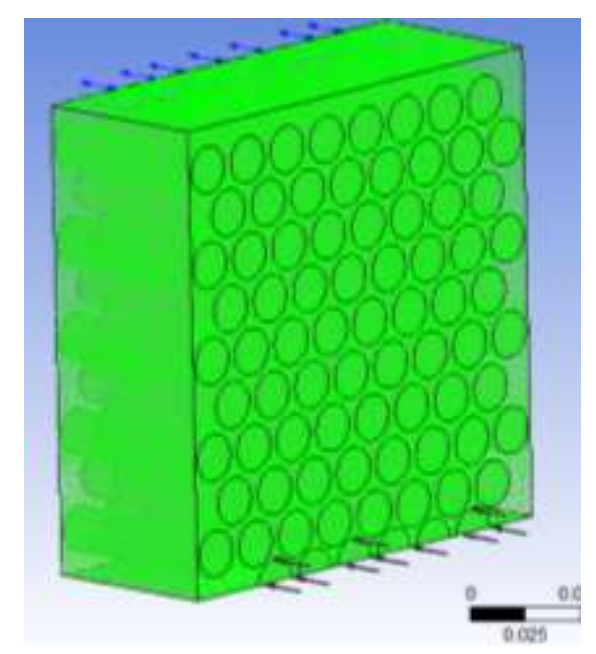

b)

Figure 12. The design of the development model:

a) - working drawing of the partition; $b$ ) - finite element model of the tubule section.

At such arrangement more uniform distribution of a stream in section and absence of a near-wall stream in comparison with option 1 (Fig. 13) is appreciable. The total pressure drop is $300 \mathrm{~Pa}$. 


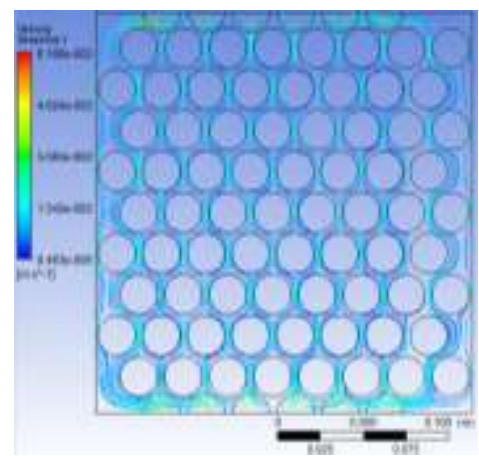

a)

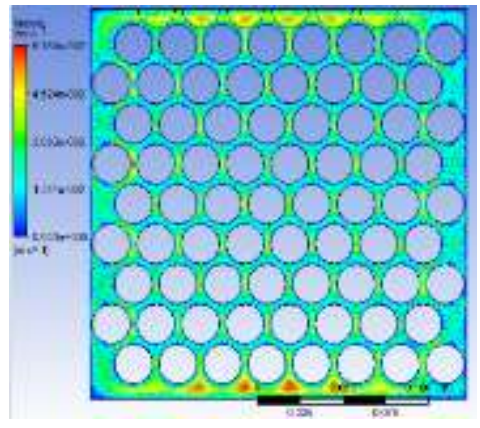

b)

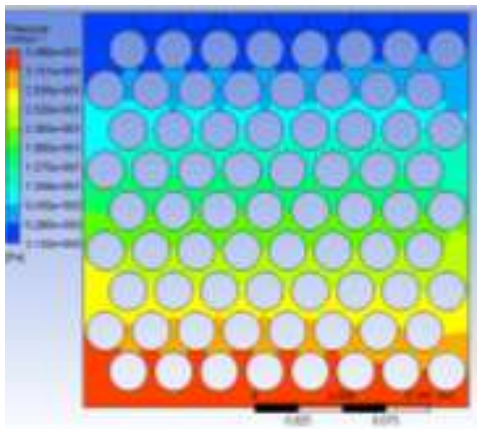

c)

Figure 13. Flow lines $(a)$, distribution of velocities $(b)$ and pressures $(c)$ in cross section.

In addition, this arrangement is characterized by the absence of speed differences with a slight decrease in pressure drop. The result is more favorable conditions for heat transfer - no stagnant zones, more uniform temperature distribution across the crosssection (Fig. 14).

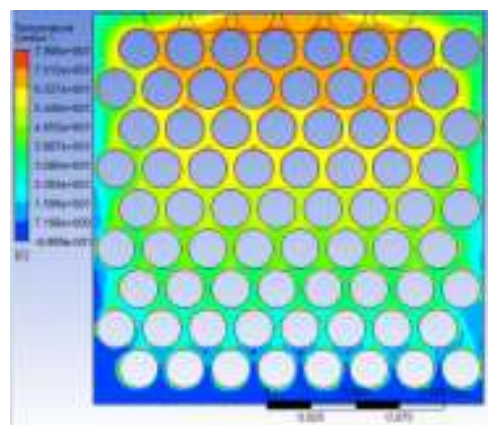

a)

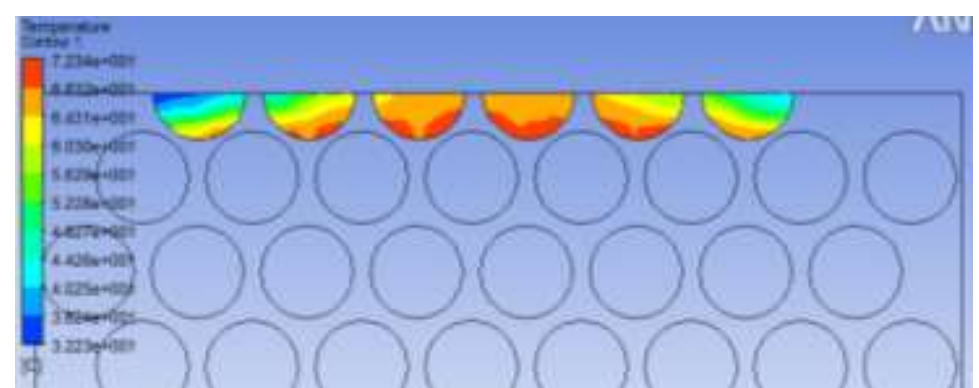

b)

Figure 14. Temperature field in the section $(a)$ and at the exit from it $(b)$.

The input simulation parameters (properties of substances and cost characteristics) fully correspond to the previous scheme. As a result, at a tube temperature of $78{ }^{\circ} \mathrm{C}$ (phase transition of barium hydroxide octahydrate), ambient temperature $-10{ }^{\circ} \mathrm{C}$, tosol cooling agent temperature at the inlet to the section $0{ }^{\circ} \mathrm{C}$ and appropriate insulation, the increase in outlet temperature averages $60{ }^{\circ} \mathrm{C}$. Thus, more heat is removed from the tubes in one pass, which corresponds to the heat transfer found in the section. However, there is a slight temperature asymmetry.

Further intensification of the heat transfer process is possible due to the use of material for the manufacture of capsules with a higher coefficient of thermal 
conductivity, as well as the creation of finning on their outer surface, which further turbulent flow.

Thus, preliminary CFD modeling of thermal preparation processes of internal combustion engines allows optimizing the design parameters of the equipment, to choose the appropriate solutions from many possible layouts, to calculate energy consumption at an early stage of design. This approach can be extended to individual calculations to determine the optimal layout of heat storage devices for a wide range of automotive equipment.

\section{The third stage is to conduct calculated studies of the dynamics of warming up}

\section{the engine elements.}

To determine the warm-up time of the engine with a heat accumulator requires detailed coordination of the hydrodynamic problem in the channels of the engine and heat transfer with the phase transition in the heat accumulator, which requires careful preparation of the heat accumulator model.

As is known, the Stefan condition is usually used on the basis of the heat balance for the phase separation surface [287]:

$$
\rho_{s o l} q_{n} \frac{\partial s_{n}}{\partial \tau}=\left.\lambda_{l i q} \frac{\partial T}{\partial n}\right|_{n \rightarrow+0}-\left.\lambda_{s o l} \frac{\partial T}{\partial n}\right|_{n \rightarrow-0},
$$

where $s_{n}$ - the displacement of the phase boundary in the normal direction $n, \tau$ - time, $T$ - the temperature, $q_{n}$ - the latent heat of fusion, $\lambda_{\text {liq }} \mathrm{i} \lambda_{\text {sol }}$-are the thermal conductivity coefficients of the liquid and solid phases, respectively.

In addition to this condition, the vast majority of Stefan-type problems use the condition of constant temperature at the interfacial boundary. However, in some cases, the simulation of the melting-freezing process of the working fluid is desirable to use the method of effective heat capacity [288] without explicit allocation of the position of the phase transition boundaries, with the calculation of convective heat transfer in the melt:

$$
c_{e f} \rho\left(\frac{\partial T}{\partial \tau}+\mathbf{v} \nabla T\right)=\nabla\left(\lambda_{e f} \nabla T\right)+q
$$


where $c_{e f}, \lambda_{e f}-$ effective values of heat capacity and thermal conductivity which take into account the heat of fusion in the Stefan's task [288], and the presence of convective heat transfer, $\mathbf{v}$-velocity field (convective currents), $q$ - power of internal heat sources, if they belong. To take into account the phase transition, the effective heat capacity includes a delta function and is represented as

$$
c_{e f}=c(T)+q_{n} \delta\left(T-T^{*}\right),
$$

where $\mathrm{T}^{*}$ - is the phase transition temperature.

In the numerical implementation in the finite temperature range $\Delta t$ for the phase transition point, the second term can be replaced by the expression $q_{n} / \Delta T$.

Some heat-accumulating substances are materials with strongly blurred boundaries of phase transformations solid-liquid. In these cases, the temperature interval of phase transformations can stretch by several degrees, so the temperature dependence of the specific heat $c=c(T)$ is used which in the phase transition have one or more peaks (Fig. 15), and the phase transition region is not a surface, it is a sphere [289]. It is also possible the presence of supercooling during crystallization which for example is characteristic of crystal hydrates without forming solid particles of additives [290] but in practice the account of this phenomenon is rarely performed.

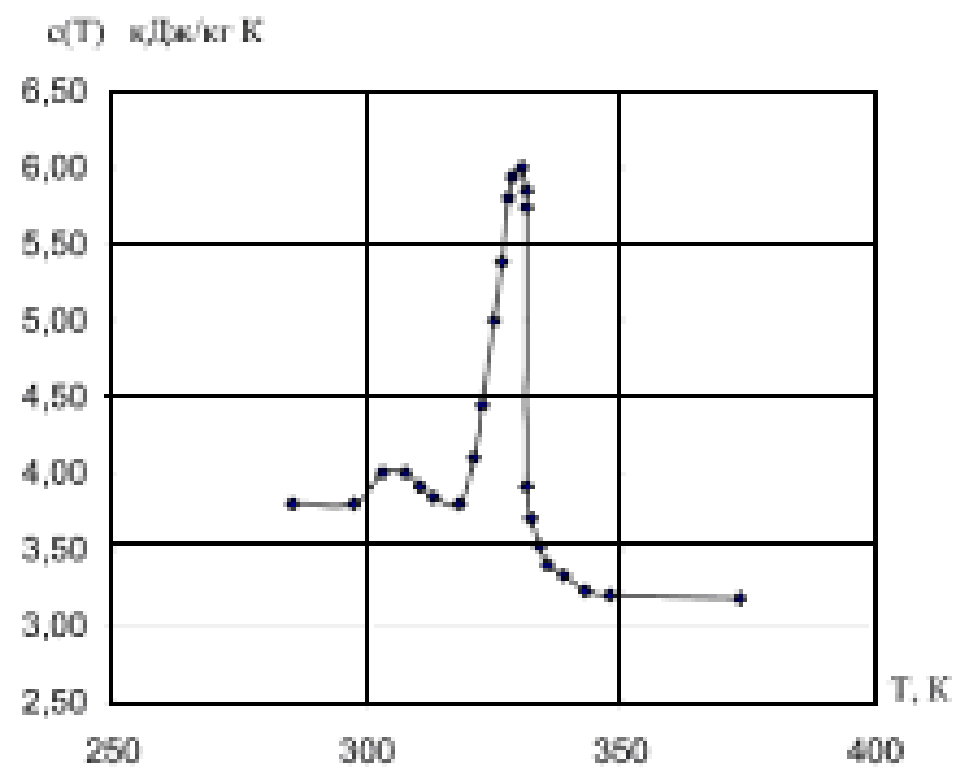

Figure 15. Heat capacity curve according to the method of effective heat capacity. 
We performed numerical calculations of the system engine-circulating fluidheat storage material-environment in two stages. In the first stage, the parameters of thermal resistance in the engine system and piping system (Fig. 16) for different coolant temperatures were calculated by the finite-volume method in the CFD system. In the second stage the problem was numerically solved by the method of equivalent thermal circuits [291].

We perform this division of the task into stages to reduce the need for computational resources. The complete finite-volume model of the system requires the significant computing capacity, and therefore it is advisable to perform calculations of the complete system in the relevant CFD programs at the final stage.

The system of equations of thermal state for each section has the form:

$$
\begin{aligned}
& C_{1} \frac{d T_{1}}{d \tau}+\Lambda_{11}\left(T_{1}-T_{2}\right)+\Lambda_{12}\left(T_{1}-T_{3}\right)+\Lambda_{13}\left(T_{1}-T_{e t}\right)=P_{1}, \\
& C_{2} \frac{d T_{2}}{d \tau}+\Lambda_{21}\left(T_{1}-T_{2}\right)+\Lambda_{22}\left(T_{1}-T_{3}\right)+\Lambda_{23}\left(T_{1}-T_{e t}\right)=P_{2}, \\
& \ldots,
\end{aligned}
$$

or in matrix form:

$$
[C] \cdot \dot{\mathbf{T}}+[\Lambda] \cdot \mathbf{T}=\mathbf{P},
$$

where $[C]$ - the matrix of heat capacities (diagonal), $\mathbf{T}-$ is the temperature column of the nodes, $T_{e t}-$ the environment temperature, $[\Lambda]-$ the matrix of thermal conductivities, and $\mathbf{P}$ - the power vector of heat sources. The heat capacity corresponding to the heat accumulating substance is given by the piecewise function in accordance with the method of effective heat capacity.

From this perspective, the system of equations of thermal state for each section has the form: 


$$
\begin{aligned}
& m_{1} c_{1} \frac{d T_{1}}{d t}=-k_{12}\left(T_{1}-T_{2}\right) F_{12}-k_{10}\left(T_{1}-T_{e .}\right) F_{13}, \\
& m_{2} c_{2} \frac{d T_{2}}{d t}=-k_{12}\left(T_{2}-T_{1}\right) F_{12}-k_{20}\left(T_{2}-T_{e .}\right) F_{20}-k_{23}\left(T_{2}-T_{3}\right) F_{23}, \\
& m_{3} c_{3} \frac{d T_{3}}{d t}=-k_{23}\left(T_{3}-T_{2}\right) F_{23}-k_{30}\left(T_{3}-T_{e}\right) F_{30},
\end{aligned}
$$

where $T_{1}, T_{2}, T_{3}$ - respectively the temperature (average of the volume in the system) of the heat storage material, engine coolant and engine;

$m_{1}$ - mass of heat storage material, $m_{2}$ - mass of cooling fluid involved in heat transfer (for different cycles is different), $m_{3}$ - payload mass of the engine (involved in heat transfer);

$c_{1}, c_{2}, c_{3}$,- corresponding to the heat capacity, while $c_{1}$ is given by the method of effective heat capacity as a piecewise function in the form;

$-k_{12}\left(T_{1}-T_{2}\right) F_{12}$ - heat current from the material to the cooling fluid (and the corresponding heat transfer coefficient and surface area);

$-k_{10}\left(T_{1}-T_{e .}\right) F_{10}$ - heat current from the material into the environment through the walls of the heat exchanger (and the corresponding heat transfer coefficient and surface area);

$-k_{20}\left(T_{2}-T_{e}\right) F_{20}$ - heat current from the material to the environment through the connecting pipes (and the corresponding heat transfer coefficient and surface area); $-k_{23}\left(T_{2}-T_{3}\right) F_{23}$ - heat current from the cooling fluid to the engine (and the corresponding heat transfer coefficient and surface area);

$-k_{30}\left(T_{3}-T_{e}\right) F_{30}-$ heat current from the engine to the environment through its surface.

Boundary conditions $\mathrm{T}_{1}\left({ }^{\circ} \mathrm{C}\right)$ - the temperature of the heat storage material after standing, $\mathrm{T}_{2}\left({ }^{\circ} \mathrm{C}\right)$ - initial temperature of cooling fluid (in calculations as average between the engine and material, but the arbitrary choice is also proportional to the ratio of volumes in the engine and in the heat exchanger), $\mathrm{T}_{3}\left({ }^{\circ} \mathrm{C}\right)-$ initial engine temperature (it takes as environment temperature). 
We performed the calculation for the engine model using Maple computer programs according to the following finite-difference scheme:

$$
\begin{aligned}
& T_{1, i+1}=T_{1, i}-\frac{1}{m_{1} c_{1}}\left[k_{12}\left(T_{1, i}-T_{2, i}\right) F_{12}+k_{10}\left(T_{1, i}-T_{e n v_{i}}\right) F_{13}\right] \Delta t, \\
& T_{2, i+1}=T_{2, i}-\frac{1}{m_{2} c_{2}}\left[k_{12}\left(T_{2, i}-T_{1, i}\right) F_{12}+k_{20}\left(T_{2, i}-T_{e n v_{i}}\right) F_{20}+k_{23}\left(T_{2, i}-T_{3, i}\right) F_{23}\right] \Delta t, \\
& T_{3, i+1}=T_{3, i}-\frac{1}{m_{3} c_{3}}\left[k_{23}\left(T_{3, i}-T_{2, i}\right) F_{23}+k_{30}\left(T_{3, i}-T_{e n v_{i}}\right) F_{30}\right] \Delta t,
\end{aligned}
$$

where $i$-iteration number by time.

Numerical calculations of engine warm-up by discharging the heat accumulator according to the above method for substances with blurred (kinds of paraffin, Fig. 16, a) and delta-like phase transition (Fig. 16, b) have characteristic areas of phase transition.

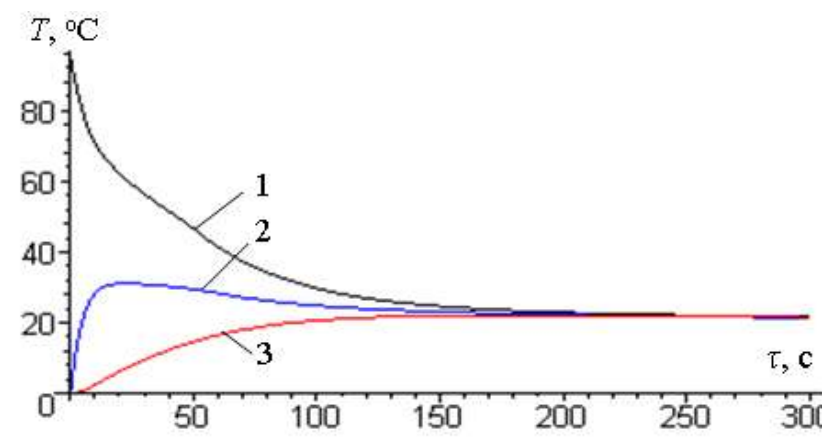

a)

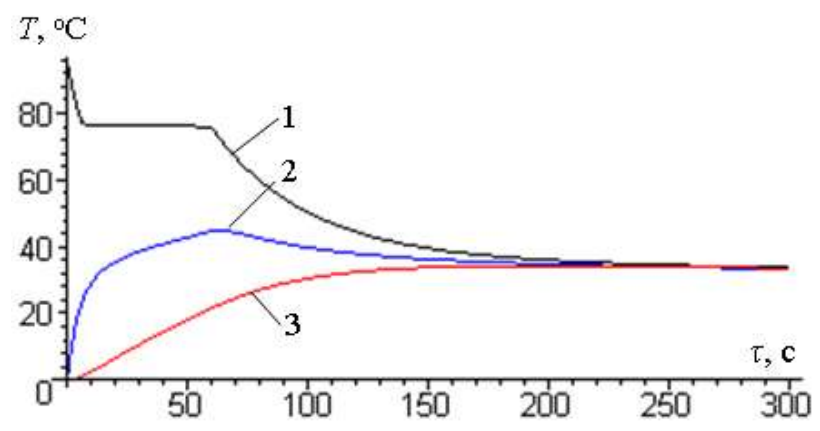

b)

Figure 16. The results of numerical calculations of engine warm-up by discharging the heat accumulator;

a) for substances with blurred (model substance - kinds of paraffin),

$b$ ) for substances with a delta-like phase transition (according to data for crystal hydrates).

1 - discharging of heat-accumulating substance, 2 - heating of coolant, 3 warming up of the engine.

The calculation of the warming dynamics of the engine elements allowed to determine the warm-up time of the engine with a heat accumulator, and the calculation results are in good agreement with experimental data, and the model can be used to select design parameters of heat accumulators. 
In fig. 17, $a-b$ presents the results of solving the system of equations (13) for a four-cylinder engine, heat accumulator, and circulation system using different design solutions TA in the second stage.

We performed the calculations under the conditions specified in the table. 1.

Table 1. Conditions for experiments

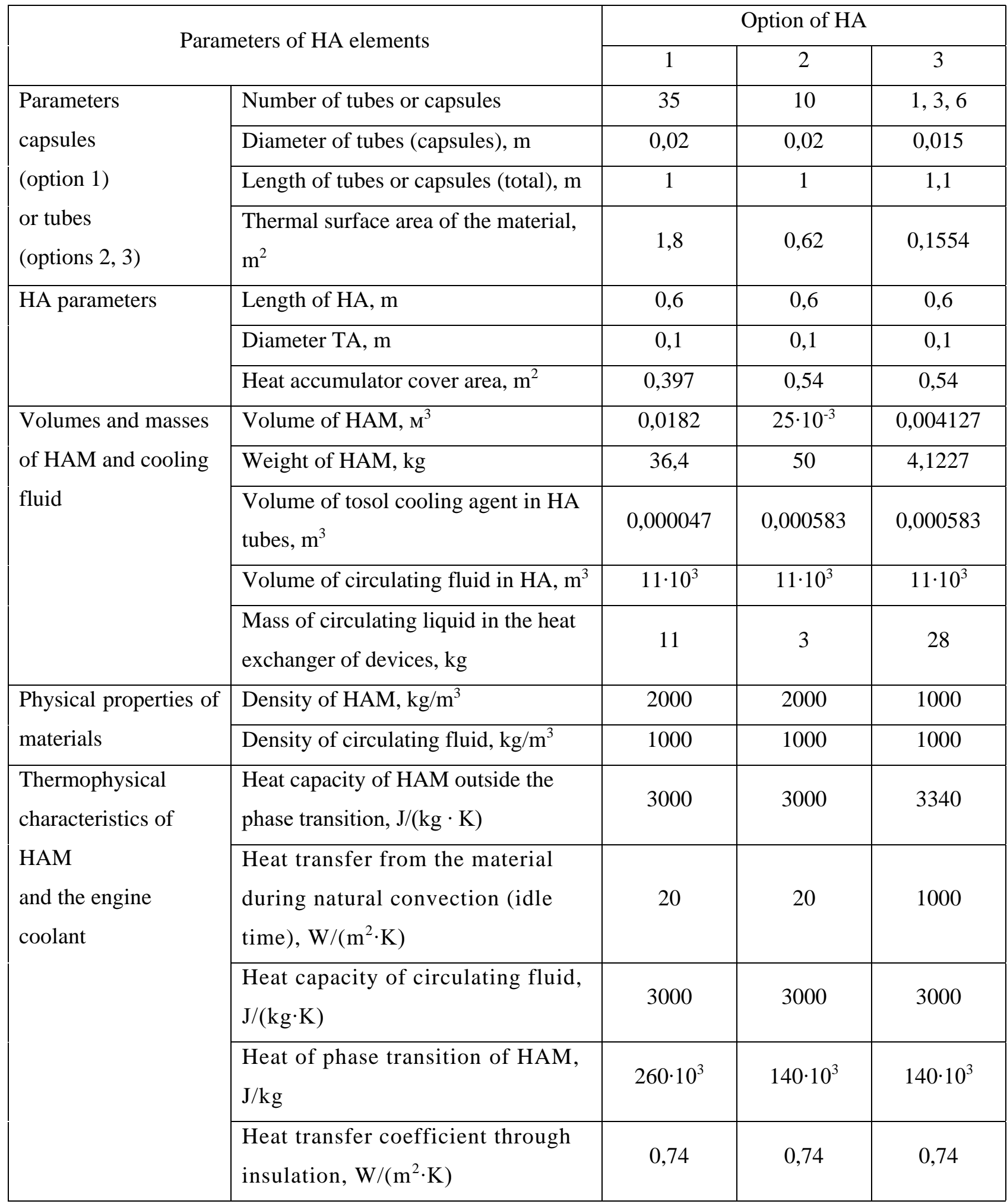




\begin{tabular}{|c|c|c|c|c|}
\hline & $\begin{array}{l}\text { Heat transfer coefficient to the } \\
\text { environment, } \mathrm{W} /\left(\mathrm{m}^{2} \cdot \mathrm{K}\right)\end{array}$ & 10 & 10 & 10 \\
\hline & $\begin{array}{l}\text { Phase transition temperature of HAM, } \\
{ }^{\circ} \mathrm{C}\end{array}$ & 78 & 78 & \\
\hline \multirow[t]{7}{*}{ Engine parameters } & $\begin{array}{l}\text { The volume of circulating fluid in the } \\
\text { engine, l }\end{array}$ & 28 & 18 & 28 \\
\hline & Engine surface area (external), $\mathrm{m}^{2}$ & 2,7 & 2,7 & 2,7 \\
\hline & Engine surface area (internal), $\mathrm{m}^{2}$ & 2.2 & 2.2 & 2.2 \\
\hline & $\begin{array}{l}\text { Weight of the engine (involved in } \\
\text { heat transfer), } \mathrm{kg}\end{array}$ & 640 & 170 & 250 \\
\hline & $\begin{array}{l}\text { Average heat capacity of the engine, } \\
\mathrm{J} /(\mathrm{kg} \cdot \mathrm{K})\end{array}$ & 550 & 550 & 550 \\
\hline & $\begin{array}{l}\text { The thickness of the insulation layer } \\
\text { (foam), mm }\end{array}$ & 50 & 50 & 50 \\
\hline & Ambient temperature, ${ }^{\circ} \mathrm{C}$ & -20 & -10 & -10 \\
\hline
\end{tabular}

\section{For option 1}
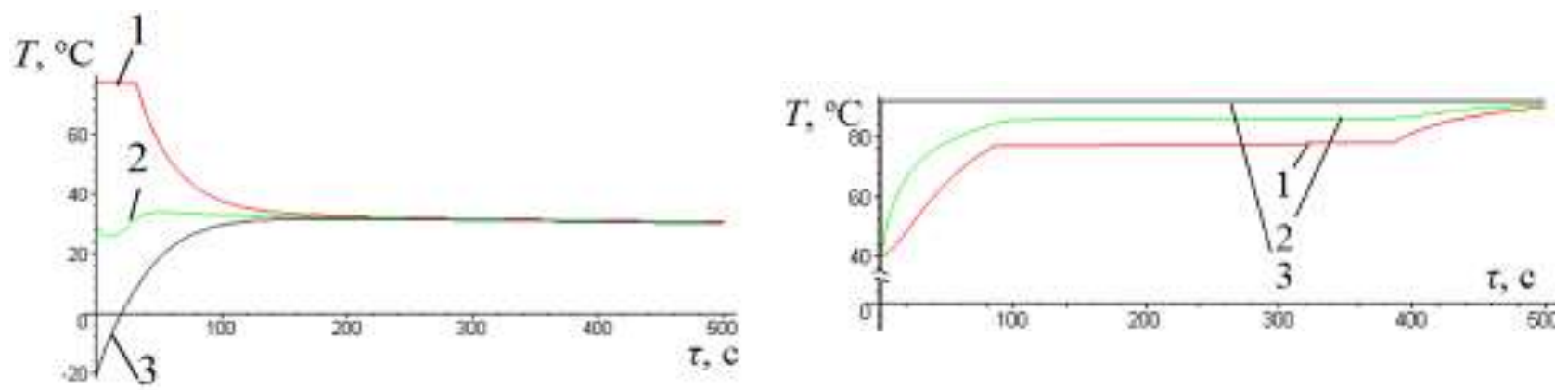

a)

b)

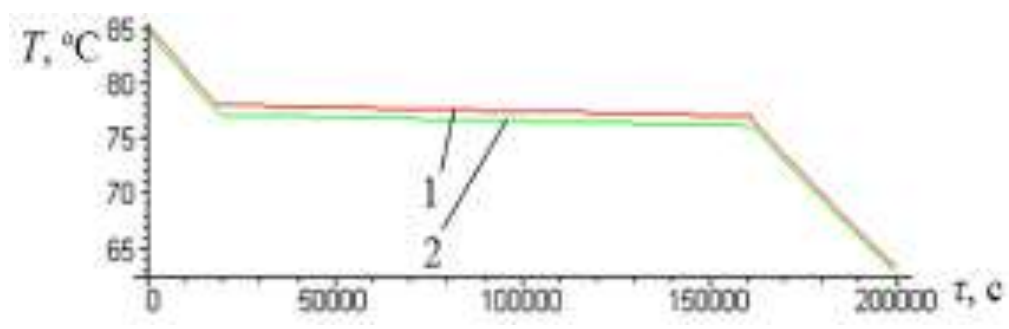

c)

Figure 17. The results of solving the system of equations (13) for a fourcylinder engine, heat accumulator, and circulation system using different design solutions of the HA in the second stage: 
a) - discharging of the heat accumulator at the standard mode of operation,

$b$ ) - charging from a warmed-up engine,

$$
\text { c) - idle of a charged battery. }
$$

1 - discharging of heat-accumulating substance, 2 - warming up of cooling liquid, 3 - warming up of the engine.

We have noticed from the results of calculations, the system with the specified parameters is acceptable for efficient heating for a satisfactory period of time of about $200 \mathrm{~s}$ (Fig. 17, a), charging from a warmed engine is about $500 \mathrm{~s}$ (Fig. 17, b), acceptable conditions for charging are maintained in the heat accumulator at correctly picked up thermal insulation within 2 days (Fig. 17, c).

\section{For option 2}

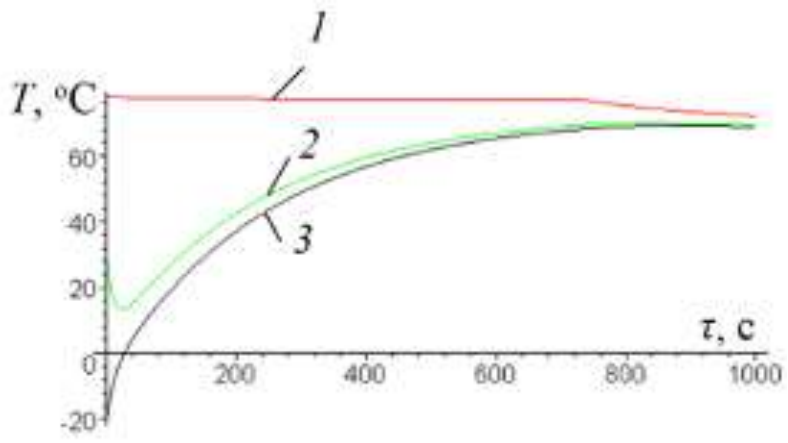

a)

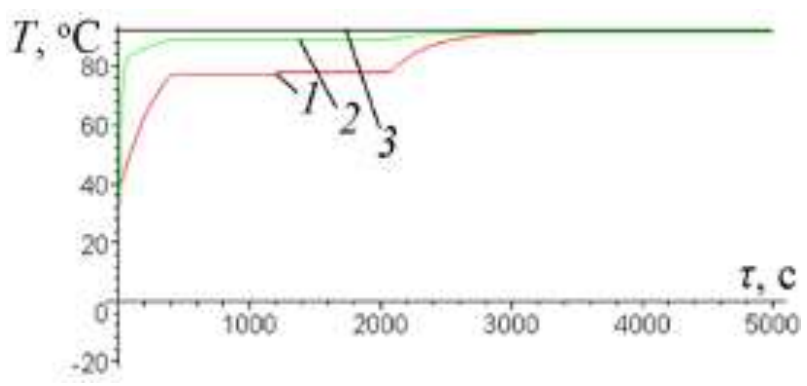

b)

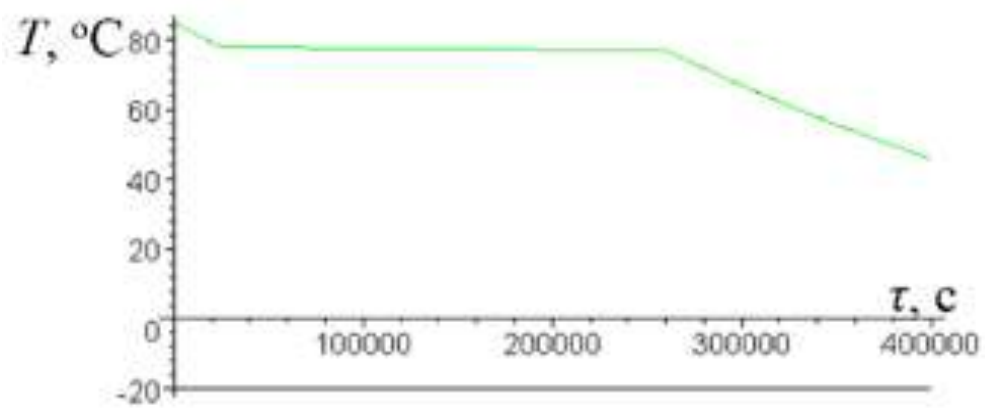

c)

Figure 18. The results of numerical calculations of the stages of thermal preparation of the internal combustion engine (the second option of the layout). The symbols are the same as for fig. 17.

As we see from the results of calculations, the system according to the second option is more suitable for efficient heating for a satisfactory period of time of about 
$600 \mathrm{~s}$ (Fig. 18, a), charging from a warmed engine is about $2000 \mathrm{~s}$ (Fig. 18, b), acceptable for charging conditions are stored in the heat accumulator at correctly picked up thermal insulation within 4 days (Fig. 18, c) that is twice more, than under the first option of execution of the heat accumulator.

\section{For option 3}

Below is the numerical solution of the system (13) for the model of the engine with HA for one, three, and six tubes (Fig. 19).

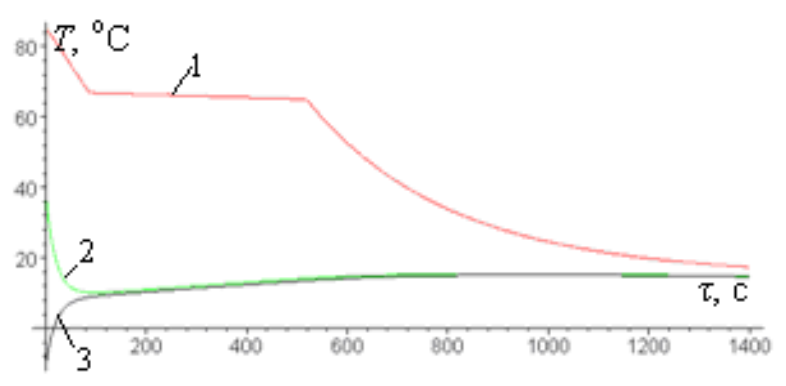

a)



c)

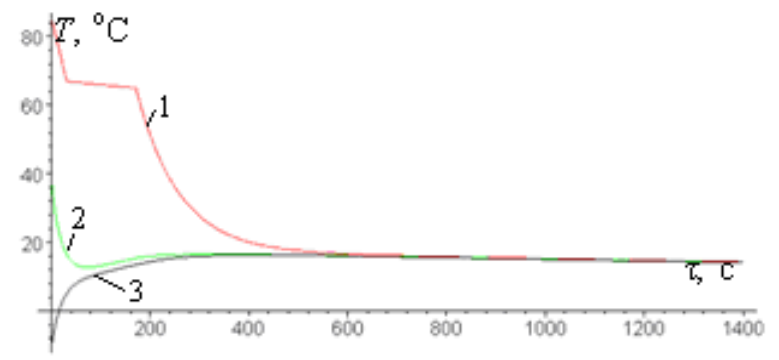

b)

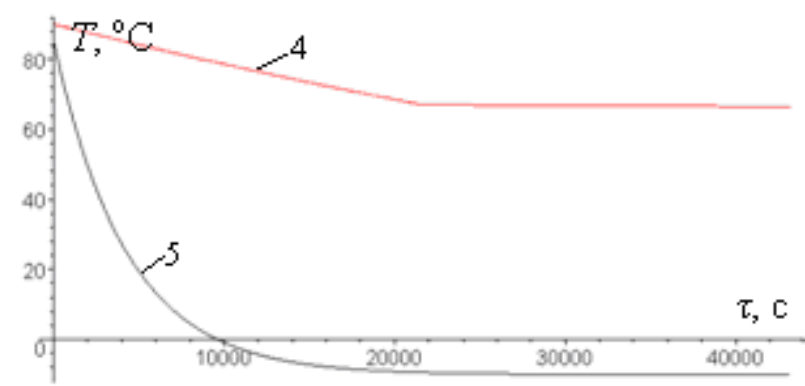

d)

Figure 19. The results of numerical calculations of the stages of thermal preparation of the internal combustion engine (the first version of the layout):

$a$ ) - the discharge process (1 U-shaped tube), b) - the discharge process

(3 U-shaped tubes), c) - the process of discharging (6 U-shaped tubes), d) - idle time of HA.

1 - discharging of the heat-accumulating substance, 2 - warming up of cooling liquid, 3 - warming up of the engine; 4 - liquid cooling;

5 - engine cooling. 
According to the results of calculations, we see that in terms of heating efficiency and economical efficiency in the perspective of metal consumption is the most profitable option for a heat accumulator with three tubes.

\section{The fourth stage is the creation of a bench model.}

At the last stage, we created a bench model with the implementation of field evidence. Here it is necessary to consider the basic requirements to the bench, namely, the bench should allow carrying out experiments:

— with different heat-accumulating materials, determining their efficiency (heat capacity, thermal conductivity, etc.) in conditions as close as possible to real;

- with various heat-insulating materials, determining the rate of self-discharge;

— with different shapes, sizes, and mutual arrangement of capsules, determining the rate of heat transfer (charging and discharging time of the heat accumulator);

— with different directions of fluid flow inside the heat accumulator to increase efficiency;

— determination of the insertion points of the heat accumulator pipes into the regular cooling system to ensure maximum efficiency.

We designed a bench (Fig. 20) to simulate the operation of the heat accumulator in real conditions. It consists of a heat accumulator, a pump that creates forced circulation of liquid, a full-size (complete) internal combustion engine, damper system to control fluid flow. 


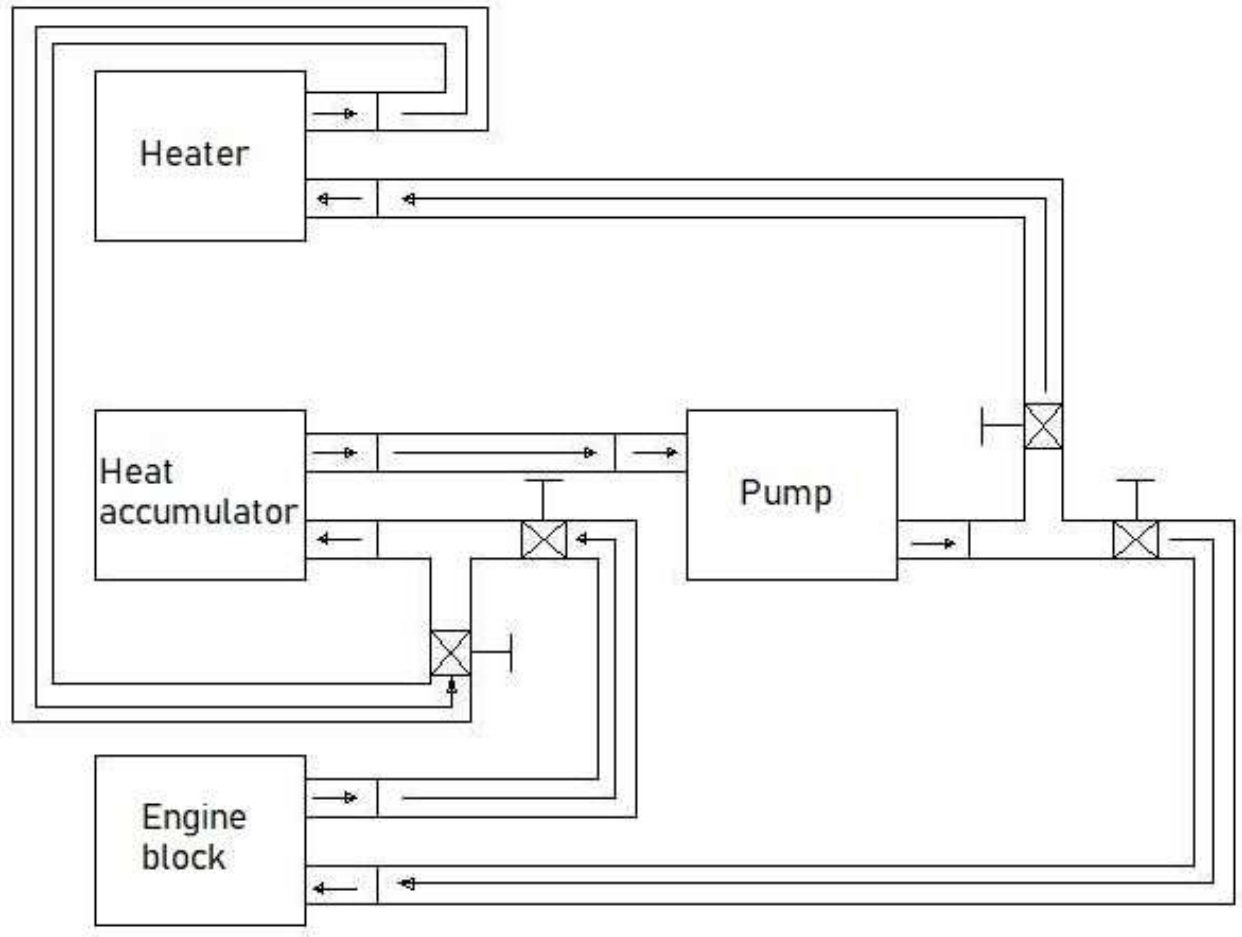

Figure 20. Bench to simulate the operation of the heat accumulator.

The heat accumulator in this scheme is a shell-and-tube heat exchanger with Ushaped tubes through which the tosol cooling agent moves, and in the intertube space, there is a heat-accumulating material ozokerite.

Heater - a capacity with a built-in tubular electric heater required to charge the battery. This unit allows us to simulate the operation of an internal combustion engine.

The initial stage of the experiment is the heating of the liquid in the heater and its circulation through the heat accumulator in order to melt the heat accumulating substance. We measured the temperature of the liquid in the heat accumulator at regular intervals to control the charging speed during the charging process. At the same time, gates prevent hit of the heated liquid in the engine. At the end of the charging process, the heating element is turned off, and we fed the liquid heated from the molten HAM to the internal combustion engine unit. The process continues until the onset of thermal equilibrium, which is characterized by the cessation of the increase in engine temperature. In the process of warming up, at regular intervals, the temperature of different parts of the engine unit is measured and a graph of the temperature change of 
this area over time is built. In addition, after the charging process was maintained for a period of time, simulating the process of heat storage.

The proposed stand was universal for experiments:

— with different heat-accumulating materials, determining their efficiency (heat capacity, thermal conductivity, etc.) in conditions as close as possible to real;

— with various heat-insulating materials, determining the rate of self-discharge;

— with different shapes, sizes, and relative positions of the tubes (or capsules in the case of the capsule version of the HA), determining the rate of heat transfer (charging and discharging time of the heat accumulator);

— with different directions of fluid flow inside the heat accumulator to increase efficiency;

— determination of the insertion points of the heat accumulator pipes into the regular cooling system to ensure maximum efficiency.

In fig. 21 shows the operation of the heat accumulator during bench tests (for the design according to option 3 ). We heated the heat accumulator by the electric heater 5 , in our case by $1.5 \mathrm{~kW}$. We performed the tests only after heating the heat-accumulating substance to a temperature of $80^{\circ} \mathrm{C}$. Cold liquid is contained in the storage tank 1 , from which after opening the tap 2 flows through pipeline 3 connecting the storage tank with the heat accumulator, passes through the heat accumulator 4 , and sequentially through pipeline 6 containing temperature control sensors $t_{2}$, $t_{3}$ enters the storage tank for heated substances 7 . 


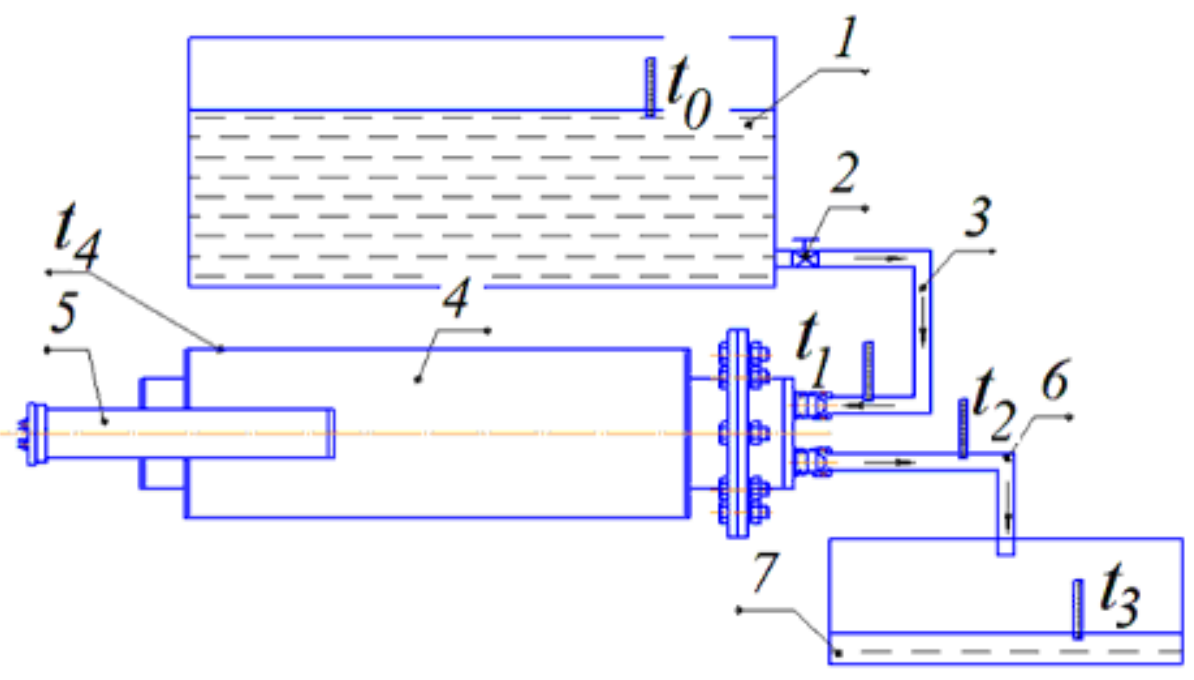

Figure 21. The bench scheme for testing HA.

1 - the storage tank with cold liquid, 2 - the crane, 3,6 - pipelines,

4 - the heat accumulator, 5 - electric heater, 7 - storage tank with the heated liquid.

We calculated the amount of heat from HAM to the liquid in one pass as

$$
Q=c_{l} G_{l}\left(t_{2}-t_{1}\right)
$$

where $c_{l}$ - heat capacity of the substance (water) $=4200 \frac{\mathrm{J}}{\mathrm{kg} \cdot \mathrm{K}}$;

$G_{l}$ - mass flow of liquid,

$$
G_{l}=V \rho,
$$

where $V$ - volume consumption; $\rho=1000 \mathrm{~kg} / \mathrm{m}^{3} ; V=\frac{300 \mathrm{ml}}{35 \mathrm{~s}}=0,0000857 \mathrm{~m}^{3}$.

$$
Q=4200 \cdot 0,00857(23-5)=647,89 \mathrm{~J} .
$$

The amount of heat lost to the environment is equal to:

$$
Q_{e n v}=\alpha\left(t_{4}-t_{e n v}\right) F,
$$

where $\alpha$ - heat transfer coefficient to the environment, W;

$F$ - the surface area of the heat interchanger shell $\left(0,32 \mathrm{~m}^{2}\right)$.

$$
Q_{\text {env }}=10(89-5) \cdot 0,32=268,8 \mathrm{~J} .
$$

Thus, we see the need for additional external insulation. 
We conducted the studies in the following sequence. Cold liquid (tosol cooling agent) with a temperature equal to the ambient temperature $t_{\text {env }}=5{ }^{\circ} \mathrm{C}$, under gravitational motion, passed through the tubular space of the heat accumulator, taking away the heat accumulated in HAM. In the first stage of the experiment, the temperature of HAM was maintained at a constant value of $t_{\mathrm{HAM}}=80^{\circ} \mathrm{C}$ due to the circulation of hot liquid (tosol cooling agent) in the shell. As a result, we obtained a set of values of fluid temperatures at the outlet after heat exchange, shown in the graph (Fig. 22 - the dependence of $\Delta T$ on time).

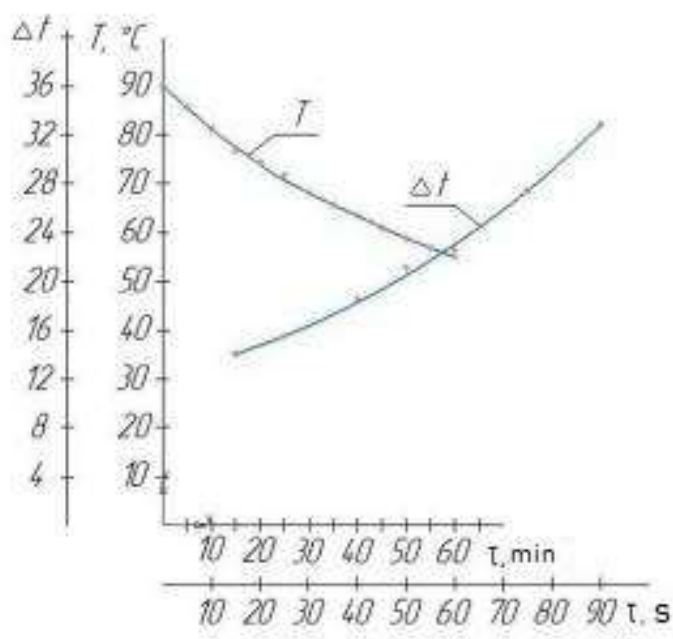

Figure 22. Graphs of temperature difference and HAM temperature change during cooling over time.

After conducting experiments and obtaining data, we can conclude that the volume of liquid $300 \mathrm{ml}$ in half a minute is heated to $15^{\circ} \mathrm{C}$. Given that each tube has one liter of coolant (total volume of 3 liters), we have heating of one liter for approximately $3 \cdot 0,5 \mathrm{~min}=1,5 \mathrm{~min}$ - one and a half minutes when the temperature changes by 15 degrees. Thus, three liters, which are the volume of a small cooling circuit, can be expected to warm up to $15^{\circ} \mathrm{C}$ in the same minute and a half when passing through three tubes. The temperature sufficient for an easy start-up can be expected, thus, in 3-4 minutes. 
The temperature of the heating element is $90{ }^{\circ} \mathrm{C}$, and the ambient temperature is $6{ }^{\circ} \mathrm{C}$. Depending on the difference in these temperatures, the time of complete phase transition of the heat-accumulating material varies from one to one and a half hours. Graph of cooling HAM without thermal insulation (Fig. 22, the dependence of $T$ on time).

Given the values of coolant temperatures obtained at the beginning of the experiment and the end, it becomes possible to predict changes in temperature over time and environmental conditions.

\section{Field tests and creation of the industrial design}

Further development of the design study, and operating conditions of the heat accumulator was the creation of an industrial design and testing of its operation.

In the proposed model of the heat accumulator as a heat-accumulating material of the phase transition was used ozokerite [melting point $56.5-76.0^{\circ} \mathrm{C}$ (in our case 67 ${ }^{\circ} \mathrm{C}$ ), specific enthalpy of melting (crystallization) $140.6 \mathrm{~kJ} / \mathrm{kg}$, density and specific heat at temperature $40{ }^{\circ} \mathrm{C}$ respectively $1076 \mathrm{~kg} / \mathrm{m}^{3}$ and $\left.3.151 \mathrm{~kJ} /(\mathrm{kg} \cdot \mathrm{K})\right]$; maintaining TAM in the molten state during engine operation was due to the heat of the coolant - tosol cooling agent, and heating and melting HAM in case of solidification after prolonged idle time was carried out using a tubular heating element (THE).

The experimental setup was a closed system of HA - a small circuit of the engine cooling system (ECS) of the car VAZ 2109 (Fig. 23).

The heat accumulator represents two coaxial cylindrical capacities. The inner storage tank is a shell-and-tube heat exchanger with U-shaped tubes through which the tosol cooling agent moves and the intertube space is filled with heat-accumulating material. The gap between the two cylinders contains a heat-insulating liquid (for example, water or antifreeze), there is a built-in the THE. 


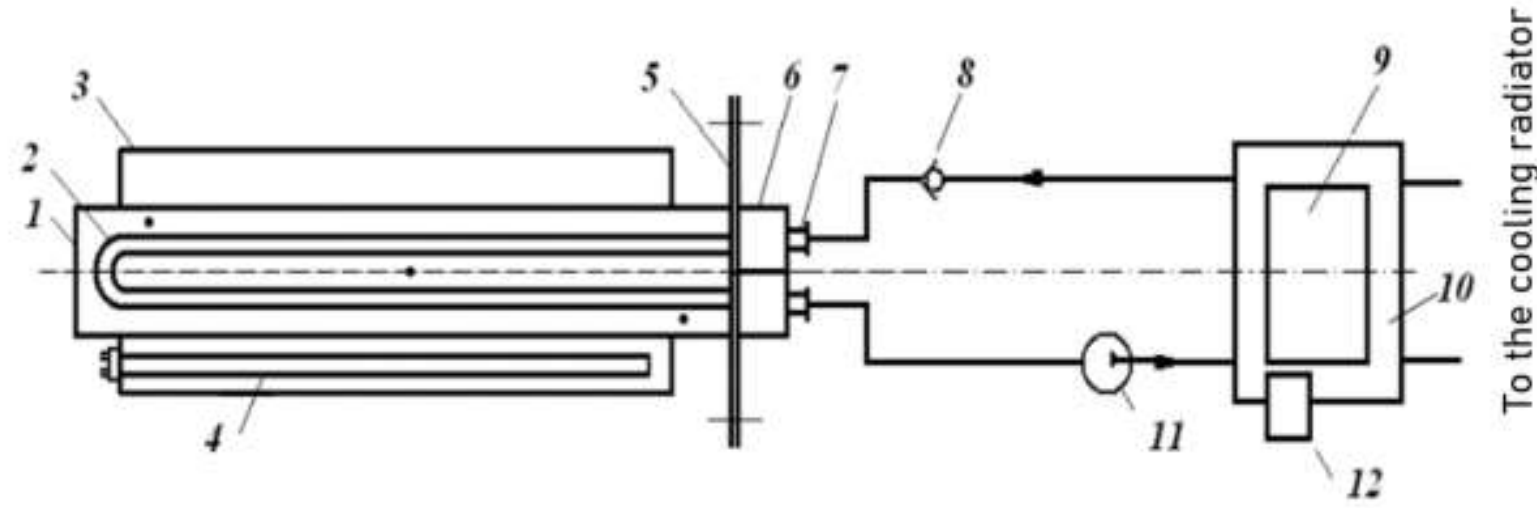

Figure 23. Experimental sample of the heat accumulator of the phase transition: 1 - cylindrical tank filled with ozokerite; 2 - U-shaped tube for tosol cooling agent circulating in the HA circuit - the engine cooling system (the number of tubes may vary); 3 - container filled with heat-insulating liquid;

4 - THE; 5 - pipe lattice; 6 - cover; 7 - branch pipes for input and output of tosol cooling agent; 8 - solenoid valves; 9 - engine; 10 - engine cooling shell; 11 - pump system of HA, 12 - engine cooling system pump.

Dots mark the places of the HAM temperature measurement.

The amount of antifreeze in the U-shaped tubes is additional to that of the tosol cooling agent contained in the small SOD circuit. Therefore, to maintain a constant volume of antifreeze in the cooling system in the absence of the need for TA (for example, when moving the car), the latter with the help of solenoid valves is removed from the ECS, and if necessary re-introduced.

The experimental sample of the heat accumulator has thermocouples to study the temperature changes of HAM and tosol cooling agent during the charging and discharging of the HA. Temperature measurement points of HA are shown in Fig. 1, the temperature of the tosol cooling agent was measured at the entrance to the outlet and out of it. We took average values of temperatures to plot. Charging of the HA is called heating HAM to a temperature close to the temperature of the running engine, and discharging - the end of the crystallization process of HAM. It should be noted 
that HAM can be cooled to ambient temperature when the stop engine for some time, which can also be used when the engine starts.

After obtaining experimental data on changes in ozokerite and tosol cooling agent temperatures over time, we determined the time required to charge and discharge the heat accumulator.

In fig. 24 shows the heating curves of HAM and tosol cooling agent from the warmed-up engine (charging of the HA). Ozokerite at a temperature below $67{ }^{\circ} \mathrm{C}$ is in the solid state. When the temperature rises to $67^{\circ} \mathrm{C}$, which occurs in about $100 \mathrm{~s}$, it begins to melt (horizontal section of line 3 ) and becomes liquid in $~ 300 \mathrm{~s}$, and then the liquid ozokerite is heated to the temperature of tosol cooling agent, which in turn is heated by the engine, cooling the latter.

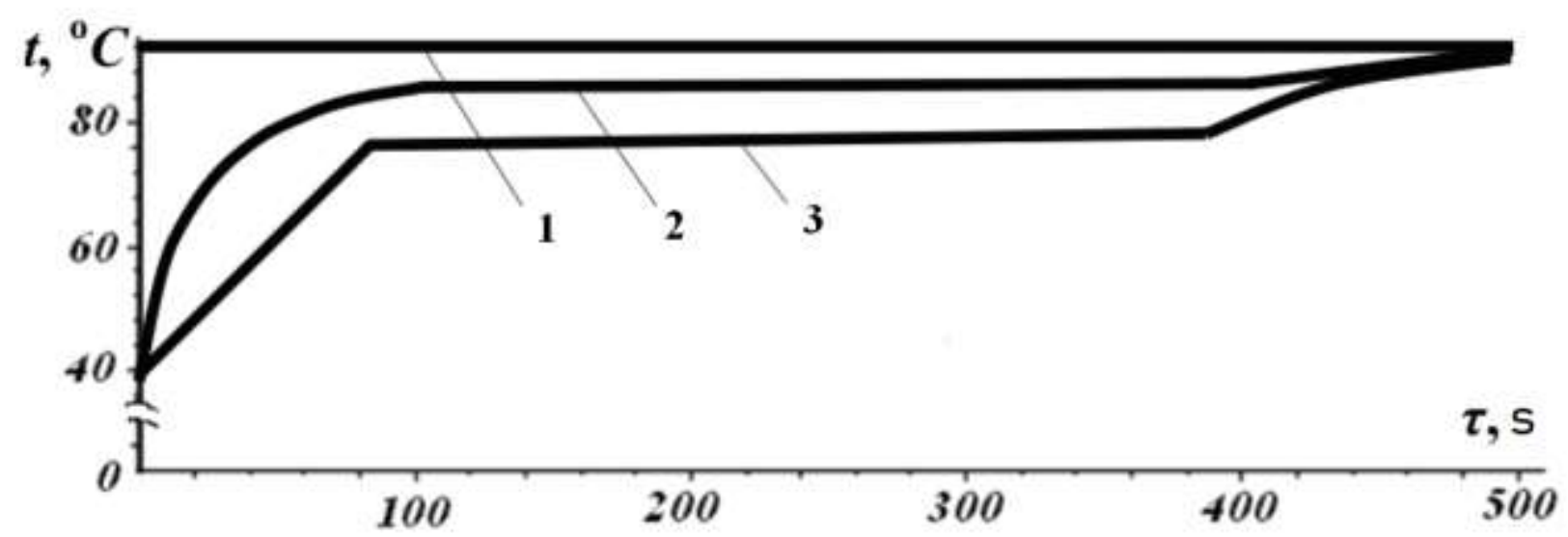

Figure 24. The HA charging and heating the tosol cooling agent from the warmed-up engine (car movement): 1 - engine temperature; 2 - tosol cooling agent temperature; 3 - HA temperature.

Thus, if the engine is already warmed up, it takes about $500 \mathrm{~s}$ or 8 minutes to charge the HA from a temperature of $40{ }^{\circ} \mathrm{C}$. This means that shortly before stopping 
the car, the heat accumulator must be included in the engine cooling system to charge it.

When it is necessary to start the engine, the pump of the HA system 11 is switched on. There is the mixing of the tosol cooling agent, which was in HA (its temperature is close to the crystallization temperature of HAM), with the rest of the tosol cooling agent, which was in the shell of the cooling system (temperature close to ambient temperature), while the tosol cooling agent temperature decreases. The resulting temperature of the tosol cooling agent depends on its mass (volume) and outside temperature. The volume of the tosol cooling agent in the HA can be adjusted by changing the number of U-shaped tubes (one tube had a volume of 0.2 liters). Thus, in our experiments, the number of tubes varied from 1 to 6 , and the volume, respectively, was from 0.2 liters to 1.2 liters.

Tables 2 and 3 show the calculations of the amount of heat given off by the tosol cooling agent in the heat accumulator and received by the tosol cooling agent from the ECS. Based on the heat balance, we determined the temperature of the mixture of two parts of tosol cooling agent - in HA ( $\left.t_{\text {тоs.HA }}\right)$ and in the shell of ECS ( $\left.t_{\text {Tos.eng. }}\right)$ (Table 2).

The temperature of tosol cooling agent in HA according to experimental data was $65^{\circ} \mathrm{C}$, the volume of tosol cooling agent in the cooling system in our experiments was 31 , the physical parameters of tosol cooling agent were taken at $40{ }^{\circ} \mathrm{C}$.

As a option of the already considered design solution, the design of a heat accumulator is proposed, in which water with a tubular electric heater immersed in it is in a single housing, and a phase-transient HAM, in the layer of which a liquid heat exchanger is placed.

A spiral (Fig. 25, a) or coil heat exchanger with coils located parallel (Fig. 25, $b$ ) or perpendicular (Fig. 25, $c$ ) to the axis of the heat accumulator is used as a liquid heat exchanger. 


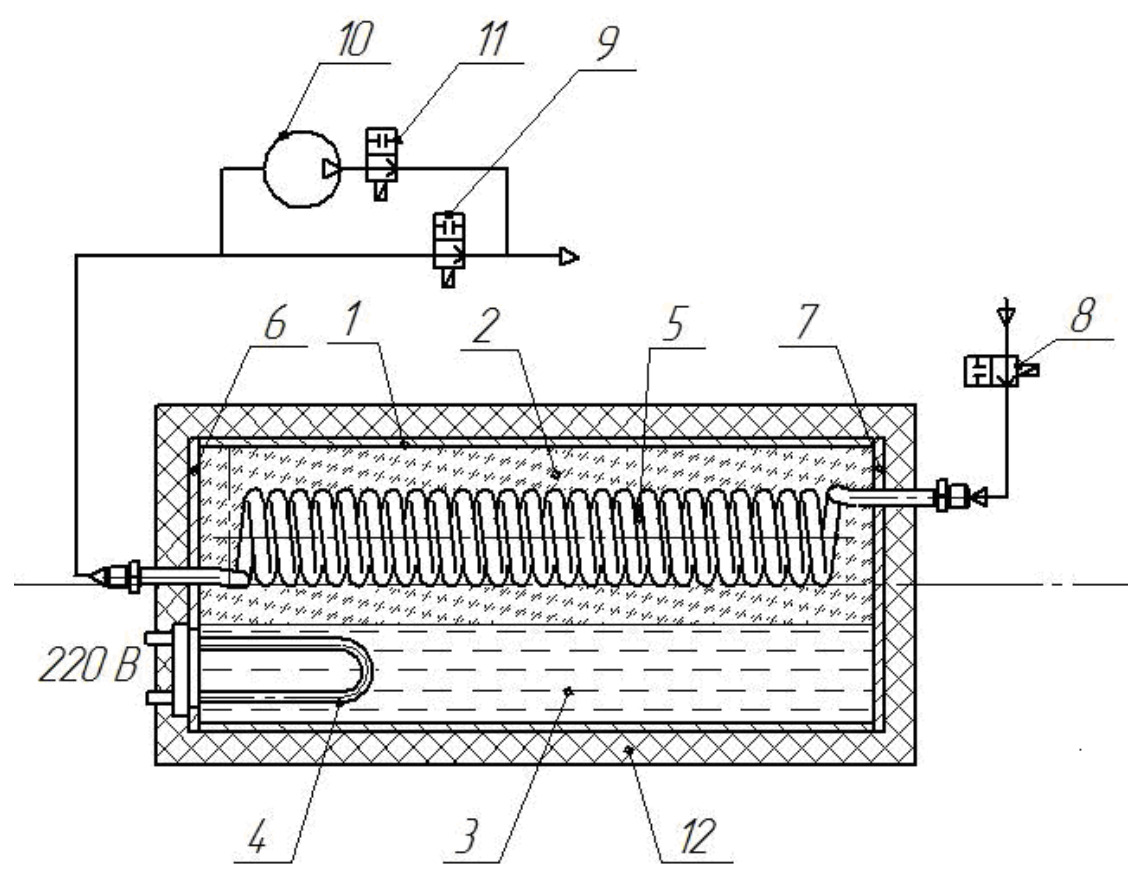

a)
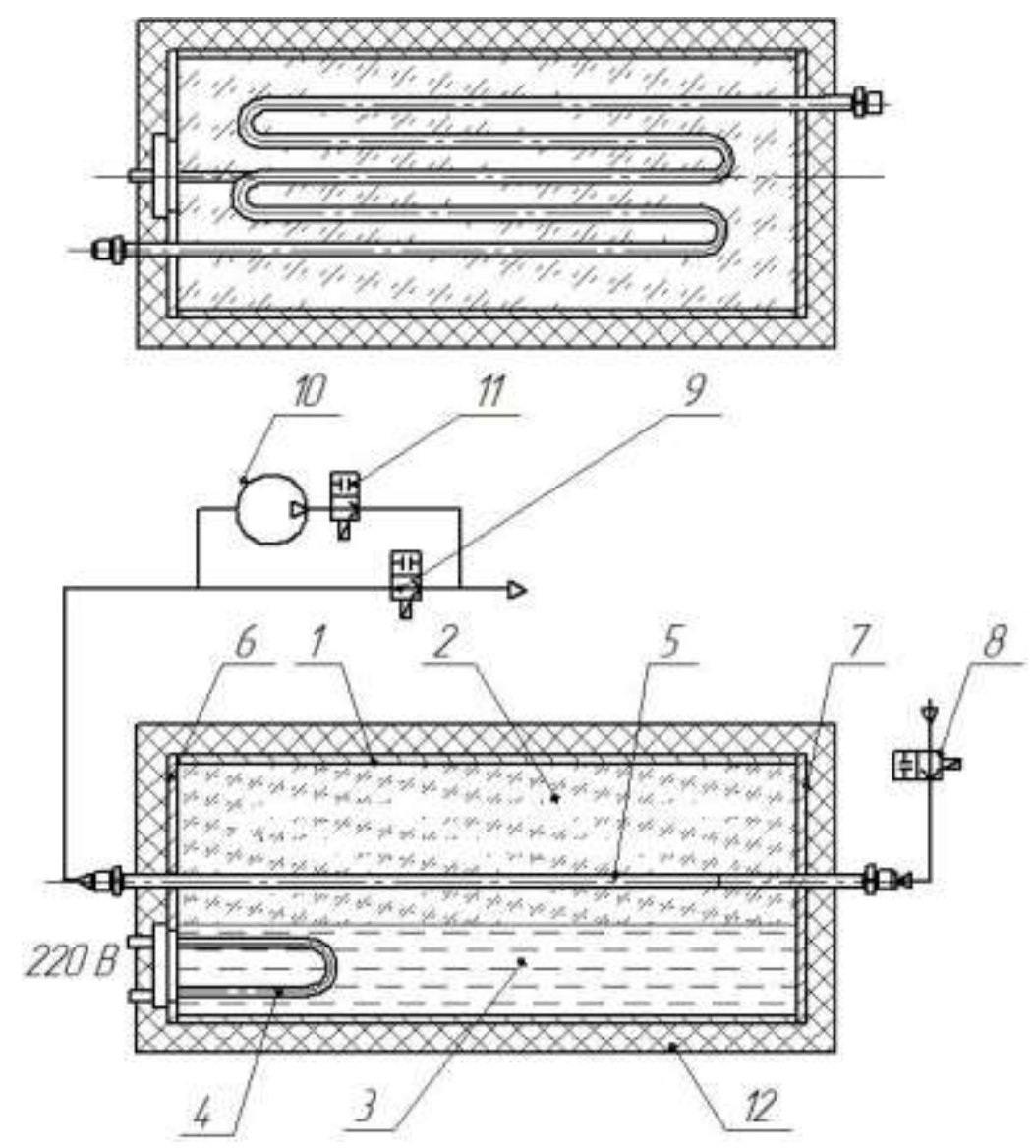

b) 




Figure 25. Heat accumulator:

a) - spiral; b) - coiled with convolutions of the heat exchanger, located parallel to the axis of HA; c) - coiled with convolutions of the heat exchanger, located perpendicular to the axis of HA.

1 - airtight casing; 2 - HAM; 3 - water; 4 - THE; 5 - the heat exchanger; 6, 7 pipe gratings; 8, 9, 11 - solenoid valves; 10 - pump; 12 - heat-insulating material. 
Table 2

The amount of heat given off by the tosol cooling agent in the heat accumulator depending on the weight of the tosol cooling agent

\begin{tabular}{|c|c|c|}
\hline $\begin{array}{c}\text { Tosol } \\
\text { temperature } \\
\text { in HA } \\
t_{\text {Tos.HA }}\end{array}$ & $\begin{array}{c}\text { Volume of } \\
\text { tosol in } \\
\mathrm{HA}, \mathrm{m}^{3}\end{array}$ & \\
\hline \multirow{3}{*}{65} & $1,2 \cdot 10^{-3}$ & $Q=c m\left(t_{\text {Tos.HA }}-t_{\text {Tos.eng. }}\right)=3,151 \cdot 1,2 \cdot 10^{-3} \cdot 1076\left(65-t_{\text {Tos.eng. }}\right)=264,46-4,07 t_{\text {Tos.eng }}$ \\
\cline { 2 - 3 } & $0,6 \cdot 10^{-3}$ & $Q=132,23-2,03 t_{\text {Tos.eng }}$ \\
\cline { 2 - 3 } & $0,2 \cdot 10^{-3}$ & $Q=44,08-0,68 t_{\text {ros.eng }}$ \\
\hline
\end{tabular}

Table 3

The amount of heat received by the tosol cooling agent in the engine cooling jacket, depending on the ambient temperature $\left(t_{\mathrm{ext}}\right)$

\begin{tabular}{|c|c|c|}
\hline$t_{\mathrm{ext}}$ & $\begin{array}{c}\text { The } \\
\text { amount } \\
\text { of tosol } \\
\text { in ECS, } \\
\mathrm{m}^{3}\end{array}$ & $Q, \mathrm{~kJ}$ \\
\hline 10 & \multirow{5}{*}{$3 \cdot 10^{-3}$} & $Q=c m\left(t_{\text {ros.eng. }-} t_{\text {ext }}\right)=3,151 \cdot 3 \cdot 10^{-3} \cdot 1076\left(t_{\text {ros.eng }}-10\right)=10,17 t_{\text {ros.eng. }}-101,71$ \\
\hline 5 & & $Q=3,151 \cdot 3 \cdot 10^{-3} \cdot 1076\left(t_{\text {ros.eng }}-5\right)=10,17 t_{\text {Tos.eng. }}-50,85$ \\
\hline 0 & & $Q=3,151 \cdot 3 \cdot 10^{-3} \cdot 1076\left(t_{\text {Tos.eng }}-0\right)=10,17 t_{\text {Tos.eng }}$ \\
\hline-5 & & $Q=3,151 \cdot 3 \cdot 10^{-3} \cdot 1076\left(t_{\text {Tos.eng }}+5\right)=10,17 t_{\text {ros.eng. }}+50,85$ \\
\hline-10 & & $Q=3,151 \cdot 3 \cdot 10^{-3} \cdot 1076\left(t_{\text {Tos.eng }}+10\right)=10,17 t_{\text {Tos.eng. }}+101,71$ \\
\hline
\end{tabular}

Solving the heat balance equation, we find the temperature of the tosol cooling agent depending on its volume in the HA and the ambient temperature. The calculation data are given in table. 4 .

Table 4

The temperature of the mixture of tosol cooling agent formed after mixing the tosol cooling agent in the HA with the tosol cooling agent of the engine cooling shell

\begin{tabular}{|c|c|c|c|c|c|}
\hline \multirow{2}{*}{$\begin{array}{c}\text { The amount of } \\
\text { tosol cooling agent } \\
\text { in the HA, 1 }\end{array}$} & 10 & 5 & 0 & -5 & -10 \\
\cline { 2 - 6 } & 25,7 & 22,1 & 18,6 & 15 & 11,4 \\
\hline 1,2 & 19,0 & 15,0 & 10,8 & 6,7 & 2,5 \\
\hline 0,6 & 13,4 & 8,7 & 4,1 & 0,6 & $-5,3$ \\
\hline 0,2 & & & & & \\
\hline
\end{tabular}


To address the question of the mass of the HAM contained in the heat accumulator, we performed experiments on the effect of the mass of the HAM on the time of discharging of the HA. In fig. 26 shows the curves of ozokerite cooling from a temperature close to the temperature of the running engine to the ambient temperature, which was $5{ }^{\circ} \mathrm{C}$. Here on the upper abscissa is the time related to the cooling of the HA without thermal insulation. We see that at a HAM mass of $5.6 \mathrm{~kg}$ discharging of HA occurs after $600 \mathrm{~s}$ (10 min), while heat-insulated HA is discharged in 8 hours. With decreasing the HAM mass discharge of HA occurs faster.

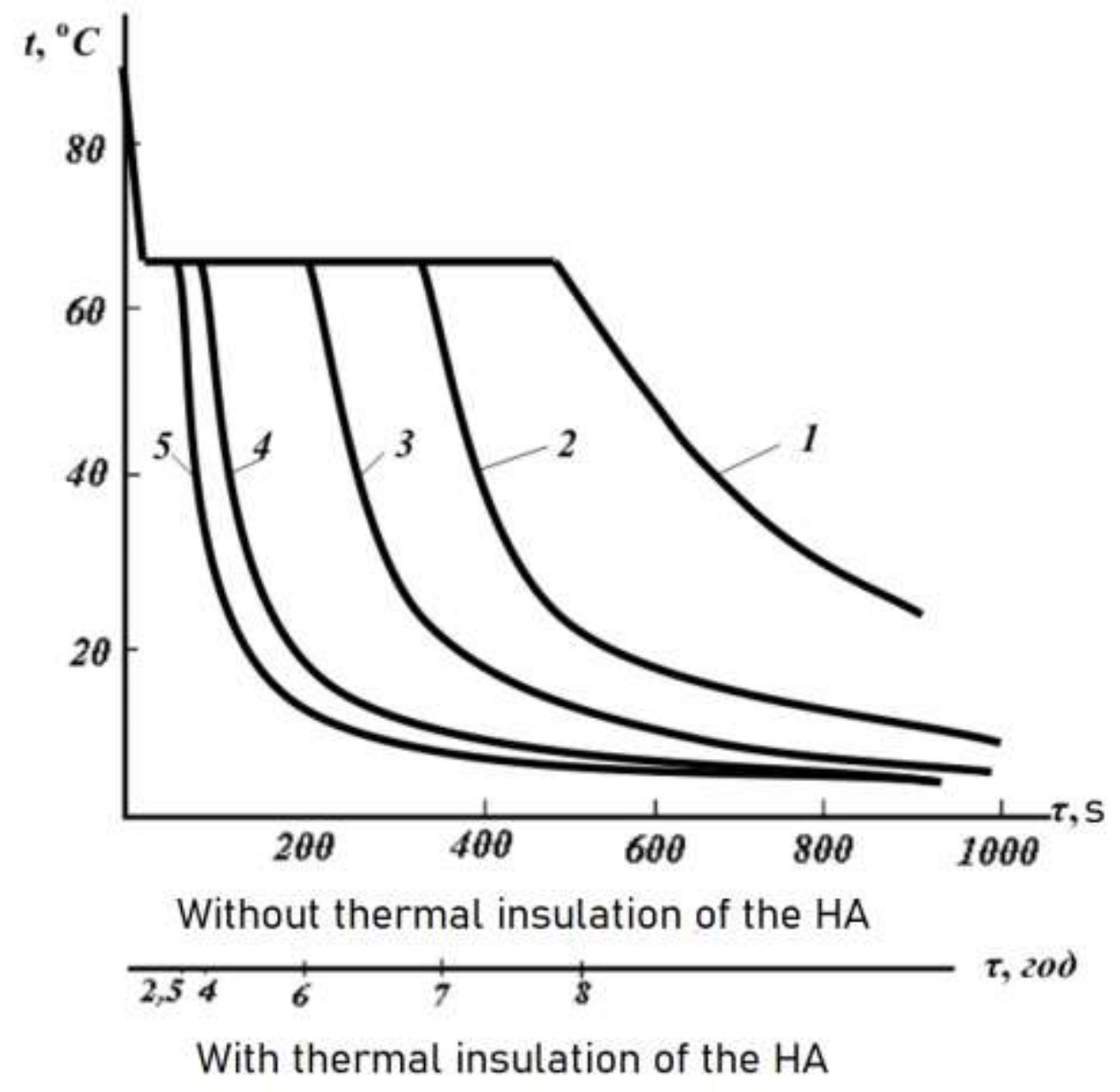

Figure 26. Discharging of the heat accumulator at different masses of HAM:

1 - mass of HAM 5,6 kg $\left(0,0052 \mathrm{~m}^{3}\right) ; 2-5,16 \mathrm{~kg}\left(0,0048 \mathrm{~m}^{3}\right) ; 3-4,52 \mathrm{~kg}(0,0042$ $\left.\mathrm{m}^{3}\right) ; 4-3,2 \mathrm{~kg}\left(0,0030 \mathrm{~m}^{3}\right) ; 5-2,7 \mathrm{~kg}\left(0,0025 \mathrm{~m}^{3}\right)$. 
The dependence of the discharge time of the heat accumulator on the HAM mass is presented in Fig. 27. These data can be the basis for calculating the dimensions of the heat accumulator.

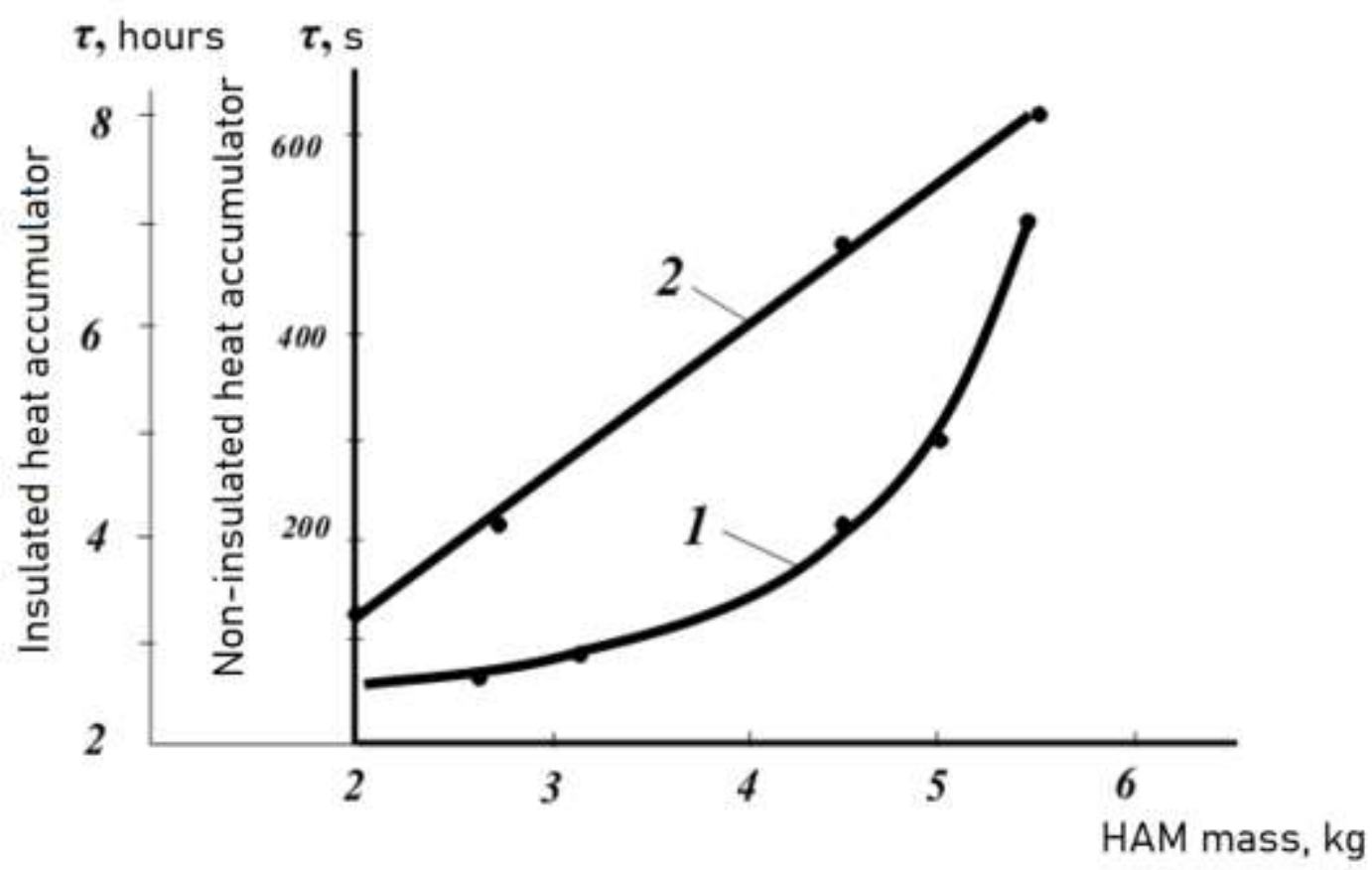

Figure 27. The dependence of the discharge time of the heat accumulator on the HAM mass:

1 - Non-insulated heat accumulator; 2 - Insulated heat accumulator (thermal insulation - a layer of mineral wool 50 mm thick).

The data given in table. 4 on the temperature of the antifreeze, allow you to calculate the HAM mass required to ensure warm-up of the engine. The calculation was performed from the heat balance between the amount of heat required to heat the antifreeze from its temperature after stirring to the starting temperature of the engine and the amount of heat released during crystallization HAM:

$$
Q_{\text {heated. }}=c_{\text {Tos. }} m_{\text {Tos. }}\left(t_{\text {eng. }}-t_{\text {amount.ros. }}\right) ; \quad Q_{\text {crystall. }}=m_{\mathrm{HAM}} \cdot r \text {, }
$$

Thus, at a weight of tosol cooling agent of $3.44 \mathrm{~kg}$ (volume $3.2 \mathrm{l}-3 \mathrm{l}$ in the cooling system and $0.2 \mathrm{l}$ in the tube of $\mathrm{HA}$ ) and an external temperature of $5{ }^{\circ} \mathrm{C}$ with stirring, the temperature of the tosol cooling agent is $8.7^{\circ} \mathrm{C}$, the temperature of the 
tosol cooling agent, required to warm up the engine to $40{ }^{\circ} \mathrm{C}$, is $50{ }^{\circ} \mathrm{C}$. Then the weight of HAM is $3.16 \mathrm{~kg}$ (volume 3 liters).

At an external temperature of $0{ }^{\circ} \mathrm{C}$, the mass of HAM is $3.85 \mathrm{~kg}$ (3.58 l), etc.

But, as evidenced by the data shown in Fig. 27, at a mass of HAM about $3 \mathrm{~kg}$ the HA is discharged in about 4 hours, and at a mass of about $4 \mathrm{~kg}$ - in 6 hours. If this time is not enough to keep the HA in a charged state, you need to strengthen the insulation.

Thus, the mass of HAM is determined depending on the ambient temperature and idle time of the car.

Our research has shown that to quickly start the engine it should be warmed up to $40{ }^{\circ} \mathrm{C}$, the tosol cooling agent temperature should be about $50{ }^{\circ} \mathrm{C}$. When the car stopped, its engine is cooled to temperatures at about one and a half hours (about 6000 s) (Fig. 28, $a$, curve 1), at which starting the car becomes difficult, and in 3 hours the engine temperature approaches the ambient temperature. Due to the heat released during its crystallization, the heat-accumulating material cools much more slowly (Fig. 28, a, curve 2). Thermal insulation of HA helps to reduce the cooling rate of HAM, as can be seen when comparing solid and dotted lines 2 (area I Fig. 28, a). Tosol cooling agent in HA has a temperature close to HAM. In the presence of thermal insulation of the HAM heat accumulator (and ozokerite of HA) maintains a high $\left(67^{\circ} \mathrm{C}\right)$ temperature for a long time (section $I$ in Fig. 28, a). We proposed design of the heat accumulator, and the discharge time was increased to 14 hours.

When engine starts the (section II in Fig. 28, $a$ ), the pump is turned on, which pumps the tosol cooling agent in a closed circuit HA-engine cooling system (ECS). The tosol cooling agent from HA $\left(65^{\circ} \mathrm{C}\right)$ is mixed with the tosol cooling agent from the cooling shell and the temperature of the mixture reaches about $9{ }^{\circ} \mathrm{C}$ (data of table. $4)$.

Due to the heat released during crystallization of HAM, the tosol cooling agent is heated to $\sim 50{ }^{\circ} \mathrm{C}$, and the engine is warmed up to $\sim 40{ }^{\circ} \mathrm{C}$, which allows you to quickly start. 
Thus, to quickly start the car engine at low temperatures requires that HAM is a long time in the crystallization stage (i.e., HA should not be discharged), and the temperature of the tosol cooling agent, which is in the ECS, was about $50{ }^{\circ} \mathrm{C}$.

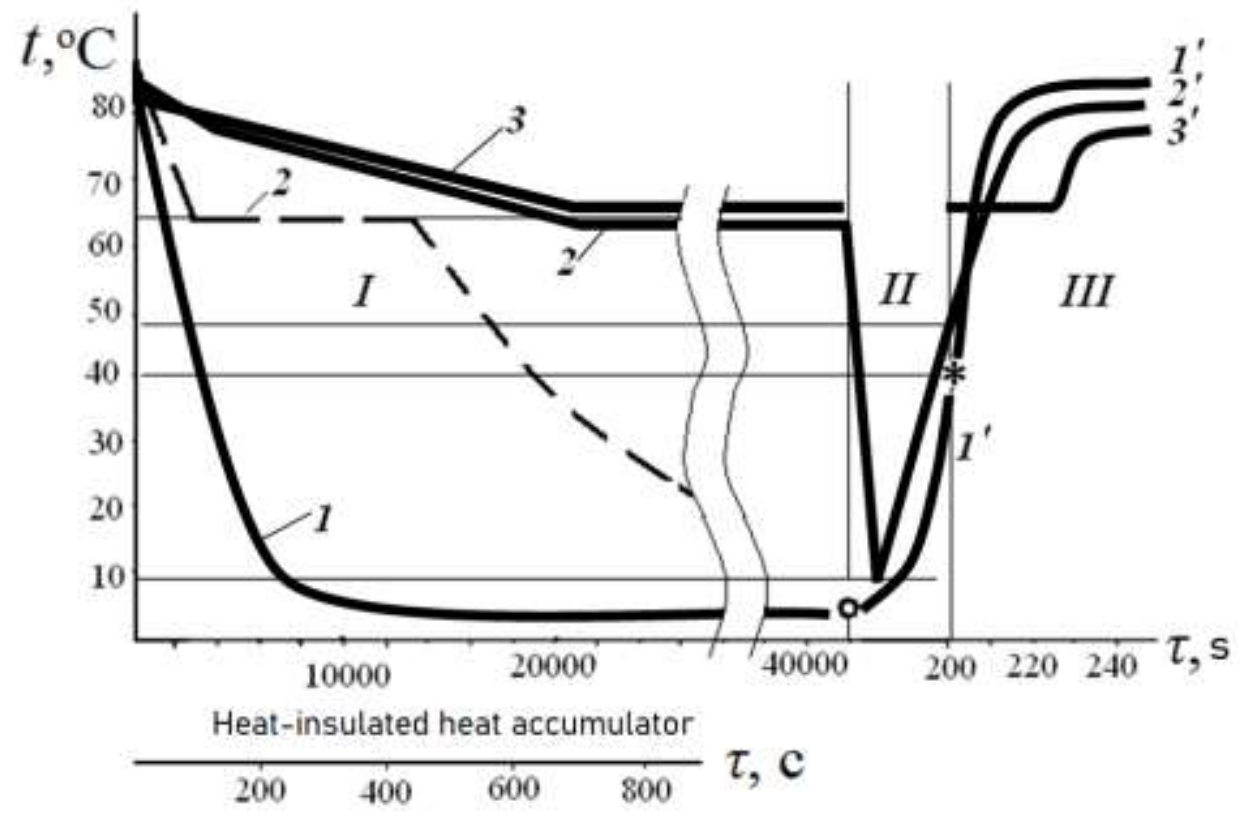

Non-insulated heat accumulator (dotted line)

o- switching on the pump * the engine start

a)

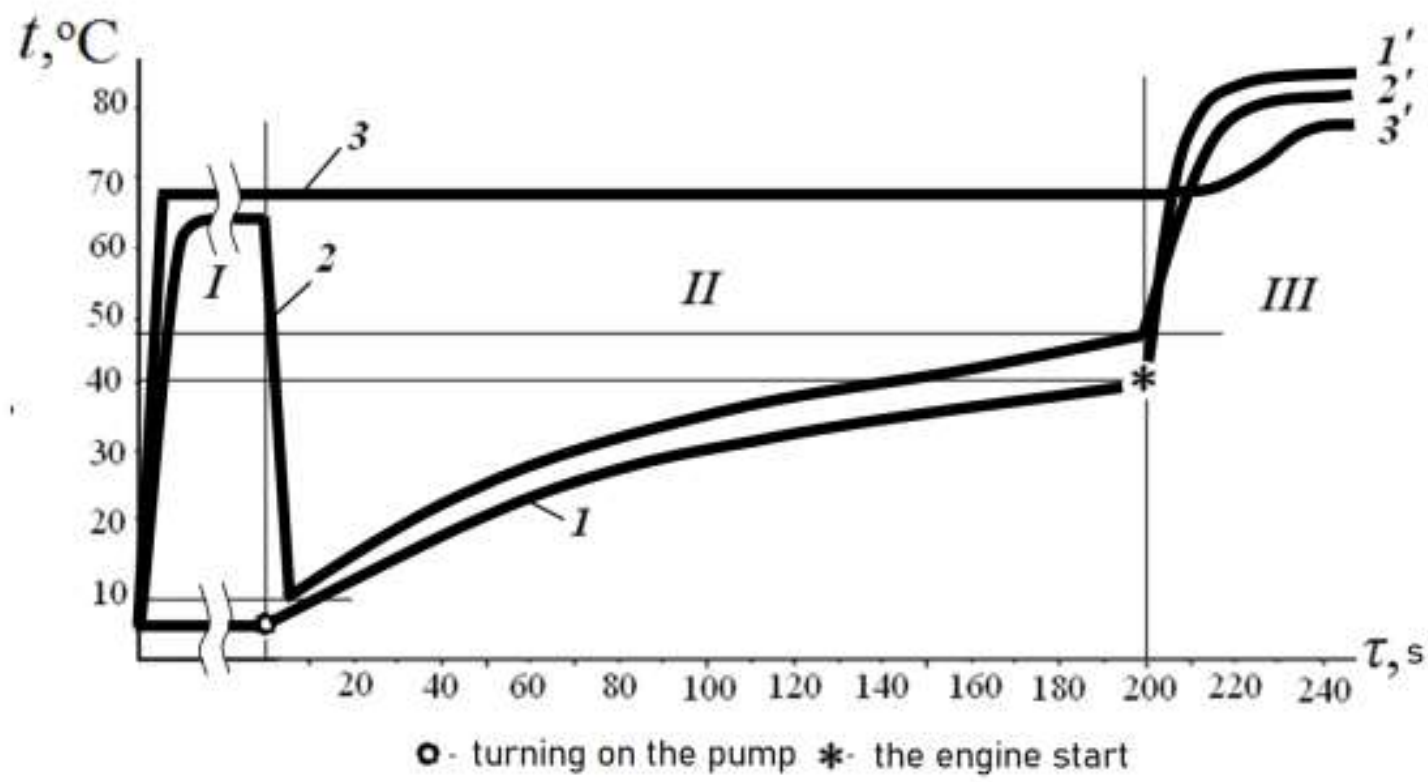

b)

Figure 28. Operating modes of the TA-SOD system:

a) - cooling of the engine and HAM when the car stands and the subsequent the engine start; $b$ ) - pre-start charging of HA and the subsequent engine start. 
$I$ - cooling area for $a$, heating with THE for $b$; $I I$ - area of warming up and starting the car; $I I I$ - area of stable operation while driving;

1 - changing in engine temperature; 2 - tosol cooling agent; 3 - HAM.

At long-standing at low temperature the air of HAM completely turns to a solid-state, acquiring ambient temperatures, therefore preliminary heating and melting of heat-accumulating material using THE (area $I$ in fig. 28, $b$ ) is carried out. Changes in temperatures of HAM, tosol cooling agent during its heating and circulation in the cooling system of the engine and the engine itself have been studied. At a temperature of $67^{\circ} \mathrm{C}$ and above, when HAM goes to the molten state, the cooling system pump is turned on, the tosol cooling agent begins to circulate in the general system HA-ECS, while it is mixed and heated from the part of tosol cooling agent that was in the heat accumulator (section II in Fig. 28, b). The temperature of the mixture can be determined from the data in table. 3 , at ambient temperature, for example, $5{ }^{\circ} \mathrm{C}$ and the volume of tosol cooling agent in HA $0.2 \mathrm{l}$, it will be about $9{ }^{\circ} \mathrm{C}$. Further heating of the tosol cooling agent is due to the heat of crystallization of HAM. In about $200 \mathrm{~s}$ the temperature of tosol cooling agent reaches about $50{ }^{\circ} \mathrm{C}$, and the engine temperature $-40{ }^{\circ} \mathrm{C}$ (area $I I$ in Fig. $28, b$ ), while the engine starts in 5-10 s. Then the temperature of the engine, tosol cooling agent and HAM go to the regime values (area III in Fig. 28, $b$ ). Thus, at idle, the engine runs for a very short time, so you can avoid the negative consequences mentioned at the beginning of the article.

On the basis of the received experimental data and calculations the operating model of the heat accumulator was created. It differs from the experimental sample by the presence of solenoid valves on the nozzles of the tosol cooling agent in the heat exchanger and out of it.

Due to the fact that increasing the volume of coolant in the ECS is undesirable, one U-shaped tube (outer diameter $15 \mathrm{~mm}$, containing 0.2 liters of tosol cooling agent) was taken. To ensure the charged state of the heat accumulator for $14 \mathrm{~h}$, the mass of ozokerite was $6 \mathrm{~kg}$ (5.6 l) in the presence of thermal insulation of mineral wool with a 
thickness of $100 \mathrm{~mm}$. The diameter of the cylindrical tank with HAM - $110 \mathrm{~mm}$, length $-0.6 \mathrm{~m}$.

The developed heat accumulator for pre-heating of the internal combustion engine was tested on such cars as HAZ-3250 bus with NISSAN DONG FENG CY4102BZLQ engine and VAZ family of cars and proved its efficiency, which determines its wide application.

\section{Using the method of factorial experiment in the study}

\section{operating conditions of the heat accumulator in the system of pre-starting start of the automobile engine}

R. Fischer proposed using of the method of the factorial experiment in 1935 [293]. This method allows using the obtained regression equation to estimate the simultaneous influence of many factors on a quantity called the optimization parameter. In the science of our country, the method became widespread in the 60's and 80's of the last century for planning and analysis of experiments, in studying the properties of materials, in the search for optimal conditions of carrying out one or another processes.

Despite the wide possibilities, the method of factorial experiment had limitations calculations. Thus, within the prescribed period, the regression equations were easily solved for two-factor, marginally more difficult - for three-factor, and for four or more factors to obtain the regression equation became quite problematic.

The availability of accessible computing technics and software [294] has now allowed us to return to the use of the factor experiment method in various fields construction [295], energy saving [296], materials processing [297, 298], motor transport [299], agriculture [300], food industry [301-303], military sphere [304], etc. [305].

Using a heat accumulator (HA) in the prelaunch procedure system of the car engine in order to accelerate the engine start at low external temperatures, the most important indicator of the HA is the time of its discharging. Prolonged discharging time allows you to leave the car outdoors for a long time, especially at night. 
The previous studies have shown that the discharging time of the HA depends on the external temperature, the mass of the heat-accumulating material (HAM) and the thickness of the insulation layer. We used a full factorial experiment to predict the simultaneous action of these factors at the time of discharging HA [306]. In this case, we took the discharging time as the optimization parameter $y$.

As far as during performance of the experiments the variable factors are inhomogeneous and have different units of measurement, we reduce them to a unified system by going from the present values to the coded ones. We presented the factor coding results in table 5, the plan-matrix of the full factorial experiment - in table 6 , the experiments results and the estimated values of the HA discharging time - in table 7.

Table 5

Natural values of the factors and variability interval

\begin{tabular}{|l|c|c|c|c|}
\hline \multirow{2}{*}{ Factors } & \multirow{2}{*}{ Basic level } & $\begin{array}{c}\text { Variability } \\
\text { interval }\end{array}$ & \multicolumn{2}{c|}{ Levels } \\
\cline { 3 - 5 } & & 0,75 & 2 & 0,5 \\
\hline$x_{1}-$ mass of ozokerite in HA, kg & 1,25 & -10 & 5 & -15 \\
\hline$x_{2}-{\text { external temperature, }{ }^{\circ} \mathrm{C}}^{*} \begin{array}{l}x_{3}-\text { the thickness of the } \\
\text { insulation layer, mm }\end{array}$ & 75 & 25 & 100 & 50 \\
\hline
\end{tabular}

Table 6

Plan-matrix of the full factorial experiment

\begin{tabular}{|c|c|c|c|c|c|c|c|c|}
\hline \multirow{2}{*}{$j$} & \multirow{2}{*}{$x_{0}$} & \multicolumn{7}{|c|}{ Planning (factors) } \\
\cline { 2 - 9 } & & $x_{1}$ & $x_{2}$ & $x_{3}$ & $x_{1} x_{2}$ & $x_{1} x_{3}$ & $x_{2} x_{3}$ & $x_{1} x_{2} x_{3}$ \\
\hline 1 & +1 & -1 & -1 & -1 & +1 & +1 & +1 & -1 \\
\hline 2 & +1 & -1 & -1 & +1 & +1 & -1 & -1 & +1 \\
\hline 3 & +1 & -1 & +1 & -1 & -1 & +1 & -1 & +1 \\
\hline 4 & +1 & -1 & +1 & +1 & -1 & -1 & +1 & -1 \\
\hline 5 & +1 & +1 & -1 & -1 & -1 & -1 & +1 & +1 \\
\hline 6 & +1 & +1 & -1 & +1 & -1 & +1 & -1 & -1 \\
\hline 7 & +1 & +1 & +1 & -1 & +1 & -1 & -1 & -1 \\
\hline 8 & +1 & +1 & +1 & +1 & +1 & +1 & +1 & +1 \\
\hline$b_{i}$ & 688,25 & 351,25 & 93,75 & 101,25 & 98,75 & 31,25 & $-46,25$ & $-1,25$ \\
\hline
\end{tabular}


Table 7

Experimental and calculated values of the heat accumulator discharging time

\begin{tabular}{|c|c|c|c|c|c|c|c|c|}
\hline \multirow{2}{*}{$j$} & \multicolumn{3}{|c|}{$\begin{array}{l}\text { Discharging time, } \\
\text { min }\end{array}$} & \multirow{2}{*}{$(\bar{\tau}-\tau)^{2}$} & \multirow{2}{*}{$S_{j}^{2}$} & \multirow{2}{*}{$\tau_{\text {calc }}$} & \multirow{2}{*}{$\bar{\tau}_{\text {exp.j- }-\tau_{\text {calc. }}}$} & \multirow{2}{*}{$\left(\bar{\tau}_{\text {exp.j- }}-\tau_{\text {calc. }}\right)^{2}$} \\
\hline & $\tau$ exp. 1 & $\tau$ exp. 2 & $\bar{\tau}_{\text {exp }}$ & & & & & \\
\hline 1 & 210 & 230 & 220 & 100 & 200 & 220 & 0 & 0 \\
\hline 2 & 440 & 460 & 450 & 100 & 200 & 449 & 1 & 1 \\
\hline 3 & 290 & 310 & 300 & 100 & 200 & 300 & 0 & 0 \\
\hline 4 & 340 & 360 & 350 & 100 & 200 & 350 & 0 & 0 \\
\hline 5 & 640 & 680 & 660 & 400 & 800 & 652 & 8 & 64 \\
\hline 6 & 1000 & 1040 & 1020 & 400 & 800 & 1004 & 16 & 256 \\
\hline 7 & 1080 & 1200 & 1140 & 3600 & 7200 & 1142 & -2 & 4 \\
\hline 8 & 1230 & 1390 & 1310 & 6400 & 12800 & 1314 & -4 & 16 \\
\hline$\sum$ & & & & & 22400 & & & 341 \\
\hline
\end{tabular}

In this work, we used the central compositional orthogonal planning of the second order (CCOP) followed by mathematical modeling in Maple software packages according to the author's algorithms.

As a result, we have obtained the regression coefficients, which are given in the bottom row of table. 6 . Thus, the regression equation in the coded quantities has the form:

$$
\begin{aligned}
& t=681,25+351,25 \cdot x_{1}+93,75 \cdot x_{2}+101,25 \cdot x_{3}+98,75 \cdot x_{1} \cdot x_{2}+31,25 \cdot x_{1} \cdot x_{3}- \\
& -46,25 \cdot x_{2} \cdot x_{3}-1,25 \cdot x_{1} \cdot x_{2} \cdot x_{3} .
\end{aligned}
$$

Full-sized equation has the form:

$$
\begin{aligned}
& \tau=-20,83+411,67 m_{o z}+6,17 t_{e x t}+1,08 \delta_{i n s}+13,67 m_{\mathrm{oz}} t_{e x t}+ \\
& +1,63 m_{o z} \delta_{i n s}-0,18 t_{e x t} \delta_{i n s}-0,0067 m_{o z} t_{e x t} \delta_{i n s} .
\end{aligned}
$$

According to the requirements of regression analysis, the variance of the matrix row must be homogeneous. Homogeneity of variances is checked by Cochran's $\mathrm{C}$ test:

$$
G=\frac{S_{j_{\max }}^{2}}{\sum_{j=1}^{N} S_{j}^{2}}
$$


where $S_{j_{\max }}^{2}$ - the largest of the dispersions calculated as $S_{j}=\frac{\sum_{n=1}^{n}(\bar{\tau}-\tau)^{2}}{k-1}$; $k$ - number of replicate observations (in this case 2).

$$
G=\frac{12800}{22400}=0,571 .
$$

The variance is considered homogeneous if the value of Cochran's $C$ test calculated by the given equation satisfies the condition

$$
G<G_{\text {tabl, }}
$$

where $G_{\text {tabl }}$ - tabulated value of Cochran's C test for a given $N$ and number of degrees of freedom $f$, moreover $f=k-1$. In our case $f=2-1=1$.

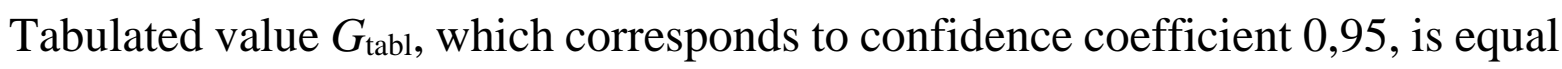
to 0,6798 . As $G(0,571)<G_{\text {tabl }}(0,6798)$, the dispersion is homogeneous.

We calculated the error mean square to assess the significance of the regression coefficients:

$$
S_{y}^{2}=\frac{1}{N} \sum_{j=1}^{N} S_{j}^{2}=\frac{1}{8} 22400=2800
$$

and the error of their definition $S_{b}$

$$
S_{b}=\sqrt{\frac{S_{y}^{2}}{N k}}=\sqrt{\frac{2800}{8 \cdot 2}}=13,23 .
$$

The significance of the regression coefficients is established according to the error of their determination and Student's t-test $t_{p}$. If the condition $t_{p} \leq b / S_{b}$ is satisfied, the regression coefficient is significant. With a probability of $95 \%$ and $N=8 t_{p}=2,31$.

Determining the values of $b / S_{b}$ for the members of the equation and comparing the calculated value with the tabular value of Student's t-test [306] allowed us to discard the last number of the regression equation, which takes into account the combined effect on battery discharging time of ozokerite, external temperature and insulation layer thickness.

Thus, the regression equation has the form: 
in coded values

$$
\begin{aligned}
& t=681,25+351,25 \cdot x_{1}+93,75 \cdot x_{2}+101,25 \cdot x_{3}+ \\
& +98,75 \cdot x_{1} \cdot x_{2}+31,25 \cdot x_{1} \cdot x_{3}-46,25 \cdot x_{2} \cdot x_{3},
\end{aligned}
$$

in full-sized

$$
\begin{aligned}
& \tau=-20,83+411,67 m_{o z}+6,17 t_{e x t}+1,08 \delta_{i n s}+ \\
& +13,67 m_{\mathrm{oz}} t_{\text {ext }}++1,63 m_{o z} \delta_{i n s}-0,18 t_{\text {ext }} \delta_{i n s} .
\end{aligned}
$$

The adequacy of the experimental equation is checked by F-test. The variance of adequacy is calculated according to table. 3 of the ratio:

$$
S_{\text {ad }}^{2}=\frac{2}{N-B} \sum_{j=1}^{N}\left(\bar{\tau}-\tau_{\text {calc. }}\right)^{2}=\frac{2}{8-7} 341=682,
$$

where $B$ - the number of significant coefficients in the regression equation.

The calculated value of the $F$-ratio is calculated as the ratio of the variances of adequacy and reproducibility, and, in the numerator of the F-ratio put the largest of the variances. By this means:

$$
F=\frac{S_{y}^{2}}{S_{a d}^{2}}=\frac{2800}{682}=4,11 .
$$

If the value of F-test obtained by this ratio does not exceed the tabular value $\left(F_{\text {tabl. }}\right)$ for a given number of degrees of freedom, the regression equation is adequate and the adequacy condition is $F \leq F_{\text {tabl. }}$. For $P=0,95, f_{1}=N-B=8-7=1$ and $f$ ${ }_{2}=N(k-1)=8(2-1)=8$ F-test is equal to 5,3 , that is $F<F_{\text {tabl. }}$ Therefore, the regression equation obtained by us is adequate to the experiment.

To test the possibility of using the obtained regression equation for any points lying between the upper and lower levels of variation, we performed the experiments to determine the discharging time HA under the conditions specified in table. 8. 
Table 8

Checking the possibility of using the regression equation for arbitrary conditions

\begin{tabular}{|c|c|c|c|c|c|c|c|}
\hline \multirow{2}{*}{$\begin{array}{c}\text { Experi } \\
\text { ment } \\
№\end{array}$} & \multirow{2}{*}{ Factors } & \multirow{2}{*}{$\begin{array}{l}\text { Factor } \\
\text { score }\end{array}$} & \multicolumn{3}{|c|}{$\begin{array}{l}\text { Discharging time, } \\
\text { min }\end{array}$} & \multirow{2}{*}{$\tau_{\text {calc. }}$} & \multirow{2}{*}{$\begin{array}{c}\text { Measu } \\
\text { rement } \\
\text { error, } \\
\%\end{array}$} \\
\hline & & & $\tau_{\text {exp. } 1}$ & $\tau$ exp.2 & $\bar{\tau}_{\text {exp }}$ & & \\
\hline \multirow[t]{3}{*}{1} & mass of ozokerite in HA, kg; & 1,25 & \multirow[t]{3}{*}{695} & \multirow[t]{3}{*}{672} & \multirow[t]{3}{*}{683} & \multirow[t]{3}{*}{679} & \multirow[t]{3}{*}{0,6} \\
\hline & outside temperature, ${ }^{\circ} \mathrm{C}$; & -5 & & & & & \\
\hline & $\begin{array}{l}\text { the thickness of the insulation layer, } \\
\mathrm{mm}\end{array}$ & 75 & & & & & \\
\hline \multirow[t]{3}{*}{2} & mass of ozokerite in HA, kg; & 0,875 & \multirow[t]{3}{*}{397} & \multirow[t]{3}{*}{425} & \multirow[t]{3}{*}{411} & \multirow[t]{3}{*}{410} & \multirow[t]{3}{*}{0,2} \\
\hline & outside temperature, ${ }^{\circ} \mathrm{C}$; & $-12,5$ & & & & & \\
\hline & $\begin{array}{l}\text { the thickness of the insulation layer, } \\
\mathrm{mm}\end{array}$ & 62,75 & & & & & \\
\hline \multirow[t]{3}{*}{3} & mass of ozokerite in HA, kg; & 1,625 & \multirow[t]{3}{*}{915} & \multirow[t]{3}{*}{953} & \multirow[t]{3}{*}{934} & \multirow[t]{3}{*}{943} & \multirow[t]{3}{*}{0,9} \\
\hline & outside temperature, ${ }^{\circ} \mathrm{C}$; & $-2,5$ & & & & & \\
\hline & $\begin{array}{l}\text { the thickness of the insulation layer, } \\
\mathrm{mm}\end{array}$ & 87,5 & & & & & \\
\hline \multirow[t]{3}{*}{4} & mass of ozokerite in HA, kg; & 2 & \multirow[t]{3}{*}{808} & \multirow[t]{3}{*}{842} & \multirow[t]{3}{*}{825} & \multirow[t]{3}{*}{828} & \multirow[t]{3}{*}{0,4} \\
\hline & outside temperature, ${ }^{\circ} \mathrm{C}$; & -15 & & & & & \\
\hline & $\begin{array}{l}\text { the thickness of the insulation layer, } \\
\mathrm{mm}\end{array}$ & 75 & & & & & \\
\hline
\end{tabular}

These data indicate the suitability of the regression equation for calculating the time of discharge of HA in the conditions limited to the table. 5 values of variable factors.

Since the HA is a device that has certain characteristics, such as the mass of ozokerite in it (determined by the size of the HA) and the thickness of the insulation, in real conditions, these values are constant. Factor experiment makes it possible to establish their optimal values, which are taken into account in the manufacture of heat accumulators for a particular car. Thus, for the conditions of experiment 4 (Table 8), the discharge of the HA occurs for almost 14 hours, i.e, at $-15^{\circ} \mathrm{C}$ you can leave the car overnight, and then start the engine for 5-10 s. 
Based on the results of our research on design involving numerical simulation and modern software, data were obtained to determine the warm-up time of the engine with a heat accumulator and a model that can be used to select design parameters of heat accumulators, justify the applicability of heat storage and forecasting system operation in different conditions.

Experimental and industrial samples of heat accumulators were created and their work was studied. To describe the operation of the heat accumulator, a regression equation is obtained, which allows to determine the discharge time of the heat accumulator depending on external conditions and its design features. 


\subsection{Analysis of the influence in loss of coolant accident on fuel rod state}

The scope of the data experimentally obtained by research the behaviour and properties of water water energy reactor (WWER) type fuel claddings from $\mathrm{Zr} 1 \% \mathrm{Nb}$ alloy under loading conditions simulating the stage of core flooding with water in loss of coolant accident (LOCA) suffices to judge the character and numerical value of criterional parameters of the embrittlement criterion in terms of the cladding stability upon flooding and subsequent implementation of fuel assembly (FA) unloading and transportation. Accidents are considered involving loss of coolant by primary circuit which are characterized by conditions of degraded heat transfer from fuels. During accidents loss of tightness by fuel rod cladding is tolerable, however, in this case, the cooling of a distorted fuel rod and the dismantling (unloading) of the core after an accident have to be feasible.

Keywords: fuel rod, heat resistance, ZR1\%NB alloy, oxidation, deformation, mechanical properties.

\section{INTRODUCTION}

The most important element of reactor plant (RP) safety validation is analysis of behaviour of nuclear fuel (fuel assemblies, fuel rods) in design basis (postulated) accidents.

The objective of the analysis is to validate the fulfillment of safety requirements placed on fuel rod condition in design basis accidents.

A design basis accident is the one for which the design defines initial events and final states as well as contemplates safety systems that with the account for a single failure of safety systems or a single staff error, independent of an initial event, provide for the limitation of its consequences via limits established for accidents of this type [307, 308].

Accidents are considered involving loss of coolant by primary circuit which are characterized by conditions of degraded heat transfer from fuels. Under these conditions, the temperature of fuel rods (fuel and/or cladding) rises compared to that under normal operating conditions. During accidents loss of tightness by fuel rod 
cladding is tolerable, however, in this case, the cooling of a distorted fuel rod and the dismantling (unloading) of the core after an accident have to be feasible.

Limitations placed on specific physical parameters that characterize the fuel rods state in a design basis accident are called safety criteria.

The conclusions on the fulfillment of the criteria are drawn based on the results of design analyses of fuel rod behaviour in design basis accidents using the RAPTA-5 code.

The paper contains the results of computer check-up of fulfilling (not exceeding) safety criteria in design basis accidents involving loss of primary circuit coolant of the large break LOCA (LB LOCA) type using RAPTA-5 code.

\section{Procedure of design modelling fuel rod behaviour in accident}

Estimation of fuel rod state during an accident and determination of criterional parameters are performed via design modelling using the computer code RAPTA-5 [309, 314, 315].

The RAPTA-5 code is designed to calculate thermomechanical and corrosion behaviour of fuel rods of water cooled power reactors in design basis accidents proceeding from poor heat transfer in a core or quick power changes.

The RAPTA-5 code uses the procedure of coupled solution of unsteady thermomechanical and corrosion problems as applied to a fuel rod; it comprises the following models:

- model of fuel rod initial state at the early moment of an accident with due account for burn-up,

- two-dimensional unsteady heat transfer in a fuel rod,

- $\quad$ parameters of mixed gas state within a cladding,

- model of fuel rod stress-strained state taking into account thermoelastic strain of fuel, tough-elastic-plastic deformation of a cladding,

- model of cladding depressurization effected by excess internal pressure,

- $\quad$ kinetics of high-temperature cladding oxidation in steam, 
- complex of analytic dependences that describe high-temperature properties of materials in the specified temperature range.

The RAPTA-5 code was verified based on the results of experimental studies into deformation and corrosion behaviour of fuel rod simulators under laboratory conditions as well as the results of integral experiments, carried out in rigs and under reactor conditions and regime simulating temperature-force loading conditions typical of LOCA [315].

The basic computer models put into practice in the RAPTA-5 code are described in the topical report "Procedure and Results of Computer Modelling Fuel Rod Condition in Accidents with Reactivity Increase (RIA)".

\section{Calculated research of fuel rod behaviour in accident attended with main circulation conduit (MCC) rupture}

Calculated research of fuel rod behaviour in design basis accidents are aimed at demonstrating the fulfillment of the safety criteria [309].

To implement the calculations, use is made of the initial data on the fuel rod loading conditions in design basis accidents. In essence, they represent limiting conditions at the fuel cladding surface (temperature of cladding outer surface and coolant pressure) and data on the fuel heat rate height distribution and its variations in the process of an accident.

The temperature conditions of fuel claddings at a different initial power level in LOCA are determined by inter-related neutron physics and thermal hydraulics calculations. Among other things, the calculations result in determining the maximal temperature of fuel rod claddings and checking up the fulfillment of the acceptance criterion, $\mathrm{T}_{\text {clad }}<T_{\text {clad }}^{\lim }=1200^{\circ} \mathrm{C}$.

The corrosion state of fuel rods is assessed and the fulfillment of the criteria equivalent cladding reacted (ECR) $<E C R_{\text {clad }}^{\lim }=18 \%$ and $\Delta \mathrm{M}\left(\mathrm{Zr} \rightarrow \mathrm{ZrO}_{2}\right)<M_{\mathrm{Zr}}^{\lim }=1 \%$ is checked up basing on the results of the calculations carried out by the RAPTA-5 code. 
The fulfillment of the criterion that limits the quantity of oxidized $\mathrm{Zr}$ in a core is checked up in the following way.

For the thermal hydraulics calculations, the core is presented as several groups of fuel rods (channels) subjected to identical (close) temperature conditions during an accident which is basically determined by the initial power level. The fraction of oxidized Zr with due account for the thermomechanical behaviour of a fuel rod during an accident and the cladding inner surface oxidation after depressurization is assessed by the RAPTA-5 code for each group of fuel rods. The assessment of the fraction of the steam reacted $\mathrm{Zr}$ in a core is implemented via summing up the fractions of oxidized Zr in fuel rods of each group multiplied by the weight factor of a particular group - the ratio of the quantity of fuel rods in the particular group to the overall quantity of fuel rods in a core.

As an example, consideration is given to the typical design basis accident attended with a prompt transverse rupture of the main circulation conduit (MCC) diameter equivalent (De) 850 in the diameter at the reactor inlet. The accident of this type is regarded to be the maximum design basis one (MDBA).

The initial data on variations in fuel heat rate, coolant pressure and temperatures of fuel cladding outer surfaces during the accident were specified basing on the results of thermohydraulic calculations (Figs. 1, 2).

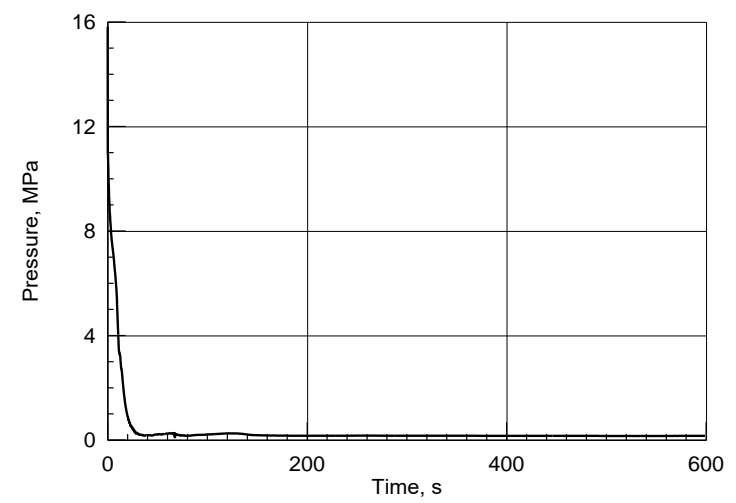

Fig. 1. Rupture of MCC. Variation in coolant pressure.



Fig. 2. Rupture of MCC. Variation in relative power.

Two versions are considered pertaining to the distribution of heat rate along the core height $\mathrm{k}_{\mathrm{z}}$ (Table 1). Version 1 corresponds to the beginning of the annual cycle, and Version 2 refers to the end of the annual cycle. 
Table 1.

Core Height Distribution of Heat Rate Non-Uniformity Coefficient $\left(\mathrm{k}_{\mathrm{z}}\right)$

\begin{tabular}{|c|c|c|c|c|c|c|c|c|c|c|}
\hline $\begin{array}{c}\text { Distance from } \\
\text { core bottom, }\end{array}$ & $\mathbf{5}$ & $\mathbf{1 5}$ & $\mathbf{2 5}$ & $\mathbf{3 5}$ & $\mathbf{4 5}$ & $\mathbf{5 5}$ & $\mathbf{6 5}$ & $\mathbf{7 5}$ & $\mathbf{8 5}$ & $\mathbf{9 5}$ \\
\hline Version $\mathrm{k}_{\mathrm{z}}-1$ & 0.36 & 0.84 & 1.13 & 1.30 & 1.39 & 1.39 & 1.27 & 1.12 & 0.84 & 0.36 \\
\hline Version $\mathrm{k}_{\mathrm{z}}-2$ & 0.71 & 0.99 & 1.01 & 1.01 & 1.02 & 1.04 & 1.08 & 1.15 & 1.10 & 0.89 \\
\hline
\end{tabular}

In the $\mathrm{k}_{\mathrm{z}}-1$ version to implement thermohydraulic calculations, the core was presented as seven channels having different relative power: $\mathrm{k}_{\mathrm{r}}=1.0,1.1,1.2,1.3,1.4$, 1.5 and 1.6. In the $\mathrm{k}_{\mathrm{z}}-2$ version it was presented as three channels: $\mathrm{k}_{\mathrm{r}}=1.0,1.34$ and 1.55. The temperature conditions of different power fuel rod claddings during an accident are illustrated in Figs. 3-12.

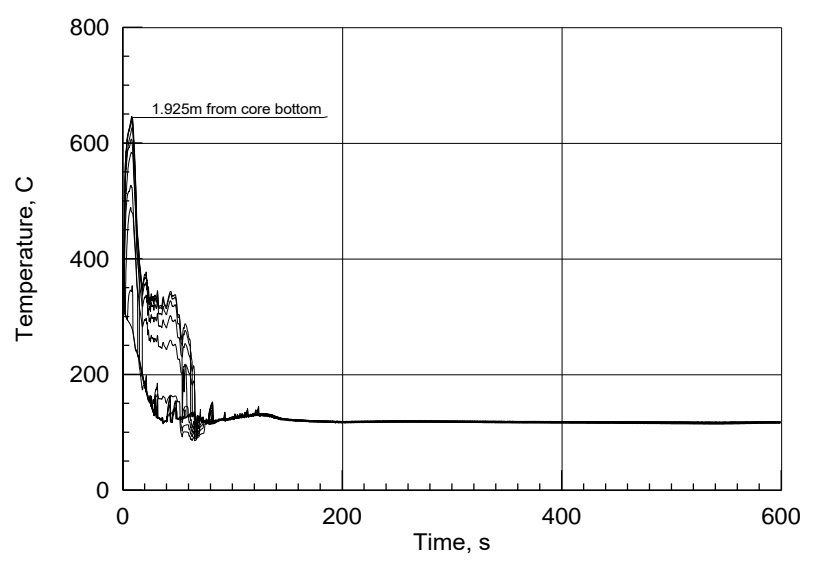

Fig. 3. Rupture of MCC. Temperature of fuel cladding outer surface. Version $k_{z}-1$, $k_{r}=1.0$, maximum linear heat generation rate (LHGR) $240 \mathrm{~W} / \mathrm{cm}$.

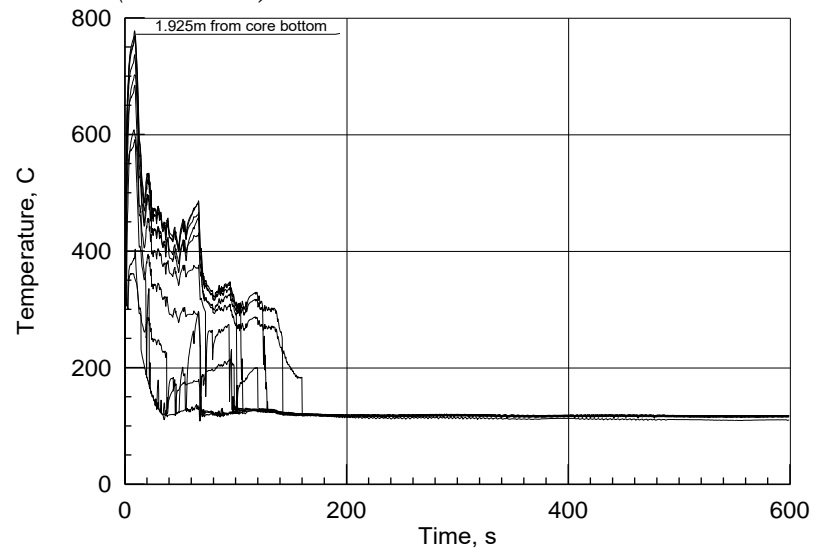

Fig. 4. Rupture of MCC. Temperature of the cladding outer surface. Version $k_{z}-1, k_{r}$ =1.1, maximum LHGR $308 \mathrm{~W} / \mathrm{cm}$.

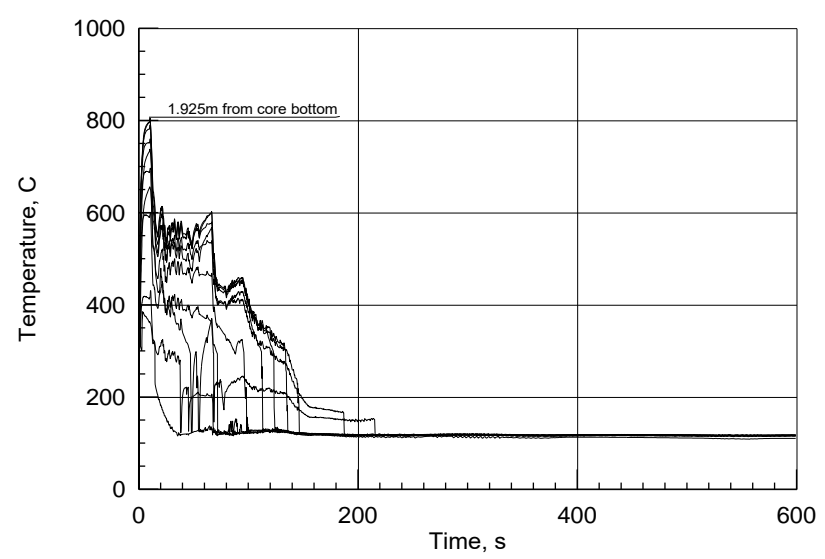

Fig. 5. Rupture of MCC. Temperature of the cladding outer surface. Version $k_{z}-1$, $k_{r}=1.2$, maximum $L H G R 336 \mathrm{~W} / \mathrm{cm}$



Fig. 6. Rupture of MCC. Temperature of the cladding outer surface. Version $k_{z}-1$, $k_{r}=1.3$, maximum LHGR $364 \mathrm{~W} / \mathrm{cm}$ 


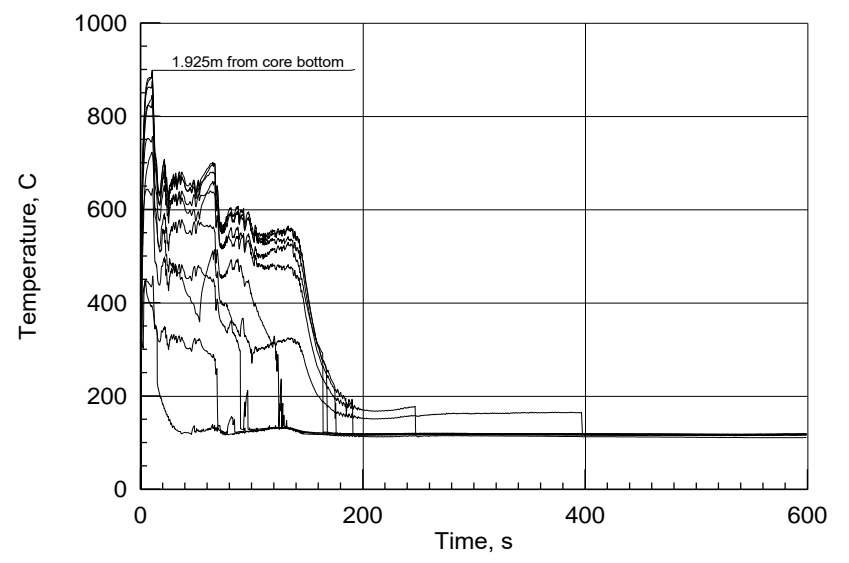

Fig. 7. Rupture of MCC. Temperature of the cladding outer surface. Version $k_{z}-1$, $k_{r}=1.4$, maximum LHGR $392 \mathrm{~W} / \mathrm{cm}$.

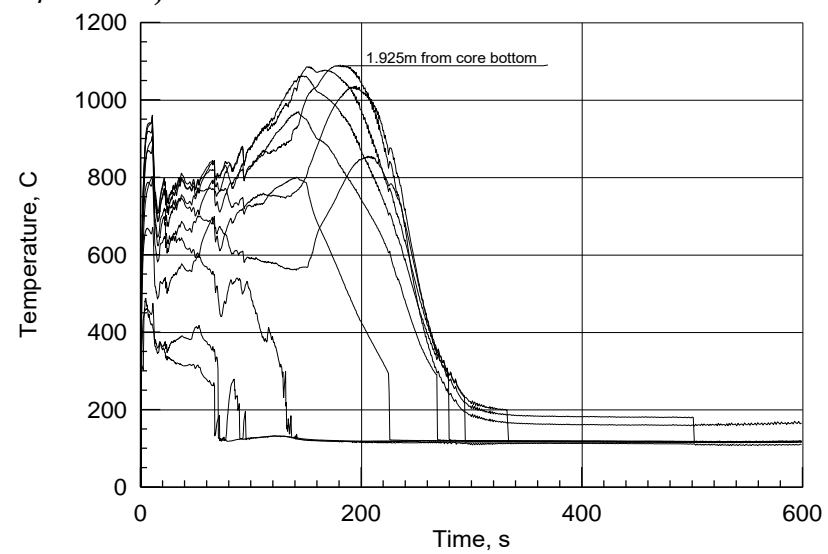

Fig. 8. Rupture of MCC. Temperature of the cladding outer surface. Version $k_{z}-1, k_{r}=1.5$, maximum LHGR $420 \mathrm{~W} / \mathrm{cm}$

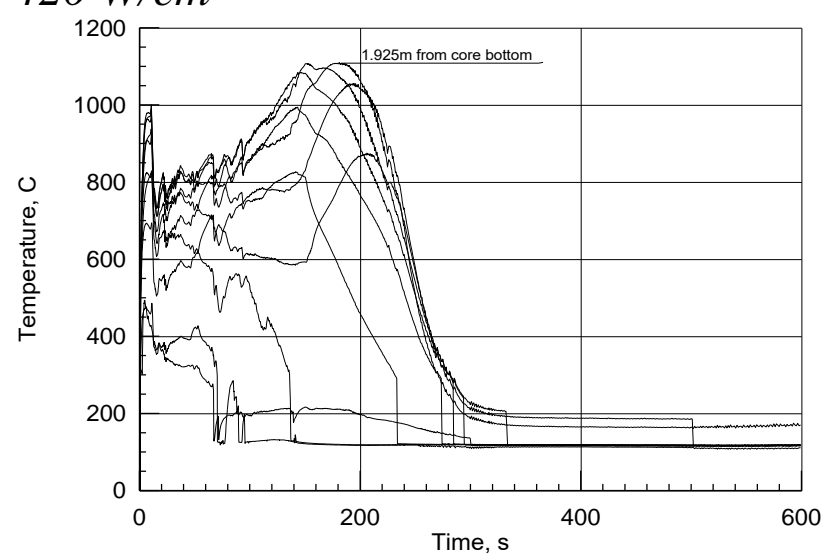

Fig. 9. Rupture of MCC. Temperature of the cladding outer surface. Version $k_{z}-1$, $k_{r}=1.6$, maximum LHGR $448 \mathrm{~W} / \mathrm{cm}$.

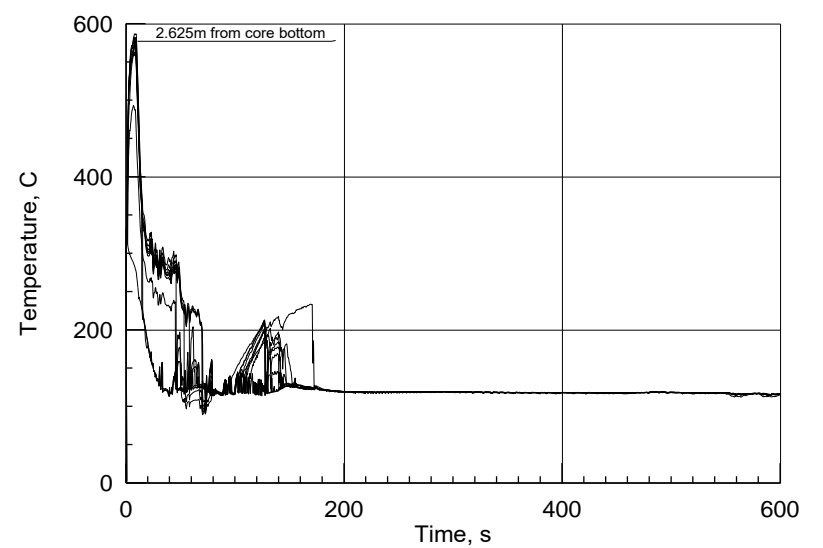

Fig. 10. Rupture of MCC. Temperature of the cladding outer surface. Version $k_{z}-2$, $k_{r}=1.0$, maximum LHGR $198 \mathrm{~W} / \mathrm{cm}$.

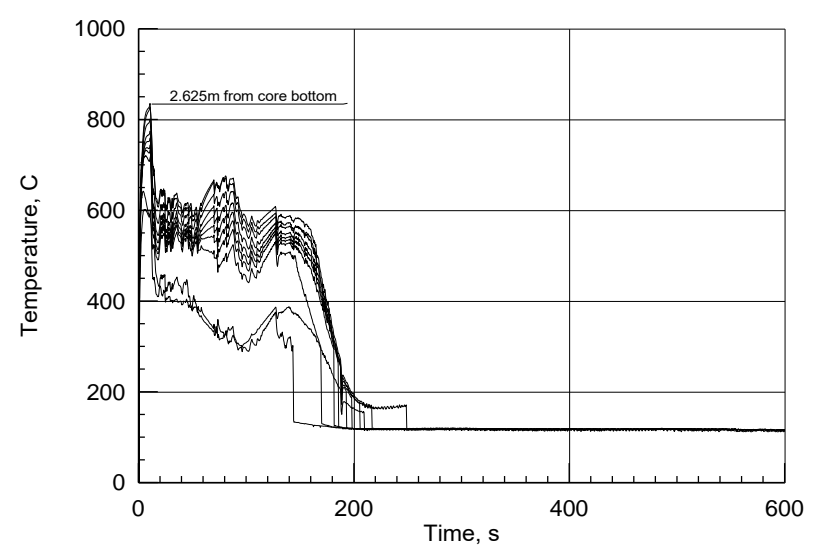

Fig. 11. Rupture of MCC. Temperature of the cladding outer surface. Version $k_{z}-2$, $k_{r}=1.34$, maximum LHGR $307 \mathrm{~W} / \mathrm{cm}$.

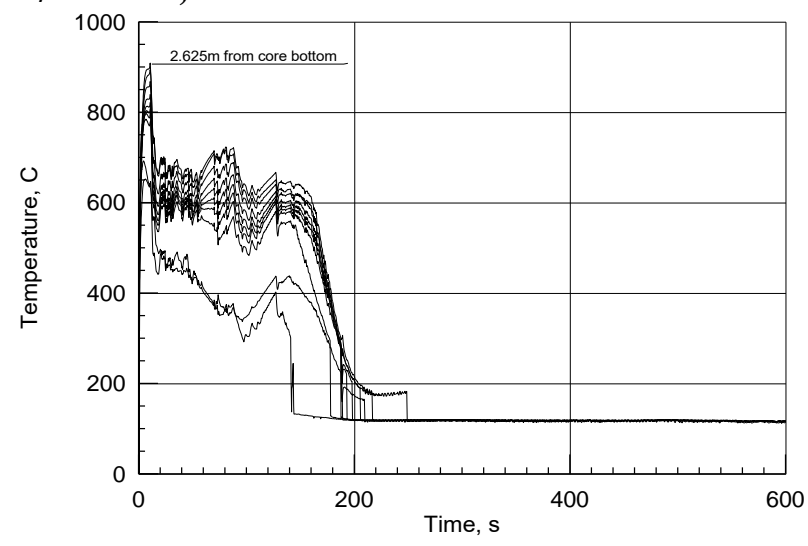

Fig. 12. Rupture of MCC. Temperature of the cladding outer surface. Version $k_{z}-2$, $k_{r}=1.55$, maximum LHGR $360 \mathrm{~W} / \mathrm{cm}$. 
Five different versions of the initial state of fuel rods are considered to be covering the range of the 4-year fuel cycle, it was assumed basing on the history of the highest burn-up fuel rod using the results of the thermophysical calculations:

1) fresh fuel rod having the maximal gap in the tolerable range,

2) early in the $2^{\mathrm{d}}$ year of the cycle (the maximum burn-up of $19 \mathrm{MW} \bullet$ day $/ \mathrm{kgU}$ per pellet),

3) early in the $3^{\mathrm{d}}$ year of the cycle (the maximum burn-up of $38 \mathrm{MW} \bullet$ day $/ \mathrm{kgU}$ per pellet),

4) early in the $4^{\text {th }}$ year of the cycle ( the maximum burn-up of $54 \mathrm{MW} \bullet$ day $/ \mathrm{kgU}$ per pellet),

5) end of the $4^{\text {th }}$ year of the cycle (the maximum burn-up of $68 \mathrm{MW} \bullet$ day/kgU per pellet).

Tables 2 and 3 summarize the basic parameters describing the thermomechanical and corrosion behaviour of fuel rods that were determined by RAPTA-5 code calculations [309].

Table 2.

Decisive parameters of fuel rod state in accident attended with main circulation conduit (MCC) rupture $\left(\mathrm{k}_{\mathrm{z}}-1\right)$

\begin{tabular}{|c|c|c|c|c|c|}
\hline \multirow{2}{*}{$\begin{array}{l}\text { No of group } \\
\text { (per power) }\end{array}$} & \multirow{2}{*}{ Parameter } & \multicolumn{4}{|c|}{ № of version of initial fuel rod state } \\
\hline & & 1 & 2 & 3 & 4 \\
\hline \multirow{5}{*}{$\begin{array}{c}1 \\
\left(k_{r}-1.0\right)\end{array}$} & Max. Temperature of fuel, ${ }^{\circ} \mathrm{C}$ & 1059.8 & 1058.4 & 1044.0 & 1112.7 \\
\hline & Max. Temperature of cladding, ${ }^{\circ} \mathrm{C}$ & 647.2 & 647.2 & 647.1 & 647.5 \\
\hline & Hoop logarithmic strain, rel. units & 0.0 & 0.0 & 0.0 & 0.0013 \\
\hline & ECR, \% & 0.023 & 0.023 & 0.023 & 0.023 \\
\hline & $\begin{array}{c}\text { Quantity of oxidized Zr in fuel } \\
\text { cladding, \% }\end{array}$ & 0.0126 & 0.0126 & 0.0126 & 0.0126 \\
\hline \multirow{5}{*}{$\begin{array}{c}2 \\
\left(k_{r}-1.1\right)\end{array}$} & Max. Temperature of fuel, ${ }^{\circ} \mathrm{C}$ & 1294.2 & 1267.8 & 1271.5 & - \\
\hline & Max. Temperature of cladding, ${ }^{\circ} \mathrm{C}$ & 779.0 & 778.9 & 779.0 & - \\
\hline & Hoop logarithmic strain, rel. units & 0.0008 & 0.0022 & 0.0053 & - \\
\hline & ECR, \% & 0.0952 & 0.0952 & 0.0952 & - \\
\hline & $\begin{array}{l}\text { Quantity of oxidized } \mathrm{Zr} \text { in fuel } \\
\text { cladding, \% }\end{array}$ & 0.0479 & 0.0479 & 0.0480 & - \\
\hline
\end{tabular}




\begin{tabular}{|c|c|c|c|c|c|}
\hline \multirow{5}{*}{$\begin{array}{c}3 \\
\left(k_{r}-1.2\right)\end{array}$} & Max. Temperature of fuel, ${ }^{\circ} \mathrm{C}$ & 1390.5 & 1352.5 & 1366.0 & - \\
\hline & Max. Temperature of cladding, ${ }^{\circ} \mathrm{C}$ & 806.4 & 806.6 & 805.8 & - \\
\hline & Hoop logarithmic strain, rel. units & 0.0043 & 0.0083 & 0.0144 & - \\
\hline & ECR, \% & 0.1315 & 0.1315 & 0.1315 & - \\
\hline & $\begin{array}{l}\text { Quantity of oxidized Zr in fuel } \\
\text { cladding, \% }\end{array}$ & 0.0682 & 0.0683 & 0.0685 & - \\
\hline \multirow{5}{*}{$\begin{array}{c}4 \\
\left(k_{r}-1.3\right)\end{array}$} & Max. temperature of fuel, ${ }^{\circ} \mathrm{C}$ & 1484.3 & 1434.0 & 1457.1 & - \\
\hline & Max. temperature of cladding, ${ }^{\circ} \mathrm{C}$ & 870.6 & 870.3 & 870.4 & - \\
\hline & Hoop logarithmic strain, rel. units & 0.0266 & $0.0539 *$ & 0.0966 & - \\
\hline & ECR, \% & 0.2241 & 0.3215 & 0.3695 & - \\
\hline & $\begin{array}{l}\text { Quantity of oxidized } \mathrm{Zr} \text { in fuel } \\
\text { cladding, \% }\end{array}$ & 0.1145 & 0.1591 & 0.1837 & - \\
\hline \multirow{5}{*}{$\begin{array}{c}5 \\
(\mathrm{kr}-1.4)\end{array}$} & Max. temperature of fuel, ${ }^{\circ} \mathrm{C}$ & 1575.8 & 1513.3 & 1546.8 & - \\
\hline & Max. temperature of cladding, ${ }^{\circ} \mathrm{C}$ & 900.1 & 899.0 & 898.8 & - \\
\hline & Hoop logarithmic strain, rel. units & $0.0492 *$ & 0.0819 & 0.1278 & - \\
\hline & ECR, \% & 0.4085 & 0.4468 & 0.5083 & - \\
\hline & $\begin{array}{l}\text { Quantity of oxidized Zr in fuel } \\
\text { cladding, \% }\end{array}$ & 0.2004 & 0.2272 & 0.2618 & - \\
\hline \multirow{5}{*}{$\begin{array}{c}6 \\
\left(k_{r}-1.5\right)\end{array}$} & Max. temperature of fuel, ${ }^{\circ} \mathrm{C}$ & 1666.4 & 1591.5 & - & - \\
\hline & Max. temperature of cladding, ${ }^{\circ} \mathrm{C}$ & 1088.9 & 1088.7 & - & - \\
\hline & Hoop logarithmic strain, rel. units & 0.3873 & 0.3867 & - & - \\
\hline & ECR, \% & 4.6607 & 4.6726 & - & - \\
\hline & $\begin{array}{l}\text { Quantity of oxidized } \mathrm{Zr} \text { in fuel } \\
\text { cladding, \% }\end{array}$ & 2.2155 & 2.2499 & - & - \\
\hline \multirow{5}{*}{$\begin{array}{c}7 \\
\left(k_{r}-1.6\right)\end{array}$} & Max. temperature of fuel, ${ }^{\circ} \mathrm{C}$ & 1755.0 & - & - & - \\
\hline & Max. temperature of cladding, ${ }^{\circ} \mathrm{C}$ & 1108.5 & - & - & - \\
\hline & Hoop logarithmic strain, rel. units & 0.3840 & - & - & - \\
\hline & ECR, \% & 5.3408 & - & - & - \\
\hline & $\begin{array}{l}\text { Quantity of oxidized Zr in fuel } \\
\text { cladding, \% }\end{array}$ & 2.5911 & - & - & - \\
\hline
\end{tabular}

Table 3.

Decisive parameters of fuel rod state in accident attended with MCC rupture $\mathrm{k}_{\mathrm{z}^{-}}$ 2

\begin{tabular}{|c|c|c|c|c|c|}
\hline \multirow{2}{*}{$\begin{array}{l}\text { No of group } \\
\text { (per power) }\end{array}$} & \multirow{2}{*}{ Parameter } & \multicolumn{4}{|c|}{ № of version of initial fuel rod state } \\
\hline & & 2 & 3 & 4 & 5 \\
\hline \multirow{5}{*}{$\begin{array}{c}1 \\
\left(k_{r}-1.0\right)\end{array}$} & Max. temperature of fuel, ${ }^{\circ} \mathrm{C}$ & 931.7 & 912.0 & 969.8 & 1047.4 \\
\hline & Max. temperature of cladding, ${ }^{\circ} \mathrm{C}$ & 587.6 & 587.6 & 587.8 & 588.2 \\
\hline & Hoop logarithmic strain, rel. units & 0.0 & 0.0 & 0.0001 & 0.0033 \\
\hline & ECR, \% & 0.0111 & 0.0111 & 0.0111 & 0.0111 \\
\hline & $\begin{array}{l}\text { Quantity of oxidized Zr in fuel } \\
\text { cladding, \% }\end{array}$ & 0.0087 & 0.0087 & 0.0087 & 0.0087 \\
\hline
\end{tabular}




\begin{tabular}{|c|c|c|c|c|c|}
\hline \multirow{4}{*}{$\begin{array}{c}2 \\
(\mathrm{k}-1.34)\end{array}$} & Max. temperature of fuel, ${ }^{\circ} \mathrm{C}$ & 1265.1 & 1269.5 & 1349.2 & - \\
\cline { 2 - 6 } & Max. temperature of cladding, ${ }^{\circ} \mathrm{C}$ & 834.7 & 833.1 & 833.1 & - \\
\cline { 2 - 6 } & Hoop logarithmic strain, rel. units & $0.0611^{*}$ & 0.1018 & 0.1327 & - \\
\cline { 2 - 6 } & $\begin{array}{c}\text { Quantity of oxidized Zr in fuel } \\
\text { cladding, \% }\end{array}$ & 0.2712 & 0.2953 & 0.3081 & - \\
\cline { 2 - 6 } & Max. temperature of fuel, ${ }^{\circ} \mathrm{C}$ & 1416.3 & - & - & - \\
\hline \multirow{4}{*}{$\begin{array}{c}3 \\
(\mathrm{k}-1.55)\end{array}$} & Max. temperature of cladding, ${ }^{\circ} \mathrm{C}$ & 905.9 & - & - & - \\
\cline { 2 - 6 } & Hoop logarithmic strain, rel. units & 0.1888 & - & - & - \\
\cline { 2 - 6 } & $\begin{array}{c}\text { ECR, \% } \\
\text { Quantity of oxidized Zr in fuel } \\
\text { cladding, \% }\end{array}$ & 0.5956 & - & - & - \\
\hline
\end{tabular}

For fuel rods of the initial relative power $k_{r} \geq 1.3$, the predicted loss of cladding tightness was calculated from the lower estimate of the deformation rupture criterion (Table 2, 3) after which the account of the cladding inner surface oxidation began. The calculation of straining continued until rupture using the mean estimate of the deformation criterion to acquire the conservative value of the oxidized $\mathrm{Zr}$ quantity taking into account an increase in the cladding surface area.

To assess the overall quantity of oxidized $\mathrm{Zr}$ in a core, the estimated fractions of oxidized zirconium in fuel rods of each group multiplied by the respective weight factors were summed up. The weight factor for each group is determined as the ratio of the fuel rod quantity per group to the overall quantity of fuel rods per core.

\section{Conclusion}

The representative maximal design limit of a fuel rod damage in terms of oxidation (the embrittlement criterion) covers all together the maximum temperature of the fuel rod cladding and ECR.

The numerical values of the criterional parameters $T_{\text {clad }}^{\lim }=1200^{\circ} \mathrm{C}$ and $E C R_{\text {clad }}^{\lim }=18 \%$ are validated by the data experimentally acquired from studying the kinetics of the Zrsteam reaction and the special thermal shock experiments.

It is demonstrated that the mechanical properties of oxidized claddings subjected to thermal shock (impact elasticity, residual ductility) are adequate for claddings to 
remain stable in flooding and implementing the subsequent activities (fuel assembly discharge and transportation).

In terms of fuel rod claddings, the limitation of hydrogen released as a result of the Zr-steam reaction is provided by meeting the following requirement: the fraction of steam reacted $\mathrm{Zr}$ in a core must not exceed $1 \%$ of its mass in fuel rod claddings.

The criterion of intolerance of fuel melting ensures that the liquid phase of the fuel does not interact with the cladding.

The computer investigations of the thermomechanical and corrosion behaviour of fuel rods in the typical design basis accident (DBA) attended with a prompt transverse rupture of MCC at a reactor inlet evidence the fulfillment of the safety criteria.

It is apparent that the safety criteria placed upon the fuel rod state in design basis accidents of the "uncompensable small break LOCA" type are met. 


\section{5 О безопасности человеческой жизни в условиях глобализации}

\section{Введение}

В современных социальных науках, идеологии и политике все большее значение приобретают концепции национального, глобального и человеческого развития. Это потому, что текущий процесс развития любого государства не проходит без этих трех столпов. По мнению известных сегодня политиков и экономистов, процессы холодной войны и «гонки вооружений» развиваются в новом направлении, называемом «энергетической войной», и порождают новые конфликты и напряженность. Глобализация - это процесс создания новой глобальной политической, экономической, культурной и информационной целостности. Этот термин впервые был представлен научному сообществу в 1983 году американским экономистом Теодором Левиттом.

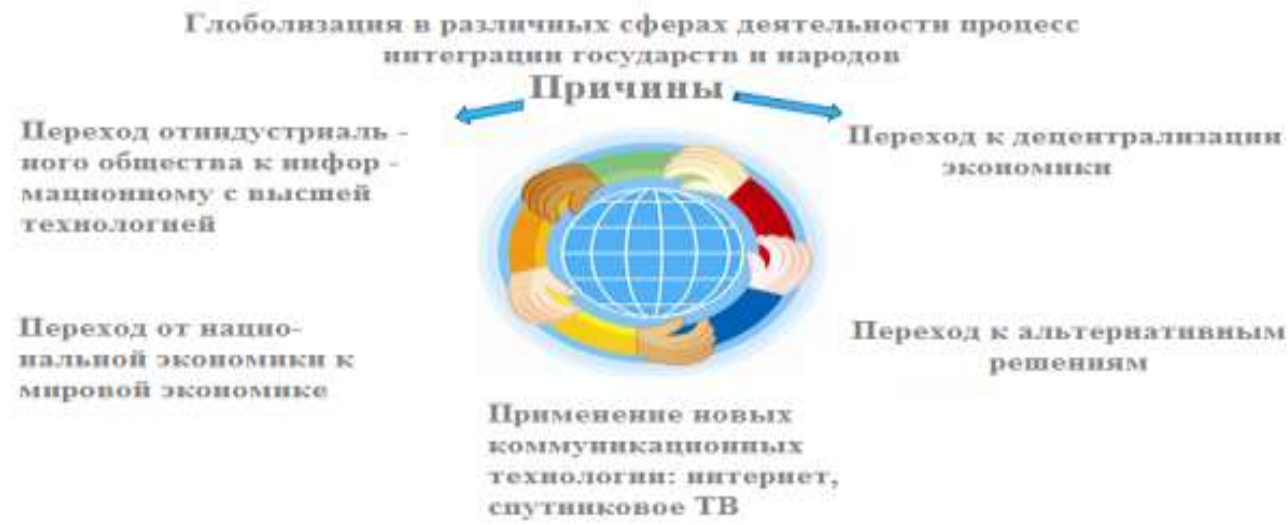

Рис.1. Основные причины глобализации

\subsubsection{0сновная часть.}

Обострение и глобализация экологических проблем со второй половины двадцатого века, прежде всего загрязнение и разрушение элементов окружающей среды, нехватка ресурсов, которые угрожают самой основе жизни и средств к существованию, и тем более для будущих поколений.

Возникновение такой ситуации было результатом практически неконтролируемого экономического роста, который требовал большего 
количества природных ресурсов, поскольку вся экономическая деятельность основана на использовании элементов окружающей среды (металлов, полезных ископаемых, почвы, лесов, рыбных ресурсов, энергии).

Глобализация мировой экономики способствовала у ухудшению окружающей среды из-за ускорения экономического роста. Хотя глобальный экономический рост ускорился, особенно за счет развивающихся стран, а финансово-экономический кризис вызвал рецессию во многих странах, в ближайшем будущем не может быть радикальных изменений в долгосрочной тенденции быстрого глобального экономического развития. .

Однако до 1960-1970 гг. Негативное влияние экономической деятельности наблюдалось только в отношении определенных компонентов окружающей среды, а затем распространялось на все ее компоненты. В последние десятилетия XX века и в начале XXI века это влияние особенно остро и носит глобальный характер, как с точки зрения его влияния на развитие мировой экономики, так и комплекса принимаемых для этого мер.

С середины двадцатого века мировая экономика и высокие темпы роста населения нанесли большой ущерб окружающей среде. В начале XXI века мировое промышленное производство увеличилось в 7 раз, население Земли увеличилось в 2,5 раза по сравнению с 1950 годом и сейчас составляет 7 миллиардов человек [316].

\subsubsection{1 Рост численности населения земного шара.}

К 2050 году население может вырасти еще на 2-2,5 миллиарда, к 2030 году растущему населению потребуется увеличить продукты питания и энергию на 50\%, пресную воду на 30\%, а к 2050 году производство продуктов питания должно вырасти на 70\%.

В начале 1990-х годов население Земли, по мнению некоторых ученых, сбросило максимально допустимую нагрузку на окружающую среду. Сегодня масштабы глобального производства и потребления привели к катастрофическому нарушению баланса природных и социальных систем и, по мнению многих ученых в различных областях науки, достигли своего предела, 
даже превышая способность окружающей среды справляться с Деятельность человека. Исследования показывают, что эти возможности превысили 25-30\%, а экологический долг человечества оценивается в 4 триллиона долларов.

Учитывая, что большинство экологических проблем возникает намного позже, чем их причины, даже если все необходимые меры будут приняты немедленно, качество окружающей среды будет ухудшаться в течение многих лет, в первую очередь из-за острых и долгосрочных проблем - изменения климата и истощения озонового

В настоящее время источниками экологически опасной деятельности являются в первую очередь транснациональные корпорации, поскольку они образуют основные производственные, инвестиционные и торговые связи в мире. В условиях глобализации обострение экологических проблем связано с ограниченными возможностями национальных правительств и международных организаций контролировать и регулировать деятельность транснациональных корпораций, что приводит к расширению их полномочий и бесконечному росту торговли и инвестиций [317].

В понятие глобальной экологической проблемы входят различные глобальные экологические проблемы, основными из которых являются нехватка ресурсов, разрушение компонентов и загрязнение окружающей среды, а также влияние социальной среды. Разделение на отдельные комплексы этих проблем условно, так как все они тесно связаны между собой, а одни приводят к возникновению других. Одна из важнейших проблем - нехватка ресурсов, что связано с чрезмерным и зачастую нерациональным характером их потребления, прежде всего в развитых странах.

\subsubsection{2 Истощение природных ресурсов.}

Уровень использования возобновляемых ресурсов, в частности пресной воды, лесов, верхнего слоя почвы и морских рыбных запасов, превышает скорость естественного восстановления на глобальном уровне. За последние 50 лет человечество использовало больше ресурсов, чем когда-либо прежде. Только в 1970-1995 годах мировое потребление сырья (за исключением продуктов 
питания и топлива) увеличилось вдвое. По данным Программы Организации Объединенных Наций по окружающей среде (ЮНЕП), нехватка пресной воды является важной экологической проблемой из-за ее высокого уровня загрязнения и нерационального использования в контекст устойчивого роста населения.

Недостаток воды отрицательно сказывается на сельском хозяйстве, особенно на искусственно орошаемых сельскохозяйственных угодьях, поскольку около 65\% воды расходуется на производство сельскохозяйственной продукции. Расход воды на единицу продукции в крупных агрокомплексах намного выше, чем в малых хозяйствах. Некоторые виды современных высокотехнологичных производств, такие как компьютерные чипы, также требуют большого количества чистой воды[318].

Вымирание компонентов окружающей среды также является глобальной экологической проблемой: вырубка лесов, особенно в тропиках - основных продуцентах кислорода в атмосфере Земли, наступление пустынь и засоление плодородных земель, коралловые рифы, угрожающие неодушевленному пространству океана. В настоящее время сохранилось только $35 \%$ девственных лесов мира, в то время как в США потеряно 85\% таких лесов, а в Европе их практически нет.

\subsection{2. Парниковый эффект}

В результате деятельности человека исчезла половина тропических лесов мира. Это 1990-2005 годы. Площадь лесов уменьшилась в среднем на 0,2\%. Их обезлесение способствует расширению зоны пустынь и влияет на глобальный климат из-за увеличения содержания углекислого газа в атмосфере. По оценкам, сокращение площади лесов равно дополнительным 20-25\% выбросов парниковых газов в атмосферу. Кроме того, обезлесение приводит к эрозии почвы и истощению пахотных земель, которые являются источником пищи, нарушением водных систем и экосистем. Существование 350 миллионов человек в мире напрямую связано с существованием лесов.

Наибольшую угрозу для жизни и здоровья человека представляет быстрое загрязнение окружающей среды в результате антропогенных процессов 
долгосрочными разлагающимися соединениями. Химическое загрязнение, которое приводит к глобальному потеплению и истощению озонового слоя Земли, имеет самые серьезные последствия [319].

Проблема глобального потепления, представляющая угрозу для человечества, признана наиболее важной и всеобъемлющей. Многие ученые связывают изменение климата с увеличением выбросов в атмосферу, в основном называемых парниковыми газами: диоксид углерода, метан, оксиды азота и некоторые виды углеводородов хлорофтора.

В 2005 году концентрация парниковых газов в атмосфере была на 35\% выше, чем полтора века назад. По мнению ученых, увеличение концентрации связано с антропогенными источниками, включая производство, переработку, использование материалов, сельское хозяйство и удаление отходов. При этом основной причиной является производство топлива и энергии, в результате чего около 65\% всех выбросов парниковых газов в мире производится за счет антропогенных источников. После промышленной революции 2007 года выбросы углекислого газа при сжигании топлива увеличились с нуля до 29 ГВт.

\subsubsection{1 Страны загрязнители атмосферы}

Основными загрязнителями являются не только развитые страны, но и такие быстрорастущие страны, как Китай и Индия. В 2007 году Китай впервые занял первое место в мире по выбросам углерода от сжигания топлива: его доля составила 20,9\%. На втором месте оказались США с долей 19,9\%. Другими основными загрязнителями были ЕС - 11,3\%, Россия - 5,4\% и Индия - менее 5\%. Глобальное потепление уже имеет серьезные негативные последствия и затрагивает многие страны, нанося ущерб их экономике. В будущем изменение климата может иметь еще более серьезные последствия, включая выживание человека.

Потепление приведет к таянию ледников и поднятию уровня Мирового океана, изменению морских течений, распространению опасных насекомых и неизвестных инфекций среди людей. Климатические дисбалансы приводят к увеличению количества и масштабов стихийных бедствий: ураганов (включая 
ураган Катрина в 2005 году), тайфунов, цунами (например, сильное цунами в Индийском океане в 2004 году), засух (например, беспрецедентной засухи в Центральная Россия в 2010 г.).) наводнения, наблюдавшиеся в последние годы в Европе, Японии, США, России, Азии и других регионах. Количество стихийных бедствий (исключая геологические причины, такие как землетрясения и извержения вулканов) увеличилось с 233 в 1950-х годах до 3800 в первом десятилетии 21 века, а число пострадавших увеличилось с 20 миллионов до 2 миллиардов [320].

Изменение климата подрывает глобальную продовольственную безопасность, влияя на продуктивность сельского хозяйства, экосистемы и утрату биоразнообразия. Последние данные показывают, что глобальное потепление может привести к сокращению посевных площадей под пшеницей в Южной Азии на 50\%. По оценкам, 17\% пахотных земель в Китае и 28\% в Индии подвержены эрозии и другим формам деградации земель. Потепление также приводит к гибели коралловых рифов, которые являются источником жизни в морях и океанах.

\subsubsection{2 Изменение мирового климата}

Изменение климата обостряет другие глобальные проблемы: уменьшает количество ресурсов (в том числе пресноводных, рыбных ресурсов), приводит к дальнейшему истощению компонентов природной среды - вырубке лесов, опустыниванию, засолению почв и другим. Сложность решения проблемы глобального потепления зависит от его долговременности.

Учитывая взаимоотношения в природе, негативные последствия изменений окружающей среды наблюдаются уже много лет. Он направлен на объединение усилий мирового сообщества на местном, региональном, национальном и международном уровнях для оценки изменений ситуации и принятия эффективных мер по решению этой важнейшей глобальной проблемы.

Проблема отходов, особенно опасных (прежде всего ядерных отходов и их захоронения), представляет большую угрозу для окружающей среды. Оценки отходов, производимых разными организациями, значительно различаются из-за 
сложности их подсчета. По одной из оценок, ежегодно в мире образуется до 100 миллиардов тонн твердых отходов, в том числе при добыче полезных ископаемых, электроэнергии, автомобилей и т. Д. появляется.

Другими крупными производителями этого типа отходов являются Китай, Япония, Бразилия, Индия и Франция. По оценкам экспертов Базельской конвенции, в 2000 году было выброшено более 300 миллионов тонн опасных отходов. Около 90\% всех выбросов были классифицированы как опасные, а 30\% - как стойкие органические загрязнители. Более 90\% отходов поступает из развитых стран. Ситуация особенно тяжелая в развивающихся странах, где собирается 30-60\% всех твердых бытовых отходов.

\subsubsection{3 Опасные отходы}

В настоящее время количество опасных отходов связано с их новыми видами - компьютерами, мобильными телефонами и т. Д. б. очень быстро растет из-за появления. К значительным глобальным экологическим проблемам относятся, прежде всего, социальные аспекты развития стран, связанные с их высокими темпами прироста населения.

Прогнозируется, что к 2050 году 85\% населения мира будет проживать в развивающихся странах, где питание, жилье, работа, образование и здравоохранение особенно затруднены. Высокие темпы роста населения в развивающихся странах обычно требуют ускоренного экономического роста, что, в свою очередь, приводит к ухудшению состояния окружающей среды.

Невозможно эффективно решать экологические проблемы без решения проблем развития, в том числе проблемы увеличения неравномерности распределения прибыли от быстрого глобального экономического роста из-за глобализации. Значительные различия в уровне благосостояния развитых и развивающихся стран препятствуют решению проблем развития. Несмотря на то, что средний доход на душу населения в мире сейчас превышает 5 тысяч долларов, 2,8 миллиарда человек в год (2 из 5) живут менее чем на 2 доллара в день. 
Около $1 \%$ самых богатых людей на Земле зарабатывают доход, сопоставимый с доходом 57\% бедных. Хотя число бедных с 1990 года уменьшилось на 0,4 миллиона, все это сокращение произошло за счет Китая, в то время как абсолютное число бедных увеличилось в странах Африки к югу от Сахары и Южной Азии. Развитые страны вкладывают значительные средства в окружающую среду, а в развивающихся странах такие возможности ограничены. Поэтому решение проблем развития - одна из важнейших задач, стоящих перед человечеством, которая является экологической потребностью и требует совместных усилий мирового сообщества [320].

\section{Выводы}

Возникновение и дальнейшее обострение глобальных экологических проблем связано с неопределенностью и неравномерностью глобализации мировой экономики, оказывающей существенное влияние на окружающую среду. В контексте глобального экономического роста, во многом благодаря ТНК, преобразование окружающей среды потребовало принятия мер, которые приведут к радикальным изменениям в регенеративной системе планеты, и начали влиять на все страны и всех людей на Земле.

Расширение мировой экономики приведет к увеличению использования природных ресурсов за счет увеличения экспорта нефти, лесов и других природных ресурсов, что приведет к увеличению загрязнения окружающей среды и обострению других глобальных проблем.

Многолетние исследования показали двойное воздействие международной торговли на окружающую среду, многие из которых имеют негативные последствия. Примерами негативного воздействия на окружающую среду расширения производства являются кожевенная, красильная и текстильная промышленность Китая и Пакистана: рост экспорта их продукции привел к резкому увеличению производства, что привело к значительному увеличению производства. экологическое давление и экологический ущерб. 


\section{SECTION 5. FOOD TECHNOLOGY}

DOI 10.46299/ISG.2021.MONO.TECH.III.5.1

\subsection{Improving food adequacy low-value collagen-containing raw materials in the technology of semi-finished products}

The modern development of technologies at meat processing enterprises is aimed at finding ways to rationally use low-value meat protein-containing raw materials and create innovative technologies for the production of organic food.

In the scientific and technological aspect, the issues of improving the efficiency of natural resources are reduced to the development and implementation of low- and zero-waste resources and energy-saving technologies, which provide the most complete, efficient use of resources and principles of a waste-free, environment.

Solving the problem of waste-free production should be borne in mind two sides of the same process. The first is the most efficient extraction and full use of resources and, as a result, the reduction of waste generation. The second is to expand the use of generated waste. These paths do not exclude but complement each other.

Waste-free is the technology of manufacturing products in which raw materials and energy resources are spent rationally. At the same time, the concept of waste-free production assumes that the impact on the environment does not lead to disruption of its functioning.

The main provisions of the concept of waste-free technologies include:

- creating the most closed systems by analogy with the natural ecosystem;

- rational use of all components of raw materials;

- achieving minimal harmful effects on the environment.

Resource-saving at the enterprises of the meat processing industry of Ukraine is a modern direction of increase of efficiency of production and cost-effective implementation, which not only saves raw materials but also affects the growth of production for the same quantities of raw meat. 
Meat and products of its processing are renewable raw materials, which are relatively expensive, and the process of their production is labor-intensive. Therefore, in terms of full economic calculation, it is necessary to direct funds and efforts to preserve raw materials, to the more complete and rational use of all its components in the processing process.

Secondary raw materials, which belong to the renewable resources of meat production, are used irrationally, in most enterprises such raw materials are sold cheaply or disposed of. Using such raw materials can solve a number of problems.

The problem of greening food production has two interrelated aspects. The first of them is the organization of rational production, which ensures the production of high quality, environmentally friendly products with minimized costs, the second - in resource-efficient production, environmental protection, reduction of man-made load, implementation of efficient waste treatment systems. [321-323]

Secondary raw materials include by-products obtained from the slaughter of farm animals, such raw materials are sometimes used irrationally due to the peculiarities of their composition and properties.

The total yield of offal to live weight is $12-16 \%$ for cattle, $12-18 \%$ for pigs, 10 $14 \%$ for small cattle, $5-6 \%$ for poultry.

Significant resources of animal protein contain by-products of the second category: spleen, lungs, etc. With the exception of the spleen and meat of beef heads, by-products of the second category contain a complete set of essential amino acids. Indicators of the content of essential amino acids of proteins selected for the experiment by-products are shown in table. 1 . 
Table 1

The content of essential amino acids of proteins of beef offal of I and II category

\begin{tabular}{|c|c|c|c|c|c|c|c|c|c|}
\hline \multirow[t]{2}{*}{ By-products } & \multicolumn{9}{|c|}{ Essential amino acids, g / 100 g of protein } \\
\hline & 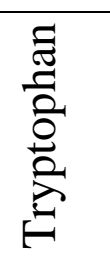 & 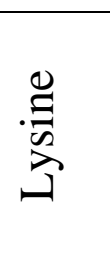 & 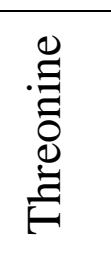 & $\underset{>}{\stackrel{\Xi}{\Xi}}$ & 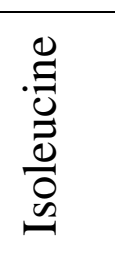 & 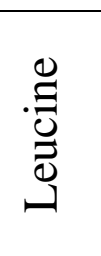 & 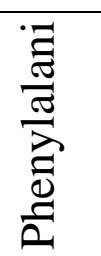 & 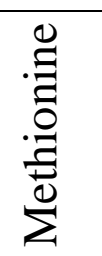 & 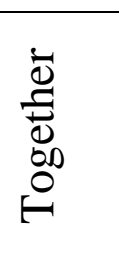 \\
\hline Lungs & 0,88 & 6,30 & 2,84 & 4,15 & 4,16 & 8,23 & 4,20 & 1,0 & 31,76 \\
\hline Meat trimmin & 0,92 & 8,41 & 4,94 & 6,05 & 4,22 & 8,02 & 3,46 & 3,80 & 39,82 \\
\hline
\end{tabular}

Most by-products has a low-fat content, which allows them to be used in the production of meat products as protein raw materials. The use of animal proteins from collagen-containing raw materials allows enriching meat products with dietary fiber, significantly improving the rheological parameters of food products, and, above all, the consistency. [324]

For more complete and rational use of available unclaimed animal raw materials, active use of biotechnologies is proposed, which allow obtaining high-value food, food supplements, medicines, and other useful products from non-edible raw materials while significantly reducing energy costs.

The use of biotechnology is one of the important areas of rapidly evolving scientific and technological progress. The technology is based on the industrial application of natural living systems (primarily microorganisms). Industrial cultivation of microorganisms, plant and animal cells is used to obtain many valuable compounds - enzymes, hormones, amino acids, vitamins, antibiotics, methanol, organic acids (acetic, citric, lactic), and more.

Enzymes - biological catalysts of protein nature, which are synthesized in the cells of living organisms, accelerate and coordinate biochemical reactions that regulate metabolism.

The use of enzyme preparations in the technology of production of meat products allows to intensify the technological process and involve in the process of non- 
traditional, lower-grade raw materials. The use of enzyme preparations has a positive effect on the tenderness, juiciness, nutritional value of raw materials, the formation of the required level of moisture-binding and adhesive ability, improves organoleptic characteristics. The advantages of this approach in relation to the technology of meat products are presented in Fig. 1. [325-326]

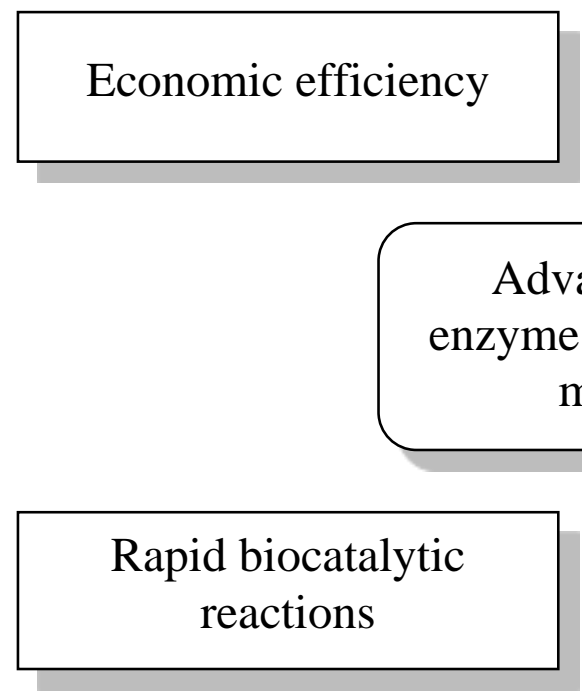

Adaptability to traditional technologies

Figure 1. Justification of the feasibility of using enzyme preparations

According to the set tasks, the by-products of cattle of the I and II categories lungs and meat trim, which are characterized by unsatisfactory organoleptic and functional-technological properties, were selected as objects of experiments. The choice is justified by the fact that the raw material contains a large number of connective tissue proteins, and especially collagen. The presented research can serve as a further basis for the development of rational use of such raw materials, as well as the possibility of its use in the food industry. [327]

The choice of enzyme preparation for the cleavage of connective tissue was guided by the following principles: ease of use, availability, the possibility of use at a $\mathrm{pH}$ close to the raw material, activity against collagen.

To improve the quality characteristics of low-grade raw materials, their biotechnological treatment with the enzyme preparation STABICOL SKIN (PRIORITY INTERNATIONAL LLC) was carried out. Protein enrichers were obtained in this way. The prepared raw material was ground in a meat grinder with a 
lattice hole diameter of 6-8 $\mathrm{mm}$ and formed a collagen-containing composition. To obtain a protein enrichment used collagen-containing raw materials of the meat industry - meat trimmings with a large inclusion of connective tissue and by-products of the second category - lungs in a ratio of 1: 1 .

In the prepared mass was made $2.5 \%$ aqua of STABICOL SKIN in a ratio of 1 : 1.5 to the mass of raw materials, stirred, and kept in production conditions for 12 hours. The biomodified mass was freed from the remains of the solution and subjected to fine grinding on a cutter.

Enzymatic treatment was performed with the following concentration of STABICOL SKIN aqua: 0.01; 0.025 and 0.05\%, within 6 and 12 hours.

It should be noted that the largest changes in the structure, which are observed visually, occurred with samples, treated with enzyme aqua STABICOL SKIN, a concentration of $0.25 \%$ for both 6 and 12 hours of treatment.

Indicators of protein and moisture obtained in the study of enzymatic processing products are shown in table. 2.

Table 2

The effect of enzymatic treatment on changes in the amount of protein and moisture in the studied systems

\begin{tabular}{|l|c|c|c|c|c|c|c|}
\hline Indexes & Control & \multicolumn{6}{|c|}{ Options for enzymatic treatment } \\
\cline { 3 - 8 } & & $0,01 / 6$ & $0,025 / 6$ & $0,05 / 6$ & $0,01 / 12$ & $0,025 / 12$ & $0,05 / 12$ \\
\hline Protein & 16,76 & 13,86 & 13,91 & 13,95 & 13,64 & 13,75 & 13,86 \\
content & $\pm 0,5$ & $\pm 0,43$ & $\pm 0,43$ & $\pm 0,43$ & $\pm 0,45$ & $\pm 0,45$ & $\pm 0,45$ \\
\hline Protein & & 2,89 & 2,85 & 2,81 & 2,99 & 3,01 & 2,89 \\
loss & - & $\pm 0,07$ & $\pm 0,07$ & $\pm 0,07$ & $\pm 0,05$ & $\pm 0,05$ & $\pm 0,05$ \\
\hline Moisture & 69,27 & 69,55 & 71,19 & 72,84 & 73,29 & 74,13 & 74,96 \\
content & $\pm 2,04$ & $\pm 2,05$ & $\pm 2,1$ & $\pm 2,14$ & $\pm 2,16$ & $\pm 2,2$ & $\pm 2,24$ \\
\hline
\end{tabular}

For the product of enzymatic treatment of the lung an increase in the mass fraction of moisture can be explained by an increase interchain distance and rupture of 
bridges between collagen subunits. In the product of enzymatic processing of meat trimmings, in addition to muscle proteins there is loose connective tissue (adipose), exposed to swelling and hydrolysis. It should be noted that minimal protein losses were characteristic, regardless of the processing parameters.

As the results of studying the effect of the parameters of enzymatic treatment on the moisture content and loss of protein substances in the samples show, dynamics of changes in the studied parameters is of a non-linear nature, which is possibly related to the peculiarity of the structure and the amount of collagen in each type of raw material.

Loss of protein substances for all samples at a preparation concentration of $0.01 \%$, regardless of the duration of treatment, were small and amounted to, 0.01 / 6 2.89\%, and $0.01 / 12-2.99 \%$. An increase in the concentration of an enzyme preparation led to an intensification of destructive changes in collagen fibers and muscle proteins and reached a maximum at a collagenase concentration of 0.025 and $0.05 \%$, due to penetration deep into the protein and additional hydrolysis of collagen. As a result, the protein breakdown occurred, it passed into a liquid fraction and was washed out of the spatial grid.

The results of changes in the functional and technological properties of the prototypes are presented in Fig. 2.

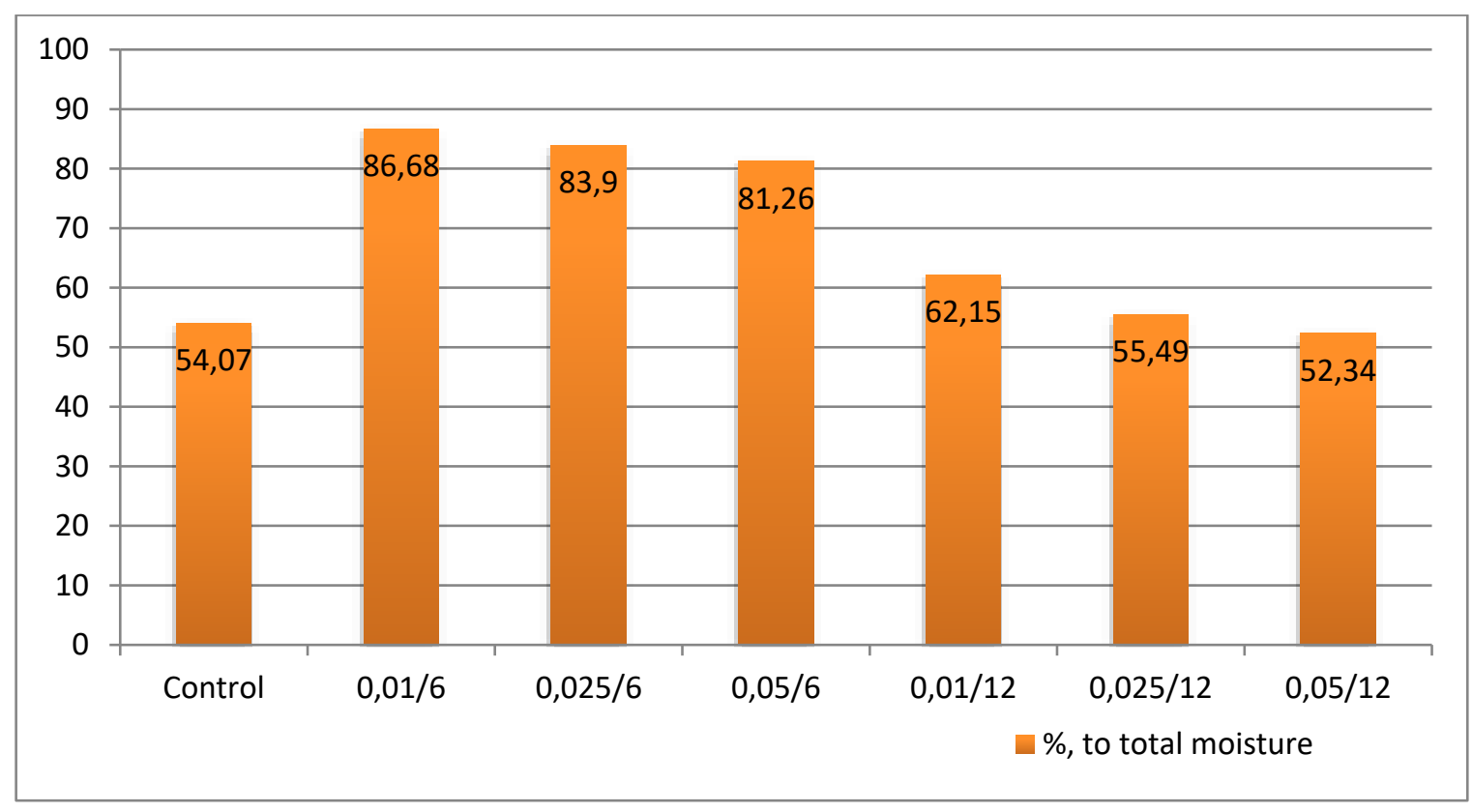

Figure 2 Moisture-binding capacity of enzymatic treatment products 
In the presented samples with 6-hour treatment, the value of moisture-binding capacity was higher than at twelve-hour, which can be explained by the degree of collagen hydrolysis.

Based on the presented results of the study, the optimal modes of processing of the composition were selected, taking into account protein losses and changes in the moisture-binding capacity of raw materials - 6 hours with a concentration of enzyme preparation of $0.025 \%$.

Technological scheme of biomodified composition production:

\begin{tabular}{|c|}
\hline Obtaining collagen-containing raw materials \\
$\downarrow$ \\
\hline Washing \\
$\downarrow$ \\
\hline $\begin{array}{c}\text { Grinding of raw materials on a meat grinder with } \\
\text { a diameter of openings of a lattice of 6-8 mm }\end{array}$ \\
$\downarrow$ \\
\hline $\begin{array}{c}\text { Processing with enzymatic preparation, } \\
\text { hydrolysis t }=18 \pm 2 \mathrm{C}^{\circ}, \tau=6 \text { h., ratio of raw } \\
\text { materials : aqua (0,025\%) }=1: 1,5\end{array}$ \\
$\downarrow$ \\
\hline Grinding of the solid fraction (enzymatic \\
treatment product) \\
$\downarrow$
\end{tabular}

Protein enrichment on the basis of by-products that have undergone biotechnological processing, are introduced into the stuffing of semi-finished products in the form of a protein-fat emulsion. [328] 
After obtaining a modified protein enrichment was prepared protein-fat emulsion by adding to it the following components: ice water in a ratio of $1: 1$ to the weight of the protein enrichment, sesame oil, in the amount of $25 \%$ by weight of protein enrichment and crushed for another 4 minutes

Minced meat for the manufacture of chopped semi-finished products was made according to the recipe specified in table. 3 . A sample made without the use of proteinfat emulsion according to the traditional recipe is accepted as a control.

The level of substitution of raw meat for protein-fat emulsion was determined by the optimal organoleptic parameters of the experimental samples with the introduction of a substitute from 10 to $20 \%$.

Table 3

Formulations of the studied products

\begin{tabular}{|c|c|c|c|c|}
\hline \multirow{2}{*}{\begin{tabular}{c} 
Type of raw material \\
\cline { 2 - 5 }
\end{tabular}} & \multicolumn{4}{|c|}{ Application rate per 100 kg,\% } \\
\hline Comi-fat pork & 50 & 6.1 & 6.2 & 6.3 \\
\hline Chicken & 15 & 25 & 25 & 20 \\
\hline Emulsion & - & 10 & 15 & 20 \\
\hline Nontreated by-products & 15 & - & - & - \\
\hline Eggs & 3 & 3 & 3 & 3 \\
\hline Onion & 5 & 5 & 5 & 5 \\
\hline Bread & 7 & 7 & 7 & 7 \\
\hline Breadcrumbs & 3 & 3 & 3 & 3 \\
\hline Table salt & 1,7 & 1,7 & 1,7 & 1,7 \\
\hline Spices & 0,3 & 0,3 & 0,3 & 0,3 \\
\hline
\end{tabular}

According to the set of organoleptic parameters, the most acceptable was the sample with the replacement of raw meat with protein enrichment in the amount of $20 \%$. The test samples were more juicy, tender and had a better consistency compared to the control sample. 
Prepared samples of cutlets were evaluated by organoleptic parameters. The advantage of organoleptic evaluation as a method of product quality analysis is the ability to quickly and simultaneously identify a set of product properties such as appearance, color in the cut, aroma, taste, texture.

Analyzing the data of Fig. 3, we can say that the prototype of the prepared cutlets on organoleptic parameters were not inferior to the control product.

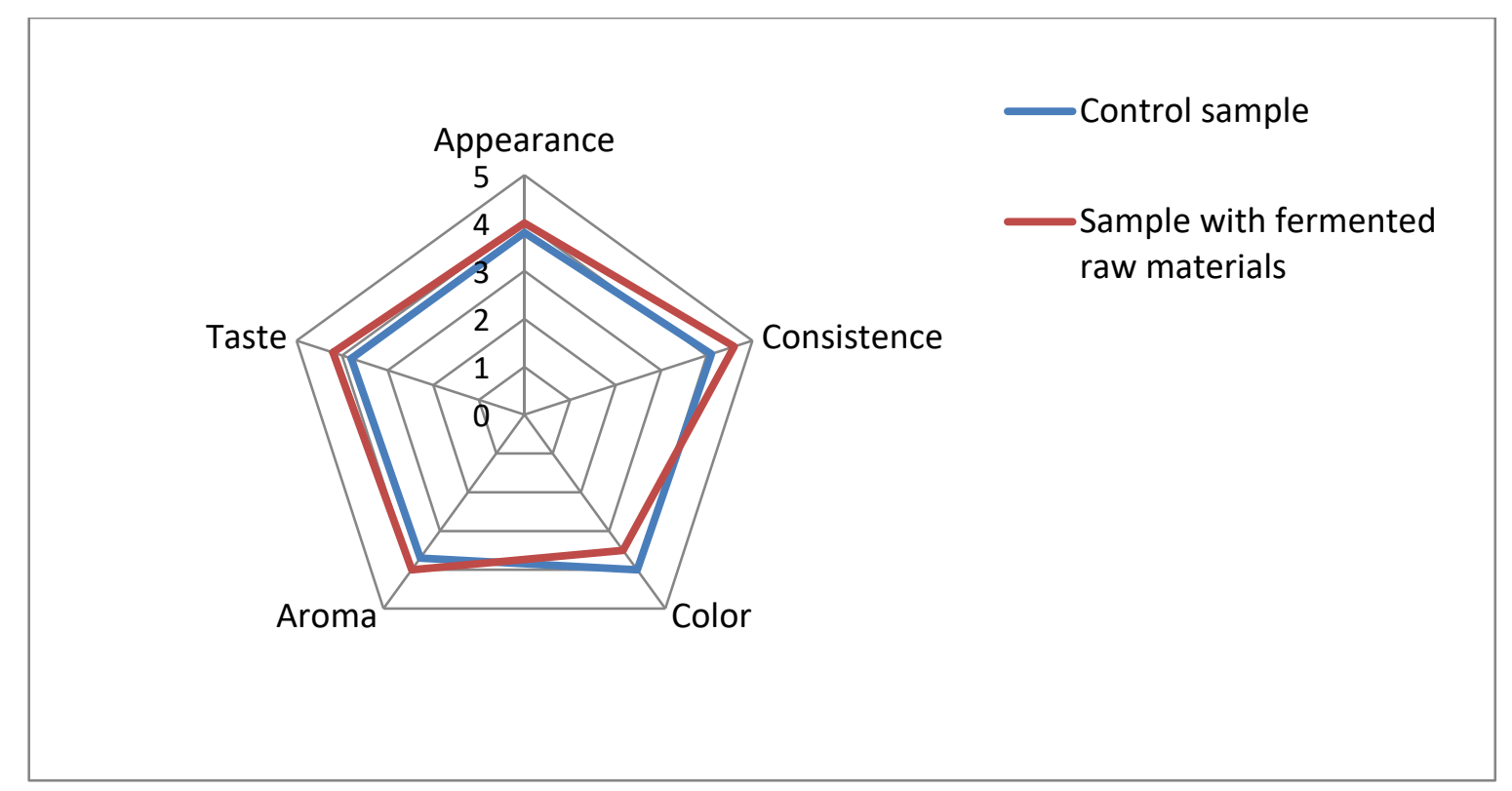

Figure 3. Profilogram of the dependence of the score of organoleptic parameters of the product that has undergone heat treatment

Thus, based on the results of research, we can draw the following conclusions: first, biotechnological processing can improve the structure of raw materials containing collagen, collagen fibers swell, there is their defibering; secondly, the microstructure of the control sample and the experimental sample with protein-fat emulsion do not differ significantly.

Based on the results of organoleptic studies, it can be concluded that the developed cutlets are not inferior to the control sample in terms of nutritional value and also meet the requirements of DSTU 4437: 2005. The sample of cutlets with the introduction of protein-fat emulsion has a juicier texture, pleasant smell and taste.

Thus, the results of research indicate a positive effect of the use of the enzyme preparation "STABICOL SKIN" for processing the composition - improves the functional and technological properties of low-value meat protein-containing raw 
materials. The technological effect of the drug can be expected in increasing the tenderness, juiciness, yield and improving the organoleptic evaluation of meat products. The results allow us to positively assess the prospects for the use of the drug "STABICOL SKIN" in the technology of meat products and the possibility of creating effective biotechnology in the industry. 


\title{
SECTION 6. INFORMATION TECHNOLOGIES
}

DOI 10.46299/ISG.2021.MONO.TECH.III.6.1

\subsection{Principles of piezoresonance sensors construction with capacitive control and their practical application for telemedicine diagnostic systems}

\begin{abstract}
The paper outlines the principles of using piezoresonance mechanotrons (PRMT) with a modulated electrode gap to create high-precision applanation pressure sensors for sphygmographic applications in telemedicine. Design features of the PRMT construction on quartz resonators with capacitive control are considered. An electrical model of a piezoresonance mechanotron was constructed and numerical analysis of the PRMT control characteristics was carried out in the presence of parasitic electrical connections. A 3-D model of an overpressure sensor based on PRMT was built and a numerical simulation of the stress-strain state of the corrugated membrane in COMSOL Multiphysics was performed. The features of linearization of the PRMT conversion characteristics in the two-frequency mode of excitation of a quartz resonator are considered. An example of the practical implementation of the Sphygmograph for telemedicine monitoring of the human cardiovascular system is given.
\end{abstract}

Keywords: telemedicine, cardiovascular system, hemodynamic monitoring, sphygmography, piezoresonance pressure mechanotron

Cardiovascular disease often develops without any symptoms and is undetected until it is far advanced. Heart attack or stroke is often the first manifestation of atherosclerosis in patients who have not had any prior symptoms of the disease. This fact highlights the importance of developing new technologies for early diagnosis in patients at high risk for cardiovascular disease [329]. The current cardiovascular diagnostic tools assess risk factors and detect atherosclerotic plaque [330]. However, the diagnosis of the risk factors in a patient provides no information about the early pathological changes in his blood vessels; and, by the time atherosclerotic plaque is detected, the disease is already well advanced. Early detection of cardiovascular 
disease, by assessing arterial stiffness and endothelial dysfunction, provides physicians with detailed and clinically valuable information and helps identify patients at high risk for cardiovascular disease.

In this regard, the development of widely available methods and devices to identify abnormalities of the cardiovascular system at early stages of disease development is a very urgent task [331].

Almost all equipment existing now intended for research of characteristics and of a velocity of propagation of a pulse wave uses a method of Doppler ultrasound [332] that evaluates blood flow through a blood vessel of the person. A disadvantage of this method is a dependence of measurements results from placement and relocation of the Doppler sensor, and also the occurrence of noise. The known plethysmographic method has a disadvantage, because of the use of poorly sensitive photoelectric sensors and piezoelectric sensors as measuring transducers $[333,334]$ that reduce the value of the results obtained. Rheography is a non-invasive method and provides much more convenience to carrying out many measurements. However, in its present form, a rheography is suitable only for research of rather simple cases as a result of an undeveloped methodology of the analysis of the received results, called rheogram. An application of electro-cardio graphical method with the use of two electrodes [335] also doesn't allow to estimate completely a condition of the cardiovascular system of the person and his central hemodynamic parameters.

One of the most promising methods for the telemedicine monitoring of the state of the cardiovascular system is the sphygmography - graphic recording method of the pulse wave and pulse oscillation. This method involves carrying out a contouring or spectral analysis of pulse oscillations recorded on the carotid, femoral and radial arteries of a person. The amplitudes of the pulse oscillations usually do not exceed (0.5...3) $\mathrm{mm} \mathrm{Hg}$. For their reliable reproduction, the accurate pressure sensors with high resolution are required [331,336-338].

The paper presents the principles of using piezoresonance mechanotrons (PRMT) with a modulated interelectrode gap for the construction of high-precision applanational pressure sensors for sphygmographic applications. By using a 
sphygmographic system on PRMT it will be possible to estimate the condition of vessels and chance of cardiovascular disease for several years before the appearance of clinical symptoms of diseases such as atherosclerosis, hypertension, heart failure, diabetes, coronary heart disease, and pre-stroke and before infarction states. This assessment is needed for sick people to control the disease and for healthy people to prevent disease development, as well as for physical activity monitoring.

Sensors based on piezoresonance mechanotrons refers to measuring transducers with frequency output. The PRMT resonance frequency is adjusted by changing the capacitance (gap) between the excitation electrodes of the piezoelectric element (PE) (usually quartz). Sensors based on PRMT have a wide versatility. The constructive combination of such transducers with elements transforming the external action of a different physical nature into displacement makes it possible to synthesize various pressure sensors, forces, accelerations, and others.

The constructive scheme of PRMT is presented in Fig.1. Under the action of a physical quantity (pressure $P$ ), the position of the moving electrode (membrane) changes. This leads to a change in the control capacitance $C_{\text {contr }}$ of the interelectrode excitation gap $x$ of the PRMT piezoelectric element (Fig.1).

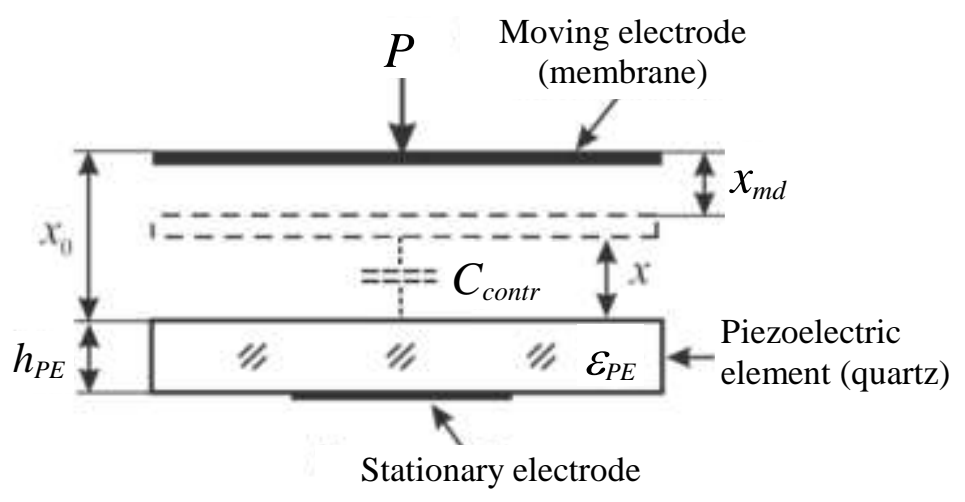

Figure 1. Construction diagram of PRMT

When PE is excited in the interelectrode gap $x$, the formula for the resonance frequency $f(x)$ of a PRMT can be written as 


$$
f(x)=f_{0} \sqrt{1+\frac{m}{1+\frac{h_{P E}}{x \cdot \varepsilon_{P E}}}} \approx f_{0}\left[1+\frac{0.5 m}{1+\frac{h_{P E}}{x \cdot \varepsilon_{P E}}}\right]
$$

where $x=x_{0}-x_{m d}$ is the current value of modulated interelectrode gap (MIG);

$x_{0}$ is the initial gap between the membrane and quartz piezoelectric element;

$x_{m d}$ is the membrane deflection at overpressure $P$;

$f_{0}$ is the nominal PRMT frequency for $x_{m d}=0$;

$m$ is the frequency coefficient of quartz PE;

$h_{P E}$ and $\varepsilon_{P E}$ is the thickness of the quartz piezoelectric element and its dielectric constant $\left(\varepsilon_{P E}=4.5\right)$.

To use PRMT as a sensor, it is included in the circuit of the oscillator. Formula (1) for the output frequency of the sensor can be represented as

$$
f(x)=f_{0}+F(x), x \in\left[x_{\min }, x_{0}\right]
$$

where $F(x)$ is the frequency calibration characteristic of the PRMT.

The calibration characteristic $F(x)$ of PRMT is described by a fractionalrational function

$$
F(x)=\frac{a_{0}+a_{1} x}{1+a_{2} x},
$$

where $a_{0}, a_{1}, a_{2}$ are the approximation coefficients, individual constants of the PRMT.

To use a pressure sensor based on PRMT in microprocessor devices, the difference frequency $F_{d i f}(x)$ is allocated

$$
F_{d i f}(x)=f_{\text {het }}-f(x)=\left(f_{0}+F_{\text {het }}\right)-f(x)=F_{\text {het }}-F(x),
$$


where $f_{\text {het }}$ is the frequency of the local oscillator (heterodyne).

Next, we turn to the period $T(x)$ of the difference frequency signal (4) with (3):

$$
T(x)=\left[F_{d i f}(x)\right]^{-1}=\left[F_{h e t}-F(x)\right]^{-1}=\frac{\left(1+a_{2} x\right)}{F_{h e t}\left(1+a_{2} x\right)-\left(a_{0}+a_{1} x\right)} .
$$

Analysis of the denominator (5) shows that the function $T(x)$ is transformed into a strictly linear function of the form

$$
T_{\text {lin }}(x)=T_{0 l i n}+S_{\text {lin }} \cdot x
$$

subject to the conditions

$$
F_{\text {het }}=F_{\text {het }}^{(o p t)}=\frac{a_{1}}{a_{2}},
$$

where $T_{0 l i n}=\left(\frac{a_{1}}{a_{2}}-a_{0}\right)^{-1}$ is the initial period for $x=x_{0}$;

$$
S_{\text {lin }}=a_{2}\left(\frac{a_{1}}{a_{2}}-a_{0}\right)^{-1} \text { is the steepness of the pressure sensor conversion on the }
$$
PRMT [336-338].

To study the electrical characteristics of the PRMT, consider its electric equivalent circuit (Fig. 2), the main element of which is a quartz resonator with equivalent dynamic inductance $L_{q}$, capacitance $C_{q}$, loss impedance $R_{q}$ and parallel capacitance $C_{0}$. In series with the quartz resonator $(\mathrm{QR})$, the control capacitance $C_{\text {contr }}$ and (if necessary) inductance $L_{\text {ext }}$ are included to increase the control range and improve linearity. Parasitic capacities $C_{p a r_{1}}$ and $C_{p a r_{2}}$ are also included in the equivalent electrical circuit, which significantly affects the characteristics of the 
control of the PRMT. If excitation of a quartz resonator in a two-frequency (multifrequency) mode is assumed, the equivalent circuit should be expanded by using additional dynamic circuits, the number of which should correspond to the number of additional modes of excited oscillations.

For the analysis of the equivalent electric circuit of the PRMT as a complex multifrequency piezoresonance oscillatory system (MPOS), we use the method proposed in [336]. We find the conductivity between the points $\mathbf{a}-\mathbf{b}$ of the equivalent scheme of the PRMT (Fig. 2):

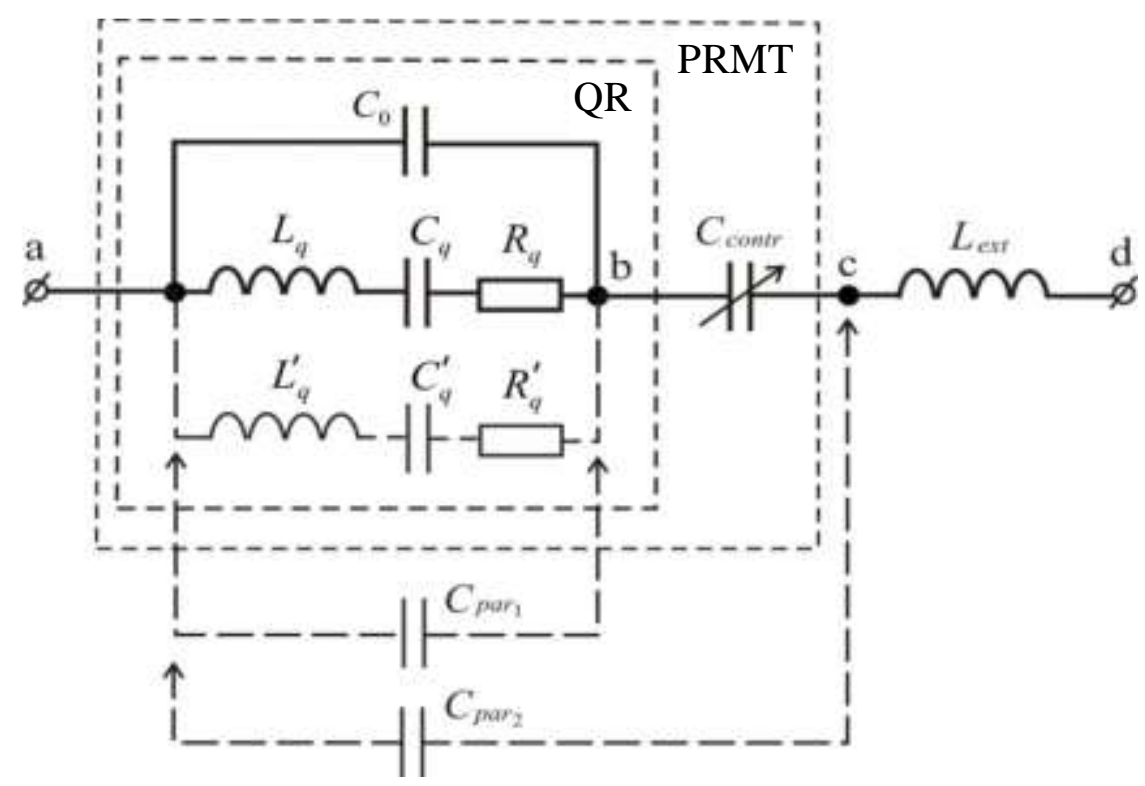

Figure 2. Equivalent electric circuit of the PRMT

$$
Y_{a b}=\frac{1}{Z_{Q R}^{\prime}}=\frac{1}{Z_{q}}+Y_{C_{0}^{\prime}}=\frac{1}{R_{q}\left(1+j \xi_{q}\right)}+j \omega C_{0}^{\prime}=\frac{1-\tau_{C}^{\prime} \xi_{q}+j \tau_{C}^{\prime}}{R_{q}\left(1+j \xi_{q}\right)},
$$

where $Z_{q}=R_{q}\left(1+j \xi_{q}\right)$ is the complex equivalent resistance of the series circuit $L_{q}, C_{q}, R_{q}$ of the QR near the resonance;

$Y_{C_{0}^{\prime}}=j \omega C_{0}^{\prime}=j \omega\left(C_{0}+C_{p a r_{1}}\right)$ is the complex conductivity parallel connected capacitances $C_{0}$ and $C_{p a r_{1}}$; 


$$
\xi_{q}=Q\left(\frac{\omega}{\omega_{q}}-\frac{\omega_{q}}{\omega}\right) \approx 2 Q \delta_{q}-\text { is the generalized detuning relative to the series }
$$

resonance frequency;

$$
\omega_{q}=2 \pi f_{q}=\frac{1}{\sqrt{L_{q} C_{q}}} ; \delta_{q}=\frac{\omega-\omega_{q}}{\omega_{q}} \text { is the relative frequency deviation, }
$$

$Q=\frac{\sqrt{L_{q} / C_{q}}}{R_{q}}$ is the $Q$-factor of $\mathrm{QR}$;

$\tau_{C}^{\prime}=\omega R_{q} C_{0}^{\prime}-$ ratio of resistance to losses $R_{q}$ and resistance of parallel capacitance $1 / \omega C_{0}^{\prime}$;

The quality factor $M=\frac{1}{\tau_{C}^{\prime}}$ (parallel $Q$ ) determines the activity of the quartz resonator when it is connected to the oscillator circuit $(M>>1)$.

Next, we find the equivalent resistance of the serial connection $Z_{Q R}^{\prime}$ and the capacity of the control $C_{\text {contr }}$ :

$$
Z_{Q R_{\text {contr }}}^{\prime}=Z_{Q R}^{\prime}+Z_{C_{\text {contr }}}=\frac{R_{q}\left(1+j \xi_{q}\right)}{1-\tau_{C}^{\prime} \xi_{q}+j \tau_{C}^{\prime}}+\frac{1}{j \omega C_{\text {contr }}}=\frac{R_{q}\left(1-\xi_{q} T_{1}+j T_{1}\right)}{-T_{2}+j\left(\tau_{\text {contr }}-T_{2} \xi_{q}\right)},
$$

where $\tau_{\text {contr }}=\omega C_{\text {contr }} R_{q}-$ similarly to the $\tau_{0}^{\prime}$, the ratio of loss resistance $R_{q}$ and the resistance of the control capacity $1 / \omega C_{c o n t r}$ is introduced;

$$
T_{1}=\tau_{\text {contr }}+\tau_{C}^{\prime} ; T_{2}=\tau_{\text {contr }} \tau_{C}^{\prime}
$$

In turn, the conductivity between the points a - c will be determined as

$$
\begin{gathered}
Y_{a c}=\frac{1}{Z_{\mathrm{ac}}}=\frac{1}{Z_{Q R_{\text {contr }}}^{\prime}}+Y_{p a r_{2}}=\frac{-T_{2}+j\left(\tau_{\text {contr }}-T_{2} \xi_{q}\right)}{R_{q}\left(1-\xi_{q} T_{1}+j T_{1}\right)}+j \omega C_{p a r_{2}}= \\
=\frac{-\left(T_{1} \tau_{C}^{\prime \prime}+T_{2}\right)+j\left(\tau_{\text {contr }}+\tau_{C}^{\prime \prime}-\xi_{q}\left(T_{1} \tau_{C}^{\prime \prime}+T_{2}\right)\right)}{R_{q}\left(1-\xi_{q} T_{1}+j T_{1}\right)},
\end{gathered}
$$


where $\tau_{C}^{\prime \prime}=\omega R_{q} C_{p a r_{2}}$ is the resistance ratio of losses $R_{q}$ and the resistance of the parasitic capacitance $1 / \omega C_{p a r_{2}}$.

Then, the analytical expression for the complex equivalent resistance of the electric circuit of the PRMT taking into account the elongation inductance $L_{\text {ext }}$ (Fig. 2) will take the form:

$$
\begin{aligned}
Z_{P R M T}=Z_{a d}=Z_{a c}+j \omega L_{e x t}= & \\
& =R_{q} \times\left\{\frac{1-\xi_{q} T_{1}-\frac{1}{\tau_{L}^{\prime}}\left(\tau_{c o n t r}+\tau_{C}^{\prime \prime}-\xi_{q} T_{3}\right)+j\left(T_{1}-\frac{T_{3}}{\tau_{L}^{\prime}}\right)}{-T_{3}+j\left(\tau_{\text {contr }}+\tau_{C}^{\prime \prime}-\xi_{q} T_{3}\right)}\right\},
\end{aligned}
$$

where $\tau_{L}^{\prime}=R_{q} / \omega L_{\text {ext }}$ is the resistance ratio of losses $R_{q}$ and the resistance of the elongation inductance $\omega L_{e x t} ; T_{3}=T_{1} \tau_{C}^{\prime \prime}+T_{2}$.

Thus, the equivalent electrical resistance of the PRMT $Z_{P R M T}$ (11) can be presented in standard form

$$
Z_{\text {PRMT }}(j \omega)=\frac{A_{1}+j B_{1}}{A_{2}+j B_{2}},
$$

where $A_{1}=R_{q}\left(1-\xi_{q} T_{1}-\frac{T_{4}}{\tau_{L}^{\prime}}\right) ; B_{1}=R_{q}\left(T_{1}-\frac{T_{3}}{\tau_{L}^{\prime}}\right) ; A_{2}=-T_{3} ; B_{2}=T_{4} ; T_{4}=\tau_{\text {contr }}+\tau_{C}^{\prime \prime}-\xi_{q} T_{3}$.

Analysis (12) allows determining the basic electrical parameters of the piezoresonance oscillatory system of the PRMT: the frequencies of the serial resonance $f_{r} \quad\left(\omega_{r}\right)$ and the parallel resonance (antiresonance) $f_{p a r}\left(\omega_{p a r}\right)$; equivalent quality factor $Q_{e q}$ (fixing ability); Equivalent Resistance Loss (ESR) and others. So, equating the imaginary part $\operatorname{Im}\left(Z_{P R M T}(j \omega)\right)$ of $Z_{P R M T}(j \omega)$ (12) to zero 
$\left(B_{1}\left(\xi_{q}\right) A_{2}\left(\xi_{q}\right)-A_{1}\left(\xi_{q}\right) B_{2}\left(\xi_{q}\right)=0\right)$, we obtain an equation for the generalized detuning $\xi_{q}$, which allows us to determine the resonance frequencies of PRMT as a multielement MPOS:

$$
k_{2} \cdot \xi_{q}^{2}+k_{1} \cdot \xi_{q}+k_{0}=0
$$

where $k_{0}=\tau_{\text {contr }}+\tau_{C}^{\prime \prime}+T_{1} T_{3}-\frac{1}{\tau_{L}^{\prime}}\left(\left(\tau_{\text {contr }}-\tau_{C}^{\prime \prime}\right)^{2}+T_{3}^{2}\right) ; k_{1}=\left(\frac{2}{\tau_{L}^{\prime}} T_{3}-T_{1}\right)\left(\tau_{\text {contr }}+\tau_{C}^{\prime \prime}\right)-T_{3}$; $k_{2}=T_{3}\left(T_{1}-\frac{T_{3}}{\tau_{L}^{\prime}}\right)$

Having distinguished the real part $\operatorname{Re}\left(Z_{P R M T}(j \omega)\right)$, we obtain the equivalent series (ESR) and parallel (EPR) resistance of the MPOS:

$$
\operatorname{ESR}=\left.\operatorname{Re}\left(Z_{P R M T}(j \omega)\right)\right|_{\omega=\omega_{r}} \mathrm{i} \operatorname{EPR}=\left.\operatorname{Re}\left(Z_{P R M T}(j \omega)\right)\right|_{\omega=\omega_{\text {par }}},
$$

where $\operatorname{Re}\left(Z_{\text {PRMT }}(j \omega)\right)=\frac{A_{1}(\omega) \cdot A_{2}(\omega)+B_{1}(\omega) \cdot B_{2}(\omega)}{\left(A_{2}(\omega)\right)^{2}+\left(B_{2}(\omega)\right)^{2}}$ is the real part of the complex equivalent resistance $Z_{P R M T}(j \omega)$.

One of the most important parameters of the oscillating system is its fixing ability $\sigma$, which is directly related to the equivalent quality factor $Q_{e q}$ :

$$
\sigma=\omega\left|\frac{d \varphi(\omega)}{d \omega}\right|_{\omega=\omega_{r}} \approx 2 Q_{e q}
$$

where $\frac{d \varphi(\omega)}{d \omega}$ is the steepness of the phase-frequency characteristic PRMT $\varphi(\omega)$ near resonance. 
To determine $\varphi(\omega)$, we represent the equivalent complex resistance of the PRMT (12) in an exponential form:

$$
Z_{P R M T}(j \omega)=|Z(\omega)| \exp ^{j \varphi(\omega)},
$$

where $\varphi(\omega)=\varphi_{1}(\omega)-\varphi_{2}(\omega)=\operatorname{arctg}\left(\frac{B_{1}}{A_{1}}\right)-\operatorname{arctg}\left(\frac{B_{2}}{A_{2}}\right)$.

Accordingly, taking into account (12) and (15) we get:

$$
\left|\frac{d \varphi(\omega)}{d \omega}\right|=\left|\frac{A_{1}(\omega) \frac{d B_{1}(\omega)}{d \omega}-B_{1}(\omega) \frac{d A_{1}(\omega)}{d \omega}}{\left(A_{1}(\omega)\right)^{2}+\left(B_{1}(\omega)\right)^{2}}-\frac{A_{2}(\omega) \frac{d B_{2}(\omega)}{d \omega}-B_{2}(\omega) \frac{d A_{2}(\omega)}{d \omega}}{\left(A_{2}(\omega)\right)^{2}+\left(B_{2}(\omega)\right)^{2}}\right|,
$$

where $\frac{d A_{1}(\omega)}{d \omega}=R_{q} \frac{\omega_{q}}{2 Q}\left(-T_{1}+T_{3} / \tau_{L}^{\prime}\right) ; \frac{d B_{1}(\omega)}{d \omega}=\frac{d A_{2}(\omega)}{d \omega}=0 ; \frac{d B_{2}(\omega)}{d \omega}=-\frac{\omega_{q}}{2 Q} T_{3}$.

We will analyze the characteristics of the oscillatory system PRMT on the basis of a flat quartz piezoelectric element with the parameters: AT-cut (diameter $12 \mathrm{~mm}$ ); frequency of the main resonance $f_{q}=10.009987 \mathrm{MHz}$ for Q-factor 103000 and dynamic resistance $R_{q}=24$ Ohm; parallel capacity $C_{0}=3.5 \mathrm{pF}$ [336].

In Figure 3 shows the dependences of the frequency of series resonance $\Delta F_{r}=f_{r}-f_{q}$ (Fig. 3,a) and parallel resonance $\Delta F_{p a r}=f_{p a r}-f_{q}$ (Fig. 3,b), the equivalent series resistance of losses ESR (Fig. 3,c), the quality factor $q=Q_{e q} / Q$ (Fig. 3,d) with a change in capacitance control $C_{\text {contr }}$ and parasitic capacitance $C_{p a r_{1}}$.

The analysis of the obtained data confirms the high efficiency of control with the use of a series-connected capacity $C_{\text {contr }}$. He shows that the characteristics of control are purely nonlinear in nature. So, for the value $C_{\text {contr }} \in[1,5 ; 5] \mathrm{pF}$, the steepness 
$S_{\text {contr }}=\Delta F_{r} / \Delta C_{\text {contr }}$ of the control characteristic should be between $(550 \ldots 600) \mathrm{Hz} / \mathrm{pF}$, and for $C_{\text {contr }} \in[20 ; 30] \mathrm{pF}$ values at the level of $30 \mathrm{~Hz} / \mathrm{pF}$.

At the same time, it is possible to distinguish areas with almost linear dependencies $\Delta F_{r}\left(C_{\text {contr }}\right)$, for example, $C_{\text {contr }} \in[1.5 ; 4] \mathrm{pF}$ or $C_{\text {contr }} \in[17.5 ; 30] \mathrm{pF}$ (Fig. 3, a, dependence 1). But, the use of the first section is accompanied by a sharp increase (almost by an order of value) of the series resistance of ESR (Fig. 3, c, dependence 1). This significantly increases the requirements for the active part of the PRMT oscillation system (its regeneration parameter), which should provide a stable mode of oscillation in conditions of a decrease in the activity of the quartz resonator ( $M$ - factors). Although in general, the $q$-losses do not exceed $1 \%$, which potentially ensures high stability of the generated oscillations (Fig. 3, d, dependence 1).

Naturally, the serial control method PRMT frequency has little effect on its frequency of parallel resonance oscillating system (Fig. 3, b, dependence 1). This is a confirmation of the adequacy of the proposed electrical model.

The connection of external additional controls to the quartz piezoelectric element of the PRMT is accompanied by negative phenomena. Thus, the presence of relatively large parasitic capacitance $C_{p a r_{1}} \in[2.5 ; 5] \mathrm{pF}$ leads to a significant reduction in the steepness of the control characteristic (up to 2 times) and a sharp increase in ESR (up to 5 times) in the area $C_{\text {contr }} \in[1.5 ; 5] \mathrm{pF}$ with maximum steepness $S_{\text {contr }}$ (Fig. 3,a,c, dependence 1 and 3).

Compensation (to some extent) of the negative effect of the presence of parasitic capacitance $C_{p a r_{1}}$ can be achieved by including the extension inductance $L_{e x t}$ (Fig. 2), which increases the frequency range and improves the linearity of control characteristics, using a frequency domain lower than $f_{q}$ (Fig. 4, a; $C_{\text {contr }} \in[17.5 ; 30] \mathrm{pF}$ ). It should be noted that at the same time, for relatively large values of $C_{p a r_{1}} \in[2,5 ; 5] \mathrm{pF}$ , the equivalent resistance of ESR also significantly increases in accordance with Fig. 3, c.

The situation is different when controlling PRMT by modulating of interelectrode excitation capacitance gap (Fig. 4,b) [338,339]. Since the parallel 
parasitic capacitance $C_{p a r_{2}}$ that occurs, in this case, is included through the control capacitance $C_{\text {contr }}$ (Fig. 2), it has a significantly lower effect on the characteristic of the PRMT control, the steepness $S_{\text {contr }}$ of which approaches the maximum possible values (Fig. 4,b, Window 2, dependence 1-3). At the same time, the variations of the equivalent resistance ESR and quality factor $q$ values within $C_{\text {contr }} \in[1.5 ; 30] \mathrm{pF}$ maximally approaching the dependencies shown in Fig. 3, c, d (dependences 1).

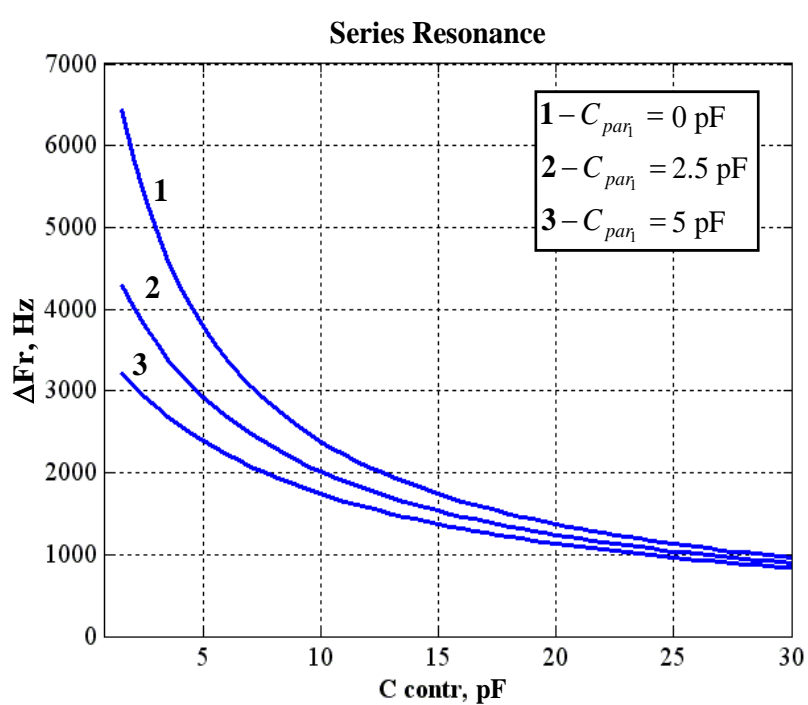

a)

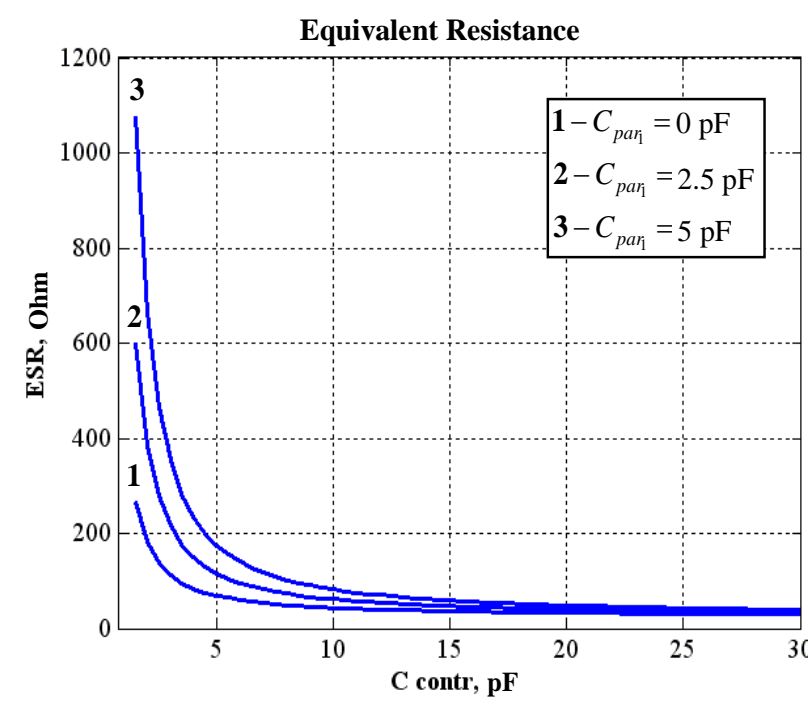

c)

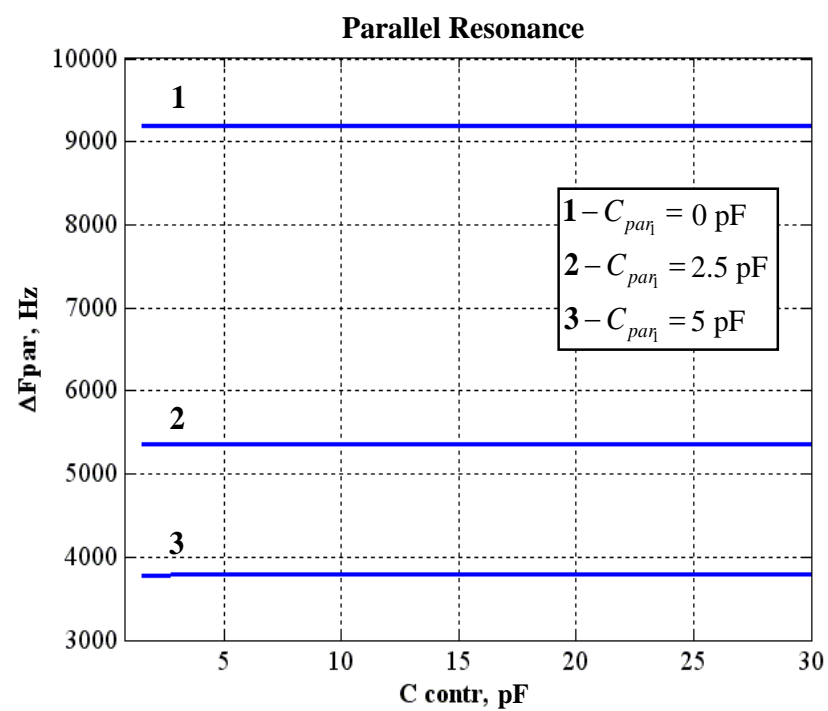

b)

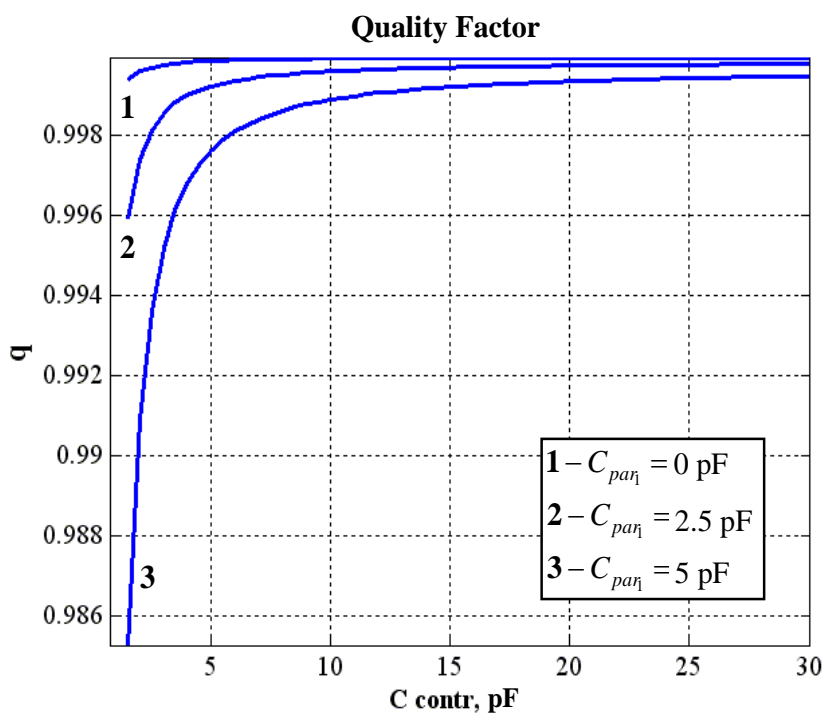

d)

Figure 3. Dependences of the serial $\Delta F_{r}$ (a) and parallel $\Delta F_{p a r}$ (b) resonances, equivalent series resistance (ESR) (c) and quality factor $q$ (d) of the PRMT oscillation system when the parasitic capacitance $C_{p a r_{1}}$ changes 
Numerical simulation of the stress-deformed state of a metal corrugated membrane (CM) is performed on the basis of the finite element method by solving the multifunctional electromechanics problem in the system of physical modelling of COMSOL Multiphysics.

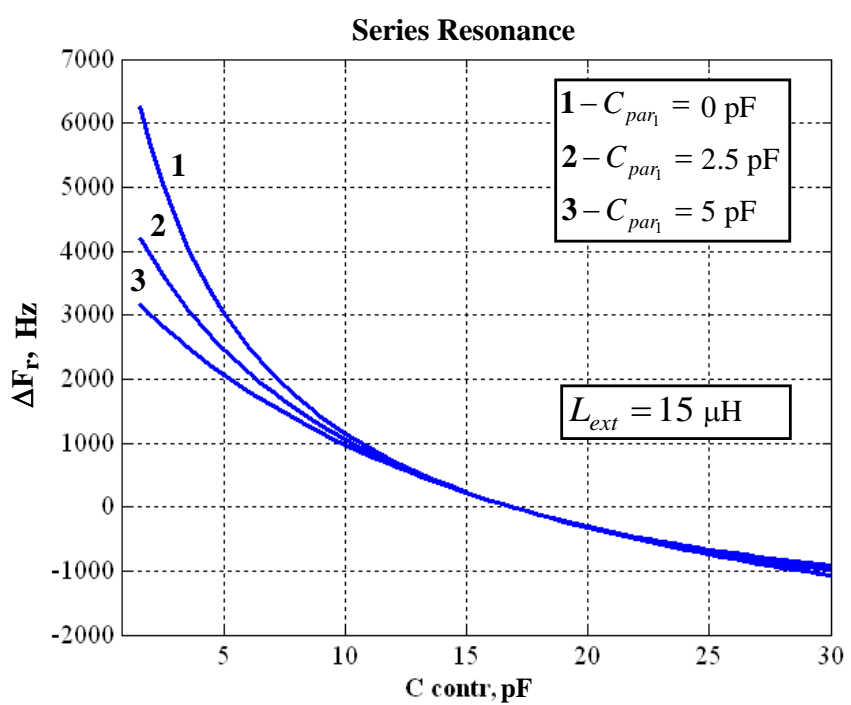

a)

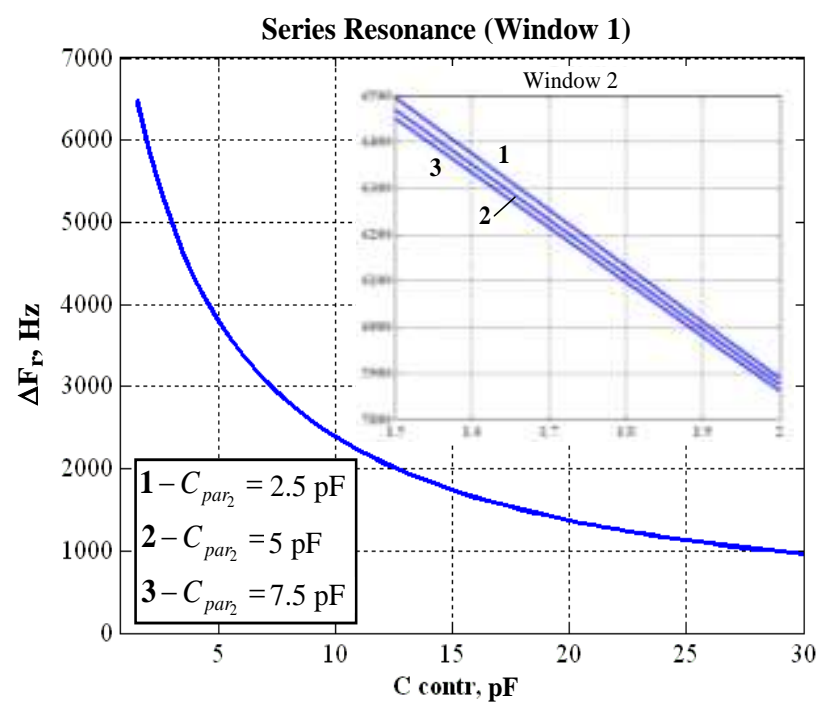

b)

Figure 4. Characteristics of the PRMT with external capacitive control with inductance $L_{e x t}$ enabled (a) and parasitic capacitance $C_{p a r_{2}}$ change (b)

The main elements of the three-dimensional (3D) model of the piezoresonance pressure sensor (Fig. 5, a) are a piezoelectric element (PE), which is located on special quartz holders and a corrugated membrane that is rigidly fixed in the contour. The piezoelectric element, which is applied in the center by the electrode and CM (Fig. 5, b), forms a quartz resonator controlled by excess pressure $\Delta P$. The resonance frequency of the sensor depends on the capacity $C_{\text {contr }}$ of the excitation gap, which is formed between the PE and the central part of the corrugated membrane (Fig. 1). 


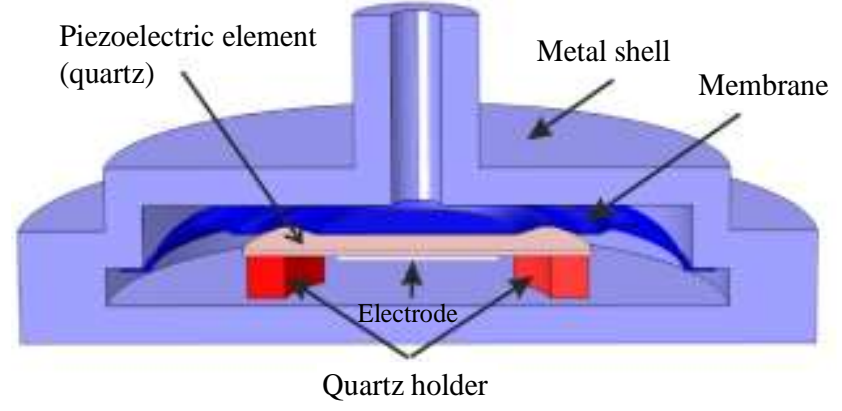

(a)

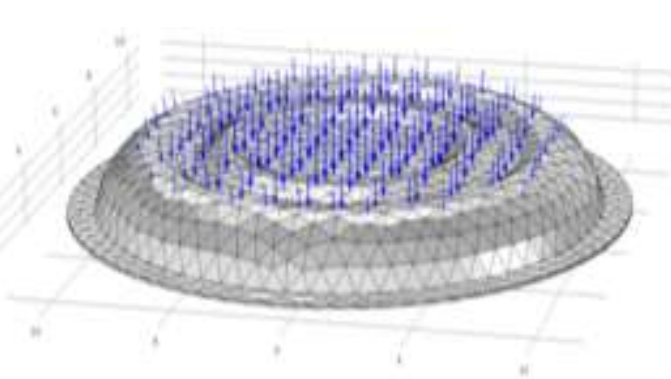

(b)

Figure 5. Three-dimensional (3D) model of the excess pressure sensor (a) and pressurized corrugated membrane (б) (COMSOL Multiphysics)

For linear conditions (small displacements), COMSOL Multiphysics software formalizes a stress-strain state using the equation:

$$
\boldsymbol{\sigma}=\mathbf{D} \boldsymbol{\varepsilon}
$$

where D - a matrix of elasticity, and vectors of mechanical stresses and deformations $\boldsymbol{\sigma}=\left[\sigma_{x} \sigma_{y} \sigma_{z} \tau_{x y} \tau_{y z} \tau_{x z}\right]^{\mathrm{T}}$ and $\boldsymbol{\varepsilon}=\left[\varepsilon_{x} \varepsilon_{y} \varepsilon_{z} \varepsilon_{x y} \varepsilon_{y z} \varepsilon_{x z}\right]^{\mathrm{T}}$ consist of three normal components $\sigma_{x}, \sigma_{y}, \sigma_{z}$ and $\varepsilon_{x}, \varepsilon_{y}, \varepsilon_{z}$ those three tangents (in symmetry $\tau_{x y}=\tau_{y x}$, $\tau_{x z}=\tau_{z x}, \tau_{y z}=\tau_{z y}, \varepsilon_{x y}=\varepsilon_{y x}, \varepsilon_{x z}=\varepsilon_{z x}, \varepsilon_{y z}=\varepsilon_{z y}$ ) component $\tau_{x y}, \tau_{y z}, \tau_{x z}$ and $\varepsilon_{x}, \varepsilon_{y}, \varepsilon_{z} \cdot$

In an isotropic interpretation, the matrix of elasticity $\mathbf{D}$ is defined as

$$
\mathbf{D}=\frac{E}{(1+\mu)(1-2 \mu)}\left[\begin{array}{cccccc}
1-\mu & \mu & \mu & 0 & 0 & 0 \\
\mu & 1-\mu & \mu & 0 & 0 & 0 \\
\mu & \mu & 1-\mu & 0 & 0 & 0 \\
0 & 0 & 0 & \frac{1-2 \mu}{2} & 0 & 0 \\
0 & 0 & 0 & 0 & \frac{1-2 \mu}{2} & 0 \\
0 & 0 & 0 & 0 & 0 & \frac{1-2 \mu}{2}
\end{array}\right] \text {, }
$$

where $E$ - Young's module; $\mu$ - Poisson coefficient. 
When applied pressure $P$, which exceeds the atmospheric pressure, the deflection of the membrane occurs (Fig. 6), resulting in a decrease in the size of the gap $x_{m d}$ between the central surface of the PE and the working surface of the CM. As you can see, the membrane gets a variable deflection. The greatest displacement has the centre of the membrane, and the smallest is its periphery (Fig. 6, a, b).

To study the characteristics of a piezoresonance overpressure sensor with a variable interelectrode excitation gap, its numerical simulation was carried out in COMSOL Multiphysics (materials temperature $-20^{\circ} \mathrm{C}$ ) (Fig. 7). The results of the simulation model confirm the high linearity of the deflection characteristics of the $\mathrm{CM}$ in the range of excess pressure $\Delta P \in[0 ; 40000] \mathrm{Pa}$ or $\Delta P \in[0 ; 300] \mathrm{mm} \mathrm{Hg}$. The membrane of the "soft" AERIS 1345 ("BrB2") alloy provides nearly 50\% more sensitive than 36NHTY membrane. However, its maximum deflection goes beyond the permissible range $x_{m d} \in[0 ; 70 \mu \mathrm{m}]$, which must be taken into account when constructing pressure sensors of this type (Fig. 7, a).

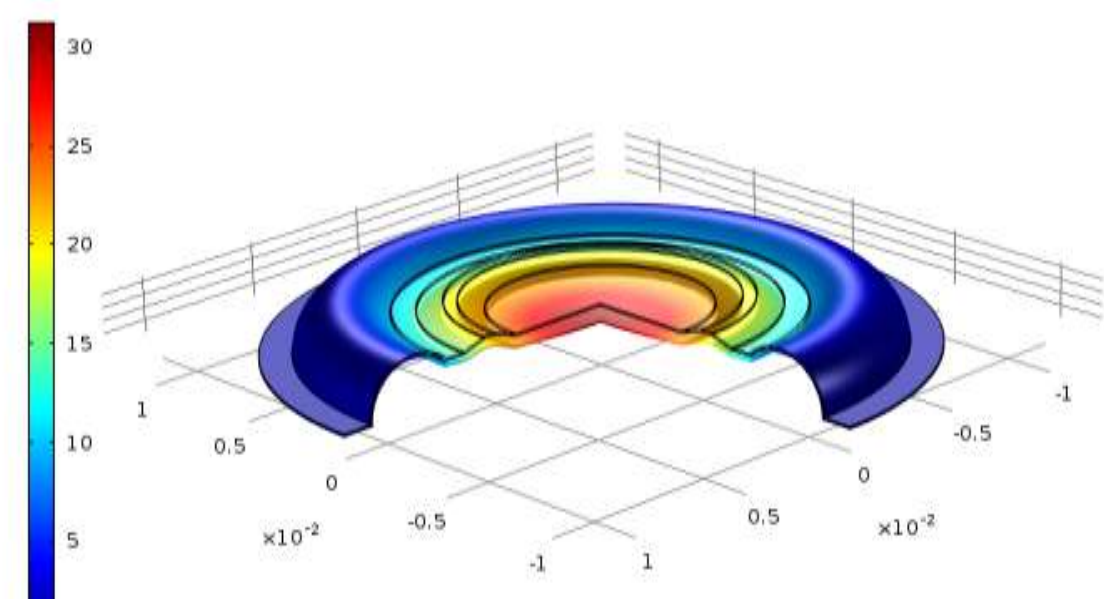

(a) 




(b)

Figure 6. Profiles of micro-displacements of a corrugated membrane: $x_{m d \max }$ $=31.28 \mu \mathrm{m}$ for $\Delta P_{1}=20000 \mathrm{~Pa} \mathrm{(a);} x_{m d \text { max }}=61.39 \mu \mathrm{m}$ for $\Delta P_{2}=40000 \mathrm{~Pa}$ (b) Accordingly, the capacity $C_{\text {contr }}$ of the interelectrode gap for overpressure $\Delta P>32500$ Pa (Fig. 7, b) is beyond the limits of the values $C_{\text {contr }} \in[1.5 ; 30]$, which are necessary for the effective control of PRMT (Fig. 3) [340].

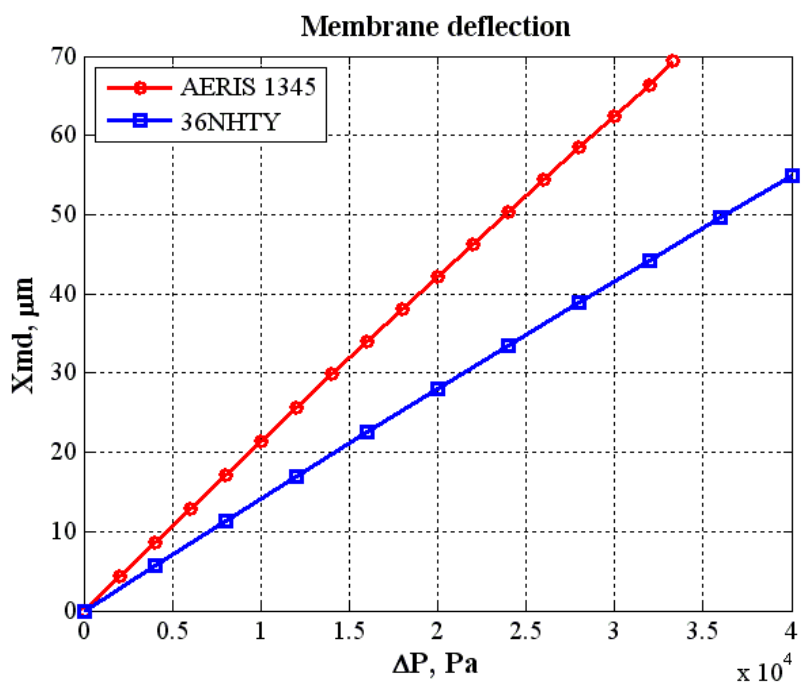

(a)

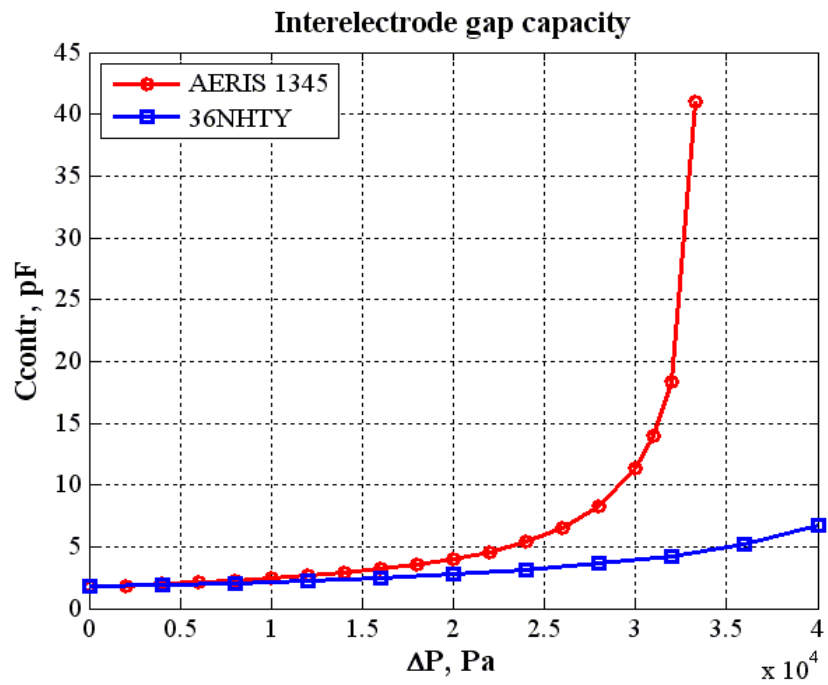

(b)

Figure 7. Dependences of the membrane deflection $x_{m d \text { max }}$ (a) and of the interelectrode gap capacity $C_{\text {contr }}$ (b) on the value of the applied pressure $\Delta P$ 
Block diagram of suggested sphygmograph based on the PRMT for telemedicine monitoring is shown in Fig. 8. The suggested device contains the sensors Sensor 1, and Sensor 2 of pulse wave oscillations, two identical channels of frequency converters Channel 1, and Channel 2, ARM microprocessor (MC) to control the process of obtaining and pre-processing of data and the Bluetooth module.

Each sensor contains the pressure measuring transducer based on the PRMT that is included in the oscillating system (see the Oscillator 1, and Oscillator 2).

A signal frequency $f^{(i)}$ at the output of the $i$-th pressure sensor is equal to

$$
f^{(i)}=f_{0}^{(i)} \pm \Delta f_{i n f}^{(i)}, \quad i=1,2,
$$

where $f_{0}^{(i)}$ is the rated frequency PRMT; $\Delta f_{\text {inf }}^{(i)}$ is the information feature value in the form of frequency deviation.

For increase the value of the information frequency deviation the multipliers (Multiplier 1, and Multiplier 2) are used in each channels Channel 1, and Channel 2. From the outputs of the multipliers Multiplier 1, and Multiplier 2 the frequencymodulated signal arrives in the frequency mixers Mix 1, and Mix 2.

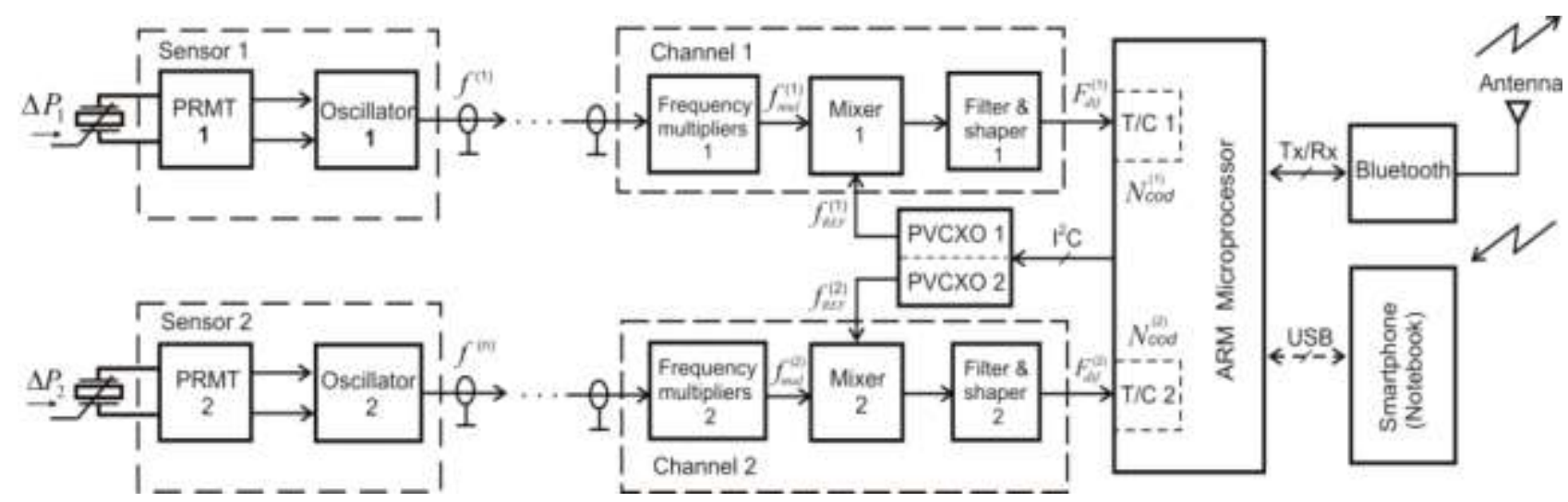

Figure 8. An electrical block diagram of the proposed Sphygmograph for telemedicine monitoring 
After filtration and shape forming procedures performed in the Filters \& Shapers 1,2, the frequency difference signal is generated at the mixers Mix 1, and Mix 2 outputs as follows

$$
F_{d i f}^{(i)}=f_{R E F}^{(i)}-f_{m u l}^{(i)}=F_{d i f_{0}}^{(i)} \pm \Delta F_{d i f}^{(i)}, i=1,2,
$$

where $f_{R E F}^{(i)}$ is the output frequency of $\mathrm{I}^{2} \mathrm{C}$ of the programmable crystal oscillators (PVCXO 1, and 2);

$$
F_{d i f_{0}}^{(i)}=f_{R E F}^{(i)}-n f_{0}^{(i)}, \Delta F_{d i f}^{(i)}= \pm n \Delta f_{i n f}^{(i)} \text { is the rated value and information }
$$
frequency component $F_{d i f}^{(i)}$.

The value of reference frequency $f_{R E F}^{(i)}$ is formed according to the approximate method of linearization (7) [336].

According to the linearization method, the period function $T_{d i f}^{(i)}(\Delta P)=1 / F_{d i f}^{(i)}$ corresponding to the difference frequency and caused by the change of pressure $\Delta P$ is transformed to the strictly linear value as

$$
T_{\text {lin }}^{(i)}(\Delta P)=1 / F_{d i f}^{(i)}=T_{0}+S_{P F} \cdot \Delta P,
$$

where the upper heterodyne frequency

$$
f_{\text {het }}=f_{\text {het }}^{(\text {opt })}=f_{\text {REF }} \text {. }
$$

For instance, typical data for the practically implemented piezoresonance frequency transformation with PRMT can be represented as follows: the nominal frequency $f_{n}=10 \mathrm{MHz}$; optimal heterodyne frequency $F_{\text {opt }}=10013691 \mathrm{~Hz}$; period $T_{0}=119.196 \mu \mathrm{s}$. 
Application for PVCXO 1, and PVCXO 2 the crystal oscillators Si599 (Silicon Labs) allows setting the optimum frequency of heterodyning (23) with an accuracy of Hertz. Programming of PVCXO 1, and PVCXO 2 is carried out on the bus $\mathrm{I}^{2} \mathrm{C}$.

Signal contained information frequency arrives on ARM Microprocessor Atmel. For measurement of the period the internal 16th- bit Timer/Counter 1 (T/C1), and Timer/Counter 2 (T/C2) are used in the microprocessor. At the output of T/C1 and T/C2 the digital code is created proportionally to the high-speed performance of counters:

$$
N_{\text {cod }}^{(i)}=k T_{\text {dif }}^{(i)}\left(\Delta t_{T}\right)^{-1}, \quad i=1,2
$$

where $\Delta t_{T}$ is the time counter status change; $k$ is the number of measured periods.

After transforming $T_{d i f}^{(i)}(\Delta P) \rightarrow N_{c o d}^{(i)}(\Delta P)$, preprocessing of data (scaling, and filtering) and forming the digital data stream for transmission on Bluetooth channel of Smartphone (Notebook) is carried out. For visualization and recording ARM microprocessor also performs functions of monitoring of the process of measurements. Initial initialization and zero adjustment Sensor 1, Sensor 2 are demonstrated in Fig. 8.

Let us analyze the accuracy of reproduction of the shape of the pulse wave oscillations. The information contained in the signal period for small deviations $\Delta F_{d i f}^{(i)}<<F_{d i f_{0}}^{(i)}$ can be represented as

$$
T_{d i f}^{(i)}=\frac{1}{F_{d i f_{0}}^{(i)} \pm \Delta F_{d i f}^{(i)}}=T_{d i f_{0}}^{(i)} \pm \Delta T_{d i f}^{(i)}, \Delta T_{d i f}^{(i)} \cong \frac{\Delta F_{d i f}^{(i)}}{\left(F_{d i f_{0}}^{(i)}\right)^{2}} .
$$

The error arising in the evaluation of the period $T_{d i f}^{(i)}$ and defining the resolution capability of the transducer $T_{d i f}^{(i)}(\Delta P) \rightarrow N_{c o d}^{(i)}(\Delta P)$ depends on the high-speed performance of counters. Then the error $\delta_{T}^{(i)}$ can be written as 


$$
\delta_{T}^{(i)}=\frac{\Delta t_{T}}{k \Delta T_{d i f}^{(i)}}=\frac{\Delta t_{T}}{k n} \frac{\left(F_{d i f_{0}}^{(i)}\right)^{2}}{\Delta f_{\text {inf }}^{(i)}} .
$$

Let us define an error of secondary transformation of the pulse oscillations shape arising in the mode of the sphygmography measurements. This mode is characterized by small changes of pressure value $\Delta P<(3 \ldots 5) \mathrm{mm} \mathrm{Hg}$ and, therefore, the small magnitude of information frequency deviation $\Delta f_{i n f}^{(i)}<F_{d i f_{0}}^{(i)}$.

For standard magnitude steepness, the following data can be obtained: transforming AMT of the pressure to the frequency can be equal to $S_{P F}=$ $(15 \ldots 20) \mathrm{Hz} / \mathrm{mm} \mathrm{Hg}$; the difference frequency $F_{d i f_{0}}^{(i)}=1 \mathrm{kHz}$, and runtime $\Delta t_{T}=5 \cdot 10^{-8} \mathrm{sec}$ ( $k=1, n=4)$. As a result, relative error $\delta_{T}^{(i)}$ is less than $0.1 \%$. It is quite enough for reproduction of pulse oscillations with high reliability.

The basic advantage of suggested pressure mechanotron is the complete absence of hysteresis effects, which are inherent in sensors with direct influence onto PE. This peculiarity substantially increases the reproducibility of graduation characteristics and, as a result, the accuracy of the measurements. A typical value of permitted ability of given PRMT with metal membrane comprises $(0.05 \ldots 0.08) \mathrm{mm} \mathrm{Hg}$, and the main error does not exceed $(0.1 \ldots 0.15) \%[336,337]$.

Piezoresonance pressure mechanotron can use both the single- and the dualfrequency excitation mode of PE with a modulated interelectrode gap (MIG). The single-frequency excitation mode of PE with MIG is considered in detail in [338,339]. In the pressure transducer shown in Fig. 9, the QR is included in the scheme of the dual-mode controlled oscillator DCXO [341]. It is excited at the fundamental mode of oscillations $f_{r}$ and at the additional mode with an anharmonic frequency $f_{a}$. Fundamental mode $f_{r}$ is informative, and the anharmonic oscillations are used as frequency of the first heterodyne $f_{a}$.

After division in DIV device by coefficient equal to $N$, the frequency of the second heterodyne $f_{a} / N$ is formed. Respectively, at the output of the first mixer 
MIX1 the first differential frequency $F_{d i f 1}=f_{a}-f_{r}$ is selected, and at the output of the second mixer MIX2 the second differential frequency $F_{\text {dif } 2}=f_{\text {dif } 1}-f_{a} / N$ is formed. After double transducing, the spectrum of an informative signal is exposed to frequency-period transform for the linearization of the through transducing PRMT characteristic.

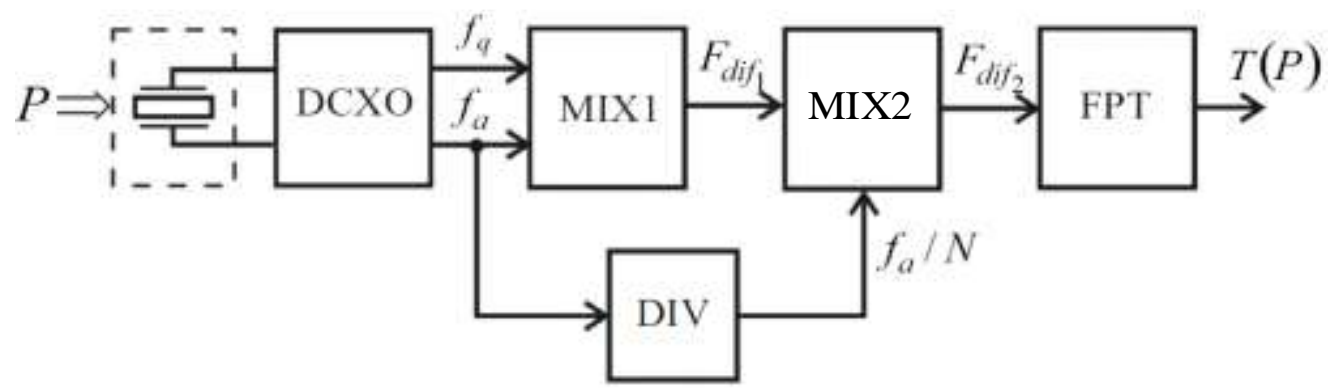

Figure 9. An electrical block diagram of the dual-mode piezoresonance pressure mechanotron

Experimental study of PRMT characteristics was performed for the quartz resonator with a nominal frequency value of the fundamental mode of oscillations $f_{r_{0}}=10010 \mathrm{kHz}$ and the additional mode with an anharmonic frequency $=10066 \mathrm{kHz}$. Graduation characteristics for the fundamental and additional oscillation modes of the QR with MIG are represented in Fig. 10. The dependence of the PRMT output signal period on the surplus pressure $T(P)$ is shown in Fig. 11.

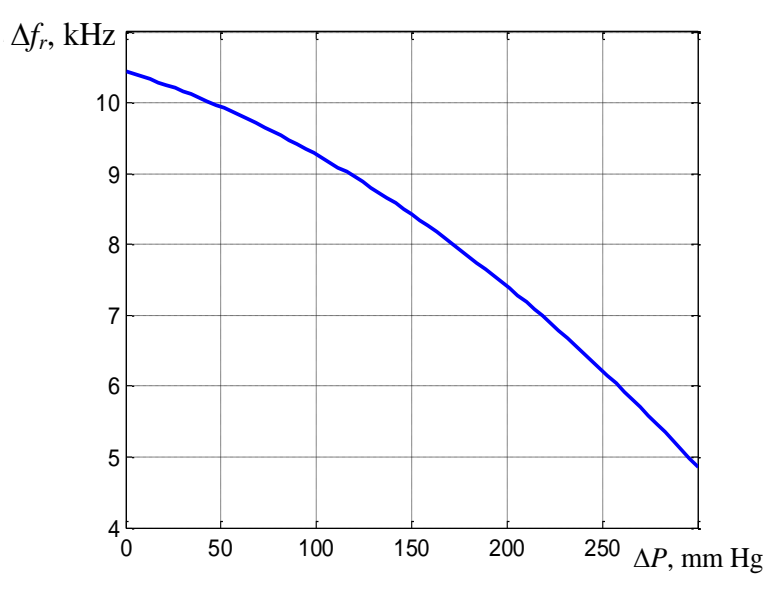

(a)

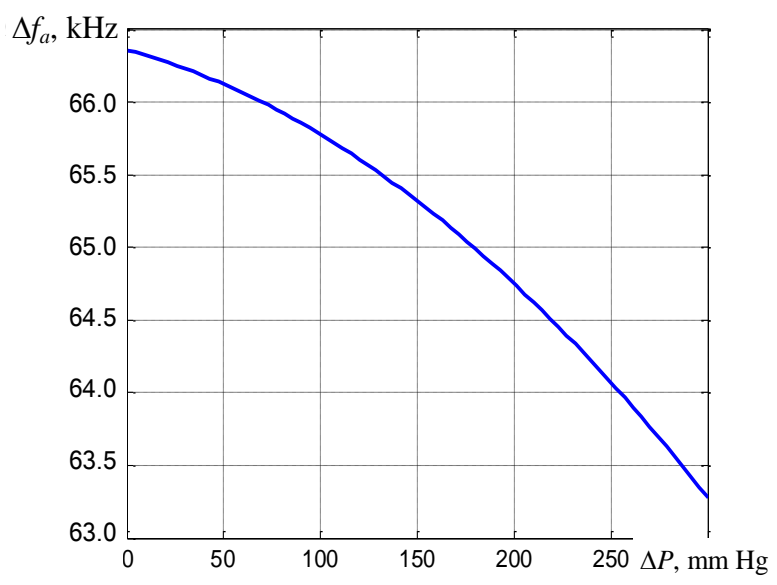

(b)

Figure 10. The graduation characteristic of the PRMT for the fundamental mode of oscillations $f_{r}$ (a) and for the additional mode with an anharmonic frequency $f_{a}$ (b) 
The analysis of the obtained results indicates that the change of the division coefficient $N$ for the frequency $f_{a}$ allows selecting an optimum period value $T_{0}$ for the output signal within the borders of a permissible error of a non-linearity transducing.

It can be seen that for these graduation characteristics of the QR with MIG demonstrated in Fig. 10, the optimum division coefficient value is $N=194$ in case of the integral non-linearity value of the pressure characteristic of no more than $0.5 \mathrm{~mm} \mathrm{Hg}$.

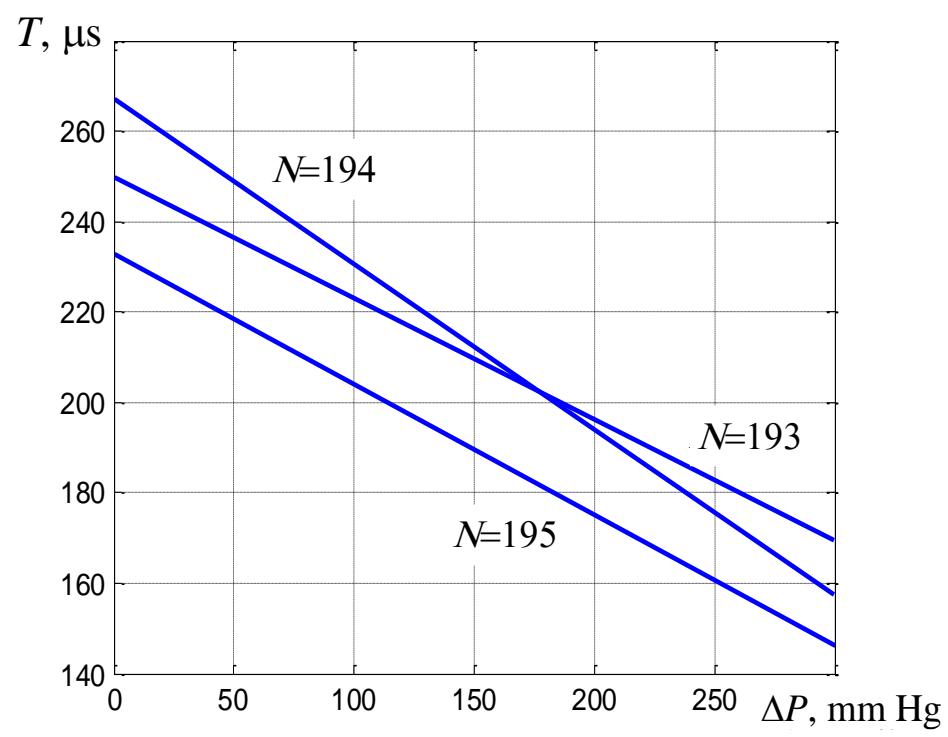

Figure 11. Dependences of the output signal period of the PRMT on the pressure $T(\Delta P)$ for different values of $N$

At the same time, satisfactory results can be obtained also at the coefficient values of $N=193$ and $N=195$ that indicates the high performance of this linearization method [341,342].

Three main areas of use of a sphygmography in clinical practice and for personal/home use where it is planned to use the Sphygmograph:

1. Sphygmography is used for the quantitative definition of hemodynamic indices of the blood circulatory system, such as of a pulse wave velocity (PWV), duration of separate phases of a cardiac cycle, the size of systolic volume and others. The singular value gets this method during the diagnosing of atherosclerosis, arterial hypertension, heart diseases, closed craniocerebral injuries, etc. Examples of synchronous measurements of sphygmogram of the central pulse (carotid artery) and 
peripheral pulse (femoral artery) obtained by the sensors PRMT 1 and PRMT 2 are shown in Fig. 8.

2. Sphygmography is used in a complex of poly- cardiographic researches of the cardiovascular system where there is a simultaneous filing of an electrocardiogram, sphygmogram, phonocardiogram, the rheocardiograms characterizing the different parties of physiologic processes in the body's circulatory system.

3. The special sphygmography is necessary for the solution of specific problems of assessment of a condition of cardiac walls at different forms of cardiovascular pathology, for example, assessment of change a pulse wave a normal form is observed at a failure of aortal valves, an aortal stenosis, and some other diseases and it needs the subsequent studying [343, 344].

Sphygmograph reads the pulse wave on the carotid and radial (femoral) artery. Then, it is synchronized with one of the gadgets via Bluetooth for storage statistics, issues derived hemodynamic parameters on its screen, and, if necessary, transmit the processed information to the server in the cloud for advice from the family doctor [329,330]. Constructive realization of the microcontroller block and PRMT of surplus pressure is shown in Fig. 12.



(a)

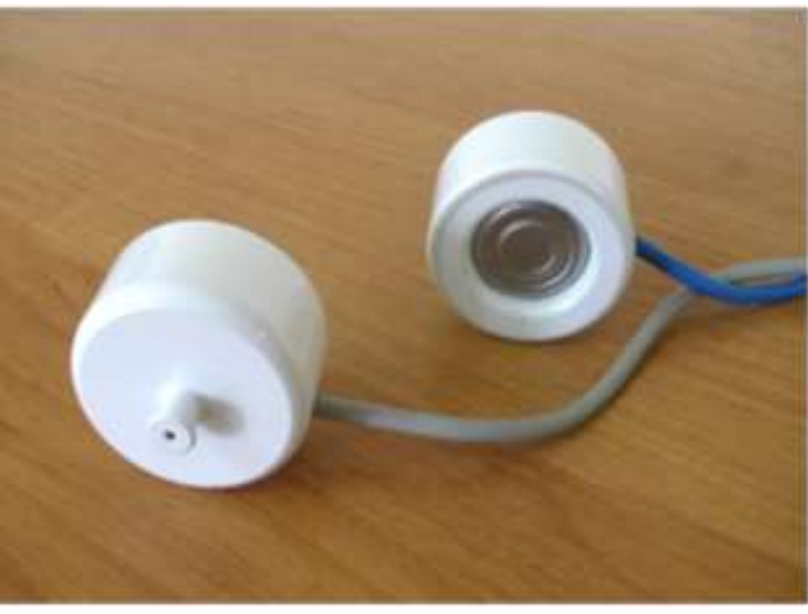

(b)

Figure 12. Constructive realization of the microcontroller block (a) and PRMT of surplus pressure (b) 
The following are typical technical characteristics of the Sphygmograph.

1. Resolution in the range of applied pressure $P \in[0 ; 300] \mathrm{mm} \mathrm{Hg}$ :

- for small pressure, less than $10 \mathrm{~mm} \mathrm{Hg}$ (0.008 - 0.01) mm Hg;

- for maximum pressure not worse $0.025 \mathrm{~mm} \mathrm{Hg}$.

2. Full change-over of frequency, not less than $9.5 \mathrm{kHz}$.

3. The value of hysteresis after maximum load, not more than $2 \mathrm{~Hz}$.

4. The basic error of measurement the surplus pressure, not more than $0.15 \%$.

Suggested Sphygmograph is used for the quantitative definition of hemodynamic indices of the blood circulatory system, such as of a PWV, duration of separate phases of a cardiac cycle, the size of systolic volume and others. The singular value gets this method during the diagnosing of atherosclerosis, arterial hypertension, heart diseases, the closed craniocerebral injuries, etc. [337].

Examples of synchronous measurements of sphygmogram of the central pulse (carotid artery) and peripheral pulse (radial artery) obtained by the sensors PRMT 1 and PRMT 2 are shown in Fig. 13. In Fig. 14 are shown the sphygmograms for carotid (a) and the radial (b) arteries take off by PRMT for patients with diagnosed aortic insufficiency and mitral valve prolapse [337,343,344].

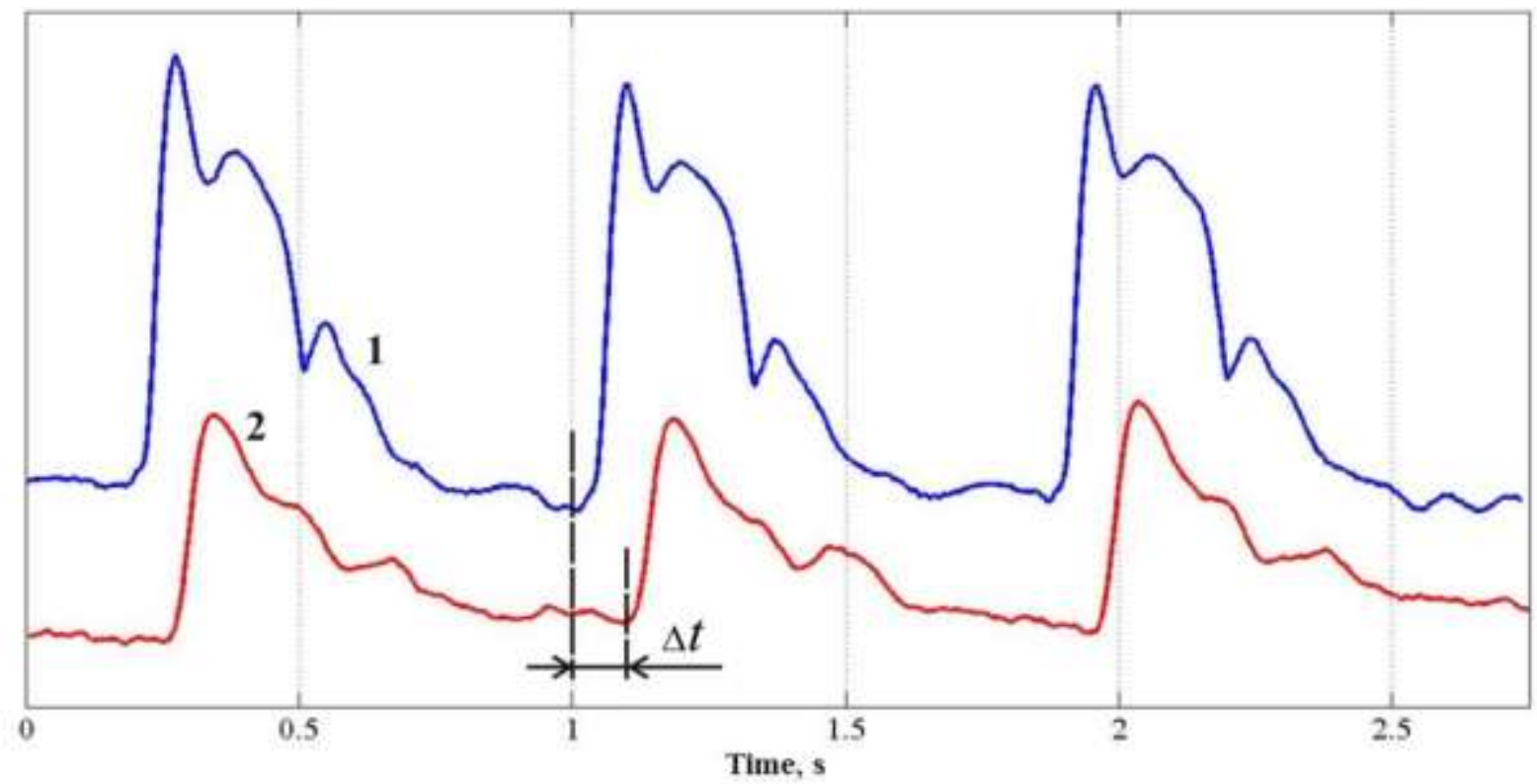

Figure 13. Defining PWV by signals on carotid artery (1) and radial artery (2), Female, 25 years old 


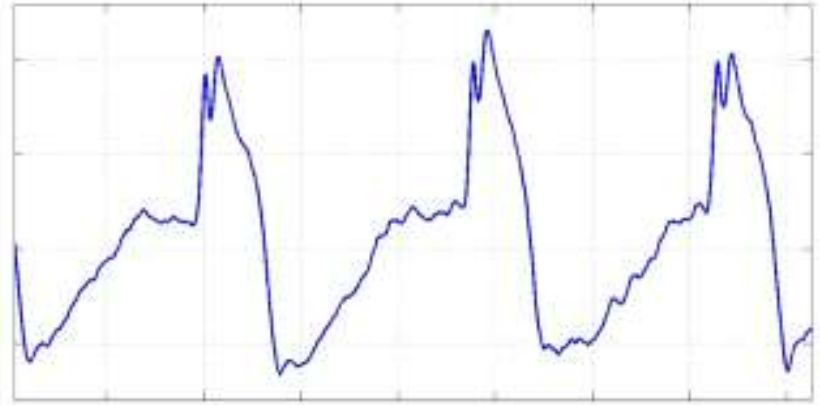

(a)

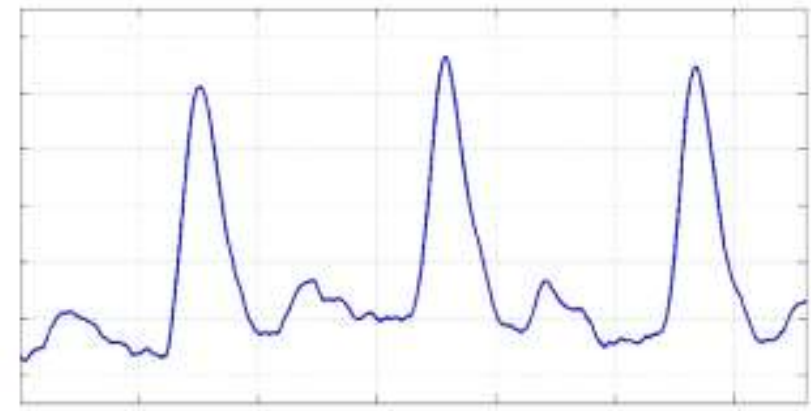

(b)

Figure 14. Sphygmograms measured for carotid (a) and the radial (b) arteries taken off by PRMT for patients with diagnosed aortic insufficiency and mitral valve prolapsed

SUMMARY. The method of sphygmography is one of the most promising diagnosis methods of cardiovascular disease and for hemodynamic monitoring of the cardiovascular system. This method involves an analysis of pulse oscillations, taken on the carotid, femoral, radial and other arteries of a person. The wide application of the method of sphygmography is hampered by the absence of precise pulse wave acoustic sensors with high resolution.

Using a new generation of pulse wave sensors such as piezoresonance pressure mechanotron (PRMT) with a modulated interelectrode gap significantly improves the accuracy and reliability of sphygmographic studies. The sphygmographic system developed on the basis of PRMT allows recording of local and volumetric sphygmograms and provides reliability of measurements in real time, solving the problems of computer diagnostics. The received results of researches confirm high efficiency of application of offered approaches at the construction of telemedical systems for monitoring of parameters of hemodynamics of the person. 


\section{2 Штучний інтелект: що змінилося за 50 років}

Науково-технічний прогрес не стоїть не місці. Розвиток систем штучного інтелекту (Artificial Intelligence), даталогії (Data Science)та машинного навчання (Machine Learning) вже сьогодні дозволяє людству робити те, що раніше могли уявити лише фантасти у своїх художніх творах: розпізнавання зображень та мови, ідентифікація особистості, прийняття надскладних рішень, прогнозування уподобань та поведінки людини, автокерування транспортом, побудова універсальних маршрутів тощо.

Діджиталізація як цифрова трансформація повсякденних речей настільки міцно увійшла в наше життя, що ще у 2001 році був введений новий показник рівня розвитку країн світу - індекс цифрової готовності NRI (Networked Readiness Index), який призваний охарактеризувати ступінь розвитку інформаційно-комунікаційних систем відповідної країни та $\epsilon$ важливим показником її розвитку і перспективності для інвестицій.

Bсе частіше в еру цифровізації науковці погоджуються 3 видатним афоризмом Натана Ротшильда: «Хто володіє інформацією - володіє світом». Вже зараз для керування людьми більше немає необхідності у тому, щоб мати велику армію підданих чи залучати для контролю спеціальні види репресій. За можливості безмежного доступу до інформації та засобів ії обробки керування думками людей стає все простішим. Це в свою чергу є першим кроком до підриву соціальних свобод особистості та недоторканності приватного життя.

Але, перш ніж говорити про перспективи чи недоліки використання сучасних систем штучного інтелекту (візьмемо для прикладу саме їх),для початку треба чітко визначити для себе, що ми будемо вважати такими системами. Що саме роблять ті чи інші технічні системи, власне, інтелектуальними?Як відомо, термін «штучний інтелект» було введено ще у 1956 році видатним американським математиком Джоном МакКарті (John McCarthy). Так, у своїй роботі «Що таке штучний інтелект?» [345]. Мак Карті 
зазначав, що слово «інтелект» відповідає за деяку обчислювальну складову здатності досягати своєї цілі. Але тут одразу виникає питання, чи все те, що досягає певної цілі, можна назвати інтелектуальним? Сьогодні більшість дослідників при спробі визначити, що ж таке «штучний інтелект», рухаються у напрямку відтворення діяльності людського мозку за допомогою технічних засобів; але саме в такому формулюванні напрямку міститься велика кількість проблем.

Якщо детально зануритися в принцип роботи штучного інтелекту на прикладі нейронних мереж, можна сказати, що,взагалі, це - ускладнена версія дерева прийняття рішень з заздалегідь прописаними правилами та величезною базою знань. Чи можемо ми насправді вважати таку систему інтелектуальною? Чи, може, це просто більш досконала версія автоматизації прийняття рішень? На цьому моменті слід зауважити, що сучасні системи штучного інтелекту вже давно є самонавченими. Але зазначимо і те, що ті алгоритми, за допомогою яких сучасні нейронні мережі можуть «навчатися», в дійсності є спробою останніх, нехай і вдалою, відшукати певні закономірності між тими чи іншими явищами. А вже на основі цих логічних побудов вони працюють зі складними структурами даних. Отже, не слід забувати і той факт, що більшість систем з самонавчанням фактично пристосовані лише до певної області і при зміні сфери своєї діяльності є доволі низька ймовірність, що вони будуть демонструвати результат досить високого рівня.

Коли ми говоримо про самонавчання, так чи інакше розуміємо те, що існує хтось, хто передає певну інформацію до системи, i, як вже було неодноразово доведено у багатьох дослідженнях, таких, наприклад, як [346] і [347], отриманий результат буде у значній мірі залежати від початкових даних.

Більш того, окреме питання, яке виникає у зв’язку 3 повсюдним застосуванням штучного інтелекту, стосується алгоритмів роботи таких систем, адже ні для кого не секрет, що зі збільшенням розмірності та складності задач, які тепер здатні розв’язувати системи штучного інтелекту, чітко зрозуміти та логічно обгрунтувати їх роботу стає все менш можливим. Тобто на практиці ми 
маємо ситуацію, коли у реальності ніхто не в змозі оцінити ні логічність, ні правильність рішення системи штучного інтелекту через помірну складність задачі, і все, що залишається, зводиться до прийняття отриманих результатів на віру. Ця ситуація стає ще більш небезпечною з урахуванням тієї кількості рішень, які все частіше людство перекладає на машини. Чого варте одне американське дослідження використання системи COMPAS в сфері кримінального судочинства [348], в результаті непрозорості якої постійно відбувалися помилки в області визначення ймовірності скоєння злочину.

Взагалі, коли ми намагаємося пристосувати системи штучного інтелекту до будь-яких сфер, які хоч трохи стосуються питань етики чи моралі, одразу потрапляємо у пастку за принципом Юма, тим самим намагаючись перейти від «є» до «повинен». І це тільки одна невелика складова спроби повсюдного впровадження штучного інтелекту.

Саме на цьому етапі виникає резонне питання: чи для всіх сфер життєдіяльності ми, насправді, можемо застосувати системи штучного інтелекту на їх сучасному рівні розвитку? Здається, що ні. На практиці системи штучного інтелекту дуже добре зарекомендували себе у тих сферах діяльності, в яких можна побудувати чіткі алгоритми та математичні моделі, і в тих, де є великий об’єм даних та інформації, з чим людині буде складно працювати, але при цьому буде чітко визначена задача. Насправді, в цілій низці сфер діяльності, в яких неможливо конкретизувати задачу, іiі параметри, де необхідно працювати в умовах невизначеності, системи штучного інтелекту стикаються 3 рядом проблем на кшталт «катастрофічного забування» (catastrophic forgetting).

Зрозуміло, що цифровізація та системи штучного інтелекту значно прискорюють вирішення багатьох виробничих процесів і процесів прийняття рішень. Але ті масштаби, з якими зараз відбувається впровадження штучного інтелекту у всі сфери життя людини, в подальшому може призвести до глобального колапсу, пов'язаного з принципами демократії та можливостей соціально-психологічного пристосування людини. Доповнюючи дійсність людини віртуальною реальністю, вони не просто змінюють традиційні установки 
суспільства - створюють новий світ зі своїми правилами та законами, діючими всередині даного світу.

Ще одне питання стосується зміни самої природи людини. Шляхом звичайного відслідковування були підмічені дві досить чіткі тенденції,пов’язані з глобальними змінами. Перша 3 них - це намагання зробити штучний інтелект людяним, навчити його мислити як людина, відчувати як людина. Друга розвиток біоінженерії та намагання за допомогою сучасних технологій не тільки продовжити та покращити життя сучасної людини, а й «покращити», власне, саму людину. Відповідно до цього, найближчим часом, скоріш за все, виникне необхідність нового визначення, кого або що вважати людиною.

Коли ми кажемо про страхи перед штучним інтелектом, в першу чергу мова йде про одну 3 двох речей. Або ми говоримо про сингулярність та можливість штучного інтелекту в значній мірі перевершити здібності самої людини, а отже,стикаємося 3 неможливістю контролювати такі системи. Або ми говоримо про певну технічну революцію, результатом якої буде заміна людей на машини в усіх (або майже усіх) сферах діяльності, i тоді вже виникає питання щодо можливості та здатності людства в повній мірі змінити усталений впродовж століть спосіб життя.

У зв’язку з вищезазначеним виникає багато питань, які потребують розгорнутих відповідей. Наприклад, яким чином з урахуванням темпів розвитку технологій та цифровізації ми в змозі захистити свободу, рівність та конфіденційність кожного індивіда в світі інформаційних систем та технологій? Яким чином можна притримуватися основних принципів демократії 3 урахуванням підвищення впливу штучного інтелекту та машинного навчання на прийняття рішення? В якій мірі ми насправді можемо доручити машинам приймати рішення у тому випадку, коли питання стосується життя людей чи справедливості?Чи є раціональне та логічне рішення в дійсності справедливим? Чи готові ми довірити своє майбутнє сухій логіці та раціональності без можливості внесення в це майбутнє дещиці творчості і емоційної людяності? 
Якщо всі рішення будуть прийматися за нас розумними машинами, то що, власне, залишиться робити нам, людям?

Окрім низки соціальних та морально-етичних питань є також чимало питань, які йдуть з області права. Адже до сьогодні, з точки зору права, відсутній відповідний рівень міжнародної та національної нормативної основи використання штучного інтелекту на практиці.

Звичайно, концентруватися виключно на негативний стороні цифровізації та впровадження штучного інтелекту не є доцільним. В нас є цілий ряд причин, які спонукають рухатися назустріч штучному інтелекту та цифровізації.

I перша причина міститься безпосередньо у можливості того, що штучний інтелект перевершить людство в цілому ряді когнітивних здібностей на кшталт просторової орієнтації, швидкості обчислень, кількості інформації, які можна запам’ятати тощо. Зрозуміло, що така ситуація в першу чергу створить досить суттєву кризу в області працевлаштування, економіки. Але така криза та їі перспектива - перший крок до скорішого замислення над тим, хто є людиною та що відрізняє людину від «розумної» машини? Це - крок до нового осмислення себе та своєї ролі, крок до творчості, до поглиблення розуміння себе як особистості; в той самий час це - шлях до покращення соціальної взаємодії, поглиблення емоційного інтелекту, пошуку нових напрямків досліджень та пізнання особистості зокрема і суспільства в цілому. Це може призвести до встановлення нового розуміння гуманізму, альтруїзму, спільності, любові, єдності.

По-друге, розповсюдження та розростання штучного інтелекту, цифровізації може призвести до миттєвого стрибка в розвитку науки та знань. Наприклад, вже зараз ми є свідками кризи в області освіти, адже сучасні школи та виші, насправді, не встигають за тими темпами, 3 якими відбувається технічний прогрес. Усі розуміють необхідність фундаментальних змін, але тепер вже важко сказати, в якому напрямку дійсно необхідно рухатися для того, щоб та освіта, яку отримують сучасні школярі та студенти, була справді актуальною. Є надія, що саме розповсюдження всіляких технічних засобів, глобалізація та 
об’єднання вчителів і науковців допоможе розробити єдину загальну стратегію щодо подальшого напрямку розвитку наших звичних закладів освіти.

Окреме питання - наука. Вже зараз зрозуміло, що нові технічні системи допоможуть у майбутньому зробити велику кількість нових відкриттів в найрізноманітніших сферах науки, починаючи від фундаментальних складових матерії і закінчуючи вивченням Всесвіту. Така революція в області науки може значно розширити базу знань людства. Зрозуміло, що саме по собі таке розширення не говорить про покращення рівня життя, адже зі збільшенням можливостей пропорційно до цього збільшаться й вимоги до користувачів цими знаннями; але перспективи рівня розвитку науки при раціональному i ефективному використанні нової бази знань та відповідних освітніх систем навіть важко уявити.

Сучасний рівень технічних систем сьогодні дає майже безмежні можливості в плані співробітництва. Спільне навчання, взаємодія, об’єднання у великі професійні групи, об'єднання за інтересами, глибоке розуміння себе та світу через порівняння та взаємодію - це вже не фантазія, а реальність. I це є першим кроком до нового принципу самоорганізації.

Ще один крок у світле майбутнє - використання сучасних інформаційних та технологічних систем у медицині та біоінженерії. Довге та здорове життя - чи не про це ми всі мріємо для наших батьків та дітей, та для нас самих? 3 використанням сучасних технологій це все стає реальністю. Згадати хоча б ситуацію з пандемією covid-19, загрозу від якої вдалося знизити в немалій кількості саме завдяки сучасним технологіям.

Деякі науковці у своїх прогнозах зазначають [349], що у майбутньому повсюдне використання штучного інтелекту в сфері економіки призведе до суттєвого зниження економічних ризиків та небезпек. Факт впровадження інформаційних технологій, як передбачається, спричинить підвищення стабільності та стійкості фінансової системи.

У роботі Синиціної Ю.П. виконаної у співавторстві наведено результати дослідження можливостей нейромережевих методів прогнозування в 
інтелектуальній системі підтримки прийняття рішень у процесі управління підприємством [350]. Інтелектуальна система підтримки та прийняття рішень дасть змогу приймати найважливіші рішення в інтерактивному режимі, аналізувати, планувати і контролювати різні маркетингові заходи і проектувати їх за принципом «що, якщо». На цій основі з'являється можливість ієрархічного прийняття рішень. У результаті велике коло досить складних завдань, яке раніше могло виконуватися лише кваліфікованими фахівцями у сфері маркетингу, за допомогою систем підтримки рішень може бути реалізовано також фахівцями суміжних підрозділів [350].

В той же час у роботі [351] наведено результати дослідження можливостей практичних аспектів застосування нейронних мереж в аналізі макроекономічних показників підприємства на базі розробленого програмного продукту на основі нейромереж, який дає змогу прогнозувати макроекономічні показники за статистичними даними не тільки України, але й інших країн під час виходу підприємства на ці зовнішні ринки.

Найкращі прогнозні властивості для побудованої математичної моделі ІСППР демонструє генетичний алгоритм за використання радіально-базисних функцій. Створений програмний продукт дасть змогу моделювати та прогнозувати показники макросередовища як внутрішнього, так і зовнішнього ринку, на якому планує працювати підприємство [350, 351].

За деякими оцінками [352], використання штучного інтелекту здатне призвести до збільшення продуктивності праці на 37\% (в 2035 році), що стосується в першу чергу розвинених країн світу. Про зростання ролі штучного інтелекту в світі свідчить збільшення кількості венчурного капіталу, який припадає на долю систем штучного інтелекту, та збільшення економічного ефекту від використання у своїй роботи напрацювань штучного інтелекту [353, 354].

Ми живемо в складну епоху. Епоху, яка наповнена змінами. В своєму намаганні зазирнути в майбутнє та захистити себе ми знов і знов пробуємо спрогнозувати майбутнє. У 1967 році видатний американський вчений в області 
штучного інтелекту Марвін Лі Мінський сказав:«За період від трьох до восьми років ми отримаємо машину, порівнянну за загальним інтелектом з середньою людською істотою» [355]. Не дивлячись на виданий інтелект західного дослідника, він помилився, і навіть сьогодні, більш ніж через 50 років, ми все ще не наблизилися до створення «справжнього» штучного інтелекту. Так, в порівнянні з 60-ми роками, дійсно,людство зробило значний крок вперед у розвитку своїх технологій, але саме тепер від нас залежить, чи зможемо ми вірно скористатися нашим попереднім твором - для скорішого настання омріяного світлого майбутнього. Чи вистачить у нас розуміння, далекоглядності та проникливості для того, щоб повернути свій погляд в славне майбутнє та зробити одночасно обережні і вірні кроки у напрямку подальшого розвитку, а не бездумного збільшення виробничих потужностей та заробляння грошей? 


\section{SECTION 7. INNOVATIVE TECHNOLOGIES}

DOI 10.46299/ISG.2021.MONO.TECH.III.7.1

\section{1 До питання моделювання лазерного зварювання та адитивних процесів}

Числове моделювання процесу зварювання є однією 3 основних тем зварювальних досліджень протягом останніх 20-30 років. Результати такого моделювання можуть бути використані для чіткого пояснення фізичної сутності деяких складних явищ у процесі зварювання, а також можуть бути використані як основа для оптимізації параметрів зварювання. Моделювання процесу лазерного зварювання дозволяє оцінити перехідні напруження, залишкові напруження та спотворення. Їх можна використовувати для оцінки структурних перекосів і несподіваних збоїв через перенапруження, викликане суперпозицією експлуатаційних навантажень i залишкових напружень, викликаних зварюванням. Проте моделювання процесу зварювання є непростим завданням, оскільки воно передбачає взаємодію теплових, механічних та металургійних явищ [356]. Для оцінки температури та розподілу напружень у процесі зварювання та прогнозування залишкових напружень та остаточних деформацій компонентів конструкції використано низку аналітичних та чисельних моделей процесів зварювання [357]. До них належать: аналітичні моделі, двовимірні скінченно-елементні моделі та тривимірні кінцево-елементні моделі лазерного зварювання.

Лазерне зварювання є досить новою технологією в порівнянні з методами дугового зварювання. Її основними перевагами є більша швидкість зварювання, низьке введення енергії в метал, вузький валик і невелика зона термічного впливу. Найпоширенішими його недоліками є горбистість зварного шва, його пористість і розбризкування матеріалу. Деякі недоліки також можуть виникнути через невеликий діаметр випромінювання. Без присаджувального матеріалу деталі що зварюються повинні бути ретельно виготовлені. Неточне позиціонування випромінювання може призвести до відсутності сплавлення, увігнутих поверхонь кореня та провисання зварних швів. Високі швидкості 
охолодження також можуть призвести до утворення пор у дуже глибоких зварних швах із недостатньою дегазацією каналу зварювання [358,359].

Експериментальні та теоретичні дослідження повинні доповнювати одне одного для більш глибокого розуміння даних процесів, причин утворення дефектів та покращення якості зварного з’єднання. Проте, для розуміння причинно-наслідкових зв'язків в моделюванні, спочатку треба розглянути напрямки дослідження, у яких використовуються дані моделі. В даному огляді розглянуто ряд сучасних робіт, пов’язаних 3 моделюванням лазерного зварювання різних матеріалів 3 використанням пакетів системного автоматизованого проектування і розрахунку (САПР).

В моделюванні процесів лазерного зварювання використовується багато різних пакетів системного автоматизованого проектування і розрахунку (САПР). Їх можна розділити на декілька груп:

- програмне забезпечення, розраховане на вирішення широкого спектру фізичних завдань з великим вибором фізичних алгоритмів розрахунку (ANSYS, COMSOL, ABAQUS);

- $\quad$ вузьконаправлене програмне забезпечення, розраховане на окремі завдання (Simufact Welding, SYSWELD);

- програмні середовища, що представляють собою набір інструментарію для компіляції задач (OpenFOAM, Fluent CFD).

Для оцінки температури та розподілу напружень у процесі зварювання та прогнозування залишкових напружень та остаточних деформацій компонентів конструкції використано низку аналітичних та чисельних моделей процесів зварювання. До них належать аналітичні моделі, двовимірні скінченноелементні моделі та тривимірні кінцево-елементні моделі лазерного зварювання. Подібні аналітичні та тривимірні скінченно-елементні моделі для лазерного формування були розроблені раніше. У згаданих вище тривимірних моделях враховані не всі параметри, що впливають на процес зварювання. Ці параметри включають: мікроструктурне перетворення внаслідок фазового перетворення, 
моделювання теплового потоку та зміна теплових і механічних властивостей матеріалу залежно від температури [356].

Методики моделювання, представлені в цьому огляді, зосереджені на лазерному зварюванні металів, але подібні методи використовуються для моделювання звичайних процесів зварювання, таких як дугове, зварювання тертям, а також легування, наплавлення та зміцнення поверхні.

Одним 3 перспективних напрямків досліджень $є$ вивчення зміни в мікроструктурі матеріалу при лазерному адитивному виробництві. Одною 3 нещодавніх робіт, яка вивчає специфіку росту зерен при лазерному адитивному процесі, є стаття Bansal та ін. [360], де авторами виконано експериментальну розробку та теоретичний аналіз процесу скануючої лазерної епітаксії (SLE), який досліджується та розробляється в Технологічному інституті Джорджії. SLE — це лазерний виробничий процес для осадження рівновісних, спрямованих затверділих і монокристалічних нікелевих тугоплавких сплавів на підкладки із тугоплавких сплавів шляхом селективного плавлення та повторного затвердіння порошків тугоплавких сплавів. Теоретичну глибину розплаву в цій роботі отримують, виходячи з критеріїв температури плавлення, де отримані графіки представляють разом із відповідними експериментальними мікрофотографіями, отриманими за допомогою металографії поперечного зрізу. В даній роботі також аналізується вплив параметрів обробки на еволюцію мікроструктури, що підтверджується спостереженнями за мікрофотографіями. Результати розрахунків було представлено як двовимірні зрізи температурного розподілу та їх порівнянням з експериментальними даними. При огляді роботи було помічено неточності у даної моделі, які виникають через неврахування зміни фази, втрат випромінювання від стінок зразка та неточного коефіцієнта конвекції, використаного в моделі. Зміщення траєкторії сканування, прийнятої в моделі, порівняно з фактичною експериментальною траєкторією сканування також може відігравати роль у меншій точності в передбачуваній глибині розплаву на торцевій кромці зразка. 3 цього можна зрозуміти, що наступна робота в цьому напрямку повинна включати моделювання мікроструктури, сформованої на 
основі даних фракції розплаву та градієнта температури. Однак, незважаючи на це, мікроструктура, отримана в роботі [360] була суттєво більш тонкою в порівнянні 3 литою підкладкою. Після встановлення належного робочого діапазону параметрів процесу відкладення не виявляли тріщин або гарячого розриву. Кутова дезорієнтація не перевищувала допустимого діапазону, про що було засвідчено мікроструктурним аналізом.

Іншою роботою, яка вивчає зміни в мікроструктурі матеріалу при лазерному зварюванні, є робота Wang та ін. [361] щодо росту зерен нікелевих сплавів при лазерному зварюванні. Тугоплавкі сплави на основі нікелю широко використовуються в багатьох галузях виробництва, особливо в аерокосмічній промисловості, ядерній енергетиці та нафтохімічній галузі, завдяки хорошим характеристикам при високій температурі та гарній корозійній стійкості [356, 357]. Через жорсткі термічні цикли лазерного зварювання та надзвичайно високі швидкості затвердіння експериментальними методами майже неможливо спостерігати поведінку затвердіння та мікроструктурну еволюцію в розплавленому басейні [361]. Ефективним способом розуміння поведінки затвердіння та мікроструктурної еволюції $є$ багатомасштабне моделювання. Поки що метод скінченних елементів зазвичай використовувався для моделювання макромасштабних теплопередач під час зварювання. Крім того, деякі комерційні пакети САПР, такі як Marc®, Simufact Welding®, ANSYS® також були запропоновані для розрахунку макромасштабних теплопередач під час зварювання. Для мікромасштабу, як потужний метод моделювання, моделювання фазового поля може безпосередньо імітувати поведінку затвердіння та мікроструктурну еволюцію в розплавленому басейні, наприклад, морфологію, відстань, бічні гілки та дифузію елементів [361]. Результати розрахунків було представлено як 2D зрізи температурного розподілу, 3D-схеми та їх порівняння з експериментальними даними. У даній роботі запропоновано багатомасштабну модель, що об'єднує макромасштабну та мікромасштабну модель для імітації росту зерна в розплавленому басейні ЛЗ сплаву Inconel 718. Результати моделювання та експериментів показують, що відстань між 
стовпчастими зернами дещо збільшується від краю оплавлення до зварного шва. За результатами моделювання було виведено та експериментально підтверджено степеневу функцію, яка систематизує ріст зерен в зоні термічного впливу (ЗТВ) при лазерному зварюванні. Ця робота поглибила теорію затвердіння розплавленої ванни та закладає основу для чисельного моделювання дефектів, що утворюються в ЗТВ, наприклад пористості та тріщин, що утворюються під час затвердіння [361].

Робота Safdar та ін. [362] представляє аналіз ефективності підходів ізотропної та анізотропної підвищеної теплопровідності для моделювання процесів лазерного плавлення. Скінченно-елементна модель була побудована 3 використанням комерційного програмного забезпечення ANSYS, щоб імітувати перехідні ефекти рухомого випромінювання для лазерного плавлення Inconel 718. Експериментальну геометрію басейну розплаву, отриману в результаті випробувань, проведених за допомогою волоконно-оптичного зв'язаного потужного діодного лазера, порівнювали з моделлю нормальної теплопередачі, ізотропної підвищеної теплопровідності та анізотропної підвищеної теплопровідності. Моделювання процесів, що включають лазерне плавлення, не є простим через ефект Марангоні та керовану плавучістю конвекцію всередині басейну розплаву. Добре встановлено, що на теплопередачу в басейні розплаву більше впливає потік рідини, ніж теплопровідність [357]. Геометрія ванни розплаву та розподіл температури значною мірою залежить від потоку ванни розплаву. Потік всередині басейну розплаву може стати турбулентним при високих числах Рейнольдса для потоків, що керуються поверхневим натягом [358], тим самим додатково змінюючи геометрію басейну розплаву. Автори досліджували вплив турбулентного транспорту в розплавленому басейні. Вони повідомили, що ширина басейну розплаву незначно менша для турбулентного потоку в порівнянні з ламінарним потоком для різної пари мідь-нікель. Автори показали, що моделі на основі чистої провідності не здатні передбачити профіль басейну розплаву та розподіл температури для металів з відносно високим числом Прандтля, таких як сталь і нікель [362]. Точне прогнозування геометрії 
басейну розплаву є важливим для прогнозування орієнтації мікроструктури, розміру зерен, розподілу напружень, викривлень та інших важливих параметрів. Таким чином, будь-яка спроба моделювання для дослідження процесів лазерного плавлення повинна враховувати конвекцію басейну розплаву внаслідок термокапілярних і гідродинамічних сил. Таким чином, для точного прогнозування геометрії басейну розплаву та розподілу температури необхідні детальні моделі розрахункової гідродинаміки (CFD). CFD-моделювання процесів лазерного плавлення вимагає значно більшого досвіду, а також вимагає відносно більшого часу обчислень у порівнянні зі звичайними моделями теплопередачі. Хоча моделі CFD мають можливість прогнозувати геометрію ванни розплаву більш точно в порівнянні зі звичайними моделями теплопередачі, але моделі CFD схильні до помилок через невизначеність значень коефіцієнта поверхневого натягу та в’язкості матеріалу в рідкому стані. Замість розв'язування складних рівнянь Нав’є-Стокса, рівняння енергії вирішується шляхом підвищення ізотропної теплопровідності за межі температури плавлення, щоб передбачити геометрію ванни розплаву та розподіл температури. Передбачається, що підвищення ізотропної теплопровідності буде впливати на розподіл температури таким чином, що ефекти будуть подібними до ефектів, викликаних конвекцією басейну розплаву. Цей підхід використовувався в минулому для моделювання лазерного наплавлення, лазерного зварювання матеріалів з відносно високим числом Прандтля, таких як сталь, тугоплавкі сплави тощо. Однак дослідники використовували значення ізотропної підвищеної теплопровідності з літератури. Ці значення мають дуже великий інтервал можливих значень, через що важко вибрати точне значення 3 літератури.

Дослідна робота, проведена Amara та ін. [363] пропонує тривимірне чисельне моделювання для імітації як потоку рідкого металу, так і впливу струменя інертного газу на потік. В результаті виходить більш реалістичне зображення відповідно до експериментальних спостережень. Потік пари, що утворюється під час поглинання енергії лазера всередині keyhole, i викликане 
тертям на стінці keyhole/розплаву басейну враховуються i розглядаються 3 поверхневим натягом, силами плавучості та тиском віддачі як основними механізмами, що відповідають для руху ванни розплаву. Еволюція інтерфейсу між басейном розплаву, keyhole та навколишнім повітрям моделюється за допомогою моделі багатофазного об’єму рідини (VOF). Зміна фази, потік пари, потік рідини та затвердіння є основними фізичними процесами, які були включені в моделювання лазерного зварювання в цій роботі. Представлене в роботі [363] 3D-моделювання показало рух розплавленого металу за основними відомими механізмами, описаними в літературі та спостережуваними експериментально. Модель дозволяє моделювати рух ванни розплаву, враховуючи складні механізми, притаманні процесу лазерного зварювання глибокого проникнення, головним чином взаємодію пара-рідина та рідинаповітря. Отримане чисельне рішення є оригінальним підходом і згодом було використано при дослідженні впливу газового струменя на структуру ванни розплаву. Результати показують, що використання струменя газу під час лазерного зварювання глибокого проникнення $\epsilon$ ефективним засобом для посилення потоку рідини, що призводить до кращих зварних з’єднань [363].

Anuratha та ін. [364] у своїй роботі глибше розглянули параметри лазерного випромінювання при лазерному зварюванні різнорідних тугоплавких металів. Вибір умов зварювання для з'єднання різнорідних матеріалів необхідний для забезпечення якості зварних з’єднань. У цьому дослідженні для визначення оптимальних умов зварювання використовували методику оптимізації. Спочатку умови зварювання були оптимізовані для геометрії зварного шва та утворення різних зон у зварному шві. На металургійні та механічні властивості зварних швів великий вплив має геометрія зварних швів. Розробка методології реакції поверхні здійснюється для експериментального дизайну шляхом розробки рівнянь регресії. Для перевірки валідності моделі використовувався дисперсійний аналіз (ANOVA). Результати розрахунків було представлено як таблиці даних, що порівнювалися 3 експериментальними даними. Лазерне зварювання різнорідних стикових зварних швів між Inconel 718 та AISI 4140 було 
оцінено для визначення впливу умов зварювання на структуру зварного шва. В процесі роботи було виявлено, що параметри швидкості зварювання та потужності лазера найбільше впливають на умови зварювання. Фактичні та прогнозовані значення геометрії зони зварювання добре збігаються з незначною різницею між цими значеннями.

Babu та ін. [365] визначили можливість певних процесів при лазерному зварюванні монокристалічних тугоплавких сплавів виробляти бажані мікроструктури, які забезпечують необхідні експлуатаційні властивості. Робота представляє собою огляд науково-технічних питань, пов'язаних зі з'єднанням монокристалічних тугоплавких сплавів на основі нікелю. Ці проблеми були продемонстровані на прикладах монокристалічних сплавів PWA-1480, CMSX-4, TMS-75 і N5, які використовуються в виробництві газових турбін. Для опису взаємодії між кристалографією, структурою зерен дендрита та формою зварювальної ванни була використана геометрична модель. Ця геометрична модель, здатна описувати напрямки росту дендритів у будь-якому довільному напрямку зварювання в системі координат кристала, була використана для інтерпретації розвитку зернової структури в електронно-випромінюванневому зварному шві PWA-1480 та лазерних зварних швах сплаву N5. Результати показують тісну кореляцію між утвореннями блукаючих зерен і розтріскуванням зварного шва в цих сплавах. На основі теорій затвердіння було представлено механізм утворення блукаючих зерен. Важливість твердотільного розпаду $\gamma$ фази на кінцеву мікроструктуру $\gamma+\gamma^{\prime}$ під час умов швидкого охолодження було проілюстровано детальною характеристикою мікроструктури за допомогою атомної зондової томографії. Розрахунки моделі теплопередачі та напружень, представлені двовимірними зрізами та багаточисленними тривимірними моделями показують, що наявність розтягуючих напружень і невеликої кількості рідини вздовж меж зерен можуть призвести до розтріскування шва. Продемонстровано застосування обчислювальної термодинаміки та кінетичної моделі для опису характеристик затвердіння та твердотільного розпаду $\gamma$-фази до мікроструктури $\gamma+\gamma^{\prime}$ в умовах безперервного охолодження. [365] 
Tsirkas та ін. [366] розробили тривимірну кінцево-елементну (FE) модель для імітації процесу лазерного зварювання та прогнозування викривлень панелі, звареної лазером за своєю методикою. Моделювання процесу лазерного зварювання виконано з використанням нелінійного аналізу теплопередачі на основі моделі утворення замкової щілини та поєднаного перехідного термомеханічного аналізу. Скінченно-елементні розрахунки проводилися за допомогою коду SYSWELD FE, який враховує теплові, металургійні та механічні аспекти. Аналіз враховує металургійні перетворення з використанням залежних від температури властивостей матеріалу та діаграми безперервного охолодження. У цій роботі також було розраховано зв’язок об'ємної частки фази Лавеса зі швидкістю охолодження. Було встановлено, що при фіксованому градієнті температури об’ємна частка зменшується зі швидкістю охолодження. Вважається, що зменшення об’ємної частки фази Лавеса є сприятливим для покращення характеристик тугоплавкого сплаву Inconel 718. Крім швидкості охолодження, градієнт температури також впливає на морфологію та розмір частинок фази Лавеса. В результаті дослідної роботи авторами статті було розроблено багатофакторну модель для моделювання еволюції мікроструктури, тобто зародження та зростання дендритів, сегрегації $\mathrm{Nb}$ та утворення частинок фази Лавеса, під час затвердіння тугоплавкого сплаву на основі нікелю. Чисельні розрахунки виявляють залежність еволюції мікроструктури від умов затвердіння, зокрема швидкості охолодження та градієнта температури. Підтверджено, що частинки фази Лавеса, які, як відомо, погіршують механічні властивості, утворюються в рідині, багатій на $\mathrm{Nb}$, i на них впливає сегрегація i розподіл багатої на $\mathrm{Nb}$ рідкої фази в міждендритній області.

Проведений огляд наукових робіт, пов’язаних 3 моделюванням лазерного зварювання та адитивних технологій, призначений для поглиблення знань про сучасне використання програмного забезпечення САПР при моделюванні даних процесів, виявив що:

- САПР-пакети програмного забезпечення використовуються в моделюванні як різних складових процесів лазерного зварювання, так і всього 
процесу, а також для вивчення значимості окремих факторів та оптимізації характеристик як лазерного випромінювання, так i структури зварного 3’єднання.

- Моделі, які використовувались під час моделювання процесів, в основному створювались 3 допомогою багатофункціональних розрахункових пакетів (ANSYS Workbench, COMSOL Multiphysics та ін.) з прямим зв'язком між віком публікації та використаними програмними пакетами САПР з переважним використанням мультифункціональних пакетів в останні роки. 


\section{SECTION 8. MECHANICAL ENGINEERING}

DOI 10.46299/ISG.2021.MONO.TECH.III.8.1

\section{1 Адаптация температурных режимов рабочей жидкости в гидроприводах экскаваторов при различных условиях эксплуатации}

Невозможно представить современные строительные машины без их оснащения гидравлическим приводом. Работа гидропривода в значительной степени определяет эффективность эксплуатации как отдельной машины, так и всего парка, состоящего из новых и старых машин [367]. Эффективность гидрофицированных машин обеспечивается при их конструировании, изготовлении, а также эксплуатации, где важную роль играют основные параметры рабочей жидкости: степень загрязнения и температура (вязкость) [368]. Воздействие температуры рабочей жидкости на эффективность работы гидропривода и возможность управления работоспособностью гидропривода с помощью температуры исследованы недостаточно.

Рабочие жидкости гидроприводов используются в качестве рабочего тела для приведения в действие различных агрегатов и механизмов. Дополнительно, рабочие жидкости гидроприводов обеспечивают смазку поверхностей трения деталей элементов гидросистемы, тем самым обеспечивается теплообмен между элементами гидросистемы, отдача тепла в окружающую среду и защиту элементов гидропривода от коррозии.

Для гидравлических приводов экскаваторов следует использовать подвижные и практически несжимаемые жидкости, способные работать в широком диапазоне температур (от +90 до -40 С и ниже) и при повышенном давлении (до 100 МПа). Поэтому жидкости для гидросистем должны: иметь высокую температуру кипения, низкую температуру замерзания, хорошие смазывающие свойства, небольшую вязкость и хорошие вязко-температурные свойства, обеспечивающие хорошее перетекание, не образовывать пробки при рабочих температурах и не изменяться в объеме. 
Одним из перспективных направлений в определении рациональной температуры рабочей жидкости является разработка новых конструкций теплообменников, нагревателей, диагностических приборов, которые смогут давать оценку технического состояния отдельных элементов и гидропривода в целом. Установка рациональной температуры рабочей жидкости, в качестве необходимого параметра гидравлической системы, является обязательной при использовании современных методов повышения эффективности эксплуатации, технического обслуживания и ремонта гидравлических приводов.

Для исследования этого воздействия используем цепь последовательно соединенных агрегатов гидропривода типичного экскаватора: насос распределитель - гидродвигатель (гидроцилиндр) - распределитель - фильтр бак и разделим на линейные участки и местные сопротивления. Для определения мощности, подводимой к гидродвигателю, в зависимости от температуры (вязкости) рабочей жидкости и общего объемного КПД гидропривода использовалась следующая математическая модель

$$
N_{\text {дв }}\left(t_{k}, \eta_{q}\right)=N_{\text {н }}\left(t_{k}, \eta_{q}\right)-\sum_{i=1}^{n} \Delta p_{i}\left(t_{k}, \eta_{q}\right) \cdot Q_{i}\left(t_{k}, \eta_{q}\right)
$$

$$
\text { где } N_{\mathrm{н}}\left(t_{k}, \eta_{q}\right) \text { - гидравлическая мощность насоса в зависимости от }
$$

температуры рабочей жидкости и коэффициента подачи; $\Delta p_{i}\left(t_{k}, \eta_{q}\right), \Delta Q_{i}\left(t_{k}, \eta_{q}\right)$ - соответственно потери давления и расход на $\mathrm{i}$-х участках в зависимости от температуры рабочей жидкости и коэффициента подачи.

Предельные значения внутренних утечек в насосе приблизительно в 50 раз превосходят значения внутренних утечек в распределителе и в сотни раз, - в гидроцилиндре [369,370], и определяют, в основном, объемный КПД всего гидропривода. Общее допустимое понижение объемного КПД гидропривода 
определяется возможностью выполнения его функционального назначения, экономической целесообразностью использования или обеспечением безопасности [371,372]. Руководствуясь этими положениями были рассмотрены насосы с $\eta=0.98,0.8$ и 0.65 (новое, граничное состояние по экономическому критерию и техническое граничное состояние вследствие потери работоспособности) в интервале температур от 10 до $70{ }^{\circ} \mathrm{C}$.

Влияние температуры рабочей жидкости на внутренние утечки гидроагрегатов гидропривода определялись по следующей зависимости $[369,370]$

$$
\begin{aligned}
& Q=Q_{\mathrm{M}}+Q_{\mathrm{p}}+Q_{\text {гц }}= \\
& =\pi d_{\mathrm{n}} N\left(\frac{\Delta p S_{\mathrm{n}}^{3}}{12 \mu_{0}\left(\frac{50}{t}\right)^{m} L}-\frac{U_{\mathrm{cp}} S_{\mathrm{n}}}{2}\right)+\frac{\pi \Delta p S_{\mathrm{p}}}{12 \mu_{0}\left(\frac{50}{t}\right)^{m} \ln \frac{R}{r}}+Q_{\mathrm{p}}+Q_{\text {гц }}
\end{aligned}
$$

где $\mathrm{Q}_{\mathrm{H}}, \mathrm{Q}_{\mathrm{p}}, \mathrm{Q}_{\text {гм }}$ - соответственно внутренние перетекания в насосе, распределителе и гидроцилиндре; $\Delta \mathrm{p}=\mathrm{p} 1-\mathrm{p} 2$ - разность давлений на входе и выходе насоса; $\mathrm{S}_{\mathrm{n}}, \mathrm{S}_{\mathrm{p}}-$ соответственно зазоры в поршневом и в распределительном блоках насоса; $\mathrm{N}$ - количество поршней в насосе; $\mathrm{U}_{\mathrm{cp}}, \mathrm{d}_{\mathrm{n}}-$ средняя скорость движения и диаметр поршня насоса; R, r - соответственно расстоянию от оси до наружной и внутренней кромок распределительного отверстия насоса; L - длина уплотняющей части поршня насоса; m - показатель степени, зависимый от свойств рабочей жидкости; $\mu$ - динамическая вязкость рабочей жидкости.

Гидрораспределители, фильтры гидропривода представляют собой сложные гидравлические сопротивления и не поддаются аналитическому расчету. Поэтому гидравлические свойства этих гидроагрегатов определяются экспериментальным методом и указываются в технической документации 
(паспортных данных агрегата). При расходах и вязкостях, отличающихся от указанных в паспортных данных, потери давления равны [367]

$$
\Delta p_{Q i}=\Delta p_{Q_{H}}\left(\frac{Q_{i}}{Q_{H}}\right)^{m}\left(\frac{v_{i}}{v_{H}}\right)^{n},
$$

где $\Delta p_{Q^{\mu}}$ - потери давления в гидроагрегате при номинальном расходе и номинальной вязкости; $\Delta p_{Q i}$ - потери давления в гидроагрегате при расчетном расходе и при расчетной вязкости.

При этом для ламинарного режима показатели степени $\mathrm{m}=1, \mathrm{n}=1$, а при турбулентном $\mathrm{m}=2, \mathrm{n}=0$. В результате большого количества местных сопротивлений, в этих гидроагрегатах возникает неустойчивый переходной режим движения рабочей жидкости. Поэтому принимают $\mathrm{m}=1.75 \ldots 1.85$, $\mathrm{n}=0.15 \ldots 0.25$.

Потери гидравлической мощности на отдельных участках гидропривода определяется

$$
\Delta N_{i}=\Delta p_{i} \cdot Q_{i}
$$

При увеличении температуры рабочей жидкости ее вязкость уменьшается и, соответственно, уменьшаются потери давления, мощности в магистралях гидропривода. Однако при этом увеличиваются внутренние пертечки гидроагрегатов, что ведет к увеличению потерь мощности.

Новые насосы $(\eta=0.98)$, действительно, наибольшую мощность подают в гидродвигатель при температуре $50^{\circ} \mathrm{C}$ (кривая 1, рис 1). Однако при эксплуатационном износе насоса и уменьшении его коэффициента подачи уменьшается и температура, при которой наибольшая мощность поступает в гидродвигатель. Для насосов, имеющих коэффициент подачи $\eta=0.8$, эта 
температура равна $30 \ldots 35^{\circ} \mathrm{C}$ (кривая 2 , рис. 1 ), а для насосов, имеющих $\eta=0.65$, $-10 . .20^{\circ} \mathrm{C}$ (кривая 3 , рис. 1$)$.

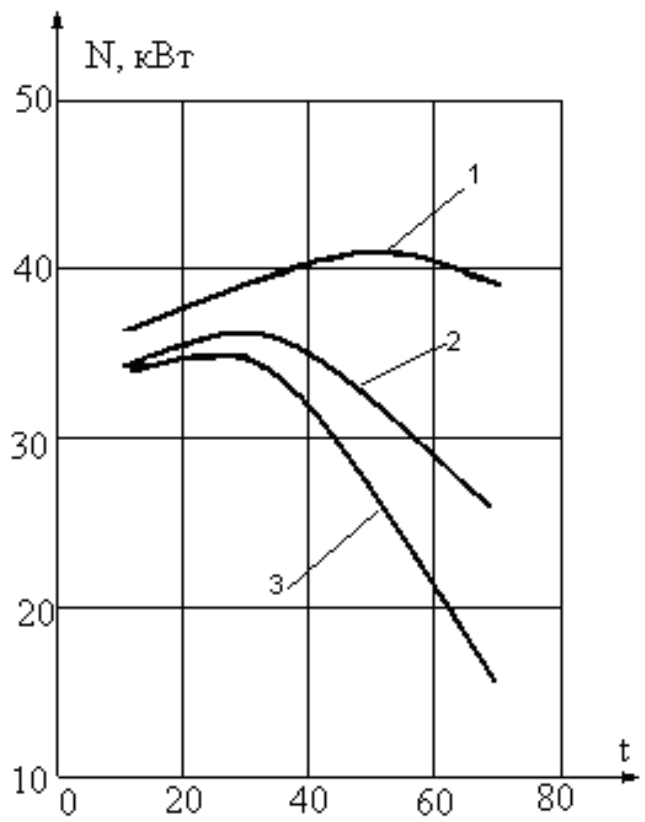

Рисунок 1. Влияние температуры рабочей жидкости на мощность, поступающий в гидродвигатель

Таким образом, проведенные исследования показали, что новые насосы и имеющие эксплуатационный износ по-разному влияют на мощность насоса и, соответственно, имеют разную рациональную температуру рабочей жидкости. При рациональных значениях температуры к гидродвигателю изношенными насосами может быть подана почти вдвое большая мощность, чем при $50^{\circ} \mathrm{C}$, рекомендованной для новых насосов (кривая 1, 2 и 3, рис. 1). Приводная мощность насоса при этом практически не меняется.

Одним из инновационных направлений для повышения производительности экскаваторов и создания благоприятных условий для обслуживания агрегатов и систем управления возможно только с использованием интеллектуальных систем автоматического управления и регулирования режимов работы при выполнении технологических процессов. 
Все системы гидропривода экскаваторов можно классифицировать по назначению:

- по параметрам регулирования, к ним относят кинематические (положение, скорость, ускорение) и динамические (усилие, момент);

- по энергетическим признакам (электрогидравлические или гидромеханические);

- по исполнению гидрорегуляторов;

- по типу датчиков обратной связи (электрические, механические, пневматические и др.);

- по характеру движения исполнительных гидроагрегатов (вращательные, поступательные, др.);

- по характеристикам процессов автоматического управления (пропорциональные, дискретные, релейные).

Анализируя классификацию можно сделать вывод, что современные гидравлические системы экскаваторов должны поддерживать необходимые регулируемые и диагностические параметры в заданных пределах при достаточно высоких кинематических и динамических показателях, высоком КПД и при заданной погрешности определяющих параметров.

При проектировании гидравлических систем автоматического управления и регулировании необходим статический анализ имеющихся параметров, кинематический и статический расчёт, определение основных параметров гидравлического оборудования, исследование работы систем на устойчивость, разработка мероприятий по обеспечению термостабилизации при различных режимах нагружения.

При эксплуатации и внедрении уже имеющихся систем автоматического регулирования необходимо учитывать наличие изменения структурных параметров в гидроагрегатах от эксплуатации, замену агрегатов на новые с последующим внесением изменения в интеллектуальную систему автоматизации. 
При выполнении рабочего или технологического процесса применяют активные рабочие органы. Регулируя основные эксплуатационные параметры, как поступательная скорость, частота вращения, температура рабочей жидкости и др., можно за один рабочий цикл экскаватора достичь высокого качества выполняемого процесса.

Имеющийся большой объем теоретических и экспериментальных исследований в области повышения эффективности работы современных экскаваторов не в полной мере учитываются их конструктивные, условия и режимы их эксплуатации с учетом технического состояния, а также системы их технического обслуживания и ремонтов. Для оценки качества выполняемой работы экскаваторов и эффективности работы часто используют нестандартизированные показатели, не всегда имеющие объективный характер в связи с отсутствием четких объективных критериев учета отдельных категорий непроизводительного времени работы.

Поэтому применение комплексного подхода к энерготехнической оценке при использовании существующих рабочих органов, a также при проектировании новых гидроприводов экскаваторов и дополнительного рабочего оборудования следует производить по объединенному показателю: отношению энергии, затраченной на полезную работу к коэффициенту качества.

Коэффициент качества выполнения технологического процесса

$$
\mathrm{k}=\mathrm{k}_{\Pi} \bullet \mathrm{k}_{\mathrm{H}} \bullet \mathrm{k}_{\mathrm{B}} \cdot \mathrm{k}_{\mathrm{p}}
$$

где $\mathrm{k}_{\text {п }}$ - коэффициент перекрытия;

$\mathrm{k}_{\mathrm{H}}$ - коэффициент наполнения ковша;

$\mathrm{k}_{\mathrm{B}}$ - коэффициент использования рабочего времени машины, представляющий собой отношение времени чистой работы ко всему затраченному;

$\mathrm{k}_{\mathrm{p}}$ - коэффициент разрыхления 1,1 - 1,3. 
Совместное решение функции коэффициента качества и затрат энергии позволит охарактеризовать процесс, определить затраты энергии для обеспечения оптимального протекания технологического процесса. Таким образом, для работы экскаватора при различных режимах работы и при соблюдении необходимых требований необходимо регулировать температурный режим, а следовательно, применять следящий интеллектуальный гидропривод управления технологическим процессом. 

DOI 10.46299/ISG.2021.MONO.TECH.III.8.2

\section{2 Математична модель сумарної вірогідності безвідмовної роботи робочого обладнання автогрейдера в процесі виконання робочих операцій}

Значна доля відмов землерийно-транспортних машин (ЗТМ) викликана через вихід з ладу навісного обладнання [373]. При цьому, як свідчать дані [373, 374 та ін.], до 90\% відмов обумовлено швидким зносом ріжучих елементів робочих органів (РО). Унаслідок чого відбувається збільшення сили різання на 60-200\%, що в свою чергу, приводить до втрати продуктивності або до збільшення енерговитрат, а це зрештою, сприяє підвищенню собівартості розробки грунту. До того ж недостатній термін служби РО ЗТМ обумовлює необхідність постійної заміни ріжучих елементів, що передбачає значні матеріальні витрати.

Таким чином, експлуатаційні якості ЗТМ в значній мірі визначаються довговічністю їх РО. Тому актуальним завданням $є$ вибір головних чинників, які, в першу чергу, впливають на передчасну втрату працездатності ріжучих елементів 3ТМ.

Чинники, які впливають на процес зношування ріжучих елементів РО ЗТМ, умовно можуть бути розділені на чотири групи [373, 374, 375 та ін.]:

- фізико-механічні властивості грунтів, до яких відносяться питоме зчеплення, гранулометричний склад, щільність, вологість, кут внутрішньо-го тертя, питомий опір різанню грунтів, вміст кам'янистих включень різної міцності тощо;

- параметри взаємодії ріжучого інструменту з грунтом, а саме швидкість руху РО, тиск, відстань різання і переміщення грунтів, а також кут різання;

- технологічні і конструктивні параметри ріжучих елементів РО ЗТМ (механічні і хімічні властивості матеріалів, форми i розміри різальних елементів);

- рівень технічного обслуговування i ремонту (відновлення) РО (кваліфікацію обслуговуючого персоналу і якість проведення ремонтних робіт). 
Експлуатація ЗТМ відбувається в різних грунтових умовах, а окремі робочі операції відрізняються один від одного схемами додатка зовнішніх навантажень і по-різному формують навантаженість вузлів робочого устаткування. Одними 3 основних показників надійності РО ЗТМ є вірогідність безвідмовної роботи і pecypc.

Усе експлуатаційне вантаження РО ЗТМ можливо розкласти на складові, що класифікуються за характерними ознаками [373]. Формування навантаженості походить від нормального робочого вантаження, граничних очікуваних навантажень i граничного випадкового навантаження. Саме нормальне робоче навантаження визначає ресурс робочого устаткування ЗТМ.

Вірогідність безвідмовної роботи різального елементу 3ТМ, зокрема ножа автогрейдера, $є$ мультиплікативною функцією вірогідностей [373, 374], залежних від наступних чинників:

- максимального навантаження на ніж автогрейдера при виконанні робочих операцій (плануванні);

- зносу робочої поверхні ножа в процесі виконання робочих операцій;

- циклічного (знакозмінного) навантаження на ніж;

- погрішності технології виготовлення ножа;

- погрішності монтування ножа при установці (зборці) тощо.

Грунтуючись на отриманих результатах досліджень надійності ЗТМ багатьох відомих учених Д.П. Волкова, Л.В. Назарова, В. В. Нічке, А.К. Рейши та ін., як основний критерій надійності була обрана сумарна вірогідність безвідмовної роботи різального елементу РО автогрейдера [374, 375]

$$
P_{\Sigma}=P\left(P_{\text {дин }}\right) \cdot P\left(h_{3 \mathrm{H}}\right) \cdot P\left(P_{3 \mathrm{H}}\right) \cdot P_{\mathrm{T}} \cdot P_{\mathrm{M}},
$$

Дві останні вірогідності, залежної від погрішності виготовлення i монтування ножа, приймаємо рівні одиниці, тобто вважаємо, що різальний елемент виготовлено без яких-небудь погрішностей і встановлено ідеально на основному відвалі автогрейдера. 
Ймовірності $P\left(P_{\text {дин }}\right), P\left(h_{3 н}\right), P\left(P_{3 н}\right)$ взаємопов'язані між собою таким чином: при зносі робочої поверхні ножа на величину $h_{3 н}$ змінюється перетин ножа, а отже, і його несуча здатність. У свою чергу, від останньої залежить максимальне значення зусилля на кромці ножа, яке він може витримати. Від несучої здатності залежить також ймовірність $P\left(P_{\text {зн }}\right)$.

В результаті досліджень процесів різання, зарізу, стопоріння і удару автогрейдера о перешкоду, що важко долається, була проведена оцінка навантаженості РО [376]. Крім того, було проведено дослідження впливу кута установки відвалу в плані на величину максимального зусилля на кромці ножа відвалу при ударі о перешкоду, що важко долається.

На рис. 1 наведено отриманий нами розрахунковим шляхом графік зміни максимального зусилля $P_{\max }=\max \left(R_{x}\right)$ на кромці ножа відвалу при ударі о перешкоду, що важко долається, в залежності від кута установки відвалу в плані $\alpha$ для трьох категорій грунту.

Апроксимував залежність $P_{\max }=\mathrm{f}(\alpha)$, представлену на рис. 1 , отримаємо:

$$
P_{\max }(\alpha)=A \cdot \sin \left(B \cdot \frac{\alpha-C}{80}\right)+D,
$$

де коефіцієнти $A, B, C$ і $D$, отримані на підставі апроксимації залежності $P_{\max }=\mathrm{f}(\alpha)$, які представлені в табл. 1.

Таблиця 1.

Значення коефіцієнтів A, B, C i D

\begin{tabular}{|c|c|c|c|c|}
\hline $\begin{array}{c}\text { Категорія } \\
\text { грунту }\end{array}$ & $A$ & $B$ & $C$ & $D$ \\
\hline I & 250 & 1,2 & 5 & -10 \\
\hline II & 305 & 1,25 & 10 & 20 \\
\hline III & 380 & 1,4 & 12 & 50 \\
\hline
\end{tabular}




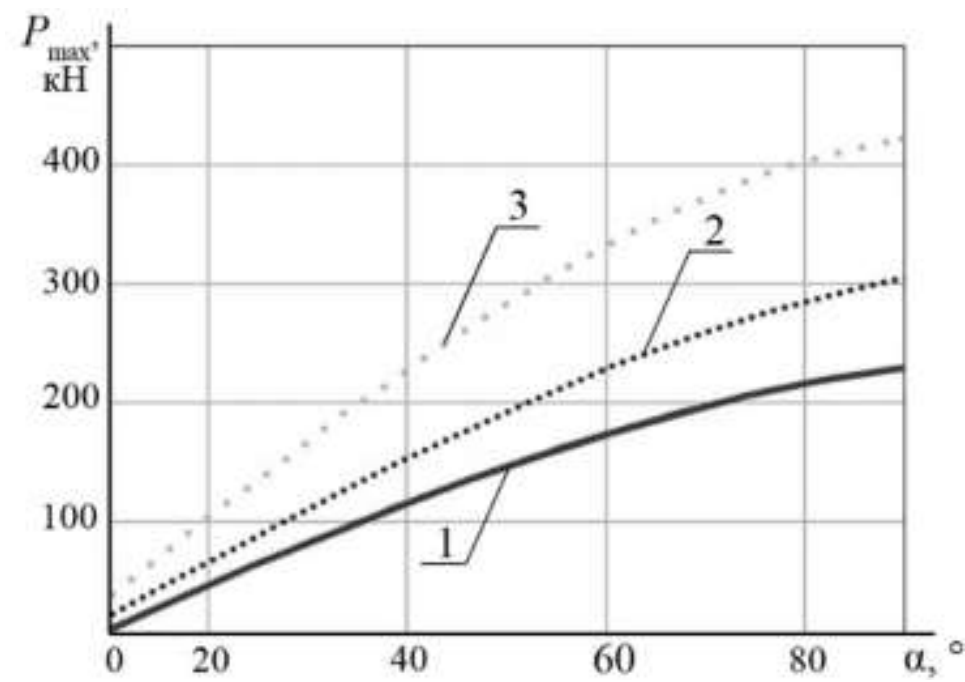

Рисунок 1. Залежність $P_{\max }$ від кута захвату відвалу $\alpha$ :

1 - I категорія грунту, 2 - II категорія, 3 - III категорія.

Згідно з [377] будемо розглядати перші 700 годин роботи ножа в грунті. Тоді залежність зносу ножа автогрейдера як випадкової функції напрацювання в загальному випадку може бути представлена у вигляді $h(t)=a_{u} t^{\beta}+b_{u}$ (рис. 2).

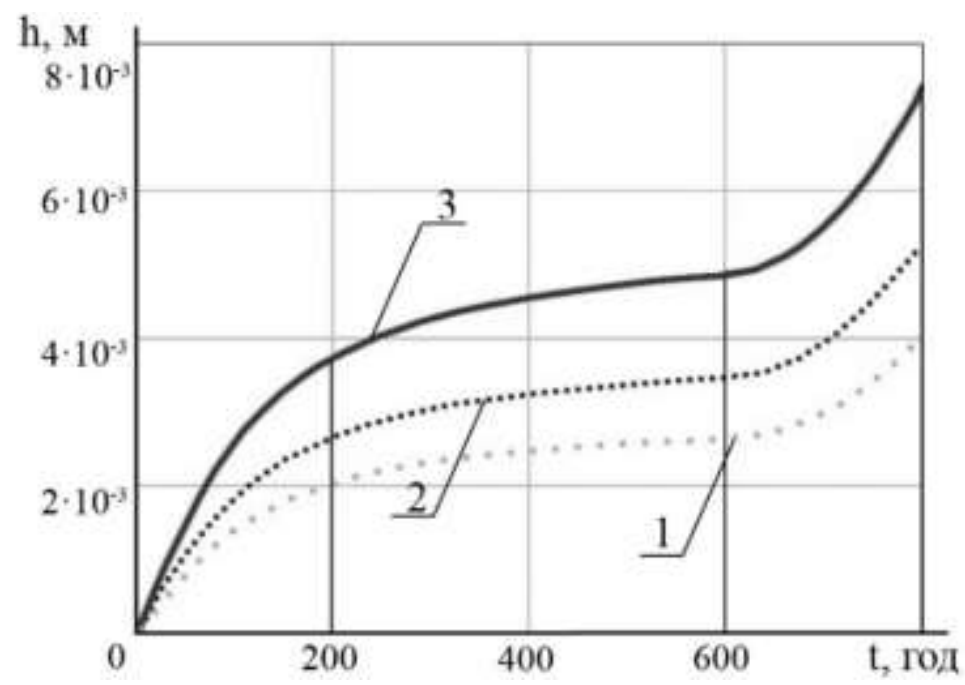

Рисунок 2. Графік залежності величини зносу $h$ від напрацювання $t$ для трьох різних категорій грунту:

1 - I категорія грунту, 2 - II категорія,3 - III категорія. 
У цьому рівнянні при розрахунках були використані статистичні дані, що отримані авторами під час експлуатації автогрейдерів. При цьому було прийнято, що показник $\beta=1 / 2, b_{u}=0$ [375].

3 графіка на рис. 2 видно, що на перших 50-100 годинах роботи знос відбувається інтенсивно і лінійно. Далі знос поступово квазістабілізується, а потім після 500-600 годин починає зростати з більшою швидкістю. Відповідно, швидкість зношування ножа автогрейдера для кожної категорії грунту може бути визначена як $v=d h_{3 н} / d t$ [374].

У рівнянні (1) перший множник, що стосується ймовірності безвідмовної роботи ножа і залежить від максимального навантаження, був перетворений таким чином:

$$
P\left(P_{\text {дин }}\right)=1-\frac{1}{2 \pi S_{x} \sigma_{v}} \int_{0}^{v} \int_{0}^{R_{x}} e^{-\left[\frac{(P-\bar{P})^{2}}{2 S_{x}^{2}}+\frac{v^{2}}{2 \sigma_{v}^{2}}\right]} d P d v \text {, }
$$

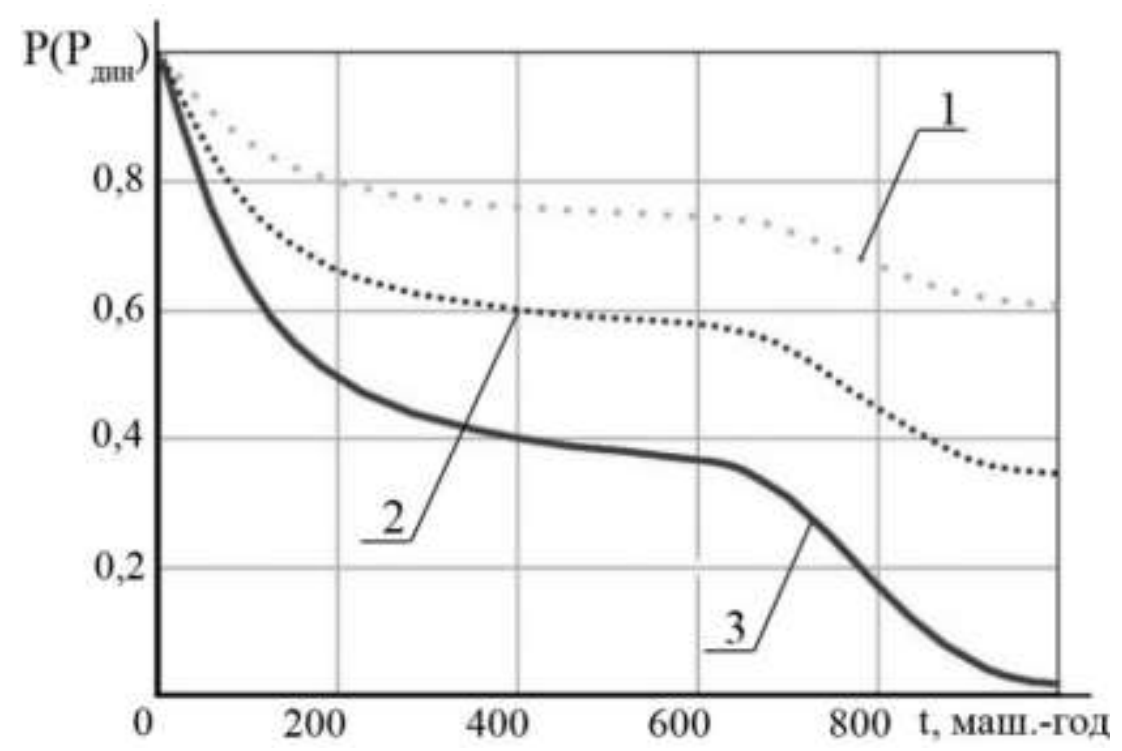

Рисунок 3. Графік зміни ймовірності безвідмовної роботи ножа автогрейдера $P\left(P_{\text {дин }}\right)$ від часу його роботи в абразивному середовищі $t$, год:

1 - I категорія грунту, 2 - II категорія, 3 - III категорія. 
На рис. 3 показано залежності ймовірності безвідмовної роботи ножа автогрейдера $P\left(P_{\text {дин }}\right)$ від часу його експлуатації в абразивному середовищі, які отримані на підставі застосування нормального закону розподілу.

Падаюча характеристика графіків на рис. 3 свідчить про зниження ймовірності безвідмовної роботи ножа $P\left(P_{\text {дин }}\right)$ у процесі експлуатації робочого обладнання автогрейдера.

У результаті апроксимації залежності ймовірності $P\left(P_{\text {дин }}\right)$ від часу роботи ножа в абразивному середовищі $t$ (рис. 3) отримана залежність

$$
P\left(P_{\text {дин }}\right)=1-0,02 \cdot t^{1 / z},
$$

де $z=2,4 ; 2,13 ; 2$ - для I, II і ІІІ категорії грунту відповідно.

Виходячи $з$ прийнятих припущень, як було сказано вище, запропоновано розглядати ймовірність безвідмовної роботи як мультиплікативну функцію ймовірностей, кожен аргумент якої залежить від аргументу іншої ймовірності. Тоді сумарна ймовірність безвідмовної роботи ножа автогрейдера становитиме:

$$
P_{\Sigma}=P\left(P_{\text {дин }}\right)\left\{1-\frac{1}{2}\left[\Phi\left[\frac{P_{-1}^{\max }-m\left(P_{-1}\right)}{\sqrt{2 D\left(P_{-1}\right)}}\right]-\Phi\left[\frac{P_{-1}^{\min }-m\left(P_{-1}\right)}{\sqrt{2 D\left(P_{-1}\right)}}\right]\right]\right\}\left\{\Phi\left[\frac{\frac{I_{\text {пр }}}{T^{\beta}}-m\left(a_{u}\right)}{\sqrt{D\left(a_{u}\right)}}\right]\right\},
$$

де $\Phi(x)=\frac{1}{\sqrt{2 \pi}} \int_{0}^{x} e^{-\frac{t^{2}}{2}} d t-$ функція Лапласу,

$P_{-1}=P_{0-1}-R_{x}$

$P_{0-1}-$ несуча здатність при втомному навантаженні;

$R_{x}$ - діюче навантаження на кромку ножа;

$m\left(P_{-1}\right)$ - математичне очікування (середнє значення) межі різниці несучої здатності ножа автогрейдера і максимального навантаження; 
$D\left(P_{-1}\right)$ - середньоквадратичне відхилення межі різниці несучої здатності i максимального навантаження;

У залежності $h(t)=a_{u} t^{\beta}+b_{u}$ розглянемо випадок граничного зносу. Для цього у формулу зносу замість $h(t)$ підставимо значення граничного зносу $I_{\text {гр } \mathrm{i}}$ вирішимо отримане рівняння щодо $t=T$ при $b_{u}=0$. Тоді ресурс ножа буде мати наступний вигляд:

$$
T=\sqrt[\beta]{\frac{I_{\text {гр }}}{a_{u}}},
$$

де $I_{\text {гр }}$ - граничний знос ножа.

На рис. 4 наведено графік-поверхню $P_{\Sigma}=\mathrm{f}\left(P\left(P_{\max }\right), P\left(h_{3 \mathrm{H}}\right)\right)$, побудована 3 використанням залежності (1).

Апроксимуючи залежність сумарної ймовірності безвідмовної роботи робочого обладнання $P_{\Sigma}$ від ймовірностей $P\left(P_{\max }\right)$ i $P\left(h_{3 н}\right)$, було отримано:

$$
\begin{aligned}
P_{\Sigma}=0,2+1,08 P\left(P_{\max }\right) & +0,24 P\left(h_{3 \mathrm{H}}\right)-0,13 P\left(P_{\max }\right)^{2}-0,08 P\left(h_{3 \mathrm{H}}\right)^{2}+ \\
& +0,846 P\left(P_{\max }\right) P\left(h_{3 \mathrm{H}}\right) .
\end{aligned}
$$

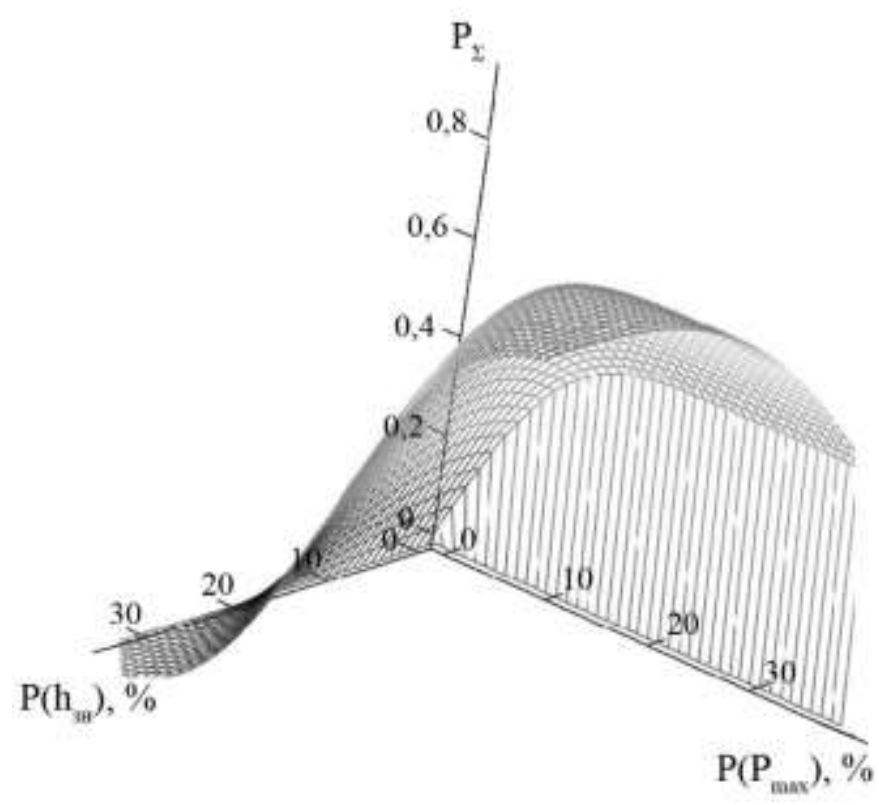

Рисунок 4. Залежність зміни сумарної ймовірності безвідмовної роботи $P_{\Sigma}$ від $P\left(P_{\max }\right)$ и $P\left(h_{3 \mathrm{H}}\right)$. 
Таким чином, отримано залежність ймовірності безвідмовної роботи ножа, до якої увійшли параметри зносу, динамічне і знакозмінне навантаження (рис. 4). Слід також мати на увазі, що рівняння регресії $P_{\Sigma}=\mathrm{f}\left(P\left(P_{\max }\right), P\left(h_{3 н}\right)\right)$ дійсно тільки в межах тих дослідних даних, зокрема, величини зносу, на підставі яких вони отримані. Якщо значення вийдуть за межі дослідних даних, то в цьому випадку прогноз ймовірності безвідмовної роботи ножа може бути отриманий зі значними помилками. Для розширення меж застосування рівнянь їх необхідно будувати на основі даних по декількох або всім сучасним моделям об'єктів одного функціонального призначення. 


\section{SECTION 9. METALLURGY AND ENERGY}

DOI 10.46299/ISG.2021.MONO.TECH.III.9.1

\section{1 Дослідження впливу технологічних факторів на втрати чавуну при видаленні сірки у ковші}

Забезпечення вимог щодо якості i конкурентоспроможності металопродукції, зниження енерговитрат на iï виробництво у сучасних сировинних умовах роботи українських металургійних підприємств є складним завданням. Суттєвий вплив на енерговитрати для виробництва конвертерної сталі має раціональне використання установок та технології попередньої ковшової десульфурації переробного чавуну перед заливанням у конвертер [378].

Для попередньої ковшової десульфурації чавуну у конвертерному цеху металургійного виробництва ПАТ «ДКХЗ» (м. Кам’янське) застосовують установку компанії «ThyssenKrupp Polysius», що працює за коінжекційною технологією вдування суміші магнію та флюідизованого вапна у чавун у 230-т заливальному ковші [379].

Авторами даної публікації визначено ряд причин відхилення результатів експлуатації установки та показників десульфурації чавуну від оптимальних. Так, причинами закупорювання каналу сопел заглибної фурми є: перепади тиску газу-носія 3 порушенням рівномірного витоку газопорошкового струменя 3 сопла; контактування рідкого чавуну та каналу сопла фурми при перепадах тиску газу-носія, що призводить до виникнення пульсацій та «зворотних» ударів, звуженню перетину каналу та, як наслідок, до закупорювання каналу сопла; відносно малий діаметр каналу сопла (12 мм), що обумовлює підвищений газодинамічний опір системи, на подолання якого потрібно забезпечити запас тиску у бункері.

Основною причиною підвищених, у порівнянні 3 використанням для десульфурації «чистого» магнію [380, 381], втрат чавуну з покривними шлаками, що скачують 3 поверхні розплаву після десульфурації (1,8-2,6 кг/т чавуну), $\epsilon$ 
фізико-хімічний стан покривного шлаку. Використання реагентів на основі сумішей з СаО призводить до підвищення в'язкості і маси шлаку, з відповідним збільшенням вмісту в ньому заліза (до $65-78$ \% Fe). При цьому максимальні втрати - 3 фракцією корольків чавуну діаметром менш ніж 2,5 мм [382].

Хімічний склад шлаку після десульфурації чавуну в досліджених умовах змінюється у широкому діапазоні (21,5-48,2\% $\mathrm{CaO}$; 37,3-46,2\% $\mathrm{SiO}_{2}$; $\mathrm{MgO}$ 4,16,9\%; 5,4-7,2\% $\left.\mathrm{Al}_{2} \mathrm{O}_{3} ; 1,2-2,2 \% \mathrm{MnO}\right)$ та має підвищену в'язкість та поверхневий натяг. Аналізом металевої частини відібраного із 230-т ковшів шлаку після десульфурації встановлено існування фракцій корольків чавуну: $<0,5 ; 0,5 \ldots 1,0$; $1,0 \ldots 2,5 ; 2,5 \ldots 5,0 ; 5,0 \ldots 10,0$ та $>10$ мм. Усі вилучені корольки розділити за формою на три групи «А», «Б» та «В». До групи «А» віднесені краплі, в основному неправильної форми, які утворюються переважним чином за рахунок сплесків металу у зоні «ока» та мають розміри більш ніж 10 мм; до групи «Б» краплі шароподібної форми розміром 2,5...10 мм та до групи «В» - краплі як шароподібної, так і неправильної форми розміром менш ніж 2,5 мм. Співвідношення характерних груп за діаметрами корольків складає: $0,5 \ldots 2,5$ мм $-10 \ldots 16 \% ; 6 \ldots 8$ мм - $10 \ldots 20 \% ;>10$ мм $-30 \ldots 45 \%$. Зі зменшенням діаметру від 2,5 мм та менше спостерігається тренд на підвищення в останніх вмісту сірки, а вміст сірки у корольках $<0,5$ мм сягає, а у більшості випадків, і перевищує цей показник для шлаку (рис. 1). Наведені на рис. 1 дані підтверджують ступінь впливу фізико-хімічного стану покривного шлаку на умови переходу сірки 3 шлаку до крапель чавуну у шлаку. 


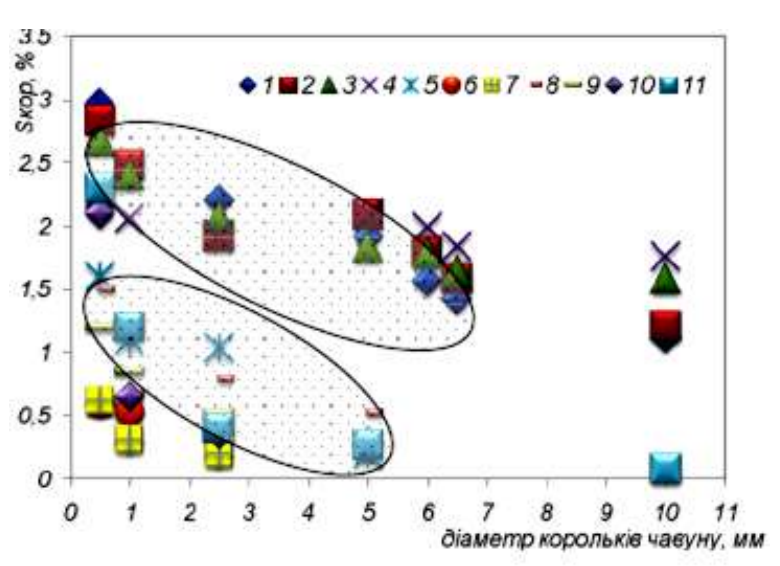

$a$

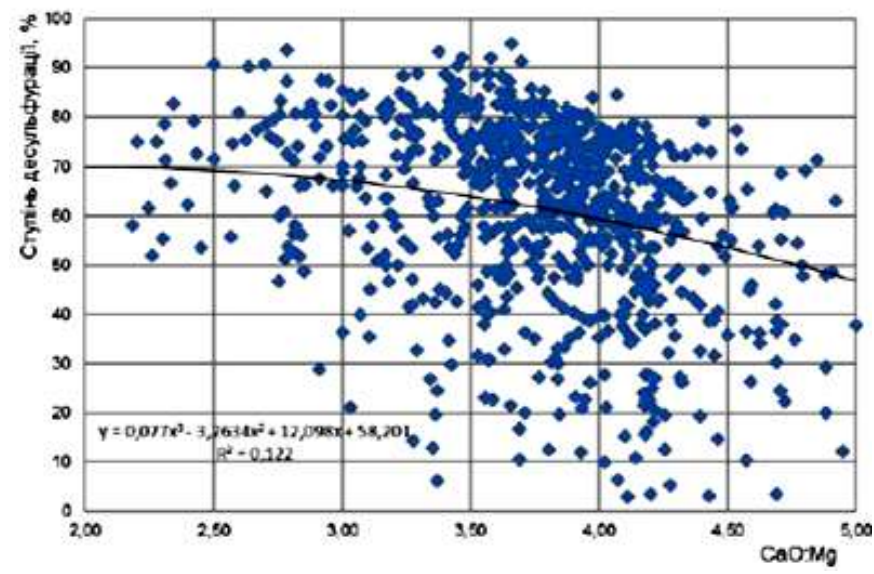

6

Рисунок 1. Залежність вмісту сірки від діаметру крапель чавуну у шлаку, що скачують після десульфурації (а) та вплив співвідношення СaO:Mg на ступінь десульфурації чавуну (б). Маркери 5, 8-11 - вдування тільки $\mathrm{Mg}$; 6, 7 - Mg, 3 накладенням електричних потенціалів; 1-4 - вдування $\mathrm{CaO}$ з $\mathrm{Mg}$

Встановлена за результатами досліджень залежність вмісту сірки $[\mathrm{S}]_{\kappa}, \%$ від діаметру корольків чавуну $\left(d_{\kappa}\right)$, мм, у шлаку представлена виразом

$$
[\mathrm{S}]_{\mathrm{K}}=0,013 \cdot d_{\mathrm{K}}^{2}-0,299 \cdot d_{\mathrm{K}}+2,915, \quad R^{2}=0,96 .
$$

а запропонована модель залежності ступеня десульфурації від співвідношення $\mathrm{CaO}: \mathrm{Mg}$ у суміші реагентів $(z)$ має вигляд:

$$
D=0,077 z^{3}-3,2634 z^{2}+12,098 z+58,201 .
$$

Визначена також залежність діаметру та загального вмісту корольків чавуну у кінцевому ковшовому шлаку від товщини шлакового покрову, що формується по ходу обробки, ступеня турбулізації ванни та розмірів «ока».

Виконано комплекс високотемпературних досліджень для встановлення напрямків, висоти та відстані переміщення металевих крапель, утворених при розриві на поверхні ванни газових пузирів. Заглибна фурма для продувки рідкого чавуну масою 100 кг у тиглі індукційної печі ICT-0,16 мала сопла розташовані під кутом 90 град, витрати аргону на продувку складали 0,08-0,04 м³/хв. Визначені характерні кути вильоту $(\alpha)$, діапазон висот вильоту крапель над 
ванною $(h)$, відстань $(L)$ та тривалість їх польоту $(\tau)$ до контакту 3 поверхнею ванни або за межі печі (рис. 2).

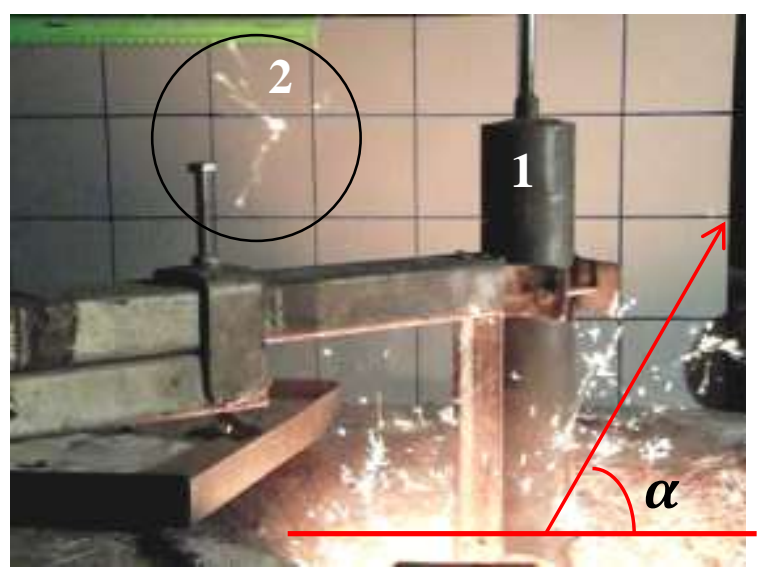

$a$

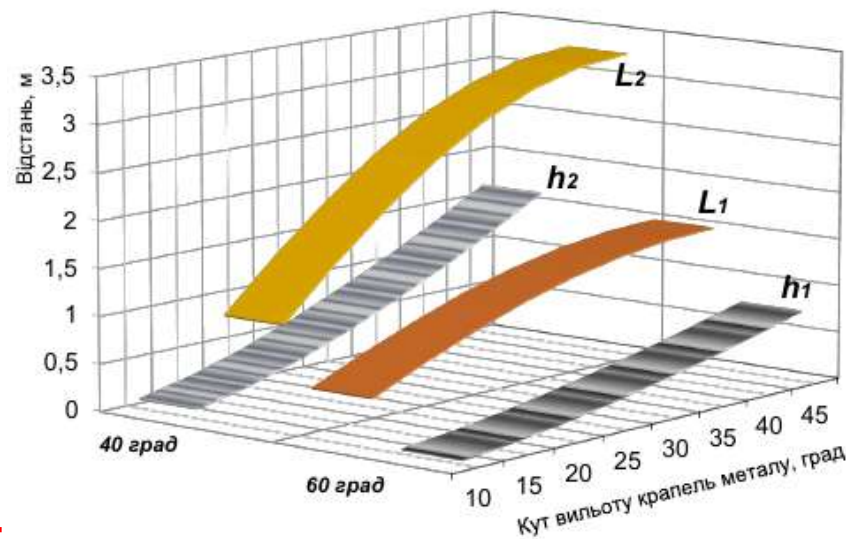

$\sigma$

Рисунок 2. Траєкторія польоту під кутом $\alpha$ крапель чавуну 2 та вибух крупної краплі, що сформовано при розриві газових пузирів на поверхні ванни при вдуванні газу крізь заглибну фурму $l(a)$; розрахункова залежність відстані та висоти від кута вильоту металевих крапель у 230-т ковші (б)

Запропоновано швидкість польоту металевих крапель визначати за виразом, м/с: $V_{0}=\sqrt{\frac{0,378 \cdot \sigma_{M} \cdot V_{n y 3}^{1 / 2}}{(1-\cos \theta) \cdot \rho_{M}^{1 / 2} \cdot \mu^{1 / 2 \cdot r_{n y 3}{ }^{1 / 2}}}}$, де $\theta-$ напівкут центрального кута пузиря у момент розриву, град; $\rho_{м} m a \mu-$ густина та динамічна в'язкість чавуну, кг $/ \mathrm{M}^{3}$ та Пас відповідно; $r_{n y з}-$ радіус газового пузиря, м.

На наступному етапі досліджено особливості затягування покривного шлаку до металевої ванни з границі «шлак-метал», умови формування вільної від шлаку зони (так званого «ока») та її геометричні параметри при використанні для продувки ванни як стаціонарної (нерухомої), так і обертової заглибної фурми [380, 381].

Для високотемпературних експериментів використали установку на базі печі ICT-0,16, для холодного моделювання - модель 230-т ковшу з плексигласу [383]. Чавун моделювали водою $\left(20{ }^{0} \mathrm{C}\right)$ (з індикаторами), газ-носій - 
компресорним повітрям, шлак - синтетичними маслами різної густини. Модельні фурми зі змінними наконечниками занурювали в рідку ванну глибиною 280 мм та шаром «шлаку» на поверхні товщиною від 6-ти до 30-ти мм. При моделюванні використовували одно- та двосоплові наконечники заглибних фурм 3 циліндровими соплами діаметром 0,0013 та 0,001 мм відповідно. При обертанні заглибної фурми навколо вертикальної осі швидкість її обертання змінювали в межах від 0 (нерухомий стан) до 240 об/хв.

Використовували методику планування експерименту (повний факторний експеримент). До факторів впливу віднесені: швидкість обертання фурми $\left(X_{1}(n)\right.$, об/хв.), товщина шару покривного «шлаку» $\left(X_{2}(\delta)\right.$, мм), витрата газу-носію $\left(X_{3}(Q)\right.$, л/хв.). Визначено, що в об’ємі ванни під покривним шлаком можна виділити декілька характерних зон: «активну», у межах якої завершується занурення газових струменів до ванни та дисипація енергії; «газорідинну», у нижній частині якої під впливом сили Архімеда та сили опору, газовий струмінь подрібнюється на пузирі, та у межах якої останні спливають до границі «шлакметал»; «зону потоків», які забезпечують масоперенесення у об’ємі ванни i визначають масообмін на границі «шлак-метал» (рис. 3).

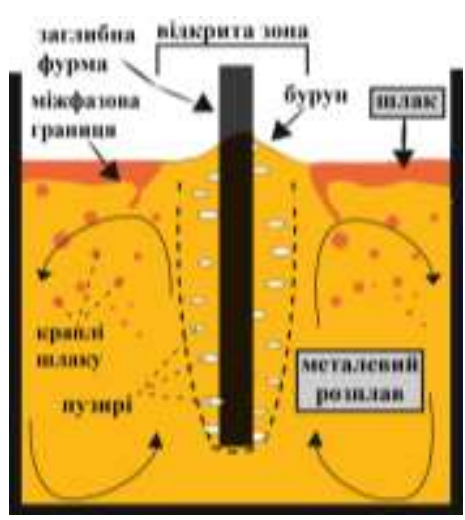

$a$

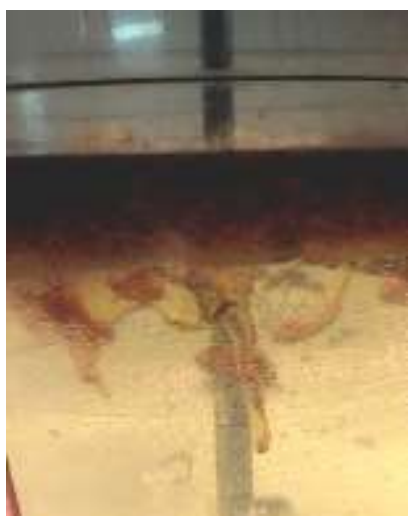

$\sigma$

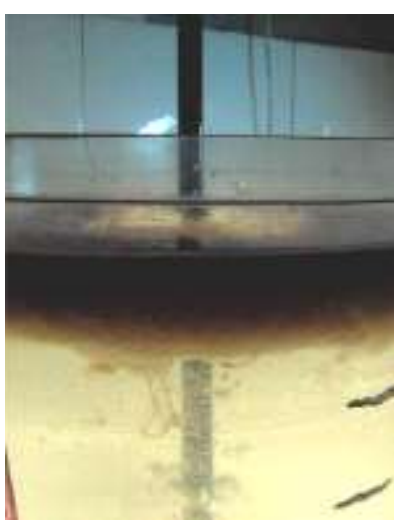

B

Рисунок 3. Схема (a) та картина затягування шлаку до ванни $(\sigma, \varepsilon)$ при вдуванні газу (з витратою 2,2 л/хв.) крізь сопла заглибної фурми з двосопловим наконечником: б) нерухома фурма, в) - обертова фурма (90 об/хв.) 
За результатами запропоновані моделі для визначення глибини $\left(Z_{\text {шл}}\right)$ затягування шлаку до ванни. До прикладу, для двосоплового наконечника:

- у діапазоні швидкостей обертання фурми 0-90 об/хв.

$$
\begin{aligned}
Z_{\text {шл }} & =0,6328-0,0068 \cdot n+0,0257 \cdot \delta+0,1673 \cdot Q+0,0077 \cdot n \cdot \delta+ \\
& +0,9702 \cdot \delta \cdot Q-0,0068 \cdot n \cdot \delta \cdot Q ;
\end{aligned}
$$

- у діапазоні швидкостей обертання фурми 120-240 об/хв.

$$
\begin{gathered}
Z_{\text {шл }}=0,6265-0,0091 \cdot n+0,0309 \cdot \delta+0,1763 \cdot Q+0,004 \cdot n \cdot \delta+0,0049 \cdot n \cdot Q+ \\
+0,9645 \cdot \delta \cdot Q-0,0048 \cdot n \cdot \delta \cdot Q .
\end{gathered}
$$

Приклад поверхні відгуку, визначеної за результатами моделювання впливу факторів на глибину затягування шлаку (відносно загальної глибини

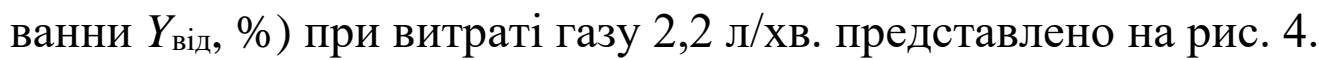

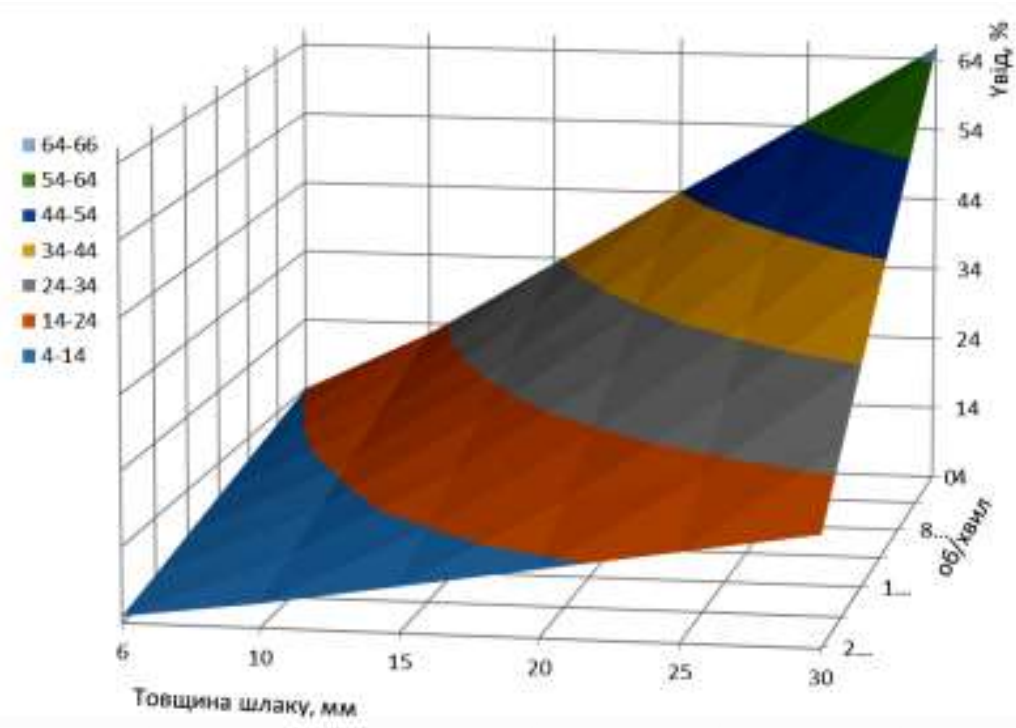

Рисунок 4. Залежність глибини затягування шлаку від швидкості обертання фурми (в діапазоні 120-240 об/хв.) та товщини шлаку.

Встановлено також, що параметри вводу газу-носія у ванну суттєво впливають на відношення площі «ока» до загальної площі ванни $\left(S_{\text {відн. }}\right)$, яке змінюється не тільки за величиною, але і за знаком. Так, наприклад, максимальне значення $S_{\text {відн }}=49,36 \%$ забезпечується при швидкості обертання фурми у 240 об/хв. при мінімальній товщині шару шлаку, а мінімальне $S_{\text {відн }}=6,03 \%$ - при 240 об/хв. та товщині шлаку у 30 мм відповідно. Тобто, зменшення кількості 
покривного шлаку призводить до збільшення розмірів «ока» більш ніж у 8 разів (рис. 5).

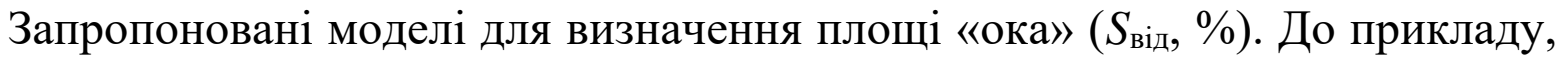
для діапазону швидкості обертання фурми 0-90 об/хвил.:



$a$

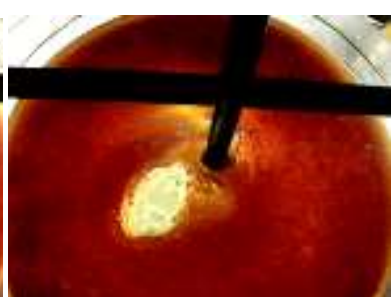

$\sigma$

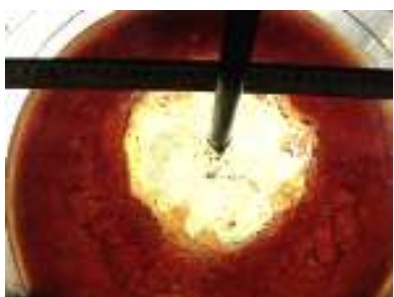

B

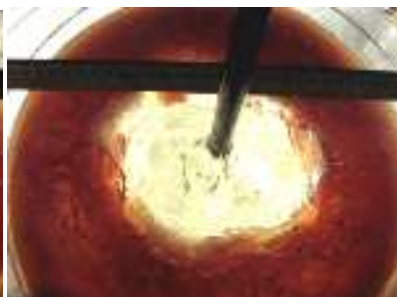

2

Рисунок 5. Зміна площі «ока» на поверхні ванни при використанні односоплового наконечника заглибної фурми при різних витратах газу-носія та товщині покривного шлаку 30 мм

$$
\begin{gathered}
S_{\text {відн }}=-29,568+0,4577 \cdot n+0,8438 \cdot \delta+39,584 \cdot Q-0,01388 \cdot n \cdot \delta-0,2447 \cdot n \cdot \delta- \\
-0,7715 \cdot \delta \cdot Q+0,0068 \cdot n \cdot \delta \cdot Q
\end{gathered}
$$

- для 120-240 об/хвил. відповідно

$$
\begin{gathered}
S_{\text {відн }}=-29,569+0,0216 \cdot n+0,8438 \cdot \delta+39,587 \cdot Q+0,00072 \cdot n \cdot \delta-0,0106 \cdot n \cdot Q- \\
-0,7718 \cdot \delta \cdot Q+0,00056 \cdot n \cdot \delta \cdot Q
\end{gathered}
$$

Отримані також математичні моделі для визначення залежності висоти буруна $\left(\mathrm{H}_{n}\right)$ (рис. 6) на поверхні ванни (рис. 3, а) від факторів впливу.
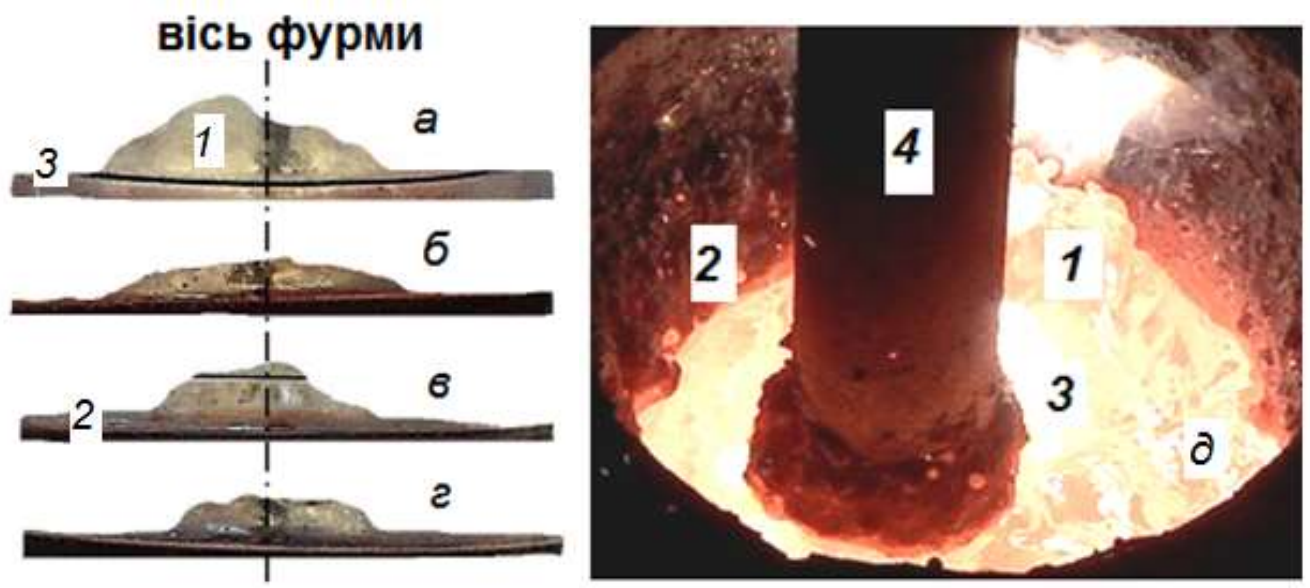

Рисунок 6. Профілі (a-2) бурунів 1 (холодне моделювання) на поверхні 3 ковшової ванни зі шлаком 2 товщиною 30 мм при використанні двосоплового 
наконечника фурми 4 та вигляд буруну 1 у тиглі печі ICT-0,16 (гаряче моделювання) (d): $a$ - нерухома фурма; $\sigma$ - швидкість обертання фурми 90 об/хв.; в - 120 об/хв.; г- 240 об/хв.

Так, до прикладу, для односоплової фурми у діапазоні обертання 120-240 об/хв. математичні моделі мають вид:

$$
\begin{aligned}
H_{1}= & 1.3888-0.00044 \cdot X_{1}-0.1178 \cdot X_{2}-0.0628 \cdot X_{3}+0.00001 \cdot X_{1} \cdot X_{2}+ \\
& +0.00158 \cdot X_{1} \cdot X_{3}+0.2425 \cdot X_{2} \cdot X_{3}-0.00148 \cdot X_{1} \cdot X_{2} \cdot X_{3}
\end{aligned}
$$

Для двосоплової фурми, відповідно:

$$
\begin{aligned}
H_{2} & =0.858+0.0041 \cdot X_{1}-0.0413 \cdot X_{2}+0.167 \cdot X_{3}-0.001 \cdot X_{1} \cdot X_{2}- \\
& -0.00072 \cdot X_{1} \cdot X_{3}+0.000625 \cdot X_{1} \cdot X_{2} \cdot X_{3}
\end{aligned}
$$

Результати чисельного моделювання 3 використанням отриманих математичних моделей наведені на рис. 7.

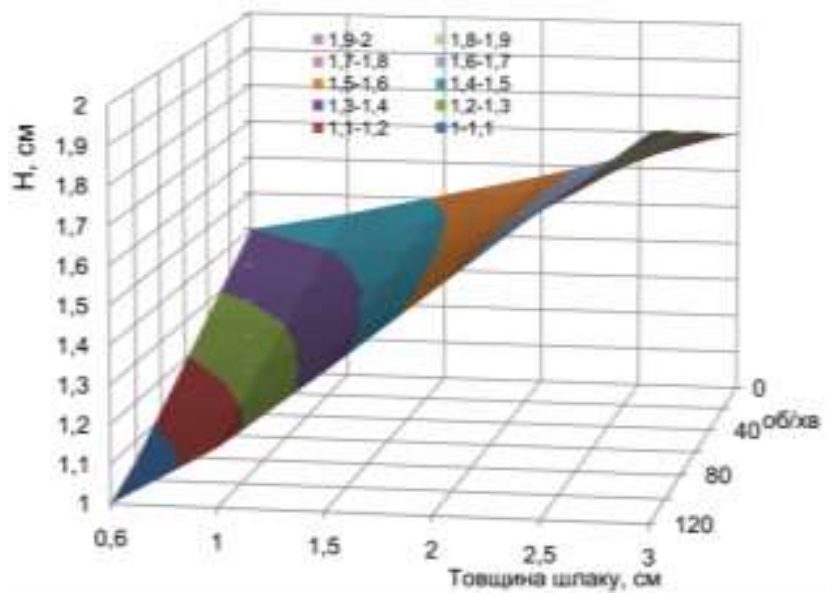

$a$

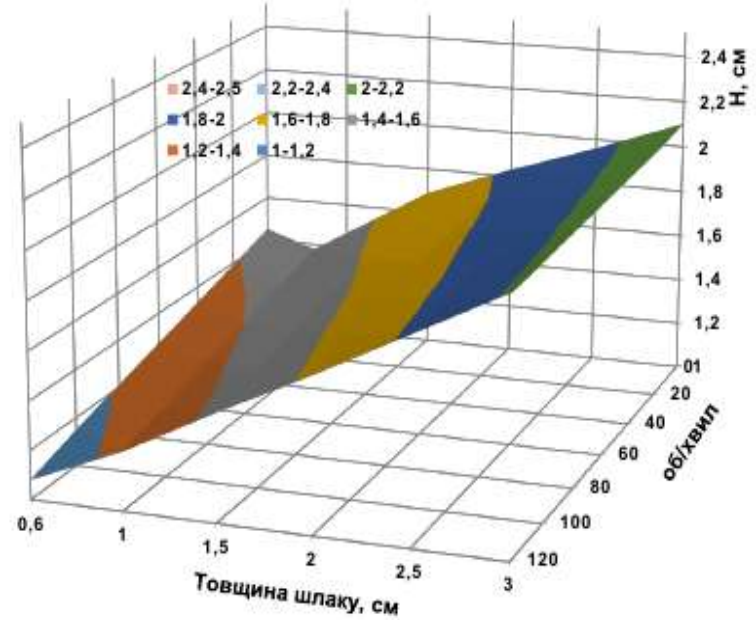

б

Рисунок 7. Висота буруна на поверхні ванни при використанні 2-х соплової фурми, яка обертається зі швидкістю 90-120 об/хв. при витратах газу 1,6 л/хв. (a) та 2,2 л/хв. (б)

За результатами проведених досліджень розроблені рекомендації для підвищення ресурсо- та енергоефективності ковшової десульфурації в умовах конвертерного цеху металургійного виробництва ПАТ «ДКХЗ». В основі рекомендацій пропозиції щодо напрямків удосконалення конструкції наконечника заглибної фурми, з метою підвищення кінетичної енергії струменя 
та зменшення впливу пульсацій у зоні контакту струменя з ванною; зменшення співвідношення $\mathrm{CaO}: \mathrm{Mg}$ у суміші реагентів, яку вдувають у розплав у другій фазі, $3(3,8-4,5): 1$ до $(2,3-3,0): 1$ із одночасним виключенням вдування флюідизованого вапна у третій фазі інжекції та впровадженням продувки ванни у вказаному періоді крізь сопла фурми або пористі донні пробки аргоном; забезпечення максимально можливої товщини покривного шлаку та використання обертової заглибної фурми; зменшення питомих витрат газу-носія до мінімально можливого рівня, який здатен забезпечити попередження «зворотних» ударів, запечатування сопел фурми за умов надійного транспортування реагентів-десульфураторів до реакційних зон у ванні. 


\section{SECTION 10. TRANSPORT AND COMMUNICATIONS, SHIPBUILDING}

DOI 10.46299/ISG.2021.MONO.TECH.III.10.1

\subsection{Theoretical researches of traffic safety conditions on displacement of rolling stock in straight, curved sections of track and in turnouts}

У даному розділі монографії побудовано математичну модель руху локомотива в прямих і кривих ділянках колії і стрілочних переводах. Модель призначена для теоретичного обгрунтування допускових параметрів зносу гребенів коліс локомотивів на основі аналізу впливу параметрів профілю поверхонь кочення коліс на динамічні характеристики локомотива. Побудована математична модель дозволяє зробити уточнення критеріїв оцінки безпеки руху щодо сходу з рейок екіпажу з колесами, що мають різний ступінь зносу - від нових до максимально зношених з граничними допусковими параметрами зносу.

10.1.1 Розрахункова схема екіпажу, незалежні координати системи, допущення і ідеалізації

Математичну модель побудовано для руху секції тепловоза 2TE116. Розрахункова схема екіпажу, показана на рис. 1. Система незалежних змінних представлена в табл. 1. Використано наступні індекси змінних: $\mathrm{m}=1,2-$ номери візків; $\mathrm{k}=1$, 2, 3 - номери колісних пар у візках; $\mathrm{j}=1,2-$ номери коліс у колісних парах ( $\mathrm{j}=1$ - ліве колесо, $\mathrm{j}=2$ - праве колесо); $\mathrm{i}=1,2$ - номери контактів колеса 3 рейкою ( $\mathrm{i}=1-$ основний контакт, $\mathrm{i}=2-$ гребеневий контакт). Позначення параметрів на розрахунковій схемі екіпажу (рис. 1):

2·А - відстань між площинами кругів кочення коліс колісних пар;

2. В - поперечна відстань між центрами буксових вузлів колісної пари;

C - поздовжня відстань між осями колісних пар одного візка;

$2 \cdot \mathrm{D}$ - відстань між шворнями візків;

$\mathrm{C}_{\text {ш }}$ - відстань від осі шворня до осі середньої колісної пари візка.

Позначення незалежних перемінних:

- $\mathrm{y}_{\text {к }}, \psi_{\text {к }}$ - поперечні та кутові в площині XОY переміщення кузова; 
- $\mathrm{y}_{\mathrm{m}}: \mathrm{y}_{\mathrm{T} 1}, \mathrm{y}_{\mathrm{T} 2} ; \psi_{\mathrm{Tm}}: \psi_{\mathrm{T} 1}, \psi_{\mathrm{t} 2}-$ поперечні та кутові в площині ХOY переміщення візків;

- $\mathrm{y}_{\mathrm{km}}: \mathrm{y}_{11}, \ldots, \mathrm{y}_{32} ; \psi_{\mathrm{km}}: \psi_{11}, \ldots, \psi_{32} ; \varphi_{\mathrm{km}}: \varphi_{11}, \ldots, \varphi_{32}$ - переміщення колісних пар, відповідно поперечні, кутові в площині ХОY і кутові навкруги осей $\mathrm{O}_{\mathrm{km}} \mathrm{Y}_{\mathrm{km}}$;

- $\mathrm{y}_{\mathrm{pjkm}}: \mathrm{y}_{\mathrm{p} 111}, \ldots, \mathrm{y}_{\mathrm{p} 111}$ - поперечні переміщення ділянок рейок у точках контакту із відповідними колесами.

Таблиця 1.

Система незалежних перемінних елементів екіпажа

\begin{tabular}{|c|c|c|c|c|}
\hline \multirow{2}{*}{ Види змінних } & \multicolumn{4}{|c|}{ Незалежні переміщення - x $_{n}$} \\
\hline & Кузов & Рами візків & $\begin{array}{c}\text { Колісні } \\
\text { пари } \\
\end{array}$ & $\begin{array}{c}\text { Ділянки рейок під } \\
\text { колесами }\end{array}$ \\
\hline Перемішення уздовж осі ОY & $\mathrm{y}_{\mathrm{K}}$ & $\mathrm{y}_{\mathrm{Tm}(\mathrm{m}=1,2)}$ & $\mathrm{y}_{\mathrm{km}(\mathrm{k}=1,3)(\mathrm{m}=1,2)}$ & $\mathrm{y}_{\mathrm{pjkm}(\mathrm{j}=1,2)(\mathrm{k}=1,3)(\mathrm{m}=1,2)}$ \\
\hline Обертання в площині XОY & $\psi_{\mathrm{K}}$ & $\psi_{\mathrm{Tm}(\mathrm{m}=1,2)}$ & $\psi_{\mathrm{km}(\mathrm{k}=1,3)(\mathrm{m}=1,2)}$ & \\
\hline $\begin{array}{l}\text { Обертання відносно осей } \\
\mathrm{O}_{\mathrm{km}} \mathrm{Y}_{\mathrm{km}}\end{array}$ & & & $\varphi_{\mathrm{km}(\mathrm{k}=1,3)(\mathrm{m}}$ & \\
\hline
\end{tabular}

Елементи розрахункової схеми - тверді тіла, з'єднані шарнірними або пружними лінійними зв'язками, паралельно яким включені гасителі коливань в’язкого тертя, опір яких пропорційний першої ступені швидкості деформації пружних елементів. Обертання колісних пар навкруги осей $\mathrm{O}_{\mathrm{km}} \mathrm{Y}_{\mathrm{km}}$ (координати $\varphi$ ) введені для урахування коливань кутових швидкостей колісних пар. Профілі поверхонь кочення всіх коліс екіпажу однакові i описуються нелінійними функціями, що відповідають реальним профілям нових або зношених коліс. 


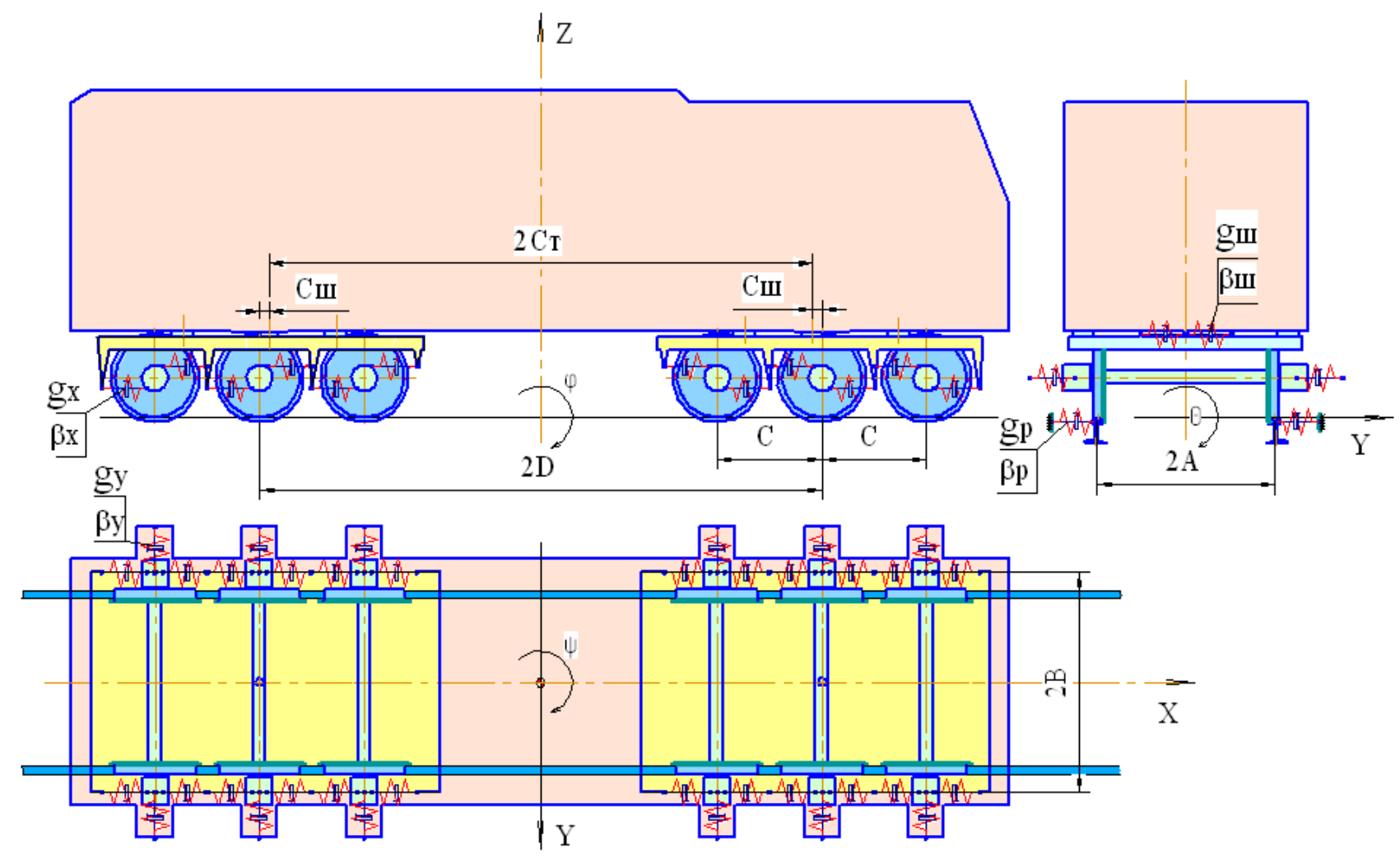

Рисунок 1. Розрахункова схема екіпажу

Передбачається, що вертикальні навантаження $\mathrm{P}_{0}$ всіх коліс на рейки однакові і дорівнюють 1/12 ваги секції локомотива. В роботі розглядається усталений рух екіпажа з різними, але постійними швидкостями $\mathrm{V}$, тому поздовжня координата виключена з розгляду.

Відповідно до результатів, наведених в роботі [384], при швидкості руху менш 100 км/год розбіжність у величинах динамічних добавок навантажень колеса на рейку при використанні моделей опори колії Вінклера, Власова або Муравського не перевищує 7-10\%. При русі зі швидкостями до 120 км/год інерційні властивості опори мало впливають на форму коливань системи, тому при складанні розрахункової схеми колії прийняті наступні ідеалізації і допущення:

- горизонтальні навантаження, які діють на праву і ліву рейки не мають взаємного впливу;

- горизонтальні поперечні переміщення ділянок рейок, взаємодіючих 3 
окремими колесами, незалежні одна від одної;

- горизонтальні поздовжні переміщення рейок відсутні.

10.1.2 Геометричні і кінематичні параметри контактування колісної пари 3 рейками

В якості геометричних параметрів контактування розглядаються i визначаються наступні величини:

- $\mathrm{K}_{\mathrm{ijkm}}\left(\mathrm{x}_{\mathrm{ijkm}}, \mathrm{y}_{\mathrm{ijkm}}, \mathrm{z}_{\mathrm{ijkm}}\right)$ - координати центрів першого $\left(\mathrm{K}_{1 \mathrm{jk}}\right) \mathrm{i}$ другого $\left(\mathrm{K}_{2 \mathrm{jk}}\right.$ ) контактів колеса з рейкою, де $\mathrm{i}=1,2$ - номери контактів колеса 3 рейкою: 1 основний контакт по поверхні кочення; 2 - гребеневий контакт;

- $\mathrm{R}_{\mathrm{ijkm}}$ - радіуси кочення коліс в центрах першого $\left(\mathrm{K}_{1 \mathrm{jk}}\right) \mathrm{i}$ другого $\left(\mathrm{K}_{2 \mathrm{jk}}\right)$ контактів;

- $\gamma_{\mathrm{ijkm}}$ - ухили профілів коліс в центрах першого $\left(\mathrm{K}_{1 \mathrm{jk}}\right) \mathrm{i}$ другого $\left(\mathrm{K}_{2 \mathrm{jk}}\right)$ контактів.

Використано наступні системи координат:

- абсолютна система координат ХОY;

- рухомі системи координат колісних пар $\mathrm{X}_{\mathrm{km}} \mathrm{O}_{\mathrm{km}} \mathrm{Y}_{\mathrm{km}}$;

- $\quad$ рухомі системи координат коліс $\mathrm{X}_{\mathrm{jkm}} \mathrm{O}_{\mathrm{jkm}} \mathrm{Y}_{\mathrm{jkm}}$.

На рис. 2 показано системи координат k-ї колісної пари і розташування контактів при двох-точковому контактуванні правого колеса k-ї колісної пари 3 рейкою. 


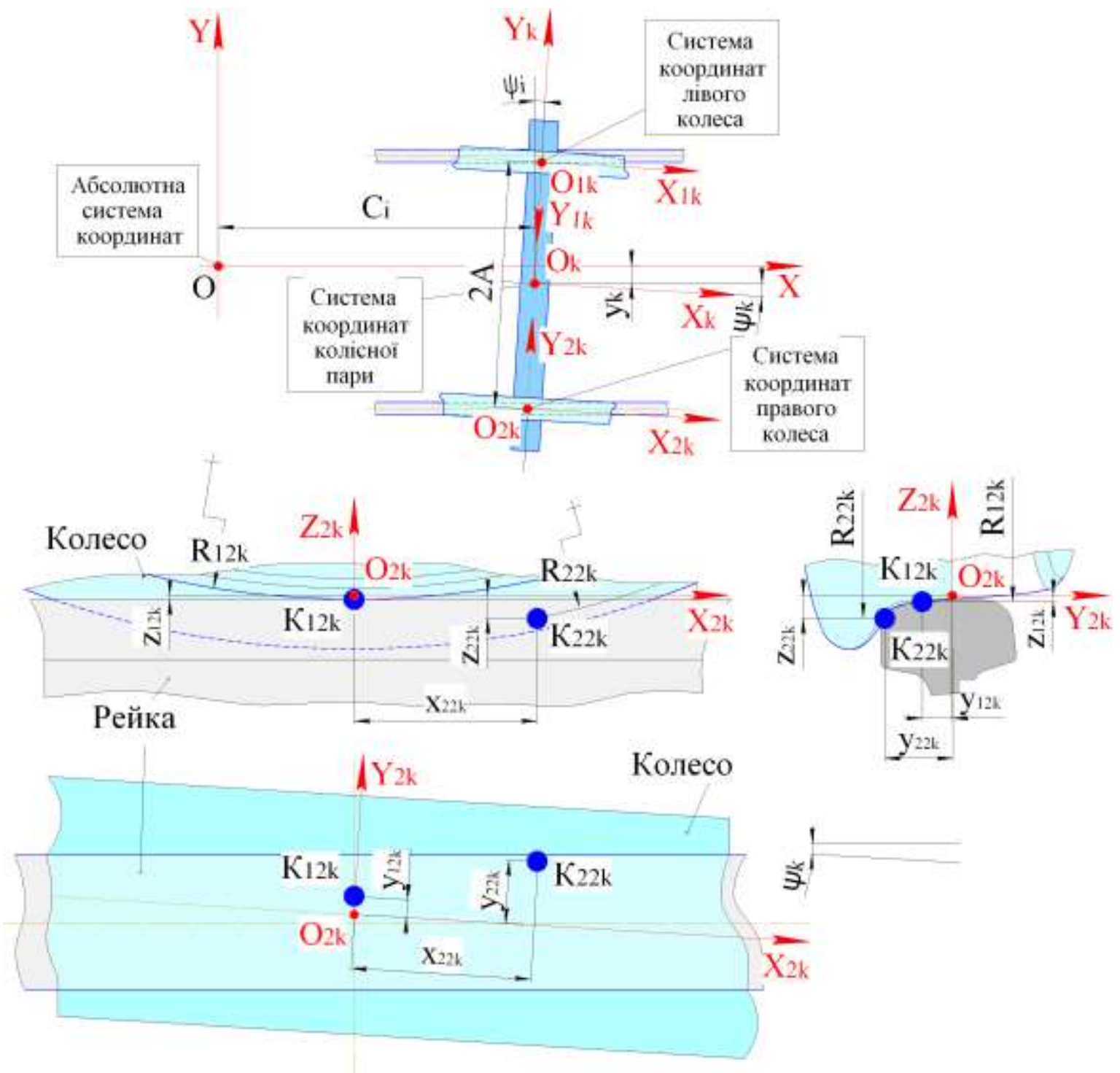

Рисунок 2. Системи координат і розташування контактів колеса з рейкою при двох-точковому контактуванні

10.1.2.1 Моделювання профілів поверхонь кочення коліс

Профілі поверхонь кочення бандажів і рейок є досить складними кривими і описуються у вигляді функцій (табл. 2)

$$
\mathrm{z}_{\mathrm{K}}=\mathrm{z}_{\mathrm{K}}\left(\mathrm{y}_{\mathrm{K}}\right) ; \quad \mathrm{z}_{\mathrm{p}}=\mathrm{z}_{\mathrm{p}}\left(\mathrm{y}_{\mathrm{p}}\right) .
$$


Таблиця 2.

Функції, що описують профілі гребеневих частин нових профілів коліс і рейки

\begin{tabular}{|c|c|c|}
\hline Профілі бандажів & $\mathrm{y}_{\mathrm{K}}$ & $\mathrm{z}_{\mathrm{K}}=\mathrm{z}_{\mathrm{K}}\left(\mathrm{y}_{\mathrm{K}}\right)$ \\
\hline \multirow{4}{*}{ ДСТУ 11018:2005 } & $-66<\mathrm{y}_{\mathrm{K}}<-30$ & $-0,143 \mathrm{y}_{\mathrm{k}}-2,79$ \\
\hline & $30<\mathrm{y}_{\mathrm{K}}<23$ & $-0,05 y_{к}$ \\
\hline & $23<\mathrm{y}_{\mathrm{\kappa}}<34$ & $-14,62+\sqrt{13,5^{2}-\left(y_{\mathrm{K}}-22\right)^{2}}$ \\
\hline & $34<\mathrm{y}_{\mathrm{K}}<50$ & $-1,732\left(\mathrm{y}_{\mathrm{k}}-29,15\right)$ \\
\hline \multirow{7}{*}{ ЗАТ «MIHETEК» } & $-10<\mathrm{y}_{\mathrm{K}}<10$ & $0,000037 \mathrm{yк}^{3}+0,00037 \mathrm{yk}^{2}-0,0952 \mathrm{y \kappa}+0,102$ \\
\hline & $10<\mathrm{y}_{\mathrm{K}}<25$ & $-0,000374 \mathrm{y}_{\mathrm{K}}{ }^{3}+0,01268 \mathrm{y}_{\mathrm{K}}^{2}-0,218 \mathrm{y}_{\mathrm{K}}+0,31$ \\
\hline & $25<\mathrm{y}_{\kappa}<33$ & $-0,000645 \mathrm{y}_{\mathrm{K}}{ }^{3}+0,03303 \mathrm{y}_{\mathrm{k}}{ }^{2}-0,726 \mathrm{y}_{\mathrm{k}}+4.547$ \\
\hline & $33<\mathrm{y}_{\mathrm{K}}<37$ & $-0,00376 \mathrm{y}_{\mathrm{K}}{ }^{3}+0,3414 \mathrm{y}_{\mathrm{K}}{ }^{2}-10,904 \mathrm{y}_{\mathrm{k}}+116,494$ \\
\hline & $37<\mathrm{y}_{\mathrm{K}}<40$ & $-0,000488 y_{\kappa}^{3}-0,02177 y_{\kappa}^{2}+2,5344 y_{k}-49,246$ \\
\hline & $40<\mathrm{y}_{\kappa}<43$ & $-0,023227 \mathrm{yk}^{3}+2,7069 \mathrm{yk}^{2}-106,6149 \mathrm{yk}^{2}+1406,079$ \\
\hline & $43<y_{\kappa}<56,87$ & $-\sqrt{156,25-\left(\mathrm{y}_{\mathrm{K}}-54.7\right)^{2}}-15,5$ \\
\hline Профіль рейки & $\mathrm{y}_{\mathrm{p}}$ & $\mathrm{z}_{\mathrm{p}}=\mathrm{z}_{\mathrm{p}}\left(\mathrm{y}_{\mathrm{p}}\right)$ \\
\hline \multirow{6}{*}{ Р65 ГОСТ 8161-75 } & $-36,5<y_{p}<-24,5$ & $-16,428+\sqrt{15^{2}-\left(y_{p}+21,55\right)^{2}}$ \\
\hline & $-24,5<y_{p}<-10,0$ & $-80,084+\sqrt{80^{2}-\left(y_{p}+8,4\right)^{2}}$ \\
\hline & $-10,0<\mathrm{y}_{\mathrm{p}}<10,0$ & $-500+\sqrt{500^{2}-y_{p}^{2}}$ \\
\hline & $10,0<y_{p}<24,5$ & $-80,084+\sqrt{80^{2}-\left(y_{p}-8,4\right)^{2}}$ \\
\hline & $24,5<y_{p}<36,5$ & $-16,428+\sqrt{15^{2}-\left(y_{p}-21,55\right)^{2}}$ \\
\hline & $36,5<y_{p}<37,5$ & $-20,0 \mathrm{yp}_{\mathrm{p}}+714,938$ \\
\hline
\end{tabular}

Для опису зношених профілів коліс і рейок автором запропонований графоаналітичний метод моделювання формоутворення зношених профілів коліс і рейок [385]. Метод дозволяє на основі нових профілів одержати можливі зношені профілі поверхонь кочення при заданих кінцевих параметрах зносу. Метод заснований на допущенні, що знос коліс і рейок, що взаємодіють, пропорційний ступеню взаємного проникнення (накладення) контурів досліджуваних профілів і коефіцієнту відносного зносу колеса і рейки.

Геометричні побудови відповідно до запропонованого методу виконуються в наступному порядку.

1. Зображуються нові профілі колеса і рейки в положенні гребеневого контактування (рис. 3,a). 


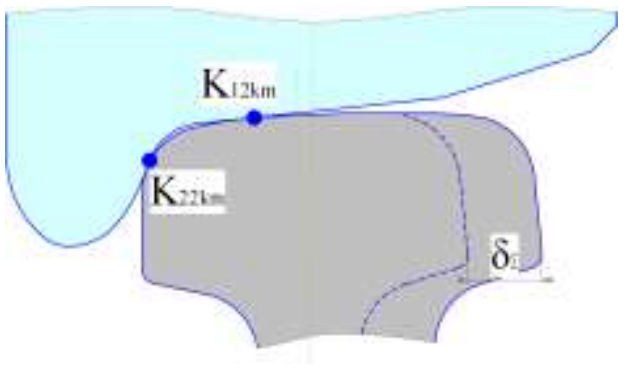

a)

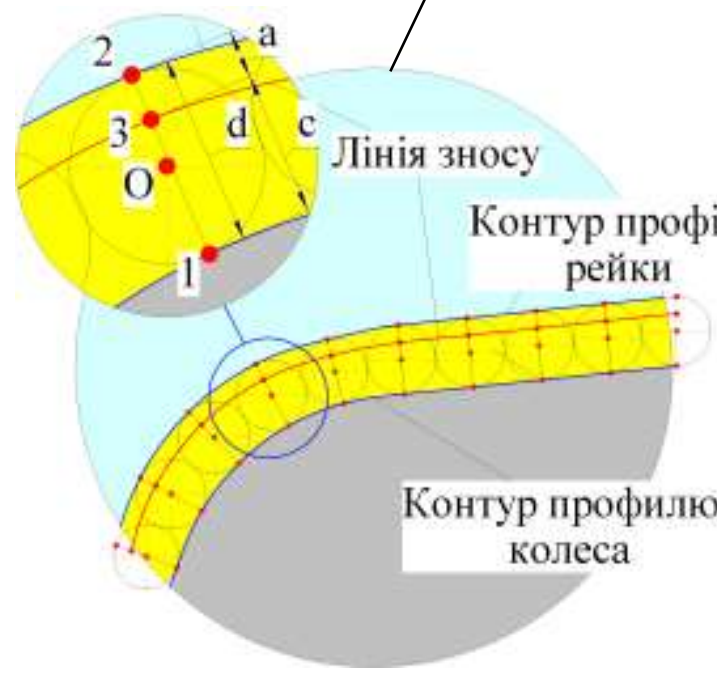

в)

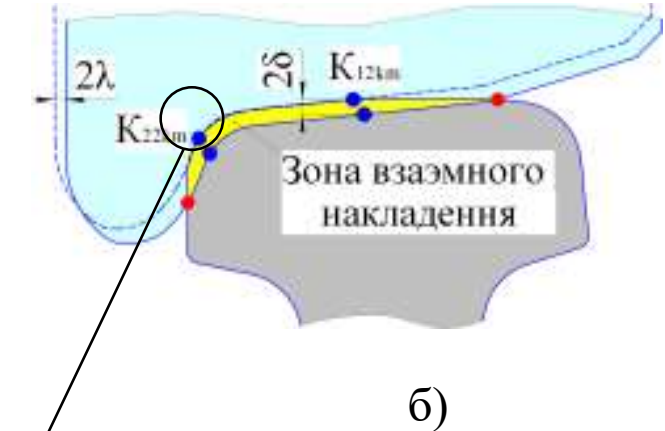

б)

Рисунок 3. Метод геометричного моделювання зношених профілів а) профілі в положенні гребеневого контактування; б) накладення профілів;

в) побудова лінії зносу

При цьому профіль рейки зображується у вигляді динамічного профілю, обмеженого геометричною множиною точок контуру рейки між іiі крайніми положеннями, які вона може займати відносно колеса в процесі поперечних переміщень колеса на величину сумарного зазору в рейковій колії $\delta_{\Sigma}$.

2. Для моделювання зношеного профілю з прокатом $\delta$ і підрізом гребеня $\lambda$ контур профілю колеса зміщається відносно контуру рейки вертикально вниз на величину $2 \cdot \delta$ і горизонтально у напрямку до рейки на величину $2 \cdot \lambda$. На рис. 3,б показано, як приклад зсув профілю колеса: вертикальний $-3,5$ мм і горизонтальний $-2,5$ мм. 
Лінія зносу будується в зоні накладення профілів (рис. 3б,в), як пропорційно-дистантна по відношенню до контурів колеса і рейки, по точках 3 (рис. 3,в). Точки 1, 2 - точки торкання вписаних в зону накладення кіл O обмежують відрізки довжиною d. Положення точок 3 на відрізках 1-2 визначається зі співвідношень

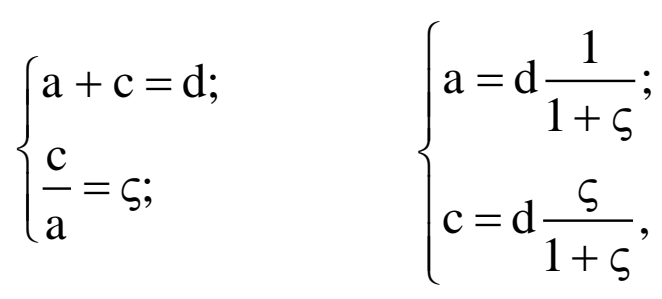

де $\varsigma$ - коефіцієнт, що враховує розходження в зносостійкості матеріалу колеса і рейки. Значення $\varsigma$ приймається таким, що дорівнює співвідношенню твердості рейки до твердості колеса

$$
\varsigma=\frac{\mathrm{HB}_{\mathrm{p}}}{\mathrm{HB}_{\mathrm{K}}}
$$

Співвідношення (2) дозволяють побудувати лінію зносу. На рис. 4 показано зношені профілі колеса (ДСТУ 11018:2005) і рейки (Р65) при значенні коефіцієнта $\varsigma=1,5$. Знос колеса склав: прокат $\delta=2,2$ мм; підріз гребеня $\lambda=2,1$ мм при товщині гребеня $b=29,8$ мм; параметр крутості гребеня $\mathrm{q}_{\mathrm{R}}=8,2$ мм.

Для введення геометрії профілю у математичну модель необхідно мати залежність $\mathrm{z}_{\mathrm{K}}=\mathrm{z}_{\mathrm{\kappa}}\left(\mathrm{y}_{\mathrm{K}}\right)$ (1). Для цього формуються вектори даних координат профілю

$$
\mathrm{y}=\left\{\begin{array}{l}
\mathrm{y}_{1} \\
\mathrm{y}_{2} \\
\ldots \\
\mathrm{y}_{\mathrm{n}}
\end{array}\right\} ; \quad \mathrm{z}=\left\{\begin{array}{l}
\mathrm{z}_{1} \\
\mathrm{z}_{2} \\
\cdots \\
\mathrm{z}_{\mathrm{n}}
\end{array}\right\} .
$$






a)

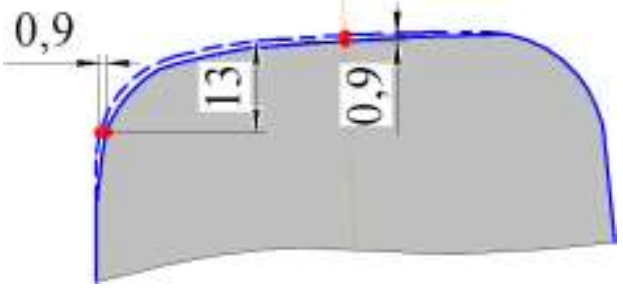

б)

Рисунок 4. Зношені профілі колеса ДСТУ 11018:2005 (а) і рейки Р65 (б) при значенні коефіцієнта $\varsigma=1,5$

Координати $\mathrm{y}_{\mathrm{i}}, \mathrm{z}_{\mathrm{i}}$ визначаються графічно за допомогою програми «Компас». На рисунку 5 зображено зношений профіль ДСТУ 11018:2005 3 координатами точок $\mathrm{y}_{\mathrm{i}}, \mathrm{z}_{\mathrm{i}}$ в системі координат $\mathrm{O}_{\mathrm{K}} \mathrm{Y}_{\mathrm{K}} \mathrm{Z}_{\mathrm{K}}$. Враховуючи складність поліноміальної апроксимації профілю бандажа і важливість як мого точного відображення профілю у математичній моделі, профіль описується кусочно-лінійною функцією (рис. 6)

$$
\mathrm{z}_{\mathrm{i}, \mathrm{i}+1}(\mathrm{y})=\mathrm{a}_{\mathrm{i}} \cdot \mathrm{y}+\mathrm{b}_{\mathrm{i}},
$$

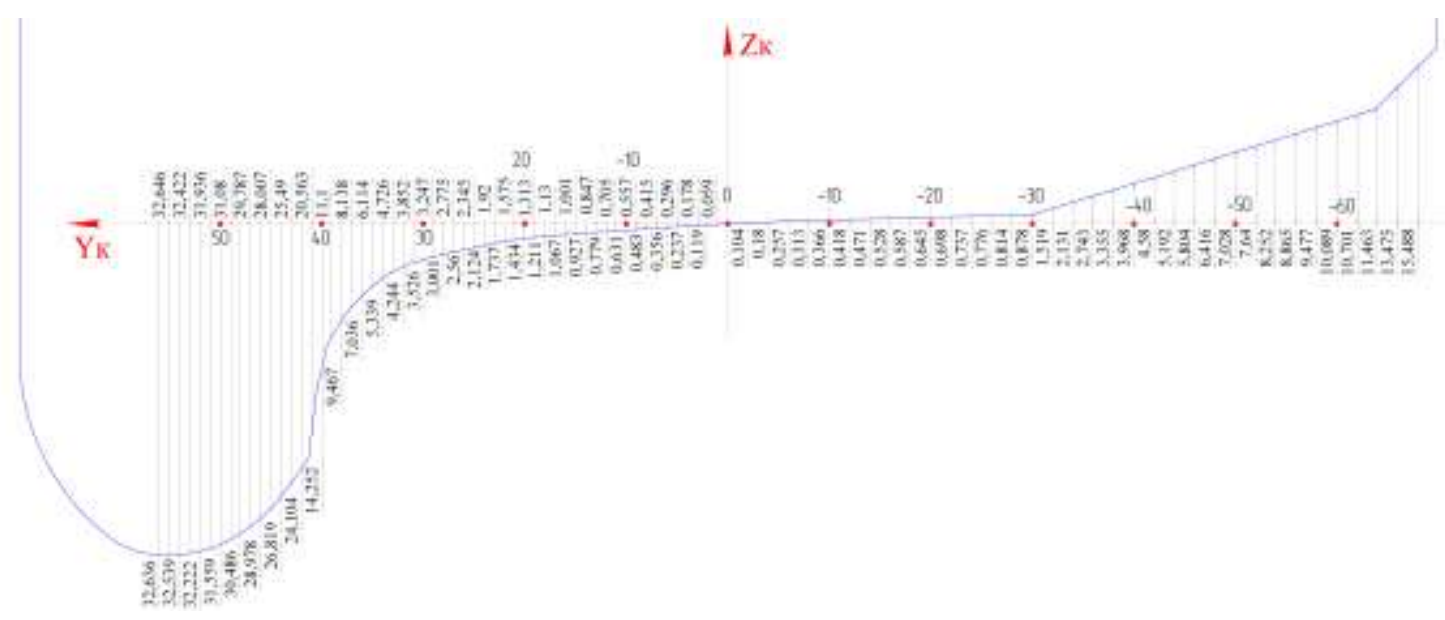

Рисунок 5. Геометрія зношеного профілю 
де $\mathrm{z}_{\mathrm{i}, \mathrm{i}+1}-$ значення координати профілю $\mathrm{z}$ на ділянці $\mathrm{y}_{\mathrm{i}+1}<\mathrm{y} \leq \mathrm{y}_{\mathrm{i}}$; $\mathrm{a}_{\mathrm{i}}, \mathrm{b}_{\mathrm{i}}-$ коефіцієнти функції на ділянці $\mathrm{y}_{\mathrm{i}}-\mathrm{y}_{\mathrm{i}+1}$.

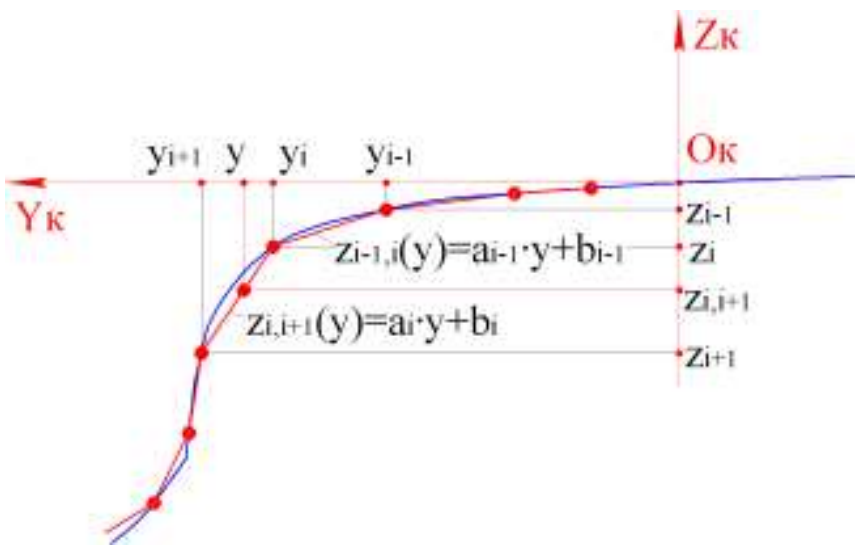

Рисунок 6. Кусочно-лінійна функція опису зношеного профілю бандажа

Значення коефіцієнтів $\mathrm{a}_{\mathrm{i}}, \mathrm{b}_{\mathrm{i}}$ функції (4)

$$
a_{i}=\frac{z_{i+1}-z_{i}}{y_{i+1}-y_{i}} ; \quad b_{i}=z_{i}-a_{i} \cdot y_{i}
$$

Радіуси кочення в центрах контактів коліс із рейками $\left(\mathrm{R}_{\mathrm{ijk}}\right)$ визначаються за наступними формулами

$$
\mathrm{R}_{\mathrm{ijkm}}=\mathrm{R}_{\mathrm{o}}-\mathrm{z}_{\mathrm{ijkm}}\left(\mathrm{dy}_{\mathrm{jkm}}, \psi_{\mathrm{km}}\right),
$$

де $\mathrm{R}_{\text {o }}$ - радіус колеса по кругу кочення;

$\mathrm{z}_{\mathrm{ijkm}}$ - вертикальне прирощення радіусу профілю у точці контакту;

$\mathrm{dy}_{\mathrm{jkm}}$ - поперечне переміщення профілю бандажу відносно рейки;

$\psi_{\mathrm{km}}-$ кут набігання колісної пари на рейку.

Алгоритм визначення параметрів контактування базується на пошуку 
значень координати $\mathrm{z}_{\mathrm{ijkm}}$, при якій відстань між точками профілів рейки і колеса по вертикалі $-\mathrm{dz}_{\mathrm{jkm}} \in$ мінімальною: $\mathrm{dz}_{\mathrm{jkm}}=\mathrm{dz}_{\mathrm{jkm}(\min )}$ (рис. 7).

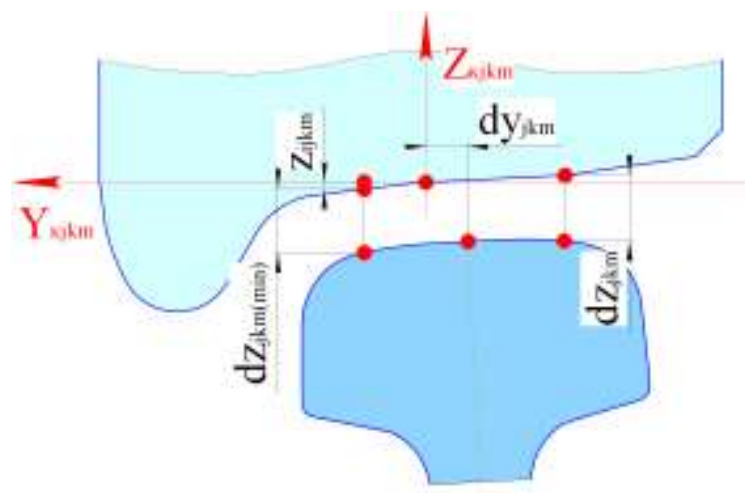

Рисунок 7. Схема для розрахунку параметрів контактування

10.1.2.2 Моделювання кінематичних характеристик контактування коліс 3 рейками

При моделюванні кінематичних характеристик контактування колісної пари 3 колією прийнято наступні параметри і їх позначення:

- V - швидкість руху центра колісної пари $\mathrm{O}_{\mathrm{k}}$ уздовж осі ОХабсолютної системи координат OXY, яка приймається рівною швидкості руху екіпажа;

- $\dot{\varphi}_{\mathrm{k}}$ - кутова швидкість обертання k-й колісної пари навколо власної осі обертання;

- $\dot{\psi}_{\mathrm{k}}$ - кутова швидкість повороту k-ї колісної пари в горизонтальній площині;

- $\mathrm{v}_{\mathrm{ijk}}$ - швидкості проковзування коліс щодо рейок у відповідних контактах: $\mathrm{v}_{1 \mathrm{jk}}-$ в основних контактах; $\mathrm{v}_{2 \mathrm{jk}}-$ в гребеневих контактах в системах координат відповідних коліс $\mathrm{X}_{\mathrm{jk}} \mathrm{O}_{\mathrm{jk}} \mathrm{Y}_{\mathrm{jk}}$;

- $\mathrm{v}_{\mathrm{xijk}}, \mathrm{v}_{\mathrm{yijk}}$ - поздовжні і поперечні складові швидкостей проковзування у відповідних контактах в системах координат відповідних коліс $\mathrm{X}_{\mathrm{jk}} \mathrm{O}_{\mathrm{jk}} \mathrm{Y}_{\mathrm{jk}}$ • 
На рис. 8 показано векторні схеми складових швидкостей проковзування в основних контактах k-ї колісної пари з рейками.

Векторні рівняння швидкостей проковзування в основних контактах коліс k-ї колісної пари, отримані на основі принципу суперпозиції, як компоненти швидкості відносного переміщення поверхонь кочення коліс і рейок мають такий вигляд

$$
\overline{\mathrm{V}}_{1 \mathrm{jk}}=\overline{\mathrm{V}}+\overline{\mathrm{V}}_{\varphi 1 \mathrm{jk}}+\overline{\mathrm{V}}_{\psi 1 \mathrm{jk}}+\overline{\mathrm{V}}_{\mathrm{y} 1 \mathrm{k}}+\overline{\mathrm{V}}_{\mathrm{p} 1 \mathrm{jk}}
$$

де $\overline{\mathrm{V}}$ - вектор швидкості руху центра колісної пари $\mathrm{O}_{\mathrm{k}}$ уздовж осі ОХ абсолютної системи координат ОХY, яка приймається рівною швидкості руху екіпажа;

$\overline{\mathrm{V}}_{\varphi 1 \mathrm{k}}$ - вектор окружної швидкості центра основного контакту ( $\left.\mathrm{K}_{1 \mathrm{jk}}\right)$, пов'язаної з обертанням колеса навколо поперечної осі колісної пари $\mathrm{O}_{\mathrm{k}} \mathrm{Y}_{\mathrm{k}}$

$$
\mathrm{V}_{\varphi 1 \mathrm{jk}}=\dot{\varphi}_{\mathrm{k}} \cdot \mathrm{R}_{1 \mathrm{jk}}
$$

де $\mathrm{R}_{1 \mathrm{jk}}$ - радіус кочення основного контакту j-го колеса $\mathrm{k}$-ї колісної пари; $\overline{\mathrm{V}}_{\psi 1 \mathrm{jk}}$ - вектор лінійної швидкості переміщення основного контакту, пов'язаної 3 обертанням колісної пари навколо вертикальної осі колісної пари $\mathrm{O}_{\mathrm{k}} \mathrm{Z}_{\mathrm{k}}$.

Швидкість переміщення основного контакту, пов'язаної 3 обертанням колісної пари навколо вертикальної осі колісної пари $\mathrm{O}_{\mathrm{k}} \mathrm{Z}_{\mathrm{k}}$.

Векторні рівняння швидкостей проковзування в основних контактах коліс k-ї колісної пари, отримані на основі принципу суперпозиції, як компоненти швидкості відносного переміщення поверхонь кочення коліс і рейок мають такий вигляд

$$
\overline{\mathrm{V}}_{1 \mathrm{jk}}=\overline{\mathrm{V}}+\overline{\mathrm{V}}_{\varphi 1 \mathrm{jk}}+\overline{\mathrm{V}}_{\psi 1 \mathrm{jk}}+\overline{\mathrm{V}}_{\mathrm{y} 1 \mathrm{k}}+\overline{\mathrm{V}}_{\mathrm{p} 1 \mathrm{jk}},
$$


де $\overline{\mathrm{V}}$ - вектор швидкості руху центра колісної пари $\mathrm{O}_{\mathrm{k}}$ уздовж осі ОХ абсолютної системи координат ОХY, яка приймається рівною швидкості руху екіпажа;

$\overline{\mathrm{V}}_{\varphi 1 \mathrm{jk}}$ - вектор окружної швидкості центра основного контакту $\left(\mathrm{K}_{1 \mathrm{jk}}\right)$, пов'язаної з обертанням колеса навколо поперечної осі колісної пари $\mathrm{O}_{\mathrm{k}} \mathrm{Y}_{\mathrm{k}}$

$$
\mathrm{V}_{\varphi 1 \mathrm{jk}}=\dot{\varphi}_{\mathrm{k}} \cdot \mathrm{R}_{1 \mathrm{jk}},
$$

де $\mathrm{R}_{1 \mathrm{jk}}$ - радіус кочення основного контакту $\mathrm{j}$-го колеса $\mathrm{k}$-ї колісної пари; $\overline{\mathrm{V}}_{\psi 1 \mathrm{jk}}-$ вектор лінійної швидкості переміщення основного контакту, пов'язаної 3 обертанням колісної пари навколо вертикальної осі колісної пари $\mathrm{O}_{\mathrm{k}} \mathrm{Z}_{\mathrm{k}}$.



Рисунок 8. Векторні схеми складових швидкостей проковзування коліс відносно рейок k-ї колісної пари в основних контактах 
Швидкість переміщення основного контакту, пов'язаної з обертанням колісної пари навколо вертикальної осі колісної пари $\mathrm{O}_{\mathrm{k}} \mathrm{Z}_{\mathrm{k}}$

$$
\mathrm{V}_{\psi 1 \mathrm{jk}}=\dot{\psi}_{\mathrm{k}} \cdot \mathrm{A},
$$

де А - відстань від центра колісної пари до основного контакту, що приймається приблизно рівною 1/2 ширини колії;

$\overline{\mathrm{V}}_{\mathrm{y} 1 \mathrm{jk}}$ - вектор швидкості поперечного переміщення колісної пари уздовж осі OY абсолютної системи координат:

$$
\overline{\mathrm{V}}_{\mathrm{y} 1 \mathrm{k}}=\overline{\mathrm{y}}_{\mathrm{k}} \text {, }
$$

де $\overline{\mathrm{V}}_{\mathrm{pjk}}$ - вектор швидкості бічного переміщення (віджаття) рейки, пов'язаний із проковзуванням відносно відповідного колеса

$$
\overline{\mathrm{V}}_{\mathrm{pjk}}=-\overline{\mathrm{y}}_{\mathrm{pjk}} \text {. }
$$

Чисельне значення поздовжніх $\mathrm{v}_{\mathrm{x} 1 \mathrm{jk}} \mathrm{i}$ поперечних $\mathrm{v}_{\mathrm{y} 1 \mathrm{jk}}$ складових швидкостей проковзування колеса відносно рейки в основних контактах коліс визначаються за формулами

$$
\begin{aligned}
& \mathrm{v}_{\mathrm{x} 11 \mathrm{k}}=\mathrm{V} \cdot \cos \psi_{\mathrm{k}}-\mathrm{V}_{\varphi 11 \mathrm{k}}+\mathrm{V}_{\psi 11 \mathrm{k}} \\
& \mathrm{v}_{\mathrm{x} 12 \mathrm{k}}=\mathrm{V} \cdot \cos \psi_{\mathrm{k}}-\mathrm{V}_{\varphi 12 \mathrm{k}}-\mathrm{V}_{\psi 12 \mathrm{k}} ; \\
& \mathrm{v}_{\mathrm{y} 11 \mathrm{k}}=\mathrm{V}_{\mathrm{yk}}-\mathrm{V} \cdot \sin \Psi_{\mathrm{k}}-\mathrm{V}_{\mathrm{p} 1 \mathrm{k}} i \\
& \mathrm{v}_{\mathrm{y} 12 \mathrm{k}}=\mathrm{V}_{\mathrm{yk}}-\mathrm{V} \cdot \sin \Psi_{\mathrm{k}}-\mathrm{V}_{\mathrm{p} 2 \mathrm{k}}
\end{aligned}
$$

3 урахуванням (8)-(11) вираження (12) будуть мати вигляд 


$$
\begin{aligned}
& \mathrm{v}_{\mathrm{x} 11 \mathrm{k}}=\mathrm{V} \cdot \cos \psi_{\mathrm{k}}-\dot{\varphi}_{\mathrm{k}} \cdot \mathrm{R}_{1 \mathrm{jk}}+\dot{\psi}_{\mathrm{k}} \cdot \mathrm{A} ; \\
& \mathrm{v}_{\mathrm{x} 12 \mathrm{k}}=\mathrm{V} \cdot \cos \psi_{\mathrm{k}}-\dot{\varphi}_{\mathrm{k}} \cdot \mathrm{R}_{1 \mathrm{jk}}-\dot{\psi}_{\mathrm{k}} \cdot \mathrm{A} ; \\
& \mathrm{v}_{\mathrm{y} 1 \mathrm{jk}}=\dot{\mathrm{y}}_{\mathrm{k}}-\mathrm{V} \cdot \sin \Psi_{\mathrm{k}}-\dot{\mathrm{y}}_{\mathrm{pjk}} ; \\
& \operatorname{tg} \vartheta_{1 \mathrm{k}}=\frac{v_{\mathrm{y} 11 \mathrm{k}}}{v_{\mathrm{x} 11 \mathrm{k}}}=\frac{\dot{\mathrm{y}}_{\mathrm{k}}-\mathrm{V} \cdot \sin \psi_{\mathrm{k}}+\dot{\mathrm{y}}_{\mathrm{p} 1 \mathrm{k}}}{\mathrm{V} \cdot \cos \psi-\dot{\varphi}_{\mathrm{k}} \cdot \mathrm{R}_{11 \mathrm{k}}+\dot{\psi}_{\mathrm{k}} \cdot \mathrm{A}} ; \\
& \operatorname{tg} \vartheta_{2 \mathrm{k}}=\frac{v_{\mathrm{y} 12 \mathrm{k}}}{v_{\mathrm{x} 12 \mathrm{k}}}=\frac{\dot{\mathrm{y}}_{\mathrm{k}}-\mathrm{V} \cdot \sin \psi_{\mathrm{k}}+\dot{\mathrm{y}}_{\mathrm{p} 2 \mathrm{k}}}{\mathrm{V} \cdot \cos \psi-\dot{\varphi}_{\mathrm{k}} \cdot \mathrm{R}_{12 \mathrm{k}}-\dot{\psi}_{\mathrm{k}} \cdot \mathrm{A}} .
\end{aligned}
$$

Сумарні швидкості проковзування в основних контактах дорівнюють

$$
\mathrm{v}_{1 \mathrm{jk}}=\sqrt{\mathrm{v}_{\mathrm{x} 1 \mathrm{jk}}^{2}+\mathrm{v}_{\mathrm{y} 1 \mathrm{jk}}^{2}} .
$$

При наявності гребеневого контакту (двох-точкового контакту) швидкість відносного поперечного переміщення колеса і рейки дорівнює нулю через відсутність поперечного переміщення, що забезпечується гребенем, тобто

$$
\overline{\mathrm{V}}_{\mathrm{y} 1 \mathrm{jk}}+\overline{\mathrm{V}}_{\mathrm{yp} 1 \mathrm{jk}}=0,
$$

$$
\text { aбo } \dot{\mathrm{y}}_{\mathrm{k}}-\dot{\mathrm{y}}_{\mathrm{pjk}}=0 \text {. }
$$

У такому випадку векторне рівняння для визначення швидкості проковзування в основному контакті колеса k-ї колісної пари має такий вигляд

$$
\overline{\mathrm{V}}_{1 \mathrm{jk}}=\overline{\mathrm{V}}+\overline{\mathrm{V}}_{\varphi 1 \mathrm{jk}}+\overline{\mathrm{V}}_{\psi 1 \mathrm{jk}} .
$$

На рис. 9 показано векторну схему швидкостей проковзування в основному 
$\left(\mathrm{K}_{12 \mathrm{k}}\right)$ і гребеневому $\left(\mathrm{K}_{22 \mathrm{k}}\right)$ контактах 2-го (правого) колеса k-ї колісної пари. Точка $\mathrm{K}_{02 \mathrm{k}}$ - миттєвий центр обертання.

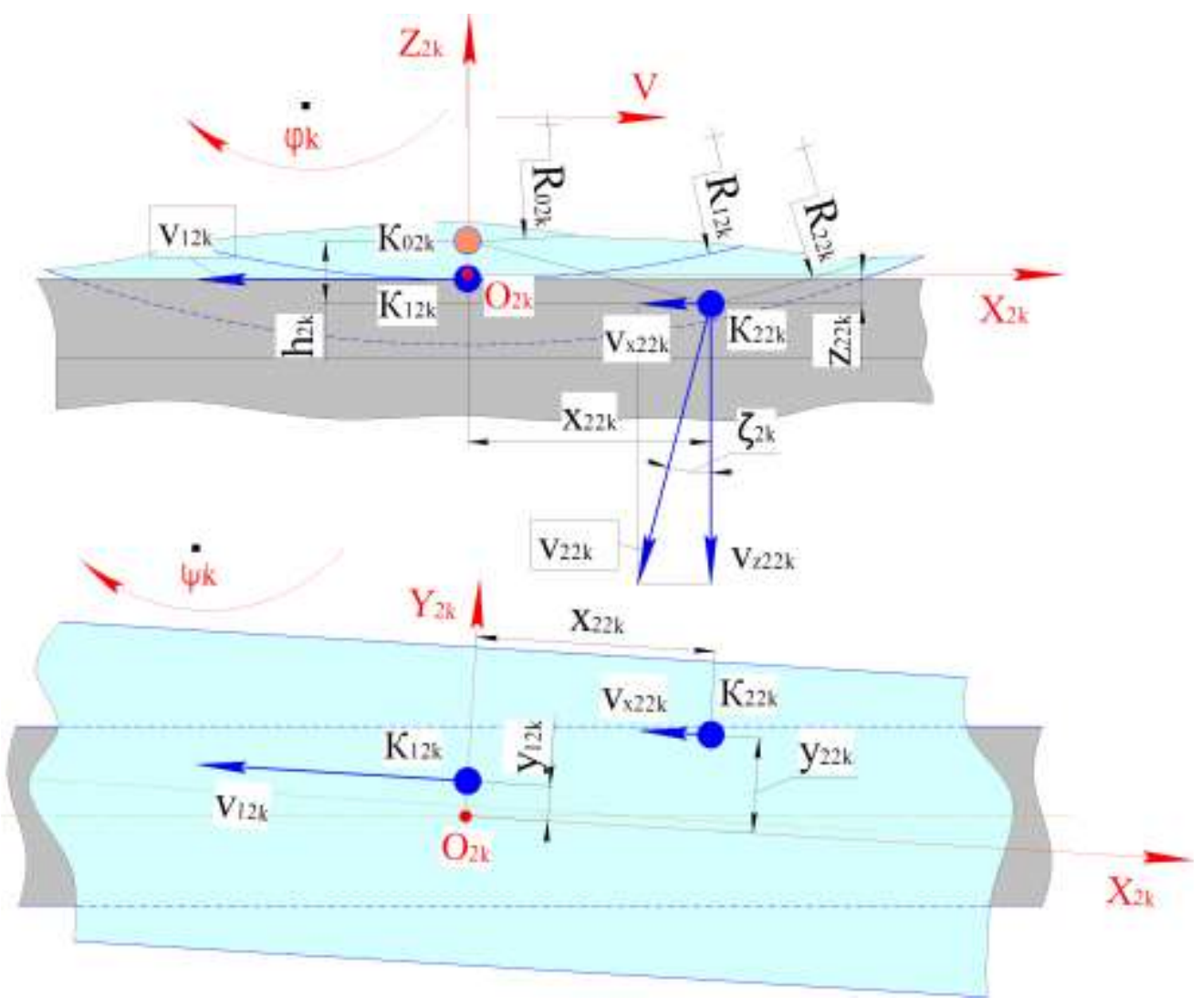

Рисунок 9. Векторна схема швидкостей проковзування у центрах контактів при двох-точковому гребеневому контактуванні

(2-ге колесо k-ї колісної пари)

У загальному випадку миттєвий радіус обертання $\mathrm{R}_{0 \mathrm{k}}-$ відстань від геометричної осі обертання колісної пари до миттєвого центра обертання відповідного колеса $\mathrm{K}_{0 \mathrm{jk}}$, визначається з наступної умови

$$
\mathrm{V}+\psi_{\mathrm{k}} \cdot \mathrm{A}=\dot{\varphi}_{\mathrm{k}} \cdot \mathrm{R}_{0 \mathrm{jk}}
$$

звідки: 


$$
\mathrm{R}_{0 \mathrm{jk}}=\frac{\mathrm{V}+\dot{\psi}_{\mathrm{k}} \cdot \mathrm{A}}{\dot{\varphi}_{\mathrm{k}}} .
$$

Швидкість проковзування в основному контакті може бути визначена по формулі

$$
\mathrm{v}_{1 \mathrm{jk}}=\dot{\varphi}_{\mathrm{k}} \cdot\left(\mathrm{R}_{0 \mathrm{jk}}-\mathrm{R}_{1 \mathrm{jk}}\right)
$$

або:

$$
\mathrm{v}_{1 \mathrm{jk}}=\mathrm{V}-\dot{\psi}_{\mathrm{k}} \cdot \mathrm{A}-\dot{\varphi} \cdot \mathrm{R}_{1 \mathrm{jk}} \cdot
$$

Швидкість проковзування в гребеневих контактах (рис. 3.9) визначається по наступних залежностях

$$
\mathrm{v}_{2 \mathrm{jk}}=\dot{\varphi}_{\mathrm{k}} \cdot\left(\mathrm{K}_{02 \mathrm{k}} \mathrm{K}_{22 \mathrm{k}}\right),
$$

де $\left(\mathrm{K}_{02 \mathrm{k}} \mathrm{K}_{22 \mathrm{k}}\right)$ - відрізок, що дорівнює миттєвому радіусу обертання центра гребеневого контакту навколо миттєвого центра обертання.

$$
\left(\mathrm{K}_{02 \mathrm{k}} \mathrm{K}_{22 \mathrm{k}}\right)=\sqrt{\mathrm{h}_{\mathrm{jk}}^{2}+\mathrm{x}_{2 \mathrm{jk}}^{2}},
$$

де $h_{j k}=\sqrt{R_{2 j k}^{2}-x_{2 j k}^{2}}-R_{0 j k}$.

3 урахуванням (14) швидкість проковзування у гребеневих контактах визначається формулою

$$
\mathrm{v}_{2 j \mathrm{k}}=\sqrt{\dot{\varphi}^{2}{ }_{\mathrm{k}} \cdot \mathrm{R}_{2 j \mathrm{k}}^{2}+\left(\mathrm{V}+\dot{\psi}_{\mathrm{k}} \cdot \mathrm{A}\right) \cdot\left(\mathrm{V}+\dot{\psi}_{\mathrm{k}} \cdot \mathrm{A}-2 \cdot \dot{\varphi}_{\mathrm{k}} \cdot \sqrt{\mathrm{R}_{2 j \mathrm{k}}^{2}-\mathrm{x}_{2 j \mathrm{k}}^{2}}\right)} .
$$

Повздовжня $\mathrm{v}_{\mathrm{x} 2 \mathrm{jk}} \mathrm{i}$ вертикальна $\mathrm{v}_{\mathrm{z} 2 \mathrm{jk}}$ складові швидкості проковзування 
$\mathrm{v}_{2 \mathrm{jk}}$ визначаються залежно від кута $\zeta_{2 \mathrm{k}}$

$$
\begin{aligned}
& \mathrm{v}_{\mathrm{x} 2 \mathrm{jk}}=\mathrm{v}_{2 \mathrm{jk}} \cdot \sin \zeta_{\mathrm{jk}} ; \\
& \mathrm{v}_{\mathrm{z} 2 \mathrm{jk}}=\mathrm{v}_{2 \mathrm{jk}} \cdot \cos \zeta_{\mathrm{jk}},
\end{aligned}
$$

де $\zeta_{j k}=\operatorname{arctg} \frac{h_{j k}}{x_{2 j k}}=\operatorname{arctg} \frac{\sqrt{R_{2 j k}^{2}-x_{2 j k}^{2}}-R_{0 j k}}{x_{2 j k}}$.

Координату $\mathrm{x}_{2 \mathrm{jk}}$ [386] можна приблизно визначити по формулі

$$
\mathrm{x}_{2 \mathrm{jk}}=\mathrm{R}_{2 \mathrm{jk}} \cdot \operatorname{tg} \psi_{\mathrm{k}} \cdot \operatorname{tg} \gamma_{\mathrm{jk}}
$$

де $\gamma_{\mathrm{jk}}-$ кут нахилу профілю в гребеневому контакті;

$\psi_{\mathrm{k}}-$ кут набігання колісної пари.

$$
\text { Тоді } \zeta_{\mathrm{jk}}=\operatorname{arctg}\left(\frac{\sqrt{1-\operatorname{tg} \psi_{\mathrm{k}} \cdot \operatorname{tg} \gamma_{2 \mathrm{jk}}}}{\operatorname{tg} \psi_{\mathrm{k}} \cdot \operatorname{tg} \gamma_{2 \mathrm{jk}}}-\frac{\mathrm{R}_{0 \mathrm{jk}}}{\mathrm{R}_{2 \mathrm{jk}}} \cdot \operatorname{tg} \psi_{\mathrm{k}} \cdot \operatorname{tg} \gamma_{2 \mathrm{jk}}\right) \text {. }
$$

10.1.3 Диференціальні рівняння руху системи

Диференціальні рівняння руху системи отримані на основі класичних рівнянь сил для інерційної системи із пружними і дисипативними зв'язками із в’язким тертям - рівнянь Лагранжа другого роду

$$
\frac{\mathrm{d}}{\mathrm{dt}} \frac{\partial \mathrm{T}}{\partial \dot{\mathrm{x}}_{\mathrm{n}}}+\frac{\partial \Phi}{\partial \dot{\mathrm{x}}_{\mathrm{n}}}+\frac{\partial \Pi}{\partial \mathrm{x}_{\mathrm{n}}}=\mathrm{F}_{\mathrm{n}}
$$


де Т, Ф, П - відповідно кінетична енергія механічної системи, енергія розсіювання демпферів і потенційна енергія пружних зв'язків;

$\dot{\mathrm{x}}_{\mathrm{n}}, \mathrm{x}_{\mathrm{n}}-$ узагальнені швидкості і переміщення елементів екіпажа;

$\mathrm{F}_{\mathrm{n}}-$ узагальнені сили системи.

\subsubsection{1 Кінетична енергія системи}

Кінетична енергія механічної системи дорівнює сумі кінетичних енергій елементів, які до неї входять

$$
\begin{aligned}
& 2 \cdot \mathrm{T}=\mathrm{m}_{\mathrm{K}} \cdot \dot{\mathrm{y}}_{\mathrm{K}}^{2}+\mathrm{J}_{\mathrm{K}} \cdot \dot{\psi}_{\mathrm{K}}^{2}+\mathrm{m}_{\mathrm{T}} \cdot \sum_{\mathrm{m}=1}^{2} \dot{\mathrm{y}}_{\mathrm{Tm}}+\mathrm{J}_{\mathrm{m}} \cdot \sum_{\mathrm{m}=1}^{2} \dot{\psi}_{\mathrm{mm}}+\mathrm{m} \cdot \sum_{\mathrm{m}=1}^{2} \sum_{\mathrm{k}=1}^{3} \dot{\mathrm{y}}_{\mathrm{km}}+ \\
& +\mathrm{J}_{\mathrm{z}} \cdot \sum_{\mathrm{m}=1}^{2} \sum_{\mathrm{k}=1}^{4} \dot{\psi}_{\mathrm{km}}^{2}+\mathrm{J}_{\mathrm{y}} \cdot \sum_{\mathrm{m}=1}^{2} \sum_{\mathrm{k}=1}^{4} \dot{\varphi}_{\mathrm{km}}^{2}+\mathrm{m}_{\mathrm{p}} \cdot \sum_{\mathrm{m}=1}^{2} \sum_{\mathrm{k}=1}^{3} \sum_{\mathrm{j}=1}^{2} \dot{\mathrm{y}}_{\mathrm{pjkm}},
\end{aligned}
$$

де $\mathrm{m}_{к}$ - маса кузова;

$\mathrm{J}_{\text {к }}$ - момент інерції кузова щодо вертикальної осі, що проходить через його центр ваги;

$\mathrm{m}_{\mathrm{m}}$ - маса, що складається 3 маси рами візка, маси гальмового обладнання, маси опор кузова, маси фрикційних гасителів коливань і половини маси комплектів пружин первинного ресорного підвішування;

$\mathrm{J}_{\mathrm{m}}$ - момент інерції рами візка відносно вертикальної осі, що проходить через вісь шкворневого шарніра;

m - маса колісної пари, що включає масу колісної пари і половину маси тягового електродвигуна і тягового редуктора;

$\mathrm{J}_{\mathrm{z}}$ - момент інерції колісної пари відносно вертикальної осі, що проходить через iii геометричний центр;

$\mathrm{J}_{\text {y }}$ момент інерції колісної пари відносно геометричної осі; 
$\mathrm{m}_{\mathrm{p}}$ - приведена маса рейки.

10.1.3.2 Енергія розсіювання у дисипативних елементах

Дисипативними елементами системи є пружні гумово-металеві шарніри буксових повідців у зв’язках колісних пар із рамами візків. Завдяки в'язкому тертю в гумі, мають властивість гасіння коливань і розсіюють енергію коливань у навколишній простір. В опорах кузова у поперечному пружному зв'язку кузова з візками також використані пружні гумово-металеві елементи. Сила опору в дисипативних елементах прийнята пропорційною швидкості деформації.

Енергія розсіювання дисипативних елементів системи

$$
2 \cdot \Phi=\beta_{\mathrm{w}} \cdot \sum_{\mathrm{T}=1}^{2} \dot{\Delta}_{\mathrm{wk}}^{2}+\beta_{\mathrm{y}} \cdot \sum_{\mathrm{T}=1}^{2} \sum_{\mathrm{k}=1}^{3} \dot{\Delta}_{\mathrm{ykm}}^{2}+\beta_{\mathrm{x}} \cdot \sum_{\mathrm{m}=1}^{2} \sum_{\mathrm{k}=1}^{3} \dot{\Delta}_{\mathrm{xkm}}^{2}+\beta_{\mathrm{p}} \cdot \sum_{\mathrm{m}=1}^{2} \sum_{\mathrm{k}=1}^{3} \sum_{\mathrm{j}=1}^{2} \dot{\Delta}_{\mathrm{pjkm}}^{2},
$$

де $\dot{\Delta}_{\text {шк }},-$ швидкості деформації пружин шкворневих пристроїв візків;

$\dot{\Delta}_{\text {ykm }}$ - швидкості поперечних переміщень колісних пар уздовж їх осей відносно відповідних кронштейнів візків обумовлені поперечними деформаціями пружних буксових зв'язків;

$\dot{\Delta}_{\mathrm{xkm}}-$ швидкості деформацій пружних буксових повідців у поздовжньому напрямку;

$\dot{\Delta}_{\text {pjkm }}$ - швидкості поперечних деформацій (швидкості віджаття) ділянок рейок у точках контактів з відповідними колесами;

$\beta_{\mathrm{x}}, \beta_{\mathrm{y}}-$ в'язкість у буксових з'єднаннях колісних пар 3 рамами візків у відповідно поздовжньому і поперечному напрямках;

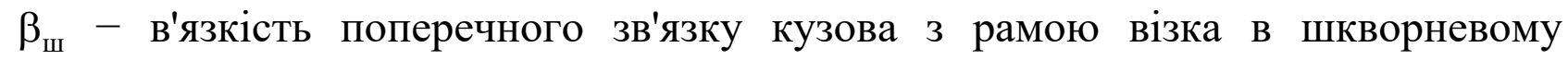
3'єднанні;

$\beta_{\mathrm{p}}$ - поперечна в'язкість рейкової колії. 
На рис.10 показана схема відносних переміщень візків і кузова по розглянутих координатах $\mathrm{y}_{\mathrm{K}}, \psi_{\mathrm{K}}, \mathrm{y}_{\mathrm{T} 1}, \mathrm{y}_{\mathrm{T} 2}$.

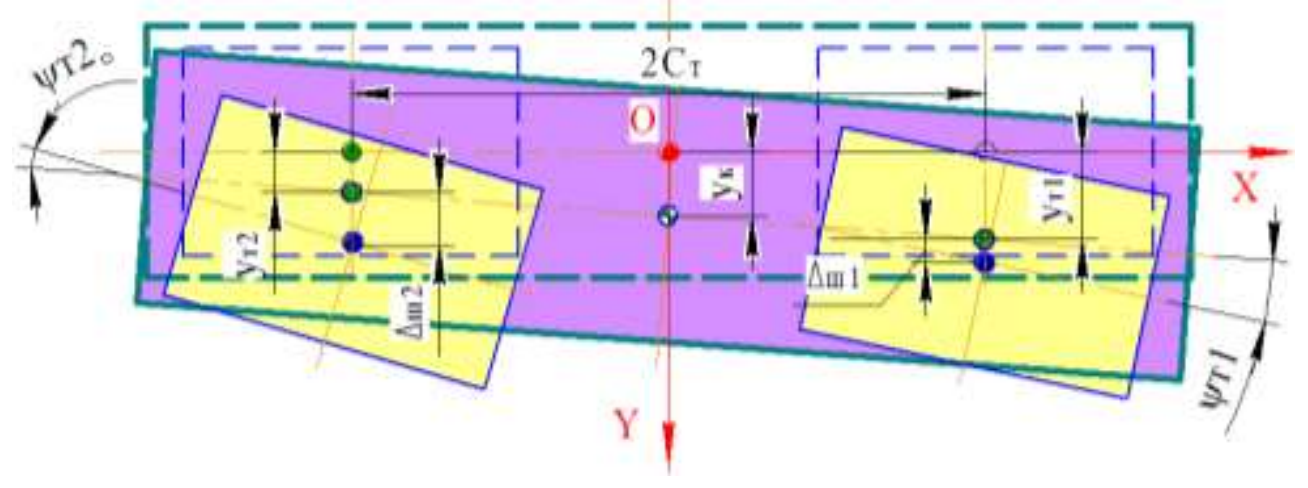

Рисунок 10. Схема відносних переміщень візків і кузова

Деформації опорних елементів кузова пов'язані 3 незалежними переміщеннями наступними рівняннями

$$
\begin{aligned}
& \dot{\Delta}_{\mathrm{I} 1}=\dot{\mathrm{y}}_{\mathrm{K}}-\dot{\mathrm{y}}_{\mathrm{T} 1}+\mathrm{C}_{\mathrm{T}} \cdot \dot{\psi}_{\mathrm{K}} ; \\
& \dot{\Delta}_{\mathrm{I} 1}=\dot{\mathrm{y}}_{\mathrm{K}}-\dot{\mathrm{y}}_{\mathrm{T} 1}-\mathrm{C}_{\mathrm{T}} \cdot \dot{\psi}_{\mathrm{K}} .
\end{aligned}
$$

Деформацій буксових повідців у поперечному напрямку пов'язані 3 переміщеннями елементів системи наступними співвідношеннями (рис. 11):

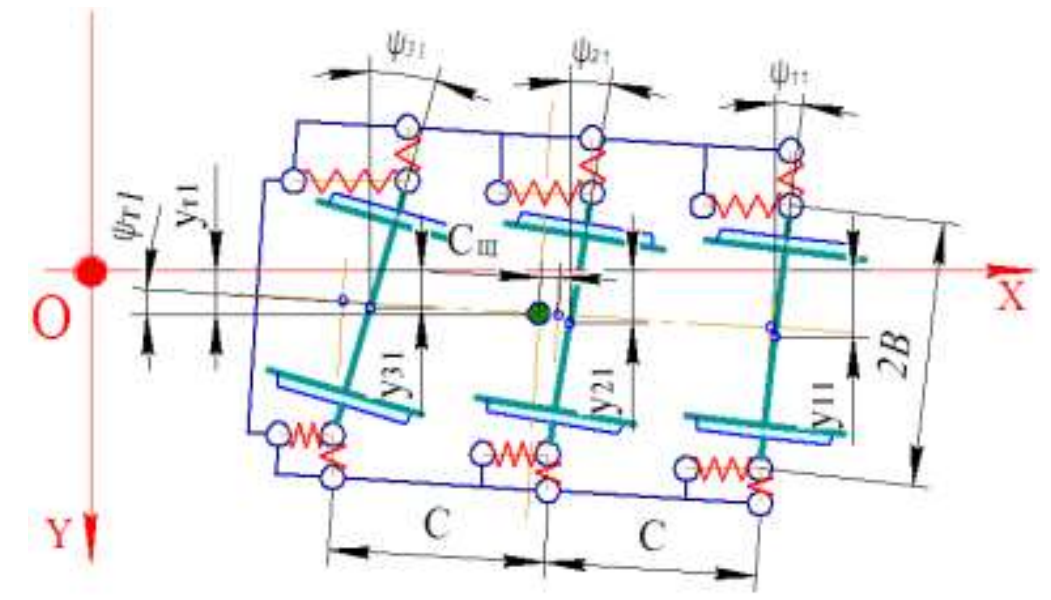

Рисунок 3.11 - Схема відносних переміщень колісних пар і рами першого візка 


$$
\begin{aligned}
& \dot{\Delta}_{\mathrm{y} 11}=\dot{\mathrm{y}}_{11}-\dot{\mathrm{y}}_{\mathrm{T} 1}-\left(\mathrm{C}+\mathrm{C}_{\mathrm{wI}}\right) \cdot \dot{\psi}_{\mathrm{T} 1} ; \\
& \dot{\Delta}_{\mathrm{y} 21}=\dot{\mathrm{y}}_{21}-\dot{\mathrm{y}}_{\mathrm{T} 1}-\mathrm{C}_{\mathrm{I}} \cdot \dot{\psi}_{\mathrm{T} 1} ; \\
& \dot{\Delta}_{\mathrm{y} 31}=\dot{\mathrm{y}}_{31}-\dot{\mathrm{y}}_{\mathrm{T} 1}+\left(\mathrm{C}-\mathrm{C}_{\mathrm{w}}\right) \cdot \dot{\psi}_{\mathrm{T} 1} ; \\
& \dot{\Delta}_{\mathrm{y} 12}=\dot{\mathrm{y}}_{12}-\dot{\mathrm{y}}_{\mathrm{T} 2}+\left(\mathrm{C}+\mathrm{C}_{\mathrm{II}}\right) \cdot \dot{\psi}_{\mathrm{T} 2} ; \\
& \dot{\Delta}_{\mathrm{y} 22}=\dot{\mathrm{y}}_{22}-\dot{\mathrm{y}}_{\mathrm{T} 2}+\mathrm{C}_{\mathrm{w}} \cdot \dot{\psi}_{\mathrm{T} 2} ; \\
& \dot{\Delta}_{\mathrm{y} 32}=\dot{\mathrm{y}}_{32}-\dot{\mathrm{y}}_{\mathrm{T} 1}-\left(\mathrm{C}-\mathrm{C}_{\mathrm{w}}\right) \cdot \dot{\psi}_{\mathrm{T} 1} \cdot
\end{aligned}
$$

У зв'язку з досить високою жорсткістю пружних елементів буксових повідців у поздовжньому напрямку прийняте допущення про те, що їх деформація зв'язана тільки з кутовими відносними переміщеннями колісних пар і рам візків. При цьому швидкості деформацій пружних буксових повідців у поздовжньому напрямку пов'язані 3 незалежними координатами системи наступними співвідношеннями

$$
\dot{\Delta}_{\mathrm{xkm}}=2 \cdot \mathrm{B} \cdot\left(\dot{\psi}_{\mathrm{km}}-\dot{\psi}_{\mathrm{mkm}}\right),(\mathrm{k}=1,2,3 ; \mathrm{m}=1,2) .
$$

Прийнято також припущення про те, що колія при деформації рейкових ниток у поперечному напрямку створює в'язкий опір, пропорційний швидкості деформації. Швидкості віджаття рейкових ниток у точках контактів 3 відповідними колесами дорівнюють відповідним швидкостям переміщень рейок

$$
\dot{\Delta}_{\mathrm{pjkm}}=\dot{\mathrm{y}}_{\mathrm{pjkm}} \text {. }
$$

3 урахуванням співвідношень (59)-(68) вираження для енергії розсіювання має такий вигляд 


$$
\begin{aligned}
2 \cdot \Phi= & \beta_{\mathrm{w}} \cdot\left[2 \cdot \dot{\mathrm{y}}_{\mathrm{K}}^{2}+\dot{\mathrm{y}}_{\mathrm{T} 1}^{2}+\dot{\mathrm{y}}_{\mathrm{T} 2}^{2}+2 \cdot \mathrm{C}_{\mathrm{T}}^{2} \cdot \dot{\psi}_{\mathrm{K}}^{2}-2 \cdot \dot{\mathrm{y}}_{\mathrm{K}} \cdot\left(\dot{\mathrm{y}}_{\mathrm{T} 1}+\dot{\mathrm{y}}_{\mathrm{T} 2}\right)-\right. \\
& \left.-2 \cdot \mathrm{C}_{\mathrm{T}} \cdot \dot{\psi}_{\mathrm{K}} \cdot\left(\dot{\mathrm{y}}_{\mathrm{T} 1}-\dot{\mathrm{y}}_{\mathrm{T} 2}\right)\right]+ \\
& +\beta_{\mathrm{y}} \cdot\left\{\dot{\mathrm{y}}_{11}^{2}+\dot{\mathrm{y}}_{21}^{2}+\dot{\mathrm{y}}_{31}^{2}+\dot{\mathrm{y}}_{12}^{2}+\dot{\mathrm{y}}_{22}^{2}+\dot{\mathrm{y}}_{32}^{2}+3 \cdot\left(\dot{\mathrm{y}}_{\mathrm{T} 1}^{2}+\dot{\mathrm{y}}_{\mathrm{T} 2}^{2}\right)+\right. \\
& +\left(2 \cdot \mathrm{C}^{2}+3 \cdot \mathrm{C}_{\mathrm{w}}^{2}\right) \cdot\left(\dot{\psi}_{\mathrm{T} 1}^{2}+\dot{\psi}_{\mathrm{T} 2}^{2}\right)+\left(2 \cdot \mathrm{C}^{2}+3 \cdot \mathrm{C}_{\mathrm{w}}^{2}\right) \cdot\left(\dot{\psi}_{\mathrm{T} 1}^{2}+\dot{\psi}_{\mathrm{T} 2}^{2}\right)- \\
& \quad-2 \cdot \dot{\mathrm{y}}_{\mathrm{T} 1} \cdot\left(\dot{\mathrm{y}}_{11}+\dot{\mathrm{y}}_{21}+\dot{\mathrm{y}}_{31}\right)-2 \cdot \dot{\mathrm{y}}_{\mathrm{T} 2} \cdot\left(\dot{\mathrm{y}}_{12}+\dot{\mathrm{y}}_{22}+\dot{\mathrm{y}}_{32}\right)- \\
- & 2 \cdot \dot{\psi}_{\mathrm{T} 1} \cdot\left[\left(\mathrm{C}+\mathrm{C}_{\mathrm{w}}\right) \cdot \dot{\mathrm{y}}_{11}+\mathrm{C}_{\mathrm{w}} \cdot \dot{\mathrm{y}}_{21}-\left(\mathrm{C}-\mathrm{C}_{\mathrm{w}}\right) \cdot \dot{\mathrm{y}}_{31}\right]+ \\
+ & 2 \cdot \dot{\psi}_{\mathrm{T} 2} \cdot\left[\left(\mathrm{C}+\mathrm{C}_{\mathrm{w}}\right) \cdot \dot{\mathrm{y}}_{12}+\mathrm{C}_{\mathrm{w}} \cdot \dot{\mathrm{y}}_{22}-\left(\mathrm{C}-\mathrm{C}_{\mathrm{w}}\right) \cdot \dot{\mathrm{y}}_{32}\right]+ \\
+ & \left.6 \cdot \mathrm{C}_{\mathrm{w}} \cdot\left(\dot{\psi}_{\mathrm{T} 1} \cdot \dot{\mathrm{y}}_{\mathrm{T} 1}-\dot{\psi}_{\mathrm{T} 2} \cdot \dot{\mathrm{y}}_{\mathrm{T} 2}\right)\right\}+
\end{aligned}
$$

$4 \cdot \mathrm{B}^{2} \cdot \beta_{\mathrm{x}} \cdot \mid\left(\dot{\psi}_{11}-\dot{\psi}_{\mathrm{T} 1}\right)^{2}+\left(\dot{\psi}_{21}-\dot{\psi}_{\mathrm{T} 1}\right)^{2}+\left(\dot{\psi}_{31}-\dot{\psi}_{\mathrm{T} 1}\right)^{2}+$

$\left.+\left(\dot{\psi}_{12}-\dot{\psi}_{\mathrm{T} 2}\right)^{2}+\left(\dot{\psi}_{22}-\dot{\psi}_{\mathrm{T} 2}\right)^{2}+\left(\dot{\psi}_{32}-\dot{\psi}_{\mathrm{T} 2}\right)^{2}\right]+$

$+\beta_{\mathrm{p}} \cdot \dot{\mathrm{y}}_{\mathrm{p} 111}^{2}+\dot{\mathrm{y}}_{\mathrm{p} 211}^{2}+\dot{\mathrm{y}}_{\mathrm{p} 121}^{2}+\dot{\mathrm{y}}_{\mathrm{p} 221}^{2}+\dot{\mathrm{y}}_{\mathrm{p} 131}^{2}+\dot{\mathrm{y}}_{\mathrm{p} 231}^{2}+$

$\left.+\dot{\mathrm{y}}_{\mathrm{p} 112}^{2}+\dot{\mathrm{y}}_{\mathrm{p} 212}^{2}+\dot{\mathrm{y}}_{\mathrm{p} 122}^{2}+\dot{\mathrm{y}}_{\mathrm{p} 222}^{2}+\dot{\mathrm{y}}_{\mathrm{p} 132}^{2}+\dot{\mathrm{y}}_{\mathrm{p} 232}^{2}\right]$.

10.1.3.3 Потенційна енергія пружних елементів підвішування екіпажа

Потенційна енергія визначається, як енергія стискання лінійних пружних елементів ресорного підвішування

$$
2 \cdot \Pi=g_{\mathrm{w}} \cdot \sum_{\mathrm{T}=1}^{2} \Delta_{\mathrm{wT}}^{2}+\mathrm{g}_{\mathrm{y}} \cdot \sum_{\mathrm{T}=1}^{2} \sum_{\mathrm{k}=1}^{3} \Delta_{\mathrm{ykm}}^{2}+\mathrm{g}_{\mathrm{x}} \cdot \sum_{\mathrm{m}=1}^{2} \sum_{\mathrm{k}=1}^{3} \Delta_{\mathrm{xkm}}^{2}+\mathrm{g}_{\mathrm{p}} \cdot \sum_{\mathrm{m}=1}^{2} \sum_{\mathrm{k}=1}^{3} \sum_{\mathrm{j}=1}^{2} \Delta_{\mathrm{pjkm}}^{2},
$$

де $\Delta_{\text {ш1 }}, \Delta_{\text {ш2 }}-$ деформація пружин пружних поперечного зв'язку візків 3 кузовом;

$\Delta_{\text {ykm }}$ - деформації пружних буксових повідців у поперечному напряму;

$\Delta_{\mathrm{xkm}}-$ повздовжні деформації пружних буксових повідців; 
$\Delta_{\text {pjkm }}$ - поперечні деформації (віджаття) ділянок рейок у точках контактів 3 колесами;

$\mathrm{g}_{\mathrm{x}}, \mathrm{g}_{\mathrm{y}}-$ жорсткість буксових зв'язків колісної пари 3 рамою візка в повздовжньому і поперечному напрямках;

$\mathrm{g}_{ш}-$ жорсткість шкворневого сполучення кузова з рамою візка в поперечному напрямку;

$\mathrm{g}_{\mathrm{p}}-$ поперечна жорсткість рейкової нитки (жорсткість віджаття рейки).

Деформації пружних елементів опорно-повертаючого пристрою, при відносному поперечному переміщенні візків і кузова залежать від переміщень кузова і візків

$$
\begin{aligned}
& \Delta_{\mathrm{m} 1}=\mathrm{y}_{\mathrm{K}}-\mathrm{y}_{\mathrm{T} 1}+\mathrm{C}_{\mathrm{T}} \cdot \psi_{\mathrm{K}} ; \\
& \Delta_{\mathrm{I} 1}=\mathrm{y}_{\mathrm{K}}-\mathrm{y}_{\mathrm{T} 1}-\mathrm{C}_{\mathrm{T}} \cdot \psi_{\mathrm{K}} .
\end{aligned}
$$

Зв'язок незалежних змінних системи рівнянь i деформацій пружних буксових повідців у поперечному напрямку описується наступними співвідношеннями

$$
\begin{aligned}
& \Delta_{\mathrm{y} 11}=\mathrm{y}_{11}-\mathrm{y}_{\mathrm{T} 1}-\left(\mathrm{C}+\mathrm{C}_{\mathrm{m}}\right) \cdot \psi_{\mathrm{T} 1} ; \\
& \Delta_{\mathrm{y} 21}=\mathrm{y}_{21}-\mathrm{y}_{\mathrm{T} 1}-\mathrm{C}_{\mathrm{w}} \cdot \psi_{\mathrm{T} 1} ; \\
& \Delta_{\mathrm{y} 31}=\mathrm{y}_{31}-\mathrm{y}_{\mathrm{T} 1}+\left(\mathrm{C}-\mathrm{C}_{\mathrm{w}}\right) \cdot \psi_{\mathrm{T} 1} ; \\
& \Delta_{\mathrm{y} 12}=\mathrm{y}_{12}-\mathrm{y}_{\mathrm{T} 2}+\left(\mathrm{C}+\mathrm{C}_{\mathrm{w}}\right) \cdot \psi_{\mathrm{T} 2} ; \\
& \Delta_{\mathrm{y} 22}=\mathrm{y}_{22}-\mathrm{y}_{\mathrm{T} 2}+\mathrm{C}_{\mathrm{w}} \cdot \psi_{\mathrm{T} 2} ;
\end{aligned}
$$




$$
\Delta_{\mathrm{y} 32}=\mathrm{y}_{32}-\mathrm{y}_{\mathrm{T} 1}-\left(\mathrm{C}-\mathrm{C}_{\mathrm{wI}}\right) \cdot \psi_{\mathrm{T} 1} .
$$

Деформації буксових повідців у повздовжньому напрямку, пов'язані із відносними переміщеннями колісних пар і рам візків

$$
\Delta_{\mathrm{xkm}}=2 \cdot \mathrm{B} \cdot\left(\psi_{\mathrm{km}}-\psi_{\mathrm{mkm}}\right),(\mathrm{k}=1,2,3 ; \mathrm{m}=1,2) .
$$

Віджаття рейкових ниток в точках контактів 3 колесами дорівнюють відповідним переміщенням рейок

$$
\Delta_{\mathrm{pjkm}}=\mathrm{y}_{\mathrm{pjkm}} \cdot
$$

3 урахуванням співвідношень (85)-(94) вираження для потенційної енергії після деяких перетворень буде виглядати в такий спосіб:

$$
\begin{aligned}
& 2 \cdot \Pi=\mathrm{g}_{\mathrm{m}} \cdot \mid 2 \cdot \mathrm{y}_{\mathrm{K}}^{2}+\mathrm{y}_{\mathrm{T} 1}^{2}+\mathrm{y}_{\mathrm{T} 2}^{2}+2 \cdot \mathrm{C}_{\mathrm{T}}^{2} \cdot \psi_{\mathrm{K}}^{2}-2 \cdot \mathrm{y}_{\mathrm{K}} \cdot\left(\mathrm{y}_{\mathrm{T} 1}+\mathrm{y}_{\mathrm{T} 2}\right)- \\
& \left.-2 \cdot C_{\mathrm{T}} \cdot \psi_{\mathrm{K}} \cdot\left(\mathrm{y}_{\mathrm{T} 1}-\mathrm{y}_{\mathrm{T} 2}\right)\right]+\mathrm{g}_{\mathrm{y}} \cdot\left\{\mathrm{y}_{11}^{2}+\mathrm{y}_{21}^{2}+\mathrm{y}_{31}^{2}+\mathrm{y}_{12}^{2}+\mathrm{y}_{22}^{2}+\mathrm{y}_{32}^{2}+3 \cdot\left(\mathrm{y}_{\mathrm{T} 1}^{2}+\mathrm{y}_{\mathrm{T} 2}^{2}\right)+\right. \\
& +\left(2 \cdot \mathrm{C}^{2}+3 \cdot \mathrm{C}_{\mathrm{m}}^{2}\right) \cdot\left(\psi_{\mathrm{T} 1}^{2}+\psi_{\mathrm{T} 2}^{2}\right)+\left(2 \cdot \mathrm{C}^{2}+3 \cdot \mathrm{C}_{\mathrm{m}}^{2}\right) \cdot\left(\psi_{\mathrm{T} 1}^{2}+\psi_{\mathrm{T} 2}^{2}\right)- \\
& -2 \cdot \mathrm{y}_{\mathrm{T} 1} \cdot\left(\mathrm{y}_{11}+\mathrm{y}_{21}+\mathrm{y}_{31}\right)-2 \cdot \mathrm{y}_{\mathrm{T} 2} \cdot\left(\mathrm{y}_{12}+\mathrm{y}_{22}+\mathrm{y}_{32}\right)- \\
& -2 \cdot \psi_{\mathrm{T} 1} \cdot\left[\left(\mathrm{C}+\mathrm{C}_{\mathrm{WI}}\right) \cdot \mathrm{y}_{11}+\mathrm{C}_{\mathrm{WI}} \cdot \mathrm{y}_{21}-\left(\mathrm{C}-\mathrm{C}_{\mathrm{WI}}\right) \cdot \mathrm{y}_{31}\right]+ \\
& +2 \cdot \psi_{\text {т2 }} \cdot\left[\left(\mathrm{C}+\mathrm{C}_{\mathrm{wI}}\right) \cdot \mathrm{y}_{12}+\mathrm{C}_{\mathrm{w}} \cdot \mathrm{y}_{22}-\left(\mathrm{C}-\mathrm{C}_{\mathrm{w}}\right) \cdot \mathrm{y}_{32}\right]+ \\
& \left.+6 \cdot \mathrm{C}_{\mathrm{II}} \cdot\left(\psi_{\mathrm{T} 1} \cdot \mathrm{y}_{\mathrm{T} 1}-\psi_{\mathrm{T} 2} \cdot \mathrm{y}_{\mathrm{T} 2}\right)\right\}+ \\
& 4 \cdot \mathrm{B}^{2} \cdot \mathrm{g}_{\mathrm{x}} \cdot \mid\left(\psi_{11}-\psi_{\mathrm{T} 1}\right)^{2}+\left(\psi_{21}-\dot{\psi}_{\mathrm{T} 1}\right)^{2}+\left(\psi_{31}-\psi_{\mathrm{T} 1}\right)^{2}+ \\
& \left.+\left(\psi_{12}-\psi_{\mathrm{T} 2}\right)^{2}+\left(\psi_{22}-\psi_{\mathrm{T} 2}\right)^{2}+\left(\psi_{32}-\psi_{\mathrm{T} 2}\right)^{2}\right]+ \\
& +\mathrm{g}_{\mathrm{p}} \cdot \mid \mathrm{y}_{\mathrm{p} 111}^{2}+\mathrm{y}_{\mathrm{p} 211}^{2}+\mathrm{y}_{\mathrm{p} 121}^{2}+\mathrm{y}_{\mathrm{p} 221}^{2}+\mathrm{y}_{\mathrm{p} 131}^{2}+\mathrm{y}_{\mathrm{p} 231}^{2}+ \\
& \left.+\mathrm{y}_{\mathrm{p} 112}^{2}+\mathrm{y}_{\mathrm{p} 212}^{2}+\mathrm{y}_{\mathrm{p} 122}^{2}+\mathrm{y}_{\mathrm{p} 222}^{2}+\mathrm{y}_{\mathrm{p} 132}^{2}+\mathrm{y}_{\mathrm{p} 232}^{2}\right] \text {. }
\end{aligned}
$$

10.1.4 Структура силової взаємодії в контактах коліс із рейками 
10.1.4.1 Розподіл нормального навантаження між контактами при двохточковому контактуванні

Приймемо наступні позначення сил контактної фрикційної взаємодії коліс iз рейками:

- $\mathrm{N}_{\mathrm{ijk}}$ - нормальне навантаження в i-му контакті j-го колеса k-ї колісної пари;

- $\mathrm{P}_{\mathrm{ijk}}$ - вертикальна реакція рейки на колесо в i-му контакті j-го колеса k-ї колісної пари - вертикальна складова нормального навантаження в контакті;

- $\mathrm{H}_{\mathrm{ijk}}$ - горизонтальна складова нормального навантаження в $i$-му контакті j-го колеса k-ї колісної пари;

- $\mathrm{S}_{\mathrm{ijk}}$ - сила зчеплення в i-му контакті j-го колеса k-ї колісної пари;

- $\mathrm{S}_{\mathrm{xijk}}, \mathrm{S}_{\mathrm{yijk}}$ - повздовжня і поперечна складові сили зчеплення в i-му контакті j-го колеса k-ї колісної пари у системах координат коліс $\mathrm{O}_{\mathrm{jk}} \mathrm{X}_{\mathrm{jk}} \mathrm{Y}_{\mathrm{jk}} \mathrm{Z}_{\mathrm{jk}}$;

- $\mathrm{F}_{\mathrm{xijk}}, \mathrm{F}_{\text {óijk }}$ - повздовжня i поперечна складові сили зчеплення в i-му контакті ј-го колеса k-ї колісної пари в абсолютній системі координат ОХY .

Вертикальні реакції рейок на колеса по контактах зв'язані між собою наступним співвідношенням

$$
P_{1 j k}+P_{2 j k}=P_{0}
$$

В роботах [387, 388] перерозподілу гравітаційного навантаження між контактами характеризується коефіцієнтом перекладки контакту $\chi$

$$
\mathrm{P}_{1 \mathrm{jk}}=(\chi-1) \cdot \mathrm{P}_{0} ; \quad \mathrm{P}_{2 \mathrm{jk}}=\chi \cdot \mathrm{P}_{0}
$$

На рис. 12 показана схема розподілу складових нормальних навантажень між контактами при одно-точковому контактуванні 1-го (лівого) колеса і двох- 
точковому контактуванні 2-го (правого) колеса колісної пари.

Нормальні реакції в контактах залежать від вертикальних навантажень і ухилів профілю колеса

$$
\mathrm{N}_{\mathrm{ijk}}=\frac{\mathrm{P}_{\mathrm{ijk}}}{\cos \gamma_{\mathrm{ijk}}}=\mathrm{P}_{\mathrm{ijk}} \cdot \sqrt{1+\operatorname{tg}^{2} \gamma_{\mathrm{ijk}}},
$$

де $\gamma_{\mathrm{ijk}}-$ кут нахилу профілю в i-му контакті j-го колеса k-ї колісної пари.

Горизонтальні поперечні складові нормальних реакцій в контактах

$$
\mathrm{H}_{\mathrm{ijk}}=\mathrm{P}_{\mathrm{ijk}} \cdot \operatorname{tg} \gamma_{\mathrm{ijk}} \cdot
$$

При наявності на одному 3 коліс двох-точкового контакту контактування колісної пари $з$ рейками стає три-точковим 3 контактами в точках $\mathrm{K}_{11 \mathrm{k}}, \mathrm{K}_{12 \mathrm{k}}$, $\mathrm{K}_{22 \mathrm{k}}$ i система перетворюється в статично невизначену систему спирання, у зв'язку із чим задача розрахунку розподілу навантажень у контактах повинна вирішуватися з урахуванням загальних деформацій елементів системи.

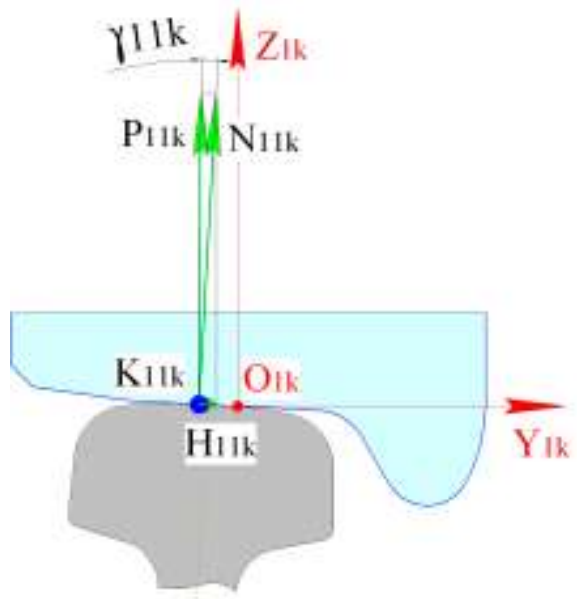

a)



б)

Рисунок 12. Схема розподілу складових нормальних навантажень між контактами коліс при двох-точковому контактуванні 2-го (правого) колеса колісної пари 
В роботах [387-389] у рівняннях деформацій розглянуті контактні деформації колеса і рейки і пов'язані з ними горизонтальні переміщення в центрі гребеневого контакту. У цьому випадку аргументом перерозподілу вертикальних навантажень між основним і гребеневим контактами є контактні деформації поверхонь кочення колеса і рейки. Це пов'язане з необхідністю обчислення дуже малих величин переміщень. В якості позиційного аргументу перерозподілу вертикальних навантажень у контактах застосовуються поперечні деформації (віджаття) рейок. При цьому прийняте допущення, що результатом віджаття рейок $€$ винятково горизонтальні поперечні складові вертикальних навантажень у контактах, а поперечні сили зчеплення не враховуються. 3 метою уточнення даного допущення, запропоновано при записі рівняння рівноваги рейкової нитки (рівняння віджаття рейки) враховувати повну бічну силу в контактах коліс із рейками. Рівняння рівноваги рейки під дією бічних контактних сил колеса має вигляд:

$$
\mathrm{m}_{\mathrm{p}} \cdot \ddot{\mathrm{y}}_{\mathrm{p}}+\mathrm{b}_{\mathrm{p}} \cdot \dot{\mathrm{y}}_{\mathrm{p}}+\mathrm{g}_{\mathrm{p}} \cdot \mathrm{y}_{\mathrm{p}}=\mathrm{F}_{\text {сцL }}+\mathrm{H}_{\mathrm{yI}}+\mathrm{H}_{\mathrm{yII}}
$$

де $\mathrm{m}_{\mathrm{p}}$ - приведена маса рейки;

$\ddot{\mathrm{y}}_{\mathrm{p}}, \dot{\mathrm{y}}_{\mathrm{p}}, \mathrm{y}_{\mathrm{p}}-$ відповідно, прискорення, швидкість віджаття і віджаття рейки в точці контакту з колесом;

$\mathrm{g}_{\mathrm{p}}, \mathrm{b}_{\mathrm{p}}$ - відповідно, наведена поперечна твердість рейки на віджаття і наведений коефіцієнт демпфірування віджаття рейки.

Автором [391] запропоновано визначати вертикальне навантаження в контактах по формулах

$$
\mathrm{P}_{\mathrm{I}}=\frac{\mathrm{m}_{\mathrm{p}} \cdot \ddot{\mathrm{y}}_{\mathrm{p}}+\mathrm{b}_{\mathrm{p}} \cdot \dot{\mathrm{y}}_{\mathrm{p}}+\mathrm{g}_{\mathrm{p}} \cdot \mathrm{y}_{\mathrm{p}}-\mathrm{P}_{0} \cdot \cos \psi}{\sqrt{1+\gamma_{\mathrm{I}}^{2}} \cdot \Psi_{0} \cdot \mathrm{k}_{\mathrm{xI}} \cdot \sin \psi+\left(\gamma_{\mathrm{I}}-\gamma_{\mathrm{II}}\right) \cdot \cos \psi},
$$




$$
\mathrm{P}_{\mathrm{II}}=\frac{\mathrm{P}_{0} \cdot\left(\sqrt{1+\gamma_{\mathrm{I}}^{2}} \cdot \psi_{0} \cdot \mathrm{k}_{\mathrm{xI}} \cdot \sin \psi+\gamma_{\mathrm{I}} \cdot \cos \psi\right)-\mathrm{m}_{\mathrm{p}} \cdot \ddot{\mathrm{y}}_{\mathrm{p}}-\mathrm{b}_{\mathrm{p}} \cdot \dot{\mathrm{y}}_{\mathrm{p}}-\mathrm{g}_{\mathrm{p}} \cdot \mathrm{y}_{\mathrm{p}}}{\sqrt{1+\gamma_{\mathrm{I}}^{2}} \cdot \Psi_{0} \cdot \mathrm{k}_{\mathrm{xI}} \cdot \sin \psi+\left(\gamma_{\mathrm{I}}-\gamma_{\mathrm{II}}\right) \cdot \cos \psi} .
$$

10.1.4.2 Сили контактної фрикційної взаємодії - сили зчеплення

Для розрахунку сил зчеплення в контактах використана методика, професора В.Ткаченка $[387,389]$, в основі якої покладена залежність поздовжньої i поперечної сил зчеплення від поздовжніх і поперечних швидкостей проковзування у контактах.

На рис.13 показана схема сил зчеплення в основних контактах $\mathrm{K}_{1 \mathrm{jk}}$.

10.2.4.2.1 Повздовжні і поперечні сили зчеплення в основних контактах

$\mathrm{B}$ основних контактах $\mathrm{K}_{1 \mathrm{jk}}$ відносне переміщення колеса і рейки має характер кочення із проковзуванням, або зчепленням.

Повздовжні $\mathrm{S}_{\mathrm{x} 1 \mathrm{jk}}$ i поперечні $\mathrm{S}_{\mathrm{y} 1 \mathrm{jk}}$ складові сил зчеплення в основних контактах [388]

$$
\begin{aligned}
& \mathrm{S}_{\mathrm{x} 1 \mathrm{jk}}=-\mathrm{N}_{1 \mathrm{jk}} \cdot \Psi_{0} \cdot \mathrm{k}_{\mathrm{x} 1 \mathrm{jk}} ; \\
& \mathrm{S}_{\mathrm{y} 1 \mathrm{jk}}=-\mathrm{N}_{1 \mathrm{jk}} \cdot \Psi_{0} \cdot \mathrm{k}_{\mathrm{y} 1 \mathrm{jk}},
\end{aligned}
$$

де $\Psi_{0}-$ фізичний коефіцієнт зчеплення, як відношення максимального значення сили зчеплення до нормального навантаження; $\mathrm{k}_{\mathrm{x} 1 \mathrm{jk}}, \mathrm{k}_{\mathrm{y} 1 \mathrm{jk}}$ - відповідно поздовжній і поперечний коефіцієнти використання зчеплення, які визначаються по формулах

$$
\mathrm{k}_{\mathrm{xjk}}=\frac{\varepsilon_{\mathrm{xjk}}}{\mathrm{a}_{\mathrm{x}} \cdot \varepsilon_{\mathrm{xjk}}^{2}+\mathrm{b}_{\mathrm{x}} \cdot\left|\varepsilon_{\mathrm{xjk}}\right|+\mathrm{c}_{\mathrm{x}}} \cdot \frac{\mathrm{d}_{\mathrm{x}}}{\mathrm{e}_{\mathrm{x}}+\varepsilon_{\mathrm{yjk}}^{g_{\mathrm{x}}}} ;
$$




$$
\mathrm{k}_{\mathrm{yjk}}=\frac{\varepsilon_{\mathrm{yjk}}}{\mathrm{a}_{\mathrm{y}} \cdot \varepsilon_{\mathrm{yjk}}^{2}+\mathrm{b}_{\mathrm{y}} \cdot\left|\varepsilon_{\mathrm{yjk}}\right|+\mathrm{c}_{\mathrm{y}}} \cdot \frac{\mathrm{d}_{\mathrm{y}}}{\mathrm{e}_{\mathrm{y}}+\varepsilon_{\mathrm{xjk}}^{\mathrm{g}_{\mathrm{y}}}},
$$

де $\mathrm{a}_{\mathrm{x}}, \mathrm{b}_{\mathrm{x}}, \mathrm{c}_{\mathrm{x}}, \mathrm{d}_{\mathrm{x}}, \mathrm{e}_{\mathrm{x}}, \mathrm{g}_{\mathrm{x}}, \mathrm{a}_{\mathrm{y}}, \mathrm{b}_{\mathrm{y}}, \mathrm{c}_{\mathrm{y}}, \mathrm{d}_{\mathrm{y}}, \mathrm{e}_{\mathrm{y}}, \mathrm{g}_{\mathrm{y}}-$ емпіричні коефіцієнти кореляції характеристик зчеплення;

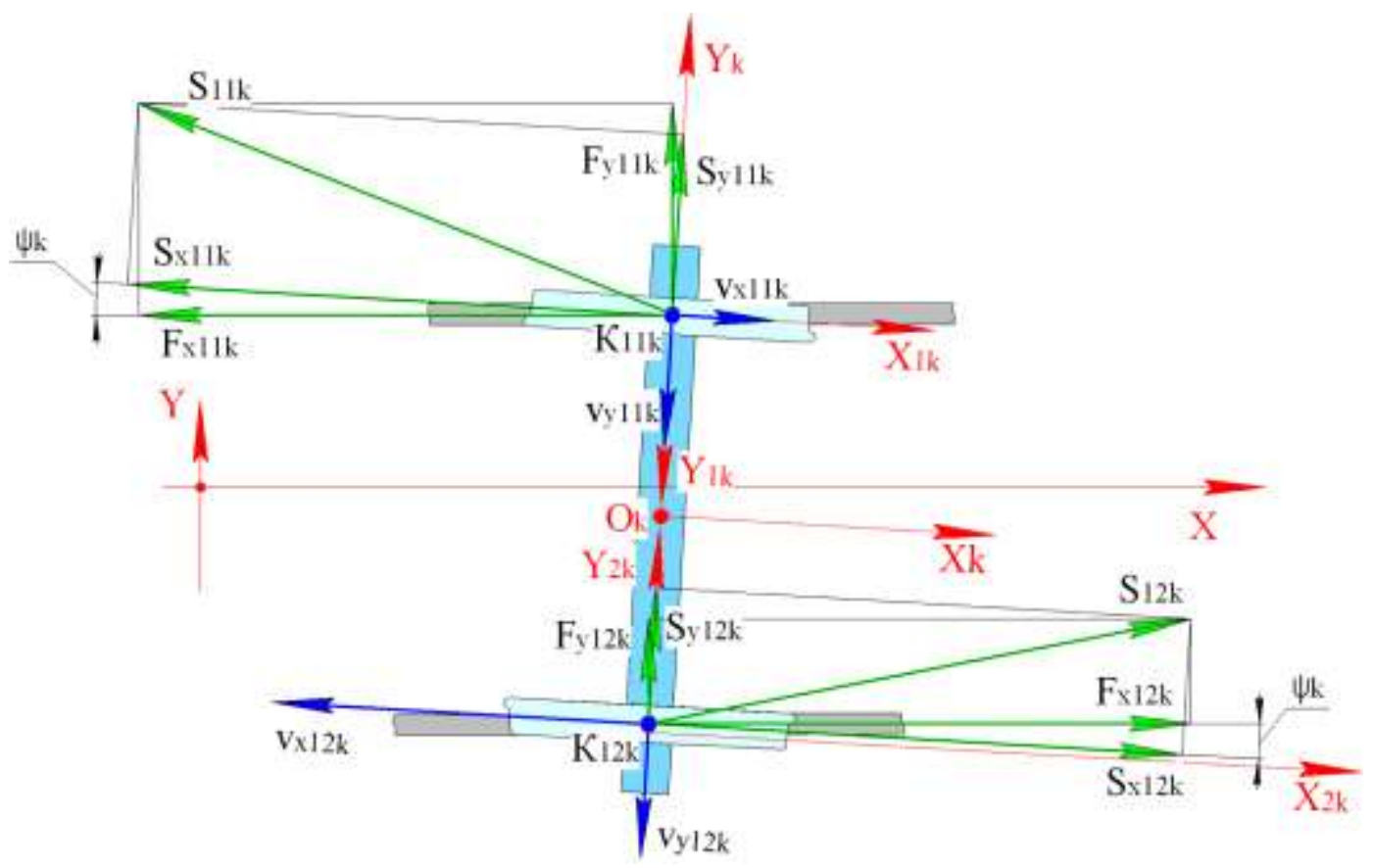

Рисунок 13. Схема сил зчеплення в основних контактах

$\varepsilon_{\mathrm{xjk}}, \varepsilon_{\mathrm{yjk}}-$ відповідно, відносні поздовжні і поперечні ковзання в основних (1-х) контактах в системах координат профілів коліс $\mathrm{O}_{\mathrm{jk}} \mathrm{X}_{\mathrm{jk}} \mathrm{Y}_{\mathrm{jk}}$

$$
\varepsilon_{\mathrm{xjk}}=\frac{\mathrm{v}_{\mathrm{x} 1 \mathrm{jk}}}{\dot{\varphi}_{\mathrm{k}} \cdot \mathrm{R}_{1 \mathrm{jk}}} ; \quad \varepsilon_{\mathrm{yjk}}=\frac{\mathrm{v}_{\mathrm{y} 1 \mathrm{jk}}}{\dot{\varphi}_{\mathrm{k}} \cdot \mathrm{R}_{1 \mathrm{jk}}},
$$

або, з урахуванням (7) 


$$
\begin{aligned}
& \varepsilon_{\mathrm{x} 1 \mathrm{k}}=\frac{\mathrm{V} \cdot \cos \psi_{\mathrm{k}}+\dot{\psi}_{\mathrm{k}} \cdot \mathrm{A}}{\dot{\varphi}_{\mathrm{k}} \cdot \mathrm{R}_{1 \mathrm{jk}}}-1 ; \\
& \varepsilon_{\mathrm{x} 2 \mathrm{k}}=\frac{\mathrm{V} \cdot \cos \psi_{\mathrm{k}}-\dot{\psi}_{\mathrm{k}} \cdot \mathrm{A}}{\dot{\varphi}_{\mathrm{k}} \cdot \mathrm{R}_{12 \mathrm{k}}}-1 ; \\
& \varepsilon_{\mathrm{yjk}}=\frac{\dot{\mathrm{y}}_{\mathrm{k}}-\mathrm{V} \cdot \sin \psi_{\mathrm{k}}-\dot{\mathrm{y}}_{\mathrm{pjk}}}{\dot{\varphi}_{\mathrm{k}} \cdot \mathrm{R}_{1 \mathrm{jk}}} .
\end{aligned}
$$

Сили зчеплення в основному контакті в абсолютній системі координат OXY :

$$
S_{1 j k}=\sqrt{S_{x 1 j k}^{2}+S_{y 1 j k}^{2}}
$$

Складові сил зчеплення $\mathrm{F}_{\mathrm{x} 1 \mathrm{jk}}$ i $\mathrm{F}_{\mathrm{y} 1 \mathrm{jk}}$ в основних контактах в абсолютній системі координат ОXY

$$
\begin{gathered}
\mathrm{F}_{\mathrm{x} 1 \mathrm{jk}}=\mathrm{S}_{\mathrm{x} 1 \mathrm{jk}} \cdot \cos \psi_{\mathrm{k}}+\mathrm{S}_{\mathrm{y} 1 \mathrm{jk}} \cdot \sin \psi_{\mathrm{k}} \\
\mathrm{F}_{\mathrm{y} 1 \mathrm{jk}}=\mathrm{S}_{\mathrm{y} 1 \mathrm{jk}} \cdot \cos \psi_{\mathrm{k}}-\mathrm{S}_{\mathrm{x} 1 \mathrm{jk}} \cdot \sin \psi_{\mathrm{k}}
\end{gathered}
$$

\subsubsection{2 Сили зчеплення в гребеневих контактах}

На рис. 14 показано схему сил зчеплення в основному i гребеневому контактах при двох-точковому контактуванні колеса $з$ рейкою.

У гребеневих контактах $\mathrm{K}_{2 j \mathrm{k}}$ відносне переміщення колеса $\mathrm{i}$ рейки має характер тертя ковзання, тому силу зчеплення в гребеневому контакті $\mathrm{S}_{22 \mathrm{k}}$ можна визначити за законом Кулона

$$
\mathrm{S}_{22 \mathrm{k}}=-\mathrm{N}_{22 \mathrm{k}} \cdot \mathrm{f}_{0} \cdot \operatorname{sign}\left(\mathrm{v}_{22 \mathrm{k}}\right) \text {, }
$$


де $\mathrm{f}_{0}$ - коефіцієнт тертя в гребеневому контакті.

Повздовжні $\mathrm{S}_{\mathrm{x} 2 \mathrm{jk}}$ i вертикальні $\mathrm{S}_{\mathrm{z} 2 \mathrm{jk}}$ складові сил зчеплення в гребеневих контактах в системах координат коліс $\mathrm{O}_{\mathrm{jk}} \mathrm{X}_{\mathrm{jk}} \mathrm{Y}_{\mathrm{jk}}$

$$
\begin{aligned}
& \mathrm{S}_{\mathrm{x} 22 \mathrm{k}}=\mathrm{S}_{22 \mathrm{k}} \cdot \sin \zeta_{2 \mathrm{k}} ; \\
& \mathrm{S}_{\mathrm{z} 22 \mathrm{k}}=\mathrm{S}_{22 \mathrm{k}} \cdot \cos \zeta_{2 \mathrm{k}} .
\end{aligned}
$$

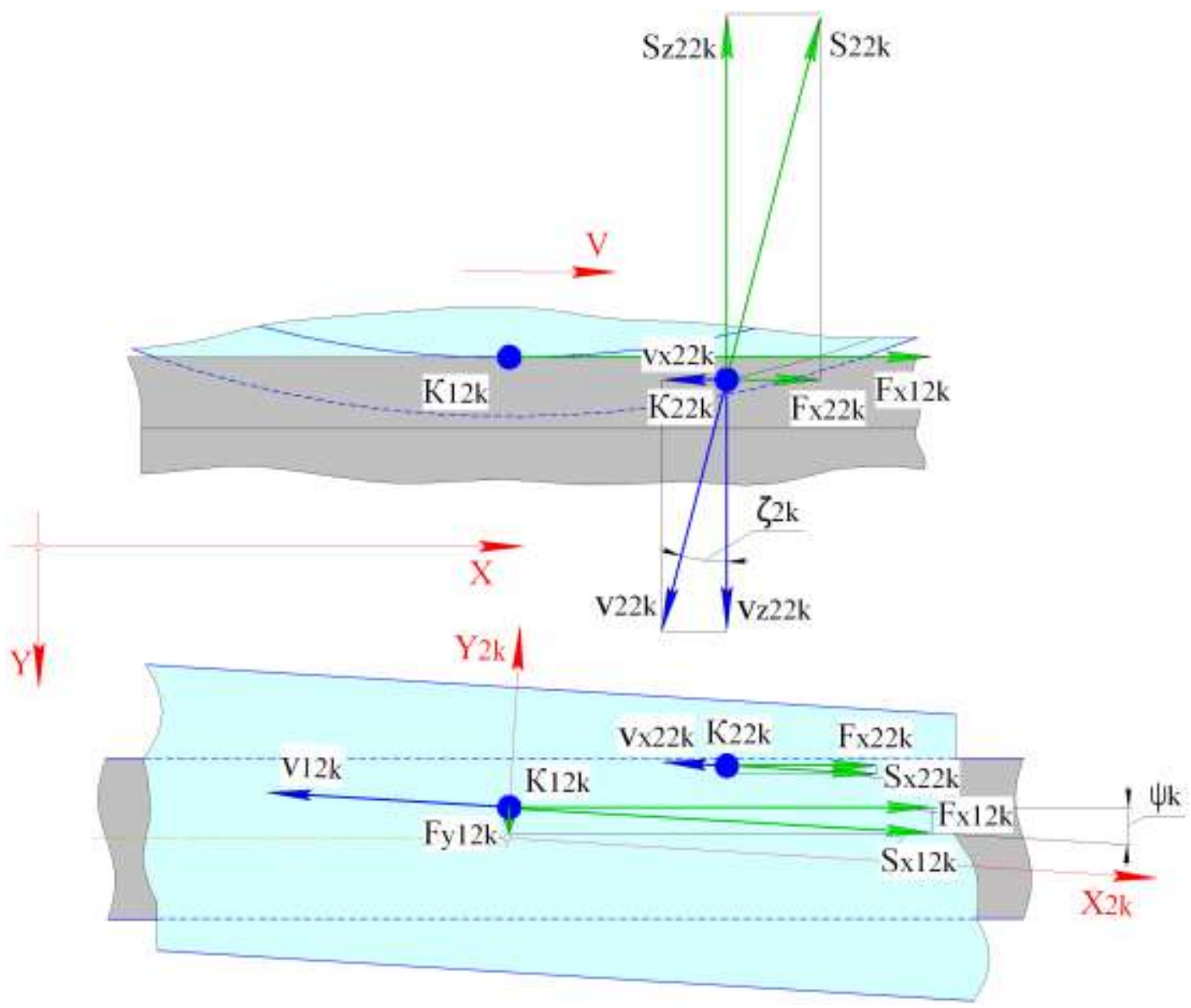

Рисунок 14. Схема сил зчеплення в гребеневих контактах

Повздовжні $\mathrm{F}_{\mathrm{x} 2 \mathrm{jk}} \mathrm{i}$ поперечні $\mathrm{F}_{\mathrm{y} 2 \mathrm{jk}}$ складові сил зчеплення в гребеневих 
контактах в абсолютній системі координат ОXY

$$
\begin{aligned}
& F_{x 2 j k}=S_{2 j k} \cdot \cos \psi_{k} ; \\
& F_{y 2 j k}=S_{2 j k} \cdot \sin \psi_{k} .
\end{aligned}
$$

На рис. 15 показано структуру контактних сил для колеса, що має двохточковий контакт із рейкою. Векторні рівняння контактних сил, які діють на колеса колісних пар з боку рейок по осях абсолютної системи координат, мають такий вигляд

$$
\begin{aligned}
& \overline{\mathrm{X}}_{\mathrm{jk}}=\sum_{\mathrm{i}=1}^{2} \overline{\mathrm{F}}_{\mathrm{xijk}} ; \\
& \overline{\mathrm{Y}}_{\mathrm{jk}}=\overline{\mathrm{F}}_{\mathrm{y} 1 \mathrm{jk}}+\sum_{\mathrm{i}=1}^{2} \overline{\mathrm{H}}_{\mathrm{ijk}} ; \\
& \overline{\mathrm{Z}}_{\mathrm{jk}}=\overline{\mathrm{F}}_{\mathrm{z} 2 \mathrm{jk}}+\sum_{\mathrm{i}=1}^{2} \overline{\mathrm{P}}_{\mathrm{ijk}} .
\end{aligned}
$$

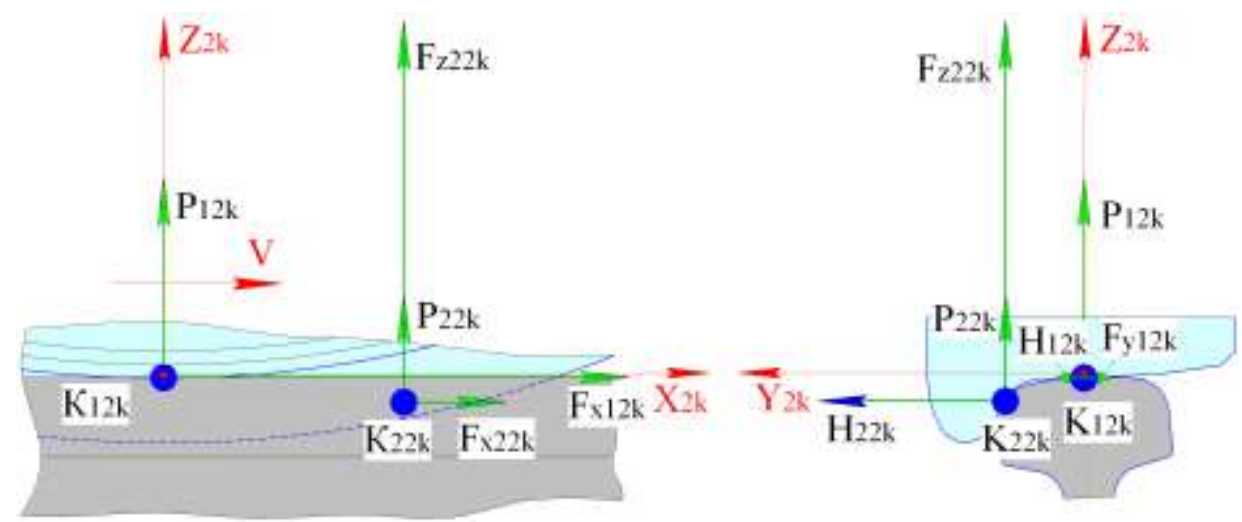

Рисунок 15. Структура контактних сил двох-точкового контакту колеса з рейкою

На рисунку 3.16 показана схема контактних сил, які діють на колеса 
першого візка. Нижче представлені вираження для узагальнених сил $\mathrm{F}_{\mathrm{n}}$, що діють по незалежних координатах.

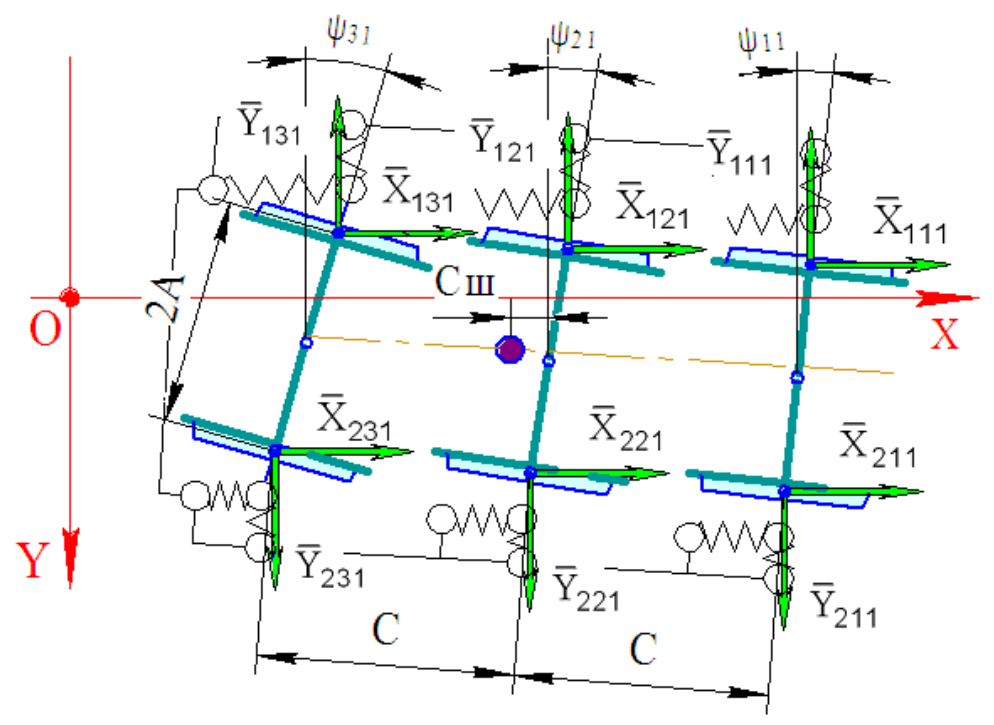

Рисунок 16. Схема контактних сил, які діють на колеса першого візка

Координата $\mathrm{y}_{\mathrm{k}}: \mathrm{F}_{1}$ - узагальнена сила, що діє на кузов 3 боку візків. $\mathrm{F}_{1}$ залежить від відносних поперечних переміщень кузова і візків

$$
\mathrm{F}_{1}=\mathrm{F}_{\mathrm{By} 1}+\mathrm{F}_{\mathrm{By} 2},
$$

де при $\quad \Delta_{\text {шт }} \leq \Delta_{1}: \quad \mathrm{F}_{\mathrm{BУm}}=\left(\mathrm{g}_{\mathrm{m} 1}-\mathrm{g}_{\mathrm{m} 2}\right) \cdot \Delta_{\text {шт }}-\Delta_{0} \cdot \mathrm{g}_{\text {ш2 }}$;

$$
\begin{aligned}
& \text { при } \quad-\Delta_{1}<\left|\Delta_{\text {шт }}\right|<\Delta_{1}: \quad \quad \mathrm{F}_{\mathrm{BУm}}=\mathrm{g}_{\text {шा }} \cdot \Delta_{\text {шт }} ; \\
& \text { при } \quad \Delta_{\text {шт }} \geq \Delta_{1}: \quad \mathrm{F}_{\mathrm{BУ}}=\left(\mathrm{g}_{\text {ш2 }}-\mathrm{g}_{\mathrm{m} 2}\right) \cdot \Delta_{\text {шт }}-\Delta_{0} \cdot \mathrm{g}_{\text {ш2 }} \text {, } \\
& \Delta_{\mathrm{m} 1}=\mathrm{y}_{\mathrm{K}}+\psi_{\mathrm{K}} \cdot \mathrm{C}_{\mathrm{T}}-\mathrm{y}_{\mathrm{T} 1} ;
\end{aligned}
$$




$$
\Delta_{\text {ш2 }}=\mathrm{y}_{\mathrm{K}}-\psi_{\mathrm{K}} \cdot \mathrm{C}_{\mathrm{T}}-\mathrm{y}_{\mathrm{T} 2} \cdot
$$

Координата $\psi_{\mathrm{\kappa}}: \mathrm{F}_{2}$ - узагальнений момент, що діє на кузов 3 боку візків, залежить від відносних кутових переміщень кузова і візків у шкворневих апаратах:

$$
\mathrm{F}_{2}=\mathrm{M}_{\mathrm{By} 1}+\mathrm{M}_{\mathrm{By} 2},
$$

де $\quad \mathrm{M}_{\mathrm{BУ}_{\mathrm{T}}}=-\mathrm{g}_{\psi} \cdot\left(\psi_{\mathrm{K}}-\psi_{\text {тт }}\right)-\mathrm{M}_{\text {тр }} \cdot \operatorname{sign}\left(\dot{\psi}_{\mathrm{K}}-\dot{\psi}_{\text {тт }}\right)$.

Координати $\mathrm{y}_{\mathrm{tm}(\mathrm{m}=1,2)}: \mathrm{F}_{2}, \mathrm{~F}_{3}$ - узагальнені сили, що діють на візки з боку кузова і колісних пар в поперечному напрямку

$$
\mathrm{F}_{2}=-\mathrm{F}_{\mathrm{By} 1} ; \quad \mathrm{F}_{3}=-\mathrm{F}_{\mathrm{By} 2} .
$$

Координати $\psi_{\mathrm{rm}(\mathrm{m}=1,2)}: \mathrm{F}_{3}, \mathrm{~F}_{4}$ - узагальнені моменти, що діють на візки 3 боку кузова і колісних пар в горизонтальній площині

$$
\mathrm{F}_{3}=-\mathrm{M}_{\mathrm{By} 1} ; \quad \mathrm{F}_{4}=-\mathrm{M}_{\mathrm{By} 2} .
$$

Координати $\mathrm{y}_{\mathrm{km}(\mathrm{k}=1,3 ; \mathrm{m}=1,2)}: \mathrm{F}_{7}-\mathrm{F}_{12}$ - контактні сили, що діють на колісні пари з боку рейкової колії в поперечному напрямку по координатах

$$
\begin{array}{lll}
\mathrm{F}_{7}=\mathrm{Y}_{111}+\mathrm{Y}_{211} ; & \mathrm{F}_{8}=\mathrm{Y}_{121}+\mathrm{Y}_{221} ; & \mathrm{F}_{9}=\mathrm{Y}_{131}+\mathrm{Y}_{231} ; \\
\mathrm{F}_{10}=\mathrm{Y}_{112}+\mathrm{Y}_{212} ; & \mathrm{F}_{11}=\mathrm{Y}_{122}+\mathrm{Y}_{222} ; & \mathrm{F}_{12}=\mathrm{Y}_{132}+\mathrm{Y}_{232} .
\end{array}
$$

Координати $\psi_{\mathrm{km}(\mathrm{k}=1,3 ; \mathrm{m}=1,2)}: \mathrm{F}_{13}-\mathrm{F}_{18}-$ моменти контактних сил, що діють на колісні пари з боку рейкової колії в плані: (рисунок 3.11) 


$$
\begin{aligned}
& \mathrm{F}_{13}=\mathrm{A} \cdot\left[\left(\mathrm{X}_{111}-\mathrm{X}_{211}\right) \cdot \cos \psi_{11}-\left(\mathrm{Y}_{111}-\mathrm{Y}_{211}\right) \cdot \sin \psi_{11}\right] ; \\
& \mathrm{F}_{14}=\mathrm{A} \cdot\left[\left(\mathrm{X}_{121}-\mathrm{X}_{221}\right) \cdot \cos \psi_{21}-\left(\mathrm{Y}_{121}-\mathrm{Y}_{221}\right) \cdot \sin \psi_{21}\right] ; \\
& \mathrm{F}_{15}=\mathrm{A} \cdot\left[\left(\mathrm{X}_{131}-\mathrm{X}_{231}\right) \cdot \cos \psi_{31}-\left(\mathrm{Y}_{131}-\mathrm{Y}_{231}\right) \cdot \sin \psi_{311}\right] ; \\
& \mathrm{F}_{16}=\mathrm{A} \cdot\left[\left(\mathrm{X}_{112}-\mathrm{X}_{212}\right) \cdot \cos \psi_{12}-\left(\mathrm{Y}_{112}-\mathrm{Y}_{212}\right) \cdot \sin \psi_{12}\right] ; \\
& \mathrm{F}_{17}=\mathrm{A} \cdot\left[\left(\mathrm{X}_{122}-\mathrm{X}_{222}\right) \cdot \cos \psi_{22}-\left(\mathrm{Y}_{122}-\mathrm{Y}_{222}\right) \cdot \sin \psi_{22}\right] ; \\
& \mathrm{F}_{18}=\mathrm{A} \cdot\left[\left(\mathrm{X}_{132}-\mathrm{X}_{232}\right) \cdot \cos \psi_{32}-\left(\mathrm{Y}_{132}-\mathrm{Y}_{232}\right) \cdot \sin \psi_{32}\right] .
\end{aligned}
$$

Координати $\varphi_{\mathrm{km}(\mathrm{k}=1,3 ; \mathrm{m}=1,2)}: \mathrm{F}_{19}-\mathrm{F}_{24}-$ моменти контактних сил, крутні моменти тягових двигунів і гальмові моменти, які обертають колісні пари навколо їх осей обертання

$$
\begin{array}{r}
\mathrm{F}_{19}=\mathrm{M}_{\text {кр }}-\mathrm{F}_{\mathrm{x} 1111} \cdot \mathrm{R}_{1111}-\mathrm{F}_{2111} \cdot \mathrm{R}_{2111}-\mathrm{S}_{\mathrm{z} 2111} \cdot \mathrm{x}_{2111}- \\
-\mathrm{F}_{\mathrm{x} 1211} \cdot \mathrm{R}_{1211}-\mathrm{F}_{\mathrm{x} 2211} \cdot \mathrm{R}_{2211}-\mathrm{S}_{\mathrm{z} 2211} \cdot \mathrm{x}_{2211} ; \\
\mathrm{F}_{20}=\mathrm{M}_{\mathrm{rp}}-\mathrm{F}_{\mathrm{x} 1121} \cdot \mathrm{R}_{1121}-\mathrm{F}_{2121} \cdot \mathrm{R}_{2121}-\mathrm{S}_{\mathrm{z} 2121} \cdot \mathrm{x}_{2121}- \\
-\mathrm{F}_{\mathrm{x} 1221} \cdot \mathrm{R}_{1221}-\mathrm{F}_{\mathrm{x} 2221} \cdot \mathrm{R}_{2221}-\mathrm{S}_{\mathrm{z} 2221} \cdot \mathrm{x}_{2221} ; \\
\mathrm{F}_{21}=\mathrm{M}_{\mathrm{кр}}-\mathrm{F}_{\mathrm{x} 1131} \cdot \mathrm{R}_{1131}-\mathrm{F}_{2131} \cdot \mathrm{R}_{2131}-\mathrm{S}_{\mathrm{z} 2131} \cdot \mathrm{x}_{2131}- \\
-\mathrm{F}_{\mathrm{x} 1231} \cdot \mathrm{R}_{1231}-\mathrm{F}_{\mathrm{x} 2231} \cdot \mathrm{R}_{2231}-\mathrm{S}_{\mathrm{z} 2231} \cdot \mathrm{x}_{2231} ; \\
\mathrm{F}_{22}=\mathrm{M}_{\text {кр }}-\mathrm{F}_{\mathrm{x} 1112} \cdot \mathrm{R}_{1112}-\mathrm{F}_{2112} \cdot \mathrm{R}_{2112}-\mathrm{S}_{\mathrm{z} 2112} \cdot \mathrm{x}_{2112}- \\
-\mathrm{F}_{\mathrm{x} 1212} \cdot \mathrm{R}_{1212}-\mathrm{F}_{\mathrm{x} 2212} \cdot \mathrm{R}_{2212}-\mathrm{S}_{\mathrm{z} 2212} \cdot \mathrm{x}_{2212} ;
\end{array}
$$




$$
\begin{aligned}
& \mathrm{F}_{23}=\mathrm{M}_{\text {кр }}-\mathrm{F}_{\mathrm{x} 1122} \cdot \mathrm{R}_{1122}-\mathrm{F}_{2122} \cdot \mathrm{R}_{2122}-\mathrm{S}_{\mathrm{z} 2122} \cdot \mathrm{x}_{2122}- \\
& -\mathrm{F}_{\mathrm{x} 1222} \cdot \mathrm{R}_{1222}-\mathrm{F}_{\mathrm{x} 2222} \cdot \mathrm{R}_{2222}-\mathrm{S}_{\mathrm{z} 2222} \cdot \mathrm{x}_{2222} \text {; } \\
& \mathrm{F}_{24}=\mathrm{M}_{\text {кр }}-\mathrm{F}_{\mathrm{x} 1132} \cdot \mathrm{R}_{1132}-\mathrm{F}_{2132} \cdot \mathrm{R}_{2132}-\mathrm{S}_{\mathrm{z} 2132} \cdot \mathrm{x}_{2132}- \\
& -\mathrm{F}_{\mathrm{x} 1232} \cdot \mathrm{R}_{1232}-\mathrm{F}_{\mathrm{x} 2232} \cdot \mathrm{R}_{2232}-\mathrm{S}_{\mathrm{z} 2232} \cdot \mathrm{x}_{2232} \cdot
\end{aligned}
$$

Координати $\mathrm{y}_{\mathrm{pjkm}(\mathrm{j}=1,2 ; \mathrm{k}=1,3 ; \mathrm{m}=1,2)}-\mathrm{F}_{25}-\mathrm{F}_{36}-$ напрямні реакції рейкових ниток

$$
\begin{array}{llll}
\mathrm{F}_{25}=-\mathrm{Y}_{111} ; & \mathrm{F}_{26}=-\mathrm{Y}_{211} ; & \mathrm{F}_{27}=-\mathrm{Y}_{121} ; & \mathrm{F}_{28}=-\mathrm{Y}_{221} ; \\
\mathrm{F}_{29}=-\mathrm{Y}_{131} ; & \mathrm{F}_{30}=-\mathrm{Y}_{231} ; & \mathrm{F}_{30}=-\mathrm{Y}_{112} ; & \mathrm{F}_{31}=-\mathrm{Y}_{212} ; \\
\mathrm{F}_{32}=-\mathrm{Y}_{122} ; & \mathrm{F}_{33}=-\mathrm{Y}_{222} ; & \mathrm{F}_{34}=-\mathrm{Y}_{132} ; & \mathrm{F}_{35}=-\mathrm{Y}_{232}
\end{array}
$$

10.1.5 Моделювання руху екіпажа в кривих ділянках колії

Для моделювання полігона обертання тепловозів i дослідження характеристик зносу в прямих і кривих ділянках колії була прийнята тестова крива, схема якої показана на рис. 17, що складається з трьох ділянок: прямої (ділянка а-б), перехідної кривої (б-в) і кругової кривої (в-г). Врахування частки прямих і кривих ділянок, визначається співвідношенням $\mathfrak{R}$

$$
\mathfrak{R}=\frac{\mathrm{L}_{\text {пк }}+\mathrm{L}_{\text {кк }}}{\mathrm{L}}=\frac{\mathrm{L}-\mathrm{L}_{\text {пр }}}{\mathrm{L}},
$$

де $\mathrm{L}, \mathrm{L}_{\text {пр }}, \mathrm{L}_{\text {пк }}, \mathrm{L}_{\text {кк }}$ - відповідно, загальна довжина колії, довжина прямих, перехідних кривих і кругових кривих полігона обертання тепловоза. 


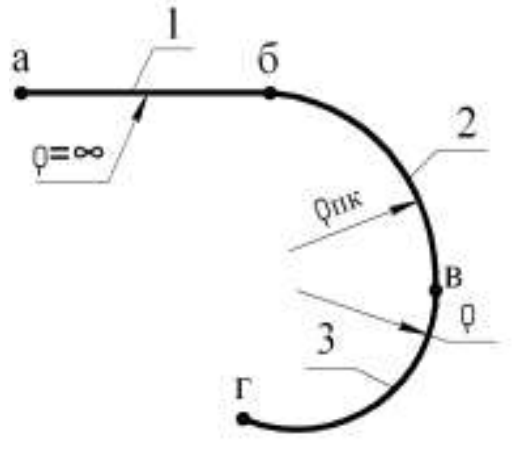

a)



б)

Риунок 17. Схема тестової ділянки колії:

а) сполучення прямої ділянки колії і кругової кривої - перехідна крива;

б) зміна узвишшя зовнішньої рейки в перехідній кривій;

1 - пряма (ділянка а-б); 2 - перехідна крива (ділянка б-в);

3 - кругова крива (ділянка в-г)

Геометричні характеристики тестової ділянки колії визначаються наступним способом.

Загальна довжина тестової ділянки прийнята $\mathrm{L}=500$ м.

Сумарна довжина перехідної $\mathrm{L}_{\text {пк }}$ і кругової $\mathrm{L}_{\text {кк }}$ кривих $-\mathrm{L}_{\mathrm{\kappa}}$ дорівнює

$$
\mathrm{L}_{\mathrm{\kappa}}=\mathrm{L}_{\text {пк }}+\mathrm{L}_{\text {кк }}=\mathrm{L} \cdot \mathfrak{R},
$$

Співвідношення $\mathfrak{R}$ для тестової ділянки колії приймається рівним $\mathfrak{R}^{*}$ для полігона обертання: $\mathfrak{R}=\mathfrak{R}^{*}$.

Довжина перехідної кривої

$$
\mathrm{L}_{\text {пк }}=\frac{\mathrm{h}}{\mathrm{i}} \text {, }
$$

де $\mathrm{h}$ - нормативне узвишшя зовнішньої рейки; 
і - кут відводу узвишшя зовнішньої рейки.

Нормативне узвишшя зовнішньої рейки

$$
\mathrm{h}=\frac{2 \cdot \mathrm{s} \cdot \mathrm{V}^{2}}{\mathrm{~g} \cdot \rho},
$$

де $\rho$ - радіус кругової кривої, що приймається рівним мінімальному радіусу кривої полігона обертання;

$2 \cdot s$ - ширина рейкової колії.

Тоді довжина перехідної кривої дорівнює

$$
\mathrm{L}_{\text {пк }}=\frac{2 \cdot \mathrm{s} \cdot \mathrm{V}^{2}}{\mathrm{~g} \cdot \mathrm{i} \cdot \rho},
$$

довжина кругової кривої буде дорівнювати

$$
\mathrm{L}_{\mathrm{\kappa \kappa}}=\mathrm{L} \cdot \Re-\frac{2 \cdot \mathrm{s} \cdot \mathrm{V}^{2}}{\mathrm{~g} \cdot \mathrm{i} \cdot \rho},
$$

а довжина прямої ділянки тестової ділянки колії

$$
\mathrm{L}_{\text {пр }}=\mathrm{L} \cdot(1-\mathfrak{R}) .
$$

На рис. 18 показано залежності довжин ділянок тестової кривої від швидкості руху: Lpk(V) - довжина перехідної кривої (м); Lkk(V) - довжина кругової кривої (м); Lpr - довжина прямої (м); V - швидкість руху (м/с)

10.1.6 Моделювання руху екіпажа у стрілочному переводі 
Стрілочний перевід $є$ невід'ємною і найбільш складною частиною колії, ділянкою підвищеної небезпеки руху поїздів. Найчастіше схід колісних пар з рейок у стрілочних переводах відбувається внаслідок вкочування коліс із гребенем, який має небезпечну форму, на гостряк стрілочного переводу при протишерстному русі.

Небезпечна форма гребеня пов'язана 3 верхньою межею значення кута нахилу гребеня, що, у відповідності із «Інструкцією» [392], визначається граничним значенням параметра крутості гребеня [qR ]. На рис. 20 показано схему наїзду колеса на гостряк стрілочного переводу в протишерсному русі.

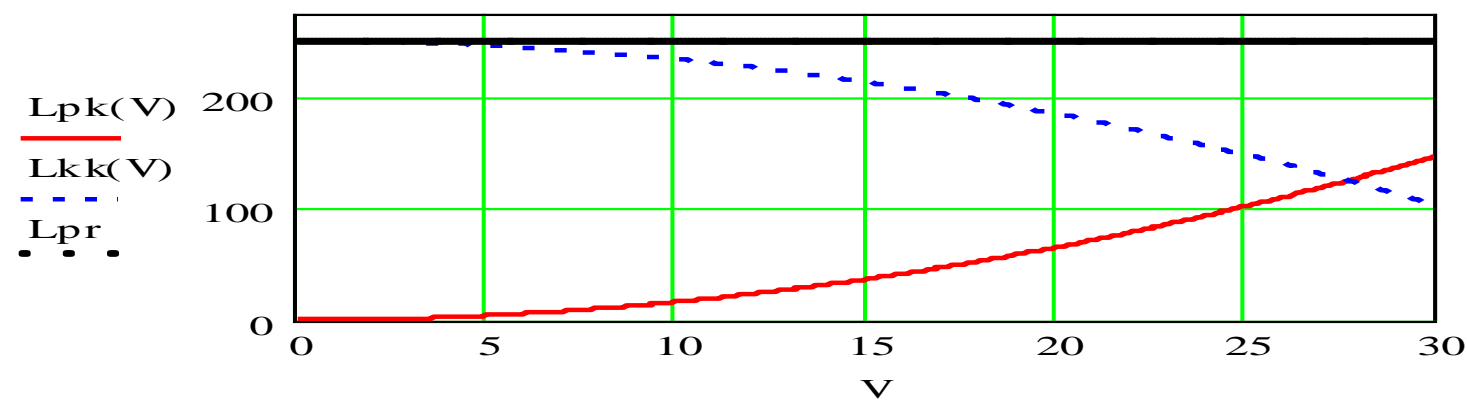

Рисунок 18. Залежності довжин ділянок тестової кривої від розрахункової швидкості руху для значень і $=0,001$ и $\mathfrak{R}=0,5$

На рис. 19 показано залежності параметрів перехідної кривої: радіусу (а) і нормативного узвишшя зовнішньої рейки (б) від установленої рівноважної швидкості руху потяга.

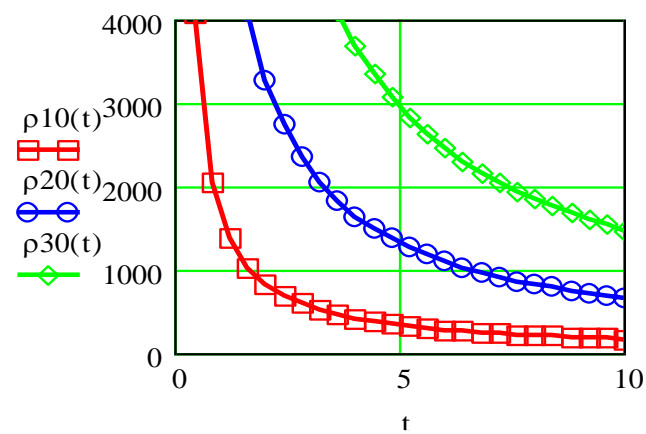

a)

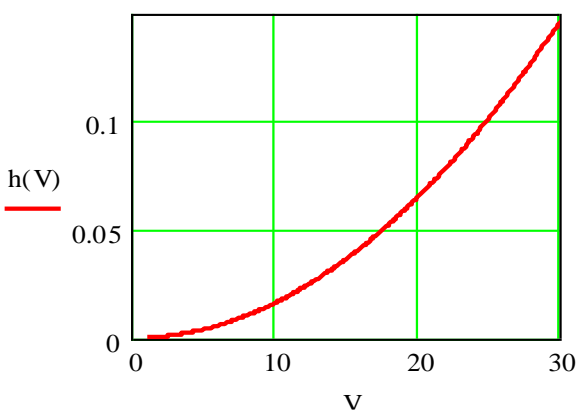

б)

Рисунок 19. Залежності параметрів кривої від встановленої рівноважної швидкості руху: а) радіусу перехідної кривої; б) нормативного узвишшя 
зовнішньої рейки $\rho 10(t), \rho 20(t), \rho 30(t)$ - радіуси перехідної кривої (м) для швидкостей руху, відповідно, 10, 20, 30 (м/c); h(V) - узвишшя зовнішньої рейки

$$
\text { (м); t - час (c); V - швидкість руху (м/с) }
$$

На рис. 21 показано схему гребеневих реакцій в контактах з рамною рейкою $\left(\mathrm{K}_{2}\right)$ і гостряком $\left(\mathrm{K}_{3}\right)$.

В залежності від картини гребеневого контактування можна визначити три фази наїзду колеса на гостряк.

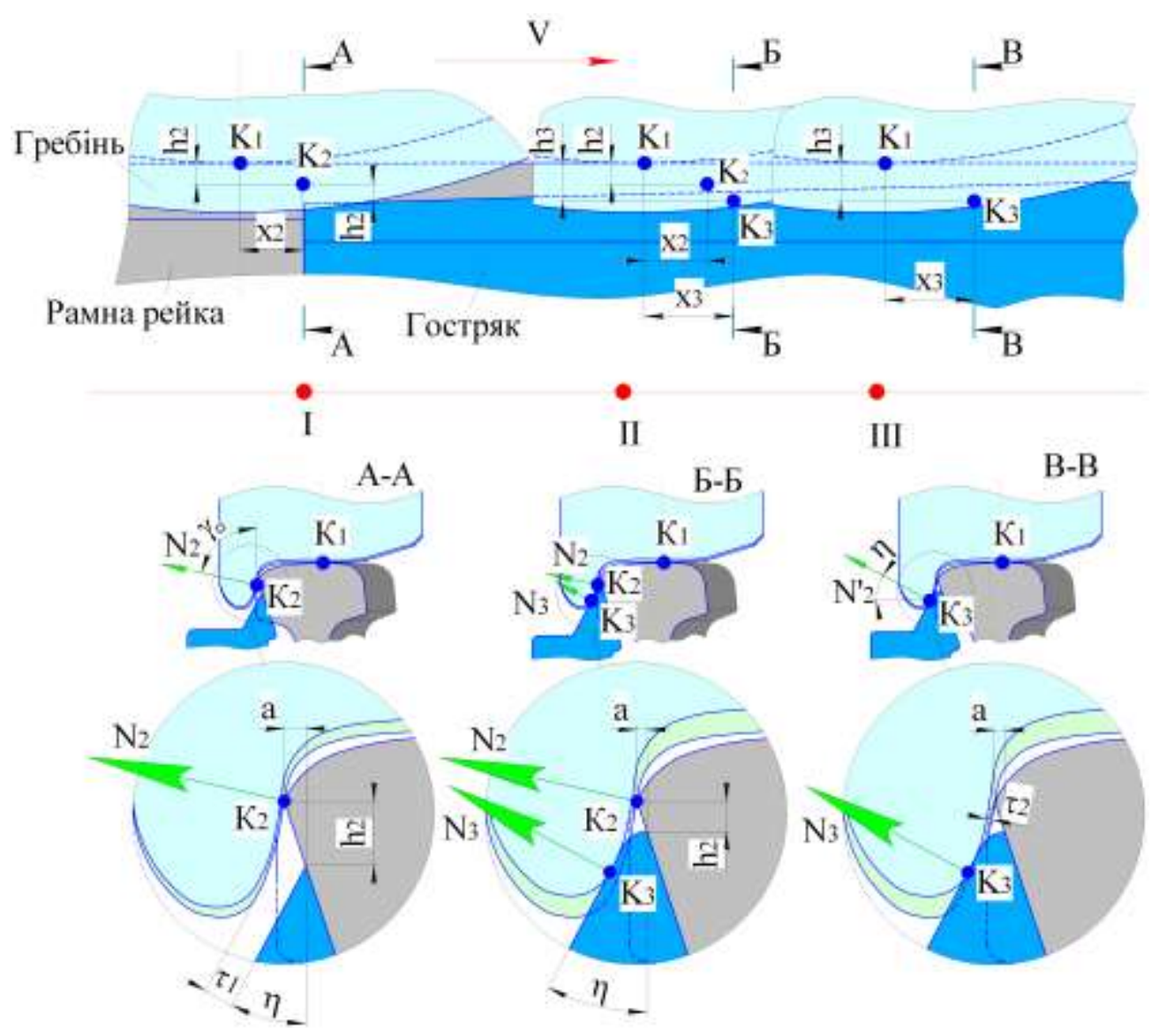

Рисунок 20. Схема наїзду гребеня максимально зношеного профілю бандажа ГОСТ 11018 на гостряк стрілочного переводу

Перша фаза - наїзд на рамну рейку - існує на ділянці від точки I до точки II. На цій фазі гребінь контактує з рамною рейкою в точці К $\mathrm{K}_{2}$, а між вістрям гостряка і гребенем існує зазор $\tau_{1}$, який зменшується в міру наближення до точки II. При 
цьому вертикальна і горизонтальна складові нормальної гребеневої реакції залежать від кута контактування $\mu$ за наступними залежностями

$$
\mathrm{P}_{2}=\mathrm{N}_{2} \cdot \sin \mu ; \quad \mathrm{H}_{2}=\mathrm{N}_{2} \cdot \cos \mu
$$

де кут контактування $\mu=90-\gamma_{2}$.
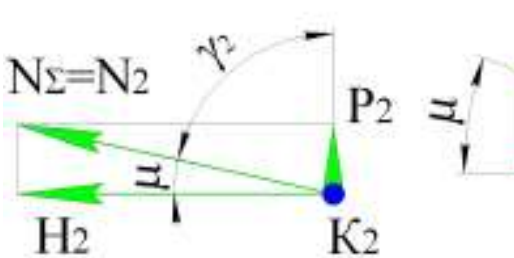

N $\Sigma$

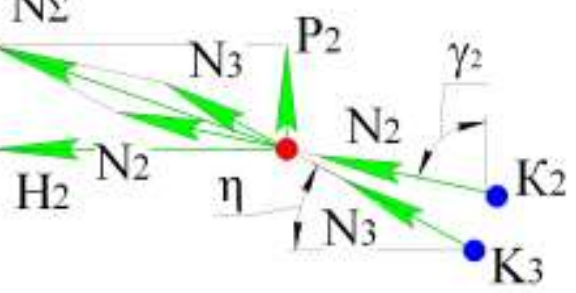



Рисунок 21. Схема гребеневих реакцій у стрілочному переводі

Друга фаза - наїзд на вістря гостряка - триває на ділянці від точки II до точки III (рис. 20). На цій фазі гребінь контактує 3 елементами стрілочного переводу у двох точках: у точці $\mathrm{K}_{2}-3$ рамною рейкою і у точці $\mathrm{K}_{3}-3$ гостряком. Зміна значень реакції $\mathrm{N}_{2}, \mathrm{~N}_{3}$ на ділянці II-III має характер перекладки: у точці II $-\mathrm{N}_{3}=0$, а у точці III $-\mathrm{N}_{2}=0$. Сумарна реакція гребеня на стрілочний перевід складається 3 реакцій у точках $\mathrm{K}_{2}$ i $\mathrm{K}_{3}\left(\overline{\mathrm{N}}_{\Sigma}=\overline{\mathrm{N}}_{2}+\overline{\mathrm{N}}_{3}\right)$ i визначається за формулою

$$
\mathrm{N}_{\Sigma}=\sqrt{\mathrm{N}_{2}^{2}+\mathrm{N}_{3}^{2}+2 \cdot \mathrm{N}_{2} \cdot \mathrm{N}_{3} \sin \left(\gamma_{2}+\eta\right)}
$$

Кут контактування $\mu$ може бути визначений за формулою:

$$
\mu=\operatorname{arctg} \frac{N_{2} \cdot \sin \eta+N_{3} \cdot \cos \gamma}{N_{2} \cdot \cos \eta+N_{3} \cdot \sin \gamma}
$$


Третя фаза - після точки III - рух колеса по гостряку. На цій фазі між рамною рейкою і гребенем з'являється зазор $\tau_{2}$ i спрямовуюче зусилля передається на гребень через точку $\mathrm{K}_{3}$.

$$
\mathrm{P}_{3}=\mathrm{N}_{3} \cdot \sin \eta ; \quad \mathrm{H}_{3}=\mathrm{N}_{3} \cdot \cos \eta .
$$

При відсутності наднормативного зношування і дефектів гостряка його геометрія не створює передумов для вкочування колеса на рейку. Відомі 3 експлуатації випадки сходів, як правило, пов'язані з дефектами гостряків.

Відповідно до «Інструкції по устрою та утриманню колії залізниць України» [393] дефектами стрілочного переводу є:

- роз'єднання стрілочних гостряків з тягою;

- відставання гостряка від рамної рейки більше ніж на 4 мм;

- викрашування гостряка, при якому створюється небезпека набігання гребеня: на головних коліях - 200 мм і більше; на приймально-відправних коліях - 300 мм і більше; на інших коліях - 400 мм і більше;

- пониження гостряка проти рамної рейки на 2 мм і більше, виміряне у перетині, де ширина голівки гостряка або рухомого сердечника зверху 50 мм і більше;

- злом гостряка або рамної рейки.

На рис. 22 показано схеми набігання гребеня на гостряк стрілочного переводу при наявності дефектів гостряка.



a)

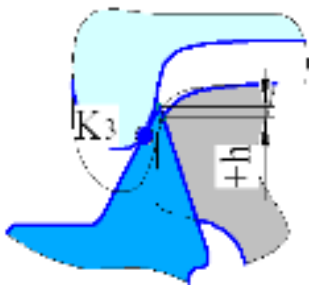

б)

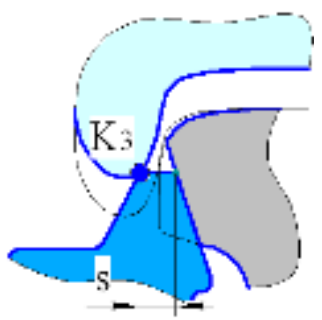

в)

Рисунку 22. Схеми наїзду гребеня на гостряк стрілочного переводу при 
дефектах гостряка:

а) зазор між рамною рейкою і гостряком $(\sigma)$; б) вертикальна деформація гостряка (h); в) відкол гостряка ( s )

Імовірність вкочування гребеня на гостряк залежить, як від кута нахилу профілю гребеня, так і від величин, які характеризують дефекти гостряка. При визначенні допускових параметрів зносу гребенів, що впливають на кут нахилу гребеня, необхідно враховувати допуски на параметри утримання стрілочних переводів.

На рис. 23 показана схема контактування гребеня з гостряком. Кут нахилу профілю $\gamma_{3}$ в точці $\mathrm{K}_{3}$ контакту гребеня 3 гостряком, від якого залежить коефіцієнт запасу стійкості проти сходу з рейок, визначається положенням точки $\mathrm{K}_{3}$ на профілі гребня.

Положення точки контакту гребеня з вістрям гостряка стрілочного переводу $\left(K_{3}\right)$ для конкретного профілю гребеня залежить від трьох основних параметрів: параметра крутості гребеня - qR ; радіусу вершини гребеня - r; зазору між рамною рейкою і гостряком - $\sigma$; заниження вершини гостряка відносно рамної рейки $-\mathrm{h}$; куту нахилу гостряка $-\alpha$.

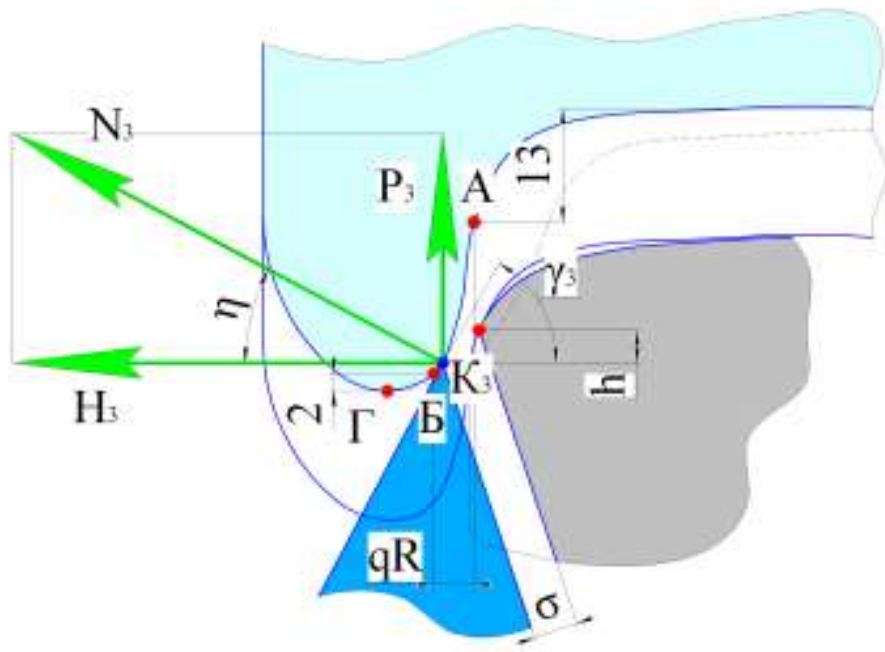

Рисунок 23. Схема контактування гребеня колеса з гостряком 
На рис. 24 показано зазор між рамною рейкою і гостряком $\sigma$ і заниження вершини гостряка відносно рамної рейки h стрілочного переводу.

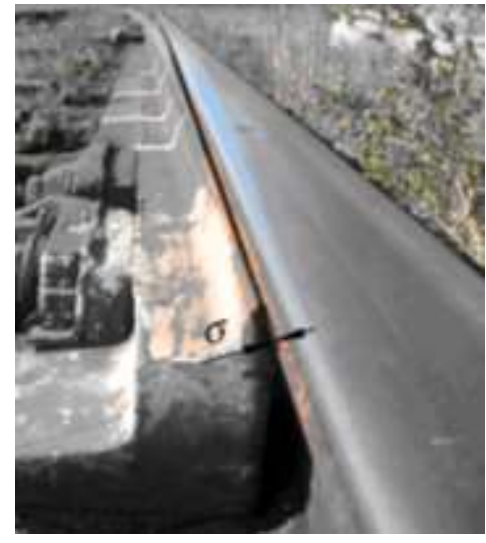

a)

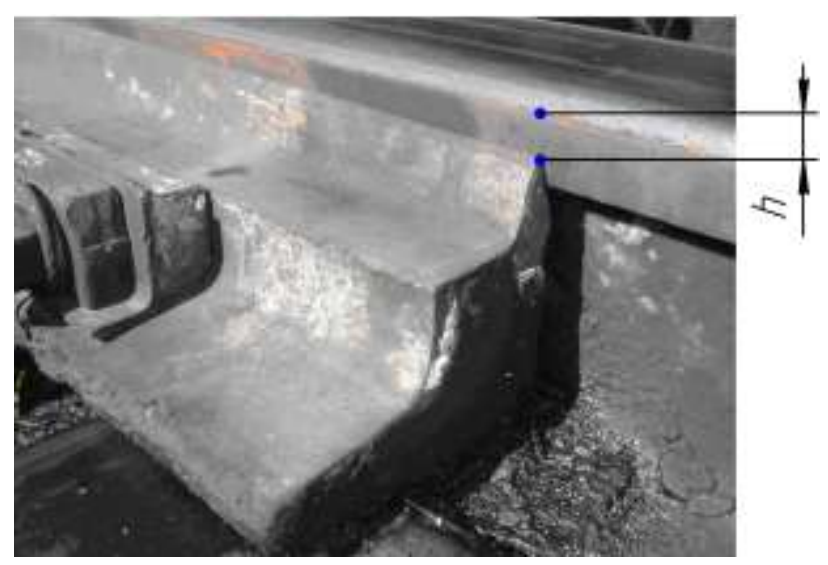

б)

Рисунок 24. Параметри прилягання гостряка до рамної рейки:

а) зазор між рамною рейкою і гостряком $\sigma$;

б) заниження вершини гостряка $h$

При дослідженні впливу параметрів $\sigma, \mathrm{h}, \alpha \mathrm{i}$ r прийнято, що параметр крутості qR має найменше можливе значення $\mathrm{qR}_{\min }$ при максимальному підрізі гребеня, коли кут нахилу гребеня буде дорівнювати $\beta=90^{\circ}$.

На рис..25 показана схема визначення мінімального значення параметра крутості $\mathrm{qR}_{\min }$.



Рисунок 25. Схема співвідношення $\mathrm{qR}, \mathrm{qR}_{\min }, \beta \mathrm{i} \mathrm{r}$ 
Зі схеми на рис. 25 мінімальне значення параметра крутості гребеня визначається за формулою

$$
\begin{aligned}
& \mathrm{qR}_{\text {min }}=\mathrm{r}-2 \cdot \sqrt{\mathrm{r}-1} . \\
& \mathrm{qR}=\mathrm{AA}^{\prime}+\mathrm{r}-2 \cdot \sqrt{\mathrm{r}-1},
\end{aligned}
$$

де $\quad \mathrm{AA}^{\prime} \approx\left(\mathrm{h}_{\mathrm{r}}+\delta-\mathrm{r}-13\right) \cdot \operatorname{ctg} \beta$, звідки

$$
\mathrm{qR}=\left(\mathrm{h}_{\mathrm{r}}+\delta-\mathrm{r}-13\right) \cdot \operatorname{ctg} \beta+\mathrm{r}-2 \cdot \sqrt{\mathrm{r}-1}
$$

На рис. 26 показано схему контактування гребеня і гостряка для розрахунку характеристик стійкості від сходу колеса з рейки при набіганні гребеня на вістря гостряка.

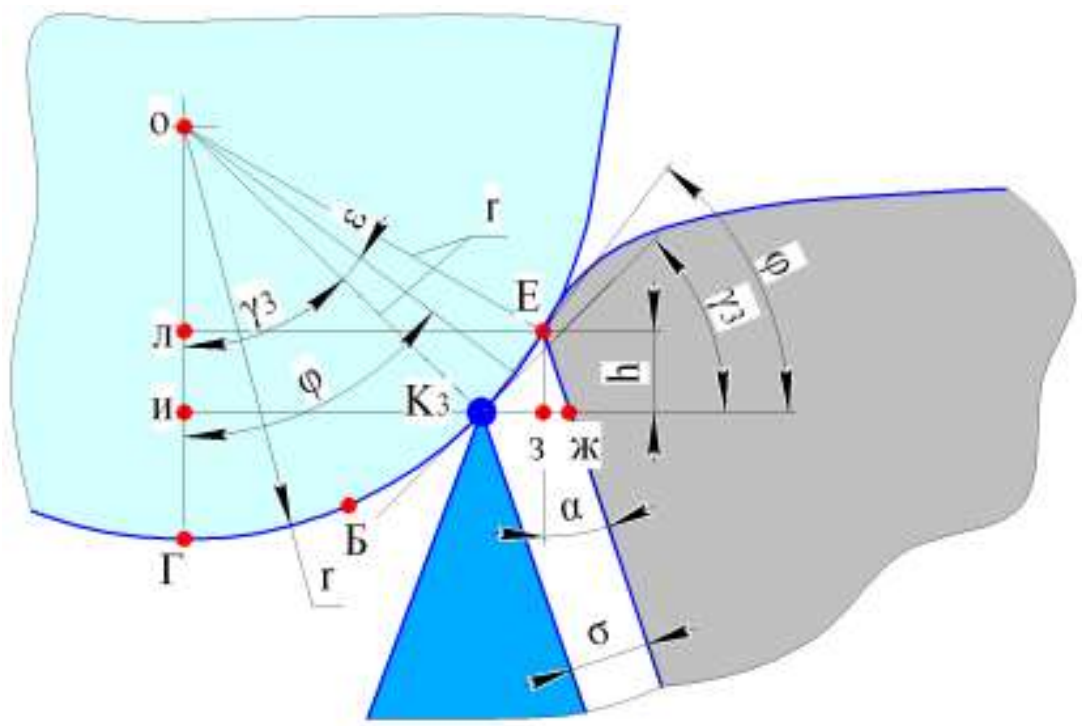

Рисунок 26. Схема контактування гребеня і гостряка

На базі схеми контактування рис. 26 можна визначити залежність кута контактування $\gamma_{3}$ у гребеневому контакті від параметрів стрілочного переводу 
за допомогою наступних виражень

$$
\gamma_{3}=\varphi-\varepsilon,
$$

де $\varphi=\arcsin \frac{\mathrm{h}}{\mathrm{K}_{3} \mathrm{E}}$;

$$
\begin{aligned}
& \mathrm{K}_{3} \mathrm{E}=\sqrt{\mathrm{h}^{2}+\mathrm{K}_{3} 3^{2}} ; \\
& \mathrm{K}_{3} 3=\mathrm{K}_{3} \text { }- \text { K3 }_{3}=\frac{\sigma}{\cos \alpha}-\mathrm{h} \cdot \operatorname{tg} \alpha=\frac{\sigma-\mathrm{h} \cdot \sin \alpha}{\cos \alpha} .
\end{aligned}
$$

Тоді

$$
\begin{gathered}
\mathrm{K}_{3} \mathrm{E}=\sqrt{\mathrm{h}^{2}+\left(\frac{\sigma-\mathrm{h} \cdot \sin \alpha}{\cos \alpha}\right)^{2}}=\frac{\sqrt{\mathrm{h}^{2}+\sigma^{2}-2 \cdot \mathrm{h} \cdot \sigma \cdot \sin \alpha}}{\cos \alpha} \\
\varphi=\arcsin \frac{\mathrm{h} \cdot \cos \alpha}{\sqrt{\mathrm{h}^{2}+\sigma^{2}-2 \cdot \mathrm{h} \cdot \sigma \cdot \sin \alpha}} \\
\varepsilon=\arcsin \frac{\mathrm{K}_{3} \mathrm{E}}{2 \cdot \mathrm{r}} \arcsin \frac{\sqrt{\mathrm{h}^{2}+\sigma^{2}-2 \cdot \mathrm{h} \cdot \sigma \cdot \sin \alpha}}{2 \cdot \mathrm{r} \cdot \cos \alpha}
\end{gathered}
$$

В результаті, залежність кута контактування $\left(\gamma_{3}\right)$ від радіусу профілю при вершині гребеня - r i параметрів стрілочного переводу - $\alpha, \sigma$ i h має наступний вигляд

$$
\gamma_{3}=\arcsin \frac{h \cdot \cos \alpha}{\sqrt{h^{2}+\sigma^{2}-2 \cdot h \cdot \sigma \cdot \sin \alpha}}-\arcsin \frac{\sqrt{h^{2}+\sigma^{2}-2 \cdot h \cdot \sigma \cdot \sin \alpha}}{2 \cdot r \cdot \cos \alpha} .
$$

В якості критерію безпечного наїзду на вістря гостряка стрілочного переводу може бути прийнята умова 


$$
\gamma_{3} \geq\left[\gamma_{3}\right]
$$

де $\left[\gamma_{3}\right]$ - мінімально-допустимий кут контактування - кут, при якому забезпечується безпечне проходження стрілочного переводу.

Для дослідження впливу параметрів стрілочного переводу (зазору між рамною рейкою і гостряком - $\sigma$, заниження вершини гостряка відносно рамної рейки - h i радіусу закруглення вершини гребеня - r) на можливість безпечного проходження колісною парою стрілочного переводу визначається залежність $\sigma=\sigma\left(\mathrm{h}, \mathrm{r}, \gamma_{3}\right)$

Зі схеми на рис. 26 зазор між рамною рейкою і гостряком можна визначити за формулою

$$
\sigma=\mathrm{K}_{3} \% \cdot \cos \alpha
$$

де $\mathrm{K}_{3}$ ж $=\mathrm{K}_{3} 3+$ жз, $\mathrm{K}_{3} 3=\sqrt{\mathrm{K}_{3} \mathrm{E}^{2}-\mathrm{h}^{2}}$, ж3 $=\mathrm{h} \cdot \operatorname{tg} \alpha, \mathrm{K}_{3} \mathrm{E}=2 \cdot \mathrm{r} \cdot \sin \varepsilon$

звідки

$$
\mathrm{K}_{3} ж=\sqrt{4 \cdot \mathrm{r}^{2} \cdot \sin ^{2} \varepsilon-\mathrm{h}^{2}}+\mathrm{h} \cdot \operatorname{tg} \alpha .
$$

Кут $\varepsilon$ можна визначити наступним образом, як різницю кутів $\varphi$ і $\gamma_{3}$

$$
\varepsilon=\varphi-\gamma_{3},
$$

де $\varphi=\arccos \frac{\mathrm{r} \cdot \cos \gamma_{3}-\frac{h}{2}}{r}=\arccos \frac{2 \cdot r \cdot \cos \gamma_{3}-h}{2 \cdot r}$. 
Тоді

$$
\varepsilon=\arccos \frac{2 \cdot \mathrm{r} \cdot \cos \gamma_{3}-\mathrm{h}}{2 \cdot \mathrm{r}}-\gamma_{3} .
$$

3 формул (115)-(118) отримуємо залежність $\sigma=\sigma\left(\mathrm{h}, \mathrm{r}, \gamma_{3}\right)$

$$
\sigma=\left(\sqrt{4 \cdot r^{2} \cdot \sin ^{2}\left(\arccos \frac{2 \cdot r \cdot \cos \gamma_{3}-h}{2 \cdot r}-\gamma_{3}\right)-h^{2}}+h \cdot \operatorname{tg} \alpha\right) \cdot \cos \alpha .
$$

10.1.7 Чисельне інтегрування системи диференціальних рівнянь руху екіпажа

Метою математичного моделювання руху екіпажа є одержання залежностей динамічних характеристики локомотива при русі в прямих і кривих ділянках колії та стрілочних переводах від параметрів зносу поверхонь кочення коліс.

У процесі інтегрування обчислювалися детерміновані залежності наступних параметрів:

- нормальні реакції в основних і гребеневих контактах;

- напрямні зусилля в гребеневих контактах;

- коефіцієнти горизонтальної динаміки;

- коефіцієнти запасу стійкості від сходу з рейок.

Амплітуди горизонтальних поперечних коливань колісних пар, як відомо, обмежені статичним і динамічним зазором рейкової колії.

Амплітуди поперечних коливань колісних пар $\mathbf{y}_{\mathbf{k m}}$, візків $\mathbf{y}_{\mathbf{m}}$ і кузова $\mathbf{y}_{\mathbf{k}}$ визначаються в процесі чисельного інтегрування системи рівнянь за наступними процедурами 


$$
\begin{gathered}
\mathbf{y}_{\mathbf{k m}}=\frac{1}{10} \cdot \sum_{\mathrm{i}=1}^{10} \max _{\mathrm{i}}\left(\mathrm{y}_{\mathrm{km}}(\mathrm{t})\right) ; \\
\mathbf{y}_{\mathbf{m}}=\frac{1}{10} \cdot \sum_{\mathrm{i}=1}^{10} \max _{\mathrm{i}}\left(\mathrm{y}_{\mathrm{m}}(\mathrm{t})\right) ; \\
\mathbf{y}_{\mathbf{k}}=\frac{1}{10} \cdot \sum_{\mathrm{i}=1}^{10} \max \left(\mathrm{y}_{\mathrm{\kappa}}(\mathrm{t})\right) .
\end{gathered}
$$

Частота коливань виляння колісних пар $\left(\mathrm{f}_{\mathrm{km}}\right)$, рам візків $\left(\mathrm{f}_{\mathrm{m}}\right)$ i кузова $\left(\mathrm{f}_{\mathrm{\kappa}}\right)$

$$
\begin{aligned}
\mathrm{f}_{\mathrm{km}} & =\frac{1}{10} \cdot \frac{1}{\mathrm{t}_{\mathrm{km}(\mathrm{n}+1)}-\mathrm{t}_{\mathrm{km}(\mathrm{n})}}, \\
\mathrm{f}_{\mathrm{m}} & =\frac{1}{10} \cdot \frac{1}{\mathrm{t}_{\mathrm{m}(\mathrm{n}+1)}-\mathrm{t}_{\mathrm{m}(\mathrm{n})}}, \\
\mathrm{f}_{\mathrm{\kappa}} & =\frac{1}{10} \cdot \frac{1}{\mathrm{t}_{\kappa(\mathrm{n}+1)}-\mathrm{t}_{\mathrm{\kappa}(\mathrm{n})}},
\end{aligned}
$$

де $\mathrm{t}_{\mathrm{km}(\mathrm{n}+1)}-\mathrm{t}_{\mathrm{km}(\mathrm{n})}, \mathrm{t}_{\mathrm{m}(\mathrm{n}+1)}-\mathrm{t}_{\mathrm{m}(\mathrm{n})}, \mathrm{t}_{\mathrm{\kappa}(\mathrm{n}+1)}-\mathrm{t}_{\mathrm{\kappa}(\mathrm{n})}-$ проміжки часу між двома сусідніми максимальними бічними відхиленнями відповідно колісних пар, рам візків і кузова.

Довжина хвилі виляння колісних пар, рам візків і кузова визначається як відстань, яку проходить колісна пара, рама візка або кузов за час, відповідно, $\Delta \mathrm{t}_{\mathrm{km}}, \Delta \mathrm{t}_{\mathrm{m}}, \Delta \mathrm{t}_{\mathrm{K}}$

$$
\mathrm{L}_{\mathrm{km}}=\mathrm{V} \cdot \Delta \mathrm{t}_{\mathrm{km}} ; \quad \mathrm{L}_{\mathrm{m}}=\mathrm{V} \cdot \Delta \mathrm{t}_{\mathrm{m}} \cdot ; \quad \mathrm{L}_{\mathrm{\kappa}}=\mathrm{V} \cdot \Delta \mathrm{t}_{\mathrm{K}} \cdot
$$


Для інтегрування системи диференціальних рівнянь обраний чисельний метод Хеммінга [395]. Програма була написана алгоритмічною мовою Fortran. Для інтегрування системи рівнянь використаний компілятор з автоматичним коректуванням кроку інтегрування по заданій точності.

Відповідно до типової програми інтегрування диференціальних рівнянь [396] система рівнянь Лагранжа повинна бути приведена до нормального вигляду Коши

$$
\ddot{x}_{\mathrm{n}}=\frac{1}{\mathrm{M}_{\mathrm{n}}}\left(\mathrm{F}_{\mathrm{n}}-\frac{\partial \Phi}{\partial \dot{\mathrm{x}}_{\mathrm{n}}}-\frac{\partial \Pi}{\partial \mathrm{x}_{\mathrm{n}}}\right), \quad \mathrm{n}=1 \ldots 36,
$$

де $\mathrm{M}_{\mathrm{n}}$ - узагальнені маси елементів системи.

Крім того, система повинна включати тільки диференційні рівняння першого порядку, тому отримана система рівнянь другого порядку (124) приводиться до системи першого порядку

$$
\left\{\begin{array}{l}
\dot{\mathrm{z}}_{\mathrm{n}}=\frac{1}{\mathrm{M}_{\mathrm{n}}}\left(\mathrm{F}_{\mathrm{n}}-\frac{\partial \Phi}{\partial \dot{\mathrm{x}}_{\mathrm{n}}}-\frac{\partial \Pi}{\partial \mathrm{x}_{\mathrm{n}}}\right), \quad \mathrm{n}=1 \ldots 36, \\
\dot{\mathrm{x}}_{\mathrm{n}}=\mathrm{z}_{\mathrm{n}}
\end{array}\right.
$$

Початкова умова інтегрування: поперечне відхилення колісних пар, що набігають - 0,005 м [390]; рух з постійними швидкостями в діапазоні 2-30 м/с.

На рис. 27 показано блок-схему алгоритму інтегрування системи рівнянь. Для отримання залежностей показників динаміки та безпеки руху необхідне обчислення наступних детермінованих характеристик руху:

- кінематичні параметри руху: амплітуди, частоти, довжини хвиль виляння колісних пар і візків; швидкості ковзання у гребеневих контактах; кути контактування;

- динамічні параметри руху: нормальні реакції в основних і гребеневих 
контактах; коефіцієнти горизонтальної динаміки; коефіцієнти запасу стійкості від сходу з рейок.

Результати дослідження допускових параметрів зносу поверхонь кочення коліс та їх впливу на динамічні характеристики локомотива приведено у четвертому розділі роботи.

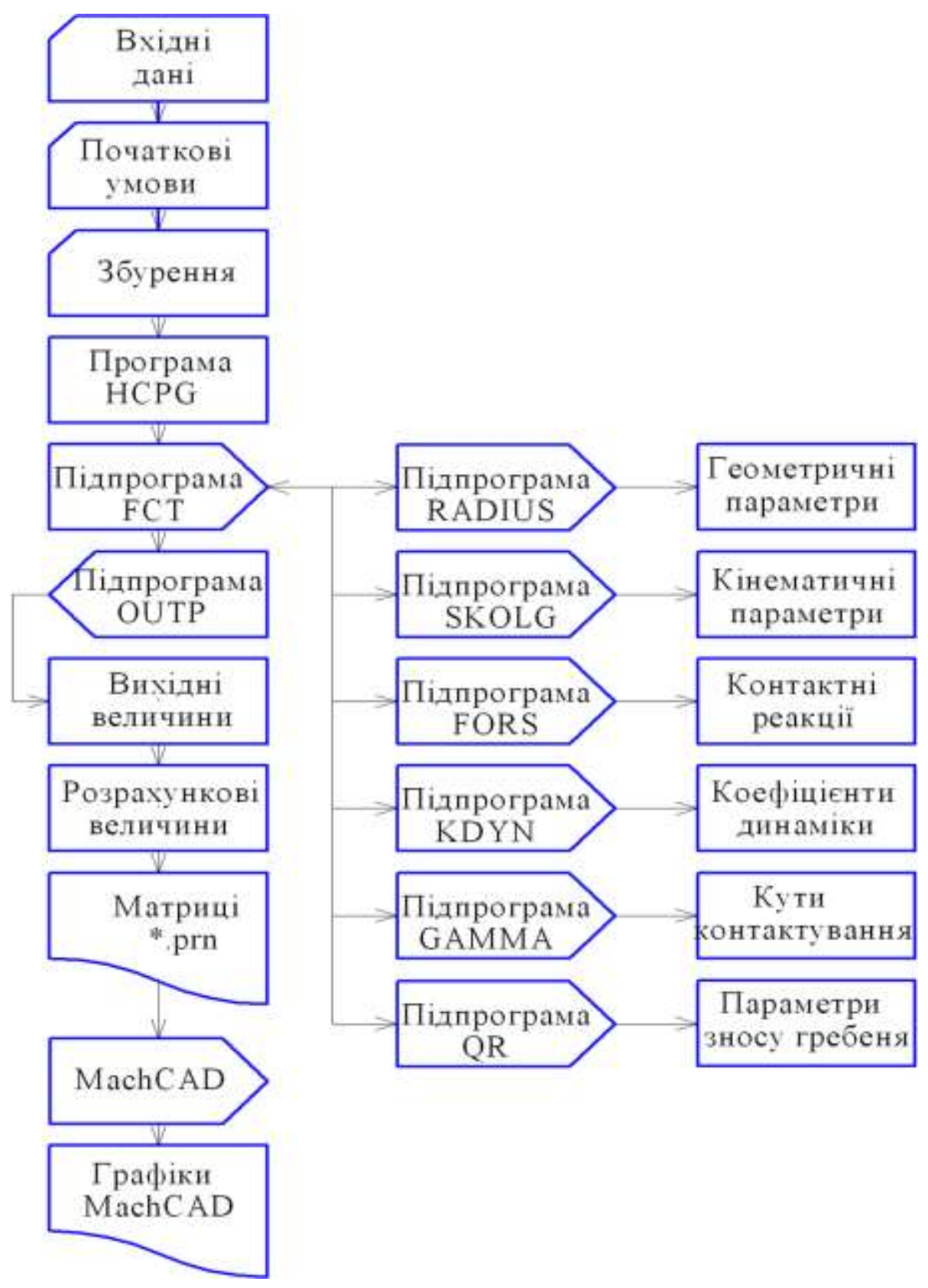

Рисунок 27. Алгоритм інтегрування системи диференційних рівнянь 
10.1.8. Висновки.

1. В монографії розроблено математичну модель руху екіпажу тепловоза 2ТЭ116, що відрізняється від відомих вдосконаленим описом гребеневої фрикційної взаємодії коліс із рейками.

2. На основі принципу суперпозиції запропоновано метод кінематичних компонентів проковзування у контакті гребеня з рейкою.

3. На основі аналізу геометричних характеристик профілів коліс і рейок визначено основні параметри гребеневого контактування, до яких відносяться:

- координати центрів контактних плям;

- радіуси профілю колеса в точках контактів;

- ухили профілю колеса в точках контактів;

- вертикальні навантаження в точках контактів.

4. Вдосконалено модель перерозподілу контактних навантажень між контактами гребеня колеса із елементами стрілочного переводу: рамною рейкою і гостряком.

5. Вдосконалено модель стрілочного переводу на основі урахування відхилень параметрів стрілочного переводу від номінальних і динамічних процесів «ущільнення» стрілки.

6. Розроблено графоаналітичний метод моделювання формоутворення зношених профілів коліс і рейок. Метод заснований на припущенні, що знос взаємодіючих коліс і рейок пропорційний ступеню взаємного проникнення контурів досліджуваних профілів і коефіцієнту відносного зносу колеса і рейки.

7. Розроблено метод динамічного моделювання відносної інтенсивності підрізу гребенів, заснований на енергетичному принципі оцінки масового зносу. Метод дозволяє отримати співвідношення прокату і підрізу в процесі формоутворення профілю на детермінованих динамічних моделях руху екіпажа. 


\subsection{The influence of the configuration of transport work on the time parameters of transport services}

The main purpose of experimental research is to test in practice the effectiveness of the proposed theoretical provisions and principles of management decisions to improve the quality of public transport services (QPTS) [397-400], to establish an empirical relationship between configuration management parameters and QPTS evaluation indicators. The purpose of the simulation experiment is to establish characteristic information about the influence of configuration parameters of the transport offer on the indicators of QPTS basic types of routes [401-403]. Simulation modeling is a process of construction and testing of the algorithm for modeling the functioning of the route, simulating the behavior and interaction of the subjects of the system, taking into account the nature of stochastic processes of passenger flow in stopping points, the range of deviations (fluctuations) passenger movements on adjacent routes [404-408]. The simulation model reproduces the stochastic process of changing discrete states of QPTS at different combinatorial variants of the number of vehicles on the route $\left(b_{t}^{r}\right)$ and their capacity $\left(g_{b}^{r}\right)$, which in combination with technical and operational indicators (turnaround time $\left(t_{e}^{r}\right)$, stop time $\left(\tau_{a}^{r}\right)$ the arrival of the vehicle $\left(j_{p}^{r}\right)$ ) forms an internal combination of the transport capability of the route. When software implementation of the model on a computer is the accumulation of statistical data on the indicators of QPTS, which is the subject of further analysis. The data obtained during the simulation are the basis for statistical processing and establishing patterns of change parametric areas of influence QPTS.

Analysis of the operating conditions of urban public passenger transport routes (PPT) showed that the main controlling influence of configuration management is the choice of capacity and number of rolling stock. This procedure must also take into account the time parameters of the formation of the transport offer at each stopping point, which is achieved by taking into account the deviation (fluctuation) of the arrival of vehicles. Three types of buses were used for the analysis: especially small class Ruta 
A048.4 ( $g_{b}^{r}=21$ pas.), small class BAZ A079 ( $g_{b}^{r}=38$ pas.), large small class MAZ 206 ( $g_{b}^{r}=72$ pas.). The number of rolling stock on each route varies from 5 un/ up to 15 un. To determine the operating costs, the actual reporting data of motor transport enterprises on variable and fixed operating costs of these brands of buses were used. On the basis of field observations, the average values of the fluctuation of the arrival of vehicles to the stopping points were determined. During the simulation, two variants of values of the range of arrival fluctuation were considered: the first - the actual value, the second - the fluctuation is determined by the conditions of permissible deviation, which for urban routes is 2 minutes. The simulation takes into account that the actual fluctuation implies the possibility of arrival of the vehicle at any time in the fluctuation range. When establishing the distribution of passenger flows between the routes, it was assumed that all adjacent routes have a fixed time of arrival of vehicles to the stopping points. The moment of arrival of buses of the studied route is determined ramdomno taking into account the interval of movement and the range of fluctuations. When conducting simulation experiments, the established laws of distribution of random variables and their indicators were used. The results of passenger questionnaires for each stopping point of the route were used as parameters to establish the degree of compliance of QPTS.

The results of the simulation experiment allow to analyze the influence of the configuration of the provided transport offer in different conditions of traffic organization (according to the schedule and with fluctuation) on the main operational indicators of QPTS. This analysis is performed in an analytical form based on preestablished statistical models and aims to identify the main characteristic types and trends of causation. To implement the procedure for analyzing the results of experimental research, it is advisable to use visual and graphical representation. This form provides for their visualization in the form of a set of typical graphs on which the system of basic coordinates reproduces the characteristic patterns of change in the parameters of the evaluation of QPTS. The number of rolling stock is the basic value that determines the transport supply. In fig. 1-3 shows the graphs of changes in QPTS 
indicators for the route №250e (Kharkiv) for buses Ruta A048.4 ( $g_{b}^{r}=21$ pas.), BAZ A079 ( $g_{b}^{r}=38$ pas.) and MAZ 206 ( $g_{b}^{r}=72$ pas.) for fluctuation of 7 minutes.

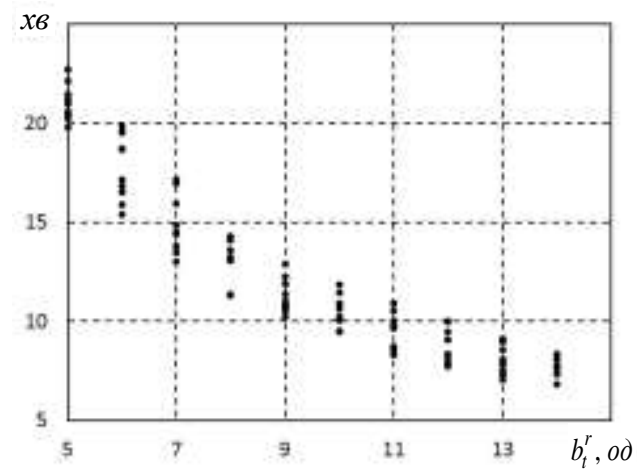

a)

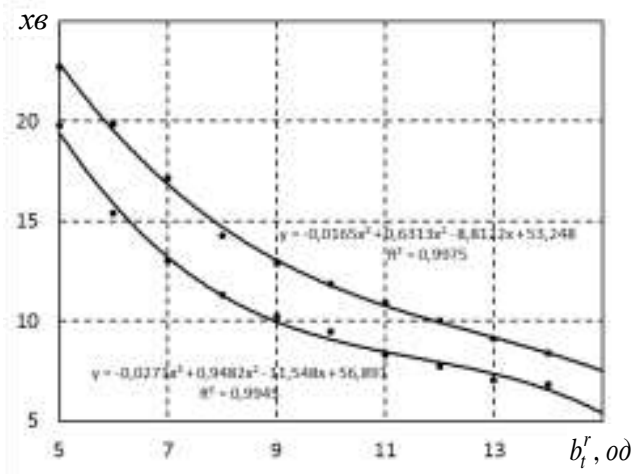

b)

$a$ - average waiting time; $b$ - distribution of waiting time change limits

Figure 1. Influence of the number of rolling stock on the average waiting time (route №250e, Ruta A048.4 ( $g_{b}^{r}=21$ pas.), fluctuation range 7 min.)



a)

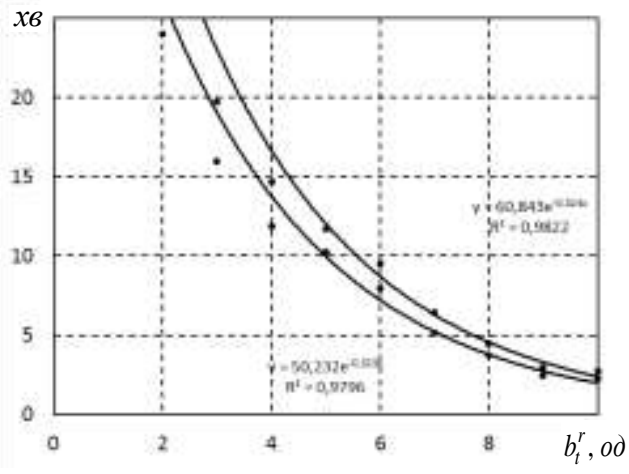

b)

$a$ - average waiting time; $b$ - distribution of waiting time change limits

Figure 2. Influence of the number of rolling stock on the average waiting time (route №250e, BAZ A079 ( $g_{b}^{r}=38$ pas.), fluctuation range $7 \mathrm{~min}$.) 


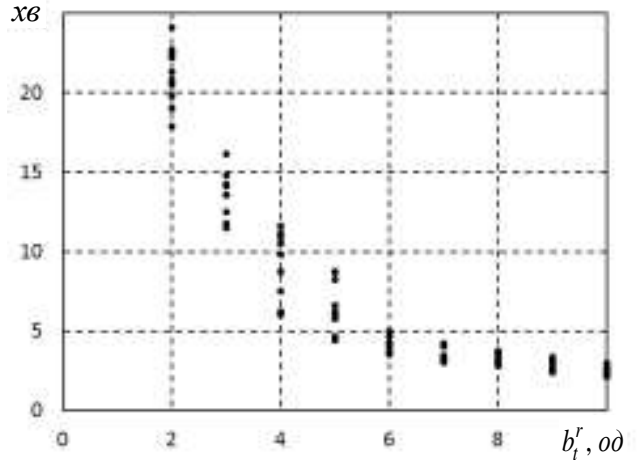

a)



b)

$a$ - average waiting time; $b$ - distribution of waiting time change limits

Figure 3. Influence of the number of rolling stock on the average waiting time (route №250e, MAZ 206 ( $g_{b}^{r}=72$ pas.), fluctuation range $7 \mathrm{~min}$.)

The presented dependences reflect the change in the indicators of QPTS in the presence of fluctuations in the movement of buses along the route. Traffic fluctuation is the deviation of the arrival time from the planned traffic interval on the route. It is assumed that the arrival can occur randomly at any time from the range of fluctuations, and the time of deviation is not described by any law of distribution of random variables. There are a number of objective and subjective factors that cause motion fluctuations. Objective factors include the complexity of the conditions for the implementation of technological operations, which is manifested in the occurrence of additional traffic delays in the objects of passenger transport infrastructure and elements of the road network. Subjective factors of traffic fluctuations are situations in which there is a downtime at stopping points associated with additional expectations of passengers or other non-productive functions. In the case of creating conditions for stabilizing the time of bus traffic through the allocation of separate lanes for PPT on routes, it is possible to completely eliminate the fluctuations of arrival at bus stops. In fig. 4 - 5 shows graphs of changes in QPTS indicators for the route №250e «Art. South Station - st. Berkosa» for without fluctuations. 


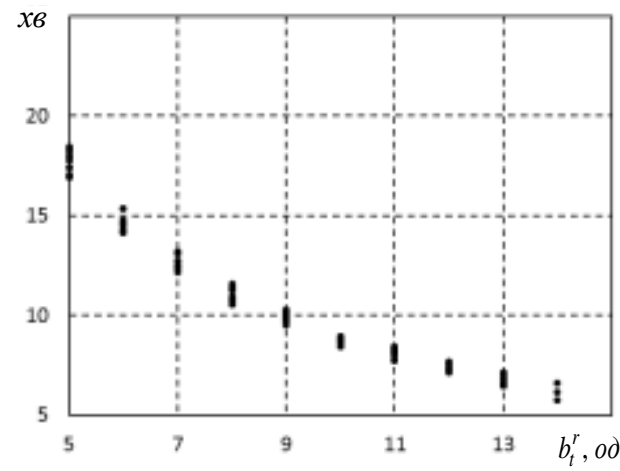

a)



b)

$a$ - average waiting time; $b$-distribution of waiting time change limits Figure 4. Influence of the number of rolling stock on the average waiting time (route №250e, Ruta A048.4 ( $g_{b}^{r}=21$ pas.), without fluctuations)

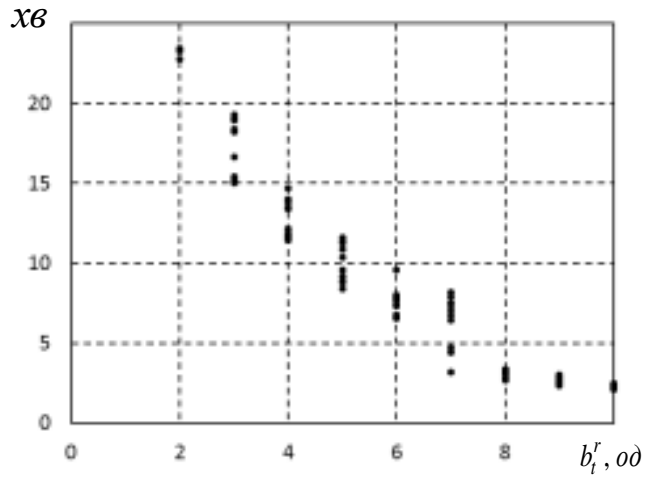

a)

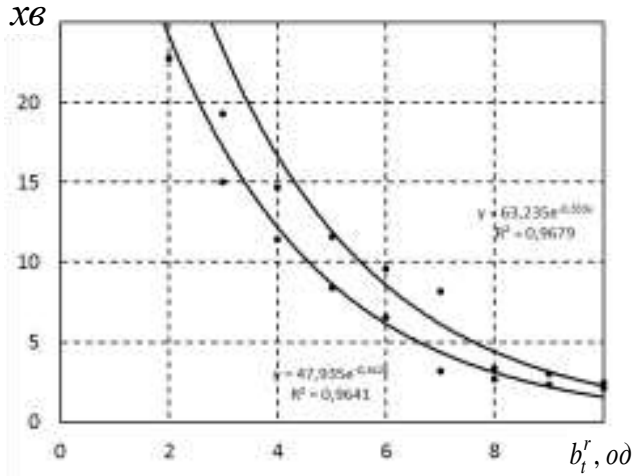

b)

$a$ - average waiting time; $b$-distribution of waiting time change limits

Figure 5. Influence of the number of rolling stock on the average waiting time (route №250e, BAZ A079 ( $g_{b}^{r}=38$ pas.), without fluctuations)

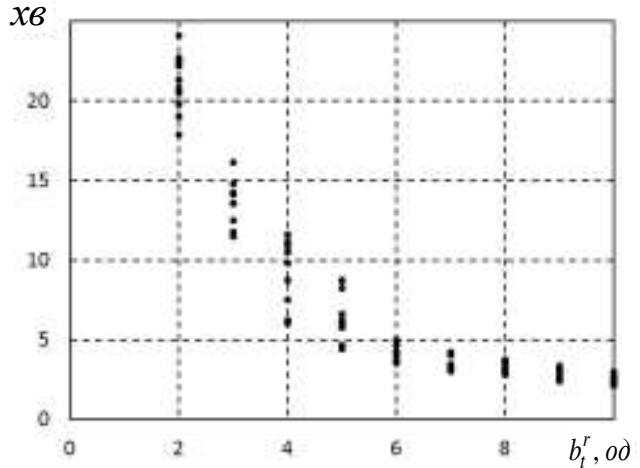

a)

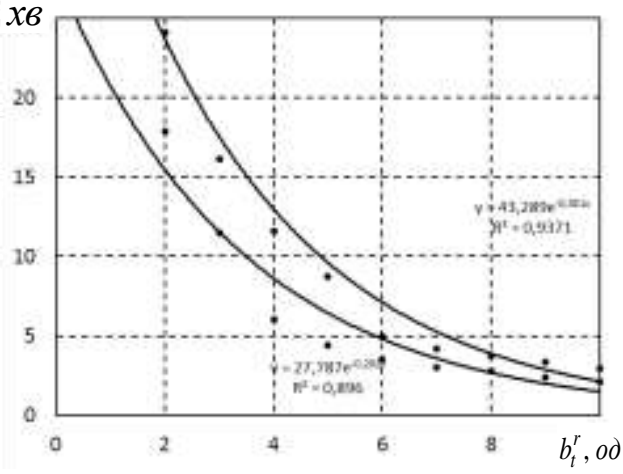

b)

$a$ - average waiting time; $b$ - distribution of waiting time change limits

Figure 6. Influence of the number of rolling stock on the average waiting time (route №250e, MAZ 206 ( $g_{b}^{r}=72$ pas.), without fluctuations) 
Analyzing the presented dependences of change of indicators of QPTS for a route №250e under conditions of use of buses of Route A048.4 it is possible to establish the following:

- the presence of traffic fluctuations on the route leads to an increase in the scattering (noise) of the values of QPTS, which is due to the instability of the intervals of arrival of buses to bus stops and fluctuations in the actual passenger flow;

- $\quad$ in accordance with the requirements for the maximum waiting time for bus passengers on the route (for the degree $A_{b}$ of $15 \mathrm{~min}$.) it is necessary that the route operates at least 8 buses for conditions with fluctuations of arrival and at least 7 for conditions without fluctuations of arrival;

- $\quad$ ensuring the permissible level of filling the cabin on the route requires at least 12 buses of rolling stock Ruta A048.4;

- $\quad$ regularity of communication at a satisfactory level is provided by 7 buses in the presence of fluctuations of arrival and 6 buses without it;

- $\quad$ travel time ranges from 12 minutes to 19 minutes, the minimum value at the upper limit of change is 14 minutes in the absence of traffic fluctuations;

- $\quad$ limits of change of QPTS indicators are described by polynomials of the second and third degree and have high levels of adequacy;

- $\quad$ elimination of traffic fluctuations makes it possible to improve the values of QPTS indicators and ensure their compliance with the requirements of passengers with the use of fewer rolling stock.

Analyzing the presented dependences it is possible to draw a conclusion about the positive nature of the impact of increasing the capacity of rolling stock. So the waiting time is less than $15 \mathrm{~min}$. it is possible to provide using on the route 5 buses BAZ A079, which is smaller in comparison with buses BAZ A079. It is also possible to improve the regularity of the connection and the level of filling the cabin through the use of larger buses. This is due to the fact that increasing the capacity of the bus leads to an increase in the level of transport supply, which eliminates the expectations associated with the lack of free seats in buses. The volume of transportation on the 
route increases with the increase in the level of transport supply and the improvement of QPTS. However, there is a clear trend, indicating that there is a limit to the feasibility of increasing supply. So for the route №250e when using Ruta A048.4 buses in the amount of more than $11 \mathrm{un}$. there is a significant decrease in the level of increase in the volume of traffic, for the bus BAZ A079 this limit is at point 7 un., and for the bus MAZ 206 - 6 un. This is explained by the conditions of formation of the marginal technological utility of PPT management, which is determined by the derivative of the total accumulated utility. In essence, this means that further increase in transport supply is ineffective in terms of impact on QPTS indicators and the need to use other methods of managing the work of PPT, including through the implementation of measures to improve traffic conditions on the road network.

The procedure for assessing QPTS involves establishing the degree of compliance with the requirements of passengers to the values of indicators. At the first stage, on the basis of the methods of distribution of passengers by consumer groups proposed in the third section, the number of observation layers is established and the required sample size is calculated. In the future, the monitoring of passengers' requirements for service parameters is carried out, followed by the recognition of YATON levels. The selected criterion requirements for the distribution of QPTS compliance degrees are a scale of parametric evaluation. In table 1 for the route №250e «art. South Station - st. Berkosa» presents the values of indicators of transition of QPTS degrees.

Table 1 - Degrees of compliance QPTS (route №250e)

\begin{tabular}{|c|c|c|c|c|c|}
\hline \multirow{2}{*}{ QPTS indicator } & \multicolumn{5}{|c|}{ Degrees of compliance QPTS } \\
\cline { 2 - 6 } & $A_{d}$ & $A_{b}$ & $A_{a}$ & $A_{w}$ & $A_{v}$ \\
\hline $\begin{array}{c}\text { Average waiting time, } \\
\text { min }\end{array}$ & over 15 & $12-15$ & $8-12$ & $5-8$ & under 5 \\
\hline $\begin{array}{c}\text { The maximum level of } \\
\text { filling of buses }\end{array}$ & over 1,3 & $1,1-1,3$ & $0,9-1,1$ & $0,7-0,9$ & under 0,7 \\
\hline
\end{tabular}


It is possible to determine the conditions of transition of the degree of conformity of QPTS according to the specified indicators on the basis of the analysis of the obtained simulation results. For this purpose, the rules of discrete selection of management decisions are used, which provide for the establishment of integer values of the number of rolling stock as an element of influence on the parameters of QPTS. To establish the number of rolling stock required to ensure the degree of compliance, a minimax model is used in which the number of rolling stock is selected at the lowest rate, provided that its value takes the maximum level from the scattering range. The conditions of the provided configuration transport offer, ensuring the achievement of different degrees of compliance are presented in table 2.

Table 2 - QPTS compliance conditions (route №250e)

\begin{tabular}{|c|c|c|c|c|c|c|}
\hline Traffic & Bus model & \multicolumn{5}{|c|}{ Degrees of compliance QPTS } \\
\cline { 2 - 7 } conditions & & $A_{d}$ & $A_{b}$ & $A_{a}$ & $A_{w}$ & $A_{v}$ \\
\hline $\begin{array}{c}\text { Fluctuation } \\
\text { range 7 min. }\end{array}$ & $\begin{array}{c}\text { Ruta A048.4 ( } \\
g_{b}^{r}=21 \text { пас.) }\end{array}$ & 7 & 9 & 11 & 13 & 14 \\
\cline { 2 - 7 } & $\begin{array}{c}\text { BAZ A079 }\left(g_{b}^{r}\right. \\
=38 \text { пас.) }\end{array}$ & 3 & 4 & 5 & 7 & 8 \\
\cline { 2 - 7 } & $\begin{array}{c}\text { MAZ 206 ( } g_{b}^{r} \\
=72 \text { пас.) }\end{array}$ & 3 & 4 & 5 & 6 & 7 \\
\hline $\begin{array}{c}\text { Without } \\
\text { fluctuations }\end{array}$ & $\begin{array}{c}\text { Ruta A048.4 ( } \\
g_{b}^{r}=21 \text { пас.) }\end{array}$ & 7 & 9 & 10 & 12 & 13 \\
\cline { 2 - 7 } & $\begin{array}{c}\text { ВAZ A079 ( } g_{b}^{r} \\
=38 \text { пас.) }\end{array}$ & 3 & 4 & 5 & 6 & 7 \\
\cline { 2 - 7 } & $\begin{array}{c}\text { MAZ 206 ( } g_{b}^{r} \\
=72 \text { пас.) }\end{array}$ & 3 & 4 & 5 & 6 & 7 \\
\hline
\end{tabular}

Analyzing the data level of table 2 and estimating the amount of costs for the operation of the route, it is possible to establish a rational option of providing transport services in which the degree of QPTS will be observed at the level of good ( $\left.A_{w}\right)$ and there will be minimal costs. For the route №250e in the presence of fluctuations such is the configuration variant of BAZ A079 ( $g_{b}^{r}=38$ pass.) in the amount of 13 buses, and for conditions without fluctuation BAZ A079 ( $g_{b}^{r}=38$ pass.) in the amount of 12 buses. 


\section{3 Використання технологій інтернету речей (IоT) у керуванні громадським транспортом у сільській місцевості}

На сьогоднішній день існує чимало способів задоволення своїх потреб у переміщенні для мешканців міст без використання власних транспортних засобів: вони можуть скористатися різноманітними послугами системи громадського транспорту і послуг шерінгу транспортних засобів, у містах розбудовується інфраструктура велотранспорту і пішохідних прогулянок (у т.ч. для осіб з обмеженими можливостями). Беручи до уваги тенденцію старіння населення, можемо припустити, що все більше і більше осіб будуть покладатись на громадський транспорт, оскільки навички водіння погіршуються 3 віком. Практично нормою стало керування транспортом у місті згідно з інформацією, зібраною з камер на вулицях, даних з транспортних засобів і т.п. Таке керування $\epsilon$ частиною концепції “розумного міста”, яка полягає у поєднанні досягнень в сфері технологій збору даних та Інтернету речей (Internet of Things, IoT). Концепція технологій ІоТ передбачає виконання пристроями певних дій без втручання людини.

Одночасно використання ІоТ дозволяє підвищити зручність користування громадським транспортом для пасажирів. Сучасно облаштовані зупинки надають можливість підзарядити портативні носії, надають доступ до мережі Інтернет за технологією $\mathrm{Wi}-\mathrm{Fi}$, демонструють карту із зображенням місця перебування транспорту та надають іншу, необхідну для пасажирів інформацію. Користувач громадського транспорту може відслідкувати рух громадського транспорту в реальному часі незалежно від свого місцезнаходження. Вагомим здобутком запровадження технологій Інтернету речей для громадського транспорту стала безготівкова оплата за проїзд, у тому числі з використанням електронного квитка.

Використання IoT та даних, які ця технологія може забезпечити, дозволяє потенційно збільшити адаптацію послуг до конкретних сегментів споживачів (наприклад, для осіб з обмеженими можливостями), покращити безпеку, 
оптимізувати частоту рейсів громадського транспорту, час обслуговування та кількість зупинок.

Міські райони часто асоціюються 3 можливостями Інтернету речей, застосуванням концепції розумного міста. Однак, оскільки наша головна мета полягає в тому, щоб дослідити, чи можуть системи громадського транспорту в сільській місцевості отримати користь від впровадження технологій Інтернету речей, ми зосередилися на розумній території (Bonomi \& Masiero, 2014; Bria \& Morozov, 2018) та розумній територіальній громаді (Махначова Н.M., 2019), які є ширшими концепціями, ніж розумне місто.

Люди, які живуть у сільській місцевості, мають значно менше варіантів використання громадського транспорту, ніж у великих містах. У той же час жителі цих територій їздять на роботу, в школу, до лікаря або в місцевий магазин так само, як і міські жителі. Їх основним засобом пересування є автомобіль, оскільки вони не можуть скористатися транспортною інфраструктурою або послугами, доступними в містах. Послуги громадського транспорту у сільській місцевості зазвичай надаються автобусними операторами або транспортом на замовлення, оскільки такий вид транспорту є найдешевшим у менш населених районах. Система громадського транспорту у сільській місцевості все ще потребує покращення, що є суттєвим викликом для забезпечення розвитку місцевих громад.

У сільських районах прослідковуються стійка тенденція демографічних змін, які в основному зумовлені асиметричним розподілом економічної діяльності між сільською та міською місцевістю. Головні офіси великих компаній, робочі місця та університети зазвичай розташовані у великих містах, що змушує сільських жителів (зокрема, молодь) прийняти важливе рішення: переїхати до міста чи залишитися в селі. В останньому випадку їм треба прикладати більше зусиль для досягнення своїх базових потреб (наприклад, робоче місце, школа). Люди часто вибирають перший варіант, в результаті чого в сільській місцевості середній вік зростає, що в кінцевому підсумку перетворює літніх людей на основну частину сільського населення. Попит на транспортні 
послуги часто важко спрогнозувати, оскільки населення розподілено на великих територіях, а пасажирів, як правило, дуже мало, через що попит на транспорт є низьким i непередбачуваним. Тому надання частих i широко доступних комерційних послуг громадського транспорту важко виправдати 3 огляду на кількість потенційних користувачів. Це призводить до поганої роботи системи громадського транспорту що, як наслідок, є додатковою причиною міграції до міста.

Процес старіння разом із міграцією молодого покоління негативно впливають на соціально-економічний стан сільської місцевості, що відображається, наприклад, у скороченні надання місцевих послуг (закриття поштових відділень, амбулаторій, закладів освіти, комунальних послуг). Тим не менш, потреба в транспортних послугах для соціально незахищених верств населення (наприклад, літніх людей, дуже молодих людей, осіб з інвалідністю) у сільській та віддаленій місцевості є незаперечна.

Ще десять років тому окремі автори (Gubbi et al., 2013; Whitmore et al., $2015)$ почали відзначати використання технологій Інтернету речей, як одного 3 інноваційних і динамічних підходів до поліпшення системи громадського транспорту в сільській та периферійній місцевості. Він зробив можливим легко та ефективно збирати та аналізувати інформацію, оскільки речі та пристрої, включені в мережу інформаційних потоків, безпосередньо виконують усі необхідні для цього дії (Zanella et al., 2014; Наконечний \& Bepec, 2016; Talari et al., 2017; Бочкарёв \& Кузнецов, 2020).

Використання Інтернету речей відкриє нові можливості майже для всіх аспектів керування громадським транспортом, зокрема планування перевезень та моніторинг і коригування перевезень пасажирів.

Основною можливістю, яку може надати використання технологій Інтернету речей і яка наразі не використовується, є збільшення кількості користувачів транспорту в сільській місцевості. Належне коригування та збалансованість послуг громадського транспорту в межах території 3 роздробленою структурою населених пунктів на базі даних, зібраних за 
допомогою Інтернету речей, може покращити якість послуг для всіх верств населення та підвищити привабливість громадського транспорту для потенційних пасажирів, що збільшить їх кількість і, відповідно, економічну привабливість пасажирських перевезень.

Одночасно існують і очевидні проблеми у впровадженні керування транспортом у сільській місцевості з використанням технологій Інтернету речей. Насамперед слід згадати відсутність у літературі та практиці єдиного набору стандартних показників для оцінювання маршруту. Маршрути можуть характеризуватися безліччю показників, які часто не всі враховуються, або які враховуються лише в одному дослідженні, але не враховуються в інших. Наявність загальноприйнятих базових показників для порівняння маршрутів дозволить краще порівнювати рішення, які спрямовані на пропозицію оптимальних маршрутів для користувачів (перевізників і пасажирів). Зокрема маршрут можна розглядати як складений 3 певної кількості однорідних сегментів, кожен з яких має свої особливості. Деякі з них є досить стабільними в довгостроковій перспективі (наприклад, наявність тротуару, ширина дороги, ухил, кількість смуг), тоді як інші змінюються в короткостроковій перспективі (наприклад, завантаженість дороги транспортними засобами, припарковані транспортні засоби на узбіччі дороги). Додатково треба брати до уваги стан доріг у різних районах у різну пору року чи залежно від погодних умов. На сільських територіях зберігається великий відсоток грунтових доріг, які можуть ставати непроїзними після сильних опадів. Загалом поганий стан сільських доріг призводить до уповільнення руху транспортних засобів між населеними пунктами, більшого зносу транспортних засобів i, відповідно, зменшення економічної привабливості таких перевезень. Правильне поєднання основних показників може в кінцевому підсумку привести до визначення набору стандартизованих показників, які можна використовувати для оцінки маршрутів і легкого порівняння рішень для планування маршрутів.

Наступним кроком повинно стати визначення вагових коефіцієнтів стандартизованих показників з метою вибору оптимального маршруту. Вагові 
коефіцієнти в ідеалі мають відображати умови навколишнього середовища в реальному часі. Оптимальний маршрут повинен залежати від середовища та користувача, тобто динамічно визначатися відповідно до контексту. Встановлення динамічних критеріїв для оптимального визначення маршруту може також враховувати загальні обмеження, які встановлюють органи місцевого самоврядування.

У контексті дій обмежень у виборі маршрутів, окрім органів місцевого самоврядування слід згадати проблему координації на національному, регіональному чи місцевому рівні пасажирських перевезень, різноманітність задіяних видів транспорту, а також велику кількість національних, регіональних та/або місцевих органів влади, які мають фінансові, інфраструктурні чи експлуатаційні права та обов'язки. Технології Інтернету речей можуть прискорити збір даних та надання інформації про сільський транспорт, що дає можливість місцевим органам влади надавати вичерпну інформацію про поточні тенденції його використання в певній місцевості. Проте налагодження взаємодії між різними органами влади на місцях у прийнятті рішень 3 регулювання пасажирських перевезень і розвиток транспортної інфраструктури вже виходить за межі суто інженерних технічних рішень.

С. Порру, Ф. Мicco, Ф. Пані і С. Репетто (Porru et al., 2020) проаналізували можливості застосування технологій Інтернету речей у керуванні громадським транспортом у сільській і міській місцевості (табл. 1 і 2).

Таблиця 1. Функції технологій Інтернету речей для аналітиків у сфері громадського транспорту

\begin{tabular}{|l|l|}
\hline \multicolumn{1}{|c|}{ Функції } & \multicolumn{1}{|c|}{$\begin{array}{c}\text { Ефективні в управлінні } \\
\text { громадським транспортом }\end{array}$} \\
\hline 3бір даних про подорожуючих & Сільським і міським \\
\hline 3бір даних про транспортні засоби & Сільським і міським \\
\hline 3бір даних про трафік & Сільським і міським \\
\hline 3бір даних про якість повітря & Сільським і міським \\
\hline 3бір даних про інфраструктуру & $\begin{array}{l}\text { Більше підходить для сільського } \\
\text { транспорту }\end{array}$ \\
\hline 3бір даних про пункти пересадки & Сільським і міським \\
\hline
\end{tabular}

Джерело: Porru et al., 2020, c.95 
Як видно з табл. 1, функції, які можуть забезпечувати технології Інтернету речей, навіть більш корисні для аналітичної діяльності щодо керування громадським транспортом у сільській місцевості. Аналогічний висновок до попереднього ми отримуємо і у випадку подорожуючих сільською місцевістю 3 табл. 2. Тут хочемо наголосити, що потенційними пасажирами є не тільки місцеві жителі та їх гості, особи, що доїжджають сюди працювати, але і неорганізовані групи туристів, які хочуть відвідати туристично привабливі об'єкти на певній території, проте не бажають 3 певних причин використовувати приватний транспорт.

Таблиця 2. Функції технологій Інтернету речей для потенційних пасажирів громадського транспорту

\begin{tabular}{|l|l|}
\hline \multicolumn{1}{|c|}{ Функції } & \multicolumn{1}{|c|}{$\begin{array}{c}\text { Ефективні в управлінні } \\
\text { громадським транспортом }\end{array}$} \\
\hline Інформація про послуги в режимі реального часу & Сільським та міським \\
\hline Інформація про пасажирів & Сільським та міським \\
\hline Інформація про транспорт у режимі реального часу & Сільським та міським \\
\hline Компенсація за низький рівень обслуговування & Сільським та міським \\
\hline Підтримка подорожуючих & $\begin{array}{l}\text { Більше підходить для сільського } \\
\text { транспорту }\end{array}$ \\
\hline Збір даних про точки пересадки & Сільським та міським \\
\hline
\end{tabular}

Джерело: Porru et al., 2020, c.96

Системи керування громадським транспортом у сільській місцевості 3 використанням ІоТ лише починають розвиватися в Україні, проте мають хороші перспективи впровадження, базуючись на досвіді міст. За допомогою ІоТ технологій можна підвищити економічну ефективність функціонування громадського транспорту i, відповідно, відновити привабливість послуг пасажирських перевезень для невеликих населених пунктів. Адаптивні транспортні системи, які використовують Інтернет речей, пропонують перспективний підхід до підвищення ефективності обслуговування пасажирських перевезень у сільській місцевості. Вони надають пасажирам 
гнучкість у виборі та можливому поєднанні різних маршрутів, виборі часу, видів транспорту, постачальника послуг або платіжних систем.

Успіх у покращенні забезпечення громадським транспортом сільських територій залежить від правильного використання технологій Інтренету речей, відповідного аналітичного забезпечення на базі сформованої системи показників для розрахунку оптимальних маршрутів, наявності фінансових засобів у місцевої і регіональної влади для розвитку транспортної інфраструктури, а у перевізників для оновлення свого транспортного парку, а також співпраця між зацікавленими сторонами. Ще одним фактором, який слід згадати у цьому контексті, $є$ ставлення сільських жителів до нових технологій. Відомо, що технологічні інновації лише на пізніх етапах приходять в сільську місцевість. Окрім того, населення сіл стає все старшим. Як наслідок, сільським жителям потрібно більше часу для ознайомлення з новими технологіями.

Сучасна система керування громадським транспорту, яка підтримується технологіями Інтернету речей, може покращити майбутні перспективи сільських територій. Добре спроектована та організована система громадського транспорту приносить користь багатьом зацікавленим сторонам. 


\section{REFERENCES}

1. Boiko T., Boiko P., Dementieva O. An analysis of the current state of dendrological objects protected by the city of Kherson // 19-th International multidisciplinary scientific geoconference SGEM 2019. ISSUE: 6.2. pp. 343-348.

2. Бойко Т.О. Таксономічна структура і стан вуличних насаджень міста Херсон // Науковий вісник НЛТУ України, 2019, т. 29, № 8, С. 51-55.

3. Кузнєцов С.І., Клименко Ю.О. Біоекологічні та фітомеліоративні засади паркознавства // Проблеми урбоекології та фітомеліорації. Науковий вісник, 2003, вип. 13.5, с. 317-320.

4. Кучерявий В.П., Кучерявий В.В. Озеленення населених місць: Підручник. Львів: Світ, 2019. 456 с.

5. Определитель высших растений Украины / Доброчаева Д.Н., Котов М.И., Прокудин Ю.Н. и др. 2 изд. Киев: Фитосоциоцентр, 1999. 548 с.

6. Антипов В.Г. Декоративная дендрология: Учебник для студентов специальности «Садово-парковое строительство». Мн.: БГТУ, 2004. 470с.

7. Абаимов В.Ф. Дендрология: учеб. пособие для студ. высш. учеб. Заведений. 3-е изд., перераб. М.: Издательский центр «Академия», 2009. 368 с.

8. Булыгин Н.Е. Дендрология. М.: Агропромиздат, 1991. 352 с.

9. Заячук В. Я. Дендролоія: підручник. Вид. 2-ге зі змін. та доповн. Львів: СПОЛОМ, 2014. 676 с.

10. Дендрофлора України. Дикорослі i культивовані дерева i кущі. Голонасінні: Довідник. Ч. I / [Кохно М. А., Трофименко Н. М., Пархоменко Л.І. та ін.]. К. : Фітосоціоцентр, 2005. 716 с., іл.

11. Дендрофлора України. Дикорослі i культивовані дерева i кущі. Покритонасінні : Довідник. Ч. ІІ / [Кохно М. А., Трофименко Н. М., Пархоменко Л. І. та ін.]. К. : Фітосоціоцентр, 2005. 716 с.

12. Алексеев В.А. Диагностика жизненного состояния деревьев и древостоев. // Лесоведение. 1989. № 4. С. 51-57.

13. Черевченко T.М., Кузнецов С.I. Біорізноманіття деревних рослин в умовах мегаполісів та його оптимізація // Науковий вісник. 2003. Вип. 13.5. C.22-27.

14. Bredyhyna J. L. (2008). Evaluation of the present dendroflora diversity in Melitopol. Ecology and noosphereology. V. 19, № 1-2, 179-181.

15. Kokhno M.A., Kuznetsov S.I., Doroshenko O.K. et al. (1983). Dendroflora of cities of southern Ukraine. Ukr. botan. zhurn., 40 (5). 12-14. 
16. Maltseva SY (2016). Dendroflora of the city of Genichesk (Kherson region, Ukraine). Journal of Kharkov national agrarian university. Biology Series, V.2 (38) p. 106-114.

17. Moysiyenko I.I. (1999). Urbanoflora Khersona: avtoref. dys.

18. Popova E.N., Artjuh N.N. (2015). Dendroflora of the park in National Scientific Centre «V.Ye. Tairov Institute of Viticulture and Wine-making». Chornomors'k. bot. z., 11 (1): 117-128. doi:10.14255/2308-9628/15.111/10.

19. Popova E.N., Kuznetsov V.O., Osadcha L.P. (2007). Dendroflora of parksights of garden-park art of Odessa. Scientific notes the State Natural History Museum. Lviv. 22. 145-156 p.

20. Potapenko I.L., Letuhova V. Yu., Rozenberg O.G., Diordienko Y.V. (2014). Ornamental arboreal plants of Feodosia. Scientists note from Taurian national university V.I. Vernadsky. Series «Biology, Chemistry». V. 27 (66), №5, 119-132.

21. Velcheva L. G., Vasin V. A., Pyurko O. Ye. (2014). Tree and shrub vegetation of arboretum of Bogdan Chmelnitskiy Melitopol state pedagogical University. Biological Bulletin Melitopol state pedagogical university, №1, 60-72.

22. Red book of Ukraine. Flora. (2009). [ed. Ya.P. Didukh]. Kyiv, Hlobalkonsaltynh, 900. (in Ukrainian).

23. Boiko M.F., Podhaynyy M.M. (2002). Red List Kherson region: Rare and endangered species of plants, fungi and animals, Kherson, 32. (in Ukrainian).

24. Boiko T. O., Dementieva O. I. The tree vegetation of the Kherson State Agrarian University Arboretum //Ukrainian Journal of Ecology. - 2018. - T. 8. - №. 2. - C. 120-127.

25. Загорулько А.О. Таксономічний аналіз і фітомоніторинг парків м. Херсона // Science and Education a New Dimension. Natural and Technical Sciences, VI (17), Issue: 157, 2018. C. 41- 44.

26. Бойко Т. Фітосанітарний стан зелених насаджень міста Херсон. Національний лісотехнічний університет України. 2020.

27. Boiko T. et al. Ornamental woody plants assortment expansion in landscaping the cities of southern Ukraine. International Multidisciplinary Scientific GeoConference: SGEM. - 2020. - T. 20. - №. 6.1 - C. 595-602.

28. Boiko P. D. T. et al. Ecological and biological characteristics of shrubs in the urban ecosystems of Kherson (Ukraine).

29. Жулавский А. Ю. Принципы сбалансированного екологоекономического развития территории / А. Ю. Журавський, В. Л. Акуленко // Вісник Сумського державного університету. - № 5 (51). - 2003. - С. 64-68. (Серія «Економіка»). 
30. Никонов А. Аграрная економика на переломе / А. Никонов // Этот трудный, трудный путь ; руководители авт. кол. Л. И. Абалкин, П. Г. Бучин. М. : Мысль, 1989. - С. 209-228.

31. Богомолов О. Нелегкие шаги к обновлению / О. Богомолов // Этот трудный, трудный путь. - М. : Мысль, 1989. - С. 78-92.

32. Федоренко Н. Стимул против затрат // Обратного хода нет (Перестройка в нар. хоз-ве : общие проблемы, практика, стоки) / $\mathrm{H}$. Федоренко ; под. общ. ред. Г. Х. Попова ; сост. С. Н. Красавченко. - М. : Политиздат, 1989. - С. 215-218.

33. Хвесик А. М. Інституціальна модель природокористування в умовах глобальних викликів : [монографія] / А. М. Хвесик, В. А. Голян. - К. : Кондор, 2007. $-480 \mathrm{c}$.

34. Другак В. М. Теоретичні i методичні основи економіки землекористування / В. М. Другак. - К. : ЦЗРУ, 2004. - 150 с.

35. Екологическое право и рынок : сборник статей. - М. : РАН, ИНИОН, 1994. $-85 \mathrm{c}$.

36. Лукінов I. І. Інвестиційна діяльність у забезпеченні сталого стабільного розвитку / І. І. Лукінов // Персонал. - 2000. - № 1. - № 2. - С. 20.

37. Мацибора Т. В. Проблеми поліпшення інвестиційного клімату в Україні / Т. В. Мацибола // Економіка АПК. - 2003. - № 10. - С. 83-85.

38. Про інвестиційну діяльність : закон України // Офіційний вісник України. - 2002. - № 31. - С. 1446.

39. Голик В. Р. Форми власності змінились, а де ж ефективні господарники? / В. Р. Голик // Землевпорядний вісник. - 2007. - № 2. - С. 25-29.

40. Шкура I. С. Тенденції в умовах іноземного інвестування в економіку України / І. С. Шкура // Академічний огляд : економіка та підприємництво. - 2002. - № 1. - С. 17-21.

41. Державна програма захисту земель України від водної та вітрової ерозії, інших видів деградації земель на 1996-2010 рр. - К. : Держкомзем України, 1996. $-81 \mathrm{c}$.

42. Штанько Л. О. До формування інвестиційної стратегії аграрних підприємств / Л. О. Штанько // Економіка АПК. - 2005. - № 7. - С. 114-118.

43. Гайдуцький А. П. Інвестиційна привабливість ринку землі в Україні / А. П. Гайдуцький // Економіка АПК. - 2005. - № 8. - С.125-131.

44. Бузлаков И. Механизм рентных отношений и проблемы его реализации / И. Бузлаков // АПК : Экономика, управление. - 1997. - № 11. - С. 43-44. 
45. Гайдуцький А. П. Інвестиційна привабливість ринку землі в Україні / А. П. Гайдуцький // Економіка АПК. - 2005. - № 8. - С.125-131.

46. Кресникова Н. И. Механізми функционирования земельного рынка / Н. И. Кресникова // Земельный вестник России. - 2003. - № 3. - С. 10-15.

47. Ковалишин О. Ф. Застосування даних державного земельного кадастру при виділенні масивів однотипного використання земель / О. Ф. Ковалишин, Н. М. Музика // Збірник наукових праць Дніпропетровського державного аграрного університету. -2006. - № 10. - (Серія “Економічні науки”).- С .

48. Ковалишин О. Ф. Удосконалення земельних відносин та формування еколого-безпечного землекористування / О. Ф. Ковалишин, Н. М. Музика // Вісник Львівського державного аграрного університету. - 2008. - № - С. 28

49. Музика Н. М. Інституціональна структура земельного ринку / Н. М. Музика, О. Ф. Ковалишин // Вісник Львівського державного аграрного університету. - 2009. - № 12. - С. 99-101.

50. Якубенко Б.С, Попович С.Ю., Устименко П.М., Дубина Д.В., \& Чурілов А.М. (2018). Геоботаніка: методичні аспекти досліджень. Навчальний посібник. К..: Видавництво Ліра К.

51. Інженерно-геологічні умови Черкаської області (2019). Отримано 3 https://geotop.com.ua/injenerno-geologicheskie-usloviya-cherkasskoy-oblasti_ua.php

52. Від пустелі до безкрайого зеленого моря (2020). Отримано 3 https://www.openforest.org.ua/20206/

53. Гриб В.М. Осадчук Л.С. \& Гриб В.І. (2016). Відтворення соснових деревостанів Східного Полісся України : монографія. Нац. ун-т біоресурсів i природокористування України, Нац. лісотехн. ун-т України. Київ: Компринт. 233 с. - Бібліогр.: с. 172-217.

54. Заячук В.Я. (2008). Дендрологія: Підручник. Л.: Апріорі. 656с.

55. Андрієнко, Шеляг-Сосонко (1983) Соснові ліси. Отримано 3 http://www.novageografia.com/vogels-157-1.html

56. Гаель А.Г. (1952). Облесение бугристых песков засушливых областей : монография. М.: Гос. издат географ. лит-ры.

57. Герушинський 3.Ю. (1996). Типологія лісів Українських Карпат : навч. посібн. Львів : Вид-во "Піраміда". 208 с.

58. Шлапак В.П., Логвіненко I.I. (1999). Чигиринський бір : монографія. Львів: Вид-во "Престиж Інформ".

59. Шлапак В.В. (2013). Типологічна оцінка насаджень притясминських борів. Науковий вісник НЛТУ України. Вип. 23(6), 46-54. Отримано 3 https://nv.nltu.edu.ua/Archive/2013/23_6/37.pdf 
60. Шлапак В.П, Шлапак В.В. (2007) Лісові культури проф. З.С. Голов'янка на Чигиринщині. Науковий вісник. Вип. 17. Отримано 3 https://nv.nltu.edu.ua

61. Мірошник Н.В. (2016). Особливості антропогенної трансформації трав'яних фітоценозів лісових екосистем Черкаської області. Біологічні системи. T.8. Вип.1. Отримано з http://nbuv.gov.ua/UJRN/Nvchu_biol_2016

62. Гайова Ю.Ю. (2013). Лісова рослинність з участю Daphne cneorum L. на території Черкасько-Чигиринського геоботанічного району. Науковий вісник НЛТУ України. Вип. 23(7). Отримано 3 https://cyberleninka.ru/article/n/lisovaroslinnist-z-uchastyu-daphne-cneorum-l-na-teritoriyi-cherkasko-chigirinskogogeobot

63. Шлапак В.В. (2013). Лісівничо-екологічні особливості відтворення сосни звичайної на Притясминських пісках : автореф. дис.. канд. с.-г. наук : 06.03.01. Нац. ун-т біоресурсів і природокористування України. - К. : [б.в.]. 21 с. Отримано $3 \mathrm{http}$ ://catalog.odnb.odessa.ua/opac/index.lt

64. Краснов В.П., Орлов О.О. \& Ведмідь М.М. (2009). Атлас рослиніндикаторів і типів лісорослинних умов Українського Полісся : монографія. За ред. В.П. Краснова. Новоград-Волинський: Вид-во "Новоград".

65. Морозюк С.С., Протопопова В.В. (2007). Трав’янисті рослини України: Навчальний посібник. Тернопіль: Навчальна книга, Богдан, 216 с.

66. Matuszkiewicz W. (2001). Przewodnik do oznaczania zbiorowisk roślinnych Polski. Warszawa: PWN. 536 p.

67. Сорока M.I. (2008). Хвойні та змішані ліси (Клас vaccinio-piceetea br.bl. 1939) та передумови їх природного формування на Розточчі. Отримано 3 http://fasu.nltu.edu.ua/index.php/nplanu/article/view/567.

68. Фукарек Ф., Хемпель В., Хюбель Г., Шустер Р. \& Сукков М. (1982). Растительный мир Земли. Том 2. Перевод и предисл. Сладкова А. Н. - Москва: Мир. с. 184

69. Якубенко Б.С, Попович С.Ю. \& Устименко П.М. (2019). Геоботаніка: Підручник. К.: Видавництво Ліра-К.

70. Сорока M.I. (2016). Класифікація рослинності: основні підходи та перспективи розвитку. Національний лісотехнічний університет України. Український ліс. Вип. 1. Отримано з http:/geobot.org.ua/files/publication

71. Проект організації та розвитку лісового господарства Державного підприємства «Чигиринське лісове господарство» Черкаського обласного управління лісового та мисливського господарства. (2014). Державне агентство лісових ресурсів України, Українське державне проектне лісовпорядне виробниче об’єднання, Українська лісовпорядна експедиція. Ірпинь. 245 с. 
72. O. V. Bereziuk, M. S. Lemeshev, V. V. Bohachuk, and M. Duk, «Means for measuring relative humidity of municipal solid wastes based on the microcontroller Arduino UNO R3», Proc. SPIE, Photonics Applications in Astronomy, Communications, Industry, and High Energy Physics Experiments 2018, vol. 10808, 2018, no. 108083G, DOI: 10.1117/12.2501557.

73. О. В. Березюк, «Системи приводів робочих органів машин для збирання та первинної переробки твердих побутових відходів», Промислова гідравліка і пневматика, № 3(57), 2017, с. 65-72.

74. В. В. Попович, О. В. Придатко, М. І. Сичевський, Н. П. Попович, та М. А. Панасюк, «Ефективність експлуатації сміттєвозів у середовищі "містосміттєзвалище"», Науковий вісник НЛТУ України, Т. 27, № 10, 2017, с. 111-116.

75. O. Berezyuk, and V. Savulyak, «Approximated mathematical model of hydraulic drive of container upturning during loading of solid domestic wastes into a dustcart», Technical Sciences, No. 20 (3), 2017, p. 259-273.

76. О. В. Березюк, «Експериментальне дослідження процесів зневоднення твердих побутових відходів шнековим пресом», Вісник ВПІ, № 5, 2018, с. 18-24.

77. В. І. Савуляк, та О. В. Березюк, Технічне забезпечення збирання, перевезення та підготовки до переробки твердих побутових відходів: монографія, Вінниця: ВНТУ, 2006, 217 с.

78. О. А. Сагдєєва, Г. В. Крусір, та А. Л. Цикало, «Оцінка рівня екологічної небезпеки звалищ твердих муніципальних відходів», Екологічна безпека, № 1, 2018 , с. $75-83$.

79. O. Bereziuk, M. Lemeshev, V. Bogachuk, W. Wójcik, K. Nurseitova, and A. Bugubayeva, «Ultrasonic microcontroller device for distance measuring between dustcart and container of municipal solid wastes», Przeglad Elektrotechniczny, No. 4, 2019, p. 146-150, http://dx.doi.org/10.15199/48.2019.04.26

80. O. V. Berezyuk, and V. I. Savulyak, «Dynamics of hydraulic drive of hanging sweeping equipment of dust-cart with extended functional possibilities», TEHNOMUS - New Technologies and Products in Machine Manufacturing Technologies, No 22, 2015, p. 345-351.

81. І. В. Коц, та О. В. Березюк, «Вібраційний гідропривод для пресування промислових відходів», Вісник ВПІ, № 5, 2006, с. 146-149.

82. В. П. Ковальський, та А. В. Бондарь, «Шламозолокарбонатий пресбетон на основі відходів промисловості», на XXIV міжнар. наук.-практ. конф. Інформаційні технології : наука, техніка, технологія, освіта, здоров'я, Харків, 2015, c. 209.

83. Лемешев, М. С., Сівак, К. К., «Особливості використання промислових техногених відходів в галузі будівельних матеріалів». Сучасні технології, матеріали і конструкції в будівництві, 29(2), 2020, с. 24-34. 
84. В. П. Ковальський, В. П. Очеретний, М. С. Лемешев, та А. В. Бондар, «Обгрунтування доцільності використання золошламового в'яжучого для приготування сухих будівельних сумішей», Ресурсоекономні матеріали, конструкції, будівлі та споруди, Випуск 26, 2013, с. 186-193.

85. М. С. Лемешев, «В'яжуче на основі промислових відходів» [Електронний ресурс], на Междунар. науч.-практ. Интернет-конф. Научные исследования и их практическое применение. Современное состояние и пути развития '2017. URL : http://ir.lib.vntu.edu.ua/bitstream/handle/123456789/18481/ statya_doclad_oct\%20.doc.

86. В. П. Ковальський, та О. С. Сідлак, «Використання золи виносу ТЕС у будівельних матеріалах», Сучасні технології, матеріали i конструкції у будівництві, № 1 (16), 2014, с. 35-40.

87. О. Р. Попович, Я. М. Захарко, та М. С. Мальований, «Проблеми утилізації та переробки будівельних відходів» // Вісник Національного університету Львівська політехніка. Теорія і практика будівництва, Вип.755, 2013, c. 321-324.

88. Лемешев, М. С. "Теоретические предпосылки создания радиопоглощающего бетона бетэла-м." Вісник Донбаської державної академії будівництва і архітектури 1: 60-64. (2005).

89. М. С. Лемешев, «Металлонасыщенные бетоны для защиты от электромагнитного излучения», Вісник Одеської державної академії будівництва та архітектури, № 33, 2013, с. 253-256.

90. М. С. Лемешев, «Електропровідні бетони для захисту від статичної електрики» [Електронний ресурс], на наук. симпоз. Перспективні досягнення сучасних вчених, Одеса, 2017. URL : http://www.sworld.education/index.php/ ru/c217-14/29403-\%D1\%81217-032.

91. М. С. Лемешев, та О. В. Березюк, «Електротехнічний бетон для виготовлення анодних заземлювачів» [Електронний ресурс], на міжнар. наук.практ. Інтернет-конф. Інтелектуальний потенціал XXI століття '2017, Одеса, 2017. URL : http://www.sworld.education/index.php/ru/arts-architecture-and-constructionu7-317/modern-construction-technologies-u7-317/29688.

92. М. С. Лемешев, та О. В. Березюк, «Антистатичні покриття із електропровідного бетону», Сучасні технології, матеріали і конструкції у будівництві, № 2, 2017, с. 26-30.

93. Г. Я. Якимечко, та О. Р. Попович, «Аспекти рециклінгу будівельних відходів», Вісник НУ «Львівська політехніка», № 700, 2011, с. 279-282.

94. О. В. Березюк, та М. С. Лемешев, «Динаміка утворення відходів будівництва і знесення у Вінницькій області», Вісник ВПІ, № 1, 2021, с. 37-41. 
95. О. В. Березюк, «Комп’ютерна програма "Планування експерименту" ("PlanExp")», Свідоцтво про реєстрацію авторського права на твір № 46876, Київ: ДСІВ України, дата реєстрації: 21.12.2012.

96. О. В. Березюк, «Моделювання компресійної характеристики твердих побутових відходів у сміттєвозі на основі комп'ютерної програми "PlanExp"», Вісник Вінницького політехнічного інституту, №6, с. 23-28, 2016.

97. О. В. Березюк, М. С. Лемешев, та С. В. Королевська, «Математичне моделювання прогнозування обсягів продукування будівельних відходів в різних країнах світу», Вісник ВПІ, № 3, с. 41-46, 2021.

98. Lykov A.V. Teoriya sushki. M., A., Energoizdat, 417 p, 1963.

99. Lucyk R.V., Malkin Je.S., Abarzhi I.I., Teplomasoobmen pri obrabotke tekstilnyh materialov. Kiev: Nauk. dumka, 344 p., 1993.

100. Crank J. The Matematics of Diffusion. Oxford: Clarendon. Press, 1957. 348p.

101. Leaderman H. Elastic and Crup. Properties of Filamentous and other High Nolymers. Washington: Textile Foundation, 380 p, 1993.

102. Koltunov M.A. Metod uprugih reshenij zadach termovjazkouprugosti. Mehanika polimerov. №4. pp. 23 - 28, 1970.

103. Абрамов Н.Н. Надежность систем водоснабжения / Н.Н. Абрамов. М.: Стройиздат, 1984. -216 с.

104. Алексеев О.Г. Комплексное применение методов дискретной оптимизации / О.Г. Алексеев. - М.: Наука, 1987. - 248 с.

105. Банди Б.Д. Методы оптимизации. Пер. с англ. / Б.Д. Банди - М.: Радио и связь, 1988. - $128 \mathrm{c}$.

106. Барлоу Р. Статистическая теория надежности и испытания на безотказность / Р. Барлоу, Ф. Прошан - М.: Наука, 1984. - 328 с.

107. Бобров В.И. Надежность технических систем / В.И. Бобров. - М.: МГУП, 2004. - 236 с.

108. Болотин В.В. Методы теории вероятностей и теории надежности в расчетах сооружений / В.В. Болотин. - М. : Стройиздат, 1981. - 351 с.

109. Волкович В.Л. Модели и алгоритмы оптимизации надежности сложных систем / В.Л. Волкович, А.Ф. Волошин, В.А. Заславский, И.А. Ушаков / Под ред. академика В.С. Михалевича. - К.: Наукова думка, 1992. - 312 с.

110. Гадасин В. А. Методы расчета структурной надежности сетей связи / В.А. Гадасин. - М.: Сов. радио, 1986. - 191 с. 
111. Ильин Ю.А. Надежность водопроводных сооружений и оборудования / Ю.А. Ильин. - М.: Стройиздат, 1985. - 240 с.

112. Капур К. Надежность и проектирование систем / К. Капур, Л. Ламберсон // Под ред. И. А. Ушакова. - М. : Мир, 1980. - 604 с.

113. Коваленко И.Н. Приближенный расчет и оптимизация надежности / И.Н. Коваленко, А.Н. Наконечный. - К.: Наук. думка, 1989. - 182 с.

114. Корнійчук М. Складні системи з випадковою зв'язністю: ймовірнісне моделювання та оптимізація: монографія // М. Корнійчук, І. Совтус. - К.: КНЕУ, 2003. $-374 \mathrm{c}$.

115. Надежность технических систем: справочник / Ю.К. Беляев, В.А. Богатырев, В.В. Болотин и др.; под ред. И.А. Ушакова. - М.: Радио и связь, 1985. $-608 \mathrm{c}$.

116. Надійність техніки. Терміни та визначення: ДСТУ 2860-94. - К.: Держстандарт України, 1994. - 92 с.

117. Новохатній В.Г. Аналіз впливу топології на надійність структури водопровідних мереж / В.Г. Новохатній, І.С. Усенко // Проблеми водопостачання, водовідведення та гідравліки: Наук.-техн. зб. Вип. 1. - К.: КНУБА, 2003. - С. 36 -40 .

118. Патон Б.Є. Стан природно-техногенної безпеки України та основні напрями підвищення іiі рівня. Міністерство України з питань надзвичайних ситуацій та у справах захисту населення від наслідків Чорнобильської катастрофи. НАН України / Б.С. Патон, В.В. Дурдинець. - Київ, 2001. - 96 с.

119. Райншке К. Оценка надежности систем с использованием графов / К. Райншке, И.А. Ушаков. - М.: Радио и связь, 1988. - 209 с.

120. Рогинский В.Н. Теория сетей связи / В.Н. Рогинский, А.Д. Харкевич, М.А. Шнепс и др. - М.: Радио и связь, 1981. - 192 с.

121. Alberto S. Recent Advances in Optimization / S. Alberto. - SpringerVerlag Berlin Heidelberg, 2006. - 455 p.

122. Computational Geometry: algorithms and applications / Mark de Berg, Mark van Kreveld, Mark Overmars, Otfried Schwarzkopf. - Berlin: Springer, 2000. $367 \mathrm{p}$.

123. Reinschke K. Application of Graph Theory for Reliability Analysis / K. Reinschke, I. Ushakov. - Berlin: Verlag Technik, 1987. - 209 pp.

124. Reinschke, K. J. Multivariable Control. A Graph Theoretic Approach. 1988.

125. Ryabinin I.A. Reliability of Engineering Systems. Principles and Analysis / I.A.Ryabinin. - Moscow: MIR Publisherrs, 1976. - 532 p. 
126. Satyanarayana A. Multi-terminal Network Reliability. - Berkeley, 1980. Oper. Res. Center, Univ. of Calif., N 80 - 6.

127. Tung Y.K. Evalution of water distribution network reliability / Y.K. Tung, Proceedings of the Specialty Conference ASCE, 1, pp. 1 - 6. 1985. http://library.wrds.uwyo.edu/wrp/85-38/85-38.pdf.

128. Usenko V. Probability of the utility networks double-ring structures' connectivity for sites with various reliability / V. Usenko, O. Kodak // Academic Journal. Series: Industrial Machine Building, Civil Engineering. - 1 (50)' 2018. - P. $270-277$.

129. Usenko V. Problematic Issues of Methodology for Ensuring the Reliability of Engineering Networks / V. Usenko, D. Pogorily, I. Usenko // Applied Mechanics Reviews. Issue 6 (2), (November). Volume 70, 2018. - Pages 1138 - 1146.

130. Wolter F. -E. Geometric Modeling for Engineering Applications / F. -E. Wolter, M. Reuter, N. Peinecke, 2004, pp. 5-8.

131. S.M. Mikhailov, A.S. Mikhailova. Design history. Moscow: Union of Designers, 2004,289 p.

132. V. Papanek. Design for the real world. M.: D. Aronov, 2004, 416 p.

133. O.V. Divnenko. Aesthetics. Moscow: Ed. Az, 1994, 274 p.

134. Oxford Illustrated Encyclopedia, Volume 5, Art. Moscow: Ed. Mir, 2001.

135. Smirnova V.V. World Art. M.: Ed. Az, 1995, 136 p.

136. V. Vlasov. Styles in art, volume 1. SPb.: Publishing house. Rings, 1995, $533 \mathrm{p}$.

137. O.M. Magnitsky, V.Yu. Pirainen, N.G. Kolbasnikov. Artistic deformation of metal. SPb.: Publishing house. SPb. STU, 2000, 256 p.

138. Yu.P. Solntsev, E.I. Pryakhin, F. Voikun. Materials Science. SPb.: Publ.: Chemistry. 2002, 696 p.

139. Буров А. Про архітектуру. -М.: Держбудвидав, 1960.

140. Зейтун Ж. Організація внутрішньої структури проектованих архітектурних систем. М.: Будвидав, 1984.

141. Зігель К. Структура та форма у сучасній архітектурі. М., Держбудвидав, 1965.

142. Голдбергер П. Навіщо потрібна архітектура, Strelka Press, 2016

143. Б. С. Черкес, С. М. Лінда Архітектура сучасності: остання третина XX - початок XXI століть: навч. посіб. М-во освіти і науки України, Нац. ун-т «Львів. політехніка». 2014. - 380, [4] с. : іл. — Бібліогр.: с. 349-351 
144. Лагоднюк О. А., Черняга П. Г. Організація прибудинкових територій житлових багатоквартирних будинків / О.А. Лагоднюк, П.Г. Черняга -Львів, Видавництво Львівська Політехніка, 2012. - 176 с.

145. Кадурина А. О. Архитектурно-художественные аспекты формирования / А. О. Кадурина. - Киев, 2005. - 20 с.

146. Коваленко А.С. Архітектурні та конструктивні заходи при проектуванні установ нового типу / Коваленко А.С., Бочарова О.А., Годун Т.Н. // Наука та виробництво: зб. наук. праць / ДВНЗ «ПДТУ». - Маріуполь, 2019. Вип. 23. - С. 167-173.

147. Крижановская Н. Я. Природо-интегрированные индивидуальные жилые дома повышенной комфортности: монография / Н. Я. Крижановская, О. В. Смирнова, И. А. Дегтев. - Белгород : БГТУ, 2013 - 246 с.

148. Ч.Лендрі - Креативне містоутворення: його сила і можливості, Харків,2020p.

149. Philip Jodidio. Green Architecture Now! Taschen, Cologne, 2009. 416 p.

150. Катола Х. О. Сучасні тенденції проектування “Зеленої архітектури”. К.: Гельветика, 2014 р. - 108 с.

151. Кріс Ван Уффелен Колекція: Ландшафтна архітектура.-М.: Магма 2010 p. 416 c.

152. Логвінов В. Від зеленого будівництва до природоінтегрованої архітектури. - М.: Байкал, 2016 р. - 49 с.

153. Ожегова О.С. Ландшафтна архітектура: Історія стилів - М.: Світ та Освіта, 2015p. - 560 с.

154. Стаття “Зелені хмарочоси. (Електронний ресурс 2015 р.) URL: https://vikna.if.ua/cikavo/43736/view .

155. Mikhailov, E., S., Sapronova, S., Tkachenko, Semenov, V., Smyrnova, I., \& Kholostenko, Y. (2019). Improved solution of guiding of railway vehicle in curves. In Transport Means-Proceedings of the International Conference, 916-921. https://transportmeans.ktu.edu/wp-content/uploads/sites/307/2018/02/Transportmeans-2019-Part-2.pdf.

156. Sapronova, S., Tkachenko, V., Fomin, O., Gatchenko, V., \& Maliuk, S. (2017). Research on the safety factor against derailment of railway vehicles. EasternEuropean Journal of Enterprise Technologies, 6 (7), 19-25. https://doi.org/10.15587/1729-4061.2017.116194.

157. Goolak, S., Gubarevych, O., Yermolenko, E., Slobodyanyuk, M., \& Gorobchenko, O. Mathematical Modeling of an Induction Motor for Vehicles. EasternEuropean Journal of Enterprise Technologies, 2(2), 25-34. https://doi.org/10.15587/1729-4061.2020.199559 
158. Goolak, S., Gerlici, J., Sapronova, S., Tkachenko, V., Lack, T., \& Kravchenko, K. (2019). Determination of Parameters of Asynchronous Electric Machines with Asymmetrical Windings of Electric Locomotives. CommunicationsScientific letters of the University of Zilina, 21(2), 24-31. https://doi.org/10.26552/com.C.2019.2.24-31.

159. Byelkina, E., \& Zhukov, A. C (2015). Analysis of methods for approximating the magnetization curve of electrical steel. Innovative Science, 2(5), 2227.

160. Sandomirskii, S. G. (2016). Structural and phase sensitivity of the maximum differential magnetic susceptibility of steel. Russian Metallurgy (Metally), 2016(7), 619-624. https://doi.org/10.1134/S0036029516070144.

161. Chang, L., Jahns, T. M., \& Blissenbach, R. (2019). Generalized dynamic hysteresis model for improved iron loss estimation of complex flux waveforms. IEEE Transactions on Magnetics, 55(7), 1-13. https://doi.org/10.1109/TMAG.2018.2889239.

162. Shi, P., Jin, K., Zhang, P., Xie, S., Chen, Z., \& Zheng, X. (2018). Quantitative inversion of stress and crack in ferromagnetic materials based on metal magnetic memory method. IEEE Transactions on Magnetics, 54(10), 1-11. https://doi.org/10.1109/TMAG.2018.2856894.

163. Kachniarz, M., \& Szewczyk, R. (2017). Study on the Rayleigh Hysteresis Model and its Applicability in Modeling Magnetic Hysteresis Phenomenon in Ferromagnetic Materials. Acta Physica Polonica, A., 131(5). https://doi.org/10.12693/APhysPolA.131.1244.

164. Meeker, D. C., Filatov, A. V., \& Maslen, E. H. (2004). Effect of magnetic hysteresis on rotational losses in heteropolar magnetic bearings. IEEE Transactions on Magnetics, 40(5), 3302-3307. https://doi.org/10.1109/TMAG.2004.831664.

165. de la Barrière, O., Ragusa, C., Appino, C., \& Fiorillo, F. (2019). Loss Prediction in DC-Biased Magnetic Sheets. IEEE Transactions on Magnetics, 55(10), 1-14. https://doi.org/10.1109/TMAG.2019.2921000.

166. Fomin, O., Kulbovsky, I., Sorochinska, E., Sapronova, S., Bambura, O. (2017). Experimental confirmation of the theory of implementation of the coupled design of center girder of the hopper wagons for iron ore pellets. Eastern-European Journal of Enterprise Technologies, 5 (1 (89)), 11-18. https://doi.org/10.15587/17294061.2017.109588.

167. Okorokov, A. M., Fomin, O. V., Lovska, A. O., Vernigora, R. V. , Zhuravel, I. L., Fomin, V. V. (2018). Research into a possibility to prolong the time of operation of universal semi-wagon bodies that have exhausted their standard resource. EasternEuropean journal of enterprise technologies. 3/7(93), 20-26. https://doi.org/10.15587/1729-4061.2018.131309. 
168. Schauerte, B., Steentjes, S., Thul, A., \& Hameyer, K. (2019). Iron-loss model for arbitrary magnetization loci in NO electrical steel. International Journal of Applied Electromagnetics and Mechanics, 61(S1), S89-S96. https://doi.org/10.3233/JAE-191599.

169. Ragusa, C., Zhao, H., Appino, C., Khan, M., de la Barrière, O., \& Fiorillo, F. (2016). Loss decomposition in non-oriented steel sheets: the role of the classical losses. IEEE Magnetics Letters, (7), $1-5$. https://doi.org/10.1109/LMAG.2016.2604204.

170. Liu, R., \& Li, L. (2019). Calculation method of magnetic material losses under DC bias using statistical loss theory and energetic hysteresis model. IEEE Transactions on Magnetics, 55(10), 1-4. https://doi.org/10.1109/TMAG.2019.2921357.

171. Zhao, H., Ragusa, C., Appino, C., de la Barrière, O., Wang, Y., \& Fiorillo, F. (2018). Energy losses in soft magnetic materials under symmetric and asymmetric induction waveforms. IEEE Transactions on Power Electronics, 34(3), 2655-2665. https://doi.org/110.1109/TPEL.2018.2837657.

172. Barg, S., Ammous, K., Mejbri, H., \& Ammous, A. (2016). An improved empirical formulation for magnetic core losses estimation under nonsinusoidal induction. IEEE Transactions on power electronics, 32(3), 2146-2154. https://doi.org/10.1109/TPEL.2016.2555359.

173. Yue, S., Yang, Q., Li, Y., \& Zhang, C. (2018). Core loss calculation for magnetic materials employed in SMPS under rectangular voltage excitations. AIP Advances, 8(5), 056121-1-056121-6. https://doi.org/10.1063/1.5007201.

174. Gubarevych, O., Goolak S., Gorobchenko, O., \& Sklyarenko, I. (2020). Specified approach to calculation of pulse current traction loss losses. Technical sciences and technologies, (1 (19)), 206-227. https://doi.org/10.25140/2411-53632020-1(19)-206-227.

175. Raulin, V., Radun, A., \& Husain, I. (2004). Modeling of losses in switched reluctance machines. IEEE Transactions on Industry Applications, 40(6), 1560-1569. https://doi.org/10.1109/TIA.2004.836225.

176. Yeremin, G. N. (2017). Standardization of electrical and precision types of metal products. Improvement paths. Steel, (2), 55-58.

177. Tey, W. Y., Lee, K. M., Asako, Y., Tan, L. K., \& Arai, N. (2020). Multivariable power least squares method: Complementary tool for Response Surface Methodology. Ain Shams Engineering Journal, 11(1), 161-169. https://doi.org/10.1016/j.asej.2019.08.002.

178. Nekhayev, V., Nikolayev, V., Smalev, A., \& Vedruchenko, V. (2019). To the estimation of the locomotive power. News of the Trans-Siberian Railway, 3 (39), 14-30. 
179. Gorobchenko, O., Fomin, O., Fomin, V., \& Kovalenko, V. (2018). Study of the influence of electric transmission parameters on the efficiency of freight rolling stock of direct current. Eastern-European Journal of Enterprise Technologies, 1(3-91), 60-67. https://doi.org/10.15587/1729-4061.2018.121713.

180. Matyuk, V., \& Osipov, A. (2011). Mathematical models of the magnetization curve and magnetic hysteresis loops. Part I. Analysis of models. Nondestructive testing and diagnostics, (2), 2-35.

181. Nayak B., Sahu S., Choudhury T.R. Parameter estimation of DC motor using adaptive transfer function based on Nelder-Mead optimization. Indonesian Journal of Electrical Engineering and Computer Science, 2018, vol. 9, no 3, pp. 696702. doi: https://doi.org/10.11591/ijeecs.v9.i3.pp696-702.

182. Drubetskyi A.Y. Approximation of universal magnetic characteristic for modelling electric traction machines. Science and Transport Progress. Bulletin of Dnipropetrovsk National University of Railway Transport, 2017, no. 1(67), pp. 106116. doi: https://doi.org/10.15802/stp2017/94031.

183. Kulinich Yu.M., Shukharev S.A., Drogolov D.Yu. Simulation of the pulsating current traction motor. VNIIZHT Scientific Journal, 2019, vol. 78, no. 5, pp. 313-319. (Rus). doi: https://doi.org/10.21780/2223-9731-2019-78-5-319.

184. Shepovalova O.V., Belenov A.T. Investigation of DC Motors Mechanical Characteristics with Powered by Comparable Capacity PV Array. Energy Procedia, 2017, vol. 119, pp. 990-994. doi: https://doi.org/10.1016/j.egypro.2017.07.132.

185. Evseev, V. Y., Savos'kin, A. N. A Mathematical Model of a Collector Traction Motor with Separate Consideration of Eddy Currents of the Main and Additional Poles. Russian Electrical Engineering, 2020, vol. 91, no 9, pp. 557-563. doi: https://doi.org/10.3103/s1068371220090047.

186. Litovchenko V.V., Nazarov D.V. Sharov V.A. Simulation Model of a Direct-Current Electric Locomotive with Commutator Traction Motors. Russian Electrical Engineering, 2020, vol. 91, no. 1, pp. 69-76. doi: https://doi.org/10.3103/s1068371220010071.

187. Spiryagin M., Wolfs P., Cole C., Spiryagin V., Sun Y.Q., McSweeney T. Design and Simulation of Heavy Haul Locomotives and Train. New York, Taylor \& Francis Group, 2016. 477 p. doi: https://doi.org/10.1201/9781315369792.

188. Castaneda C.E., Loukianov A.G., Sanchez E.N., Castillo-Toledo B. Discrete-Time Neural Sliding-Mode Block Control for a DC Motor With Controlled Flux. IEEE Transactions on Industrial Electronics, 2012, vol. 59, no. 2, pp. 1194-1207. doi: https://doi.org/10.1109/TIE.2011.2161246. 
189. Kharchenko V., Kostenko I., Liubarskyi B., Shaida V., Kuravskyi M., Petrenko O. Simulating the traction electric drive operation of a trolleybus equipped with mixed excitation motors and a DC-DC converter. Eastern-European Journal of Enterprise Technologies, 2020, vol. 3, no. 9 (105), pp. 46-54. doi: https://doi.org/10.15587/1729-4061.2020.205288.

190. Goolak S., Tkachenko V., Bureika G., Vaičiūnas G. Method of spectral analysis of traction current of AC electric locomotives. Transport, 2020, vol. 35, no 6, pp. 658-668. doi: https://doi.org/10.3846/transport.2020.14242.

191. Liu R., Li L. Calculation Method of Magnetic Material Losses Under DC Bias Using Statistical Loss Theory and Energetic Hysteresis Model. IEEE Transactions on Magnetics, 2019, vol. 55, no 10, pp. 1-4. doi: https://doi.org/10.1109/TMAG.2019.2921357.

192. Zhang H., Mueller M. Electromagnetic properties of curved HTS trapped field stacks under high-frequency cross fields for high-speed rotating machines. Superconductor Science and Technology, 2021, vol. 34, no 4, pp. 045018. doi: https://doi.org/10.1088/1361-6668/abe4b6.

193. Kwon H., Park H. Numerical Investigation of Optimal Air Flowrate for Cooling $600 \mathrm{~W}$ Brushless Direct-Current Motor. Journal of Thermal Science and Engineering Applications, 2021, vol. 13, no 4, pp. 041008 . doi: https://doi.org/10.1115/1.4048755.

194. Rens J., Vandenbossche L., Dorez O. Iron Loss Modelling of Electrical Traction Motors for Improved Prediction of Higher Harmonic Losses. World Electric Vehicle Journal, 2020, vol. 11, no 1, p. 24. doi: https://doi.org/10.3390/wevj11010024.

195. Zhao J., Quan X., Jing M., Lin M., Li N. Design, Analysis and Model Predictive Control of an Axial Field Switched-Flux Permanent Magnet Machine for Electric Vehicle/Hybrid Electric Vehicle Applications. Energies, 2018, vol. 11, no. 7, pp. 1859. doi: https://doi.org/10.3390/en11071859.

196. Cheng G., Guo X., Wen Y., Wang Q., Li G., Zhou R. Electromagnetic Modeling and Analysis of 3-DOF Permanent Magnet Spherical Motor Using Magnetic Equivalent Circuit Method. 2018 21st International Conference on Electrical Machines and Systems (ICEMS), 2018, pp. 2643-2648. doi: https://doi.org/10.23919/ICEMS.2018.8548998.

197. Goolak S., Sapronova S., Tkachenko V., Riabov I., Batrak Y. Improvement of the model of power losses in the pulsed current traction motor in an electric locomotive. Eastern-European Journal of Enterprise Technologies, 2020, vol. 6, no. 5 (108), pp. 38-46. doi: https://doi.org/10.15587/1729-4061.2020.218542.

198. Goolak S., Tkachenko V., Sapronova S., Spivak O., Riabov I., Ostroverkh O. Determination of inductances for pulsating current traction motor. Technology audit and production reserves, 2021, vol. 2, no. 1(58), pp. 40-43. doi: https://doi.org/10.15587/2706-5448.2021.229217. 
199. Petrenko A.N., Liubarskiy B.G., Pliugin V.E. Determination of railway rolling stock optimal movement modes. Electrical Engineering \& Electromechanics, 2017, no. 6, pp. 27-31. doi: https://doi.org/10.20998/2074-272X.2017.6.04.

200. Buriakovskyi S.G., Maslii A.S., Panchenko V.V., Pomazan D.P., Denis I.V. The research of the operation modes of the diesel locomotive CHME3 on the imitation model. Electrical Engineering \& Electromechanics, 2018, no. 2, pp. 59-62. doi: https://doi.org/10.20998/2074-272X.2018.2.10.

201. Нормы для расчета и оценки прочности несущих элементов и динамических качеств и воздействия на путь экипажной части локомотивов железных дорог МПС РФ колеи 1520 мм. М.: МПС России, 1998. 145 с.

202. Сергиенко А. Н. Рациональное использование энергии автомобиля с гибридной силовой установкой и электроамортизаторами : дис. ... канд. техн. наук : 05.22.02. Харьков, 2014. 279c.

203. Любарський Б. Г. Теоретичні основи для вибору та оцінки перспективних систем електромеханічного перетворення енергії електрорухомого складу : дис. ... д-ра техн. наук : 05.22.09. Харків, 2014. 368 с.

204. P. P. Silvester, Finite elements for electrical engineers, Cambridge University Press, 1990.

205. Данилов Ю. А. Многочлены Чебышева : Мн. : Выш. Шк., 1984. 157с.

206. Колпахчьян П. Г. Методология комплексного моделирования и способы управления асинхронным тяговым приводом магистральных электровозов : дис. ... д-ра техн. наук : 05.09.03/ Колпахчьян Павел Григорьевич - Новочеркасск, 2006. 402 с.

207. Сегё Г. Ортогональные многочлены : пер. с англ. М. : Гос. изд. Физико-математической литературы, 1962. 500с.

208. Болюх В. Ф., Данько В. Г. Электромеханические импульсные преобразователи с криорезистивными обмотками. Харьков : Изд. ХНАДУ, 2001. 215 c.

209. Сика 3. К., Курлаков И. И., Петров Б. А. Электродинамическая левитация и линейные синхронные двигатели транспортных систем. - Рига : Зинатне, 1988. 258 с.

210. Афонин А. А., Гребеннико В. В. Линейные двигатели с концентраторами магнитного потока. Proceedings of the 3rd International scientific and technical conference «Unconventional electromechanical and electrical systems».- Alushta, The Crimea, Ukraine. Szczein, 1997. Vol. 2. P. 189-194. 
211. Уваров Г. Г. Основные принципы и пути повышения силовых и энергетических показателей линейных электромагнитных двигателей для импульсных технологий : Механика горных пород, технология горных работ.Новосибирск: Ин-т горного дела Сиб. отделения АН России, 1993. С. 107-110.

212. Электрические ударные машины возвратно-поступательного действия / под ред. П. М.Аблужева.- Новосибирск: Наука, 1969. 287 с.

213. Ижелия Г. И., Ребров С. А., Шаповаленко А. Г. Линейные асинхронные двигатели. - К.: «Техника», 1975. 136 с.

214. Омельяненко В. И. Линейные двигатели постоянного тока с тиристорным коммутатором. - Харьков : Основа, 1994. 76 с.

215. Якунин, Д. И. Электромеханическая система привода с линейным двигателем для наклона кузовов скоростного подвижного состава : дис. ... канд. техн. наук : 05.22.09. Харьков, 2010. 202 с.

216. Сріцян Б. Х. Синтез комбінованої системи нахилу кузова швидкісного електричного рухомого складу : автореф. дис. ... канд. техн. наук. 05.22.0.9 Харків, 2016. 21 с.

217. Евсеев М. Е. Теоретические основы электротехники. Анализ линейных электрических цепей при установившихся режимах работы: Рекомендовано Учебно-методическим объединением по университетскому политехническому образованию в качеств учебного пособия для студентов высших учебных заведений. - СПб. : СЗТУ, 2006. 244 с.

218. Ибраев Б.М. Параметры пневматического рессорного подвешивания рельсового автобуса для Казахстанской железной дороги: дис. ... канд. техн. наук. - М., 2009. 167 с.

219. Вериго М.Ф., Коган А.Я., Взаимодействие пути и подвижного состава / Под ред. М.Ф. Вериго. - М.: Транспорт, 1986. 559 с.

220. Байорунас Э.К. Анализ погрешностей импульсного метода измерения параметров рассеяния СВЧ транзисторов. / Труды научно-технической конференции. Радиоэлектроника. - Каунас: Политехнический институт, 1972. T. 8. - C. $254-285$.

221. Федюшко Ю.М. Анализ систематической погрешности рефлектометрических систем для измерения диэлектрических параметров биообъектов / Ю.М. Федюшко, А.Д. Черенков // Вісник Національного технічного університету «ХПІ». - Харків: НТУ «ХПІ». - 2009. - № 7. - С. 146 149.

222. Чайковский В.И. Повышение эффективности дискретного преобразования Фурье путем предварительной фильтрации сигналов / В.И. Чайковский // Технические средства управляющих машин. - К.: Ин-т кибернетики АН УССР, 1983. - С. 15 - 21. 
223. Зюко А.Г. Теория передачи сигналов / А.Г. Зюко, Ю.Ф. Коробов. - М.: Связь, 1972. - 280 с.

224. Установка высшей точности для средств измерений комплексных коэффициентов отражения электромагнитаых волн в прямоугольных волноводах / Е.Г. Алябьев, О.Ф. Киселев, Б.А. Хворостов и др. // Измерительная техника. 1991. - № 11. - С. 15-16.

225. Певнева Н. А. СВЧ метод определения диэлектрических свойств жидкостей / Н. А. Певнева, А. В. Гусинский, А. Л. Гурский // Доклады БГУИР. 2012. - № 5 (67). - С. 46-50.

226. Гурский А. Л. Повышение точности определения формы оптических спектров путем исключения результатов интерференционных эффектов с помощью фурье-анализа // А. Л. Гурский, Н. А. Певнева // Журнал прикладной спектроскопии. - 2013. - Т. 80, № 4. - С. 643-645.

227. Adam S.F. A new automatic microwave measurement system / S.F. Adam // IEEE Trans. on MTT. - 1969. - V. MTT-17, № 4. - P. 304 - 308.

228. Евграфов В.И., Хворостов Б.А. Сравнительный анализ критериев оценки неопределенностей средств измерений // Тез. докл. третьей Всерос. НТК. "Метрологическое обеспечение обороны и безопасности в Российской федерации" / В. И. Евграфов, Б. А. Хворостов. - Мытищи: - 2000. - С. 23-25.

229. Weinschel B.O. Air field coaxial lines as absolute impedance standards. Microwawe Journal / B.O. Weinschel. - 1984. - № 4. - P. 304 - 308.

230. Гуткина Э.М. Эталонные коаксиальные линии передачи и их применение для повышения точности измерения комплексного коэффициента отражения / Э.М. Гуткина // Труды СНИИМ. - 1971, - Вып. 8. - С. 16 - 24.

231. Андриянов А.В. К вопросу о погрешностях измерения параметров цепей во временной области с использованием преобразования Фурье / А.В. Андриянов, А.В. Чепурнов // Техника средств связи. сер. РИТ. - 1982. - Вып. 1. - C. $107-109$.

232. Определение комплексного коэффициента отражения электромагнитной волны с помощью зондовых измерений / О. В. Пилипенко, Н. Б. Горев, А. В. Доронин, П. И. Заболотный, И. Ф. Коджеспирова // Техническая механика. - 2015. - № 4. - С. 139-147.

233. Sysuev, V.A., Alyoshkin, A.V., Savinyh P.A. (2009) Kormoprigotovitelnie mashini. Teoriya, razrabotka, eksperiment (Feed Preparation Machines. Theory, Development, Experiment). V.2. NIISH Severo-Vostoka, Kirov.

234. Sysuev, V., Ivanovs, S., Savinyh, P., Kazakov, V. (2015) Movement and transformation of grain in two-stage crusher. Engineering for rural development, Jelgava, 22-25. 
235. Chuanzhong Xuan, Liying Cao, Pei Wu, Yanhua Ma, Ding Han. (2012) Development on a Hammer Mill with Separate Sieving Device. Telkomnika, Indonesian Journal of Electrical Engineering 10(6), 1151 1156.

236. Nwadinobi Chibundo Princewill. Development and Performance Evaluation of Improved Hammer Mill. Journal of Scientific and Engineering Research. 2017, 4(8):159-164

237. Guritno,P., Haque, E. Relationship between energy and size reduction of grains using a threeroller mill. Transactions of the American Society of Agricultural Engineers. 4, 1243-1249 (1994).

238. Savinyh, P., Aleshkin, A., Nechaev, V., Ivanovs S. Simulation of particle movement in crushing chamber of rotary grain crusher. 16th International Scientific Conference Engineering for Rural Development, pp. 309-316, Jelgava (2017).

239. Tumuluru, J.S., Tabil, L.G., Song, V., Iroba, K.L. Meda, V. Grinding energy and physical properties of chopped and hammer-milled barley, wheat, oat, and canola straws. Biomass and bioenergy, 60, 58-67 (2014).

240. Vaculik, P., Maloun,J., Chladek, L., Poikryl, M. Disintegration process in disc crushers Researchin Agricultural Engineering. 59(3), 98-104 (2013).

241. Promtov, M.A. Pulsatsionnie apparati rotornogo tipa: teoriya i praktika (Rotary type pulsation devices: theory and practice). Mashinostroyenie, Moscow (2001).

242. Basok, B.I., Avramenko, A.A., Pirozhtnko, I.A., Hidrodinamika, tploobmen I effekti drobleniya vo vraschatelno-pulsiruyuchsih potokah (Hydrodynamics, heat transfer and effects of crushing in rotating pulsating flows). Expres, Kiev (2012).

243. Kukhlenko, A.A., Orlov, S.E., Ivanova, D.B., Vasilishin, M.S. Process of Dissolution of Polydisperse Materials in a Unit with a Rotary Pulsation Apparatus. Journal of Engineering Physics and Thermophysics, 88(1), 23-34 (2015).

244. Erenkov, O.Yu., Lopushanskii, I.Ya., Yavorskaya, E.V. A New Design of Rotary Pulsation Apparatus. Chemical and Petroleum Engineering 54, 890-893 (2019).

245. Dolinskiy, A.A., Ivanitskiy G.K., Obodovich A.N. Ispolzovaniye mekhanizmov DIVE pri rotorno-pulsatsionnoy obrabotke geterogennih sred (Use of DPEI mechanisms in rotor-pulsation processing of heterogeneous media). Promishlennaya teploteknika, 30(4), 5-13 (2008).

246. Obodovich, A.N., Limar, A.Yu. Researches hydraulic characteristics of a rotor-pulsation apparatus in processing of water-grain mix. Eastern-European Journal of Enterprise Technologies. V.1, No 7(67), 19-22 (2014). 
247. Vlasova E.A. (2001) Priblizhennye metody matematicheskoj fiziki (Approximate Methods of Mathematical Physics). M.: Izd-vo MGTU im. N.E. Baumana.

248. Dul'nev G.N., ParfenovV.G., Sigalov A.V. (1990) Primenenie EVM dlya resheniya zadach teploobmena (Computer application for solving heat transfer problems). M.: Vysshaya shkola.

249. Patankar S.V. (1984) CHislennye metody resheniya zadach teploobmena i dinamiki zhidkosti (Numerical methods for solving problems of heat transfer and fluid dynamics). Per. s angl. pod. red. V.D. Vilenskogo. - M.: Energoatomizdat.

250. Ferziger J.H. (2002) Computational Methods for Fluid Dynamics. M. Perić. - 3, rev. ed. - Berlin; Heidelberg; New York; Barcelona; Hong Kong; London; Milan; Paris; Tokyo: Springer.

251. Schlichting H. (1979) Boundary-Layer Theory. 7th Edition. - McGraw-Hill, Inc., New York, USA.

252. Launder B. E., Spalding D.B. (1972) Lectures in Mathematical Models of Turbulence. - Academic Press, London, England.

253. Shih T.-H., Liou W.W., Shabbir A., Yang Z., Zhu J. Eddy-Viscosity Model for High Reynolds Number Turbulent Flows / Model Development and Validation. Computers Fluids, 1995. - No 24(3). - P. 227-238.

254. Yakhot V. Renormalization Group Analysis of Turbulence I Basic Theory. / V. Yakhot, S. A. Orszag. Journal of Scientific Computing, 1986.- No 1(1).- P.1-51.

255. Hanjalic, K. Advanced Turbulence Closure Models: A View on the Current Status and Future Prospects, Int. J. Heat \& Fluid Flow, 1994. - vol. 15, - P. 178-204.

256. Speziale C.G., Gatski T., Hussaini M., Lumley J. (1996) Modeling of Turbulent Transport Equations. Simulation and Modeling of Turbulent Flows, Oxford University. - Press.

257. Bardina J.E., Huang P.G., Coakley T.J. (1997) Turbulence Modeling Validation, Testing and Development. California, NASA reports - April.

258. Henkes R. A.W. M., , Van der Flugt F.F., Hoogendoorn C. J. Natural Convection Flow in a Square Cavity Calculated with Low-Reynolds-Number Turbulence Models. Int. J. Heat Mass Transfer, 1991. - No 34. - P. 1543-1557.

259. Sarkar S., Balakrishnan L. Application of a Reynolds-Stress Turbulence Model to the Compressible Shear Layer. - ICASE Report 90-18 // NASA CR 182002, 1990. 
260. Gorobec' V.G. Rotorno-pul'sacijnij aparat dlya prigotuvannya kormiv na bazi zernovih ta ovochevih kul'tur (Rotary pulsation apparatus for feed preparation based on cereals and vegetables). Materiali 5 mizhnarodnoï konferenciï "Problemi suchasnoï energetiki i avtomatiki v sistemi prirodokoristuvannya" Kiïv, 15-19 travnya 2017, p. 27

261. Gorobets V.G., Serdyuk A.M. Rotor-pulsating apparatus for the preparation of liquid feeds on the grain basis. Energetika i avtomatika (Elektronnij zhurnal). 2018, №6. S. 51-57.

262. V.G. Gorobets, V.I. Trokhaniak, A.M. Serdyuk, Numerical simulation of hydrodynamics and heat transfer processes in rotor-pulsing apparatus for preparation of liquid feed. Energetika i avtomatika, (elektronnij zhurnal) 2019, №5, s. 22-29.

263. Gorobec' V.G., Trohanyak V.I., Serdyuk A.M. CHisel'ne modelyuvannya procesiv prigotuvannya ridkih zernovih kormiv z vikoristannyam rotorno-pul'sacijnih tekhnologij (Numerical modeling of processes of preparation of liquid grain forages with use of rotor-pulsation technologies). Materiali IH Mizhnarodnoï naukovotekhnichnoï konferenciï "Problemi suchasnoï energetiki i avtomatiki v sistemi prirodokoristuvannya", m. Kiïv, 22 travnya 2020 r.

264. Gorobets V.G., Trokhanyak V.I., Serdiuk A.M. Numerical simulation of the processes of the preparation of liquid grain feed with the use of rotor-pulsation technologies. Problemi suchasnoï energetiki $\mathrm{i}$ avtomatiki $\mathrm{v}$ sistemi prirodokoristuvannya: IX Mizhnarodna naukovo-praktichna konferenciya, m. Kiïv, 19-22 travnya 2020 roku, tezi dopovidi. Kiïv, 2020. S.

265. Gorobets, V., Trokhaniak, V., Antypov, I., Serdiuk, A. Investigation of Preparation Processes of Liquid Feed Mixtures in Rotary Pulsating Apparatus. Lecture Notes in Civil Engineering, 2021, 100 LNCE, p. 118-126.

266. Vasiliev L.L., Burak V.S., Kulakov A.G., Mishkinis D.A., Bohan P.V. Latent heat storage modules for preheating internal combustion engines: application to a bus petrol engine. Applied Thermal Engineering. 2000. Vol. 20, Issue 10. P. 913923. DOI: 10.1016/S1359-4311(99)00061-7.

267. Sarbu I, Dorca A. Review on heat transfer analysis in thermal energy storage using latent heat storage systems and phase change materials. Int J Energy Res.2019;43:29-64. https://doi.org/10.1002/er.4196.

268. Sarbu I, Sebarchievici C. A comprehensive review of thermal energy storage. Sustainability. 2018;10 (art.191):1-33.

269. Pereira da Cunha J, Eames P. Thermal energy storage for low and medium temperature applications using phase change materials - a review. Applied Energy 2016;177:227-238. 
270. Sharma RK, Ganesan P, Tyagi VV, Metselaar HSC, Sandaran SC. Developments in organic solid-liquid phase change materials and their applications in thermal energy storage. EnergConver Manage. 2015;95:193-228.

271. Kenisarin M, Mahkamov K. Passive thermal control in residential buildings using phase change materials. Renew Sustain Energy Rev. 2016;55:371-398.

272. Корінчевська Т.В. Теплофізичні властивості теплоакумулюючих матеріалів з фазовим переходом на основі органічних сполук: дис. ... канд. техн. наук: 05.14.06 / Корінчевська Тетяна Володимирівна. - Київ, 2017. - 211 с.

273. Косенков И.А. Требования к системам предпусковой подготовки ДВС транспортных средств. /П.В.Дружинин, А.А. Коричев, И.А.Косенков/ Двигателестроение, СПб, - 2009. - № 4. - С.15-19.

274. Вашуркин И.О. Тепловая подготовка и пуск ДВС мобильных транспортных и строительных машин зимой. - СПб.: Наука, 2002. - 145 с.

275. Пыхтя В. А. Экспериментальные исследования системы предпускового разогрева двигателя с тепловым аккумулятором // Вісник Східноукраїнського національного університету ім. Володимира Даля - 2010. № 6 (148). - C. 246-251.

276. Solomon L, Zheng Y, Tuzla K, Neti S, Oztekin A. Analysis of an encapsulated phase change material based energy storage system for high temperature applications. International Journal of Energy Research. 2018;42(7):2518-2535.

277. Mahdi JM, Lohrasbi S, Ganji DD, Nsofor EC. Accelerated melting of PCM in energy storage systems via novel configuration of fins in the triplex tube heat exchanger. International Journal of Heat and Mass Transfer. 2018;124:663-676.

278. Zhang H, Baeyens J, Caceres G, Degreve J, Lv Y. Thermal energy storage: recent developments and practical aspects . Progress in Energy and Combustion Science. 2016;53:1-40.

279. Pielichowska K, Pielichowski K. Phase change materials for thermal energy storage. Progress in Materials Science. 2014;65:67-123.

280. Heat storage apparatus and heat exchanger element for use therein: pat.4270523 USA: Int. Cl. F28D20/02. № 19461 ; filed 9 03.79; publ. 2.06.81.

281. Nakaso K., Teshima H., Yoshimura A., Nogami S., Hamada Y., Fukai J. Extension of heat transfer area using carbon fiber cloths in latent heat thermal energy storage tanks. Chemical Engineering and Processing. 2008. Vol. 47, Issue 5. P. 879885. DOI: 10.1016/j.cep.2007.02.001.

282. Hamada Y., Fukai J. Latent heat thermal energy storage tanks for space heating of buildings: Comparison between calculations and experiments. Energy Conversion and Management. 2005. Vol. 46, Issue 20. P. 3221-3235. DOI: 
283. Косенков И.А. Результаты экспериментальных исследований системы предпусковой подготовки двигателей / А.П. Картошкин, И.А. Косенков, Д.С.Агапов // Сб. науч. трудов Международной научно-технической конференции «Улучшение эксплуатационных показателей автомобилей, тракторов и двигателей», СПбГАУ, - СПб. - 2010. - С. 302 - 310.

284. Черный С.Г., Грязин Ю.А., Шашкин П.А. Численное моделирование пространственных турбулентных течений несжимаемой жидкости на основе k-e моделей // Вычислительные технологии. - 1999. - Т. 4. № 2. - С. 74-94.

285. CFX-5 Solver Theory, 2004, 261 p.

286. Исаченко В.П., Осипова В.А., Сукомел А.С. Теплопередача. - М.: Энергоиздат, 1981. - $486 \mathrm{c.}$

287. Эккерт Э.Р., Дрейк Р.М. Теория тепло- и массообмена. - М.Л.: Госэнергоиздат, 1961. - 521 с.

288. Самарский А. А., Моисеенко Б. Д. Экономичная схема сквозного счета для многомерной задачи Стефана // Ж. вычисл. матем. и матем. физ., 1965. - С. 816-827.

289. Россихин Н.А. Расчет и проектирование аккумуляторов теплоты на фазовых переходах (капсульного типа). Методические указания. - Москва: МГТУ им. Н.Э.Баумана, 2007. - 33 с.

290. Мозговой А.Г., Шпильрайн Э.Э. и др. Теплофизические свойства теплоаккумулирующих материалов. Кристаллогидраты. - М.: ИВТАН СССР, 1990. - $106 \mathrm{c}$.

291. Галайко Л.П., Гаевская Н.А. Сравнение методов эквивалентных тепловых схем и конечных элементов для теплового расчета вентильноиндукторного двигателя / Л.П. Галайко, Н.А. Гаевская // Вестник НТУ "ХПИ". 2008. - №25.

292. Дьяконов В.П. Maple 8 в математике, физике и образовании. Полное руководство пользователя. М.: «СОЛОН-Пресс»,2003,-656 с.

293. R. A. Fisher. The Design of Experiments. 6-th ed, London, Oliver and Boyd, 1951. aбo http://lib.mdpu.org.ua/e-book/teor_plan/Lection2/Lection2.html - Критерій Фшера.

294. Дрейпер Н. Прикладной регрессионный анализ / Н. Дрейпер, Г. Смит. - М. : Вильямс, 2007. - 912 с.

295. Ужегов С. О. Дослідження впливу окремих факторів на міцність сталефібробетону методом математичного планування експерименту / С. О. Ужегов // Сучасні технології та методи розрахунків у будівництві : збірник наукових праць. - Випуск 5. - Луцьк : Луцький НТУ. 2016. - С. 174-183. 
296. Fumo N., Biswas M.A.R. Regression analysis for prediction of residential energy consumption. Renewable Sustainable Energe Reviews. 47: 322-343. Доступ: https://www.scopus.com/record/display.uri?eid

297. В.О. Скирденко, О.В. Акімов. Оптимізація режимів високочастотної електромагнітної обробки епоксидних композитів методом математичного планування експерименту. Вісник ЖДТУ. 2013. № 4 (67), с. 28-36.

298. Лапач С.М. Проблеми побудови регресивних моделей процесів різання металів. Вісник НТУУ «КПІ». Серія машинобудування, № 3 (72). 2014, с. 40-47.

299. Дмитрів І.В. Автомобільний транспорт. Теорія і практика наукових досліджень: навч. посіб. /В.Дмитрів. СПОЛОМ, 2010. - 316 с.

300. Adamchuk V., Dmytriv V., Dmytriv I. Experimental studies of duration of air pumping out from the „TEAT CUP - PULSATOR” system. Econtechmod: an International quarterly journal on economics in technology new technologies and modeling processes. Lublin : Rzeszow, 2015. Vol. 4, № 4. P. 3-6.

301. Ткаченко Н.А., Некрасов О. Інгібування процесу кристалізації функціональних жирів. Збагачених діацилгліцеринами. Харчова наука i технологія. С. 39-44.

302. Box G.E.P. Response surfaces, mixtures, and ridge analyses, 1st ed. / G. E. P. Box, N. R. Draper. - Hoboken, N.J.: John Wiley, 2007. - 857 p.

303. Калина В.С., Куниця К.В., Гладкий ФФ., Луценко М.В., Литвиненко О.А. Визначення раціональних умов фракційної кристалізації жирної коріандрової кислоти. Вісник НТУ “ХПІ». 2015. № 52 (1161). С. 88-94.

304. Дергильова О. В., Рома О. М., Пашков О. С. Планування досліджень iз застосуванням системи імітаційного моделювання JCATS - Збірник наукових праць центру досліджень Національного університету оборони України імені Івана Чкпняховського, 2016, № 3 (58), с. 66-69.

305. Darlington R.B., Haves A.F. Regression Analysis and Linear Models: Consects, Application and Implementation. New York: Guiford Press. Доступ: https://books.google.com.ua/books?id=YDgoDAAAQBAJ\&pg=PA62\&hl=ru\&sourc $\mathrm{e}=$ gbs_selected_pages\&cad $=3 \# \mathrm{v}=$ onepage $\& \mathrm{q} \& \mathrm{f}=\mathrm{false}$.

306. Основи наукових досліджень і технічної творчості: навч. посібник / Г.М. Лисюк, О.Г. Шидакова-Каменюка, О.В. Самохвалова, О.В.Нєміріч, О.Г.Дьяков; за ред. Г.М. Лисюк. - Х. : ХДУХТ, 2014. - 202 с.

307. General concept of safety provision at NРР, ОПБ-88/97. НП-001-97 (ПНАЭ Г-01-011-97). Approved by RF Gosatomnadzor statement N9 of 14.11.97. (in Russ.) 
308. Rules of nuclear safety of NPP reactor plants. ПБЯ РУ AC-89. Effective since 01.09.90. (in Russ.)

309. Preliminary report on validation of safety. Topical reports on fuel. Validation of meeting requirements of ОПБ-88/97 of 01.2001. (in Russ.)

310. Semerak M.M. Research the behaviour and properties of WWER type fuel claddings from Zr1\%Nb alloy in loss of the coolant accident / M.M. Semerak, S.S. Lys // Problems of atomic science and technology. - Kharkiv, 2021. - №2(132). - P. 8086.

311. Yu.K.Bibilashvili, N.B. Sokolov, L.N. Andreeva-Andrievskaya, V.Yu. Tonkov, A.V. Salatov, A.M. Morosov, V.P. Smirnov. The oxydized Zr1\%Nb VVERtype fuel rod claddings heat resistance during quenching in loss of the coolant accident conditions. 6th International QUENCH Workshop, Forschungszentrum Karlsruhe, October 10-12, 2000.

312. Yu.K. Bibilashvili, N.B. Sokolov, V.V. Dranenko et al. "Influence of High Temperature Oxidation and Thermal Shocks on Zr-Base Alloy Cladding Strain to Fracture" - Voprosy Atomnoi Nauki i Tekhniki. Series: Materials Science and Novel Materials, 1991, issue 2(42), pp.34-39.

313. V.Yu. Tonkov, A.M. Kaptel'sev, I.V. Golikov et al. "Influence of Steam Oxidation on Tensile Properties of Zr1\%Nb Alloy within 20-10000C"- Voprosy Atomnoi Nauki i Tekhniki. Series: Materials Science and Novel Materials, 1990, issue 4(38), pp.7-11.

314. Kawasaki, S. A review of studies on behaviour of fuel cladding under LOCAs . Proceedings of Japan-USSR seminar on LWR Fuels, held in Tokyo, Japan, 29-31 October, 1990.

315. L.N. Andreeva-Andrievskaya, O.A. Nechaeva, A.V. Salatov, N.B. Sokolov. "RAPTA-5: Programme of Computer Modelling Behaviour of Power Water Cooled Reactor Fuels under Design Basis Accident Conditions"- ФНР ЯРБ (GAN), Certification passport № 60 of 17.101996 .

316. Актуальные вопросы глобализаций.// Миорвая экономика и международные отношения. 2019г., с.202 -214.

317. Азорянц Э.А. Глобализация как науычная проблема // Полигнозис. 2018.c.106

318. Сильвестров С. Глобальная модернизация: последствия для человека и общества // Общество и экономика.2013.-с.2274

319. Сорж Дж. Открытое общество. Реформируя лобальный капитализм. М.,2015.-c.20-21.

320. Сильвестров С. Глобальня модернизация: последствия для человека и общества // Общество и эконмика. 2000.- с..223. 
321. Scientific bases of waste-free technologies of renewable raw materials: textbook / O.V. Grek, O.O. Onopriychuk. - K., NUFT, 2020. - 323 p.

322. Lisicyn, A.B. Integrated use of raw materials in the meat industry of the agro-industrial complex/ A.B. Lisicyn, N.F. Neburchilova, I.V. Petrunina// Food industry. - 2016. - No. 5. - P. 58-62.

323. Horishnii P.O., Topchiy O.A. Wasteless technologies as a way to expand resource opportunities. Innovative technologies and prospects for the development of the meat processing industry ("Realities and prospects of meat processing"): Program and abstracts of the International Scientific and Practical Conference, September 15, 2021, Kyiv. - K .: NUFT, 2021 p.- 92 p.

324. Nutritional science. Part 1. General nutritional science. Tutorial. / Pavlotskaya LF, Dudenko NV, Tsykhanovskaya IV, Lazareva TA, Alexandrov OV, Kovalenko VO, Skurikhina LA, Yevlash VV - Kharkiv: UIPA, 2012. - 371 p.

325. Enzymes in the meat food industry / O.V. Zinina, A.A. Solovyova, Ya.M. Rebezov et al. // International student scientific bulletin. -2015. - No. 6.

326. Enzymes in Food Technology by Robert J. Whitehurst, Maarten Van Oort; translation from English. S.V. Makarov. - SPb. : Profession, 2013 .-- 408 p.

327. Product technologies with modified fat composition: realities and trends: monograph / O.A. Savchenko, O.V. Grek, O.A. Topchiy, A.B. Petrina, O.O. Krasulya. - K., PC«Komprint», 2018.- 250 p.

328. Gorishnii P.O., Pasichniy V.M., Topchiy O.A. Production of protein-fat emulsions using biomodified by-products. Innovative technologies and prospects for the development of the meat processing industry: Program and abstracts of the International Scientific and Practical Conference, November 24, 2020, Kyiv. - K .: NFHT, 2020 - P. 49.

329. American Heart Association, http://www.heart.org/HEARTORG/, last accessed 2019/03/30.

330. I. Korhonen, J. Parkka, and M. van Gils, "Health monitoring in the home of the future", vol. 22, no. 3, pp. 66-73, IEEE Eng. Med. Biol. Mag. (2003).

331. A. Taranchuk, S. Pidchenko, "Diagnosis methods of cardiovascular disease, based on the acoustic-mechanotron principle of pulse wave sensing", 2017 XXIInd Int. Seminar/Workshop on Direct and Inverse Problems of Electromagnetic and Acoustic Wave Theory (DIPED)], pp. 75 - 79, IEEE publ., 25-28 Sept., Dnepr, Ukraine (2017).

332. B. Sigel, "A brief history of Doppler ultrasound in the diagnosis of peripheral vascular disease", Ultrasound in Medicine \& Biology, vol. 24, no. 2, pp. 169-176 (1998).

333. T. Togawa, T. Tamura, P. Oberg, "Biomedical Sensors and Instruments", 2nd ed., pp. 19-190, CRC Press: New York, NY, USA (2011). 
334. C. Steinern, A. Janshoff, "Piezoelectric Sensors". Springer Series on Chemical Sensors and Biosensors, vol. 5, Published by Springer, Berlin Heidelberg, New York (2006).

335. S. L. Toral, J. M. Quero, M. E. Perez and L. G. Franquelo, "A microprocessor based system for ECG telemedicine and telecare", pp. 526-529, IEEE Int. Symp., Circuits and Systems (2001).

336. A. Taranchuk, S. Pidchenko, "Design Methodology to Construct Information Measuring Systems Built on Piezoresonant Mechanotrons with a Modulated Interelectrode Gap", Applied Measurement System, pp. 229-258, Published by InTech, Janeza Trdine 9, 51000 Rijeka, Croatia (2012).

337. A. Taranchuk, "Construction of measuring piezoresonance mechanotrons and their practical implementation for telemedicine diagnostic systems", Telecommunication and Radio Engineering, vol. 77, issue 3, pp. 269-281, Published by Begell House, Inc., USA (2018).

338. A. Taranchuk, S. Pidchenko, A. Opolska, "Utilization Features of the Mechanotron for Information Measurement Systems", Proc. of the 10th Int. Conf. TCSET: Modern Problems of Radio Engineering, Telecommunication and Computer Science, p. 358, Lviv-Slavske, Ukraine, February (2010).

339. A. Taranchuk, S. Pidchenko, O. Skovryha, "Design methodology of piezoresonant sensors construction with a modulated interelectrode gap", IEEE 35th Int. Conf. on Electronics and Nanotechnology, ELNANO 2015 - Conf. Proc., pp. 374 - 377, 21-24 April, Kiev, Ukraine (2015).

340. A. Taranchuk, S. Pidchenko and A. Zhyznevskyi "Modeling of Electromechanical Characteristics of Piezoresonance Pressure Sensors with Membrane Control of the Interelectrode Gap of a Piezoelectric Element", Visnyk NTUU KPI Seriia - Radiotekhnika Radioaparatobuduvannia, (74), pp. 51-59 (2018).

341. A. Taranchuk, S. Pidchenko, "Pressure transducer based on the dual-mode piezoresonant sensors with modulated interelectrode gap", 2016 IEEE 36th Int. Conf. on Electronics and Nanotechnology, ELNANO 2016 - Conf. Proc., pp. 261 - 263, 1921 April, Kiev, Ukraine (2016).

342. A. Taranchuk, S. Pidchenko, R. Khoptinskiy, "Dynamics of temperaturefrequency processes in multifrequency crystal oscillators with digital compensations of resonator performance instability", Radioelectronics and Communications Systems, vol. 58, no 6, pp. 250-257, USA: Allerton Press Inc, June 2015 (2015).

343. A. Taranchuk, S. Pidchenko, "High-informative medical diagnostic sphygmosystem on the basis on piezoresonant mechanotron pressure sensor", CriMiCo 2013 - 23rd Int. Crimean Conf. Microwave and Telecommunication Technology, Conf. Proc., pp. 1107-1108, September 8-14, Sevastopol, Crimea, Ukraine (2013). 
344. A. Taranchuk, S. Pidchenko, "Quartz Pulse Wave Sensor with a Capacitive Control for Healthcare Solutions," IEEE Sensors Journal, 21(6), pp. 8613-8620 (2021).

345. McCarthy, John. What is artificial intelligence? URL: http://35.238.111.86:8080/jspui/bitstream/123456789/274/1/McCarthy_John_What\% 20is\%20artificial\%20intelligence.pdf

346. Osoba, Osonde A., and William Welser.An Intelligence in Our Image: The Risks of Bias and Errors in Artificial Intelligence. Santa Monica, Calif., RAND Corporation, RR-1744-

URL: https://www.rand.org/pubs/research_reports/RR1744.html

347. Goodfellow, Ian \& Shlens, Jonathon \& Szegedy, Christian.Explaining and Harnessing Adversarial Examples. 2014. URL: https://arxiv.org/abs/1412.6572.

348. Angwin, Julia L., Jeff Larson, Surya Mattu, and Lauren Kirchner.Machine Bias: There's Software Used Across the Country to Predict Future Criminals. And It's Biased Against Blacks. 2016. URL: https://www.propublica.org/article/machine-biasrisk-assessments-in-criminal-sentencing.

349. Пантєлєєва Н. Фінансова безпека в умовах цифрової економіки: очікування і реальність. Міжнародний науково-практичний журнал «Фінансовий простір», 2020. Т. 2 (38), С. 22-37.

350. Синиціна Ю.П., Каут О.В., Фонарева Т.А. Інтелектуальні системи підтримки прийняття рішень у процесі управління підприємством. Інфраструктура ринку. 2019. № 32. C.208-212. URL: http://www.marketinfr.od.ua/journals/2019/32_2019_ukr/32.pdf

351. Синиціна Ю.П., Каут О.В., Бушуєв К.М. Використання нейронних мереж у прогнозуванні макроекономічних показників підприємства. Причорноморські економічні студії. 2019. № 41. C.126-130 URL: http://bses.in.ua/journals/2019/41_2019/25.pdf

352. Daugherty, Mark Purdy and Paul.Why Artificial Intelligence is the Future of Growth. 2016. URL: https://www.accenture.com/t20170524T055435_w__caen/_acnmedia/PDF52/Accenture-Why-AI-is-the-Future-of-Growth.pdf.

353. Nicholas Chen, Lau Christensen,Kevin Gallagher, Rosamond Mate, Greg Rafer.Global Economic Impacts Associated with Artificial Intelligence. URL: https://www.analysisgroup.com/globalassets/content/insights/publishing/ag_full_repo rt_economic_impact_of_ai.pdf]

354. Станіна О.Д. Роль штучного інтелекту в забезпеченні економічної безпеки держави. Науковий вісник Дніпропетровського державного університету внутрішніх справ: Науковий журнал. 2021. № 1 (110). С 328-333

355. Баррат, Джеймс.Последнее изобретение человечества: Искусственный интеллект и конец эры Ното. Москва : Альпина нон-фикшн, 2015. 308 с. 
356. Tsirkas, Sotirios \& Papanikos, Paraskevas \& Kermanidis, Th. (2003). Numerical Simulation of the Laser Welding Process in Butt-Joint Specimens. Journal of Materials Processing Technology. 134. 59-69. doi:10.1016/S0924-0136(02)009214.

357. A.P. Mackwood, R.C. Crafer; Thermal modelling of laser welding and related processes: a literature review, Optics \& Laser Technology 37 (2005) 99 - 115

358. Josefine Svenungsson, Isabelle Choquet, Alexander F.H. Kaplan, Laser Welding Process - A Review of Keyhole Welding Modelling, Physics Procedia, Volume 78, 2015, Pages 182-191, ISSN 1875-3892, https://doi.org/10.1016/j.phpro.2015.11.042.

359. Courtois, Mickael, Muriel Carin, Philippe Le Masson, Sadok Gaied, and Mikhaël Balabane. "A New Approach to Compute Multi-Reflections of Laser Beam in a Keyhole for Heat Transfer and Fluid Flow Modelling in Laser Welding." Journal of Physics D: Applied Physics 46, no. 50 (2013): 505305. doi:10.1088/00223727/46/50/505305.

360. R. Bansal, R. Acharya, J. J. Gambone, and S. Das; Experimental and theoretical analysis of scanning laser epitaxy applied to nickel-based superalloys, Woodruff School of Mechanical Engineering, Georgia Institute of Technology Atlanta, GA 30332-0405

361. Lei Wang, Yong Huang, Dongqing Yang, He Li, Yong Peng, Kehong Wang, Multi-scale simulation of grain growth during laser beam welding of nickel-based superalloy, Journal of Materials Research and Technology, Volume 9, Issue 6, 2020, Pages 15034-15044, ISSN 2238-7854, https://doi.org/10.1016/j.jmrt.2020.10.091.

362. Shakeel Safdar, Andrew J. Pinkerton, Lin Li, Mohammed A. Sheikh, Philip J. Withers, An anisotropic enhanced thermal conductivity approach for modelling laser melt pools for Ni-base super alloys, Applied Mathematical Modelling, Volume 37, Issue 3, 2013, Pages 1187-1195, ISSN 0307-904X, https://doi.org/10.1016/j.apm.2012.03.028.

363. Amara, El-Hachemi \& Fabbro, Remy. (2008). Gas jet effect on the molten bath movements produced during deep penetration laser welding. 3rd Pacific International Conference on Applications of Lasers and Optics, PICALO 2008 Conference Proceedings. 179-184.

364. Anuratha, M. \& Chittaranjan Das, Vemulapalli \& Devuri, Venkateswarlu \& Cheepu, Murali Mohan. (2019). Parameter Optimization for Laser Welding of High Strength Dissimilar Materials. Materials Science Forum. 969. 558-564. doi:10.4028/www.scientific.net/MSF.969.558.

365. S. S. Babu, S. A. David, J. W. Park, and J. M. Vitek, Joining of nickel-base superalloy single crystals, "The Microstructure and Performance of Joints in HighTemperature Alloys,” London, UK, 20th November, 2002. 
366. Nie, Pulin \& Ojo, O.A. \& Li, ZhuGuo. (2014). Numerical modeling of microstructure evolution during laser additive manufacturing of a nickel-based superalloy. Acta Materialia. 77. 85-95. doi:10.1016/j.actamat.2014.05.039.

367. Факторы, влияющие на средний возраст парка машин. Обзор по материалам зарубежной печати. // Строительные и дорожные машины. 2008. №3. C. $28-29$

368. Васильченко В.А. Гидравлическое оборудование мобильных машин // Справочник. - М.: Машиностроение, 1983. - 301 с.

369. Пимонов И.Г., Фомин Р.А. Повышение эффективности диагностирования гидроприводов строительных машин. Науковий вісник будівництва. - Харків: ХДТУБА - 2009. Випуск 52. - с.361 - 365.

370. Аврунін Г.А., Пімонов І.Г., Мороз I.І. Регулирование температуры рабочей жидкости в объемных гидропривод ах мобильных машин. Вінницький національний аграрний університет, Асоціація спеціалістів промислової гідравліки і пневматики. Промислова гідравліка і пневматика, 2016. №1

371. Я. Лур'є, В. Б. Самородов, Г.А. Аврунін, Є.Н. Цента // Вісник Національного технічного університету «ХПІ». Серія: Гідравлічні машини та гідроагрегати: - Х.: - НТУ «ХПІ». - 2019. - № 2 (2019). - С. 68-76.

372. Orbital Motors Type OMP, OMR and OMH. - Danfoss. - Technical Information. - ENGINEERING TOMORROW. - powersolutions.danfoss.com.- 2 | Danfoss | January 2018. - 520L0262 | BC00000084en- US0402. - 116 p.

373. Анилович В.Я. Надёжность машин в задачах и примерах / В.Я. Анилович, А.С. Гринченко, В.Л. Литвиненко. - Х.: Око, 2001. - 318 с.

374. Волков Д.П. Надежность строительных машин и оборудования : учебное пособие / Д.П. Волков, С.Н. Николаев. - М. : Высшая школа, 1979. - 400 c.

375. Волков Д.П. Надёжность роторных траншейных экскаваторов / Д.П. Волков, С.Н. Николаев, И.А. Марченко. - М. : Машиностроение, 1972. - 207 с.

376. Воронович А.В. Совершенствование автогрейдеров массой $15 \ldots 16$ т комплектацией энергосиловыми модулями повышенной надежности : дис. ... кандидата техн. наук : 05.05.04 / Воронович Андрей Викторович. - Харьков, 2007. $-172 \mathrm{c}$.

377. Рейш А.К. Повышение износостойкости строительных и дорожных машин / А.К. Рейш. - М.: Машиностроение, 1986. - 184 с.

378. Сігарьов Є.М. Енергоефективність інтенсифікації ківшової десульфурації чавуну // Восточно-Европейский журнал передовых технологий. - 2015. - № 2/1(74). - C. 38-42. 
379. Сігарьов Є.М., Недбайло М.M., Кривцун I.В. Напрямки удосконалення ковшової десульфурації чавуну // Зб. наук. праць ДДТУ: (технічні науки) - Дніпродзержинськ. - 2016, вип. 2(28). - С. 3-9.

380. E. N. Sigarev, A. G. Chernyatevich, K. I. Chubin and S.A. Zarandiya Desulfurization of hot metal by the injection of disperse magnesium through a submerged rotating // Steel in Translation. - 2011, V.41. - № 6. - p. 487-491.

381. Sigarev E.N., Chernyatevich A.G., Chubin K.I. // Desulfurization of iron using magnesium // Steel in Translation. - 2002, V.32; P.2. - p. 7-9.

382. Сігарьов Є.М., Похвалітий А.А., Довженко О.В., Чубіна О.А. Характеристика металевих корольків у шлаку після десульфурації чавуну за схемою коінжекції реагентів // Зб. наукових праць ДДТУ: (технічні науки) Кам’янське. - 2019. - №35, Т.2. - С. 10-16.

383. Сігарьов С.М., Кочмола Д.С., Чубін К.І. Вплив покривного шлаку на перебіг ковшової десульфурації чавуну // Теорія і практика металургії. - 2018. №1-2. - С. 67-75.

384. Гарг В.К., Дуккипати Р.В. Динамика подвижного состава. Транспорт, 1988. 392 c.

385. Sapronova, Svetlana (2010). Modeling of Locomotive wheel profile form / Svetlana Sapronova. TEKA. Commission of motorization and power industry in agriculture. Vol. XC. 270-278.

386. Вершинский С.В., Данилов В.Н., Хусидов Д. Динамика вагона; под ред. С. В. Вершинского. М.: Транспорт, 1991. 360 с.

387. Sapronova, S., Tkachenko, V., Fomin, O., Kulbovskiy, I., Zub, E. Rail vehicles: resistance to movement and handleability: monograf. Dnipro: Ukrmetallurginform STA, 2017. 160p., англ. URL: https://www.metaljournal.com.ua/assets/MonographKyivverstka.pdf

388. Ткаченко, В.П. Управляемость рельсовых экипажей. Луганськ: Видво СУДУ, 1997. 92 с.

389. Ткаченко В. П. Розрахунок та прогнозування шляхового фрикційного опору руху рейкових екіпажів: дис. ... доктора техн. наук: 05.22.07/ Ткаченко Віктор Петрович. Луганськ, 1999. 371 с.

390. Сапронова С. Ю. Розрахунок характеристик поперечних коливань залізничних екіпажів 3 урахуванням доточкового контактування коліс iз рейками : дис. ... кандидата техн. наук : 05.22.07/ Сапронова Світлана Юріївна. Харків, 2003. 172 с. 
391. Сапронова, С.Ю. Моделювання руху екіпажа в стрілочних переводах. Збірник наукових праць Донецького інституту залізничного транспорту Української державної академії залізничного транспорту. Донецьк, 2011. Вип. 28. C.219-224.

392. Інструкція з формування, ремонту й утримання колісних пар тягового рухомого складу залізниць України колії 1520 мм. Відомчий нормативний документ 32.0.07.001.2001 (нова редакція). Київ: Державна адміністрація залізничного транспорту України. Укрзалізниця, 2011. 168 с.

393. Інструкція по устрою та утриманню колії залізниць України / Е. I. Даниленко, А. М. Орловський, А.П. Татуревич та ін. К.: Транспорт України, 1999. $248 \mathrm{c}$.

394. Воронько, О.М., Сапронова, С.Ю. Форма профілю поверхонь кочення коліс рухомого складу і проблеми безпеки руху залізниць. Вісник Східноукраїнського нац. ун-ту ім. В. Даля. 20 08. №1E. URL.: http://www.nbuv.gov.ua/e-journals/Vsunud/2008-1E/08vanbrz.htm.

395. Мак-Кракен Д., Дорн. У. Численные методы и программирование на Фортране. М.: Мир, 1977. 271с.

396. Бахвалов Н.С. Численные методы. М.: Наука, 1975. 237с.

397. Вдовиченко В.О. Методологічні основи формування системної ефективності громадського пасажирського транспорту в умовах сталого розвитку: монографія. Харків: ХНАДУ, 2017. 212 с.

398. Vuchic V.R. Urban Transit Systems and Technology. New Jersey, 2007. $602 \mathrm{p}$.

399. Андреев К. П., Терентьев В. В. Современные проблемы городского пассажирского транспорта. Научный альманах. 2016. №. 11-2. С. 19-21.

400. Іванов I.Є., Вдовиченко В.О. Структура адаптивної резонансної моделі управління якістю транспортного обслуговування міським громадським пасажирським транспортом. Автомобіль і електроніка. Сучасні технології. 2021. №19. C. 54-67.

401. Vdovychenko V., Samchuk G., Velikodnyi D. Formation of system efficiency of urban public passenger transport under conditions of open competition. Innovative Economy: Processes, Strategies, Technologies: International scientific conference, Part I. Kielce, Poland: Baltija Publishing, 27 January 2017. P. 150-152.

402. Hjorthol R. Transport resources, mobility and unmet transport needs in old age. Ageing and Society. 2013. T. 33. №7. P. 1190-1211. 
403. Вдовиченко В.О., Самчук Г.О. Формування математичної моделі функціонування транспортно-пересадочних вузлів міського пасажирського транспорту. Вісник національного технічного університету «ХПІ». Серія «Механіко-технологічні системи та комплекси». 2016. №17(1189). С. 56-61.

404. Вдовиченко В.О. Слот-координація руху міського громадського пасажирського транспорту в умовах транспортно-пересадочних терміналів. Вісник КрНУ імені Михайла Остроградського. 2017. №5(106). С. 51-55.

405. Алексієв В. О., Алексієв О. П., Видмиш А. А., Хабаров В. О. Інтерактивний моніторинг автомобільних доріг: монографія. Вінниця: ВНТУ, 2012. 144 c.

406. Vdovychenko V. Development of a model for determining the time parameters for the interaction of passenger transport in a suburban transport and transfer terminal. Технологічний аудит та резерви виробництва. 2017. №3/2(35). С. 41-46.

407. Вдовиченко В.О. Формування соціально-маркетингової оцінки сервісної якості міських пасажирських транспортних послуг. Технологічний аудит та резерви виробництва. 2016. №5/2(31). С. 42-48.

408. Markevych A., Vdovychenko V., Ivanov I. Influence of bus service downtime in the transport interchange on the duration of inter-route transfer of passengers. Technology audit and production reserves. 2021. №3(2(59), p. 41-45.

409. Bonomi, A., Masiero, R., (2014). Dalla Smart City alla Smart Land. Marsilio, Venezia.

410. Bria, F., Morozov, E., (2018). Ripensare la Smart City. Codice Editori, Torino.

411. Махначова Н.М. (2019). Інноваційний розвиток території на основі смарт-критеріїв. Публічне управління та адміністрування в Україні, № 11, 148152.

412. Gubbi, J., Buyya, R., Marusic, S., Palaniswami, M. (2013). Internet of Things (IoT): a vision, architectural elements, and future directions. Future Generation Computer Systems, 29 (7), 1645-1660.

413. Whitmore, A., Agarwal, A., Da Xu, L., 2015. The internet of thingsea survey of topics and trends. Information Systems Frontiers, 17 (2), 261-274.

414. Zanella, A., Bui, N., Castellani, A., Vangelista, L., Zorzi, M. (2014). Internet of things for smart cities. IEEE Internet of Things Journal, 1 (1), 22-32.

415. Наконечний, А. Й., \& Верес, 3. Є. (2016). Інтернет речей і сучасні технології. Вісник Національного університету "Львівська політехніка". Автоматика, вимірювання та керування, № 852, 3-9 
416. Talari, S., Shafie-khah, M., Siano, P., Loia, V., Tommasetti, A., Catalão, J.P.S. (2017) A Review of Smart Cities Based on the Internet of Things Concept. Energies, 10(4), 421.

417. Бочкарёв, П.В., \& Кузнецов, И.А. (2020). Использование концепции "умный порт" в рамках развития и цифровой трансформации арктической зоны Российской Федерации. Информационные технологии и математическое моделирование систем 2020. Труды международной научно-технической конференции. Издательство: Федеральное государственное бюджетное учреждение науки Центр информационных технологий в проектировании Российской академии наук (Одинцово), 99-108.

418. Porru, S., Misso, F. E., Pani, F. E., \& Repetto, C. (2020). Smart mobility and public transport: Opportunities and challenges in rural and urban areas. Journal of traffic and transportation engineering (English edition), 7(1), 88-97. 